UNIVERSIDADE DE BRASÍLIA

INSTITUTO DE CIÊNCIAS BIOLÓGICAS

DEPARTAMENTO DE BIOLOGIA CELULAR

PÓS-GRADUAÇÃO EM BIOLOGIA MOLECULAR

\title{
Análise transcritômica de linfócitos T humanos tratados com anticorpos anti-CD3
}

Kelly Cristina Rodrigues Simi

Orientador: Prof Dr. Marcelo de Macedo Brígido

Co-orientadora: Prof ${ }^{a}$ Dra. Andréa Queiroz Maranhão

Brasília - DF

2014 
UNIVERSIDADE DE BRASÍLIA

INSTITUTO DE CIÊNCIAS BIOLÓGICAS

DEPARTAMENTO DE BIOLOGIA CELULAR

PÓS-GRADUAÇÃO EM BIOLOGIA MOLECULAR

\title{
Análise transcritômica de linfócitos T humanos tratados com anticorpos anti-CD3
}

\author{
Kelly Cristina Rodrigues Simi \\ Tese apresentada ao Departamento \\ de Biologia Celular do Instituto de \\ Ciências Biológicas da Universidade \\ de Brasília como requisito parcial à \\ obtenção do grau de Doutor em \\ Biologia Molecular
}

Orientador: Prof. Dr. Marcelo de Macedo Brígido

Co-orientadora: Prof ${ }^{a}$ Dra. Andréa Queiroz Maranhão

$$
\text { Brasília - DF }
$$


Banca Examinadora:

Prof. Niels Olsen Saraiva Camara (USP - Banca Externa)

Dra. Priscila Grynberg (Embrapa - Banca Externa)

Prof. Dra. Ildinete Silva-Pereira (UnB - Banca Interna)

Prof. Dra. Kelly Grace Magalhães (UnB - Banca Interna)

Dra. Galina Gulis (UnB - Suplente)

Prof Dr. Marcelo de Macedo Brígido (UnB - Orientador)

Prof $^{\mathrm{a}}$ Dra. Andréa Queiroz Maranhão (UnB - Co-orientadora)

Trabalho desenvolvido no Laboratório de Biologia Molecular da Universidade de Brasília, sob a orientação do Prof. Dr. Marcelo de Macedo Brigido. 
Dedico este trabalho ao meu marido, Gideone Nobre Bandeira e aos meus pais, que sempre me apoiaram e acreditaram nos meus sonhos. E a minha pequena, que está prestes a chegar e me concederá o maior título de todos! 
"Um pouco de ciência nos afasta de Deus. Muito, nos aproxima"

(Louis Pasteur) 


\section{AGRADECIMENTOS}

Agradeço a Deus pela força concedida em todos os momentos difíceis, determinação nos momentos de dúvidas e serenidade nos momentos de conflitos. Agradeço de coração aos meus orientadores Marcelo e Andrea pela oportunidade que me deram. Por terem acreditado em mim. Devo à vocês o meu crescimento científico e profissional.

A todos da minha família por acreditar nos meus sonhos. Ao meu marido, que sempre foi paciente e tanto me ajudou. Sem você, eu não teria conseguido. Aos meus pais que sempre me apoiaram nos momentos difíceis. A minha querida Melissa, que tem me dado uma gestação tranquila que permitiu a finalização desse doutorado. Saiba que você pequena, me concederá o mais nobre título, o de mãe!

Aos meus grandes amigos do grupo de Imunologia Molecular, pelos momentos de alegrias e os de desesperos.

A Maryani e Isabel, minhas companheiras de experimentos. Sempre foi fácil trabalhar com vocês. Agradeço pela paciência, amizade, carinho. Amo vocês! A Manu, que embarcou em parte desse projeto. Sempre à disposição, com seu jeitinho meigo.

Ao meu querido amigo Rafa, de longa data. Que sempre esteve disposto a ajudar. Saiba que te amo como um irmão! A Galina, essa pessoa simplesmente sensacional e atenciosa. Ao Thompson, que sempre foi prestativo e gentil.

A querida professora lldinete, que acompanhou minha evolução desde o início. Saiba que tenho um carinho muito especial por você, conterrânea!

A todos os que participam desse grupo ou já participaram. A Bárbara, Fernanda, Isabella, Luana, Janaína, Izabel, Flávia, Mariana, Victor e Yuri. Com cada um, aprendi um pouquinho. Mesmo não estando mais no grupo, tornaramse pessoas especiais.

Agradeço a Fátima e Ivonildes, sem vocês, o laboratório pararia. Obrigada pelo carinho! 


\section{SUMÁRIO}

Índice de Figuras__ $\quad x$

Índice de Tabelas__ xi

Lista de Abreviaturas__ xii

Resumo_ xiv

Abstract_ XV

Introdução__ 1

1. Sistema imune e tolerância imunológica___ 2

2. Diferenciação e funções dos Linfócitos T CD4+__ 4

2.1 Linfócitos Th1 5

2.2 Linfócitos Th2_ 6

2.3 Linfócitos Th17__ 7

2.4 Família de Linfócitos T com fenótipo supressor __ 9

2.4.1 Linfócitos T reguladores de ocorrência natural (nTregs)__ 10

2.4.2 Linfócitos T reguladores induzidos (iTregs)__ 12

2.5 Mecanismos de supressão__ 13

2.5.1 Supressão por meio de citocinas__ 13

2.5.2 Supressão pela modulação das células dendríticas (DCs)__ 14

3. Anticorpos recombinantes_ 15

4. Anticorpos anti-CD3 _ 23

5. Tecnologia de RNA-Seq__ 27

Justificativa e Objetivos_ 30

Material e Métodos_ 33

Material__ 34

1. Células__ 34

2. Soluções, meios e regentes__ 34

3. Soluções e material para ensaios imunológicos___ 38

4. Soluções e material para citometria de fluxo__ 39

5. Anticorpos utilizados nos imunoensaios__ 40

6. Reagentes e Kits de isolamento de PBMC e linfócitos T__ 42

7. Reagentes e Kits para RNA__ 42 
8. Kits e placas para validação de genes por PCR Array 42

Métodos 43

1. Cultura de células de mamíferos 43

2. Congelamento de células de mamíferos 43

3. Descongelamento de células de mamíferos 43

4. Tripsinização, passagem das células e formação de monocamada celular 44

5. Estimativa do número de células 44

6. Acúmulo de sobrenadante de cultura 45

7. ELISA (Enzyme-linked immunosorbent assay) 45

8. Purificação das proteínas recombinantes por cromatografia de afinidade 46

9. Análise de proteínas por Dot Blot 47

10. Análise de proteínas em gel de SDS-PAGE 47

11. Coloração de gel de SDS-PAGE___ 48

12. Análise de proteínas por Western Blot__ 48

13. Ensaio de ligação direta utilizando citometria de fluxo__ 48

14. Separação de PBMC por gradiente de Ficoll

15. Estimulação de PBMC com os anticorpos anti-CD3

16. Isolamento dos Linfócitos T por meio de beads magnéticas___ 50

17. Extração de RNA total de Linfócitos T__ 51

18. Tratamento de RNA total com DNAse__ $\quad 51$

19. Quantificação de RNA e análise de qualidade por Bioanalyzer___ 51

20. Preparo das amostras de RNA e sequencimaneto__ 52

21. Análises por bioinformática__ 52

22. Ferramentas de bioinformática__ $\quad 53$

22.1 FastQC__ 54

22.2 Segemehl.x_ 54

22.3 HTSeq-count__ 55

22.4 DESeq2

$22.5 \mathrm{~g}: G O S t$

23. Validação por PCR Array__

Desenho Experimental__ 59

Resultados e Discussão___ 61

1. Produção e purificação dos FvFc anti-CD3__ 62

2. Ensaio de ligação direta dos FvFc à molécula CD3 por citometria de fluxo__ 65 
3. Estimulação de PBMC humano e isolamento de Linfócitos T__ 66

4. Análise da qualidade do RNA total__ 67

5. Análise da qualidade dos dados de RNA-Seq__ 69

6. Análise da expressão gênica global de Linfócitos T após estimulação___ 70

7. Expressão diferencial de genes envolvidos com a regulação do sistema imune_ 78

7.1 Expressão de genes envolvidos com anergia ou morte celular___

7.2 Regulação de genes codificadores de citocinas e fatores de transcrição__ 81

7.3 Expressão de genes envolvidos com imunorregulação___ 85

7.4. Regulação da expressão do VDR e da enzima CYP27B1__ 94

7.4 Dualidade das respostas induzidas pelos anti-CD3__ 97

Conclusões e perspectivas__ 101

Referências Bibliográficas__ 104

Anexos 119

Anexol_r 120

Anexoll__ 123 


\section{ÍNDICE DE FIGURAS}

Figura 1 - Diferenciação de Linfócitos T CD4+ 8

Figura 2 - Desenvolvimento de Tregs 9

Figura 3 - Estrutura de anticorpo inteiro e seus fragmentos 17

Figura 4 - Mecanismos efetores mediados por anticorpos 18

Figura 5 - Representação esquemática das diferentes versões de anticorpos $\underline{20}$

Figura 6 - Desenho esquemático das diferentes versões dos anti-CD3 26

Figura 7 - Experimento típico de RNA-Seq 28

Figura 8 - Pipeline de análise empregado para os dados de RNA-Seq 53

Figura 9 - Gráfico comparativo de eficiência de purificação 63

Figura 10 - Análise dos anticorpos anti-CD3 por SDS-PAGE 64

Figura 11 - Análise da separação de Linfócitos T da cultura de PBMC 67

Figura 12 - Análise da pureza do RNA por Bioanalyzer 68

Figura 13 - Representação gráfica da qualidade dos dados Illumina 70

Figura 14 - Análise da expressão gênica global 73

Figura 15 - Diagrama de Venn 74

Figura 16 - Representação gráfica das ontologias gênicas (GO) 77

Figura 17 - Regulação dos genes envolvidos com anergia e morte celular 81

Figura 18 - Expressão de Foxp3 e seus alvos 87

Figura 19 - Expressão de IRF4 e seus alvos 88

Figura 20 - Regulação de Foxp3 e IRF4 88

Figura 21 - Expressão de MIR155HG 89

Figura 22 - Comparação de genes obtidos por RNA-Seq e dados de Birzele et al (2011)

Figura 23 - Expressão do gene codificador de granzima B (GZMB) 94

Figura 24 - Expressão dos genes codificadores de Vitamina D (VDR) e a enzima 1-alfa-hidroxilase (CYP27B1) 86

Figura 25 - Sequencimento do tipo paired-end 120

Figura 26 - Representação gráfica da qualidade dos dados Illumina 122 
Tabela 1 - Citocinas e fatores de transcrição que regulam o programa de diferenciação de Linfócitos T CD4+ 5

Tabela 2 - Principais marcadores de Tregs 10

Tabela 3 - Anticorpos monoclonais aprovados pelo FDA até 2013 21

Tabela 4 - Produtividade específica dos anticorpos anti-CD3 62

Tabela 5 - Concentração dos FvFc após purificação e diálise em PBC 64

Tabela 6 - Medianas de intensidade de fluorescência (MIF) de FITC e porcentagem de linfócitos $\mathrm{T}$ marcados com os FvFc recombinantes 66

Tabela 7 - Estatística do mapeamento 71

Tabela 8 - Genes diferencialmente expressos em cada tratamento 72

Tabela 9 - Ontologias gênicas (GO) 75

Tabela 10 - Genes envolvidos com anergia e morte celular (RNA-Seq) 80

Tabela 11 - Expressão de fatores de transcrição, citocinas e receptores 84

Tabela 12 - Genes específicos de Tregs ativadas 90

Tabela 13 - Lista de genes codificadores de interleucinas 98 


\section{LISTA DE ABREVIATURAS}

\begin{tabular}{|c|c|}
\hline $\begin{array}{l}\text { ADCC } \\
\text { AlCD }\end{array}$ & $\begin{array}{l}\text { Citotoxicidade Celular Dependente de Anticorpos } \\
\text { Morte Celular Induzida por Ativacão }\end{array}$ \\
\hline $\begin{array}{l}\text { AlCD } \\
\text { APC }\end{array}$ & $\begin{array}{l}\text { Morte Celular Induzida por Ativação } \\
\text { Allophycocyanin }\end{array}$ \\
\hline APS & Persulfato de amônio \\
\hline $\mathrm{BCIP}$ & 5-Bromo-4Cloro-indolil fosfato \\
\hline CD & Cluster of diferentiation (Marcador de diferenciação) \\
\hline CDR & Região Determinante de Complementariedade \\
\hline $\mathrm{CH}$ & Cadeia constante pesada de anticorpo \\
\hline $\mathrm{CHO}$ & Células de ovário de hamster chinês \\
\hline Ск & Porção constante kappa da cadeia leve \\
\hline $\mathrm{CL}$ & Cadeia constante leve de anticorpo \\
\hline EDTA & Ácido etilenodiaminotetracético \\
\hline ELISA & Ensaio de ligação imunoenzimático \\
\hline Fab & Fragmento de ligação ao antígeno de um anticorpo \\
\hline FACS & Fluorescence Activated Cell Sorter \\
\hline Fc & Fragmento cristalizável de anticorpo (porção constante) \\
\hline FDA & Food and Drug Administration (EUA) \\
\hline FL & Fluorescência \\
\hline FR & Arcabouço (Framework) \\
\hline Fv & Fragmento variável de anticorpo \\
\hline IL & Interleucina \\
\hline $\mathrm{kDa}$ & Kilodalton \\
\hline M & Molar \\
\hline $\mathrm{mAb}$ & Anticorpo monoclonal \\
\hline $\mathrm{mg}$ & Miligrama \\
\hline MHC & Complexo principal de histocompatibilidade \\
\hline$\mu \mathrm{g}$ & Micrograma \\
\hline $\mathrm{mL}$ & Mililitro \\
\hline$\mu \mathrm{L}$ & Microlitro \\
\hline $\mathrm{mM}$ & Milimolar \\
\hline$\mu \mathrm{m}$ & Micrômetro \\
\hline$\mu \mathrm{M}$ & Micromolar \\
\hline mRNA & Ácido ribonucléico mensageiro \\
\hline NBT & Nitro Blue Tetrazole \\
\hline $\mathrm{ng}$ & Nanograma \\
\hline OKT3 & Anticorpo monoclonal anti-CD3 clone OKT3 \\
\hline ori & Origem de replicação \\
\hline & Par de base \\
\hline PBMC & Células mononucleares de sangue periférico \\
\hline PBS & Tampão salina fosfato \\
\hline PCR & Reação em cadeia de polimerização \\
\hline FITC & Fluoresceína isotiocianato \\
\hline pH & Potencial hidrogeniônico \\
\hline pmol & Picomol \\
\hline PMSF & Fluoreto de fenilmetilsulfonato \\
\hline
\end{tabular}


rpm Rotações por minuto

RNA Ácido ribonucléico

RNAse Ribonuclease

RNAse Free Livre de Ribonuclease

scFv Fragmento variável de anticorpo de cadeia única

SDS Sódio Duodecil Sulfato

SDS-PAGE Eletroforese em gel de poliacrilamida/SDS

SFB Soro fetal bovino

TCR Receptor de célula $T$

TEMED N,N,N',N'-tetrametil etilenodimetilamina

$\mathrm{VH} \quad$ Domínio variável da cadeia pesada de um anticorpo

VL Domínio variável da cadeia leve de um anticorpo 


\section{RESUMO}

O sistema imune é constituído de uma complexa rede de células, tecidos e órgãos que trabalham em conjunto para a proteção do organismo. Um importante componente do sistema imunológico é o linfócito $T$. Há dois tipos principais de linfócitos T: T CD4+ (T auxiliares) e T CD8+ (T citotóxicos). Os linfócitos T auxiliares podem estar envolvidos com a proteção do organismo contra microorganismos ou no desenvolvimento de algumas doenças. O receptor de linfócitos T está associado ao complexo da molécula CD3. Estimulação dessa complexo com anticorpos anti-CD3 induz a ativação dos linfócitos $T$. Depois da ativação, o linfócito $T$ pode se diferenciar em subpopulações envolvidas com respostas inflamatórias para eliminação de patógenos (Th1, Th2 e Th17) ou antiinflamatórias (Tregs) para a manutenção da homeostase do organismo. Anticorpos anti-CD3 pode induzir a diferenciação dos linfócitos T nos subgrupos de Tregs e pode ser usado como moléculas terapêuticas para tratar doenças autoimunes e processos de rejeição a transplantes. No presente estudo foi analisado o efeito imunomodulatório in vitro de versões humanizadas de anti-CD3 (FvFc R, T e M) comparando com o anticorpo murino anti-CD3 (OKT3) usando sequenciamento de alto desempenho (RNA-Seq). RNA-Seq foi realizado em linfócitos T não estimulados e estimulados com as diferentes versões de anti-CD3. Diversos genes envolvidos com imunorregulação foram regulados positivamente após o tratamento com os anti-CD3. Alguns desses genes codificam marcadores exclusivos de Tregs, tais como, CD25, FOXP3, CTLA4 e GITR. Outros genes codificavam importantes proteínas envolvidas com a função supressora das células Tregs (Ex. GZMB). Por outro lado, alguns marcadores de células Th17 também foram regulados positivamente. Citocinas de perfil Th17, tais como, IL17 e IL17F foram induzidas por todos os tratamentos. Porém, IL21 e IL22 foram regulados positivamente somente em OKT3. Embora os anticorpos anti-Cd3 humanizados apresentaram um efeito imunomodulatório, mais estudos são necessários para compreender os mecanismos envolvidos nessa imunomodulação.

Palavras-chaves: Linfócitos T, anti-CD3, OKT3, Treg, Th17, RNA-Seq 


\section{ABSTRACT}

The imune system is made up of network of cells, tissues and organs that work together to protect the body. An important component of immune system is T cell. There are two kinds of T cell: T CD4+ (T helper) and T CD8+ (T cytotoxic). T helper cells can be involved with organism protection against microorganism or in the development of some diseases. The receptor of T cells is associated with the CD3 molecule complex. Stimulation of this complex with anti-CD3 antibodies induces T cell activation. After activation antigen-dependent $\mathrm{T}$ cell drives the differentiation into subpopulation involved with inflammatory response to eliminate patogens (Th1, Th2 and Th17) or antiinflamatory reponse (Tregs) to maintain organism hemeostasis. Antibodies anti-CD3 can induce differentiation of T cell into Treg subsets and can be used as terapeutic molecules to treat autoimune diseases and allograft rejection. We studied immunomodulatory effect in vitro of humanized version of anti-CD3 (FvFc R, T and M) comparing with comercial murine anti-CD3 antibody (OKT3) using deeping sequencing (RNA-Seq). RNA-Seq was performed in $\mathrm{T}$ cells not stimulated or stimulated with anti-CD3. We found several genes involved with immunorregulation that were upregulated after treatment with antiCD3 antibodies. Some of genes encodes exclusive markers of Tregs, such as, CD25, FOXP3, CTLA4 and GITR. Some others encodes important proteins involved with supressive function of Tregs (eg. GZMB). Otherwise, some markers of Th17 cells were also upregulated. Th17 cytokines profile, such as IL17 and IL17F were upregulated in all treatment. But, IL21 and IL22 were upregulated only with OKT3. Despite of the humanized anti-CD3 presented an immunomodulatory effect further studies are necessary in order to understand the mechanisms of this effect.

Key words: T cells, anti-CD3, OKT3, Treg, Th17, RNA-Seq 
INTRODUÇÃO 


\section{INTRODUÇÃO}

\section{Sistema imune e tolerância imunológica}

O sistema imune é constituído de células e moléculas interconectadas, capazes de manter a homeostase do organismo. As funções do sistema imune são rigidamente controladas e são capazes de montar respostas contra ameaças vindas do meio externo ou reparação tecidual.

O grande diferencial da resposta imune nos vertebrados consiste na montagem da imunidade adaptativa, que é capaz de gerar uma resposta especializada e específica dirigida a um determinado antígeno, além de ser capaz de gerar uma memória imunológica. O sistema imune aprende e é modulado frente às diferentes experiências imunológicas. Ele é moldado de forma a identificar e neutralizar ameaças e ainda distinguir moléculas próprias e não próprias (Cohen, 2005).

As respostas imunológicas podem se dividir em inatas ou adaptativas. O linfócito T é uma célula importante da imunidade adaptativa e é classificado em duas subpopulações: linfócitos T CD4+ (conhecidos como "T auxiliares" ou "T helper") e linfócitos T CD8+ (conhecidos como "T citotóxicos"). Ao interagir com células apresentadoras de antígenos (APC, do inglês, antigen presenting cells) os linfócitos $\mathrm{T}$ são influenciados pelo microambiente molecular direcionando as respostas imunes efetoras ou reguladoras. O linfócito $T$ reconhece o antígeno através de seu receptor (TCR, do inglês $T$ cell receptor) apresentado dentro do contexto de moléculas MHC (Complexo Principal de Histocompatibilidade, do inglês, Major Histocompatibility Complex), presentes nas APCs (Viola e Lanzavecchia, 1996). O TCR é um heterodímero associado com a molécula CD3, CD4 ou CD8. Essas duas últimas moléculas são 
responsáveis em estabilizar a interação do TCR com a MHC específica (MHC de classe I, para CD8 e MHC de classe II, para CD4). O TCR possui uma estrutura transmembrânica conservada, capaz de desencadear uma cascata de sinalização intracelular que leva à ativação do linfócito T naive (ingênuo, que nunca entrou em contato com o antígeno), desencadeando a sua proliferação e a ativação de diversos genes importantes para a sua atividade funcional. O TCR é gerado nas primeiras etapas de maturação do linfócito no timo. Sua diversidade advém da recombinação de genes variáveis, de modo que cada célula resultante é única, clonal, e capaz de reconhecer formas moleculares compatíveis com a interação com este receptor, dentro do contexto da apresentação pelas moléculas MHC (Scollay et at, 1980).

O sistema imune é capaz de reagir constantemente às diferentes moléculas que podem induzir uma resposta protetora, no caso de agentes patogênicos ou na perturbação da tolerância imunológica, no caso de auto antígenos. Nesse último caso, o sistema imune pode induzir lesão tecidual e desenvolvimento de autoimunidades. O desiquilíbrio imune provocado por antígenos patogênicos ou auto antígenos pode ser controlado por processos de imunorregulação dependente de uma rede de diferentes tipos de células e moléculas, incluindo citocinas e quimiocinas, células dendríticas (DC) e diferentes tipos de linfócitos com atividade imunorreguladora.

Dentro desse contexto, as células $T$ reguladoras ( $\left.T_{\text {reg }}\right)$ têm um papel fundamental na homeostase, e é hoje foco de intensa pesquisa científica pelo seu potencial de uso para terapia celular em condições patológicas nas quais é necessário restaurar a tolerância imunológica, como em doenças autoimunes e processo de rejeição de transplante alogênico.

A tolerância imunológica é o estado de não responsividade a antígenos próprios (para proteção dos tecidos do hospedeiro) ou a antígenos não próprios (importante para não desencadear reações de hipersensibilidade). 
A indução da tolerância imunológica pode ocorrer tanto na periferia quanto nos órgãos linfóides centrais. Na tolerância central, linfócitos que reconhecem com alta avidez antígenos próprios sofrem apoptose por um processo de seleção negativa. Por outro lado, os linfócitos com baixa avidez por antígenos próprios são selecionados positivamente e migram para os tecidos linfóides periféricos (Liu, 2006). A tolerância periférica é mediada por diferentes tipos celulares e moléculas envolvendo mecanismos tanto depletores quanto imunorreguladores, provavelmente por um processo contínuo de reconhecimento de antígenos próprios. A deleção consiste, geralmente, na eliminação de células efetoras autorreativas por apoptose, ou ainda mediada por perforina e granzima (Wells et al., 2001). Falhas que envolvam o processo de indução de tolerância imunológica quanto periférica pode levar ao desenvolvimento de doenças autoimunes locais ou sistêmicas.

\section{Diferenciação e funções dos Linfócitos T CD4 ${ }^{+}$}

A diferenciação dos linfócitos $\mathrm{T} \mathrm{CD}^{+}{ }^{+}$naive envolve estimulação antigênica como resultado da interação do receptor de linfócito T (TCR/CD3), e CD4 como co-receptor, com o complexo MHC II + antígeno apresentado pelas células APCs. Essa diferenciação pode dar origem aos subtipos de CD4+: Th1, Th2, Th17 (Figura 1) e Tregs (Figura 2). Muitos fatores influenciam o programa de diferenciação do linfócito $T$ naive, tais como as citocinas e fatores de transcrição. Esses fatores são capazes não apenas de controlar a expressão de grupos gênicos que promovem a diferenciação de um fenótipo específico mas também de suprimir o desenvolvimento de outras linhagens celulares. A tabela 1 lista os principais fatores de transcrição e citocinas importantes para a diferenciação dos subtipos de Linfócitos T auxiliares. 
Tabela 1 - Citocinas e fatores de transcrição que regulam o programa de diferenciação dos Linfócitos T CD4 ${ }^{+(1)}$

\begin{tabular}{|c|c|c|c|}
\hline $\begin{array}{r}\text { Subtipo } \\
\text { CD4+ }\end{array}$ & Citocinas & $\begin{array}{l}\text { Fatores de } \\
\text { transcrição }\end{array}$ & $\begin{array}{l}\text { Fatores de } \\
\text { transcrição } \\
\text { repressores }\end{array}$ \\
\hline Th1 & IL12, INF-y & $\begin{array}{l}\text { T-bet(2), STAT1, } \\
\text { STAT4, Runx 3, } \\
\text { Eomes, HIx }\end{array}$ & GATA3 \\
\hline Th2 & IL4 & $\begin{array}{l}\text { GATA3 }^{(2)} \text {, STAT6, } \\
\text { STAT5, STAT3, Gfi-1, } \\
\text { c-Maf, IRF4 }\end{array}$ & T-bet, Runx3 \\
\hline Th17 & $\begin{array}{l}\text { IL-6, IL-21, IL-23, } \\
\text { TGF- } \beta\end{array}$ & $\begin{array}{l}\text { RORyt(2), STAT3, } \\
\text { RORa, Runx1, Batf, } \\
\text { IRF4, AHR }\end{array}$ & $\begin{array}{l}\text { T-bet+ Runx1, } \\
\text { Smad3 } \\
\text { Runx1+FOXP3 }\end{array}$ \\
\hline iTreg & TGF- $\beta$, IL-2 & $\begin{array}{l}\text { FOXP3 }{ }^{* *}, \text { Smad2, } \\
\text { Smad3, STAT5, NFAT, } \\
\text { IRF4 }\end{array}$ & T-bet \\
\hline Tr1 & IL-27, IL-10 & c-Maf, AhR & \\
\hline
\end{tabular}

\subsection{Linfócitos Th1}

Membro da família T-box de fatores de transcrição, T-bet parece ser expresso para a programação da diferenciação do linfócito T em Th1. Esse fator foi identificado como um indutor da produção de IFN-y, da expressão da subunidade $\beta 2$ do receptor IL-12 (IL-12Rß2) e estabilização da sua própria expressão, ou por meio de auto loop ou por efeitos autócrinos da sinalização de IFN-y (Szabo et al, 1997; Zhu et al, 2010)

Os linfócitos Th1 estão envolvidos na eliminação de patógenos intracelulares e são as principais células associadas com autoimunidade órgão- 
específica. As principais citocinas secretadas por esse tipo celular são: IFN-y, IL12 e TNF- $\alpha$. A citocina IFN-y está associada com a eliminação de patógenos por meio da ativação de fagócitos mononucleares, incluindo macrófagos e microglias. IL-12 promove a proliferação de linfócitos T $\mathrm{CD} 8^{+}$, com atividade citolítica (Moser e Murphy, 2000).

As propriedades pro-inflamatórias das células Th1 são importantes para a eliminação de patógenos e para a imunidade antitumoral, contudo, se essas respostas não forem estritamente controladas, podem levar a injúria tecidual desencadeando doenças inflamatórias e auto reatividade (Bierdermann et al, 2004).

\subsection{Linfócitos Th2}

Os linfócitos Th2 estão envolvidos com a resposta imune humoral. O seu processo de diferenciação envolve fatores de transcrição como STAT5 e GATA3, que regulam a transcrição de diversas citocinas de perfil Th2. IL4 e IL2 são essenciais para a diferenciação de Th2. IL4 por exemplo, induz a expressão de STAT6, que por sua vez, regula a expressão do principal fator de transcrição importante para Th2, GATA3 (Kaplan et al, 1996; Zhu et al, 2010).

As células Th2 atuam principalmente na defesa do organismo contra parasitos extracelulares, incluindo helmintos. Além disso, possui papel importante na indução e persistência da asma e outras doenças alérgicas. As principais citocinas secretadas por essas células são: IL-4, IL-5, IL13, IL-10 e IL25 (Jankovic et al, 2000). A IL-4 está envolvida com a troca de classe e secreção de IgE por linfócitos $B$. Além disso, ela regula a afinidade dos receptores de lgE presente nos mastócitos (que ao sofrer degranulação, potencializa a resposta inflamatória). A citocina IL-10, por sua vez, é uma citocina anti-inflamatória. Após 
a eliminação do patógeno, essa citocina ajuda alcançar a homeostase através da inibição das células Th1 e de células da imunidade inata (Couper et al, 2008).

\subsection{Linfócitos Th17}

O programa de desenvolvimento das células de Th17 é regulado pelo fator de transcrição RORyt. Essa diferenciação pode ser induzida por diversas citocinas, incluindo, IL-6, IL-21, IL-23 e TGF- $\beta$ (Lee et al, 2008). Essa última citocina é crítica no desenvolvimento das células Th17, contudo, a via de sinalização de TGF- $\beta$ também é importante na diferenciação das células Treg induzidas (iTregs), maior antagonista de Th17 (Yang et al, 2008; Korn et al, 2009; Zhu et al, 2010).

As células Th17 são responsáveis em montar a resposta imune contra bactérias e fungos extracelulares. Por outro lado, elas estão envolvidas na indução de doenças autoimunes (Bettelli et al, 2008). As principais citocinas secretadas por essas células incluem IL-17A, IL-17F, IL-21 e IL-22. As células Th17 levam a indução de citocinas pró-inflamatórias, tais como, IL-6, IL-1 e TFN$\alpha$, além de quimiocinas que promovem a quimiotaxia de diversas células inflamatórias para os sítios de inflamação (Stockinger e Veldohoen, 2007). 


\section{APC}

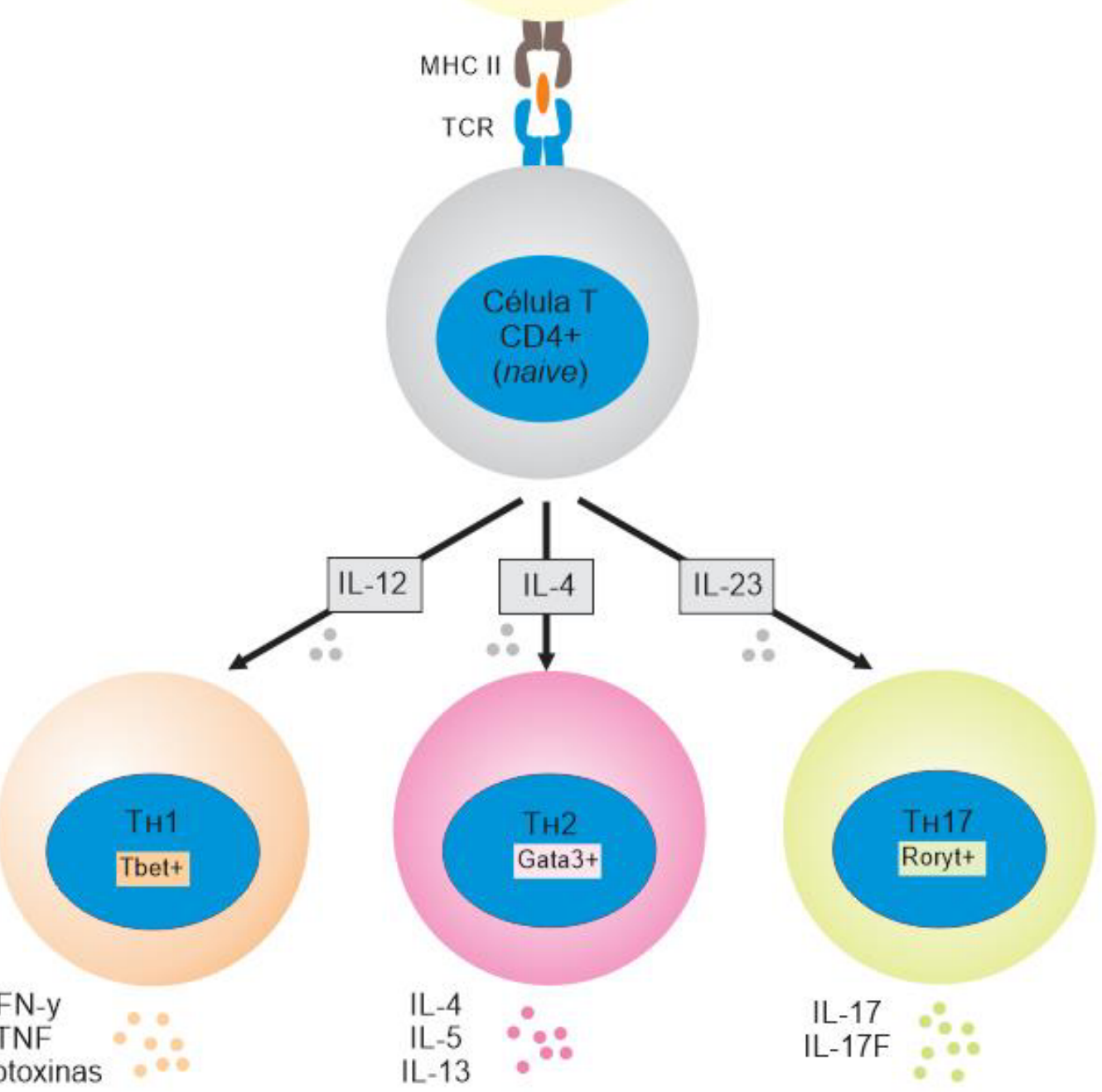

Figura 1 - Diferenciação de Linfócitos T CD4+. A ativação da célula T CD4+ naive pela célula apresentadora de antígenos (APC) induz a diferenciação em células efetoras (Th1, Th2, Th17). As citocinas presentes no microambiente determinam os programas de diferenciação pela indução de fatores de transcrição específicos. 


\subsection{Família de Linfócitos T com fenótipo supressor}

Os linfócitos T com fenótipo supressor são conhecidos como células T reguladoras (Tregs). São caracterizadas fenotipicamente como CD4+CD25+, e podem ser de ocorrência natural (nTreg) ou podem ser induzidas (iTreg) na periferia. As nTregs são desenvolvidas e maturadas no timo e regulam o processo de tolerância periférica ao inibirem linfócitos $\mathrm{T}$ auto reativos (Sakaguchi, 2005). As iTregs são células desenvolvidas a partir de células T CD4+ naives (Figura 2) que são expostas a sinais específicos, como citocinas reguladoras (IL-10, Fu et al, 2004), drogas imunossupressoras (glicocorticoides, Kreijveld et al., 2007), anticorpos anti-CD3 (Abraham et al, 2008), células apresentadoras de antígenos (Faunce et al., 2004; Kushwah e Hu, 2011) e vitaminas (Vitamina D3, Penna et al, 2005). Atualmente as células iTregs são classificadas em três subtipos diferentes: Treg, Tr1 e Th3.

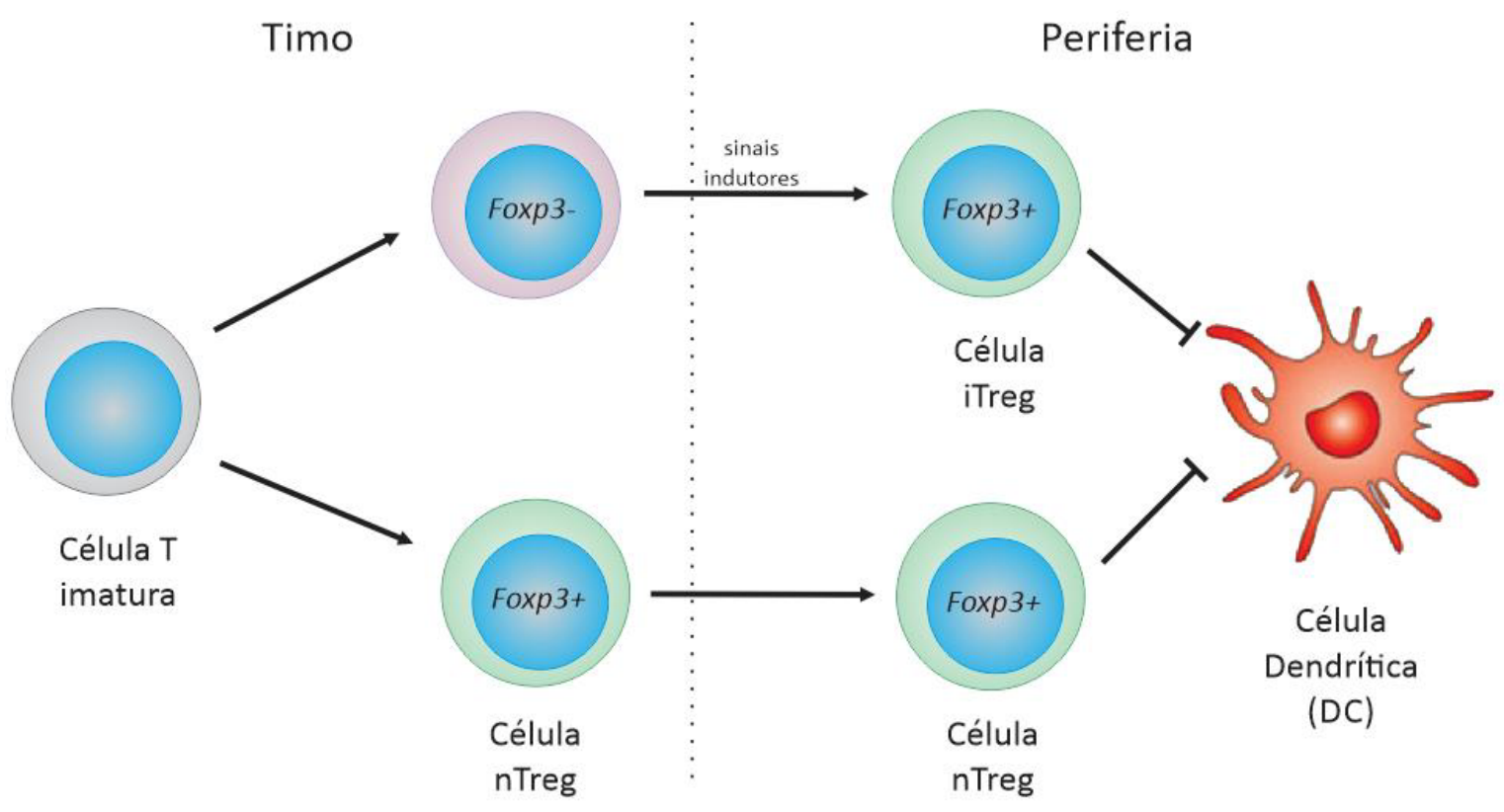

Figura 2 - Desenvolvimento de Tregs. Os linfócitos T reguladores podem ser de ocorrência natural (nTregs) que são desenvolvidos no timo, ou podem ser induzidos a partir de células T CD4+ efetoras sob a influência de sinais indutores específicos. 


\subsubsection{Linfócitos $T$ reguladores de ocorrência natural (nTregs)}

As células Tregs de ocorrência natural são fenotipicamente caracterizadas como CD4+CD25+Foxp3+e tem importante papel na tolerância imunológica central e periférica. Elas foram inicialmente descritas pelo grupo de Sakaguchi (1995), como células capazes de induzir anergia e supressão de outras células em modelo murino. Essas células são desenvolvidas durante a maturação dos linfócitos T no timo, contudo o programa de diferenciação dessas células ainda não está totalmente esclarecido (Schmetterer et al, 2012). Sabese que o fator de transcrição FOXP3 é constitutivamente expresso em nTregs e age como o regulador principal para o desenvolvimento e função supressora dessas células. Esse fator regula a expressão de diversas moléculas importantes para diferenciação das nTregs, tais como, CD25, CTLA4, OX40 e LAG3 (Tabela 2).

Tabela 2 - Principais marcadores de Tregs ${ }^{(1)}$

\begin{tabular}{lll}
\hline Molécula & Expressão & Comentário \\
\hline CD25 & Alta; superfície & $\begin{array}{l}\text { Também expressa em Teff } \\
\text { ativadas }\end{array}$ \\
Foxp3 & Alta; intracelular & $\begin{array}{l}\text { Também expressa em Teff } \\
\text { ativadas }\end{array}$ \\
CTLA-4 & Alta; superfície & $\begin{array}{l}\text { Também expressa em Teff } \\
\text { ativadas }\end{array}$ \\
GITR & Alta; superfície & $\begin{array}{l}\text { Também expressa em Teff } \\
\text { ativadas }\end{array}$ \\
CD127 & Baixa; superfície & $\begin{array}{l}\text { Regulada negativamente em } \\
\text { Teff ativadas }\end{array}$ \\
CD62L & Alta; superfície & $\begin{array}{l}\text { Expressa em Teff naive, } \\
\text { denota subgrupo de Treg com }\end{array}$
\end{tabular}


superior

PD-1/CD279 Alta; intracelular, superfície (?)

\begin{tabular}{|c|c|c|}
\hline CD39 & Alta; superfície & - \\
\hline CD44 & Alta; superfície & $\begin{array}{l}\text { Denota subgrupo de Tregs } \\
\text { produtora de IL-10 }\end{array}$ \\
\hline $\begin{array}{l}\text { MHCII/HLA- } \\
\text { DR }\end{array}$ & Alta; superfície & $\begin{array}{lr}\text { Denota } & \text { subgrupo } \\
\text { capacidade } & \text { supressora } \\
\text { superior } & \end{array}$ \\
\hline LAP & Alta; superfície & $\begin{array}{lr}\text { Denota subgrupo com } \\
\text { capacidade } \\
\text { superior }\end{array}$ \\
\hline CD103 & Alta; superfície & $\begin{array}{l}\text { Expressa em } 30 \% \text { de } \\
\text { CD4+CD25+ }\end{array}$ \\
\hline CCR6 & Alta; superfície & $\begin{array}{l}\text { Denota subgrupo de Tregs } \\
\text { produtora de IL-10 }\end{array}$ \\
\hline LAG-3 & Alta; superfície & Expressa em Tregs ativadas \\
\hline GARP & Alta; superfície & Expressa em Tregs ativadas \\
\hline Galectin-1 & Alta; superfície & - \\
\hline Galectin-10 & Alta; intracelular & - \\
\hline Helios & Alta; intracelular & $\begin{array}{l}\text { Expressa exclusivamente em } \\
\text { nTregs }\end{array}$ \\
\hline TNFRSF25 & Alta; superfície & - \\
\hline
\end{tabular}

Expressão constitutiva na superfície não foi encontrada, expressão na superfície distingue Teffs ativadas das Tregs não ativadas

Denota subgrupo de Tregs 


\subsubsection{Linfócitos $T$ reguladores induzidos (iTregs)}

\section{a) Linfócitos Tregs}

Essas células foram as primeiras Tregs induzidas a serem caracterizadas e a mais amplamente estudada. Elas possuem fenótipo e funções similares as nTregs. A diferenciação das células Tregs envolve o fator de transcrição FOXP3 que regula a expressão de diversos genes envolvidos com as funções dessas células. Embora vários sinais indutores da expressão de Foxp3 terem sido identificados (Huehn et al., 2009), os mecanismos envolvidos no controle da expressão dessa proteína permanecem desconhecidos.

\section{b) Linfócitos Tr1}

As células $\operatorname{Tr} 1$ são um subtipo de linfócitos $T$ reguladores desenvolvidas a partir das células T CD4+ efetoras. São caracterizadas pela habilidade de produzir altos níveis de IL-10 e baixos a moderados níveis de TGF$\beta$. Dada as suas funções imunossupressoras, células Tr1 têm sido utilizadas em patologias inflamatórias, particularmente em transplantes e doenças autoimunes (Pot et al, 2011). Em humanos, elas foram inicialmente descritas em pacientes com Síndrome da Imunodeficiência Combinada Severa (SCID) que desenvolveram processos de rejeição após o transplante de medula óssea, sugerindo o desenvolvimento natural dessas células em humanos (Bacchetta et al, 1994).

O desenvolvimento dessas células parece depender da citocina IL-27. Essa citocina induz a ativação de Stat3 que regula o fator de transcrição Blimp1, responsável pela expressão de IL-10. As células dendríticas também podem influenciar o desenvolvimento das $\operatorname{Tr} 1$ por mecanismos dependentes da enzima indolamina 2,3-dioxigenase (IDO). A atividade supressora dessas células parece não depender de Foxp3, uma vez que essas células têm sido caracterizadas como Foxp3- (Zhu et al, 2010; Pot et al, 2011). 


\section{c) Linfócitos Th3}

Essas células têm sido caracterizadas pela alta produção de TGF- $\beta$ e suas propriedades supressoras direcionadas para as células Th1 e Th2. Parece que a diferenciação da célula T CD4+ efetora em Th3 depende da via de sinalização de TGF- $\beta$. In vitro, a diferenciação de Th3 pode ser obtida utilizando IL-4, IL-10, TGF- $\beta$ e anti-IL-12 (modelo murino, Chen et al, 1994) e o seu programa é similar ao que induz Th2. As células Th3 têm sido associadas com a tolerância oral e é a única T reguladora induzida pela administração oral de antígenos. O microambiente de citocinas pode ser crucial para a determinação do desenvolvimento de Th2 ou Th3 no intestino. Após a administração oral de antígenos, a expressão de IL-4, IL-10 e TGF- $\beta$ na mucosa intestinal é aumentada induzindo a diferenciação da célula Th3 (Weiner, 2001; Jonuleit e Schmitt, 2003).

\subsection{Mecanismos de supressão}

Os mecanismos desenvolvidos pelas Tregs de suprimir respostas próinflamatórias ainda não estão totalmente esclarecidos e têm sido alvos de diversos estudos. Esses mecanismos são importantes para a manutenção da homeostase imunológica, ao prevenir autoimunidade e moderando a inflamação induzida por patógenos. Os principais mecanismos desenvolvidos pela Tregs podem ser dependentes do contato célula-célula (nTregs) ou por meio de secreção de citocinas (iTregs).

\subsubsection{Supressão por meio de citocinas inibitórias}

As Tregs podem secretar citocinas com potencial supressor, incluindo IL-10 e TGF- $\beta$. IL-10 é uma das principais citocinas no contexto das Tregs, e está envolvida com funções anti-inflamatórias. Ela é capaz de regular 
negativamente a produção de citocinas de perfil Th1 pelas APCs, tais como, TNF- $\alpha$, IL-1, IL-12 e IFN-y (Vignali et al, 2008). O efeito inibitório de IL-10 envolve a indução de anergia celular e inibição da proliferação tanto de Th1 e Th2. Além disso, IL-10 também regula a ativação e função dos mastócitos, bem como a produção de citocinas por eosinófilos (Akdis e Blaser, 2001).

Uma segunda citocina comumente associada com a função de Treg é a TGF- $\beta$. Essa citocina pleitrópica possui propriedades imunossupressoras e, embora os seus mecanismos de ação não terem sido totalmente esclarecidos, ela tem sido associada com a manutenção da autotolerância imunológica. Alguns estudos demonstraram que, além de TGF- $\beta$ ser requerida para o desenvolvomento das iTregs, ela pode controlar a infiltração das células T CD8+ nas ilhas pancreáticas e diminuir a progressão da diabetes (Green at al, 2003).

\subsubsection{Supressão pela modulação das células dendríticas (DCs)}

A função reguladora de Tregs não é restrita à supressão das respostas de células $T$ efetoras, mas também afeta as funções das células apresentadoras de antígenos, principalmente as células dendríticas (DCs). Vários mecanismos moleculares contribuem para esta função, levando a regulação negativa de moléculas, tais como, MHC e CD80 (B7), mudando o perfil das DCs para um perfil não-estimulador ou tolerogênico (Schmetterer et al, 2012).

A interação entre Tregs-DC se dá por meio da molécula CTLA-4, a qual é constitutivamente expressa em Tregs. Essa molécula interage com seu ligante CD80/86 presente nas DCs e induz a produção da enzima indolamina 2,3-dioxigenase (IDO) por essas células. A enzima IDO é a chave para o metabolismo do triptofano, convertendo esse componente em formilcinurenina, que atua como um potente agente imunossupressor (Vignali et al, 2008). Além 
disso, alguns estudos demonstraram que a enzima IDO é capaz de induzir o desenvolvimento de Tregs por meio das células T efetoras.

Além de alterar a função das DCs, as Tregs podem bloquear a maturação dessas células por meio da molécula de superfície LAG3. Essa molécula é um homólogo de CD4 que interage com MHC de classe II com alta afinidade. Essa interação suprime a maturação das DCs e sua capacidade imunoestimuladora (Schmetterer et al, 2012).

Atualmente, diversos esforços têm sido direcionados para uma melhor compreensão dos mecanismos funcionais das células $\mathrm{T}$ reguladoras. Interessante notar que anticorpos específicos para o antígeno CD3 de linfócitos T podem induzir a formação dessas células promovendo um estado de tolerância (Chatenoud, 2004).

\section{Anticorpos recombinantes}

O desenvolvimento de anticorpos recombinantes tem facilitado o estudo da interação antígeno-anticorpo específico para alvos terapêuticos. A construção de anticorpos recombinantes compreende usualmente a molécula inteira, contudo, fragmentos de anticorpos têm sido utilizados em diversas situações (Reiter et al., 1996; Kim et al., 2005). Dentre as classes de imunoglobulinas, a lgG é a que tem maior importância do ponto de vista biotecnológico. As moléculas de lgG têm peso molecular aproximado de 150 kDa e são constituídas de duas cadeias polipeptídicas diferentes: uma de aproximadamente $50 \mathrm{kDa}$, conhecida como cadeia pesada $(\mathrm{H})$ e outra de aproximadamente $25 \mathrm{kDa}$, conhecida como cadeia leve (L). Cada molécula de IgG consiste de duas cadeias pesadas e duas cadeias leves unidas por pontes de dissulfeto. Tanto as cadeias pesadas quanto as leves, são constituídas de 
regiões variáveis $(\mathrm{V})$ e regiões constantes $(\mathrm{C})$. VH é o termo utilizado para o domínio variável pesado, VL para domínio variável leve, $\mathrm{CH}$ para domínio constante pesado e CL para domínio constante leve. A cadeia pesada do anticorpo contém três domínios constantes denominadas de $\mathrm{CH} 1, \mathrm{CH} 2$ e $\mathrm{CH} 3$ (Figura 3).

O anticorpo é dividido em regiões ligantes ao antígeno (Fab e Fv) e região efetora $(\mathrm{Fc})$. $\mathrm{O}$ fragmento de ligação ao antígeno (Fab) é formada pelos domínios $\mathrm{CH} 1, \mathrm{CL}, \mathrm{VH}$ e VL, sendo que os domínios VH e VL, que interagem diretamente com o antígeno, formam o fragmento variável (Fv) do anticorpo. Essa última porção contém as Regiões Determinantes de Complementariedade (CDR), sequências de aminoácidos hipervariáveis, que determinam a especificidade ao antígeno. $\mathrm{O}$ fragmento cristalizável $(\mathrm{Fc})$ do anticorpo contém os domínios constantes pesados $\mathrm{CH} 2$ e $\mathrm{CH} 3$ e desempenham papel efetor, recrutando células ou o sistema complemento (Goldsby et al., 2002).

O papel efetor mediado pela porção $\mathrm{Fc}$ do anticorpo está relacionado com a citotoxidade. No mecanismo de citotoxidade celular dependente de anticorpo (ADCC), os anticorpos ligam-se aos receptores Fc (FcR) encontrados na superfície de células efetoras (ex.: NK, macrófagos) e mediam fagocitose ou lise das células alvos. No mecanismo de citotoxidade dependente de complemento (CDC), o anticorpo, na interação com o antígeno, pode ativar a cascata da via clássica do sistema complemento levando à morte da célula alvo (Figura 4). Das quatro classes de lgG, a lgG1 é a mais eficiente para promover a ADCC e CDC (Wang, 2010). Diversos anticorpos que agem dependentemente desses mecanismos de citotoxidade têm sido utilizados na clínica (Cragg et al., 2004; Wu et al., 2010). 
Anticorpo Inteiro

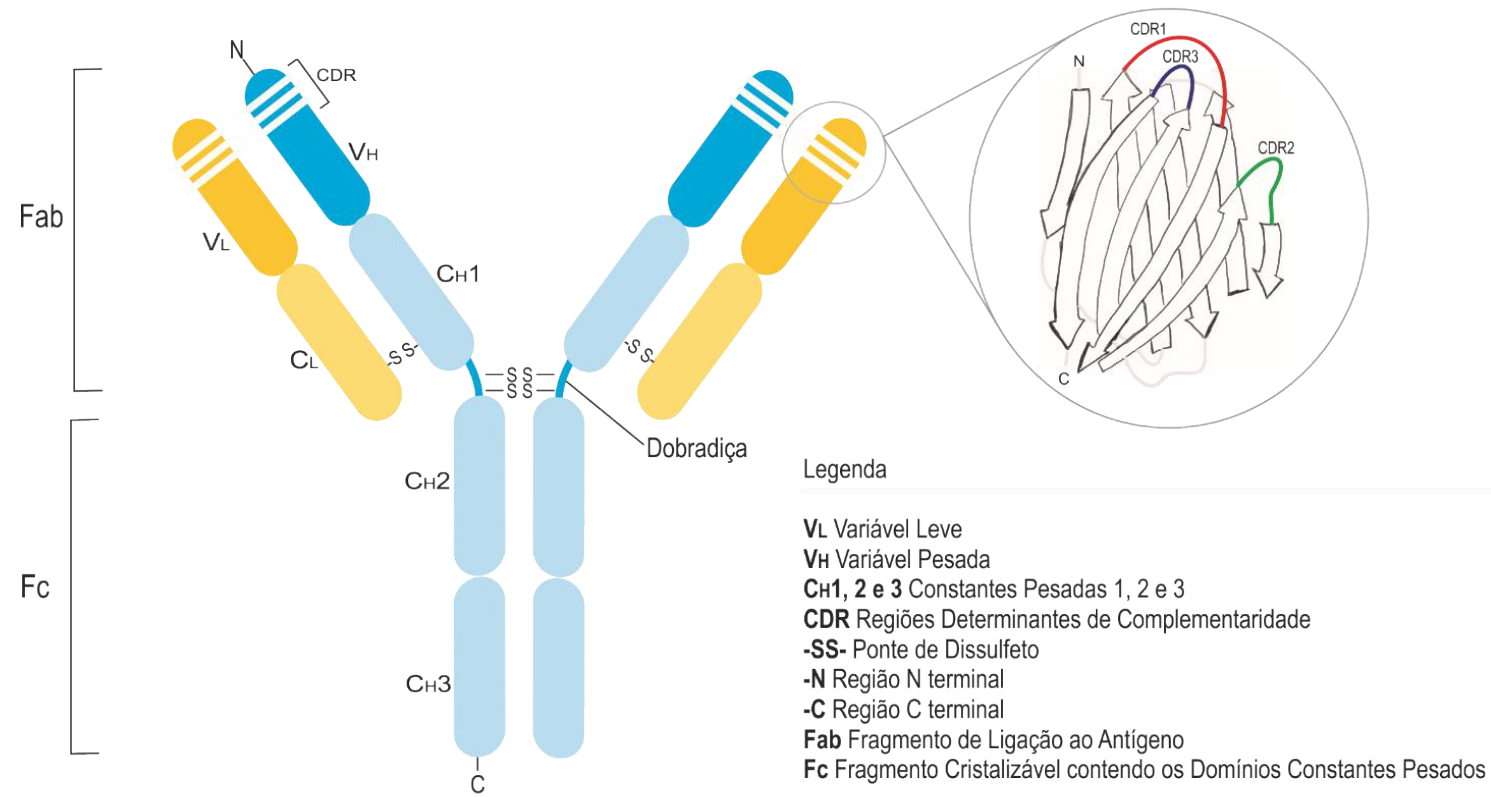

Fragmentos de Anticorpo

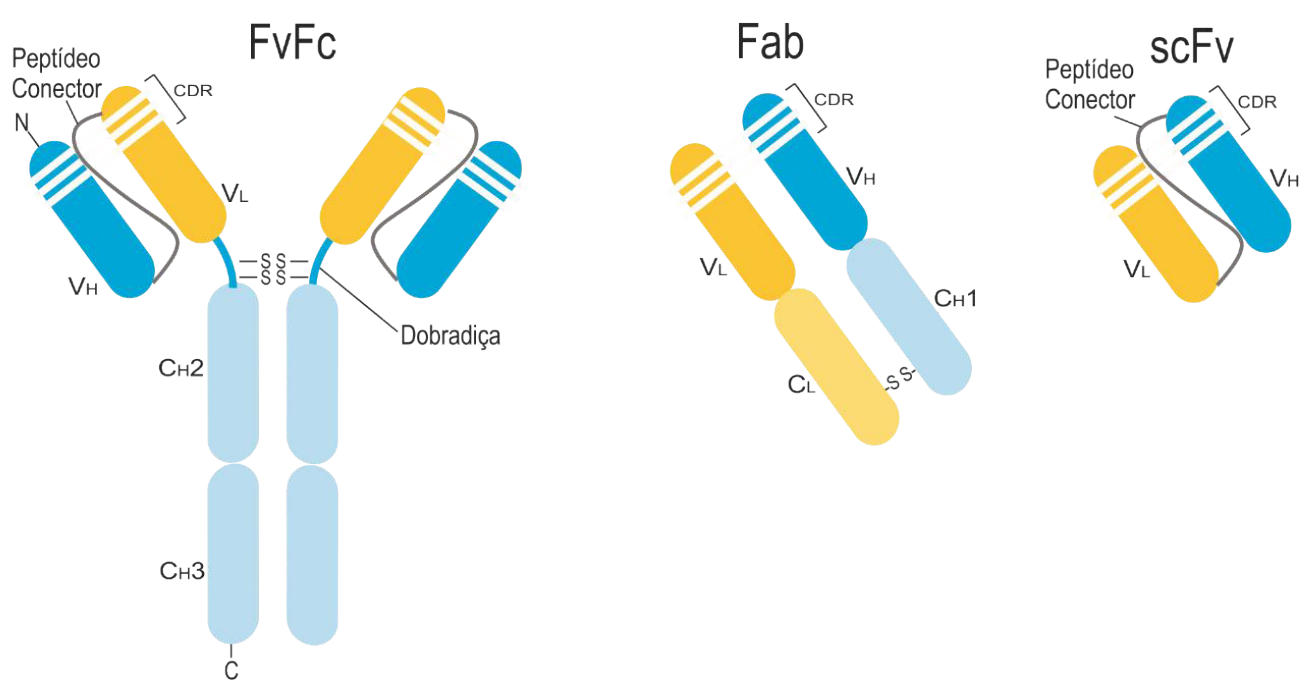

Figura 3 - Estrutura de anticorpo inteiro e seus fragmentos. $O$ anticorpo é constituído de uma região $\mathrm{Fc}$ e uma região $\mathrm{Fab}$. A porção Fv está contida na região Fab e é a região do anticorpo que se liga ao antígeno. Os fragmentos de anticorpos podem ser FvFc (constituído da porção Fc + scFv), Fab (constituído de um dos braços do anticorpo) e scFv (cadeia simples da porção Fv). Nos fragmentos recombinantes, a porção $F v$ é unida por uma sequência peptídica flexível que liga as duas cadeias variáveis, conhecida como peptídeo conector (MARANHÃO et al, no prelo) 
Por meio de engenharia genética é possível gerar diversos fragmentos de anticorpos e ainda manter suas funções biológicas. A tecnologia de fragmentos de anticorpos recombinantes pode gerar moléculas de Fab, constituída dos domínios $\mathrm{CH} 1, \mathrm{CL}, \mathrm{VH}$ e VL; scFv que contem VH e VL unidas por um "linker" e o fragmento FvFc, formada pela porção Fc mais um scFv (Figura $3)$.

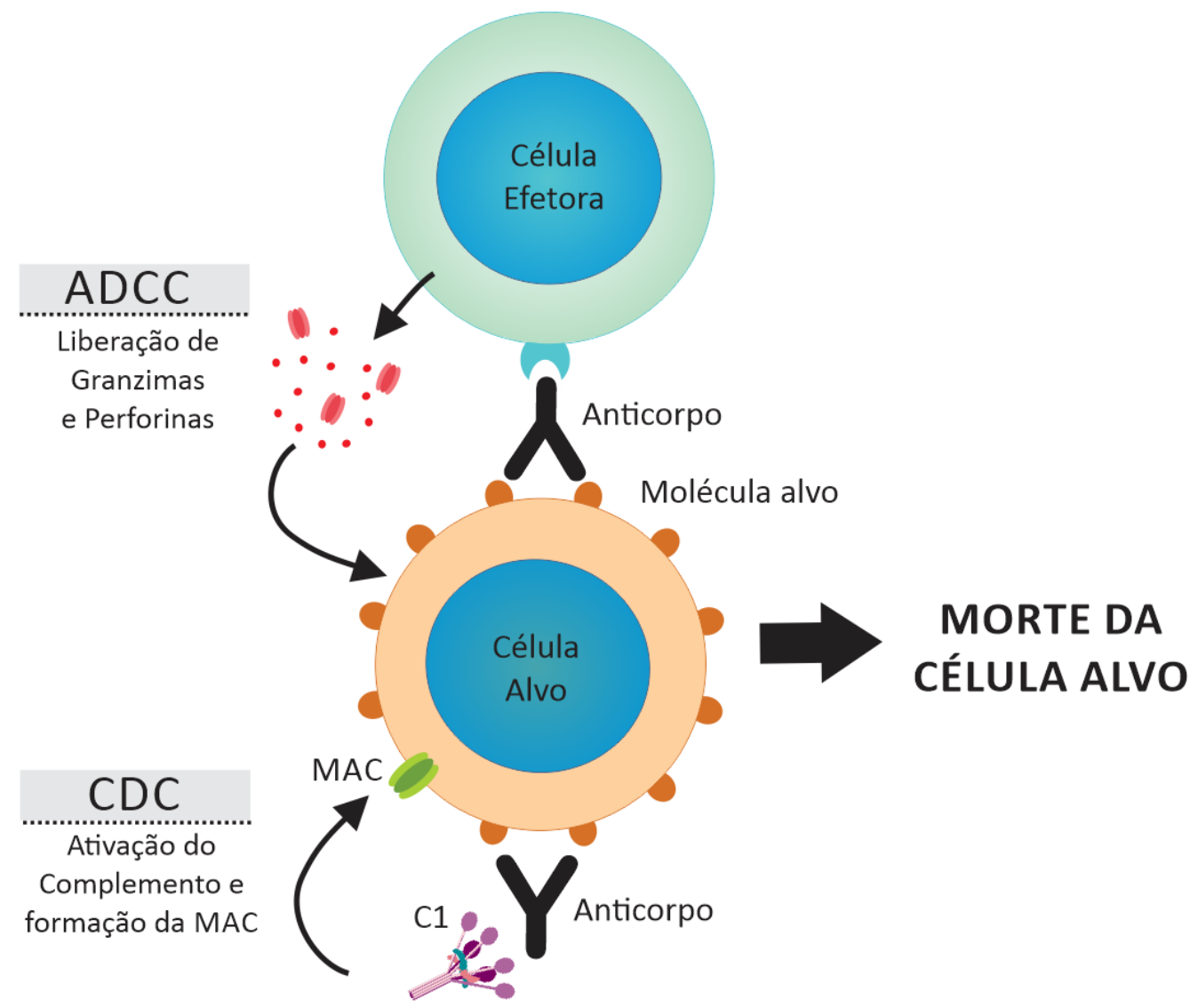

Figura 4 - Mecanismos efetores mediados por anticorpos. O mecanismo de citotoxidade dependente do complemento $(\mathrm{CDC})$ leva à ativação da via clássica do complemento pela interação entre anticorpo e molécula alvo expressa na superfície celular. A cascata de ativação da via clássica inicia com a molécula C1 e a resposta tardia é a formação do complexo de ataque à membrana (MAC), que leva à lise celular. $\mathrm{O}$ mecanismo de citotoxidade celular dependente de anticorpo (ADCC) promove à ativação de células efetoras, que reconhecem os anticorpos ligados à célula-alvo via receptor de porção $F c$ do anticorpo $(F c R)$. Essa ativação leva à liberação de granzimas, por exemplo, no caso da célula efetora ser uma célula NK. Os dois mecanismos levam à morte da célula-alvo. 
Atualmente, existem diversas tecnologias disponíveis para produção heteróloga de anticorpos recombinantes. Esses anticorpos têm sido produzidos com sucesso em diversos sistemas de expressão (eucarióticos ou procarióticos). Contudo, o sistema de expressão em eucariotos é o mais usado principalmente por causa do padrão de glicosilação da proteína que é crucial para a sua atividade biológica. A glicosilação é crítica para o dobramento correto, estabilidade e eficácia de um grande número de proteínas, incluindo os anticorpos. O perfil humano de glicosilação é mais bem reproduzido em células de mamíferos (ex.: célula de ovário de hamster chinês - $\mathrm{CHO}$ ), tornando esse sistema de expressão a melhor escolha para produção de proteínas recombinantes para fins terapêuticos (Andersen et al., 2004; Li et al., 2010).

Os anticorpos utilizados para fins terapêuticos podem ser de origem murina, quimérica, humanizada ou humana e dependendo da sua origem podem receber os seguintes sufixos: "omabe", para os murinos, "ximabe" para os quiméricos, "zumabe" para os humanizados e "umabe" para os anticorpos completamente humanos (Figura 5).

Os anticorpos murinos são aqueles originados de hibridomas de camundongo e, portanto, possuem todas as cadeias com sequências peptídicas murinas. Esses anticorpos desencadeiam uma resposta imunológica conhecida como HAMA (Human Anti-Mouse Antibody) que gera diversos efeitos colaterais para o paciente (Kimball et al., 1995). As primeiras tentativas para minimizar o potencial imunogênico desses anticorpos foram feitas por meio de engenharia genética, onde se construiu um anticorpo contendo somente as regiões variáveis (Fv) murinas. As regiões constantes desse anticorpo eram humanas, e por esse motivo ele ficou conhecido como anticorpo quimérico (Morrison et al., 1984). Embora anticorpos quiméricos tenham se demostrado menos imunogênico que os murinos, os efeitos colaterais provocados pela resposta HACA (Human Antichimeric Antibody, similares à HAMA) ainda foram observados. 
A)

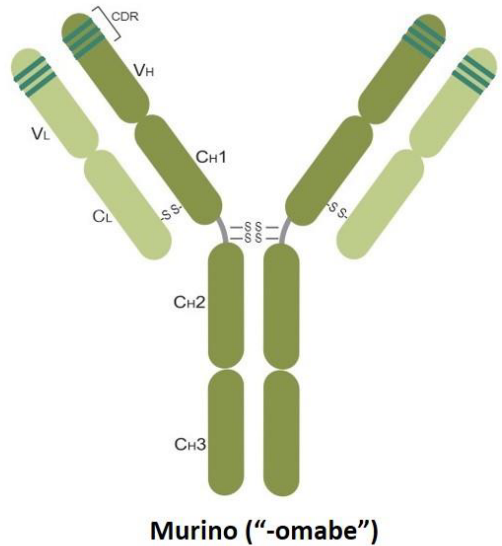

C)

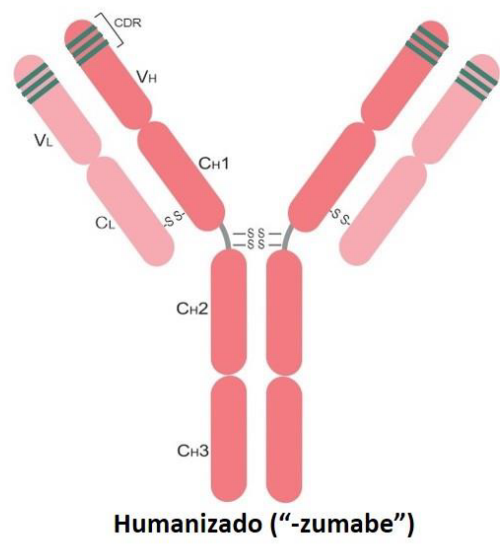

B)

D)
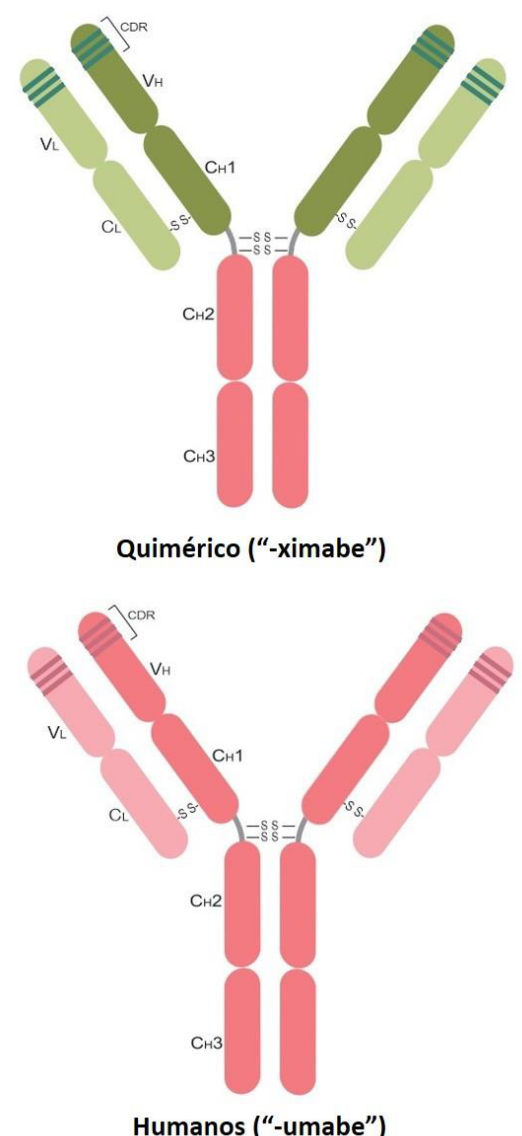

Figura 5 - Representação esquemática das diferentes versões de anticorpos. O anticorpo murino (A) possui todas as sequências de origem murina. $O$ anticorpo quimérico $(B)$ é uma junção do anticorpo murino (porção Fab) com o anticorpo humano (porção $\mathrm{Fc}$ ). $O$ processo de humanização realiza o transplante das CDRs murinas (linhas verdes - $C$ ) para as cadeias variáveis humanas (Rosa claro e escuro). Os anticorpos humanos (D) possuem todas as sequências humanas.

No intuito de diminuir essas respostas, foram desenvolvidas técnicas que visavam gerar um anticorpo praticamente humano. Esses anticorpos, conhecidos como humanizados, possuem apenas as regiões CDRs murinas. Todas as cadeias leves e pesadas de anticorpos humanizados são humanas (Jones et al., 1986; Maranhão e Brígido, 2001). Essas técnicas estão sendo utilizadas para diversos anticorpos com importância terapêutica, por diversos 
grupos no mundo inteiro, no intuito de minimizar os efeitos colaterais promovidos pelo uso de anticorpos murinos ou quiméricos na clínica. Diversos anticorpos já foram aprovados para utilização na clínica (Tabela 3), e dezenas estão em fases de testes clínicos. Em sua maioria anticorpos quiméricos e humanizado.

Tabela 3. Anticorpos monoclonais aprovados pelo FDA até $2013^{(1)}$

\begin{tabular}{|c|c|c|c|c|c|}
\hline Anticorpo & $\begin{array}{c}\text { Molécula } \\
\text { Alvo }\end{array}$ & Tipo & Indicação & Empresa & $\begin{array}{c}\text { Ano de } \\
\text { aprovação }\end{array}$ \\
\hline $\begin{array}{c}\mathrm{OKT3}^{(2)} \\
\text { (Muromonab-CD3) }\end{array}$ & CD3 & Murino & $\begin{array}{l}\text { Rejeição a } \\
\text { transplantes }\end{array}$ & $\begin{array}{c}\text { Johnson \& } \\
\text { Johnson }\end{array}$ & 1986 \\
\hline $\begin{array}{c}\text { Reopro } \\
\text { (Abciximab) }\end{array}$ & CA17-1A & Quimérico & $\mathrm{PTCA}^{(3)}$ & Centocor & 1994 \\
\hline $\begin{array}{c}\text { Panorex } \\
\text { (Edrecolomab) }\end{array}$ & GPIIb/IIla & Quimérico & $\begin{array}{l}\text { Câncer } \\
\text { Colorectal }\end{array}$ & Centocor & 1995 \\
\hline $\begin{array}{c}\text { Rituxan } \\
\text { (Rituximab) }\end{array}$ & CD20 & Quimérico & $\begin{array}{l}\text { Linfoma Non- } \\
\text { Hodgkin }\end{array}$ & $\begin{array}{l}\text { Biogen } \\
\text { IDEC }\end{array}$ & 1997 \\
\hline $\begin{array}{c}\text { Zenapax }^{(2)} \\
\text { (Daclizumab) }\end{array}$ & IL2R & Humanizado & $\begin{array}{l}\text { Rejeição a } \\
\text { transplantes }\end{array}$ & Prot Design Labs & 1997 \\
\hline $\begin{array}{c}\text { Simulect } \\
\text { (Basiliximab) }\end{array}$ & IL2R & Quimérico & $\begin{array}{l}\text { Rejeição a } \\
\text { transplantes }\end{array}$ & Novarts & 1998 \\
\hline $\begin{array}{c}\text { Synagis } \\
\text { (palivizumab) }\end{array}$ & RSV F & Humanizado & Profilaxia de RSV & Medlmmune & 1998 \\
\hline $\begin{array}{l}\text { Remicade } \\
\text { (Infliximab) }\end{array}$ & TNF- $\alpha$ & Quimérico & $\begin{array}{l}\text { Artrite reumatóide } \\
\text { e doença de Crohn }\end{array}$ & Centocor & 1998 \\
\hline $\begin{array}{c}\text { Herceptin } \\
\text { (Trastuzumab) }\end{array}$ & Her2/neu & Humanizado & $\begin{array}{l}\text { Metástase de } \\
\text { câncer de mama }\end{array}$ & Genentech & 1998 \\
\hline $\begin{array}{c}\text { Mylotarg }^{(2)} \\
\text { (Gemtuzumab) }\end{array}$ & CD33 & Humanizado & Leucemia mielóide & Wyeth & 2000 \\
\hline $\begin{array}{c}\text { Campath } \\
\text { (Alemtuzumab) }\end{array}$ & CD52 & Humanizado & $\begin{array}{l}\text { Leucemia } \\
\text { linfocítica }\end{array}$ & $\begin{array}{l}\text { Millennium/ } \\
\text { ILEX }\end{array}$ & 2001 \\
\hline $\begin{array}{c}\text { Zevalin } \\
\text { (Ibritumomab) }\end{array}$ & CD20 & Murino & $\begin{array}{c}\text { Linfoma Non- } \\
\text { Hodgkins }\end{array}$ & $\begin{array}{l}\text { Biogen } \\
\text { IDEC }\end{array}$ & 2002 \\
\hline
\end{tabular}




\begin{tabular}{|c|c|c|c|c|c|}
\hline $\begin{array}{c}\text { Humira } \\
\text { (Adalimumab) }\end{array}$ & TNF- $\alpha$ & Humano & $\begin{array}{c}\text { Artrite } \\
\text { reumatóide,doença } \\
\text { de Crohn }\end{array}$ & Abbott & 2002 \\
\hline $\begin{array}{c}\text { Xolair } \\
\text { (Orlalizumab) }\end{array}$ & $\lg \mathrm{E}$ & Humanizado & Asma & Genentech & 2003 \\
\hline $\begin{array}{c}\text { Bexxar } \\
\text { (Tositumomab- } \\
\text { I131) }\end{array}$ & CD20 & Murino & $\begin{array}{l}\text { Linfoma Non- } \\
\text { Hodgkins }\end{array}$ & Corixa & 2003 \\
\hline $\begin{array}{c}\text { Raptiva }^{(2)} \\
\text { (Efalizumab) }\end{array}$ & CD11a & Humanizado & Psoríase & Genentech & 2003 \\
\hline $\begin{array}{c}\text { Erbitux } \\
\text { (Cetuximab) }\end{array}$ & EGFR & Quimérico & Câncer colorectal & Imclone Systems & 2004 \\
\hline $\begin{array}{c}\text { Avastin } \\
\text { (Bevacizumab) }\end{array}$ & VEGF & Humanizado & $\begin{array}{c}\text { Câncer coloretal, } \\
\text { renal }\end{array}$ & Genentech & 2004 \\
\hline $\begin{array}{c}\text { Tysabri } \\
\text { (Natalizumab) }\end{array}$ & $\begin{array}{c}\text { Integrina } \\
\text { A4 }\end{array}$ & Humanizado & $\begin{array}{c}\text { Doença de crohn, } \\
\text { esclerose }\end{array}$ & $\begin{array}{l}\text { Biogen } \\
\text { IDEC }\end{array}$ & 2004 \\
\hline $\begin{array}{c}\text { Lucentis } \\
\text { (Renibizumab) }\end{array}$ & VEGF-A & Humanizado & $\begin{array}{c}\text { Degeneração } \\
\text { macular }\end{array}$ & Genentech & 2006 \\
\hline $\begin{array}{c}\text { Vectibix } \\
\text { (Panitumomab) }\end{array}$ & EGFR & Humano & Câncer colorectal & Amgen & 2006 \\
\hline $\begin{array}{c}\text { Soliris } \\
\text { (Eculizumab) }\end{array}$ & C5 & Humanizado & $\begin{array}{l}\text { Hemoglobinúria } \\
\qquad(\mathrm{PNH})\end{array}$ & Alexion Pharm & 2007 \\
\hline Milatuzumab & CD74 & Humanizado & $\begin{array}{c}\text { Mieloma múltiplo, } \\
\text { Linfoma Non- } \\
\text { Hodgkin }\end{array}$ & Immunomedics & 2008 \\
\hline $\begin{array}{c}\text { Cimzia } \\
\text { (Certolizumab) }\end{array}$ & Integrina & Humanizado & Doença de Crohn & $\begin{array}{l}\text { Biogen } \\
\text { IDEC }\end{array}$ & 2008 \\
\hline $\begin{array}{c}\text { Simponi } \\
\text { (Golimumab) }\end{array}$ & TNF- $\alpha$ & Humano & Artrite reumatoide & $\begin{array}{l}\text { Johnson \& } \\
\text { Johnson }\end{array}$ & 2009 \\
\hline $\begin{array}{c}\text { Ilaris } \\
\text { (Canakinumab) }\end{array}$ & IL-1 $\beta$ & Humano & $\mathrm{CAPS}^{(4)}$ & Novartis & 2009 \\
\hline $\begin{array}{c}\text { Stelara } \\
\text { (Ustekinumab) }\end{array}$ & $\begin{array}{l}\mathrm{IL}-12 \text { e } \\
\mathrm{IL}-23\end{array}$ & Humano & Psoríase & $\begin{array}{l}\text { Johnson } \\
\text { \&Johnson }\end{array}$ & 2009 \\
\hline
\end{tabular}




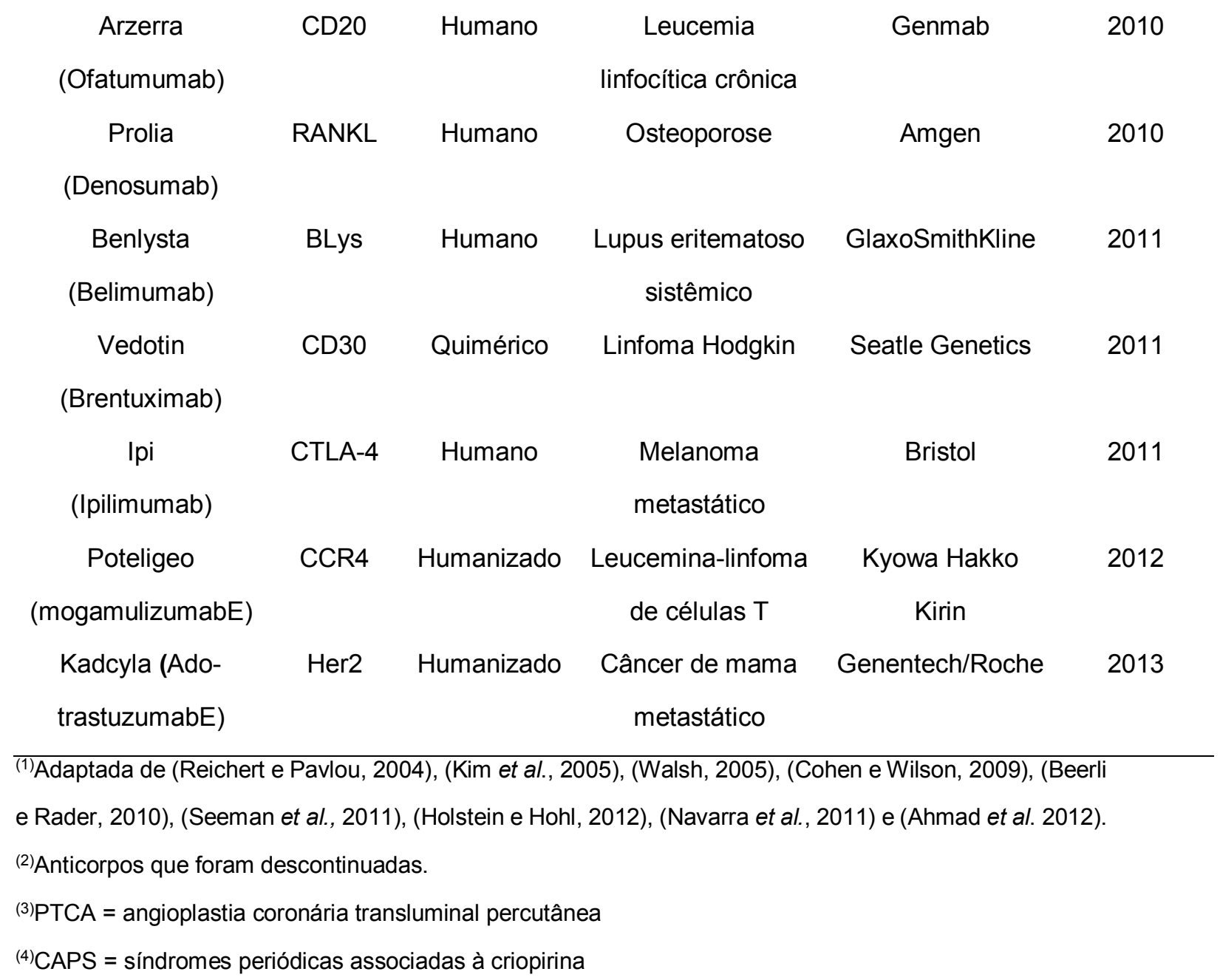

\section{Anticorpos anti-CD3}

A molécula CD3 é um antígeno de superfície específico de linfócito T e integra o complexo do TCR. É formado por dois peptídeos transmembrânicos, as cadeias épsilon e gama do complexo, e está envolvido na transdução de sinal do TCR para o citoplasma.

Estudos in vitro e in vivo sugerem que anticorpos direcionados para a molécula CD3 podem ter diversos efeitos biológicos tais como: promoção de apoptose (Carpenter et al., 2000), indução de anergia nos linfócitos T ou até o surgimento de células $\mathrm{T}$ reguladoras $\mathrm{CD}^{+}{ }^{+} \mathrm{CD} 25^{+}$(Belghith et al., 2003) e $\mathrm{CD}^{+}{ }^{+} \mathrm{CD} 25^{+}$(Bisikirska et al., 2005) que suprimem respostas imunes. 
O anticorpo anti-CD3 murino, OKT3, foi o primeiro anticorpo utilizado na clínica. Foi produzido em 1979 por P. Kung e G. Goldstein e é indicado para pacientes que receberam transplantes de órgãos. De uma forma geral, o anticorpo anti-CD3 OKT3 diminui a severidade em grande parte dos episódios de rejeição (Cosimi et al., 1981). A rejeição aos transplantes resulta de ativação coordenadas de células $T$ aloreativas e células apresentadoras de antígenos (APCs). Embora a rejeição aguda seja um processo dependente de células $\mathrm{T}$, a destruição do enxerto resulta de vários mecanismos efetores do sistema imunológico (Rocha et al., 2003). As interações célula-célula e a liberação de diversas citocinas (IL-2, IL-4, IL-5, IL-7, IL-10, IL-15, TNF- $\alpha$, e INF- $\gamma$ ) recrutam não apenas células T CD4+, CD8+ e linfócitos B específicos do doador, mas também células inflamatórias, as quais constituem a maior parte das células presentes nos infiltrados no enxerto (Chinen e Buckley, 2010).

Atualmente, os anticorpos anti-CD3 são considerados como representantes de uma nova categoria de agentes imunoterapêuticos, podendo promover a cura de autoimunidades estabelecidas ou permitir uma sobrevida duradoura de órgãos transplantados. Em modelos murinos de diabetes autoimune, anticorpos específicos para CD3 induz a remissão da doença ao restaurar à tolerância de células betas pancreáticas (Chatenoud, 2003).

O Grupo de Imunologia Molecular da UnB, iniciou o processo de humanização do anticorpo OKT3 em 1997, utilizando a técnica de CDR grafting (Caldas et al., 2000). Visando manter a especificidade de ligação característica do OKT3, o grupo escolheu arcabouços humanos para o domínio variável pesado $(\mathrm{VH})$ e leve (VL) que possuíam a maior similaridade com a sequência do anticorpo murino. A sequência germinal humana H1VB foi utilizada por possuir uma identidade de $71,4 \%$ com o VH do OKT3. A estrutura cristalográfica do anticorpo resultante foi analisada e a partir dessa análise o resíduo 86 presente no aracabouço do domínio variável pesado foi considerado estruturalmente 
importante, pois situava-se na base das CDRs 2 e 3 . A patir daí, foram criadas duas novas versões do domínio variável pesado, uma contendo o resíduo murino treonina (hVH ${ }^{\mathrm{T} 86}$ - "versão T") na posição 86 , e outra contendo o resíduo humano arginina (hVHR86 - "versão R") (Fonseca, 2000).

Após a verificação da manutenção da atividade ligante dos anticorpos humanizados (Costa, 2004), uma nova humanização foi realizada para o domínio variável leve. Para tal, foi adotada a estratégia de transplante de CDR por melhor encaixe. Buscou-se sequências germinais humanas que possuíam maior similaridade com a sequência do anticorpo murino, visando a manutenção da especificidade de ligação característica do OKT3. A procura resultou no anticorpo humano CAB37836 (L6), sendo este o escolhido para o procedimento de transplante de CDR (Silva, 2008).

Para verificar o sucesso do novo processo de humanização foram construídas versões recombinantes humanizadas com os domínios variáveis pesados $\mathrm{hVH} \mathrm{R}^{\mathrm{R} 86} \mathrm{e} \mathrm{hVH}^{\mathrm{T} 86}$ em conjunto com a nova cadeia leve ( $\mathrm{hVL}$ ) na forma de FvFc gerando duas novas versões totalmente humanizadas, FvFc T e FvFc $\mathrm{R}$ (Silva, 2008). Além disso, uma versão FvFc do OKT3 foi construída com a porção Fc humana. Essa última versão foi denominada de FvFc M (Figura 6) (Bezerra, 2014). Todas as três versões de FvFc (T, R e M) direcionadas para a molécula CD3 humana foram objetos de estudo deste trabalho.

Apesar dos trabalhos anteriores do grupo demostrarem que os anticorpos anti-CD3 humanizados eram capazes de se ligar ao antígeno CD3 humano, era preciso entender se o efeito biológico desses anticorpos sobre os linfócitos T era similar ou não ao efeito do OKT3. Nesse sentido passamos a identificar o efeito desses anticorpos sobre a célula T em nível transcricional. 

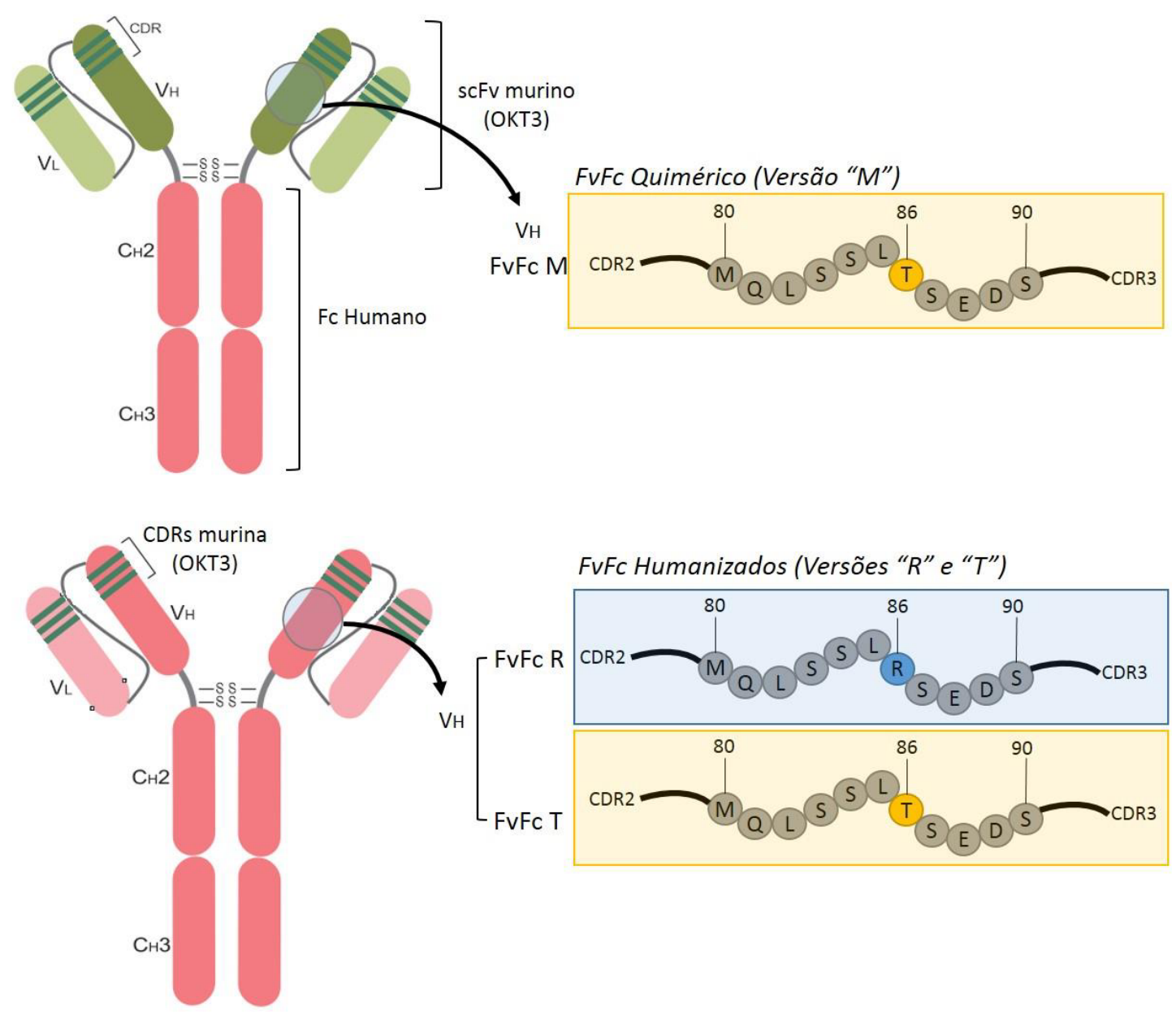

Figura 6 - Desenho esquemático das diferentes versões dos anticorpos anti-CD3. A versão FvFc M é uma versão quimérica do anticorpo OKT3 e possui a porção scFv do anticorpo murino. A porção $F c$ da quimérica é humana. As versões FvFc humanizadas possuem as CDRs murinas do OKT3. As diferenças entre as versões "R" e "T" consiste na mudança do aminoácido na posição 86 no arcabouço entre as CDR 2 e 3 . A versão "T" retém o resíduo treonina original, enquanto que a versão "R" possui uma arginina nesta posição. 


\section{Tecnologia de RNA-Seq}

O entendimento do transcritoma é essencial para a interpretação dos elementos funcionais do genoma humano, uma vez que pode revelar constituintes de células e tecidos, permitindo um olhar mais global dos processos biológicos. A principal função de uma análise trascritômica é catalogar os transcritos de uma espécie, incluindo mRNAs, ncRNAs (RNA não codificadores) e pequenos RNAs. Além disso, é possível determinar a estrutura transcricional de genes, detectar splicing alternativos e modificações pós transcricionais, e ainda, quantificar mudanças na expressão gênica durante o desenvolvimento e sob uma condição determinada (Wang et al, 2009).

Diversas tecnologias têm sido desenvolvidas para quantificar o transcritoma. Atualmente, o desenvolvimento de sequenciamento de alto desempenho tem sido amplamente empregado nas análises transcritômicas. Esse método, conhecido como RNA-Seq, tem claras vantagens em relação aos outros métodos que visam quantificar transcritos.

RNA-Seq é uma técnica de sequenciamento de alto desempenho e utiliza uma população de RNA (total ou fracionada, tal como poly $(A)+$ ) que é convertida em uma biblioteca de fragmentos de cDNA com adaptadores fusionados em ambas as extremidades. A figura 7 demonstra de forma resumida as etapas de RNA-Seq. Cada molécula, com ou sem amplificação, é então sequenciada em sequenciador de alto desempenho (plataforma Illumina, por exemplo) para obter pequenas sequências de uma (single-end) ou ambas (paired-end) as extremidades. As pequenas sequências, conhecidas como reads, podem possuir de 30-400 pb, dependendo da tecnologia usada. Após o sequenciamento, as reads resultantes são então alinhadas no genoma de referência (Wang et al, 2009). Utilizando ferramentas de bioinformática é possível então determinar o nível de expressão de cada gene. 


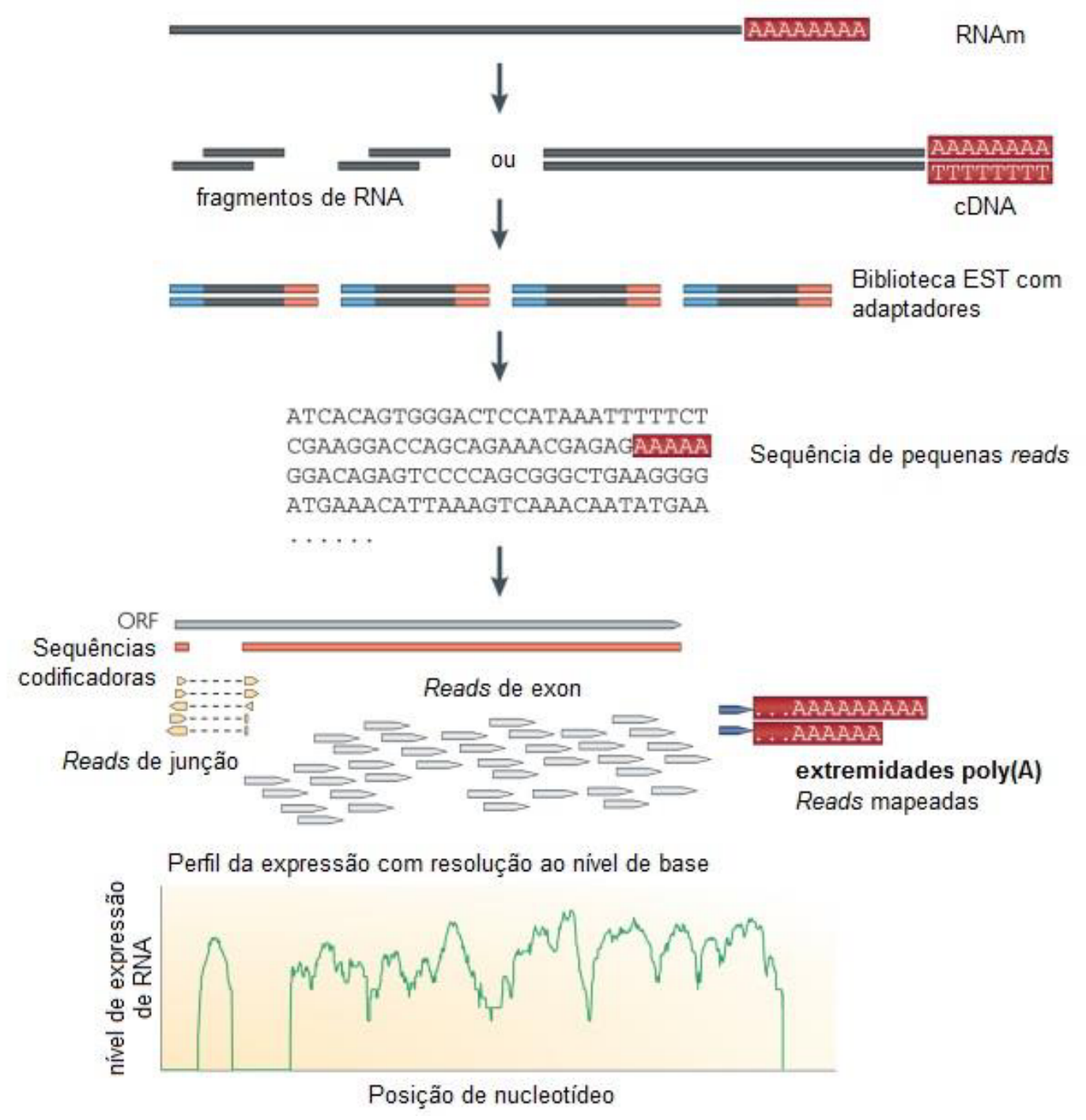

Figura 7 - Experimento típico de RNA-Seq. O esquema mostra as principais etapas de sequenciamento de alto desempenho. Em síntese, o RNA mensageiro (RNAm) é convertido em pequenos fragmentos ou em cDNA. Adaptadores são adicionados em cada fragmento e pequenas sequências são obtidas pelo sequenciamento de alto desempenho. As sequências resultantes são alinhadas no genoma de referência e o peril de expressão gênica é determinada (Adaptado de Wang et al, 2009). 
Empregando a plataforma de RNA-Seq da lllumina para análise do nível de expressão gênica, Marioni e colaboradores (2008) demonstraram a alta reprodutibilidade dos dados de sequenciamento de RNA que, quando comparados aos resultados de microarranjos realizados com as mesmas amostras de RNA, 30\% a mais de genes expressos diferencialmente foram identificados. Por meio da comparação dos resultados do RNA-Seq e de microarranjos com uma terceira metodologia, a RT-PCR em tempo real (qPCR), ficou demonstrado uma maior concordância dos resultados desta última com o RNA-Seq (Marioni et al., 2008). Além disso, o ruído intrínseco e outras idiossincrasias da hibridização de DNA são evitados por essa técnica que tem se mostrado uma alternativa mais rápida e mais eficiente.

A grande vantagem do RNA-Seq está no fato de que não é necessário o conhecimento do trascritoma e não se limita na detecção de genes para os quais existam sondas. Por essa razão, a transcritômica de alto desempenho tem a capacidade de detectar genes novos (não previstos nos atuais mapas genômicos) e também novos eventos de splicing alternativo (AS) (Sultan et al., 2008). O splicing alternativo é um evento conhecido há muitas décadas, mas seu impacto sobre os RNAs maduros e o conjunto de isoformas na proteômica da célula foi sempre subestimado. Com o fechamento do genoma humano em 2003, admitiu-se que 40 a $60 \%$ dos RNAs pudessem ser processados alternativamente (Modrek e Lee, 2002), mas hoje se considera que esse número é muito maior e pode chegar a $95 \%$.

Por essas características, a técnica de RNA-Seq foi a escolhida para a análise trascritômica dos linfócitos T tratados com os anticorpos anti-CD3. 
JUSTIFICATIVAE

OBJETIVOS 


\section{JUSTIFICATIVA}

Os anticorpos anti-CD3 são representantes de uma nova categoria de agentes imunoterapêuticos, podendo promover o tratamento de auto-imunidades estabelecidas ou permitir uma sobrevida duradoura de órgãos transplantados (Chatenoud, 2003). O primeiro anticorpo aprovado para uso clinico pelo FDA (órgão regulador americano em eventos de rejeição aguda de enxertos foi o Muronomab ou Orthoclone (OKT3). Esse anticorpo era específico para o antígeno CD3 e se mostrou eficiente na depleção de linfócitos aloreativos. Contudo, recentemente seu uso foi suspenso devido a sua toxidade. Os efeitos colaterais promovidos pelo OKT3 deviam-se à sua origem murina. O grupo de Imunologia Molecular da UnB investiu no processo de humanização do anticorpo OKT3, por meio de um procedimento próprio de utilização de genes variáveis germinais e transplante de CDR.

A caracterização das versões humanizadas do OKT3 tem sido realizada por diversos trabalhos do grupo de Imunologia Molecular, contudo, o conhecimento do perfil transcritômico de linfócitos $T$ tratados com as versões humanizadas (FvFc R e T) do anti-CD3 poderá aumentar a compreensão dos mecanismos desenvolvidos por esses anticorpos. Esse conhecimento pode ainda subsidiar o desenvolvimento de novas terapias.

\section{OBJETIVOS}

\section{Objetivo Geral}

- Realizar a análise transcritômica de linfócitos T humanos tratados com diferentes versões humanizadas de anticorpos anti-CD3. 


\section{Objetivos Específicos}

- Produzir e purificar as diferentes versões dos anticorpos anti-CD3;

- Analisar o transcritoma de linfócitos T humanos na presença dos anticorpos recombinantes anti-CD3;

- Prospecção dos dados do transcritoma para detecção de genes expressos diferencialmente;

- Validação por PCR em tempo real dos principais genes expressos diferencialmente; 
MATERIAL

E

MÉTODOS 


\section{MATERIAL}

\section{Células}

- CHO-K1 (ATCC noCCL-61) transfectadas com o plasmídio pMIRES contendo os genes codificadores do anticorpo FvFc humanizado anti-CD3 nas versões R, T e M. Esse plasmídio contém: AmpR ,ori ColE1, múltiplos sítios de clonagem, promotor pCMV, peptídeo sinal de imunoglobulina, sítio de entrada ribossomal interno (IRES), NEO $R$, sinal de poliadenilação SV40polyA, origem de replicação ORI e gene da $\beta$ lactamase (bla). As células transfectadas foram cultivadas em meio HAMF12 (GIBCO) contendo SFB a uma concentração de 5\% (v/v).

- Células mononucleares do sangue periférico (PBMC): os linfócitos humanos utilizados na realização deste trabalho foram obtidos do sangue periférico de doador saudável, para o teste de ligação ao antígeno CD3, cultivo com os anti-CD3 e extração de RNA. Todos os termos éticos foram atendidos.

\section{Soluções, Meios e Reagentes}

\section{Soluções estoques de Inibidores de Proteases}

- PMSF (PhenilmethylsulfonylFluoride) 0,1 M Solubilizado em isopropanol e estocado a temperatura ambiente por até 1 ano. É um inibidor de serino e tiol proteases como, por exemplo, tripsina, quimiotripsina, trombina, papaína etc. Adicionar a uma concentração final de $1 \mathrm{mM}$. 
- EDTA (Ácido Tetracético Etilenodiamina) 0,5M Solubilizado em água, pH 8-9, estocado a $4^{\circ} \mathrm{C}$ por até 6 meses. É um inibidor de metaloproteases. Adicionar a uma concentração final de $5 \mathrm{mM}$.

\section{Meios de cultura de células de mamíferos}

- Meio HAM-F12 com L-glutamina a $2 \mathrm{mM}$ (Invitrogen $®$, $\mathrm{n}^{\circ}$ de catálogo: 21700-075)

- Meio RPMI 1640 com L-glutamina a 2 mM Suplementado (Invitrogen $\circledast, \mathrm{n}^{\circ}$ de catálogo: 31800-022)

- Meio de Congelamento de Células (contendo DMEM ou RPMI, Soro Fetal Bovino $20 \%$ e DMSO $5 \%$ ).

- Tripsina-EDTA (Invitrogen ${ }^{\circledR}, \mathrm{n}^{\circ}$ de catálogo: 27250-018)

- Soro Fetal Bovino (Invitrogen ${ }^{\circledR}, \mathrm{n}^{\circ}$ de catálogo: 10438-026)

- Soro Fetal Bovino, Ultra low - IgG (Invitrogen®, nde catálogo: 16250086)

\section{Antibióticos}

- Antibiótico/Antimicótico 100X (GIBCO). Solução utilizada como antibacteriano e antimicótico que foi adicionada aos meios de cultura das células de mamífero, na concentração final $1 \mathrm{X}$.

- Geneticina - G418 (GIBCO) Ageneticina liofilizada foi ressuspendida em água Mili-Q na concentração de $50 \mathrm{mg} / \mathrm{mL}$. Após a ressuspensão, ela foi 
esterilizada por filtração em membrana Millipore de 0,22 $\mu \mathrm{m}$. Após a filtração, ela foi estocada a $4^{\circ} \mathrm{C}$ e protegida da luz. Este antibiótico foi utilizado como marca de seleção em transfecções estáveis para plasmídios que continham o gene de resistência a geneticina (NEOR).

\section{Soluções e tampões de uso geral}

- Azul de Tripan $(400 \mathrm{mg} / \mathrm{mL}$ preparado em PBS pH 7,2)

- Azida Sódica 5\%:Esta solução era utilizada para a conservação dos tampões PBS e PBS-T em concentração final de 0,05\% (p/v).

- Tampão PBS (Phosphate-Buffered Saline) 10X, pH 7,4: NaCl1,5 M; $\mathrm{Na}_{2} \mathrm{HPO}_{4} 0,1 \mathrm{M}$ e NaN${ }_{3} 0,02 \%$ (p/v).Solução de uso 1x.

- Tampão PBST 1X, pH 7,4:PBS 1X acrescido de Tween 20 na concentração final de $0,1 \%(v / v)$

Soluções e reagentes para eletroforese em gel de agarose e de poliacrilamida

- Tampão de corrida TAE 50X (GIBCO, nº de catálago 24710-030)

- Tampão de amostra para gel de agarose 10X (RNAsefree): TAE 1x (50\% v/v); Glicerol ( $50 \% \mathrm{v} / \mathrm{v})$ e azul de bromofenol $(0,1 \% \mathrm{p} / \mathrm{v})$

- Solução de brometo de etídeo $10 \mathrm{mg} / \mathrm{mL}$ (RNAsefree)

- Tampão de corrida para SDS-PAGE 5X:Trizma base 125 mM; Glicina 125 $\mathrm{mMe}$ SDS $0,5 \%(\mathrm{p} / \mathrm{v})$. Solução de uso $1 \mathrm{X}$. 
- Tampão de amostra 5X para SDS-PAGE: Tris-HCl pH 6,8 250 mM; SDS 10\% (p/v); Glicerol 50\% (v/v); ß-mercaptoetanol10\% (v/v) e azul de bromofenol $0,5 \%(p / v)$. Solução de uso $1 X$.

- Acrilamida 30\% (29:1Acrilamida:bis-acrilamida).

- Tris- $\mathrm{HCl} 1,5 \mathrm{M}, \mathrm{pH} 8,8$

- Tris-HCl 0,5M, pH 6,8

- $\operatorname{SDS} 10 \%(\mathrm{p} / \mathrm{v})$

- $\operatorname{APS} 10 \%(\mathrm{p} / \mathrm{v})$

- TEMED (N,N,N',N'- tetrametiletilenodimetilamina)

- Gel Concentrador SDS-PAGE: Solução Acrilamida/Bis-acrilamida (29:1) 4\% (p/v); Tris-HCl pH 6,8 125 mM; SDS 0,1\% (p/v); APS 0,1\% (p/v) e TEMED $0,01 \%(\mathrm{p} / \mathrm{v})$.

- Gel Separador SDS-PAGE: Solução Acrilamida/Bis-acrilamida (29:1) 10\% (p/v); Tris-HCl pH 8,8 400 mM; SDS 0,1\% (p/v); APS 0,1\% (p/v) e TEMED $0,01 \%(p / v)$ 
3. Soluções e material para ensaios imunológicos (ELISA, Western e Dotblot)

- Tampão de Fosfatase Alcalina (APB): Tris-HCl pH 9,5100 mM; NaCl100 $\mathrm{mM}$ e $\mathrm{MgCl}_{2} 5 \mathrm{mM}$.

- Tampão para Transferência Semi-Seca de Proteínas: Trizma-base 48 mM; Glicina 39 mM; SDS 0,037\% (p/v) e Metanol 20\% (v/v).

- Solução de Bloqueio: Leite em pó desnatado5\% (p/v) dissolvido em PBST $1 \mathrm{X}$.

- Solução Reveladora para ELISA: pNPP (para-nitro-fenil-fosfato) 1 mg/mL dissolvido em APB.

- Solução Reveladora para Western e Dotblot: NBT/BCIP (Invitrogen) diluído 10x em água destilada.

- Membrana de Nitrocelulose: Hybond-C Extra (Amersham® Bioscience $n^{\circ}$ de catálogo RPN 303E)

- Placas de microtitulação de poliestireno com 96 poços com fundo chato para ELISA (Nunc® Maxisorp, $n^{\circ}$ de catálogo 456537)

- Resina e coluna para cromatografia de afinidade: ImmunoPure Plus ImmobilizedProtein A $25 \mathrm{~mL}$ (Pierce, $\mathrm{n}^{\circ}$ de catálogo 22812). Para purificação dos anticorpos recombinantes. Coluna K9/15 (GE Healthcare, $\mathrm{n}^{\circ}$ de catálogo 19-0870-01) 
- Soluções para cromatografia de afinidade: Protein A Binding Buffer 3,75 L (Pierce, $n^{\circ}$ de catálogo. 21007); Protein A Elution Buffer 3,75 L (Pierce, $n^{0}$ de catálogo. 21009)

- Materiais utilizados para concentração dos anticorpos purificados: Concentradores Amicon ${ }^{\circledR}$ Bioseparations -CentriconYM-30 $\left(n^{\circ}\right.$ de catálogo 4209)

- Marcadores moleculares para proteína:Spectra Multicolor Broad Range ProteinLadder (ThermoScientific, $n^{\circ}$ de catálogo 26634)

- PlusOne Silver Staining kit Protein. Para coloração de géis de poliacrilamida com prata. (GE Healthcare, $n^{\circ}$ de catálogo. 17-1150-01).

- Kit BCA Ácido Bicincrônico - para quantificação de proteínas. Pierce® $\left(n^{\circ}\right.$ de catálogo 23225)

\section{Soluções e material para citometria de fluxo}

- Solução Salina 0,9\%

- Tampão de lavagem para reação de FACS: Soro fetal bovino $2 \%(\mathrm{v} / \mathrm{v})$ e azida sódica $\quad 0,02 \%(p / v)$ dissolvidos em PBS $1 X$

- Solução Salina Isotônica G 20 L (FACSflow) (BD Pharmigen $®, n^{\circ}$ de catálogo 990992)

- Placas de microtitulação de 96 poços com fundo em U não estéril 
5. Anticorpos utilizados nos imunoensaios (ELISA, Western Blot, Dotblot e Citometria de Fluxo)

- Anti-lgG humana $(H+L)$ feito em cabra (KPL $® n^{\circ}$ de catálogo 01-10-06). Concentração: $1 \mathrm{mg} / \mathrm{mL}$. Titulação de uso: 1:1000 (ELISA)

- Anti-lgG humana (Fc específico) feito em cabra conjugado com fosfatase alcalina(Sigma ${ }^{\circledR} \mathrm{n}^{\circ}$ decatálogo A9544). Concentração: $1 \mathrm{mg} / \mathrm{mL}$. Titulação de uso: 1:5000 (ELISA) e 1:2500 (Western blot e Dotblot)

- IgG Humana (Pierce ${ }^{\circledR} \mathrm{n}^{\circ}$ decatálogo 31154)Concentração: $11,3 \mathrm{mg} / \mathrm{mL}$. Utilizado à 22,6 ou $113 \mathrm{ng} / \mathrm{mL}$ como padrão nos experimentos de ELISA.

- FcRBlockingReagent (MACS $\mathrm{n}^{\circ}$ de catálogo 130-059-901). Titulação de uso: 1:50 (FACS)

- Anti-lgG de camundongo feito em cabra conjugado a FITC (Sigma ${ }^{\circledR}, n^{\circ} \mathrm{de}$ catálogo F0257). Concentração: 1 mg/mL. Titulação de uso: 1:100 (FACS)

- Anti-lgG humana feito em camundongo conjugado a FITC $\left(B D \circledast, n^{\circ}\right.$ de catálogo 555786). Concentração: $1 \mathrm{mg} / \mathrm{mL}$. Titulação de uso: 1:10 (FACS)

- Anti-CD4 humano feito em camundongo conjugado a PE (eBioscience $®$, $n^{\circ}$ de catálogo12-0048-042). Clone: OKT4. Titulação de uso: 1:50 (FACS)

- Anti-CD4 humano feito em camundongo conjugado a APC (eBioscience®), $n^{\circ}$ de catálogo 12-0048-042) Clone: OKT4. Titulação de uso: 1:50 (FACS) 
- Anti-CD8 humano feito em camundongo conjugado a PE (BD Pharmigen ${ }^{\circledR}, n^{\circ}$ de catálogo: 557086$)$ Clone: RPA-T8. Titulação de uso: $1: 50$ (FACS)

- Anti-CD8 humano feito em camundongo conjugado a APC (eBioscience®, nº de catálogo: 17-0086-42) Clone: OKT8. Titulação de uso: 1:50 (FACS)

- Anti-CD3 humano feito em camundongo conjugado a FITC (eBioscience ${ }^{\circledR}, n^{\circ}$ de catálogo 11-0037-73) Clone: OKT3. Titulação de uso: 1:50 e 1:500 (FACS)

- $\mathrm{OKT3} \circledast$, Anti-CD3 humano feito em camundongo (muronomab - CD3) (eBioscience ${ }^{\circledR}, \mathrm{n}^{\circ}$ de catálogo: 14-0037-82). Concentração $1 \mathrm{mg} / \mathrm{mL}$. Utilizado como controle positivo nos ensaios de ligação e estimulação de PBMC.

- Anti-CD18 humano feito em camundongo conjugado com FITC (BD Pharmigen ${ }, n^{\circ}$ de catálogo:5649) Clone: MOPC-21. Titulação de uso: $1: 50$ (FACS)

- Anti-CD19 humano feito em camundongo conjugado com PE (BD Pharmigen ${ }^{\circledR}, n^{0}$ de catálogo:562292) Clone: X40. Titulação de uso: 1:50 e 1:500 (FACS).

- Anti-CD56humano feito em camundongo conjugado a FITC (eBioscience ${ }^{\circledR}, \mathrm{n}^{\circ}$ de catálogo 17-0569-42) Clone:MEM188. Titulação de uso: 1:50 (FACS) 


\section{Reagentes e kit de isolamento depbmc e linfócitos $t$}

- Ficoll-PaquePlus (GE, $n^{\circ}$ de catálago17-1440-02)

- Dynabeads ${ }^{\circledR}$ Untouched ${ }^{\mathrm{TM}}$ Human T Cells Kit (Invitrogen, $\mathrm{n}^{\circ}$ de catálogo: 11344D)

\section{Reagentes e Kits para RNA}

- Kit de extração de RNA: RNeasy mini kit (QIAGEN nº catálogo 74104)

- RNase-FreeDNase Set(QIAGEN nº catálogo 79254)

- DNase: TURBO DNase ${ }^{\mathrm{TM}}(2 \mathrm{U} / \mathrm{uL})\left(\right.$ Ambion ${ }^{\circledR}, \mathrm{n}^{\circ}$ de catálogo AM2238)

- Kit para quantificação de RNA: Qubit ${ }^{\mathrm{TM}}$ RNA Assay Kits (Invitrogen, $\mathrm{n}^{\circ}$ de catálogo Q32852)

- Água NucleaseFree: Nuclease-FreeWater (Ambion ${ }^{\circledR}, \mathrm{n}^{\circ}$ de catálogo AM9937)

- Kit de tubos para transporte de RNA: RNAstable ${ }^{\circledR}$ Tube Kit (Biomatrica)

8. Kits e placas para validação de genes por PCR ARRAY

- $\mathrm{RT}^{2}$ FirstStrand Kit (QIAGEN, $\mathrm{n}^{\circ}$ de catálogo 330401)

- $\mathrm{RT}^{2}$ Custom Profiler PCR Array (QIAGEN, $n^{\circ}$ de catálogo CAPH12583C)

- $\mathrm{RT}^{2}$ qPCR SYBR Green/ROX MasterMix (QIAGEN, $\mathrm{n}^{\circ}$ de catálogo 330523) 


\section{MÉTODOS}

\section{Cultura de células de mamíferos}

Durante todo o procedimento de cultura, as células mantidas a $37^{\circ} \mathrm{C}$, $5 \%$ de $\mathrm{CO}_{2}$ e $70 \%$ de umidade. A viabilidade das células foi observada em microscópio invertido Leica DMIL.

\section{Congelamento de células de mamíferos - Criopreservação} (Ruggiero, 2002).

As células em cultura aderente foram lavadas com meio HAM F12 (contendo $10 \%$ de Soro Fetal Bovino - SFB) e tripsinizadas. Após esse procedimento, as células em suspensão foram transferidas para um tubo de centrífuga contendo $5 \mathrm{~mL}$ de meio (HAM + 10\% SFB) para inativação da tripsina e centrifugadas por 8 minutos a 130 x g. Após a centrifugação, o sobrenadante foi descartado e o sedimento foi ressuspendido no meio de cultura remanescente no tubo. As células foram divididas em alíquotas de $500 \mu \mathrm{L}$ em criotubos, onde $500 \mu \mathrm{L}$ de meio de congelamento eram adicionados. Os criotubos eram incubados a $4^{\circ} \mathrm{C}$ por 30 minutos, depois a $-20^{\circ} \mathrm{C}$ por 30 minutos e depois a $-80^{\circ} \mathrm{C}$ durante a noite. As células poderiam permanecer estocadas a esta temperatura ou ser transferidas para a estocagem em nitrogênio líquido.

3. Descongelamento de células de mamíferos (Ruggiero, 2002).

Os criotubos contendo as células foram incubados em banho de $37^{\circ} \mathrm{C}$ até o total descongelamento das células. As células foram adicionadas em garrafas de $25 \mathrm{~cm}^{2}$ contendo meio HAM + 10\% SFB numa densidade de $2 \times 10^{2}$ células. 
4. Tripsinização, passagem das células e formação de monocamada celular (Ruggiero, 2002).

Após uma confluência de $100 \%$, que recobre toda a superfície da placa de cultura, as células foram repicadas. Para isso, o meio de cultura da garrafa foi descartado e foi adicionado à garrafa $5 \mathrm{~mL}$ de tripsina numa concentração de 1:250. Após 3 minutos, o descolamento das células podia ser observado por visualização a olho nu. A tripsina foi neutralizada adicionando 5 $\mathrm{mL}$ de meio acrescido de $10 \%$ de SFB. Esse passo é importante, uma vez que a tripsina é deletéria às células. A suspensão celular foi transferida para tubos falcon de $50 \mathrm{~mL}$ e centrifugados a $130 \times \mathrm{g}$ por 8 minutos. O sobrenadante foi descartado e o sedimento ressuspendido em $3 \mathrm{~mL}$ de meio acrescido de SFB. A passagem era feita em garrafas de 75 ou $150 \mathrm{~cm}^{2}$ contendo $10 \mathrm{~mL}$ ou $30 \mathrm{~mL}$ de meio acrescido de SFB respectivamente.

5. Estimativa do número de células por meio de contagem em câmara de Neubauer (adaptado de Spector et al., 1998).

A viabilidade células e o número de células foi verificada utilizando câmara de Neubauer. Para isso, após tripsinização, $1 \mathrm{~mL}$ de células era coletada para a contagem. Foram aplicados $10 \mu \mathrm{L}$ de suspensão de células em cada compartimento da câmara. As células foram observadas em microscópio óptico e o número de células foi contado para cada quadrante. Caso alguma diluição tivesse sido necessária, o número de células contado foi multiplicado por esse fator de diluição. Em seguida, foi utilizada a fórmula: número de células contadas/número de quadrantes contados $X$ fator de diluição $X 10_{4}=n^{\circ}$ de células $/ \mathrm{mL}$ 


\section{Acúmulo de sobrenadante de cultura}

A cada sete dias, o sobrenadante foi coletado e meio novo foi adicionado à cultura. O sobrenadante foi preservado com $5 \mathrm{mM}$ de EDTA, $1 \mathrm{mM}$ de PMSF e $0,05 \%$ de azida sódica. O sobrenadante foi acumulado durante 6 meses, num total de 1 litro para cada uma das construções de FvFc.

\section{Quantificação da produção de proteína recombinante por} ensaio ELISA (Enzyme-linked immunosorbent assay)

Foram realizados ensaios do tipo ELISA sanduíche para detecção e quantificação das proteínas recombinantes. Após cada lavagem as placas de

microtitulação (Nunc ${ }^{\circledR}$ ) foram invertidas sobre uma pilha de papel toalha e batidas vigorosamente até a retirada completa das soluções presentes. Durante as incubações as placas permaneciam fechadas para evitar a evaporação das soluções. Os anticorpos utilizados estão detalhados na seção "MATERIAL E MÉTODOS".

Primeiramente, os poços foram sensibilizados com $150 \mu \mathrm{L}$ do anticorpo anti-IgG humana $H+L$ feito em cabra, diluído em PBS 1X 1:1.000, e foram incubados durante 1 hora a temperatura ambiente. Os poços foram lavados com $200 \mu \mathrm{L}$ três vezes com PBST 1X. Os poços foram bloqueados com $180 \mu \mathrm{L}$ de solução de bloqueio e incubados durante 1 hora a temperatura ambiente ou durante a noite a $4^{\circ} \mathrm{C}$. Após o tempo, foram lavados três vezes com PBST 1X e o sobrenadante de cultura das células transfectadas eram adicionados. Foram feitas diluições seriadas de fator comum 3 dos anticorpos em PBS, onde o volume final foi de $100 \mu \mathrm{L}$ por poço e títulos de $1: 1 ; 1: 3 ; 1: 9$; 1:27; 1:81 e 1:243. A mesma diluição foi realizada para todas as amostras. Como padrão, utilizava-se IgG humana purificada na concentração especificada na seção "MATERIAL" (diluída na mesma solução/meio que as proteínas recombinantes). As reações foram feitas em triplicatas e foram incubadas por 1 
hora a temperatura ambiente. Os poços foram lavados novamente três vezes com PBST 1X e $150 \mu \mathrm{L}$ do anticorpo anti-Fc humano conjugado a fosfatase alcalina feito em cabra na diluição de 1:5.000 foram incubados por 1 hora a temperatura ambiente. Os poços foram lavados três vezes com PBST 1X e uma vez com tampão para fosfatase alcalina (APB).

O ensaio foi revelado com $100 \mu \mathrm{L}$ de pNPP (para-nitro-fenil-fosfato) 1 $\mathrm{mg} / \mathrm{mL}$ dissolvido em APB. Este foi incubado por 20 a $30 \mathrm{~min}$ a temperaturta ambiente. A partir daí a absorbância foi lida no leitor de ELISA "Microplate Reader BioRad ${ }^{\circledR}$ " modelo 450 a um comprimento de onda de $405 \mathrm{~nm}$. Os cálculos de concentração foram feitos baseados na curva padrão de lgG humana.

\section{Purificação das proteínas recombinantes por cromatografia de} afinidade

A purificação dos FvFcs e IgGs recombinantes foi realizada por meio da resina ImmunoPure Plus Immobilized Protein A (Pierce ${ }^{\circledR}$ ) de acordo com o protocolo do fabricante com algumas adaptações. Primeiro, os microtubos de coleta da eluição foram preparados adicionando $100 \mu \mathrm{L}$ de Tris- $\mathrm{HCl} 1 \mathrm{M} \mathrm{pH} \mathrm{9,0}$ por $\mathrm{mL}$ de fração a ser coletado. A coluna contendo a resina foi lavada com 5 volumes de tampão de ligação mantendo uma taxa de passagem do tampão pela coluna em $2 \mathrm{~mL} / \mathrm{min}$. O sobrenadante de cultura filtrado e foi aplicado. A coluna foi lavada com 15 volumes de tampão de ligação. Os anticorpos recombinantes ligados foram eluidos com 20 volumes de tampão de eluição, sempre coletando as amostras nos microtubos de coleta preparados com Tris- $\mathrm{HCl}$. A resina contida na coluna foi lavada com mais 5 volumes de tampão de ligação. Foram aplicados 5 volumes de água MiliQ com $0,02 \%$ de azida sódica, no qual se estocava novamente a resina a $4^{\circ} \mathrm{C}$.

Imediatamente após o fim da coleta, $5 \mu \mathrm{L}$ de cada amostra foram 
aplicados em uma membrana de nitrocelulose para análise por Dot Blot. As amostras onde se detectavam proteínas foram passadas nas colunas Centricon YM-30 e YM-50 (Amicon ${ }^{\circledR}$ ), com membrana de exclusão para proteínas maiores que 30 e 50 kDa, respectivamente, para diálise e concentração.

\section{Análise de proteínas por Dot Blot (adaptado de Sambrook e} Russel, 2001).

Cinco microlitros das frações obtidas durante o processo de purificação foram adicionadas diretamente a uma membrana de nitrocelulose. A membrana foi bloqueada utilizando solução de bloqueio por 1 hora a temperatura ambiente. Após a incubação, a solução de bloqueio foi descartada e a membrana lavada três vezes com PBST 1X. A membrana foi incubada com o anticorpo antiFc humano conjugado a fosfatase alcalina na diluição de 1:2.500 por 1 hora a temperatura ambiente. Após a incubação, a membrana foi lavada três vezes com PBST 1X e uma vez com APB. A solução reveladora (NBT/BCIP) foi adicionada

e as frações contendo as proteínas recombinantes foram reveladas. A membrana foi lavada com água destilada até retirar o excesso da solução reveladora e interromper a reação da enzima. A membrana seca foi preservada sobre papel filtro.

10. Análise de proteínas por eletroforese em gel de SDS-PAGE (adaptado de Sambrook e Russel, 2001).

Após a purificação dos anticorpos recombinantes foi realizada a análise da integridade em gel desnaturante de poliacrilamida. O gel separador foi preparado em concentração de $10 \%(p / v)$. Após a polimerização, foi preparado o gel concentrador a 4\% (p/v). Antes da aplicação, as amostras foram fervidas em banho a $100^{\circ} \mathrm{C}$ por 10 minutos. Os poços foram lavados com tampão de corrida e procedia-se a aplicação das amotras. A corrida do gel foi 
realizada a $20 \mathrm{~mA}$ por gel. Após a corrida, o gel foi submetido à coloração com prata ou transferido para membrana de nitrocelulose para realização do Western Blot.

\section{Coloração do gel de SDS-PAGE}

A coloração foi realizada utilizando o kit PlusOne Silver Staining Protein seguindo as instruções do fabricante.

12. Análise de proteínas por Western Blot (adaptado de Sambrook e Russel, 2001).

Após a corrida, o gel de poliacrilamida foi transferido para a membrana de nitrocelulose utilizando-se o sistema de transferência semi-seca com eletrodos de grafite (Pharmacia-LKB ${ }^{\circledR}$ ) conforme instruções do fabricante. Após este procedimento, a membrana, contendo as proteínas transferidas, foi incubada em solução de bloqueio e por $1 \mathrm{~h}$ à temperatura ambiente. Após a incubação, a mebrana foi lavada três vezes PBST 1X. A membrana lavada foi incubada com o anticorpo anti-Fc humano conjugado a fosfatase alcalina. Após essa etapa a membrana foi lavada três vezes com PBST 1X e uma vez com APB. A solução reveladora (NBT/BCIP) foi então adicionada. Após a reação, as bandas correspondentes a proteína recombinante foi visualizada. A membrana foi lavada com água destilada até retirar o excesso da solução reveladora e interromper a reação da enzima. A membrana seca foi preservada sobre papel filtro.

\section{Ensaio de Ligação direta utilizando citometria de fluxo}

Nesse experimento os reagentes e as etapas metodológicas eram protegidos da luz. 
Para citometria de fluxo foi utilizado de 3 a $4 \times 10^{5}$ células por reação em poços de placa de microtitulação de 96 poços com fundo em $U$. As células foram centrifugadas a $1.800 \mathrm{rpm}$ a $4^{\circ} \mathrm{C}$ por $5 \mathrm{~min}$. Após a centrifugação, o sobrenadante foi descartado por inversão rápida em folha de papel toalha, para a retirada do excesso de tampão. As células foram ressuspendidas por forte agitação (vortex) com o tampão remanescente nos poços. Na primeira incubação, foram adicionados $50 \mu \mathrm{L}$ do bloqueador de Fc, os FvFcs recombinantes purificados, IgGs recombinantes ou anticorpos diluídos em tampão de lavagem de FACS conforme especificado na seção de "MATERIAL". As células foram incubadas no gelo por $30 \mathrm{~min}$ ao abrigo da luz. Após a incubação foram adicionados $150 \mu \mathrm{L}$ de tampão de lavagem de FACS e procedeu-se com a centrifução nas condições já descritas. As células foram ressuspendidas em $400 \mu \mathrm{L}$ de tampão de lavagem de FACS e transferidas para tubos apropriados para o aparelho de FACS. A leitura da reação no citômetro de fluxo foi realizada preferencialmente no dia da reação para evitar a morte celular.

$$
\text { O citômetro de fluxo utilizado foi o FACS Verse (BD bioscience }{ }^{\circledR} \text { ). } \mathrm{O}
$$
programa utilizado para aquisição e análise dos dados foi o FACSuite. As células foram adquiridas e selecionadas de acordo com seu tamanho e granulosidade de maneira a analisar a população de linfócitos, e a seguir foram adquiridas 10.000 células para cada amostra dentro da região de linfócitos. Os dados foram obtidos a partir da análise dos histogramas ou gráficos de pontos fornecidos pelo programa. Os resultados foram expressos em porcentagem de células positivas para cada proteína em estudo. O parâmetro considerado foi a mediana de intensidade de fluorescência. 


\section{Separação de células mononucleares do sangue periférico}

(PBMC) por gradiente de Ficoll.

A separação de PBMC foi realizada a partir de sangue periférico de doador saudável, com materiais e soluções estéreis em fluxo laminar. Todos os procedimentos para coleta de sangue foram aprovados pelo Comitê de Ética e Pesquisa. O sangue foi coletado em tubos contendo EDTA e a separação foi realizada utilizando centrifugação em gradiente de densidade com Ficoll-Paque Plus (GE). Esse método baseia nas diferenças de densidade entre as células mononucleares e os outros elementos do sangue. Após a separação, as células PBMC e plaquetas, por serem menos densas que a solução de Ficoll, ficavam localizadas acima dessa solução, enquanto as hemácias e os granulócitos (por terem densidades maiores que o ficoll) ficavam localizadas abaixo. Todo o procedimento para a separação seguiu as instruções do fabricante.

\section{Estimulação de PBMC com os anticorpos anti-CD3}

O cultivo celular foi realizado com PBMC previamente separado com Ficoll de doador saudável. Era preparado meio RPMI contendo 10\% de SFB, $4 \mathrm{mM}$ de L-glutamina, antibiótico e antimicótico. As células foram diluídas no meio previamente preparado em uma densidade de $1 \times 10^{6}$ células por $\mathrm{mL}$.Em garrafas de $25 \mathrm{~cm}^{2}$ foi adicionado $5 \mathrm{~mL}$ do meio contendo as células e os anticorpos antiCD3 em uma concentração de $250 \mathrm{ng} / \mathrm{mL}$. Como controle, foi realizada o cultivo das células sem anticorpos. $\mathrm{O}$ cultivo foi incubado à $37^{\circ} \mathrm{C}-5 \% \mathrm{CO}^{2}$ durante 72 horas. Após $72 \mathrm{~h}$ as células foram coletadas por centrifugação e preparadas para o isolamento dos Linfócitos T por beads magnéticas.

\section{Isolamento dos Linfócitos $\mathrm{T}$ por meio de beads magnéticas}

Os linfócitos T foram isolados de PBMC utilizando o kit que isola essas células negativamente. Esse tipo isolamento foi importante para garantir que as 
células estimuladas na cultura não sofressem nenhum outro tipo de estimulação devido a ligação de outros ligantes. O procedimento seguiu as instruções do kit Dynabeads ${ }^{\circledR}$ Untouched ${ }^{\mathrm{TM}}$ Human T Cells (Invitrogen).

\section{Extração de RNA total de Linfócitos T}

Os linfócitos $\mathrm{T}$ isolados foram submetidos imediatamente a extração de RNA. Para essa técnica, seguia-se todos os procedimentos e cuidados para não haver degradação de RNA, tais como: limpeza da bancada com reagentes que eliminavam qualquer traço de nucleases, materiais plásticos utilizados eram RNase free, as pipetas utilizadas eram exclusivas para RNA e mantidas em ambiente RNAse free. A extração foi realizada com o kit RNeasy Mini (Qiagen) seguindo todas as instruções do fabricante.

\section{Tratamento de RNA total com DNAse}

O tratamento com a DNAse foi realizado segundo as instruções do fabricante utilizando material RNase free e a Turbo DNAse (Ambion).

19. Quantificação de RNA e análise da qualidade por Bioanalyzer

As amostras de RNA total após o tratamento com DNAse foram quantificadas utilizando o equipamento Qubit $₫$ Fluorometric Quantification e o kit Qubit $^{\text {TM }}$ RNA Assay (Life Technologies) seguindo as instruções do fabricante.

A integridade do RNA foi analisada utilizando o equipamento BioanalyzerAgilent 2100 e o kit Agilent RNA 6000 pico chips (Agilent) seguindo as instruções do fabricante. O resultado foi exibido na forma de um gráfico através do qual é possível calcular a razão 28S/18S a partir dos picos gerados. A integridade era considerada adequada com RIN (RNA IntegrityNumber) acima de 7.0 (escala varia de 1 a 10). 


\section{Preparo das amostras de RNA e sequenciamento}

Para o envio das amostras, $1500 \mathrm{ng}$ de RNA total de cada tratamento foi liofilizado utilizando tubos que mantinham a integridade do RNA (RNA stable, da Biomatrica). O preparo da amostra seguiu rigidamente as instruções do fabricante.

A biblioteca de cDNA e o sequenciamento foram realizados junto a empresa Macrogen Korea (Seoul, República da Corea) utilizando tecnologia Illumina - Hiseq 2500 (http://www.macrogen.com/eng/). Para o preparo da biblioteca de cDNA foram utilizados $1000 \mathrm{ng}$ de RNA total empregando a seleção de RNA polyA+ utilizando o kit Illumina TrueSeq RNA. A estratégia empregada foi a de sequenciamento a partir de ambas as extremidades (paired-end) com fragmentos de $150 \mathrm{pb}$. Foram utilizados duas lanes para o sequenciamento, cada uma contendo replicata de todos os tratamentos.

\section{Análises por bioinformática}

As análises de bioinformática foram conduzidas em colaboração com o Laboratório de Bioinformática do Prof. Dr. Peter F. Stadler, sob a orientação do Prof. Dr. Steve Hoffmann na Universidade de Leipzig, Alemanha. Na figura 8 está representado o pipeline de análise empregado para os dados de RNA-Seq. Após a análise da qualidade das sequencias (FastQC), o mapeamento foi realizado utilizando a ferramenta Segemehl.x. Após o mapeamento as reads mapeadas foram contadas com HTSeq. As análises dos genes diferencialmente expressos foram realizadas pelos softwares do pacote DESeq2 em ambiente R. A partir dessas informações foram realizadas as anotações dos genes pelos termos do Gene Ontology (GO terms) utilizando a base de dados g:GOSt (http://biit.cs.ut.ee/gprofiler/index.cgi). A caracterização dos genes diferencialmente expressos entre os tratamentos, bem como a avaliação de seus 
níveis de expressão, foi feita a partir do cálculo do Fold Change (Log2) com $p<0.01$.

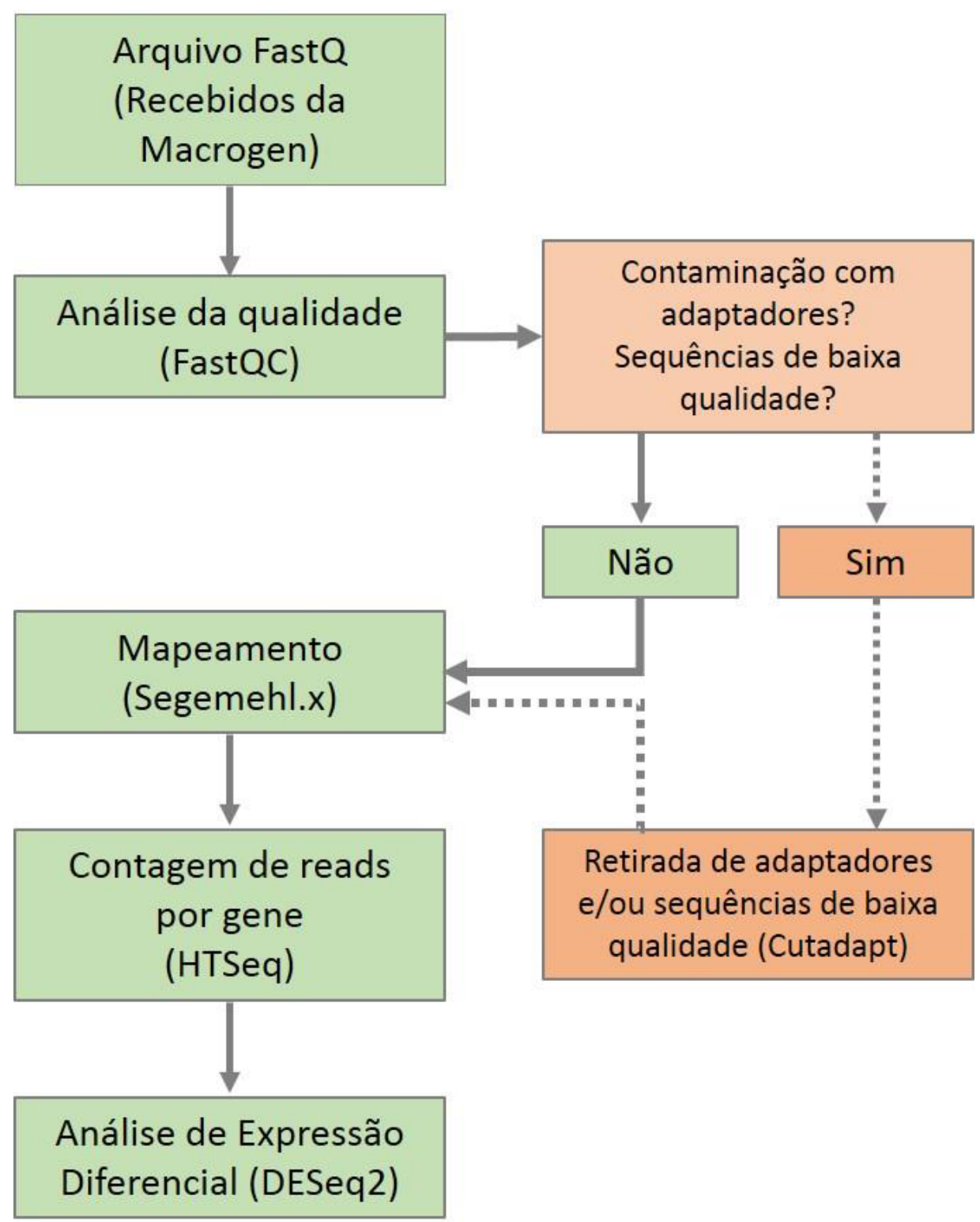

Figura 8 - Pipeline de análise empregado para os dados de RNA-Seq

22. Ferramentas de bioinformática

Os dados recebidos do centro de sequenciamento da Macrogen foram disponibilizados no formato FastQ (tamanho aproximado de 3,2GB/arquivo de 


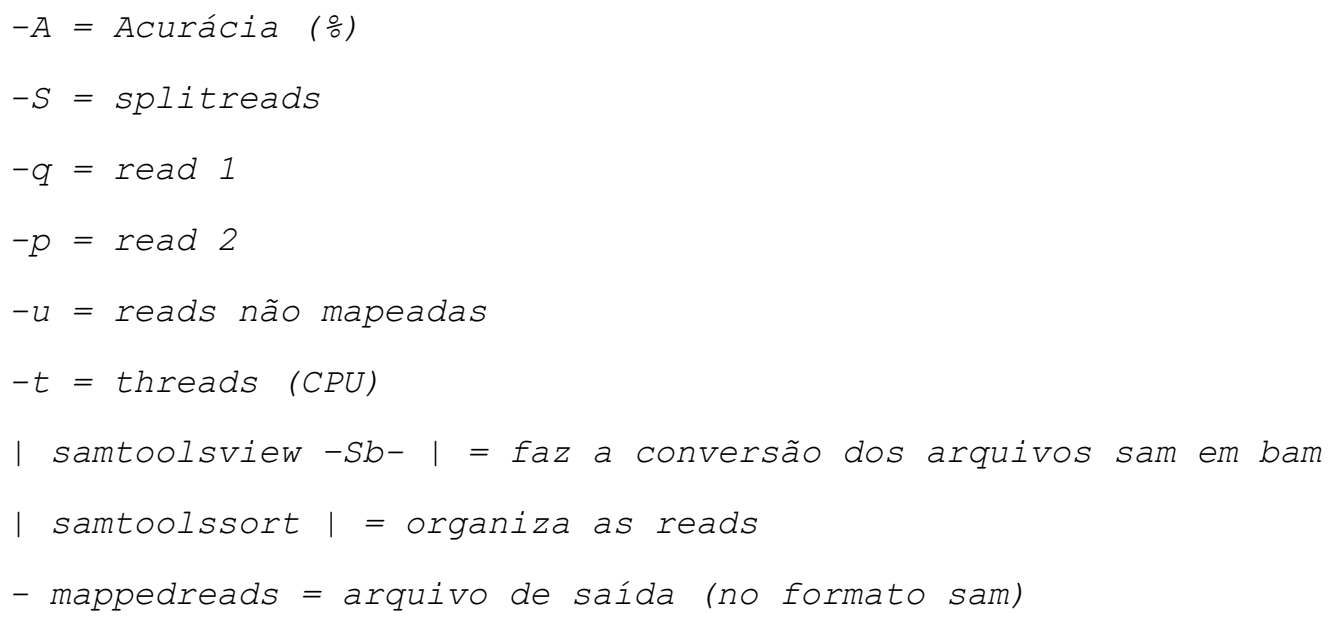

\subsection{HTSeq-count (v. 0.6.1)}

O programa HTSeq-count (Anders et al, 2014) faz a quantificação da expressão por meio da contagem do número de reads que foram mapeadas em um determinado gene. Para a realização do HTSeq-count é necessário o arquivo GTF que contém a informação dos genes codificadores das proteínas anotadas do genoma de referência (v19).

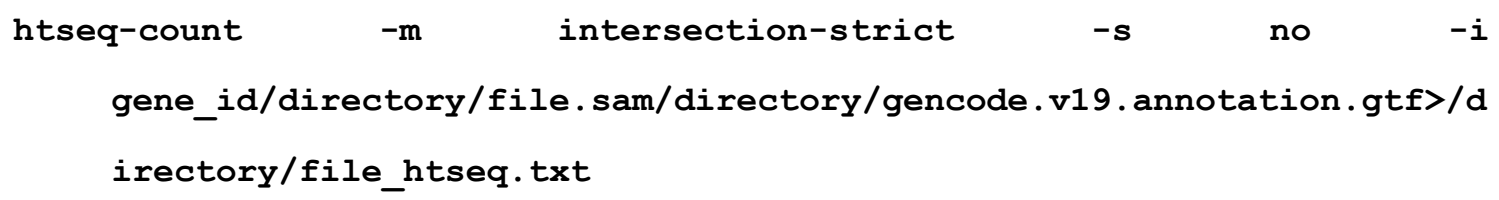




\section{4 DESeq2 (v. 1.6.3)}

A ferramenta DESeq2 (Love et al, 2014) estima a dispersão de cada gene e analisa se há expressão diferencial entre as condições definidas. Nesse caso, a comparação sempre foi realizada entre os dados provenientes das amostras tratadas com anti-CD3 e das não tratadas. O arquivo de saída continha a lista de genes organizados pelo código ensembl (ensembl_id) com as seguintes informações: baseMean, log2FoldChange, pval, padj, FDR. Além dessas informações, o DESeq2 também é capaz de gerar gráficos de dispersão de variabilidade (MA-plot). Esse gráfico elucida sobre a dispersão associada com cada gene. Os genes representados em vermelho são os que possuem FDR menor que 0.1 .

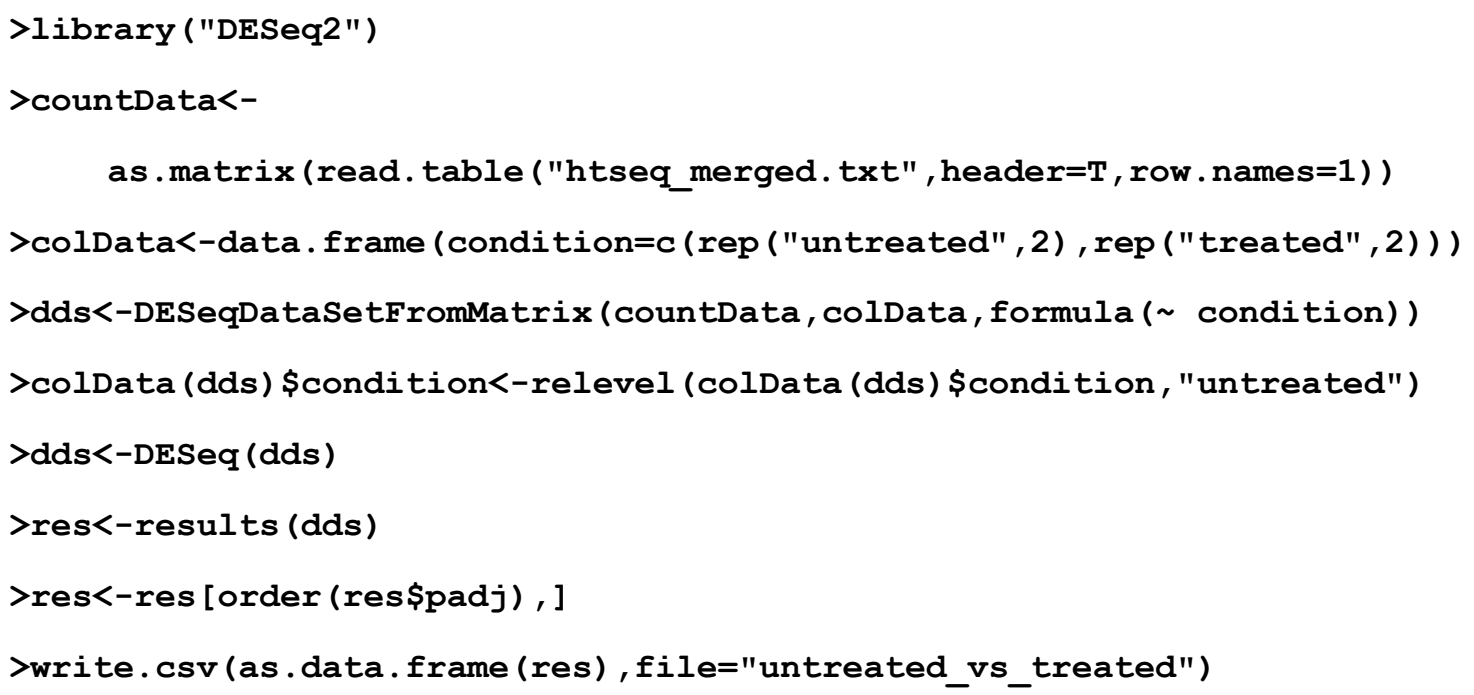

\section{$22.5 \mathrm{~g}:$ GOSt}

Essa ferramenta foi utilizada para a geração dos termos referentes a ontologia de genes (Gene Ontology - GO). A GO compreende termos referentes a três categorias: componentes celulares, processos biológicos e funções celulares. Os dados obtidos de cada tratamento foram utilizados para a realização da análise de GO pela ferramenta disponível em http://biit.cs.ut.ee/gprofiler/ (g:profiler), g:GOSt (Gene GroupFunctionalProfiling). 
Essa ferramenta gerou uma lista de genes usando vários tipos de evidência biológica. A ferramenta realiza uma análise estatística de enriquecimento para encontrar super-representação da informação referente aos termos de GO.

\section{Validação por PCR Array (placa customizada)}

Para a validade dos genes por PCR Array foram utilizadas amostras provenientes de cultura de linfócitos $T$ de três indivíduos diferentes.

\section{Sintese de $c D N A$}

Foram utilizados $500 \mathrm{ng}$ de cada amostra para a síntese do cDNA utilizando o Kit $R T^{2}$ First Strand (Qiagen) seguindo as instruções estabelecidas pelo fabricante.

\section{PCR Array}

O cDNA obtido foi misturado aos componentes do kit RT2 SYBR Green/ROX qPCR Master MIX (Qiagen) conforme as instruções do fabricante. Após a realização do mix, $25 \mu \mathrm{L}$ foi adicionado em cada poço da placa de 96 poços contendo os iniciadores dos genes customizados. A placa customizada (catálogo $n^{\circ} \mathrm{CAPH} 12583 \mathrm{C}$ ) continha 32 genes em triplicatas. Os genes, com seus respectivos códigos de referência, estão listados logo a seguir.

\begin{tabular}{cccccc}
\hline & Gene Symbol & Gene RefSeq \# & Gene Symbol & Gene RefSeq \# \\
\hline 1 & CTLA4 & NM_005214 & 17 & XCL1 & NM_002995 \\
2 & FASLG & NM_000639 & 18 & IL12RB2 & NM_001559 \\
3 & FOXP3 & NM_014009 & 19 & IFNG & NM_000619 \\
4 & GATA3 & NM_002051 & 20 & VDR & NM_000376 \\
5 & GZMB & NM_004131 & 21 & IL7R & NM_002185 \\
6 & IL2RA & NM_000417 & 22 & IL6R & NM_000565 \\
7 & IRF4 & NM_002460 & 23 & IFNGR1 & NM_000416 \\
8 & NFKB1 & NM_003998 & 24 & ITGA6 & NM_000210 \\
9 & PDCD1 & NM_005018 & 25 & B2M & NM_004048 \\
10 & STAT3 & NM_003150 & 26 & HPRT1 & NM_000194
\end{tabular}




\begin{tabular}{cccccc}
11 & TNFRSF18 & NM_004195 & 27 & RPL13A & NM_012423 \\
12 & TNFSF4 & NM_003326 & 28 & GAPDH & NM_002046 \\
13 & TNFRSF4 & NM_003327 & 29 & ACTB & NM_001101 \\
14 & LIF & NM_002309 & 30 & HGDC & SA_00105 \\
15 & CD38 & NM_001775 & 31 & RTC & SA_00104 \\
16 & ABIN-3 & NM_024873 & 32 & PPC & SA_00103 \\
\hline
\end{tabular}

Para cada placa de PCR-Array, foram utilizados cinco genes de controle endógeno: beta-2-microglobulina (B2M), hipoxantina fosforibosil transferase 1 (HPRT1), proteína ribossomola L13a (RPL13A), gliceraldeído-3fosfato desidrogenase (GAPDH) e o beta actina (ACTB). Além dos controles endógenos, foram utilizados ainda controles referente a contaminação genômica de DNA (HGDC), controle da transcrição reversa (RTC) e controle positivo da amplificação (PPC). A PCR em tempo real foi realizada no equipamento $A B I$ StepOne (AppliedBiosytem) com a seguinte programação: 1 ciclo de 10 min a $95^{\circ} \mathrm{C}$ e 40 ciclos de $15 \mathrm{seg}$ a $95^{\circ}$ e $1 \mathrm{~min}$ a $60^{\circ} \mathrm{C}$. Os dados foram exportados no formato de planilha do excelpara as análises. Os valores de Ct foram agrupados e submetidos à análise no software PCR Array Data Analysis disponibilizado pela SABioscience (http://www.sabiosciences.com/RTPCR.php). Esse software gerou valores de FoldChange a partir dos valores de Ct. O FoldChange foi normalizado pela razão entre os $\mathrm{Ct}$ da amostra teste e os $\mathrm{Ct}$ da amostra controle. Foi gerado o FoldRegulation, que representa de uma maneira biológica os valores positivos e negativos, referentes a regulação positiva (superexpressão) e regulação negativa (supressão). No final, os valores de FoldChange foram convertidos em Log (base de 2) para comparação com os dados de RNA-Seq. Foram desconsiderados da análise os genes expressos com valores de $\mathrm{Ct}$ maiores que 35. A escolha do controle endógeno deu-se por escolha automática do software, que foi capaz de avaliar o melhor controle endógeno. 
DESENHO

EXPERIMENTAL 


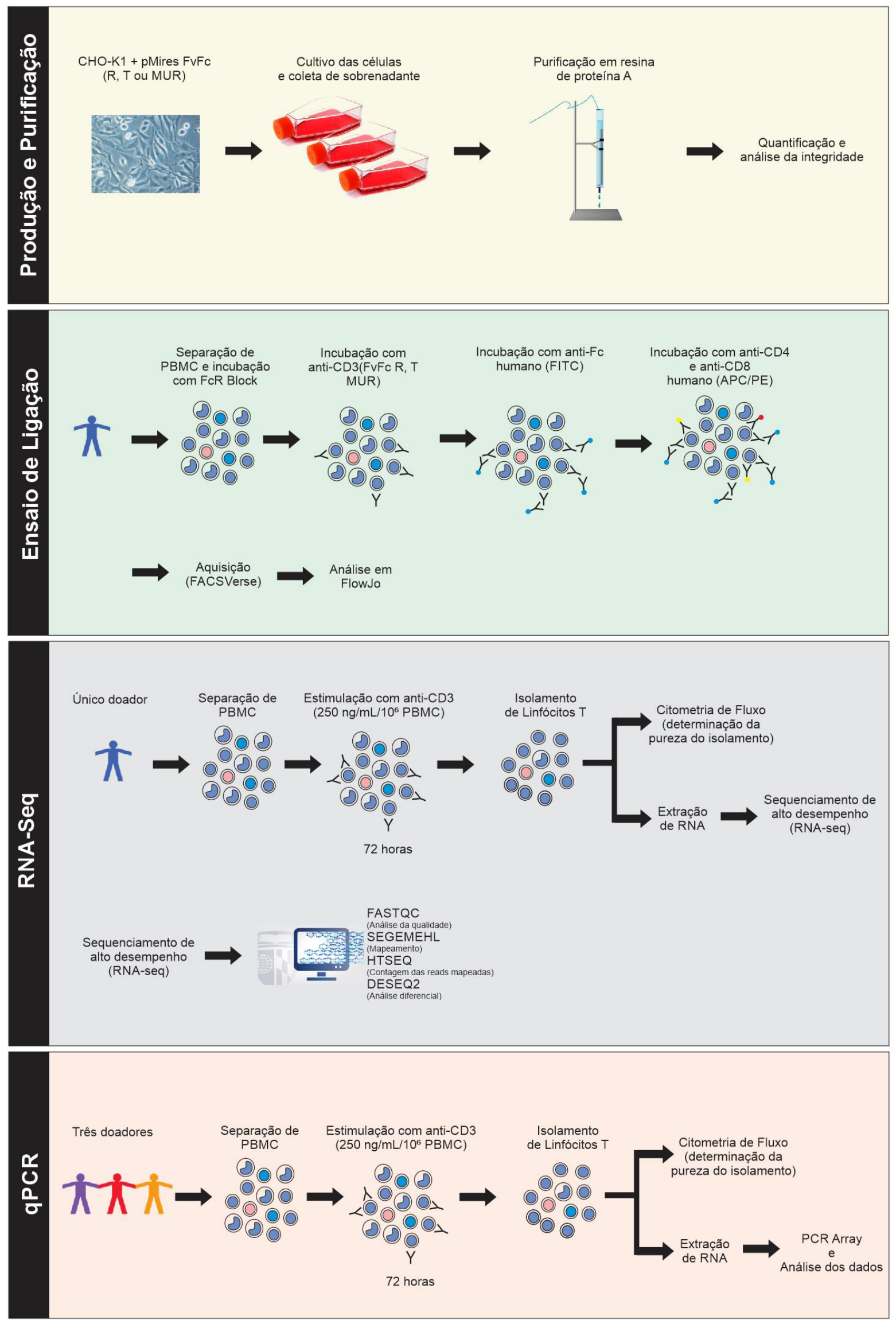


RESULTADOS

$E$

DISCUSSÃO 


\section{RESULTADOS E DISCUSSÃO}

\section{Produção e purificação dos FvFc anti-CD3}

Células $\mathrm{CHO}-\mathrm{K} 1$ transfectadas com os plasmídeos contendo as diferentes versões de FvFc anti-CD3 ( $T, R$ e $M$ ) foram cultivadas à $37^{\circ} \mathrm{C}$. Os sobrenadantes de cultura de cada transfectoma foram acumulados por um período de seis meses e a produtividade específica de cada construção foi avaliada (Tabela 4). Foi observada uma produtividade entre 12 e 17 em todas as construções em forma de $\mathrm{FvFc}$, sendo a construção $\mathrm{FvFc} T$ obteve a maior produtividade específica.

Tabela 4. Produtividade específica dos anticorpos anti-CD3*

\begin{tabular}{lccc}
\hline Construção & $\begin{array}{c}\text { Concentração } \\
(\mathbf{n g} / \mathbf{m L})\end{array}$ & $\begin{array}{c}\text { Quantidade de } \\
\text { células por garrafa de } \\
\mathbf{1 5 0} \mathbf{~ c m}^{\mathbf{2}}\end{array}$ & $\begin{array}{c}\text { Produtividade } \\
\text { específica } \\
\text { (pg/dia/célula) }\end{array}$ \\
\hline FvFc T & 233 & $1,9 \times 10^{6}$ & 17 \\
FvFc R & 113 & $1,1 \times 10^{6}$ & 14 \\
FvFc M & 110 & $1,3 \times 10^{6}$ & 12 \\
\hline * Os resultados foram obtidos a partir da quantificação do anticorpo dos sobrenadantes nos \\
diferentes transfectomas por ELISA, acumulados por um período de sete dias, e da contagem \\
das células viáveis em câmara de Neubauer pelo método de exclusão do corante vital azul de \\
trypan.
\end{tabular}

Após o acúmulo dos sobrenadantes contendo os anticorpos recombinantes, foram testadas várias técnicas de purificação utilizando colunas HiTrap de proteína A da GE $(5 \mathrm{~mL})$ ou resina de proteína $A$ da Pierce (ImmunoPure Plus Immobilized Protein). Foram utilizados para essa purificação sobrenadantes de cultura contendo o anticorpo recombinante FvFc T. Para a purificação com a coluna da GE o sobrenadante necessitava ser dialisado em 
tampão de ligação específico. Já para a purificação com a resina da Pierce não era necessário esse procedimento, pois utilizava-se sobrenadante equilibrado com o tampão de ligação específico da Pierce. O mmelhor rendimento de purificação obtido foi com a resina de proteína A da Pierce, na qual obteve uma eficiência de purificação de $96 \%$, enquanto que na técnica utilizando coluna da GE, a eficiência obtida foi de cerca de $73 \%$. Além disso, as proteínas eluídas eram mais concentradas com a técnica da resina imobilizada, uma vez que elas eram eluídas em poucas frações (Figura 9). Logo, esta técnica foi a escolhida para proceder com a purificação dos FvFc R, T e M.
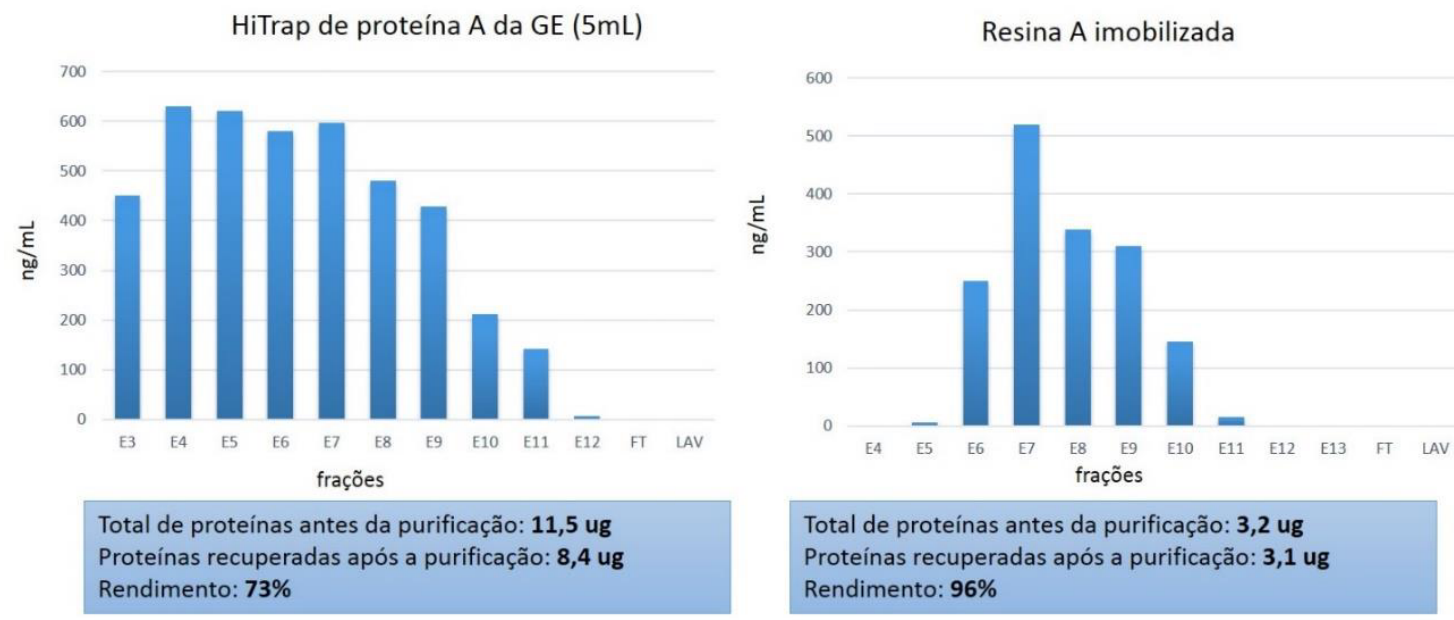

Figura 9 - Gráfico comparativo de eficiência de purificação. $O$ gráfico demostra o rendimento obtido pela técnica de purificação com coluna de $5 \mathrm{~mL}$ da GE e com Resina proteína A imobilizada.

Após as purificações, as frações que continham a maior quantidade de proteína detectada pela técnica de Dot Blotting (dados não mostrados) foram concentradas e dialisadas em PBS. Para quantificação foi realizado ELISA indireto utilizando concentrações conhecidas de IgG humana que permitiram a obtenção de uma curva padrão. As concentrações obtidas para cada FvFc estão listadas na Tabela 5. Houve um melhor rendimento de proteína purificada do FvFc R e menor para FvFc T. 
Tabela 5 - Concentração $(\mu \mathrm{g} / \mathrm{mL})$ dos FvFc após purificação e diálise em PBS

\begin{tabular}{lc}
\hline & $\begin{array}{c}\text { Concentração } \\
(\mu \mathbf{g} / \mathbf{m L})\end{array}$ \\
\hline FvFc R & 451 \\
FvFc T & 122 \\
FvFc M & 298 \\
\hline
\end{tabular}

Os anticorpos purificados, dialisados em PBS e concentrados foram submetidos a SDS-PAGE seguido por coloração com Comassie e Western Blot para a análise da integridade. Os fragmentos referentes as cadeias pesadas e leves dos anticorpos recombinantes podem ser observados em torno de $55 \mathrm{kDa}$ e $27 \mathrm{kDa}$, respectivamente. As demais bandas observadas podem ser produtos de degradação ou agregados (Figura 10).

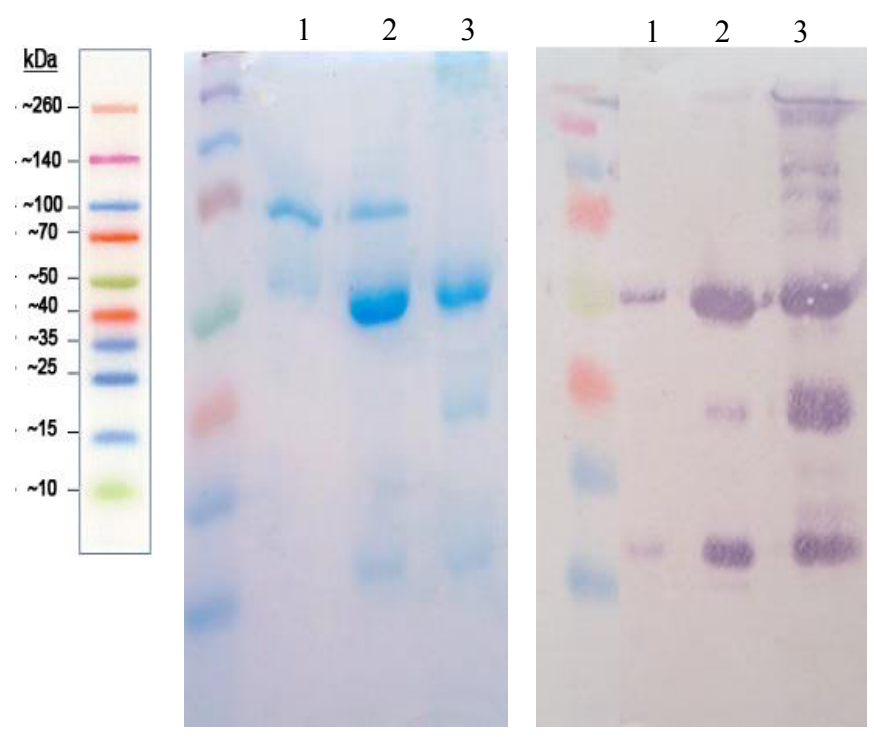

Figura 10 - Análise dos anticorpos anti-CD3 por SDS-PAGE. Purificados a partir de sobrenadante de cultura de transfectomas de CHO-K1. Foi realizada uma eletroforese em gel SDS 12\%, para separação dos anticorpos purificados. Foi feita coloração com prata utilizando o Comassie e Western Blot revelado com um anticorpo anti-Fc humano conjugado com fosfatase alcalina. Marcador Spectra Multicolor Broad Range (Fermentas) 1) FvFc M. 2) FvFc R. 3) FvFv T. 


\section{Ensaio de ligação direta dos FvFc à molécula CD3 por}

citometria de fluxo.

Após confirmação da integridade dos anticorpos foi analisada a capacidade de ligação destes ao CD3 humano presente na superfície de linfócitos T. Para essa investigação foi realizado um ensaio de ligação direta às células mononucleares de sangue periférico. As células foram incubadas com 62 ng ou $1000 \mathrm{ng}$ dos FvFc recombinantes, separadamente. Após lavagem, a incubação foi realizada utilizando o anticorpo anti-lgG humana FITC. A incubação final foi feita com os anticorpos anti-CD4 e CD8 humanos conjugados com PE e APC respectivamente. A análise da ligação foi realizada por citometria de fluxo e os gráficos gerados no software FlowJo.

Não foram observadas diferenças significativas quando foi comparada a porcentagem de células marcadas para as diferentes concentrações (1000 ng e $62 \mathrm{ng}$ ) e entre as diferentes versões dos FvFcs humanizados.

Além da porcentagem de células marcadas com os anticorpos antiCD3 também foi avaliada a mediana de intensidade de fluorescência (MIF). Essa mediana indica a quantidade de anticorpo adsorvido à superfície das células. Os resultados de MIF foram obtidos a partir da análise do quadrante das marcações para CD4 e CD8. Foram observadas que as medianas tinham valores maiores no quadrante referente às células T CD8+, tanto com 62 ng quanto com 1000 ng, para todos os FvFcs (Tabela 6).

Todos os anticorpos anti-CD3 humano mostraram-se capazes de se ligar à molécula CD3 presente em linfócitos $\mathrm{T}$. Os anticorpos humanizados na versão T e R apresentaram atividade ligante similar a versão quimérica do OKT3 (FvFc M). Além disso, foi possível observar que os valores de MIF eram maiores na população T CD8+. 
Tabela 6 - Medianas de intensidade de fluorescência (MIF) de FITC e porcentagem de linfócitos $\mathrm{T}$ marcados com os FvFc recombinantes.

\begin{tabular}{lcccccc}
\hline & \multicolumn{5}{c}{ MFI (1000 ng) } & \multicolumn{4}{c}{ MFI (62,5 ng) } \\
\hline FvFc R & CD4 & CD8 & Freq (\%) $^{*}$ & CD4 & CD8 & Freq (\%) $^{*}$ \\
FvFc T & 341 & 246 & 10,0 & 47,8 & 285 & 10,3 \\
FvFc M & 40,1 & 211 & 10,2 & 49,1 & 218 & 11,2 \\
& 40,3 & 308 & 10,6 & 37,1 & 294 & 10,8 \\
\hline
\end{tabular}

\section{Estimulação de PBMC humano e isolamento de Linfócitos $T$}

Para comparar o perfil de expressão gênica após a estimulação da molécula CD3, PBMC foram cultivados com as versões de FvFc (humanizadas $\mathrm{R}$ e T, quimérica M) e com o anticorpo murino comercial anti-CD3 (OKT3). Tanto as amostras destinadas para RNA-Seq (de um único doador) ou destinadas para PCR Array (três doadores) foram cultivadas nas mesmas condições. Depois de 72 horas, as células foram coletadas e os Linfócitos $T$ foram isolados negativamente utilizando bilhas magnéticas. A pureza dos Linfócitos T obtida foi maior que $96 \%$ para todas as amostras. As células contaminantes nas amostras foram: células B e NK (aproximadamente 3\%) e monócitos (menos que 1\%) determinadas por citometria de fluxo (Figura 11). 

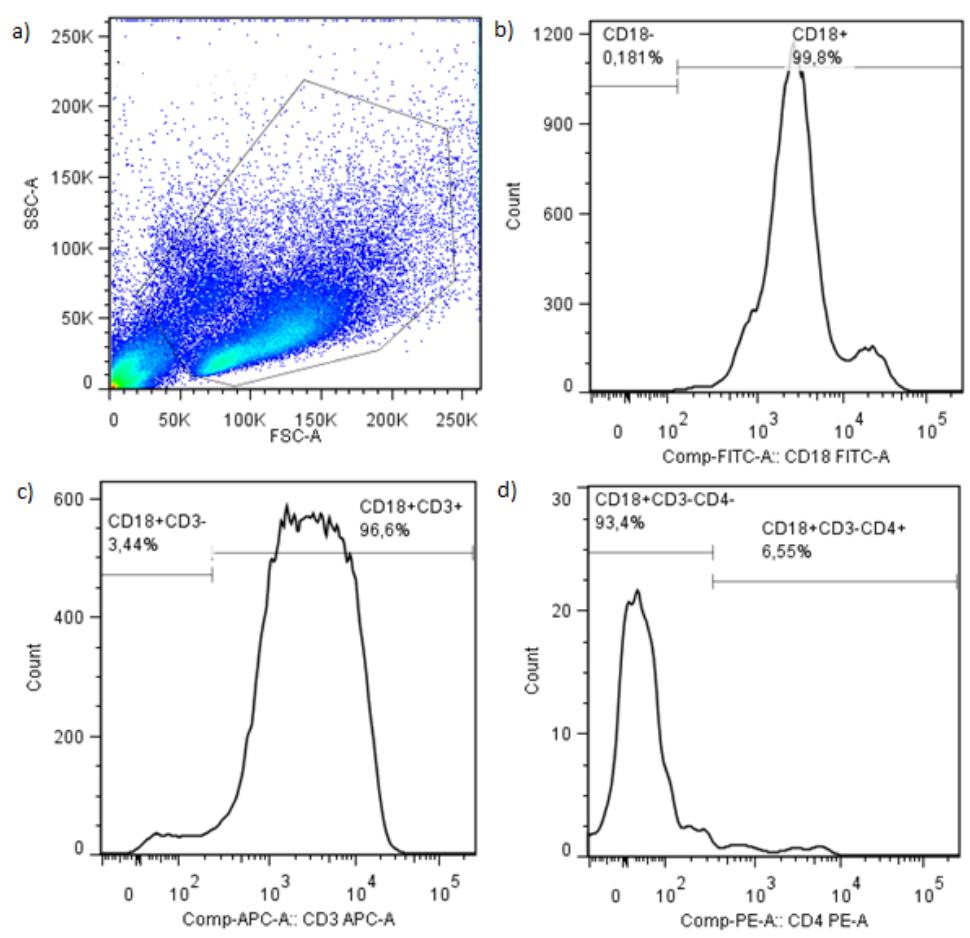

Figura 11 - Análise da separação de Linfócitos T da cultura de PBMC. As amostras foram incubadas com anticorpo anti-CD18 FITC, anti-CD3 APC e anti-CD4 PE. Em a) representação gráfica as características físicas das células determinadas por dispersão. O FSC (foward scatter) representa o tamanho das células e SSC a granulosidade celular. Em b) expressão da molécula CD18, em c) a expressão da molécula CD3 dentro da população CD18+ e em d) a expressão da molécula CD4 dentro da população CD18+CD3-. Representação da separação para o tratamento com FvFc R. Todos as outras amostras obtiveram o mesmo perfil de separação.

\section{Análise da qualidade do RNA total}

Após a separação dos linfócitos T e análise por citometria de fluxo, o RNA total foi extraído e a sua integridade e rendimento foram checados. A quantidade de células obtidas após o isolamento variou entre $1-3 \times 10^{6}$ células. O rendimento da extração variou de $3 \mu \mathrm{g}$ a $35 \mu \mathrm{g}$ de RNA total, sendo que o tratamento com o OKT3 foi o que obteve o maior rendimento em todas as amostras, seguido pelo FvFc R. As amostras de linfócitos T não tratadas com os anticorpos foram as que obtiveram o menor rendimento de RNA. 
As amostras de RNA foram submetidas a tratamento com DNAse para eliminação de qualquer traço de DNA genômico. Para avaliar a pureza das amostras de RNAs foi utilizado o equipamento Bioanalyzer 2100 (Agilent). Esse instrumento utiliza um corante fluorescente que permite avaliar tanto a integridade quanto a concentração de RNA na amostra. O princípio é similar à eletroforese em gel de agarose, contudo, a corrida é realizada em um capilar contendo o polímero e é gerado um eletroferograma o qual é analisado automaticamente pelo aparelho que detecta qualquer traço de degradação. $O$ resultado é exibido na forma de um gráfico (Figura 12). É possível calcular a razão 28S/18S com maior precisão a partir dos respectivos picos e ainda calcular o RIN (RNA Integrity Number) que pode variar de 1 a 10. Os valores de RIN são considerados bons quando são superiores a 7. Todas as amostras obtiveram RIN variando entre 7.0 - 9.0 (a maioria, era superior a 8.0).
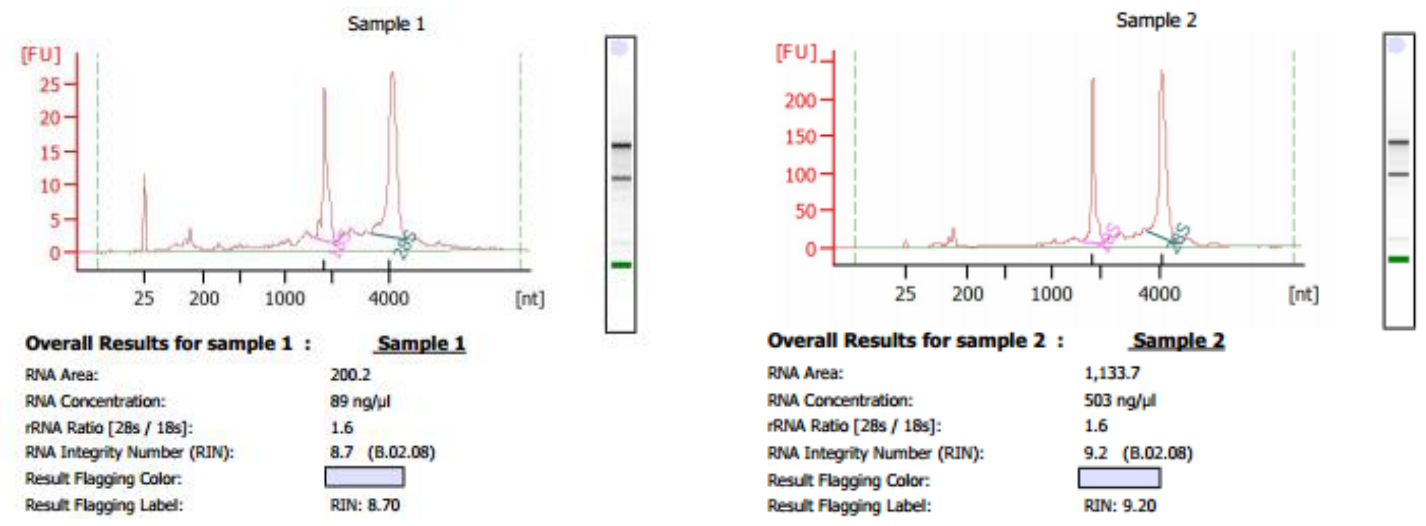

Figura 12 - Análise da pureza do RNA por Bioanalyzer. As amostras de foram analisadas após o tratamento com DNase. As amostras acima são originadas da primeira cultura. Em a) Sample $1=$ RNA da cultura não tratada. Sample $2=$ RNA da cultura tratada com FvFc R. Todas as outras análises seguiram um padrão similar com RIN variando entre 7.0 a 9.0 . 


\section{Análise da qualidade dos dados de RNA-Seq}

Após a análise da qualidade, 1500 ng de RNA total extraídos de linfócitos T tratados com as diferentes versões de FvFc e OKT3 (em duplicata, de um único indivíduo) foram submetidas ao sequenciamento na plataforma Illumina (HiSeq 2500). Os dados do sequenciamento foram disponibilizados no formato FastQ. Esse formato de arquivo, gerado pelo sequenciador Illumina, contêm sequências de nucleotídeos juntamente com a representação dos níveis de qualidade. A partir desse arquivo foi analisada a qualidade das sequências utilizando o programa FastQC. Este programa permite gerar gráficos das sequências levando em consideração a qualidade média total por base, a qualidade média de todas as leituras e o conteúdo $G+C$, além de informar se existe sequências super-representadas, que podem referir-se a contaminação com os iniciadores utilizados no sequenciamento ou mesmo uma escassez de variabilidade na amostra. Caso haja presença de sequencias ou subsequências de iniciadores é necessário a realização das etapas de filtragem dos dados. Nenhum dos dados obtiverem sequências super-representadas eliminando a etapa de retirada de iniciadores. Em relação à qualidade, todos os dados apresentaram boa qualidade. A Figura 13 representa um exemplo da qualidade da sequência. Todos os outros dados obtiveram um padrão de qualidade similar (Anexo I). 


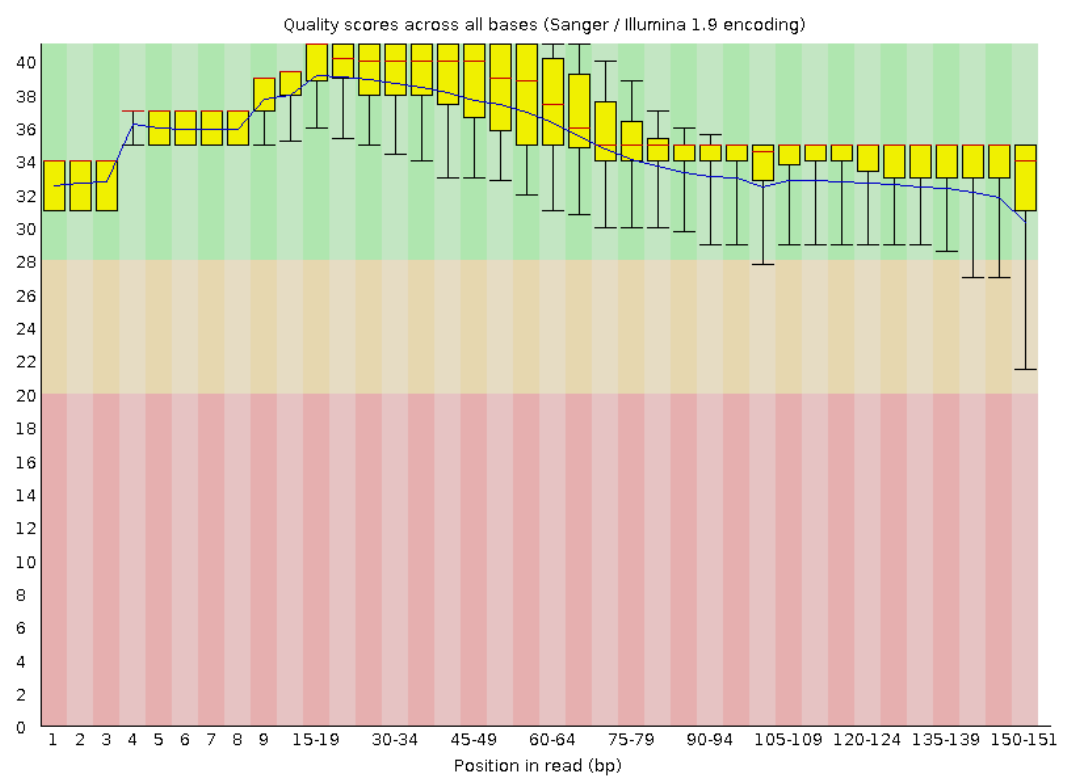

Figura 13 - Representação gráfica da qualidade dos dados de RNA-Seq provenientes de sequenciadores Illumina. Qualidade boa em verde, razoável em laranja e ruim em vermelho (FvFc M (1)).

6. Análise da expressão gênica global de Linfócitos $T$ após estimulação

Para analisar o perfil de expressão gênica de Linfócitos $T$ tratados com anticorpos contra a molécula CD3, foi sequenciado o transcritoma de células estimuladas e não estimuladas de um único indivíduo em replicatas técnicas. Foi utilizada a metodologia "paired-end" da plataforma Illumina. Mais de 55 milhões de reads de tamanho de $150 \mathrm{pb}$ foram obtidas. As pequenas sequências foram mapeadas contra o genoma de referência humano (versão hg19). O objetivo do mapeamento é encontrar um único local onde a pequena sequência é idêntica à de referência. Nesse trabalho foi utilizado o software segemehl.x para mapeamento das sequências. Segemehl é capaz de detectar não apenas divergências mas também inserções e deleções. Os resultados do mapeamento estão apresentados na Tabela 7. Essa Tabela mostra o total de reads mapeadas 
contra o genoma de referência. Para todos os tratamentos, mais de $84 \%$ de reads foram mapeadas.

Tabela 7 - Estatística do mapeamento

\begin{tabular}{rccc}
\hline Replicatas & $\begin{array}{c}\text { Todas as } \\
\text { Reads }\end{array}$ & Reads mapeadas & $\begin{array}{c}\text { \% Reads } \\
\text { mapeadas }\end{array}$ \\
\hline Não estimulado (1) & 59.623 .760 & 54.990 .450 & 92 \\
Não estimulado (2) & 61.444 .968 & 58.149 .032 & 94 \\
FvFc R (1) & 57.712 .398 & 54.065 .899 & 93 \\
FvFc R (2) & 54.633 .094 & 51.012 .088 & 93 \\
FvFC T(1) & 58.368 .986 & 53.230 .646 & 91 \\
FvFC T (2) & 60.268 .834 & 56.718 .611 & 94 \\
FvFC M (1) & 62.274 .364 & 58.117 .856 & 93 \\
FvFC M (2) & 65.142 .278 & 60.452 .698 & 92 \\
OKT3 (1) & 60.724 .236 & 51.446 .623 & 84 \\
OKT3 (2) & 59.435 .924 & 50.336 .034 & 84 \\
\hline
\end{tabular}

Depois do mapeamento, o número de reads mapeadas em cada gene foi determinado por HTSeq. A normalização foi realizada utilizando DESeq2. Esse pacote informa o valor da razão da expressão (fold-change) em logaritmo de base 2 (Fold Change $\left(\log _{2}\right)$ ). As linhas de comando utilizadas tanto para a contagem das reads (HTSeq) quanto na normalização utilizando DESeq2 estão disponíveis na seção de "métodos". A normalização tornou os dados das amostras tratadas comparáveis com a amostra controle. A amostra controle foi a amostra com os Linfócitos T não estimulados. Os genes utilizados para as análises foram os que obtiveram Fold Change $\left(\log _{2}\right)>1.0$ e $<-1.0$ com valor de $p(p v a l)<0.01$. Por ter obtido um número baixo de genes diferencialmente expressos comparado aos outros tratamentos (58 com $\mathrm{p}<0.05)$, os dados de FvFc T foram retirados das análises. A visualização dos genes diferencialmente 
expressos foi representada utilizando gráfico de dispersão de variabilidade (MAplot) conforme a Figura 14.

O tratamento com o anticorpo murino OKT3 mostrou o maior número de genes diferencialmente expressos (8805), seguido do tratamento com FvFc $R$ (3202) e FvFc M (1831). A Tabela 8 resume a quantidade de genes que foram negativa ou positivamente regulados entre os tratamentos. A lista completa dos genes regulados comumente com $\mathrm{p}<0.01$ está disponível no Anexo II.

Tabela 8. Genes diferencialmente expressos em cada tratamento

\begin{tabular}{lcc}
\hline Tratamento & FC $>\mathbf{1 . 0}$ & FC $<-1.0$ \\
\hline OKT3 & 3247 & 3684 \\
FvFc R & 1811 & 1216 \\
FvFc M & 912 & 952 \\
\hline A Tabela mostra o número de genes que são ou regulados positivamente $(F C>1.0)$ ou \\
negativamente (FC<-1.0). FC= Fold Change (Log $($ tratado/controle)). Todos os genes com valor \\
de $p<0.01$.
\end{tabular}

Foi realizada uma comparação da expressão gênica global entre os tratamentos com os três anticorpos (Figura 15). Para essa comparação, somente os genes expressos diferencialmente com valor de $p<0.01$ foram utilizados. Foram encontrados 1053 genes igualmente regulados entre os tratamentos. Os grupos de genes dos diferentes tratamentos estão demonstrados no diagrama de Venn na Figura 15. 

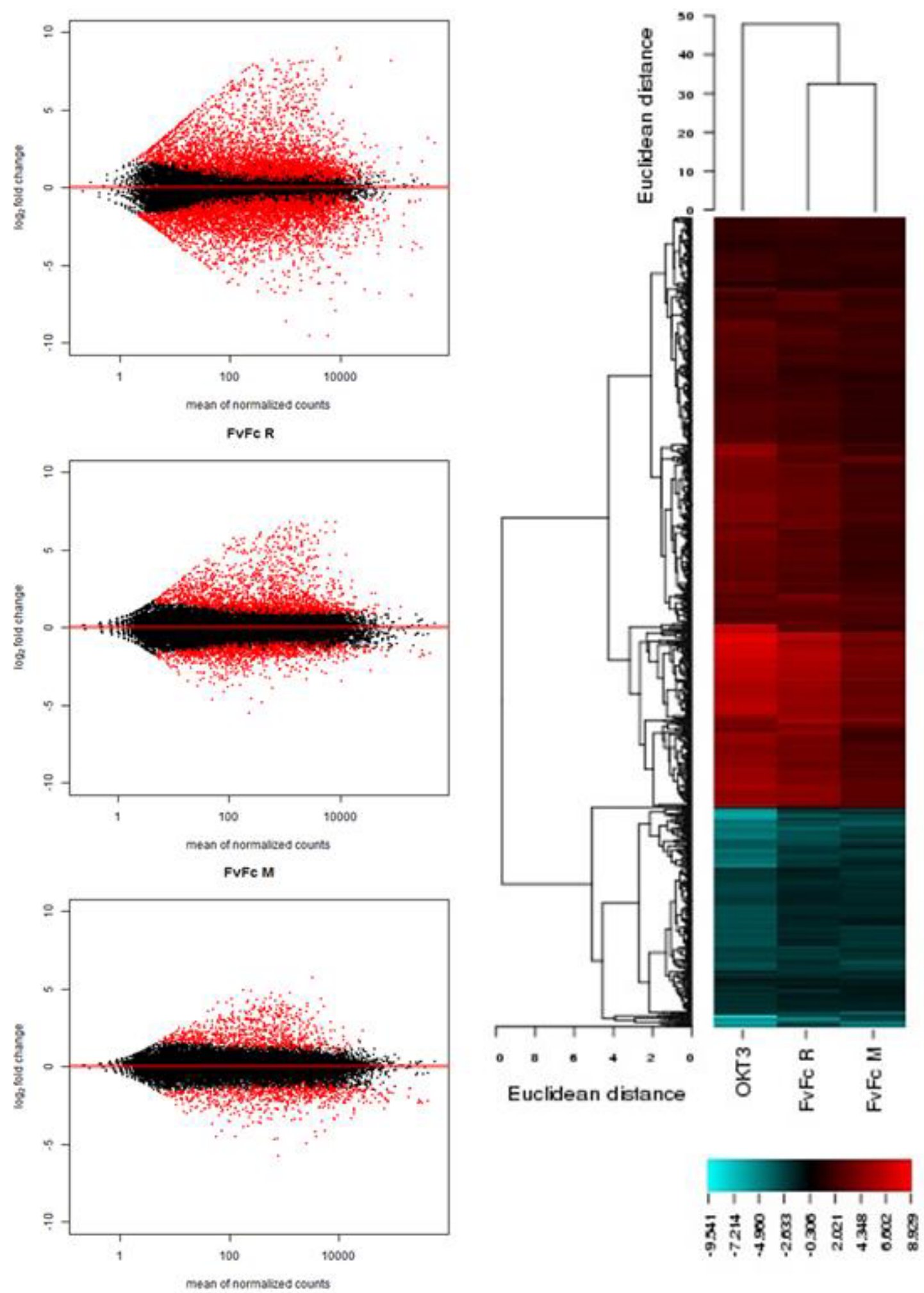

Figura 14 - Análise da expressão gênica global. Gráfico de dispersão do tipo MA-plot (esquerda) e heatmap (a direita). Os pontos em vermelho no gráfico MA-plot representam os genes induzidos ou reprimidos. Para o heatmap foram utilizados 1000 genes com maiores valores de Fold Change (Log2), tanto com regulação negativa e positiva. 
O tratamento FvFc R compartilha 62 genes igualmente regulados com o tratamento FvFc M e 1823 com OKT3. Contudo, o tratamento com FvFc M compartilha apenas 561 genes quando comparado com o OKT3. Em geral, o tratamento com OKT3 resultou no maior número de genes regulados. A regulação gênica promovida pelo anticorpo FvFc $R$ foi mais similar com o OKT3 do que o FvFc M (que estruturalmente, é mais similar ao OKT3).

FvFc R

3202

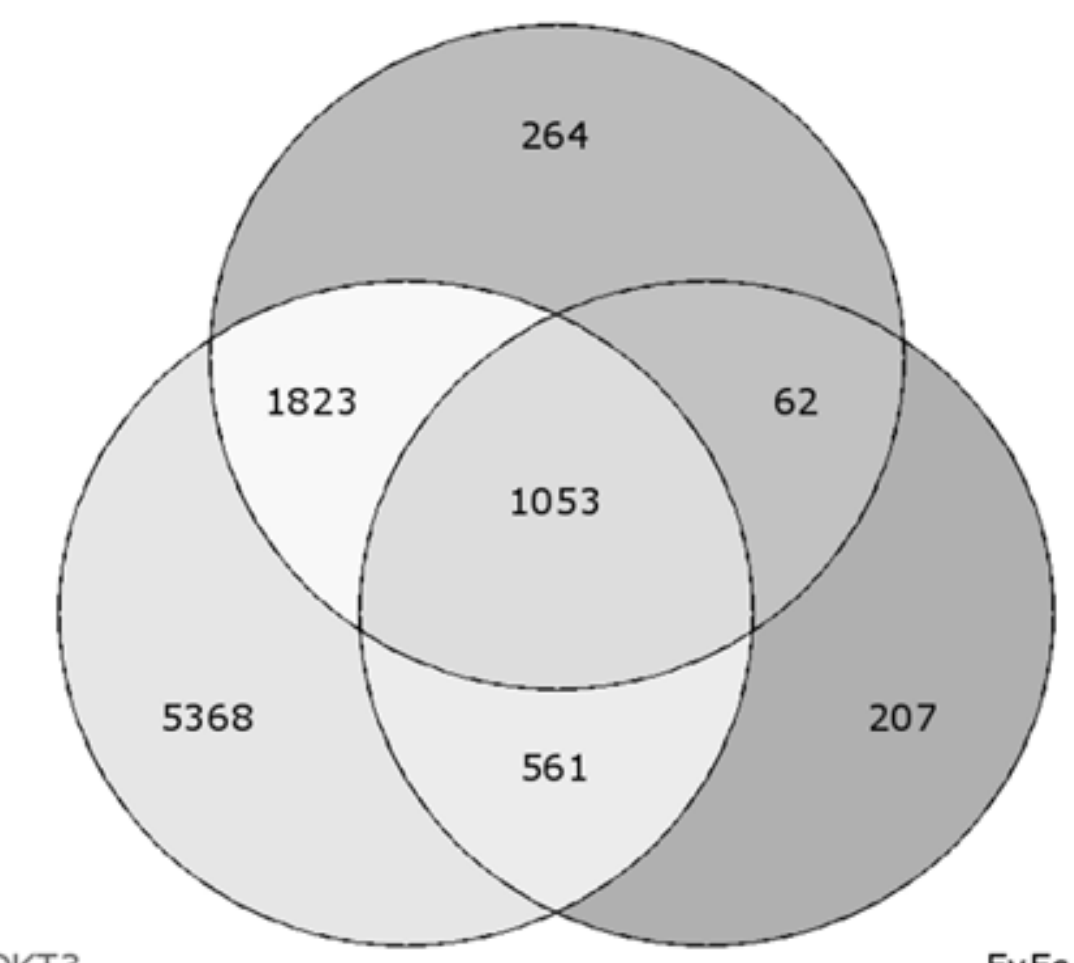

OKT3

FvFc M

8805

1883

Figura 15 - Diagrama de Venn. Demonstração da contagem de genes regulados em comum ou em um único tipo de tratamento, a partir dos dados de RNA-Seq. Todos as análises empregaram valor de $p<0.01$ como critério de significância estatística.

Para analisar o papel biológico dos genes diferencialmente expressos entre os diferentes tratamentos, foram utilizadas análises de enriquecimento de termos de ontologia gênica (Gene Ontology (GO), g:Profiler, Institute of Computer Science, University of Tartu, Estonia). Essa ferramenta tem como 
objetivo produzir um vocabulário dinâmico, controlado e precisamente definido para descrever as funções dos genes em qualquer organismo. Cada gene é nomeado em três categorias de ontologia: processos biológicos, função molecular e componente celular.

As análises de enriquecimento de GO foram realizadas na lista de genes diferencialmente expressos com valor de $p<0.01$, com um total de 8805 , 3202 e 1883 genes para OKT3, FvFc R e FvFc M respectivamente. Essas análises geraram listas gigantescas de genes classificados por termos dentro das três categorias já descritas. Destacamos apenas os processos biológicos enriquecidos, dentre eles, os principais termos envolvidos com a função imunológica e ciclo celular (Figura 16). Os dados foram normalizados e expressos em porcentagem (Tabela 9). O termo "resposta ao estresse" apresentou o maior número de genes classificados (1358 (22\%), 372 (11\%) e 427 (15\%) para OKT3, FvFc R e FvFc M, respectivamente).

Tabela 9 - Ontologias gênicas (GO) de funções e processos celulares alterados pelo tratamento com os anticorpos anti-CD3

\section{FvFc MUR}

FvFc R

OKT3

Termos $n^{\circ}$ Genes

(\%) $\quad n^{\circ}$ Genes

(\%) $\quad n^{\circ}$ Genes

$(\%)$

adaptive immune

$\begin{array}{rrrrrrr}\text { response } & 49 & 2,60 & 42 & 1,31 & 127 & 1,44 \\ \text { adaptive immune } & 44 & 2,34 & 37 & 1,16 & 113 & 1,28\end{array}$

response based on

somatic recombination

of immune receptors

built from

immunoglobulin

superfamily domains 


\begin{tabular}{|c|c|c|c|c|c|c|}
\hline apoptotic process & 204 & 10,83 & 171 & 5,34 & 674 & 7,65 \\
\hline $\mathrm{B}$ cell activation & 43 & 2,28 & 171 & 5,34 & 63 & 0,72 \\
\hline cell activation & 153 & 8,13 & 23 & 0,72 & 356 & 4,04 \\
\hline cell cycle checkpoint & 39 & 2,07 & 57 & 1,78 & 13 & 0,15 \\
\hline cell cycle process & 194 & 10,30 & 269 & 8,40 & 544 & 6,18 \\
\hline cell proliferation & 258 & 13,70 & 215 & 6,71 & 676 & 7,68 \\
\hline cytokine production & 90 & 4,78 & 66 & 2,06 & 224 & 2,54 \\
\hline immune response & 212 & 11,26 & 160 & 5,00 & 575 & 6,53 \\
\hline $\begin{array}{r}\text { immune system process } \\
\text { immunoglobulin } \\
\text { mediated immune }\end{array}$ & 329 & 17,47 & 243 & 7,59 & 910 & 10,34 \\
\hline response & 26 & 1,38 & 14 & 0,44 & 60 & 0,68 \\
\hline leukocyte activation & 115 & 6,11 & 86 & 2,69 & 278 & 3,16 \\
\hline \multicolumn{6}{|l|}{ leukocyte mediated } & 2,01 \\
\hline immunity & 52 & 2,76 & 39 & 1,22 & 127 & 1,44 \\
\hline leukocyte proliferation & 48 & 2,55 & 42 & 1,31 & 15 & 0,17 \\
\hline $\begin{array}{l}\text { lymphocyte activation } \\
\text { lymphocyte mediated }\end{array}$ & 97 & 5,15 & 78 & 2,44 & 233 & 2,65 \\
\hline immunity & 38 & 2,02 & 35 & 1,09 & 105 & 1,19 \\
\hline $\begin{array}{l}\text { lymphocyte proliferation } \\
\text { mononuclear cell }\end{array}$ & \multicolumn{5}{|c|}{ mononuclear cell } & 1,24 \\
\hline proliferation & 46 & 2,44 & 39 & 1,22 & 111 & 1,26 \\
\hline \multicolumn{7}{|l|}{$\begin{array}{l}\text { production of molecular } \\
\text { mediator involved in }\end{array}$} \\
\hline inflammatory response & 13 & 0,69 & 25 & 0,78 & 62 & 0,70 \\
\hline programmed cell death & 205 & 10,89 & 173 & 5,40 & 677 & 7,69 \\
\hline response to cytokine & 83 & 4,41 & 71 & 2,22 & 259 & 2,94 \\
\hline response to stress & 427 & 22,68 & 372 & 11,62 & 1358 & 15,42 \\
\hline $\mathrm{T}$ cell proliferation & 33 & 1,75 & 31 & 0,97 & 76 & 0,86 \\
\hline
\end{tabular}




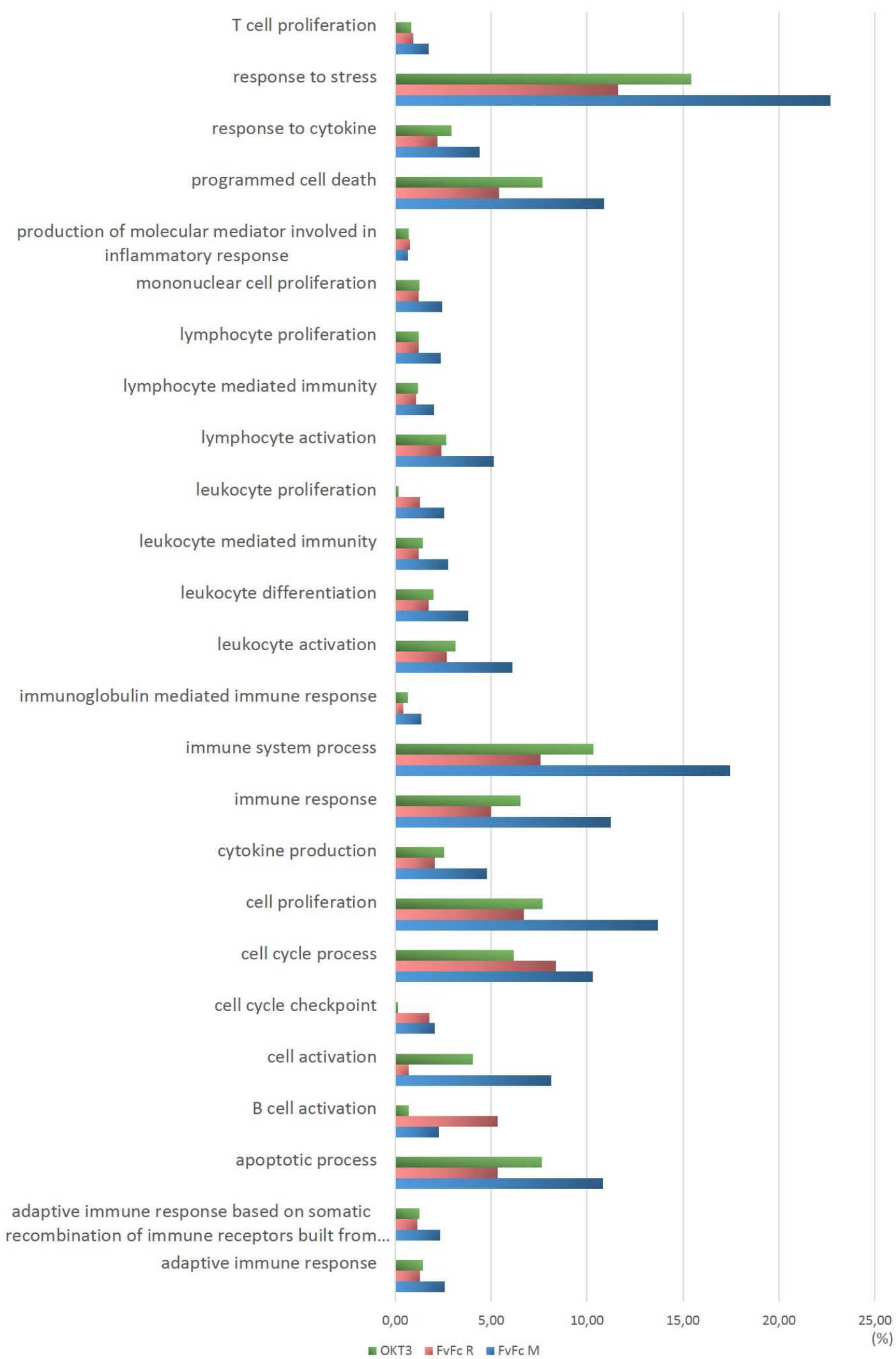

Figura 16 - Representação gráfica das ontologias gênicas (GO) de funções e processos celulares alterados pelo tratamento com os anticorpos anti-CD3. Dados normalizados e expressos em porcentagem (\%). 
Os termos "morte celular programada" e "processo apoptótico" também apresentaram grande quantidade de genes. $\mathrm{O}$ tratamento com FvFc M apresentou as maiores porcentagens de genes em todos os termos, seguido de FvFc R. Muitos genes envolvidos com "ativação celular", "proliferação celular" e "processo de ciclo celular" foram observados. Entre estes, 76, 31 e 33 genes estavam envolvidos especificamente com proliferação de Linfócito T para OKT3, FvFc R e FvFc M, respectivamente.

\section{Expressão diferencial de genes envolvidos com a regulação do} sistema imune

Genes envolvidos em vários aspectos da regulação imune foram diferencialmente expressos em todos os tratamentos. Dentre eles, genes codificadores de várias moléculas de superfície celular (ex. IL2RA, CTLA4, CD2, CD22, CD27), de citocinas (IL4, IL6, INFG), de proteínas envolvidas com transdução de sinal (família MAPK, família JAK), fatores de transcrição (NFKB1, FOXP3, IRF4, IRF6) e muitos outros genes.

\subsection{Expressão de genes envolvidos com anergia ou morte celular}

As vias de anergia e de morte celular têm papel fundamental na função imune, particularmente a morte celular induzida por ativação (AICD). Tanto a AICD quanto a anergia são mecanismos essenciais para a manutenção da homeostase celular nos organismos multicelulares (Salmena et al, 2003). Vários estudos demostraram que anticorpos anti-CD3 podem induzir a expressão de genes envolvidos com anergia e a morte celular (Smith et al, 1989; Ishida et al, 1992; Grossmann et al, 2004). 
O efeito do tratamento com as versões humanizadas e quimérica dos anticorpos anti-CD3 na regulação de genes envolvidos com esses dois mecanismos foi verificada. Foram identificados diversos genes regulados positivamente para todos os tratamentos, tais como, CD38, FAS, CD27, CTLA4, PDCD1, XCL1, e TNFRSF18 (GITR) (Figura 17). Todos esses genes codificam proteínas importantes para a regulação da resposta imune. A molécula PD-1 (também conhecido como CD279), por exemplo, é uma proteína de superfície celular codificada pelo gene PDCD1. Atua como um receptor, que quando interage com seu ligante (PDL1 e PDL2) induz a anergia ou apoptose. Similarmente, mas não pela mesma via, a molécula CTLA-4 bloqueia a progressão do ciclo celular, induzindo a anergia (Parry et al, 2005).

A molécula CD27 tem importante papel na indução da apoptose. Membro da família dos fatores de necrose tumoral, CD27 atua como um receptor que reconhece a molécula CD70, expressa principalmente em linfócitos $T$ ativados. A interação entre CD27-CD70 induz a morte celular mediada pela molécula CD27 (Prasad et al, 1997). A molécula Fas (também conhecida como CD95) possui um domínio de sinalização morte intracelular e pertence à mesma família da molécula CD27. A apoptose mediada por Fas é desencadeada pelo seu ligante FasL (ou CD95L) (van Parijis e Abbas, 1996; Zhang et al, 1997). Em um trabalho recente do grupo de Imunologia Molecular (Laboratório de Biologia Molecular - UNB - DF) foi mostrado por meio de citometria de fluxo, que as versões dos anticorpos anti-CD3 FvFc R e M induzem a expressão de Fas e CTLA-4 nas subpopulações de células T CD4+ e CD8+ em diferentes concentrações $(62,5 \mathrm{ng} / \mathrm{mL}$ e $250 \mathrm{ng} / \mathrm{mL}$ ) (Bezerra, 2014). Por meio dos dados de RNA-Seq, foi possível observar que 72 horas após a estimulação com os anticorpos anti-CD3 houve um aumento na expressão de FAS em níveis similares entre as versões de FvFc. O tratamento com OKT3 demonstrou o maior aumento no nível de expressão desse gene (Tabela 10 e Figura 17). 
Tabela 10 - Genes envolvidos com anergia e morte celular (RNA-Seq)

\begin{tabular}{rcccccc}
\hline \multicolumn{4}{c}{ OKT3 } & \multicolumn{2}{c}{ FvFc R } & \multicolumn{2}{c}{ FvFc M } \\
GENES & FC (Log2) & valor de $p$ & FC (Log2) & valor de $p$ & FC (Log2) & valor de $p$ \\
\hline CD38 & 3,71 & $3,24 \mathrm{E}-28$ & 3,99 & $1,11 \mathrm{E}-18$ & 2,30 & $2,76 \mathrm{E}-05$ \\
FAS & 2,07 & $1,62 \mathrm{E}-22$ & 1,26 & $9,00 \mathrm{E}-04$ & 1,39 & $1,00 \mathrm{E}-04$ \\
CD27 & 1,71 & $1,00 \mathrm{E}-04$ & 2,52 & $8,44 \mathrm{E}-09$ & 1,50 & $2,00 \mathrm{E}-03$ \\
CTLA4 & 3,86 & $1,26 \mathrm{E}-18$ & 2,79 & $1,83 \mathrm{E}-10$ & 3,12 & $2,92 \mathrm{E}-12$ \\
PDCD1 & 2,14 & $3,69 \mathrm{E}-05$ & 2,55 & $1,20 \mathrm{E}-07$ & 1,99 & $2,22 \mathrm{E}-05$ \\
XCL1 & 3,20 & $6,04 \mathrm{E}-47$ & 4,98 & $2,66 \mathrm{E}-31$ & 5,66 & $8,27 \mathrm{E}-14$ \\
TNFRSF18 & 4,37 & $1,44 \mathrm{E}-38$ & 3,57 & $2,65 \mathrm{E}-20$ & 3,55 & $7,31 \mathrm{E}-20$ \\
\hline
\end{tabular}

Os genes XCL1 e TNFRSF18 (GITR) codificam moléculas, que além de estarem associadas com anergia e morte celular, são importantes marcadores de imunorregulação (Nguyen et al, 2008).

O perfil transcritômico definido por RNA-Seq foi confirmada por qPCR (realizada com amostras de três doadores diferentes) para os genes: GITR, XCL1, CD38, PDCD1 e CTLA4 (Figura 17).

A indução de genes envolvidos com anergia e morte celular sugere que os anticorpos anti-CD3 possuem um perfil pró-apoptótico o que os tornam moléculas com potencial imunorregulador. Contudo, mais estudos devem ser realizados para confirmação desse potencial. 

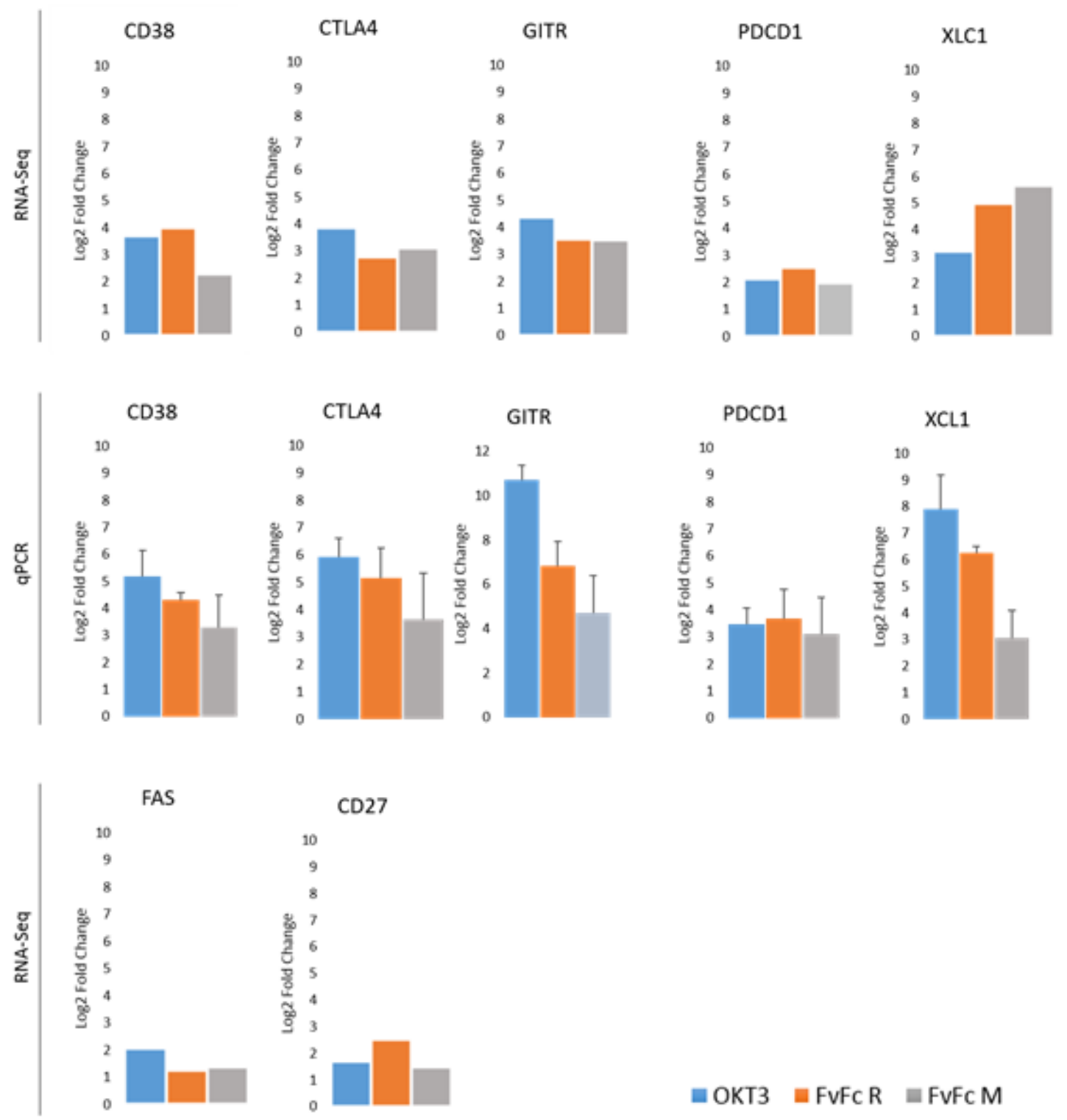

믄 $\mathrm{OKVFCR}=\mathrm{FvFcM}$

Figura 17 - Regulação dos genes envolvidos com anergia e morte celular. Detectada por RNA-Seq $(n=1)$ e confirmada por qPCR $(n=3)$. Valor de $p<0.01$ para ambas as técnicas.

7.2 Regulação de genes codificadores de citocinas e fatores de transcrição envolvidos na diferenciação de Linfócitos T CD4+

Os linfócitos T CD4+ têm papel fundamental na mediação da imunidade adaptativa para uma variedade de patógenos. Elas também estão 
envolvidas com autoimunidade, asma, respostas alérgicas, imunidade à tumor e processos de rejeição a transplantes de órgãos (Cosimi et al, 1981). Após a ativação via TCR dentro de um contexto específico de citocinas, os Linfócitos T CD4+ naive diferenciam-se em uma das linhagens de células T efetoras, tais como, Th1, Th2, Th17 e Treg. Essa diferenciação definirá a função e perfil de citocinas liberadas (Luckheeram et al, 2012). A diferenciação segue curso dependente da expressão de diversos fatores de transcrição, tais como, GATA3, T-bet/Eomes, Foxp3 e Roryt/Rora. Na tentativa de avaliar o perfil da expressão de genes envolvidos com a diferenciação dos linfócitos T após ativação, foram analisados os principais fatores de transcrição e citocinas envolvidas nesse processo.

\section{$\underline{\text { Roryt e Stat3 }}$}

Esses fatores de transcrição agem sinergicamente para a diferenciação do Linfócito T naive no subtipo Th17. Ambos ligam-se aos locus de IL17A e IL17F direcionando a expressão dessas citocinas. Outras moléculas relacionadas com a diferenciação de Th17, dependente de Roryt e Stat3, é o receptor de IL23 e a citocina IL21 (Stockinger e Veldhoen, 2007). Todos os genes codificadores para essas moléculas (IL17a, IL17f, IL23R e IL21) foram regulados positivamente em todos os tratamentos. O gene para Roryt (RORC) foi regulado apenas nos tratamentos com OKT3 e FvFc M (Tabela 11). Já o gene codificador de Stat3 foi regulado positivamente nos tratamentos com OKT3 e FvFc R. A regulação de STAT3 foi confirmada por qPCR para todos os tratamentos, com Fold Change $\left(\log _{2}\right)$ de 6.01, 5.69 e 3.98 (OKT3, FvFc R e M, respectivamente).

\section{Tbet e Stat4}

A diferenciação dos Linfócitos T em Th1 é dirigida pelos fatores de transcrição Tbet (codificado pelo gene TBX21) e Stat4. Os linfócitos Th1 secretam diversas citocinas que contribuem para sua função nas respostas inflamatórias contra diversos patógenos, dentre elas, a principal é o IFN-y 
(Biedermann et al, 2004). Alguns receptores também são importantes para a função dos linfócitos Th1, tais como, IL18R1, IL12Rß2 e CXCR3. A expressão de todas essas moléculas é dependente de Tbet e Stat4, exceto CXCR3 (dependente apenas de Tbet) (Moser e Murphy, 2000). A regulação positiva do gene TBX21 foi observada apenas no tratamento com o anticorpo OKT3, e o gene STAT4 em todos os tratamentos. Em relação aos genes codificadores dos receptores IL18R1 e IL12Rß2, importantes para as células Th1, também foram positivamente regulados em todos os tratamentos. Contudo, o receptor CXCR3 foi regulado apenas nos tratamentos com as versões de FvFc (R e M). A expressão de IL12RB2 foi confirmada por qPCR (Fold Change $\left(\log _{2}\right)$ de 5.64, 6.02 e 8.01 para OKT3, FvFc R e M, respectivamente). O gene codificador de IFN-y foi regulado positivamente em todos os tratamentos, apresentando níveis elevados com o tratamento com OKT3. Embora não foi possível confirmar essa expressão por qPCR, Bezerra (2014), realizando dosagens de citocinas no sobrenadante de PBMC tratados com os mesmos anticorpos, observou a expressão de IFN-y.

\section{$\underline{\text { Gata3 e Stat5 }}$}

O fator de transcrição Gata3, juntamente com Stat5, promove a diferenciação dos Linfócitos T em Th2 (Kaplan et al, 1996; Jankovic et al, 2000). Não foi observado a regulação dos genes codificadores para nenhum desses fatores de transcrição. Contudo, um outro fator importante para a diferenciação desse tipo celular, IRF4, foi fortemente regulado. Esse fator, por outro lado, também está envolvido com a diferenciação de outros subtipos de Linfócitos $T$ CD4+, Th17 e Tregs.

\section{Foxp3}

Foxp3 (forkhead box P3) é um importante fator de transcrição envolvido com a ativação e diferenciação das células $T$. Tem um papel crítico no 
desenvolvimento das células $T$ reguladoras $\mathrm{CD} 4^{+} \mathrm{CD} 25^{\text {high }}$ de ocorrência natural (nTregs) (Hueh et al, 2009). Na ausência de Foxp3 as células T efetoras podem induzir doenças autoimunes pela falta das nTregs (Sakaguchi, 2005). Foi observado a expressão de FOXP3 em todos os tratamentos. Essa regulação foi também confirmada por qPCR.

Tabela 11 - Expressão de fatores de transcrição, citocinas e receptores (RNA-Seq)

\begin{tabular}{|c|c|c|c|c|c|c|}
\hline & \multicolumn{2}{|c|}{ OKT3 } & \multicolumn{2}{|c|}{ FvFc R } & \multicolumn{2}{|c|}{ FvFc M } \\
\hline & \multicolumn{3}{|c|}{ valor de } & \multicolumn{3}{|c|}{ FC } \\
\hline & FC $(\log 2)$ & $p$ & FC $(\log 2)$ & valor de $p$ & $(\log 2)$ & valor de $p$ \\
\hline \multicolumn{7}{|c|}{ Fatores de transcrição } \\
\hline STAT4 & 1,96 & 1,93E-07 & 1,10 & $6,42 \mathrm{E}-03$ & 1,15 & $4,15 \mathrm{E}-03$ \\
\hline RORC & 1,23 & $6,92 \mathrm{E}-03$ & ND & ND & 1,51 & $1,39 \mathrm{E}-03$ \\
\hline TBX21 & 2,13 & $1,09 E-05$ & ND & ND & ND & ND \\
\hline STAT3 & 1,06 & $2,55 \mathrm{E}-03$ & 1,01 & $7,70 \mathrm{E}-03$ & ND & ND \\
\hline FOXP3 & 0,88 & $3,42 \mathrm{E}-04$ & 1,37 & 1,56E-04 & 1,73 & $7,94 \mathrm{E}-06$ \\
\hline
\end{tabular}

Citocinas

$$
\text { 2,42E- }
$$

$\begin{array}{ccccccc}\text { IFNG } & 8,97 & 137 & 3,71 & 3,80 \mathrm{E}-16 & 2,71 & 2,45 \mathrm{E}-06 \\ \text { IL17F } & 7,67 & 1,27 \mathrm{E}-97 & 4,40 & 1,38 \mathrm{E}-18 & 3,64 & 1,92 \mathrm{E}-10 \\ \text { IL17A } & 6,33 & 6,42 \mathrm{E}-28 & 3,70 & 2,07 \mathrm{E}-09 & 3,36 & 5,47 \mathrm{E}-09\end{array}$

Receptores

\begin{tabular}{|c|c|c|c|c|c|c|}
\hline \multirow[t]{2}{*}{ CXCR3 } & ND & ND & 1,62 & $5,38 \mathrm{E}-06$ & 1,23 & $9,99 \mathrm{E}-04$ \\
\hline & & $2,26 \mathrm{E}-$ & & & & \\
\hline IL12RB2 & 6,69 & 189 & 3,54 & 8,30E-09 & 3,20 & $7,91 \mathrm{E}-11$ \\
\hline IL18R1 & 1,82 & $2,36 \mathrm{E}-07$ & 1,38 & $4,99 \mathrm{E}-04$ & 1,73 & $1,35 \mathrm{E}-05$ \\
\hline IL23R & 3,19 & 5,09E-06 & 1,85 & $3,16 \mathrm{E}-03$ & 1,72 & $2,86 \mathrm{E}-03$ \\
\hline
\end{tabular}

$\overline{N D}=$ não determinado 


\subsection{Expressão de genes envolvidos com imunorregulação}

A estimulação da molécula CD3 por anticorpos anti-CD3 pode induzir a diferenciação de uma subpopulação específica de Linfócito $T$ com perfil imunorregulador (Chatenoud, 2004). Essas células, conhecidas como células T reguladoras (Tregs) expressam altos níveis da molécula de superfície CD25 (CD25 $\left.{ }^{\text {high }}\right)$ e do fator de transcrição Foxp3 (Foxp3 ${ }^{\text {high }}$ ) (Sakaguchi, 2005). Diversas outras moléculas têm sido associadas com as Tregs, tais como, GITR (TNFRSF18), GZMB, CTLA-4, CD103, CD62L e CD38 (Schmetterer et al, 2012). A expressão dessas moléculas juntas, caracterizam o fenótipo desse tipo celular, subgrupo das células T CD4+. Para verificar se as versões dos anticorpos antiCD3 modularam um perfil imunorregulador nas células $T$ estimuladas, a expressão diferencial de diversos genes envolvidos com células $T$ reguladoras foi analisada.

\section{FOXP3 e seus alvos}

Embora o incremento nos níveis de expressão de FOXP3 tenha sido baixo comparado aos outros genes, ficou evidente que esse fator de transcrição foi induzido pelos anticorpos anti-CD3. Além disso, a expressão de alguns alvos de Foxp3 foi observada (Figura 18). O tempo de cultivo (72h) é um fator importante que deve ser considerado. Muitos estudos demostraram que a expressão de FOXP3 pode acontecer entre 12-24 horas após a estimulação com anti-CD3 ou anti-CD3/anti-CD28 (Birzele et al, 2011; Zhao et al, 2014).

Para identificar a expressão dos alvos de Foxp3, os dados obtidos pelo RNASeq foram comparados com os dados do trabalho de Birzele e colaboradores (2011). Esses autores combinaram as metodologias de ChiP-seq (Foxp3) e mRNA-seq com o objetivo de entender as diferenças transcricionais entre as células T CD4+ auxiliares e células T reguladoras, além de estudar o papel de Foxp3 na geração dessas diferenças. 
Diversos alvos de Foxp3 se mostraram regulados em todos os tratamentos, tais como, CTLA4, IL2RA, DUSP4, CCR4, IRF4 e CREM (genes regulados positivamente) e DPEP2 (gene regulado negativamente). Interessantemente, a regulação positiva de IRF4 (Fold Change $\left(\log _{2}\right)$ de 3.71, 2.66 e 2.31 para OKT3, FvFc R e FvFc M, respectivamente) pode ter influenciado a expressão de FOXP3. Embora mais estudos devem ser realizados para confirmar essa hipótese. IRF4 é um membro da família de fatores reguladores de interferon que contribui para vários aspectos da imunidade inata e adquirida (Murphy et al, 2013). Estudos demostraram que IRF4 age regulando negativamente Foxp3 (Biswas et al, 2010, Cretney et al, 2011). Além disso, esse fator ainda regula negativamente diversos receptores do tipo Toll (TLRs). Receptores TLRs, tais como, TLR4, 5, 6 e 7 foram regulados negativamente em todos os tratamentos. Outro gene regulado negativamente por IRF4 é o CD68 (O’Reilly et al, 2003), e essa regulação também foi observada nesse estudo (Figura 19 e 20).

Para confirmar a regulação positiva da expressão de FOXP3, IRF4 e IL2RA, foi realizada qPCR em amostras tratadas de três doadores diferentes. Foi confirmada a regulação para todos esses genes. Interessantemente, a detecção da expressão de FOXP3 e IRF4 por qPCR foi maior quando comparada com a detecção por RNA-Seq (Figura 18). 

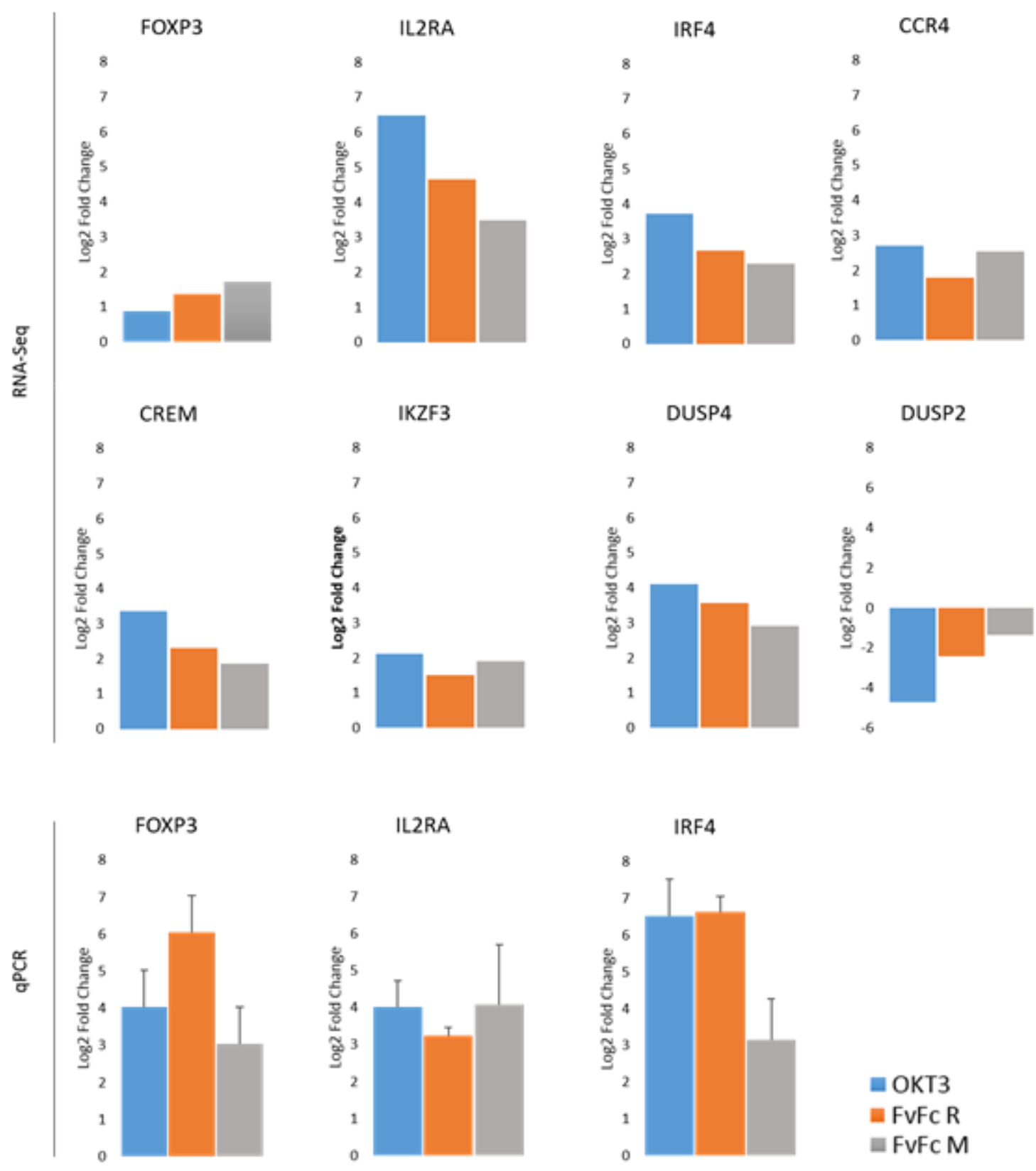

Figura 18 - Expressão de Foxp3 e seus alvos. Detectada por RNA-Seq $(n=1)$ e confirmada por $q P C R(n=3)$. Valor de $p<0.01$ para ambas as técnicas. 


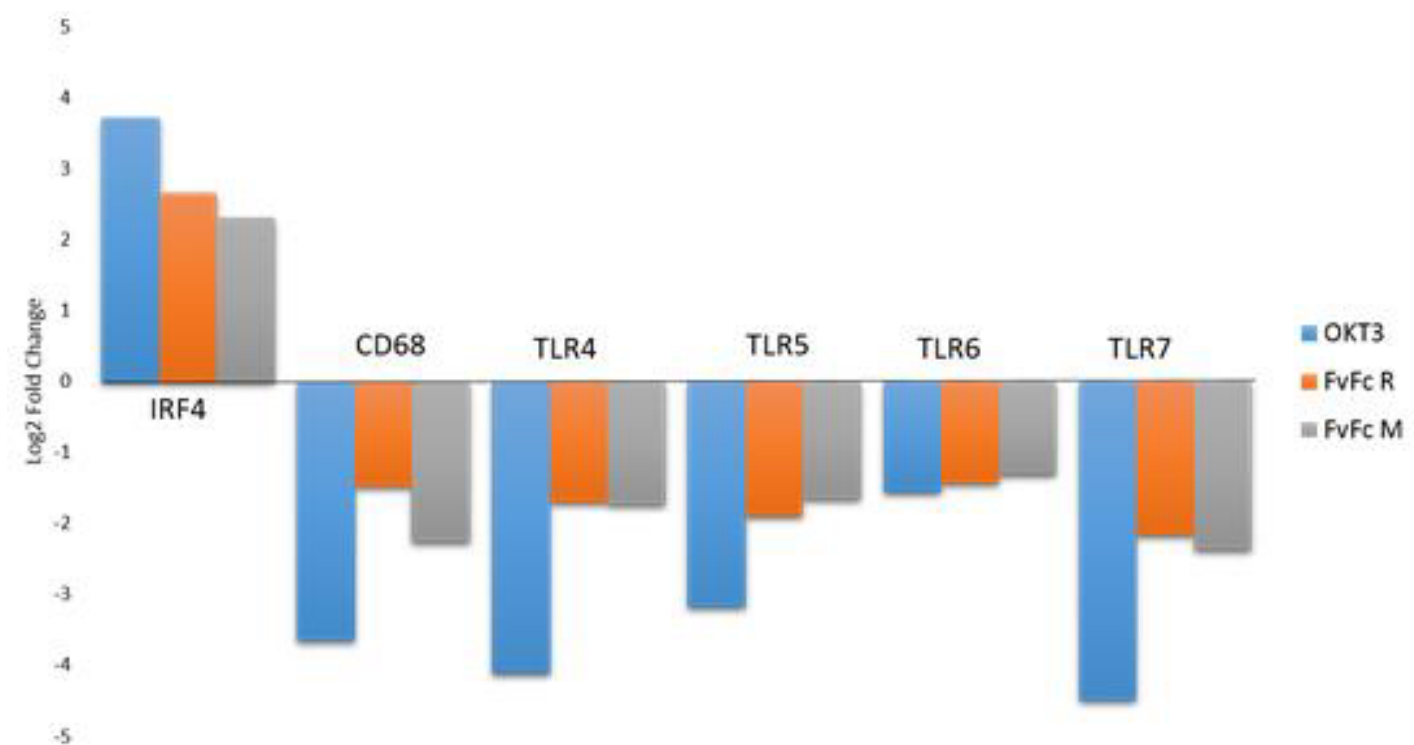

Figura 19 - Expressão de IRF4 e seus alvos. Detectada por RNA-Seq $(n=1)$. Valor de $p<0.01$

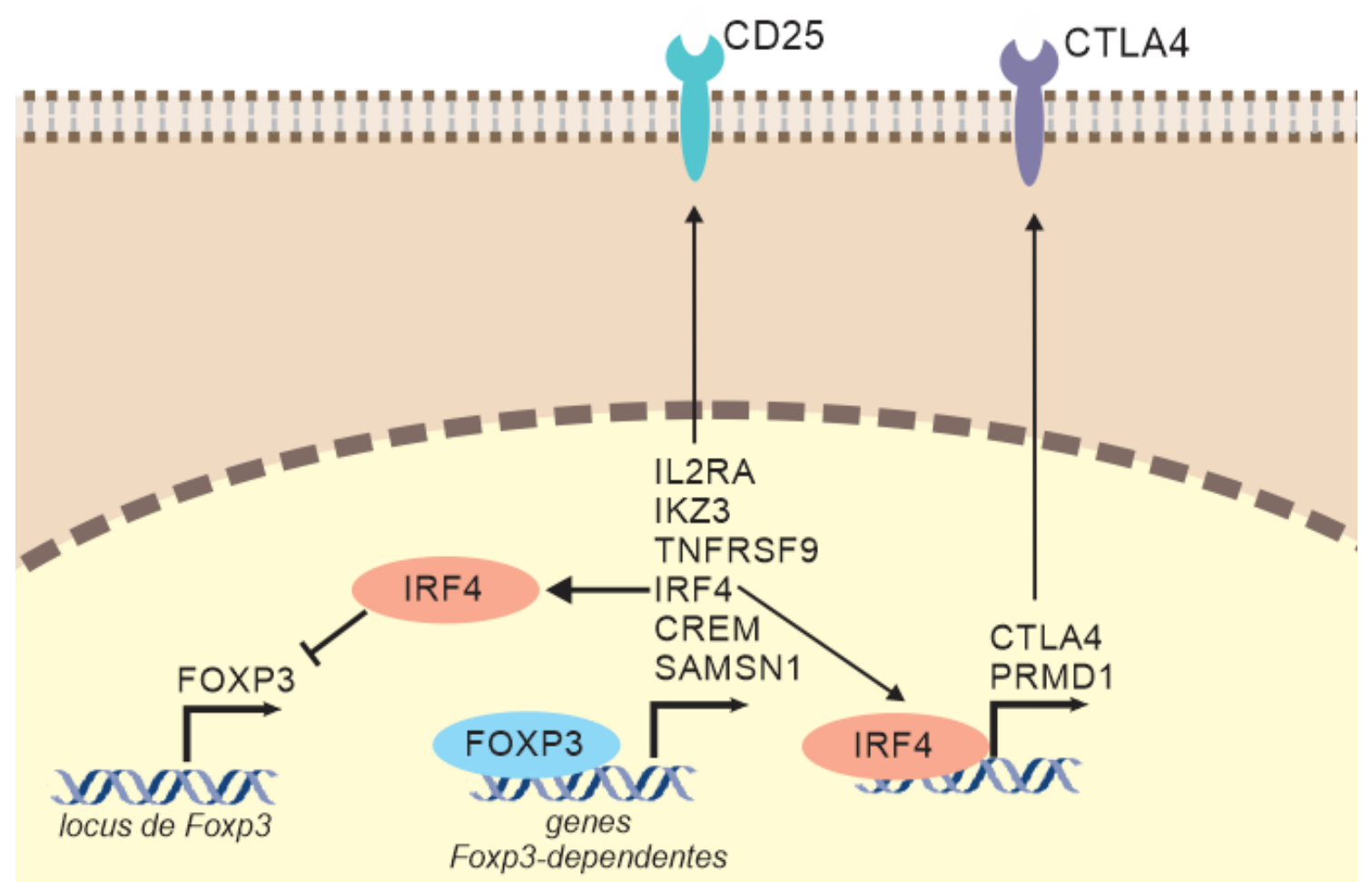

Figura 20 - Regulação de Foxp3 e IRF4. Foxp3 controla diretamente e indiretamente a expressão de diversas moléculas que conferem a função supressora de células Tregs. IRF4, juntamente com Foxp3 regula uma variedade de genes, alguns dos quais contribuem para a função efetora de Treg (tal como CTLA-4 e PRMD1). PRDM1 induz a produção de IL-10. 


\section{Regulação da expressão do mir155}

Os miRNAs têm sido implicados na regulação da expressão gênica para o desenvolvimento e diferenciação celular. Estudos recentes têm investigado o papel dos miRNAs na biologia das células T (Seth et al, 2013). Diversos miRNAs foram descritos como essenciais para o desenvolvimento de células Tregs Foxp3+, sugerindo uma regulação gênica mediada por miRNA na diferenciação de Tregs. Os miRNAs são diferencialmente expressos entre as células Tregs e as não-Tregs, dentre eles, o mir155 (Kohlhaas et al, 2009).

Von Essen e colaboradores (2010) demonstraram que a alta quantidade de mir155 em Treg é requerida para a expressão continua de Foxp3 em modelo murino. Dentre os resultados obtidos na análise diferencial de genes de células T estimuladas com os anticorpos anti-CD3, foi observada a expressão diferencial do mir155 (host gene). O Fold Change (Log2) observado foi de 2.80, 2.64 e 2.30 para o tratamento com OKT3, FvFc R e M, respectivamente (Figura 21).

\section{MIR155}

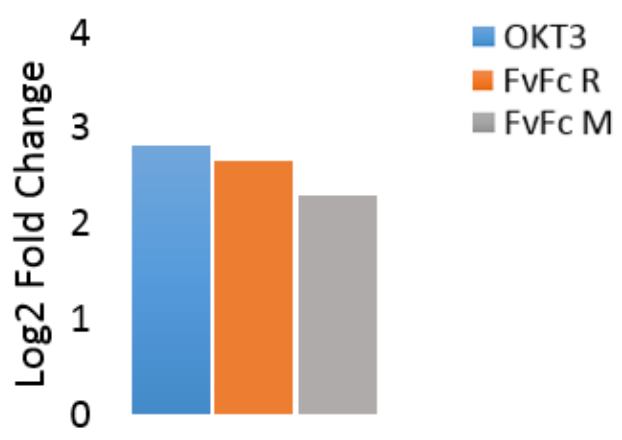

Figura 21 - Expressão de MIR155HG. Detectada por RNA-Seq. Valor de $p<0.01$.

\section{Genes especificos de Tregs ativadas}

As células Tregs expressam em sua superfície diversos marcadores de células $T$ efetoras, mas alguns genes são positivamente regulados especificamente em Tregs ativadas. Com o objetivo de estudar os genes relacionados com Tregs ativadas, foi realizada uma comparação entre genes 
comuns para os tratamentos e os dados dos genes específicos em Tregs ativadas de Birzele e colaboradores (2011). Foram encontrados 54 genes em comum, como demostrado na Tabela $12(p<0.01)$ e na Figura 22.

Tabela 12 - Genes específicos de Tregs ativadas

\begin{tabular}{|c|c|c|c|c|}
\hline \multirow[b]{2}{*}{ GENE } & \multirow[b]{2}{*}{ GENE DESCRIPTION } & \multicolumn{3}{|c|}{ FC $\left(\log _{2}\right)$} \\
\hline & & OKT3 & $\begin{array}{l}\text { FvFc } \\
\quad R\end{array}$ & FvFc M \\
\hline ADAM19 & ADAM metallopeptidase domain 19 & 2,69 & 1,06 & 2,04 \\
\hline ANP32E & $\begin{array}{l}\text { acidic (leucine-rich) nuclear phosphoprotein } 32 \\
\text { family, member E }\end{array}$ & 2,49 & 1,91 & 1,39 \\
\hline BAG2 & BCL2-associated athanogene 2 & 2,81 & 2,10 & 1,36 \\
\hline BATF & basic leucine zipper transcription factor, ATF-like & 2,06 & 1,72 & 1,73 \\
\hline BHLHE40 & basic helix-loop-helix family, member e40 & 2,13 & 1,44 & 0,97 \\
\hline BLM & Bloom syndrome, RecQ helicase-like & 2,48 & 1,70 & 1,25 \\
\hline C170RF96 & chromosome 17 open reading frame 96 & 3,84 & 2,85 & 2,09 \\
\hline CCND2 & cyclin D2 & 2,76 & 2,07 & 1,64 \\
\hline CCR8 & chemokine (C-C motif) receptor 8 & 2,23 & 3,06 & 2,48 \\
\hline CD27 & CD27 molecule & 1,71 & 2,52 & 1,50 \\
\hline CD300A & CD300a molecule & $-3,80$ & $-1,78$ & $-1,70$ \\
\hline CDK2 & cyclin-dependent kinase 2 & 2,15 & 1,93 & 1,28 \\
\hline CKAP2 & cytoskeleton associated protein 2 & 2,54 & 2,18 & 1,61 \\
\hline CREM & cAMP responsive element modulator & 3,37 & 2,30 & 1,88 \\
\hline CTSD & cathepsin D & $-4,01$ & $-1,50$ & $-2,17$ \\
\hline DCLRE1A & DNA cross-link repair $1 \mathrm{~A}$ & 1,57 & 1,66 & 1,20 \\
\hline DUSP4 & dual specificity phosphatase 4 & 4,10 & 3,56 & 2,91 \\
\hline GCH1 & GTP cyclohydrolase 1 & 2,09 & 1,73 & 1,35 \\
\hline GIMAP4 & GTPase, IMAP family member 4 & 1,17 & 0,79 & 0,90 \\
\hline GRAMD3 & GRAM domain containing 3 & 1,71 & 1,30 & 1,54 \\
\hline GZMB & $\begin{array}{l}\text { granzyme B (granzyme 2, cytotoxic T- } \\
\text { lymphocyte-associated serine esterase 1) }\end{array}$ & 8,18 & 4,69 & 2,78 \\
\hline IL12RB2 & interleukin 12 receptor, beta 2 & 6,69 & 3,54 & 3,20 \\
\hline IL17F & interleukin 17F & 7,67 & 4,40 & 3,64 \\
\hline IL18R1 & interleukin 18 receptor 1 & 1,82 & 1,38 & 1,73 \\
\hline IL1R2 & interleukin 1 receptor, type II & 3,37 & 2,35 & 3,12 \\
\hline ITGA4 & $\begin{array}{l}\text { integrin, alpha } 4 \text { (antigen CD49D, alpha } 4 \text { subunit } \\
\text { of VLA-4 receptor) }\end{array}$ & 1,52 & 1,67 & 1,33 \\
\hline JAKMIP1 & janus kinase and microtubule interacting protein 1 & 2,49 & 1,82 & 1,92 \\
\hline
\end{tabular}




\begin{tabular}{|c|c|c|c|c|}
\hline LAYN & layilin & 4,79 & 5,84 & 3,59 \\
\hline LDHA & lactate dehydrogenase $\mathrm{A}$ & 2,29 & 1,65 & 1,00 \\
\hline MARCKSL1 & MARCKS-like 1 & 0,81 & 0,92 & 0,90 \\
\hline MCM2 & $\begin{array}{l}\text { minichromosome maintenance complex } \\
\text { component } 2\end{array}$ & 3,07 & 2,81 & 1,57 \\
\hline MCM6 & $\begin{array}{l}\text { minichromosome maintenance complex } \\
\text { component } 6\end{array}$ & 3,49 & 3,06 & 2,11 \\
\hline NR4A1 & nuclear receptor subfamily 4 , group $A$, member 1 & 1,85 & 2,49 & 1,91 \\
\hline PIK3CG & $\begin{array}{l}\text { phosphatidylinositol-4,5-bisphosphate 3-kinase, } \\
\text { catalytic subunit gamma }\end{array}$ & 2,40 & 1,51 & 1,26 \\
\hline PLIN2 & perilipin 2 & $-2,62$ & $-1,83$ & $-1,45$ \\
\hline POLA1 & $\begin{array}{l}\text { polymerase (DNA directed), alpha 1, catalytic } \\
\text { subunit }\end{array}$ & 2,34 & 2,02 & 1,34 \\
\hline PYCR1 & pyrroline-5-carboxylate reductase 1 & 3,24 & 2,94 & 1,94 \\
\hline RAB32 & RAB32, member RAS oncogene family & $-3,37$ & $-1,45$ & $-1,94$ \\
\hline RAP2B & RAP2B, member of RAS oncogene family & $-2,11$ & $-1,32$ & $-1,75$ \\
\hline RFC3 & replication factor C (activator 1) 3, 38kDa & 3,29 & 2,58 & 1,60 \\
\hline RGS16 & regulator of G-protein signaling 16 & 5,54 & 3,83 & 3,19 \\
\hline SGK3 & $\begin{array}{l}\text { serum/glucocorticoid regulated kinase family, } \\
\text { member } 3\end{array}$ & $-2,86$ & $-1,56$ & $-1,44$ \\
\hline SH2D2A & SH2 domain containing $2 \mathrm{~A}$ & 4,33 & 3,11 & 2,43 \\
\hline SLC16A1 & $\begin{array}{l}\text { solute carrier family } 16 \text { (monocarboxylate } \\
\text { transporter), member } 1\end{array}$ & 2,25 & 1,54 & 1,17 \\
\hline SLC35F2 & solute carrier family 35 , member F2 & 2,70 & 2,34 & 1,79 \\
\hline SLC39A8 & $\begin{array}{l}\text { solute carrier family } 39 \text { (zinc transporter), member } \\
8\end{array}$ & 2,69 & 1,76 & 1,81 \\
\hline SLC7A5 & $\begin{array}{l}\text { solute carrier family } 7 \text { (amino acid transporter } \\
\text { light chain, L system), member } 5\end{array}$ & 3,35 & 2,69 & 2,34 \\
\hline TNFRSF18 & $\begin{array}{l}\text { tumor necrosis factor receptor superfamily, } \\
\text { member } 18\end{array}$ & 4,37 & 3,57 & 3,55 \\
\hline TNFRSF4 & $\begin{array}{l}\text { tumor necrosis factor receptor superfamily, } \\
\text { member } 4\end{array}$ & 4,06 & 2,76 & 2,66 \\
\hline TNFRSF9 & $\begin{array}{l}\text { tumor necrosis factor receptor superfamily, } \\
\text { member } 9\end{array}$ & 5,16 & 4,86 & 3,61 \\
\hline TNIP3 & TNFAIP3 interacting protein 3 & 3,09 & 3,04 & 2,17 \\
\hline TRAF4 & TNF receptor-associated factor 4 & 2,77 & 1,98 & 1,84 \\
\hline ZBED2 & zinc finger, BED-type containing 2 & 8,43 & 6,79 & 5,71 \\
\hline ZBTB32 & zinc finger and BTB domain containing 32 & 5,30 & 4,06 & 2,46 \\
\hline
\end{tabular}




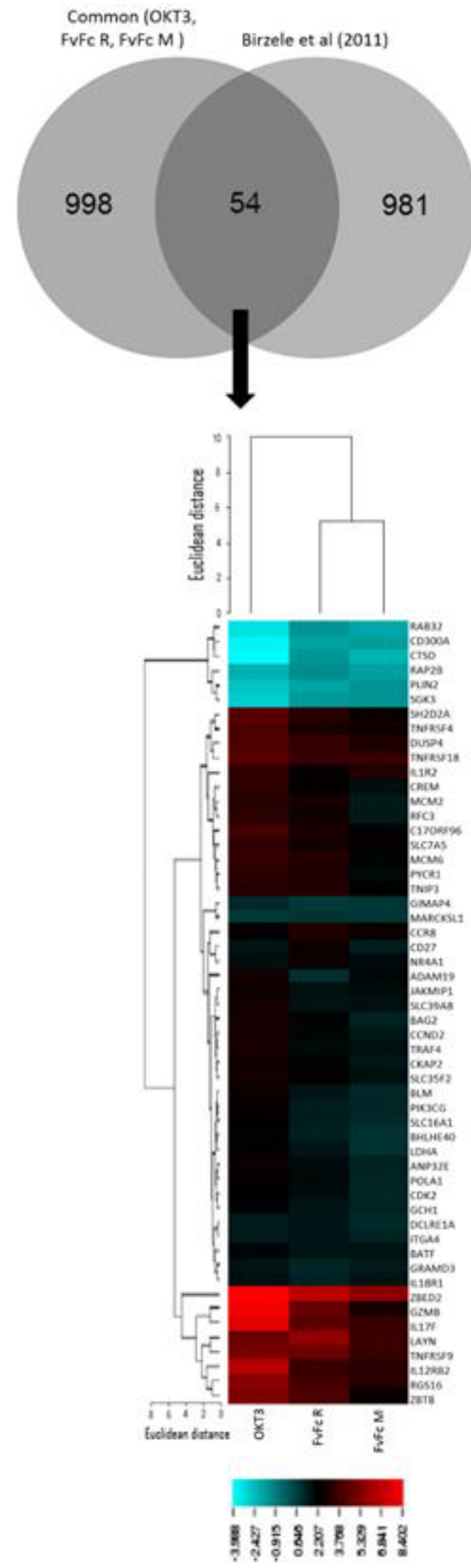

Figura 22 - Comparação de genes obtidos por RNA-Seq e dados de Birezele et al (2011). 


\section{Regulação negativa da molécula IL7R (CD127)}

O receptor da interleucina 7 subunidade alfa (IL7Ra), também conhecida como CD127, é uma proteína codificada pelo gene IL7R. A expressão de CD127 é inversamente correlacionada com a expressão de FOXP3 e com a função supressora das Tregs CD25 high (Liu et al, 2006). Células T CD4+ que expressam baixos níveis de CD127 expressam altos níveis de Foxp3 e essas células CD4+CD127 low são altamente supressoras in vitro (Shen et al, 2009). Logo, a expressão da molécula CD127 permite discriminar e isolar Tregs dos outros subtipos de células $T$.

Foi observado a partir dos dados de RNA-Seq que o gene IL7R é negativamente regulado pelos anticorpos OKT3 e FvFc R, com Fold Change $\left(\log _{2}\right)$ de -1.36 e -1.34 , respectivamente. Não foi observado regulação significativa com o anticorpo FvFc M. A regulação negativa de IL7R é importante para o potencial imunorregulador desses anticorpos, uma vez que as células que respondem a citocina IL-7 passam a ter um perfil mais inflamatório. Além disso, alguns estudos in vitro demostraram que células Tregs com alta expressão de IL7Ra são responsivas a IL7 e podem se converter em células Th1 (Heninger et al, 2012).

\section{Regulação positiva da Granzima B}

A granzima B é uma proteína essencial para o mecanismo de morte induzida pelas células NK e células T CD8+. Contudo, as células Tregs também podem utilizar granzima B como um mecanismo para suprimir a função de células imunes, induzindo sua morte. Estudos in vitro mostraram o aumento de expressão da granzima B em células Tregs ativadas, embora não esteja claro se, in vivo, Tregs ativadas expressam granzimas B (Efimova e Kelley, 2009). O gene GZMB foi um dos genes mais fortemente regulados por todas as versões dos anticorpos anti-CD3, principalmente nas versões OKT3 e FvFc R. O Fold Change $\left(\log _{2}\right)$ obtido para os tratamentos foram $8.18,4.69$ e 2.78 para OKT3, 
FvFc R e $M$, respectivamente. Essa regulação foi confirmada por qPCR (3 indivíduos) (Figura 23). Bezerra (2014), demonstrou por meio de citometria de fluxo, que os linfócitos T estimulados com as mesmas versões dos anti-CD3, mudavam a sua morfologia, tornando-se células maiores e mais granulosas quando comparadas com os linfócitos sem estimulação. Embora não testado experimentalmente, é possível que esse aumento de granulosidade seja devido à alta produção de granzima $\mathrm{B}$.

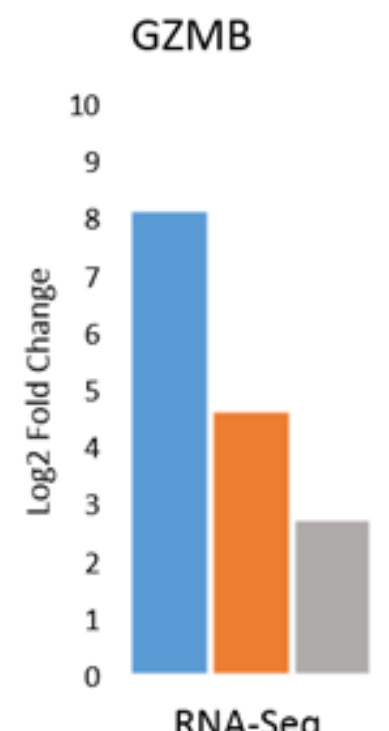

RNA-Seq

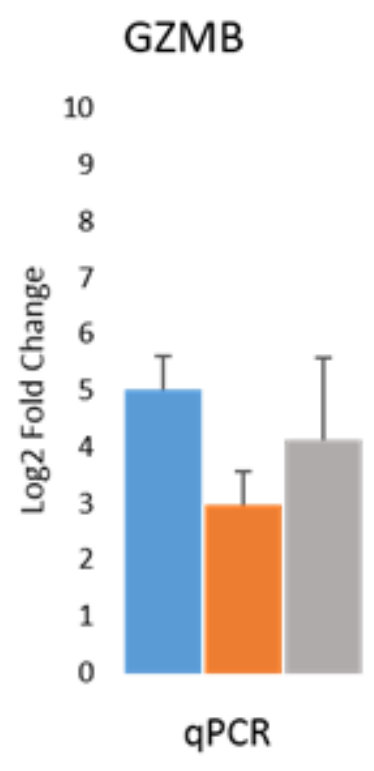

- OKT3 $\square$ FvFcR $=$ FvFcM

Figura 23 - Expressão do gene codificador de granzima B (GZMB). Detectada por RNA-Seq $(n=1)$ e confirmada por qPCR $(n=3)$. Valor de $p<0.01$ para ambas as técnicas.

7.4 Regulação da expressão do Receptor de Vitamina $D$ e da enzima 1-alfa-hidroxilase (CYP27B1)

O receptor de Vitamina D (VDR) é um receptor nuclear que regula mais de 900 genes envolvidos com funções fisiológicas (Handel et al, 2013). 
Estudos recentes têm demonstrado o impacto da sinalização do VDR na função imune após interação com seu ligante (Vitamina D 1,25(OH) $2 \mathrm{D} 3$ ). Esses estudos associaram a $1,25(\mathrm{OH})_{2} \mathrm{D} 3$ à susceptibilidade a diversas infecções e ao desenvolvimento de doenças inflamatórias (Haug et al, 1994; Boxer et al, 2008).

O receptor VDR tem sua expressão regulada positivamente em células T após estimulação do TCR juntamente com sinais co-estimulatórios, mostrando que esse receptor tem um papel importante no desenvolvimento, diferenciação e funções efetoras das células T (von Essen et al, 2010). Além do do receptor VDR, a enzima 1-alfa-hidroxilase também tem sido relacionada com doenças autoimunes. Alguns estudos demonstraram que o polimorfismo no gene codificador dessa enzima estava associada com a incidência das doenças autoimunes de Addison e de Hashimoto (Lopez et al, 2004). A enzima 1-alfahidroxilase (CYP27B1) é utilizada pelas células para conversão da Vitamina D 25(OH)D3 na forma ligante de VDR $\left(1,25\left(\mathrm{OH}_{3}\right) \mathrm{D} 3\right)$ (Atkins et al, 2007).

No presente estudo, foi observado uma regulação positiva da expressão tanto do transcrito de VDR quanto de CYP27B1 após estimulação com todas as versões de anti-CD3 (Figura 24). Para VDR foi observado Fold Change $\left(\log _{2}\right)$ de 1.56, 1.97 e 1.6 para OKT3, FvFc $R$ e FvFc M, respectivamente. Para o transcrito da enzima CYP27B1 os valores encontrados foram 4.06, 3.37 e 2.38 para OKT3, FvFc R e FvFc M, respectivamente.

Alguns estudos relacionam a deficiência de vitamina $D$ com várias doenças autoimunes, tais como, diabetes melito insulino-dependente, esclerose múltipla, doença inflamatória intestinal, lúpus eritematoso sistêmico e artrite reumatoide (Bailey et al, 2007). Embora ainda um assunto bastante controverso, sugere-se que a vitamina $D$ e seus análogos, não só previnam 0 desenvolvimento de doenças autoimunes, como também poderiam ser utilizados no seu tratamento (Adorini e Penna, 2008). 
Embora os mecanismos de imunomodulação da Vitamina $D$ não estejam totalmente esclarecidos, estudos têm demonstrado uma modificação do fenótipo de apresentação de antígenos das células dendríticas (DCs) para um fenótipo mais tolerogênico, com diferenciação de Tregs induzidas (iTregs) ao invés de Th1 e Th17 inflamatórias (Penna et al, 2005). Experimentos in vitro em modelo murino de encefalomielite autoimune mostraram que a suplementação da Vitamina D reduziram a expressão de citocinas de perfil Th17, tais como, IL17 e IL17F (Chang et al, 2010).

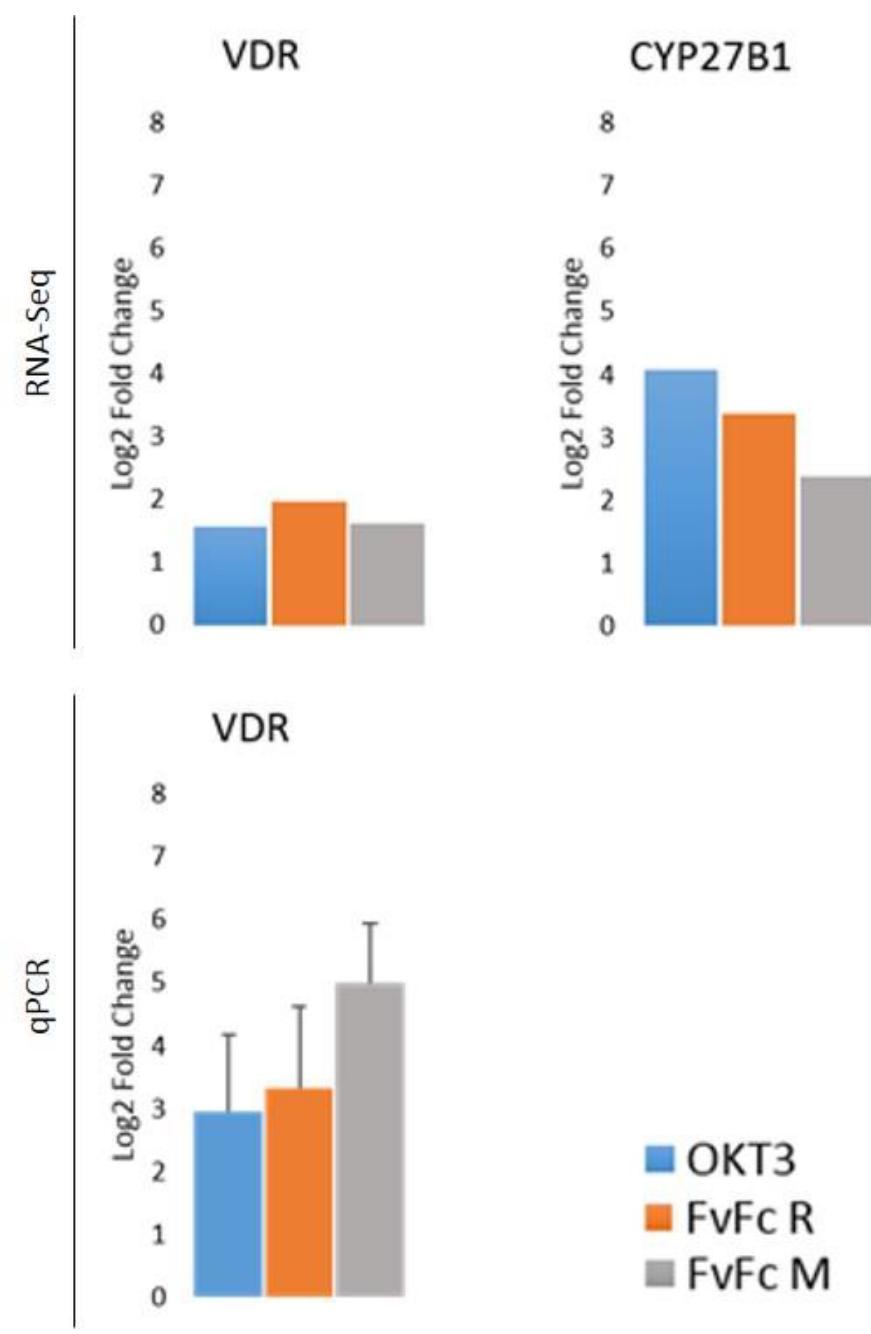

Figura 24 - Expressão dos genes codificadores de Vitamina $D$ (VDR) e a enzima 1-alfa-hidroxilase (CYP27B1). Detectada por RNA-Seq $(n=1)$. A confirmação por $q P C R(n=3)$ só foi realizada para VDR. Valor de $p<0.01$ para ambas as técnicas. 


\subsection{Dualidade das respostas induzidas pelos anti-CD3}

A indução de genes codificadores de moléculas envolvidas no desenvolvimento das células com fenótipo regulador é, sem dúvida, um dos mecanismos mais importante observado em resposta aos anticorpos anti-CD3. Atualmente, essas células se tornaram alvos de diversos estudos devido a sua importância para o tratamento de doenças que envolvem uma resposta inflamatória exagerada, tais como, doenças autoimunes e processos de rejeição ao transplante (Putnam et al, 2008; Trzonkowaski et al, 2009; Di lanni et al, 2011). Entretanto, apesar das fortes evidências que sugerem a diferenciação de Tregs, é impossível ignorar a indução de marcadores associados com a resposta de perfil Th17, observada nos dados de RNA-Seq em níveis de mRNA.

O desenvolvimento de Th17 e Tregs tem sido o grande desafio dos anticorpos anti-CD3. Estudos que envolvem a ativação de linfócitos $\mathrm{T}$ pelos anticorpos anti-CD3, com ou sem coestimulação via molécula CD28, tem demostrado que marcadores de Th17 e Tregs são induzidos paralelamente. Além disso, tem sido demostrado que ambas as células possuem uma plasticidade no seu desenvolvimento, podendo mudar o seu programa de diferenciação em resposta a diversos estímulos. Um grande exemplo disso é a conversão de Th17 ou Treg em Th1, em resposta a IL12 (Feng et al, 2011).

Outro exemplo do paradigma Th17-Treg é a função dualística da citocina TGF- $\beta$. Antes proposta como uma citocina importante para o desenvolvimento de células Tregs, atualmente diversos trabalhos demostraram que essa citocina promove o desenvolvimento tanto de Tregs quanto de Th17 (Veldhoen et al, 2006; Bettelli et al, 2006), suprimindo em contrapartida, a diferenciação de Th1 e Th2 (Li Mo et al, 2005).

Foi observada no presente trabalho a indução de genes codificadores de de citocinas associadas com o perfil Th17, como IL17A e sua homóloga IL17F 
(Tabela 13). Em humanos, níveis elevados dessas citocinas estão associadas com doenças inflamatórias locais e sistêmicas. Contudo, Voo et al (2009) identificaram que tanto tecido linfóide e sangue periférico humanos continham uma subpopulação de Treg CD4+Foxp3+CCR6+ com capacidade de produzir IL-17 após ativação com anti-CD3/anti-CD28. Outro grupo (Ayyoub et al, 2009) também caracterizou Treg de memória secretora de IL17. Porém, a capacidade supressora dessas células é controversa.

É importante notar que o tratamento com OKT3 apresentou um maior aumento na expressão de citocinas de perfil Th17, mostrando uma capacidade inflamatória maior quando comparado a versão humanizada e quimérica (FvFc $\mathrm{R}$ e $\mathrm{M})$. Além disso, outras citocinas que tem potencial inflamatório tiverem seus genes induzidos apenas após o tratamento das células com OKT3, dentre elas, IL3, IL5, IL-21 e IL-22 (Tabela 13). As citocinas IL-21 e IL-22 também são citocinas secretadas em altos níveis pelas células Th17. E as citocinas IL3 e IL5 têm sido associadas com algumas condições patológicas, tais como, inflamação crônica e leuceminas mielóides (Broughton et al, 2012).

Tabela 13 - Lista dos genes codificadores de interleucinas regulados após tratamento com os anti-CD3

Interleucinas reguladas em comum

\section{OKT3 FvFc R $\quad$ FvFc M}

GENE FC (Log2) valor de p FC (Log2) valor de p FC (Log2) valor de $p$ IL17F $\quad 7,67 \quad 1,27 \mathrm{E}-97 \quad 4,40 \quad 1,38 \mathrm{E}-18 \quad 3,64 \quad 1,92 \mathrm{E}-10$

IL17A 6,33 6,42E-28 3,70 2,07E-09 3,36 5,47E-09

IL6 $3,82 \quad 3,29 \mathrm{E}-10 \quad 1,92 \quad 1,87 \mathrm{E}-03 \quad 2,20 \quad 1,49 \mathrm{E}-04$

Interleucinas reguladas em comum entre OKT3 e FvFc $R$

\section{OKT3 FvFc R}

$\begin{array}{rcccc}\text { GENE } & \text { FC (Log2) } & \text { valor de p } & \text { FC (Log2) } & \text { valor de p } \\ \text { IL32 } & 1,95 & 4,42 E-06 & 1,18 & 5,89 E-03 \\ \text { IL2 } & 3,67 & 1,82 E-15 & 1,61 & 4,09 E-03\end{array}$


$\begin{array}{lllll}\text { ILF2 } & 1,47 & 1,49 \mathrm{E}-09 & 1,12 & 1,77 \mathrm{E}-03 \\ \text { IL24 } & -2,93 & 4,34 \mathrm{E}-08 & -1,60 & 1,65 \mathrm{E}-03\end{array}$

Interleucinas reguladas em comum entre OKT3 e FvFc M

OKT3 FvFc M

\begin{tabular}{rcccc}
\hline GENE & $F C$ (Log2) & valor de $p$ & $F C($ Log2) & valor de $p$ \\
IL18BP & $-2,73$ & $1,53 \mathrm{E}-19$ & $-2,36$ & $3,79 \mathrm{E}-10$ \\
IL26 & 2,18 & $5,66 \mathrm{E}-06$ & 1,95 & $5,33 \mathrm{E}-04$ \\
IL1B & 1,88 & $3,08 \mathrm{E}-05$ & 1,55 & $7,95 \mathrm{E}-03$ \\
IL23A & 2,12 & $6,74 \mathrm{E}-17$ & 1,53 & $4,02 \mathrm{E}-03$ \\
IL13 & 3,42 & $2,72 \mathrm{E}-09$ & 1,52 & $9,38 \mathrm{E}-03$ \\
\multicolumn{3}{l}{ Interleucinas reguladas apenas em FvFc $R$} \\
\hline
\end{tabular}

\section{FvFc R}

GENE FC (Log2) valor de $p$

IL36A $\quad 1,70 \quad 7,52 \mathrm{E}-03$

IL27 2,03 9,83E-04

Interleucinas reguladas apenas em OKT3

\begin{tabular}{rcr}
\hline \multicolumn{3}{c}{ OKT3 } \\
\hline GENE & FC $($ Log2) & valor de $p$ \\
IL9 & 6,61 & $6,82 \mathrm{E}-23$ \\
IL3 & 4,69 & $6,99 \mathrm{E}-23$ \\
IL21 & 4,43 & $4,37 \mathrm{E}-09$ \\
IL22 & 3,33 & $2,57 \mathrm{E}-05$ \\
IL5 & 2,40 & $3,44 \mathrm{E}-03$ \\
IL10 & $-2,07$ & $7,64 \mathrm{E}-04$ \\
IL18 & $-1,95$ & $6,00 \mathrm{E}-04$ \\
IL16 & $-1,37$ & $3,30 \mathrm{E}-04$ \\
\hline
\end{tabular}

Outra citocina associada com inflamação, com regulação positiva observada no presente trabalho foi a citocina IFN-y. Essa citocina participa tanto da imunidade inata, quanto da adaptativa, desempenhando funções distintas no combate à patógenos. Sua expressão sempre esteve associada com respostas pró-inflamatórias, sendo a responsável pelo agravamento de diversas doenças. 
Contudo, Volker e colaboradores (2011) utilizando linfócitos do sangue periférico de pacientes transplantados caracterizaram uma subpopulação de células Tregs induzidas (iTreg) produtoras de IFN-y. Eles demonstraram que a frequência de Tregs $\mathrm{CD} 4^{+} \mathrm{CD} 25^{+} \mathrm{Foxp} 3^{+} \mathrm{IFN}-\mathrm{y}^{+}$era maior em pacientes transplantados renais estáveis do que em aqueles que tinham algum processo de rejeição, sugerindo o papel imunorregulador desse subtipo de iTreg. Outro estudo anterior demostrou ainda que essa mesma subpopulação de iTreg, secretora de IFN- $\mathbf{y}^{+}$, exibiram uma notável capacidade de inibir a expansão de células T aloreativas (Stroopinksky et al, 2009).

O conhecimento atual do papel das iTregs na manutenção e tolerância imunológica pode ser descrito como um conhecimento em construção. Enquanto o paradigma Th1-Th2 revolucionou nosso entendimento da imunidade adaptativa, pela introdução do conceito de desenvolvimento alternativo induzido por citocinas secretadas por células do sistema imune, ativadas por patógenos, o paradigma Th17-Treg está longe de ser totalmente compreendido. 
CONCLUSÕES

E

PERSPECTIVAS 


\section{CONCLUSÕES E PERSPECTIVAS}

Por meio de RNA-Seq foi possível identificar diversos genes envolvidos com imunorregulação e fenótipo Tregs, induzidos pelos anticorpos anti-CD3. A versão humanizada (FvFc R) do anti-CD3 foi a que apresentou um perfil mais similar ao do OKT3, que por muito tempo foi utilizado na clínica para tratamento de rejeição a transplantes. Esse anticorpo foi descontinuado pelo seu potencial imunogênico devido a sua origem murina. Essa imunogenicidade induzia diversos efeitos colaterais para o paciente e, muitos deles, eram eventos adversos sérios, como convulsão e perda do órgão transplantado. A caracterização do potencial imunorregulador de versões humanizadas de antiCD3 é importante para a proposição de novos biofármacos capazes de induzir um estado de tolerância com menor efeito colateral.

A regulação positiva de genes envolvidos com morte celular induzida pelos anti-CD3 é um fator importante que pode estar associado com o menor potencial mitogênico desses anticorpos. Como por exemplo, a expressão de FAS, CD38, GZMB, CTLA-4 e GITR. Embora esse potencial tenha sido confirmado em outros estudos do nosso grupo, ainda é necessário realizar novas abordagens para determinar a via indutora de apoptose.

Um receptor importante induzido pelos anticorpos anti-CD3 foi o receptor da Vitamina D. Pela sua importância no tratamento de doenças autoimunes é fundamental a realização de mais estudos para verificar a ação conjunta da vitamina $D$ com os anticorpos anti-CD3, visto que poucos estudos fizeram essa abordagem. Além disso, a regulação da hidroxilase CYP27B1 mostra que a via de sinalização da vitamina $D$ pode ser um mecanismo importante para a indução da tolerância imunológica por esses anticorpos. E ainda, pode ser a chave para a inibição de citocinas de perfil Th17. 
As análises de RNA-Seq demonstraram que fatores de transcriçãol responsáveis pela diferenciação dos linfócitos T em Th1, Th17 e Treg foram induzidos com os anticorpos anti-CD3. E, embora, marcadores de Tregs foram os mais regulados positivamente é importante a determinação da frequência das subpopulações de linfócitos T induzidos pelos anticorpos anti-CD3 em trabalhos futuros.

Como perspectivas para trabalhos futuros, no intuito de uma melhor caracterização dos anticorpos anti-CD3, é fundamental a solução das seguintes questões:

a) Como é a dinâmica da produção de Foxp3 nos linfócitos $T$ estimulados com anticorpos anti-CD3?

b) Qual a subpopulação de linfócitos $T$ é predominantemente diferenciada após estimulação com esses anticorpos?

c) As células Tregs induzidas por esses anticorpos possuem atividade supressora?

d) Quais são as vias de apoptose induzidas por esses anticorpos?

e) Como é a regulação dos miRNA envolvidos com diferenciação de linfócitos T? 
REFERENNCIAS

BIBLIOGRÁFICAS 


\section{REFERÊNCIAS BIBLIOGRÁFICAS}

Adorini, L., \& Penna, G. (2008). Control of autoimmune diseases by the vitamin D endocrine system. Nature clinical practice Rheumatology, 4(8), 404-412.

Ahmad, Z. A.; Yeap, S. K.; Ali, A. M.; Ho, W. Y.; Banu, N.; Alitheen, M. e Hamid, M. (2012) ScFv Antibody: Principles and Clinical Application. Clinical and Developmental Immunology.

Akdis, C. A., \& Blaser, K. (2001). Mechanisms of interleukin-10-mediated immune suppression. Immunology, 103(2), 131-136.

Andersen, D. C., Reilly, D. E. (2004). Production technologies for monoclonal antibodies and their fragments. Cur. Op. Biotech. 15:458-462.

Anders, S., Pyl, P. T., Huber, W. (2014). HTSeq - a Python framework to work with high-troughput sequencing data. Bioinformatics, 31:166-169.

Ayyoub, M., Deknuydt, F., Raimbaud, I., Dousset, C., Leveque, L., Bioley, G., \& Valmori, D. (2009). Human memory FOXP3+ Tregs secrete IL-17 ex vivo and constitutively express the $\mathrm{TH} 17$ lineage-specific transcription factor RORyt. Proceedings of the National Academy of Sciences, 106(21), 86358640 .

Atkins, G. J., Anderson, P. H., Findlay, D. M., Welldon, K. J., Vincent, C., Zannettino, A. C., ... \& Morris, H. A. (2007). Metabolism of vitamin D< sub> $3</$ sub $>$ in human osteoblasts: Evidence for autocrine and paracrine activities of 1a, 25-dihydroxyvitamin D3. Bone, 40(6), 1517-1528.

Bacchetta R, Bigler M, Touraine JL, Parkman R, Tovo PA, Abrams J, et al. High levels of interleukin 10 production in vivo are associated with tolerance in 
SCID patients transplanted with HLA mismatched hematopoietic stem cells. J Exp Med. 1994; 179:493-502.

Bailey, R., Cooper, J. D., Zeitels, L., Smyth, D. J., Yang, J. H., Walker, N. M., ... \& Todd, J. A. (2007). Association of the vitamin D metabolism gene CYP27B1 with type 1 diabetes. Diabetes, 56(10), 2616-2621.

Beerli, R. R., \& Rader, C. (2010, July). Mining human antibody repertoires. InMAbs (Vol. 2, No. 4, p. 365). Landes Bioscience.

Belghith, M., Bluestone, J. A., Barriot, S., Megret, J., Bach, J. F. \& Chatenoud, L. (2003) TGF-beta-dependent mechanisms mediate restoration of selftolerance induced by antibodies to CD3 in overt autoimmune diabetes. Nat Med, 9: 1202-1208

Bettelli, E., Korn, T., Oukka, M., \& Kuchroo, V. K. (2008). Induction and effector functions of TH17 cells. Nature, 453(7198), 1051-1057.

Bezerra, M.A.G,. (2014). Estudo do perfil imunorregulatório de anticorpos humanizados anti-CD3. Tese de Doutorado. Programa de Biologia Molecular. Universidade de Brasília.

Biedermann, T., Röcken, M., \& Carballido, J. M. (2004, January). TH1 and TH2 Lymphocyte Development and Regulation of TH Cell-Mediated Immune Responses of the Skin. In Journal of Investigative Dermatology Symposium Proceedings (Vol. 9, No. 1, pp. 5-14). Nature Publishing Group.

Birzele, F., Fauti, T., Stahl, H., Lenter, M.C, Simon, E., Knebel, D., Weith, A., Hildebrandt, T., Mennerich, D. Next generation insights into regulatory $T$ cells: expression. (2011). Profiling and FoxP3 occupancy in Human. Nucleic Acids Research, 1-15. 
Bisikirska, B., Colgan, J., Luban, J., Bluestone, J.A. e Herold, K.C. (2005) TCR stimulation with modified anti-CD3 mAb expands CD8+ $T$ cell population and induces CD8+CD25+ Tregs. J Clin Invest, 115: 2904-2913

Biswas, P. S., Bhagat, G., \& Pernis, A. B. (2010). IRF4 and its regulators: evolving insights into the pathogenesis of inflammatory arthritis?.Immunological reviews, 233(1), 79-96.

Boxer, R. S., Dauser, D. A., Walsh, S. J., Hager, W. D., \& Kenny, A. M. (2008). The Association Between Vitamin $D$ and Inflammation with the 6-Minute Walk and Frailty in Patients with Heart Failure. Journal of the American Geriatrics Society, 56(3), 454-461.

Broughton, S. E., Dhagat, U., Hercus, T. R., Nero, T. L., Grimbaldeston, M. A., Bonder, C. S., ... \& Parker, M. W. (2012). The GM-CSF/IL-3/L-5 cytokine receptor family: from ligand recognition to initiation of signaling.Immunological reviews, 250(1), 277-302.

Caldas, C., Coelho, V. P., Rigden, D. J., Neschich, G., Moro, A. M., \& Brígido, M. M. (2000). Design and synthesis of germline-based hemi-humanized singlechain Fv against the CD18 surface antigen. Protein Engineering, 13(5), 353360 .

Carpenter, P., Pavlovic, S., Tso, Y., Press, O.W. et al. (2000) Non-Fc ReceptorBinding Humanized Anti-CD3 Antibodies Induce Apoptosis of Activated Human T Cells. The Journal of Immunol. 165: 6205-6213.

Chatenoud L. (2003) CD3-specific antibody-induced active tolerance: from bench to bedside. Nat Rev Immunol. 3:123-32.

Chatenoud, L. (2004, January). CD3 antibody treatment stimulates the functional capability of regulatory T cells. In Novartis Found. Symp (Vol. 252, pp. 279286). 
Chen, Y., Kuchroo, V. K., Inobe, J. I., Hafler, D. A., \& Weiner, H. L. (1994). Regulatory $\mathrm{T}$ cell clones induced by oral tolerance: suppression of autoimmune encephalomyelitis. Science, 265(5176), 1237-1240.

Chinen, J., \& Buckley, R. H. (2010). Transplantation immunology: solid organ and bone marrow. Journal of Allergy and Clinical Immunology, 125(2), S324S335.

Cohen, I.R. (2005) Tending Adam's Garden. Elsevier Academic Press ed., San Diego, EUA.

Cohen, J., \& Wilson, A. (2009, January). New challenges to medicare beneficiary access to mAbs. In MAbs (Vol. 1, No. 1, pp. 56-66).

Cosimi A. B., Burton R. C., Colvin R. B., Goldstein G., Delmonico F. L., et al. (1981). Treatment of acute renal allograft rejection with OKT3 monoclonal antibody. Transplantation. 32: 535-539.

Costa, P. L. N. (2004) Caracterização da atividade ligante de domínios variáveis humanizados de um anticorpo anti-CD3 humano. Dissertação de Mestrado. Departamento de Biologia Celular, Universidade de Brasília, Brasília.

Couper, K. N., Blount, D. G., \& Riley, E. M. (2008). IL-10: the master regulator of immunity to infection. The Journal of Immunology, 180(9), 5771-5777.

Cragg, M., Glennie, M. J. (2004) Antibody specificity controls in vivo effector mechanisms of anti-CD20 reagents. Blood. 103:2738-2743.

Cretney, E., Xin, A., Shi, W., Minnich, M., Masson, F., Miasari, M., ... \& Kallies, A. (2011). The transcription factors Blimp-1 and IRF4 jointly control the differentiation and function of effector regulatory $T$ cells. Nature immunology, 12(4), 304-311. 
Di lanni, M., Falzetti, F., Carotti, A., Terenzi, A., Castellino, F., Bonifacio, E., ... \& Martelli, M. F. (2011). Tregs prevent GVHD and promote immune reconstitution in HLA-haploidentical transplantation. Blood, 117(14), 39213928.

Efimova, O. V., \& Kelley, T. W. (2009). Induction of granzyme B expression in Tcell receptor/CD28-stimulated human regulatory $T$ cells is suppressed by inhibitors of the PI3K-mTOR pathway. BMC immunology, 10(1), 59.

Faunce, D. E., Terajewicz, A., \& Stein-Streilein, J. (2004). Cutting edge: in vitrogenerated tolerogenic APC induce CD8+ $T$ regulatory cells that can suppress ongoing experimental autoimmune encephalomyelitis. The Journal of Immunology, 172(4), 1991-1995.

Feng, T., Cao, A. T., Weaver, C. T., Elson, C. O., \& Cong, Y. (2011). Interleukin12 Converts Foxp3+ Regulatory T Cells to Interferon- $\gamma$-Producing Foxp3+ T Cells That Inhibit Colitis.Gastroenterology, 140(7), 2031-2043.

Fonseca, A. S. D. (2000) Construção e expressão de duas versões humanizadas scFv de um anticorpo Anti-CD3. Dissertação de Mestrado. Departamento de Biologia Celular, Universidade de Brasília, Brasília.

Goldsby, R.A. et al. (2003). Immunology . 5.ed. New York : W.H. Freeman, 551 p.

Green, E. A., Gorelik, L., McGregor, C. M., Tran, E. H., \& Flavell, R. A. (2003). CD4+ CD25+ $T$ regulatory cells control anti-islet CD8+ $T$ cells through TGF$\beta-$ TGF- $\beta$ receptor interactions in type 1 diabetes. Proceedings of the National Academy of Sciences, 100(19), 10878-10883.

Grossman, W. J., Verbsky, J. W., Barchet, W., Colonna, M., Atkinson, J. P., \& Ley, T. J. (2004). Human T regulatory cells can use the perforin pathway to cause autologous target cell death. Immunity, 21(4), 589-601. 
Handel, A. E., Sandve, G. K., Disanto, G., Berlanga-Taylor, A. J., Gallone, G., Hanwell, H., ... \& Ramagopalan, S. V. (2013). Vitamin D receptor ChIP-seq in primary CD4+ cells: relationship to serum 25-hydroxyvitamin D levels and autoimmune disease. BMC medicine, 11(1), 163.

Haug, C., Müller, F., Aukrust, P., \& Frøland, S. S. (1994). Subnormal serum concentration of 1, 25-vitamin D in human immunodeficiency virus infection: correlation with degree of immune deficiency and survival. Journal of Infectious Diseases, 169(4), 889-893.

Heninger, A. K., Theil, A., Wilhelm, C., Petzold, C., Huebel, N., Kretschmer, K., ... \& Monti, P. (2012). IL-7 abrogates suppressive activity of human CD4+ CD25+ FOXP3+ regulatory T cells and allows expansion of alloreactive and autoreactive T cells. The Journal of Immunology, 189(12), 5649-5658.

Holstein, S. A. e Hohl, R. J. (2012) Therapeutic Additions and Possible Delections in Oncology in 2011. Clinical pharmacology \& Therapeutics, v.91, n.1, p.1518.

Huehn, J., Polansky, J. K., \& Hamann, A. (2009). Epigenetic control of FOXP3 expression: the key to a stable regulatory T-cell lineage?. Nature Reviews Immunology, 9(2), 83-89.

Ishida, Y., Agata, Y., Shibahara, K., \& Honjo, T. (1992). Induced expression of PD-1, a novel member of the immunoglobulin gene superfamily, upon programmed cell death. The EMBO journal, 11(11), 3887.

Jankovic, D., Kullberg, M. C., Noben-Trauth, N., Caspar, P., Paul, W. E., \& Sher, A. (2000). Single cell analysis reveals that IL-4 receptor/Stat6 signaling is not required for the in vivo or in vitro development of CD4+ lymphocytes with a Th2 cytokine profile. The Journal of Immunology, 164(6), 3047-3055. 
Jones, P. T., Dear, P. H., Foote, J., Neuberger, M. S., Winter, G. (1986) Replacing the complementarity-determining regions in a human antibody with those from a mouse. Nature. 321:522-525.

Jonuleit, H., \& Schmitt, E. (2003). The regulatory T cell family: distinct subsets and their interrelations. The Journal of Immunology, 171(12), 6323-6327.

Kaplan, M. H., Schindler, U., Smiley, S. T., \& Grusby, M. J. (1996). Stat6 is required for mediating responses to IL-4 and for the development of Th2 cells. Immunity, 4(3), 313-319.

Kim, S. J., Park, Y., \& Hong, H. J. (2005). Antibody engineering for the development of therapeutic antibodies. Mol Cells, 20(1), 17-29.

Kimball, J. A., Norman, D. J., Shield, C. F., Schroeder, T. J., Lisi, P., Garovoy, M., ... \& Wall, W. (1995). The OKT3 antibody response study: a multicentre study of human anti-mouse antibody (HAMA) production following OKT3 use in solid organ tranplantation. Transplant immunology, 3(3), 212-221.

Kohlhaas, S., Garden, O. A., Scudamore, C., Turner, M., Okkenhaug, K., \& Vigorito, E. (2009). Cutting edge: the Foxp3 target miR-155 contributes to the development of regulatory T cells. The Journal of Immunology, 182(5), 2578-2582.

Korn, T., Bettelli, E., Oukka, M., \& Kuchroo, V. K. (2009). IL-17 and Th17 Cells. Annual review of immunology, 27, 485-517.

Kreijveld, E., Koenen, H. J. P. M., Klasen, I. S., Hilbrands, L. B., \& Joosten, I. (2007). Following Anti-CD25 Treatment, A Functional CD4+ CD25+ Regulatory T-Cell Pool Is Present in Renal Transplant Recipients. American journal of transplantation, 7(1), 249-255. 
Kushwah, R., \& Hu, J. (2011). Role of dendritic cells in the induction of regulatory T cells. Cell Biosci, 1(1), 20.

Lee, Y. K., Turner, H., Maynard, C. L., Oliver, J. R., Chen, D., Elson, C. O., \& Weaver, C. T. (2009). Late developmental plasticity in the T helper 17 lineage. Immunity, 30(1), 92-107.

Li, F., Vijayasankaran, N., Shen, A. Y., Kiss, R., Amanullah, A. (2010) Cell culture processes for monoclonal antibody production. mAbs 2:5, 466-477.

Liu, K. J. (2006). Dendritic cell, toll-like receptor, and the immune system. J Cancer Mol, 2(6), 213-215.

Liu, W., Putnam, A. L., Xu-Yu, Z., Szot, G. L., Lee, M. R., Zhu, S., ... \& Bluestone, J. A. (2006). CD127 expression inversely correlates with FoxP3 and suppressive function of human CD4+ $\mathrm{T}$ reg cells. The Journal of experimental medicine, 203(7), 1701-1711.

Lopez, E. R., Zwermann, O., Segni, M., Meyer, G., Reincke, M., Seissler, J., ... \& Badenhoop, K. (2004). A promoter polymorphism of the CYP27B1 gene is associated with Addison's disease, Hashimoto's thyroiditis, Graves' disease and type 1 diabetes mellitus in Germans. European journal of endocrinology, 151(2), 193-197.

Love MI, Huber W and Anders S (2014). "Moderated estimation of fold change and dispersion for RNA-seq data with DESeq2." Genome Biology, 15, pp. 550

Luckheeram, R. V, Zhou, R., Verma, A. D., Xia, B. (2012) CD4 ${ }^{+}$T Cells: Differentiation and Functions, Clinical and Developmental Immunology, 2012: doi:10.1155/2012/925135 
Maranhão, A.Q., Simi, K.C.R, Brigido, M.M, Burtet, R.T. in: Resende., R. Biotecnologia Aplicada à Agro\&Indústria: Fundamentos e Aplicações. Editora Blucher. No prelo.

Maranhão, A. Q., Brigido, M.M. (2001) Anticorpos Humanizados. Biotecnologia Ciência e Desenvolvimento. 23. Nov/Dez.

Marioni, J.C., Mason, C.E., Mane, S.M. et al. (2008) Comparison with gene expression arrays. RNA-seq: An assessment of technical reproducibility. Genome Res. 18: 1509-1517

Modrek, B. \& Lee, C. (2002) A genomic view of alternative splicing. Nature genetics 30: 13-19

Morrison, S. L., Johnson, M. J., Herzenberg, L. A., \& Oi, V. T. (1984). Chimeric human antibody molecules: mouse antigen-binding domains with human constant region domains. Proceedings of the National Academy of Sciences, 81(21), 6851-6855.

Moser, M., \& Murphy, K. M. (2000). Dendritic cell regulation of TH1-TH2 development. Nature immunology, 1(3), 199-205.

Murphy, T. L., Tussiwand, R., \& Murphy, K. M. (2013). Specificity through cooperation: BATF-IRF interactions control immune-regulatory networks.Nature Reviews Immunology, 13(7), 499-509.

Navarra, S. V., Guzmán, R. M., Gallacher, A. E., Hall, S., Levy, R. A., Jimenez, R. E., ... \& Petri, M. A. (2011). Efficacy and safety of belimumab in patients with active systemic lupus erythematosus: a randomised, placebocontrolled, phase 3 trial. The Lancet, 377(9767), 721-731. 
Nguyen, K. D., Fohner, A., Booker, J. D., Dong, C., Krensky, A. M., \& Nadeau, K. C. (2008). XCL1 Enhances Regulatory Activities of CD4+ CD25highCD127low/- T Cells in Human Allergic Asthma. The Journal of Immunology, 181(8), 5386-5395.

O'Reilly, D., Quinn, C. M., El-Shanawany, T., Gordon, S., \& Greaves, D. R. (2003). Multiple Ets factors and interferon regulatory factor-4 modulate CD68 expression in a cell type-specific manner. Journal of Biological Chemistry,278(24), 21909-21919.

Penna, G., Roncari, A., Amuchastegui, S., Daniel, K. C., Berti, E., Colonna, M., \& Adorini, L. (2005). Expression of the inhibitory receptor ILT3 on dendritic cells is dispensable for induction of CD4+ Foxp3+ regulatory T cells by 1 , 25-dihydroxyvitamin D3. Blood, 106(10), 3490-3497.

Pot, C., Apetoh, L., \& Kuchroo, V. K. (2011, June). Type 1 regulatory T cells (Tr1) in autoimmunity. In Seminars in immunology (Vol. 23, No. 3, pp. 202-208). Academic Press.

Putnam, A. L., Brusko, T. M., Lee, M. R., Liu, W., Szot, G. L., Ghosh, T., ... \& Bluestone, J. A. (2009). Expansion of human regulatory T-cells from patients with type 1 diabetes. Diabetes, 58(3), 652-662.

Reiter, Y., \& Pastan, I. (1996). Antibody engineering of recombinant FV immunotoxins for improved targeting of cancer: disulfide-stabilized Fv immunotoxins. Clinical cancer research, 2(2), 245-252.

Rocha, P. N., Plumb, T. J., Crowley, S. D., \& Coffman, T. M. (2003). Effector mechanisms in transplant rejection. Immunological reviews, 196(1), 51-64.

Ruggiero, L. A. (2002) Clonagem e expressão de anticorpos recombinantes em células de ovário de hamster chinês $(\mathrm{CHO})$ em cultura. Dissertação de 
Mestrado. Departamento de Biologia Celular, Universidade de Brasília, Brasília.

Reichert, J., \& Pavlou, A. (2004). Monoclonal antibodies market. Nature Reviews Drug Discovery, 3(5), 383-384.

Sakaguchi S. (2005) Naturally arising Foxp3-expressing CD25+CD4+ regulatory T cells in immunological tolerance to self and non-self. Nat Immunol. 6:34552

Salmena, L., Lemmers, B., Hakem, A., Matysiak-Zablocki, E., Murakami, K., Au, P. B., ... \& Hakem, R. (2003). Essential role for caspase 8 in T-cell homeostasis and T-cell-mediated immunity. Genes \& development, 17(7), 883-895.

Sambrook, J. e Russel, D. W. (2001) Molecular Cloning - a laboratory manual. $3^{a}$ edição. Cold Spring Harbor, Nova York: Cold Spring Harbor Laboratory

Silva, H.M (2008) Caracterização da atividade ligante e da função efetora de Anticorpos humanizados Anti CD3 Humano. Dissertação (Mestrado em Ciências Biológicas (Biologia Molecular)) - Universidade de Brasília.

Schmetterer, K. G., Neunkirchner, A., \& Pickl, W. F. (2012). Naturally occurring regulatory $T$ cells: markers, mechanisms, and manipulation. The FASEB Journal, 26(6), 2253-2276.

Scollay, R., Jacobs, S., Jerabek, L., Butcher, E., \& Weissman, I. (1980). T cell maturation: thymocyte and thymus migrant subpopulations defined with monoclonal antibodies to MHC region antigens. The Journal of Immunology,124(6), 2845-2853. 
Schmetterer, K. G., Neunkirchner, A., \& Pickl, W. F. (2012). Naturally occurring regulatory $T$ cells: markers, mechanisms, and manipulation. The FASEB Journal, 26(6), 2253-2276.

Seeman, E., Delmas, P. D., Hanley, D. A., Sellmeyer, D., Cheung, A. M., Shane, E., ... \& Zanchetta, J. (2010). Microarchitectural deterioration of cortical and trabecular bone: differing effects of denosumab and alendronate. Journal of Bone and Mineral Research, 25(8), 1886-1894.

Sethi A, Kulkarni N, Sonar S and Lal G (2013) Role of miRNAs in CD4 T cell plasticity during inflammation and tolerance.Front. Gene. 4:8. doi: 10.3389/fgene.2013.00008

Shen, L. S., Wang, J., Shen, D. F., Yuan, X. L., Dong, P., Li, M. X., ... \& Xu, D. (2009). CD4 (+) CD25 (+) CD127 (low/-) regulatory T cells express Foxp3 and suppress effector $T$ cell proliferation and contribute to gastric cancers progression. Clinical immunology (Orlando, Fla.), 131(1), 109-118.

Smith, C. A., Williams, G. T., Kingston, R., Jenkinson, E. J., \& Owen, J. J. (1989). Antibodies to CD3/T-cell receptor complex induce death by apoptosis in immature T cells in thymic cultures.

Stockinger, B., \& Veldhoen, M. (2007). Differentiation and function of Th17 T cells. Current opinion in immunology, 19(3), 281-286.

Sultan, M., Schulz, M.H., Richard, M., Magen, A., et al. (2008) A Global View of Gene Activity and Alternative Splicing by Deep Sequencing of the Human Transcriptome. Science 321: 956-960

Szabo, S. J., Dighe, A. S., Gubler, U., \& Murphy, K. M. (1997). Regulation of the interleukin (IL)-12R $\beta 2$ subunit expression in developing T helper 1 (Th1) and Th2 cells. The Journal of experimental medicine, 185(5), 817-824. 
Trzonkowski, P., Bieniaszewska, M., Juścińska, J., Dobyszuk, A., Krzystyniak, A., Marek, N., ... \& Hellmann, A. (2009). First-in-man clinical results of the treatment of patients with graft versus host disease with human ex vivo expanded CD4+ CD25+ CD127- $T$ regulatory cells. Clinical immunology, 133(1), 22-26.

van Parijs, L., \& Abbas, A. K. (1996). Role of Fas-mediated cell death in the regulation of immune responses. Current opinion in immunology, 8(3), 355361.

von Essen, M. R., Kongsbak, M., Schjerling, P., Olgaard, K., Ødum, N., \& Geisler, C. (2010). Vitamin D controls T cell antigen receptor signaling and activation of human T cells. Nature immunology, 11(4), 344-349.

Vignali, D. A., Collison, L. W., \& Workman, C. J. (2008). How regulatory T cells work. Nature Reviews Immunology, 8(7), 523-532.

Viola, A., \& Lanzavecchia, A. (1996). T cell activation determined by T cell receptor number and tunable thresholds. Science, 273(5271), 104-106.

Walsh, G. (2005). Biopharmaceuticals: recent approvals and likely directions.Trends in biotechnology, 23(11), 553-558.

Wang, S. Y. (2010) Interactions between complemente and cellular mediated mechanisms of monoclonal antibody therapy. Dissertação. Universidade de lowa.

Wang, Z., Gerstein, M. \& Snyder, M. (2009) RNA-seq: a Revolutionary Tool for Transcriptomics. Nature Rev. Genetics 10: 57-63 
Weiner, H. L. (2001). Induction and mechanism of action of transforming growth factor- $\beta$-secreting Th3 regulatory cells. Immunological reviews, 182(1), 207214.

Wells, A. D., Li, X. C., Strom, T. B. e Turka, L. A. (2001). The role of peripheral T-cell deletion in transplantation tolerance. Philos Trans R Soc Lond B Biol Sci. 356(1409): 617-23.

Wu, L., Wang, C., Zhang, D., Zhang, X., Qian, W., Zhao, L., ... \& Guo, Y. (2010). Characterization of a humanized anti-CD20 antibody with potent antitumor activity against B-cell lymphoma. Cancer letters, 292(2), 208-214.

Yang, X. O., Nurieva, R., Martinez, G. J., Kang, H. S., Chung, Y., Pappu, B. P., ... \& Dong, C. (2008). Molecular antagonism and plasticity of regulatory and inflammatory T cell programs. Immunity, 29(1), 44-56.

Zhang, X., Brunner, T., Carter, L., Dutton, R. W., Rogers, P., Bradley, L., ... \& Swain, S. L. (1997). Unequal death in T helper cell (Th) 1 and Th2 effectors: Th1, but not Th2, effectors undergo rapid Fas/FasL-mediated apoptosis. The Journal of experimental medicine, 185(10), 1837-1849.

Zhao, S., Fung-Leung, W. P., Bittner, A., Ngo, K., \& Liu, X. (2014). Comparison of RNA-Seq and microarray in transcriptome profiling of activated $T$ cells. PloS one, 9(1), e78644.

Zhu, J., Yamane, H., \& Paul, W. E. (2010). Differentiation of effector CD4 T cell populations. Annual review of immunology, 28, 445. 
ANEXOS 


\section{ANEXO I}

Resultados das análises da qualidade das sequências obtidas por RNASeq

O sequenciamento de RNA do tipo paired-end do Illumina gera sequências a partir das duas extremidades dos fragmentos de RNA (Figura 25). As sequências geradas foram analisadas pelo software FastQC. Os resultados desses softwares são gráficos que determina os valores em escala Phred. Sequências com valores > 20 são considerados bons e > 30 são considerados de ótima qualidade. A figura 26 representa os gráficos contendo informações da qualidade das sequencias de ambas as reads (R1 e R2) de os tratamentos (replicatas 1 e 2).

\section{Read 1}

Figura 25 - Sequenciamento do tipo paired-end

Read 2
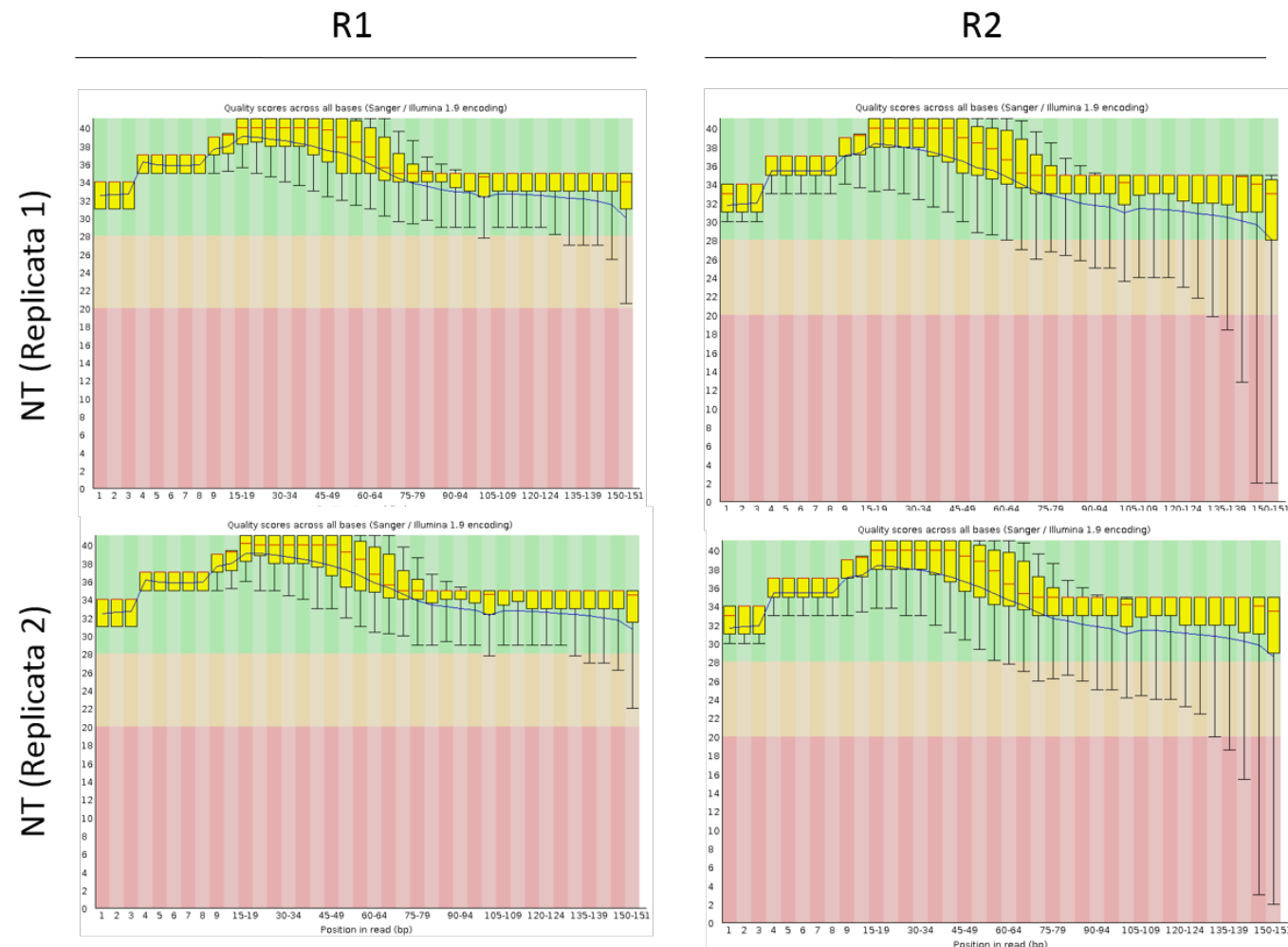

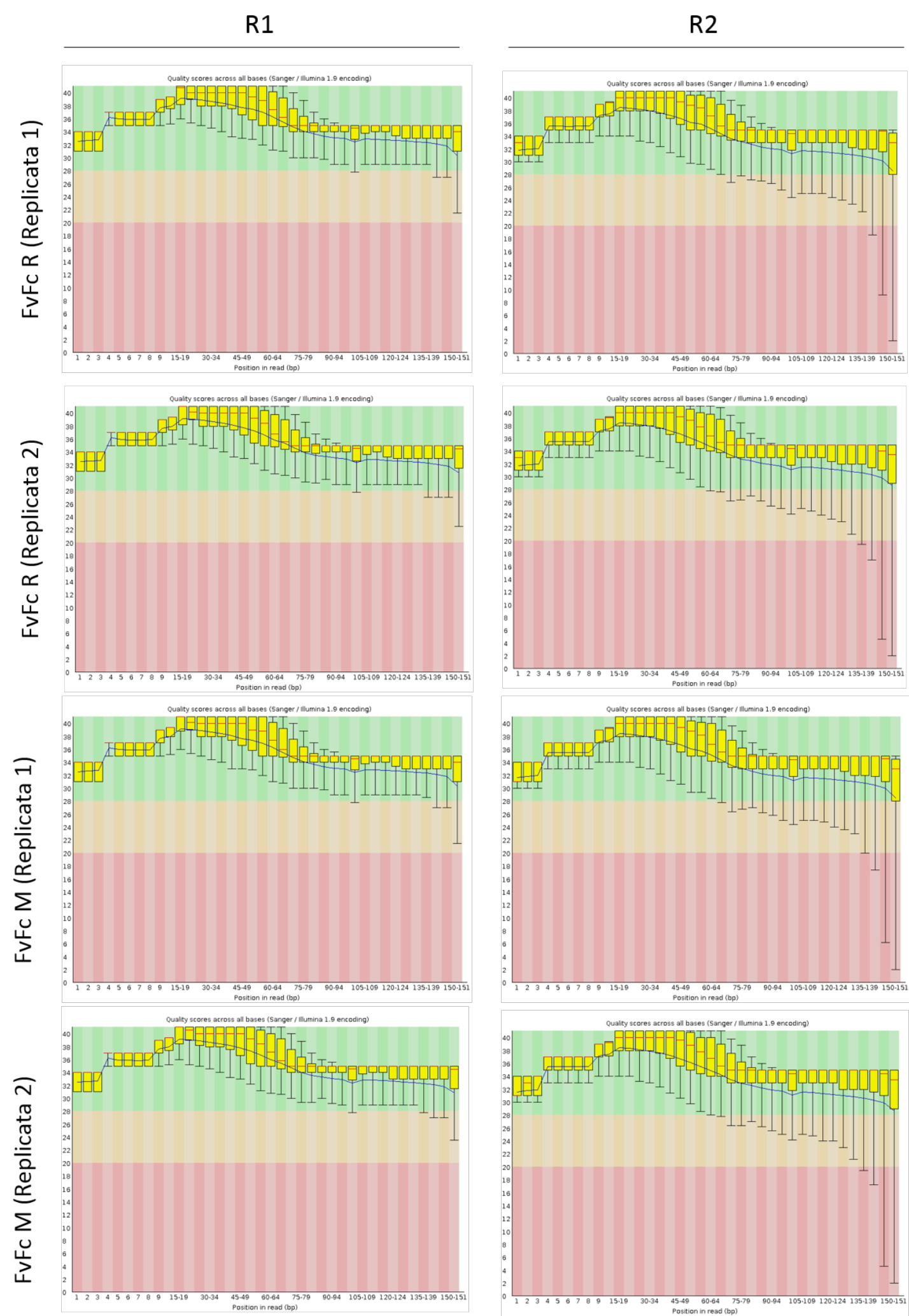
R1
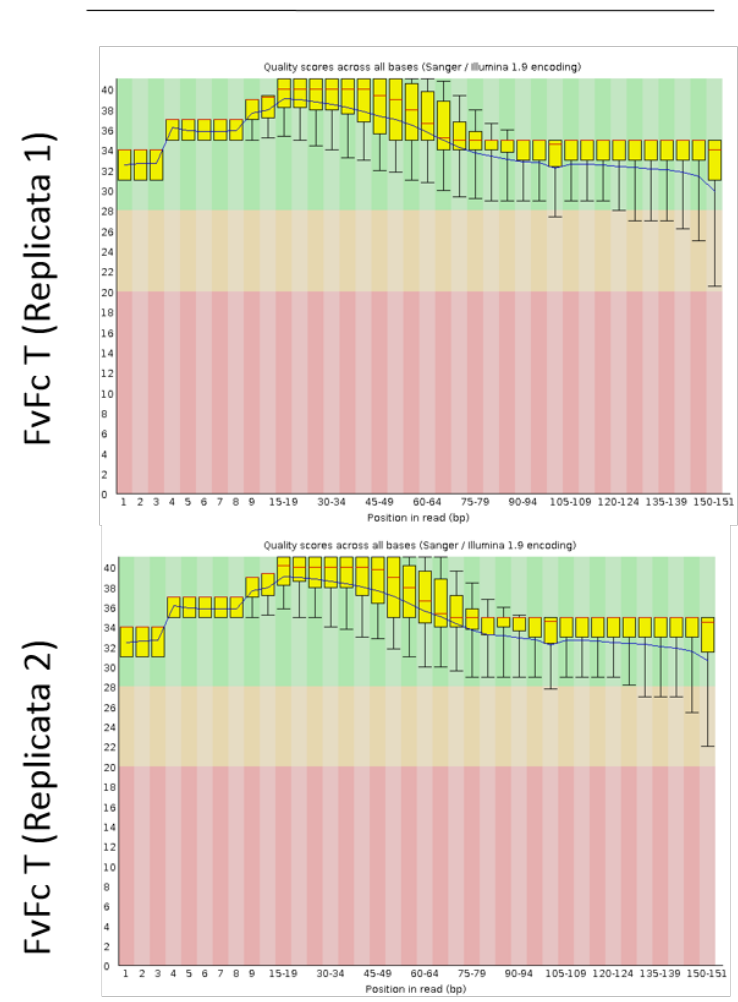

R2
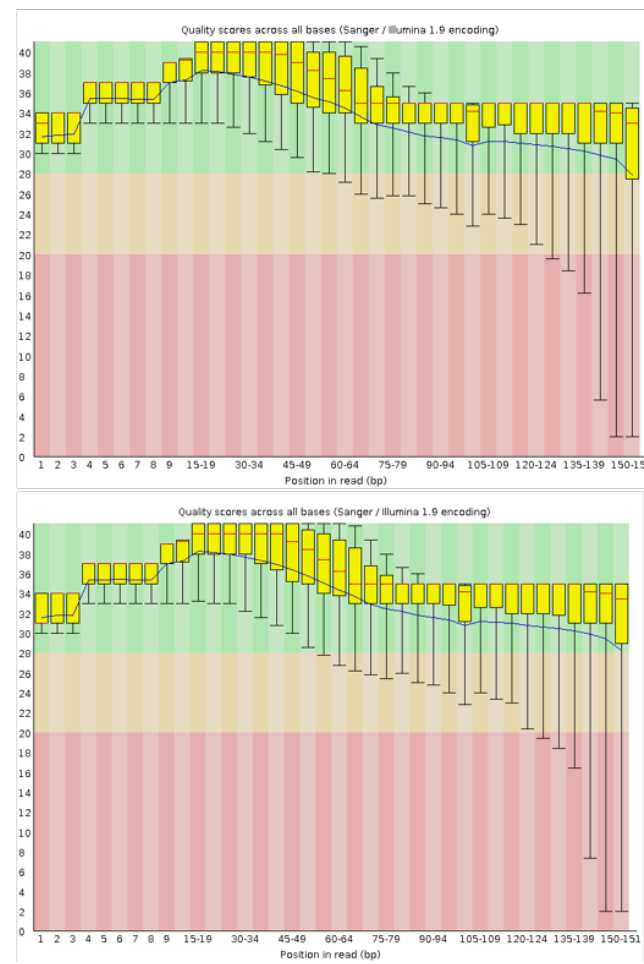

Figura 26 - Representação gráfica da qualidade dos dados de RNA-Seq provenientes de sequenciadores Illumina. Qualidade boa em verde, razoável em laranja e ruim em vermelho 
ANEXO II

Lista de genes comuns entre os tratamentos $(p<0,01)$ organizados em ordem alfabética.

\section{1) Genes regulados comumente entre os tratamentos}

\begin{tabular}{|c|c|c|c|c|c|c|}
\hline \multirow[b]{2}{*}{ Gene } & \multicolumn{2}{|c|}{ OKT3 } & \multicolumn{2}{|c|}{ FvFc R } & \multicolumn{2}{|c|}{ FvFc M } \\
\hline & $\begin{array}{c}F C \\
\text { (Log2) }\end{array}$ & $p$ value & $\begin{array}{c}\text { FC } \\
(\log 2)\end{array}$ & $p$ value & $\begin{array}{c}F C \\
(\log 2)\end{array}$ & $p$ value \\
\hline $\mathrm{A} 2 \mathrm{M}$ & $-2,92$ & $8,48 \mathrm{E}-36$ & $-2,25$ & $4,89 \mathrm{E}-10$ & $-3,40$ & $6,60 \mathrm{E}-13$ \\
\hline AC002314,4 & 3,97 & $2,28 \mathrm{E}-07$ & 2,52 & $9,83 \mathrm{E}-05$ & 1,47 & $9,16 \mathrm{E}-03$ \\
\hline AC004381,6 & 3,80 & $8,13 \mathrm{E}-34$ & 3,39 & 1,77E-14 & 2,14 & $1,10 \mathrm{E}-04$ \\
\hline AC005077,14 & 3,52 & 2,09E-07 & 2,46 & 8,09E-05 & 1,67 & $4,21 \mathrm{E}-03$ \\
\hline AC005932,1 & $-2,88$ & $1,26 \mathrm{E}-06$ & $-1,65$ & $5,60 \mathrm{E}-03$ & $-2,58$ & $5,30 \mathrm{E}-06$ \\
\hline AC006465,4 & 6,98 & $2,12 \mathrm{E}-81$ & 5,83 & $9,26 \mathrm{E}-32$ & 3,57 & $2,98 \mathrm{E}-10$ \\
\hline AC007620,3 & $-2,77$ & $4,42 \mathrm{E}-06$ & $-1,44$ & $8,51 \mathrm{E}-03$ & $-1,80$ & $1,19 \mathrm{E}-03$ \\
\hline AC011893,3 & 3,72 & 1,84E-07 & 5,72 & 1,82E-28 & 2,93 & $4,70 \mathrm{E}-07$ \\
\hline AC011899,9 & $-5,05$ & $1,81 \mathrm{E}-21$ & $-1,63$ & 6,61E-03 & $-3,62$ & $1,35 \mathrm{E}-14$ \\
\hline AC017002,1 & 3,65 & $3,28 \mathrm{E}-15$ & 2,13 & 1,11E-04 & 3,13 & $2,74 \mathrm{E}-10$ \\
\hline AC018693,5 & $-3,38$ & $6,00 \mathrm{E}-08$ & $-1,88$ & $3,74 \mathrm{E}-04$ & $-2,06$ & $1,17 \mathrm{E}-04$ \\
\hline AC024560,2 & 3,17 & $6,26 \mathrm{E}-06$ & 3,75 & $6,43 \mathrm{E}-11$ & 1,95 & $8,27 \mathrm{E}-04$ \\
\hline AC064834,3 & $-2,55$ & 1,71E-03 & $-1,92$ & $2,88 \mathrm{E}-03$ & $-1,74$ & $2,47 \mathrm{E}-03$ \\
\hline AC068580,6 & $-3,24$ & $8,53 \mathrm{E}-12$ & $-1,56$ & $2,56 \mathrm{E}-03$ & $-2,01$ & $5,41 \mathrm{E}-05$ \\
\hline AC069213,1 & 2,65 & $1,35 \mathrm{E}-13$ & 2,55 & 1,30E-09 & 1,97 & $2,57 \mathrm{E}-04$ \\
\hline AC083899,1 & 3,43 & $1,05 \mathrm{E}-12$ & 3,01 & 5,26E-09 & 1,47 & $9,94 \mathrm{E}-03$ \\
\hline AC087645,1 & 4,71 & $4,89 \mathrm{E}-12$ & 3,58 & 4,16E-09 & 2,05 & $4,44 \mathrm{E}-04$ \\
\hline AC104297,1 & 2,47 & $2,10 \mathrm{E}-26$ & 1,55 & $9,12 \mathrm{E}-06$ & 1,09 & $3,06 \mathrm{E}-03$ \\
\hline AC104809,4 & $-2,85$ & $1,81 \mathrm{E}-04$ & $-2,16$ & $7,52 \mathrm{E}-04$ & $-2,46$ & $2,52 \mathrm{E}-05$ \\
\hline AC112721,2 & 2,68 & $3,43 \mathrm{E}-06$ & 2,60 & $2,15 \mathrm{E}-06$ & 2,18 & $5,64 \mathrm{E}-05$ \\
\hline ACBD7 & 4,29 & $1,93 \mathrm{E}-10$ & 3,14 & $5,04 \mathrm{E}-07$ & 2,01 & $5,85 \mathrm{E}-04$ \\
\hline ACOT7 & 2,90 & $3,71 \mathrm{E}-32$ & 2,45 & $5,06 \mathrm{E}-12$ & 1,55 & $1,80 \mathrm{E}-04$ \\
\hline ACPP & $-2,81$ & $4,85 \mathrm{E}-09$ & $-2,11$ & $1,54 \mathrm{E}-06$ & $-2,25$ & $4,25 \mathrm{E}-06$ \\
\hline ACTG2 & 3,12 & $2,89 \mathrm{E}-07$ & 3,33 & $8,22 \mathrm{E}-10$ & 1,65 & $4,58 \mathrm{E}-03$ \\
\hline AD000684,2 & $-3,55$ & $8,92 \mathrm{E}-20$ & $-2,16$ & 1,35E-07 & $-1,26$ & $2,24 \mathrm{E}-03$ \\
\hline ADAM19 & 2,69 & $6,98 \mathrm{E}-75$ & 1,06 & $9,23 \mathrm{E}-04$ & 2,04 & $1,55 \mathrm{E}-09$ \\
\hline ADAP2 & $-3,26$ & 2,17E-09 & $-1,52$ & $6,07 \mathrm{E}-03$ & $-1,64$ & $2,57 \mathrm{E}-03$ \\
\hline ADORA2B & $-3,49$ & 8,77E-09 & $-1,82$ & 5,55E-04 & $-2,48$ & $1,07 \mathrm{E}-06$ \\
\hline ADORA3 & $-4,91$ & $1,68 \mathrm{E}-12$ & $-3,17$ & 1,54E-07 & $-3,26$ & $2,60 \mathrm{E}-10$ \\
\hline AGMAT & 1,21 & $1,19 \mathrm{E}-03$ & 1,34 & $1,40 \mathrm{E}-03$ & 1,13 & $9,73 \mathrm{E}-03$ \\
\hline AHNAK & $-2,11$ & $2,53 \mathrm{E}-13$ & $-1,58$ & $6,57 \mathrm{E}-06$ & $-1,21$ & $3,45 \mathrm{E}-03$ \\
\hline AHNAK2 & $-3,96$ & $5,47 \mathrm{E}-14$ & $-2,22$ & $8,69 \mathrm{E}-07$ & $-2,45$ & $3,11 \mathrm{E}-08$ \\
\hline AIF1 & $-2,11$ & $6,28 \mathrm{E}-08$ & $-1,13$ & $5,58 \mathrm{E}-03$ & $-1,67$ & $7,26 \mathrm{E}-05$ \\
\hline AIM2 & 3,05 & $8,94 \mathrm{E}-36$ & 1,45 & $8,33 \mathrm{E}-04$ & 2,09 & $2,93 \mathrm{E}-06$ \\
\hline AKAP5 & 1,44 & $3,06 \mathrm{E}-04$ & 1,60 & $7,58 \mathrm{E}-04$ & 1,45 & $1,56 \mathrm{E}-03$ \\
\hline AL591704,5 & 2,05 & $1,44 \mathrm{E}-04$ & 4,09 & $4,65 \mathrm{E}-18$ & 2,86 & $5,98 \mathrm{E}-08$ \\
\hline ALDH18A1 & 1,87 & $2,64 \mathrm{E}-13$ & 1,48 & 4,43E-04 & 1,11 & $5,18 \mathrm{E}-03$ \\
\hline ALDH3A2 & $-2,43$ & 1,92E-07 & $-1,35$ & $3,44 \mathrm{E}-03$ & $-1,46$ & $1,20 \mathrm{E}-03$ \\
\hline ANKRD13B & 2,84 & $1,95 \mathrm{E}-08$ & 2,18 & $8,36 \mathrm{E}-06$ & 1,53 & $1,09 \mathrm{E}-03$ \\
\hline ANKRD18DP & 4,83 & $2,01 \mathrm{E}-11$ & 3,09 & $1,20 \mathrm{E}-06$ & 1,81 & $1,83 \mathrm{E}-03$ \\
\hline ANKRD22 & 5,82 & $1,74 \mathrm{E}-66$ & 5,33 & $5,57 \mathrm{E}-40$ & 3,01 & $2,50 \mathrm{E}-11$ \\
\hline ANLN & 6,84 & $2,18 \mathrm{E}-117$ & 5,65 & $7,16 \mathrm{E}-35$ & 3,84 & $5,02 \mathrm{E}-13$ \\
\hline ANP32E & 2,49 & $4,91 \mathrm{E}-18$ & 1,91 & 1,57E-05 & 1,39 & $2,01 \mathrm{E}-03$ \\
\hline ANXA2 & $-2,18$ & 1,37E-07 & $-1,49$ & 8,82E-04 & $-2,30$ & $1,80 \mathrm{E}-07$ \\
\hline ANXA2P2 & $-2,03$ & $8,95 \mathrm{E}-06$ & $-1,48$ & $1,10 \mathrm{E}-03$ & $-2,23$ & $1,29 \mathrm{E}-06$ \\
\hline ANXA9 & $-1,33$ & $1,40 \mathrm{E}-03$ & $-1,39$ & 2,34E-03 & $-1,41$ & $1,61 \mathrm{E}-03$ \\
\hline AP001007,1 & $-4,30$ & $2,68 \mathrm{E}-23$ & $-1,75$ & 1,33E-03 & $-2,85$ & $3,38 \mathrm{E}-09$ \\
\hline AP001055,6 & $-3,97$ & $1,01 \mathrm{E}-13$ & $-2,02$ & $2,41 \mathrm{E}-04$ & $-2,24$ & $2,25 \mathrm{E}-06$ \\
\hline APBA1 & $-4,02$ & $2,62 \mathrm{E}-19$ & $-1,55$ & $5,46 \mathrm{E}-03$ & $-2,75$ & $1,06 \mathrm{E}-09$ \\
\hline APLP1 & 5,09 & $1,13 \mathrm{E}-14$ & 2,76 & $1,45 \mathrm{E}-05$ & 1,88 & $1,30 \mathrm{E}-03$ \\
\hline APOBEC3C & 1,95 & $1,91 \mathrm{E}-39$ & 1,86 & 1,03E-06 & 1,14 & $6,62 \mathrm{E}-03$ \\
\hline APOBEC3F & 1,87 & $5,92 \mathrm{E}-12$ & 1,64 & 1,99E-05 & 1,03 & $8,65 \mathrm{E}-03$ \\
\hline APOBEC3H & 3,53 & $2,45 \mathrm{E}-69$ & 2,51 & $4,18 \mathrm{E}-11$ & 1,22 & $7,59 \mathrm{E}-03$ \\
\hline APOC1 & $-6,14$ & $2,46 \mathrm{E}-34$ & $-1,77$ & $3,26 \mathrm{E}-03$ & $-3,32$ & $3,21 \mathrm{E}-10$ \\
\hline APOC1P1 & $-2,75$ & $6,23 \mathrm{E}-04$ & $-1,66$ & $6,62 \mathrm{E}-03$ & $-3,09$ & $1,23 \mathrm{E}-08$ \\
\hline APOC2 & $-3,96$ & $3,98 \mathrm{E}-09$ & $-1,67$ & $3,32 \mathrm{E}-03$ & $-1,83$ & $1,38 \mathrm{E}-03$ \\
\hline APOD & 5,25 & $5,63 \mathrm{E}-30$ & 3,83 & $8,57 \mathrm{E}-16$ & 4,31 & $4,81 \mathrm{E}-17$ \\
\hline ARHGAP11A & 3,95 & $1,84 \mathrm{E}-56$ & 3,25 & $5,94 \mathrm{E}-13$ & 2,22 & $1,79 \mathrm{E}-05$ \\
\hline ARHGAP11B & 2,48 & $4,82 \mathrm{E}-19$ & 1,96 & $2,99 \mathrm{E}-05$ & 1,39 & $6.49 \mathrm{E}-03$ \\
\hline ARHGEF34P & 3,23 & $8,42 \mathrm{E}-15$ & 2,14 & $3,47 \mathrm{E}-06$ & 1,63 & $7,34 \mathrm{E}-04$ \\
\hline ARHGEF39 & 2,62 & $1,99 \mathrm{E}-15$ & 2,48 & $2,50 \mathrm{E}-08$ & 1,41 & $6,14 \mathrm{E}-03$ \\
\hline ARHGEF40 & $-3,17$ & $1,38 \mathrm{E}-08$ & $-1,48$ & $5,82 \mathrm{E}-03$ & $-1,51$ & $5,08 \mathrm{E}-03$ \\
\hline ARHGEF6 & 1,01 & $5,89 \mathrm{E}-07$ & 1,24 & $3,35 \mathrm{E}-04$ & 1,15 & $7,93 \mathrm{E}-03$ \\
\hline ARNT2 & 3,28 & $9,25 \mathrm{E}-07$ & 2,49 & 1,37E-05 & 2,50 & $1,31 \mathrm{E}-05$ \\
\hline ASB2 & 2,87 & $1,04 \mathrm{E}-06$ & 3,74 & $2,73 \mathrm{E}-10$ & 2,81 & $1,21 \mathrm{E}-06$ \\
\hline ASF1B & 4,93 & $3,43 \mathrm{E}-147$ & 4,42 & $2,32 \mathrm{E}-33$ & 2,74 & $9,72 \mathrm{E}-08$ \\
\hline ASGR1 & $-2,97$ & $1,50 \mathrm{E}-05$ & $-1,60$ & $8,18 \mathrm{E}-03$ & $-1,66$ & $3,47 \mathrm{E}-03$ \\
\hline ASPM & 7,93 & $8.53 \mathrm{E}-109$ & 6,40 & $2.92 E-37$ & 4.19 & $7.62 \mathrm{E}-14$ \\
\hline ATAD2 & 3,72 & $5,51 \mathrm{E}-87$ & 2,98 & $1,39 \mathrm{E}-13$ & 2,07 & $8,68 \mathrm{E}-06$ \\
\hline ATP6V0D2 & $-6,80$ & $2,65 \mathrm{E}-33$ & $-2,82$ & $6,95 \mathrm{E}-07$ & $-3,47$ & $6,09 \mathrm{E}-10$ \\
\hline
\end{tabular}

\begin{tabular}{|c|c|c|c|c|c|c|}
\hline AUNIP & 4,29 & $3,64 \mathrm{E}-28$ & 3,22 & $9,69 \mathrm{E}-12$ & 1,94 & $4,79 \mathrm{E}-04$ \\
\hline AURKA & 4,78 & $1,11 \mathrm{E}-31$ & 3,55 & $2,15 \mathrm{E}-14$ & 2,13 & $5,79 \mathrm{E}-05$ \\
\hline AURKB & 7,01 & $2,99 \mathrm{E}-92$ & 6,04 & $2,43 E-43$ & 3,72 & $1,32 \mathrm{E}-11$ \\
\hline AZU1 & $-5,18$ & $8,80 \mathrm{E}-17$ & $-2,30$ & $1,17 \mathrm{E}-04$ & $-1,75$ & $1,26 \mathrm{E}-03$ \\
\hline B3GNT7 & $-2,59$ & $1,20 \mathrm{E}-12$ & $-2,28$ & $1,74 \mathrm{E}-08$ & $-1,76$ & $9,35 \mathrm{E}-04$ \\
\hline B3GNT8 & $-2,96$ & $2,69 \mathrm{E}-13$ & $-1,63$ & $4,82 \mathrm{E}-04$ & $-2,05$ & $1,67 \mathrm{E}-06$ \\
\hline B4GALNT1 & 3,33 & $1,26 \mathrm{E}-09$ & 2,02 & $6,78 \mathrm{E}-04$ & 1,90 & $5,41 \mathrm{E}-04$ \\
\hline BAG2 & 2,81 & $2,45 \mathrm{E}-36$ & 2,10 & $6,81 \mathrm{E}-07$ & 1,36 & $1,53 \mathrm{E}-03$ \\
\hline BAIAP2 & $-2,45$ & $8,16 \mathrm{E}-12$ & $-1,33$ & $3,17 \mathrm{E}-03$ & $-1,71$ & $7,02 \mathrm{E}-05$ \\
\hline BAIAP2-AS1 & $-3,32$ & $2,29 \mathrm{E}-19$ & $-1,48$ & $4,04 \mathrm{E}-04$ & $-1,64$ & $9,79 \mathrm{E}-05$ \\
\hline BATF & 2,06 & $1,22 \mathrm{E}-12$ & 1,72 & $1,27 \mathrm{E}-06$ & 1,73 & $4,85 \mathrm{E}-06$ \\
\hline BATF3 & 5,69 & $3,51 \mathrm{E}-16$ & 3,84 & $2,65 \mathrm{E}-10$ & 2,95 & $1,75 \mathrm{E}-07$ \\
\hline BCL2L14 & 3,20 & $7,88 \mathrm{E}-14$ & 1,84 & $2,82 \mathrm{E}-04$ & 2,06 & $9,26 \mathrm{E}-05$ \\
\hline BCOR & 1,11 & $1,66 \mathrm{E}-09$ & 1,30 & $3,73 \mathrm{E}-04$ & 1,34 & 5,84E-05 \\
\hline BEND3P2 & $-2,98$ & $8,14 \mathrm{E}-05$ & $-2,18$ & $2,66 \mathrm{E}-04$ & $-2,59$ & $7,63 \mathrm{E}-06$ \\
\hline BFSP2 & 2,36 & $1,98 \mathrm{E}-03$ & 2,61 & $1,12 \mathrm{E}-05$ & 1,51 & $9,49 \mathrm{E}-03$ \\
\hline BHLHE40 & 2,13 & $3,17 \mathrm{E}-30$ & 1,44 & $3,26 \mathrm{E}-05$ & 0,97 & $4,75 \mathrm{E}-03$ \\
\hline BHLHE40-AS1 & 2,67 & $4,64 \mathrm{E}-10$ & 2,40 & $2,26 \mathrm{E}-05$ & 2,01 & $1,38 \mathrm{E}-04$ \\
\hline $\mathrm{BIRC} 3$ & 1,80 & $5,80 \mathrm{E}-15$ & 0,94 & $4,13 \mathrm{E}-03$ & 1,17 & $8,93 \mathrm{E}-03$ \\
\hline BIRC5 & 7,13 & $2,75 \mathrm{E}-130$ & 6,21 & $1,71 \mathrm{E}-45$ & 3,95 & $6,64 \mathrm{E}-13$ \\
\hline BIRC7 & $-4,59$ & $5,43 \mathrm{E}-12$ & $-1,55$ & $8,22 \mathrm{E}-03$ & $-3,57$ & $2,12 \mathrm{E}-12$ \\
\hline BLM & 2,48 & $2,94 \mathrm{E}-11$ & 1,70 & $3,11 \mathrm{E}-05$ & 1,25 & $5,82 \mathrm{E}-03$ \\
\hline BLVRB & $-2,87$ & 5,74E-17 & $-1,39$ & $4,08 \mathrm{E}-03$ & $-2,36$ & $2,02 \mathrm{E}-09$ \\
\hline BNC2 & $-4,98$ & $1,30 \mathrm{E}-15$ & $-3,34$ & $7,28 \mathrm{E}-12$ & $-2,76$ & $3,48 \mathrm{E}-08$ \\
\hline BRCA1 & 3,61 & $2,08 \mathrm{E}-32$ & 3,00 & $2,91 \mathrm{E}-11$ & 1,76 & $6,59 \mathrm{E}-04$ \\
\hline BRCA2 & 2,76 & $2,63 \mathrm{E}-08$ & 2,06 & $2,13 \mathrm{E}-05$ & 1,35 & $8,47 \mathrm{E}-03$ \\
\hline BRIP1 & 4,42 & $4,88 \mathrm{E}-50$ & 3,72 & $5,17 \mathrm{E}-18$ & 2,53 & $1,38 \mathrm{E}-06$ \\
\hline BRSK1 & 2,22 & $3,48 \mathrm{E}-06$ & 1,51 & $1,15 \mathrm{E}-03$ & 1,33 & $5,96 \mathrm{E}-03$ \\
\hline BSPRY & 5,12 & $2,99 \mathrm{E}-68$ & 3,98 & $1,17 \mathrm{E}-26$ & 1,52 & $1,06 \mathrm{E}-03$ \\
\hline BTLA & 1,51 & $1,27 \mathrm{E}-04$ & 1,93 & $2,80 \mathrm{E}-06$ & 1,49 & $3,53 \mathrm{E}-04$ \\
\hline BUB1 & 5,17 & $2,75 \mathrm{E}-49$ & 4,36 & $3,84 \mathrm{E}-20$ & 2,82 & $2,65 \mathrm{E}-07$ \\
\hline BUB1B & 6,05 & $2,56 \mathrm{E}-115$ & 5,06 & $3,20 \mathrm{E}-26$ & 3,30 & $2,22 \mathrm{E}-09$ \\
\hline C100RF11 & $-3,26$ & $1,02 \mathrm{E}-09$ & $-1,48$ & $3,62 \mathrm{E}-03$ & $-2,15$ & $3,04 \mathrm{E}-05$ \\
\hline C11ORF82 & 3,74 & $5,19 \mathrm{E}-34$ & 3,17 & $4,26 \mathrm{E}-16$ & 2,06 & $2,58 \mathrm{E}-05$ \\
\hline C14ORF182 & 3,19 & $6,40 \mathrm{E}-19$ & 1,75 & $4,06 \mathrm{E}-05$ & 1,44 & $1,14 \mathrm{E}-03$ \\
\hline C150RF52 & $-4,26$ & $2,18 \mathrm{E}-11$ & $-1,57$ & $9,31 \mathrm{E}-03$ & $-1,67$ & $2,68 \mathrm{E}-03$ \\
\hline C16ORF45 & 2,16 & 5,77E-07 & 2,66 & $6,20 \mathrm{E}-09$ & 1,60 & $1,26 \mathrm{E}-03$ \\
\hline C160RF59 & 5,14 & $5,33 \mathrm{E}-65$ & 4,55 & $8,70 \mathrm{E}-32$ & 2,86 & $7,26 \mathrm{E}-09$ \\
\hline C170RF53 & 4,86 & $9,09 \mathrm{E}-76$ & 3,68 & $1,93 \mathrm{E}-19$ & 2,30 & $2,16 \mathrm{E}-06$ \\
\hline C170RF96 & 3,84 & $1,93 \mathrm{E}-28$ & 2,85 & $1,67 \mathrm{E}-13$ & 2,09 & $1,22 \mathrm{E}-06$ \\
\hline C18ORF56 & 5,03 & $1,71 \mathrm{E}-12$ & 4,33 & $5,08 \mathrm{E}-13$ & 2,13 & $2,62 \mathrm{E}-04$ \\
\hline C19ORF57 & 2,55 & $1,99 \mathrm{E}-07$ & 2,15 & $6,13 \mathrm{E}-06$ & 1,33 & $5,93 \mathrm{E}-03$ \\
\hline C1ORF106 & 6,22 & $1,80 \mathrm{E}-32$ & 6,00 & $1,99 \mathrm{E}-29$ & 4,26 & $1,30 \mathrm{E}-14$ \\
\hline C1ORF127 & $-4,65$ & $1,40 \mathrm{E}-16$ & $-3,08$ & $3,60 \mathrm{E}-11$ & $-2,54$ & $1,85 \mathrm{E}-06$ \\
\hline C1ORF162 & $-3,41$ & $2,91 \mathrm{E}-82$ & $-1,71$ & $9,58 \mathrm{E}-05$ & $-1,43$ & $4,70 \mathrm{E}-04$ \\
\hline $\mathrm{C} 1 \mathrm{QC}$ & $-2,97$ & $8,36 \mathrm{E}-32$ & $-1,32$ & $1,05 \mathrm{E}-03$ & $-2,07$ & $2,98 \mathrm{E}-05$ \\
\hline C1QL1 & 3,03 & $4,28 \mathrm{E}-05$ & 2,10 & $8,53 \mathrm{E}-04$ & 1,93 & $8,23 \mathrm{E}-04$ \\
\hline C1QTNF1 & 3,16 & $1,88 \mathrm{E}-08$ & 1,65 & $4,72 \mathrm{E}-03$ & 2,35 & $5,44 \mathrm{E}-05$ \\
\hline C2ORF48 & 6,33 & $4,10 \mathrm{E}-31$ & 4,78 & $8,27 \mathrm{E}-19$ & 3,01 & $1,70 \mathrm{E}-07$ \\
\hline C3ORF67 & 2,10 & $7,83 \mathrm{E}-03$ & 2,07 & $1,09 \mathrm{E}-03$ & 1,53 & $8,97 \mathrm{E}-03$ \\
\hline C4BPB & 3,57 & $3,86 \mathrm{E}-10$ & 2,51 & $1,54 \mathrm{E}-05$ & 2,11 & $1,71 \mathrm{E}-04$ \\
\hline C4ORF46 & 2,24 & $3,69 \mathrm{E}-21$ & 1,82 & $1,42 E-05$ & 1,31 & $1,06 \mathrm{E}-03$ \\
\hline CACNA2D3 & $-5,08$ & $1,39 \mathrm{E}-12$ & $-4,61$ & $8,76 \mathrm{E}-15$ & $-2,39$ & $3,38 \mathrm{E}-05$ \\
\hline CALD1 & 3,80 & $5,78 \mathrm{E}-13$ & 1,67 & $5,44 \mathrm{E}-03$ & 2,95 & $9,49 \mathrm{E}-09$ \\
\hline $\begin{array}{l}\text { CAMKK1 } \\
\text { CAMKK }\end{array}$ & $-2,70$ & $3,54 \mathrm{E}-15$ & $-1,36$ & $8,40 \mathrm{E}-04$ & $-1,44$ & $3,35 \mathrm{E}-04$ \\
\hline CAMP & $-5,23$ & $1,29 \mathrm{E}-13$ & $-3,64$ & $5,84 \mathrm{E}-12$ & $-4,50$ & $1,10 \mathrm{E}-16$ \\
\hline CAPN3 & $-2,84$ & $1,24 \mathrm{E}-08$ & $-1,74$ & $4,56 \mathrm{E}-05$ & $-1,11$ & $5,75 \mathrm{E}-03$ \\
\hline CARD14 & $-2,97$ & $6,02 \mathrm{E}-15$ & $-1,74$ & $1,05 \mathrm{E}-04$ & $-2,12$ & $5,93 \mathrm{E}-06$ \\
\hline CASC5 & 5,42 & $2,92 \mathrm{E}-104$ & 4,69 & $9,22 \mathrm{E}-25$ & 3,14 & $1,33 \mathrm{E}-08$ \\
\hline CBR3 & 2,03 & $3,06 \mathrm{E}-10$ & 1,77 & $4,30 \mathrm{E}-06$ & 1,35 & $2,45 \mathrm{E}-03$ \\
\hline CCDC102A & 1,83 & $4,01 \mathrm{E}-07$ & 1,51 & $3,20 \mathrm{E}-04$ & 1,11 & $6,58 \mathrm{E}-03$ \\
\hline CCDC112 & $-2,82$ & $2,96 \mathrm{E}-10$ & $-1,69$ & $1,07 \mathrm{E}-04$ & $-1,48$ & $1,08 \mathrm{E}-04$ \\
\hline CCDC149 & $-4,08$ & $1,29 \mathrm{E}-17$ & $-1,70$ & $3,50 \mathrm{E}-04$ & $-2,44$ & $6,49 \mathrm{E}-07$ \\
\hline CCDC150 & 4,18 & $4,75 \mathrm{E}-51$ & 3,07 & $7,22 \mathrm{E}-11$ & 1,85 & $4,92 \mathrm{E}-04$ \\
\hline CCDC171 & 2,31 & $2,47 \mathrm{E}-11$ & 1,80 & $4,04 \mathrm{E}-05$ & 1,43 & $4,35 \mathrm{E}-03$ \\
\hline CCDC34 & 3,18 & $2,27 \mathrm{E}-13$ & 3,05 & $5,70 \mathrm{E}-11$ & 1,91 & $5,50 \mathrm{E}-04$ \\
\hline CCDC74A & 2,52 & $2,99 \mathrm{E}-15$ & 2,75 & $6,86 \mathrm{E}-12$ & 2,73 & $1,01 \mathrm{E}-08$ \\
\hline CCDC74B & 2,42 & $2,45 \mathrm{E}-11$ & 2,68 & $3,42 \mathrm{E}-10$ & 2,67 & $1,26 \mathrm{E}-07$ \\
\hline CCL24 & 4,08 & $1,21 \mathrm{E}-55$ & 2,62 & $3,26 \mathrm{E}-07$ & 1,69 & $3,36 \mathrm{E}-03$ \\
\hline CCL25 & 2,52 & $2,08 \mathrm{E}-03$ & 3,10 & $1,20 \mathrm{E}-06$ & 2,19 & $1,64 \mathrm{E}-04$ \\
\hline CCNA2 & 5,59 & $1,04 \mathrm{E}-137$ & 5,01 & $3,10 \mathrm{E}-29$ & 3,14 & $7,68 \mathrm{E}-09$ \\
\hline CCNB1 & 6,30 & $3,71 \mathrm{E}-118$ & 4,98 & $8,30 \mathrm{E}-27$ & 3,17 & $6,38 \mathrm{E}-09$ \\
\hline CCNB2 & 6,43 & $3,67 \mathrm{E}-67$ & 5,83 & $2,95 \mathrm{E}-34$ & 3,74 & $1,61 \mathrm{E}-11$ \\
\hline CCND2 & 2,76 & $2,69 \mathrm{E}-15$ & 2,07 & $9,47 \mathrm{E}-07$ & 1,64 & $2,66 \mathrm{E}-05$ \\
\hline CCND2P1 & 4,02 & $5,83 \mathrm{E}-24$ & 2,49 & $2,52 \mathrm{E}-07$ & 1,69 & $9,56 \mathrm{E}-04$ \\
\hline CCNE1 & 4,02 & $5,83 \mathrm{E}-28$ & 3,68 & $1,35 \mathrm{E}-19$ & 2,20 & $8,60 \mathrm{E}-06$ \\
\hline CCNE2 & 2,69 & $8,32 \mathrm{E}-10$ & 2,34 & $1,06 \mathrm{E}-06$ & 1,69 & $4,59 \mathrm{E}-04$ \\
\hline CCNF & 4,27 & $3,59 \mathrm{E}-129$ & 3,45 & $1,72 \mathrm{E}-19$ & 2,00 & $7,92 \mathrm{E}-05$ \\
\hline CCR4 & 2,71 & $1,01 \mathrm{E}-11$ & 1,79 & $3,02 \mathrm{E}-05$ & 2,53 & $6,39 \mathrm{E}-10$ \\
\hline CCR8 & 2,23 & $3,34 \mathrm{E}-04$ & 3,06 & $9,51 \mathrm{E}-09$ & 2,48 & $2,17 \mathrm{E}-06$ \\
\hline CD101 & $-1,77$ & $6,98 \mathrm{E}-07$ & 1,10 & $7,40 \mathrm{E}-03$ & 1,50 & $3,46 \mathrm{E}-03$ \\
\hline CD14 & $-5,14$ & $1,62 \mathrm{E}-43$ & $-1,77$ & $2,93 \mathrm{E}-03$ & $-1,44$ & $6,89 \mathrm{E}-03$ \\
\hline CD163L1 & $-5,54$ & $1,97 \mathrm{E}-13$ & $-4,61$ & $9,62 \mathrm{E}-15$ & $-2,63$ & $5,72 \mathrm{E}-06$ \\
\hline CD180 & $-4,75$ & $4,46 \mathrm{E}-43$ & $-3,24$ & $9,34 \mathrm{E}-10$ & $-2,01$ & $2,34 \mathrm{E}-04$ \\
\hline CD1D & $-3,31$ & $2,07 \mathrm{E}-11$ & $-2,02$ & $7,41 \mathrm{E}-05$ & $-2,46$ & $6,43 \mathrm{E}-07$ \\
\hline CD2 & 1,92 & $2,33 \mathrm{E}-06$ & 1,49 & $3,63 \mathrm{E}-04$ & 1,34 & $1,72 \mathrm{E}-03$ \\
\hline CD200 & 4.08 & $6.74 \mathrm{E}-62$ & 3.68 & $224 \mathrm{E}-25$ & 293 & $196 \mathrm{E}-15$ \\
\hline
\end{tabular}




\begin{tabular}{|c|c|c|c|c|c|c|}
\hline CD22 & $-5,38$ & $2,84 \mathrm{E}-45$ & $-2,08$ & $3,59 \mathrm{E}-04$ & $-2,55$ & $1,38 \mathrm{E}-06$ \\
\hline CD226 & 2,79 & $1,73 \mathrm{E}-22$ & 1,89 & $1,43 \mathrm{E}-04$ & 1,78 & $1,58 \mathrm{E}-05$ \\
\hline CD27 & 1,71 & $1,19 \mathrm{E}-04$ & 2,52 & $8,45 \mathrm{E}-09$ & 1,50 & $2,91 \mathrm{E}-03$ \\
\hline CD300A & $-3,80$ & $3,15 \mathrm{E}-23$ & $-1,78$ & $1,29 \mathrm{E}-03$ & $-1,70$ & $5,30 \mathrm{E}-04$ \\
\hline CD300LB & $-4,47$ & $7,00 \mathrm{E}-15$ & $-3,34$ & $1,84 \mathrm{E}-12$ & $-2,56$ & $4,59 \mathrm{E}-09$ \\
\hline CD36 & $-5,20$ & $7,00 \mathrm{E}-46$ & $-2,95$ & $2,37 \mathrm{E}-15$ & $-4,17$ & $2,64 \mathrm{E}-29$ \\
\hline CD38 & 3,71 & $3,25 \mathrm{E}-28$ & 3,99 & $1,11 \mathrm{E}-18$ & 2,30 & $2,76 \mathrm{E}-05$ \\
\hline CD68 & $-3,65$ & $3,84 \mathrm{E}-14$ & $-1,48$ & $3,85 \mathrm{E}-03$ & $-2,26$ & $7,72 \mathrm{E}-06$ \\
\hline CD7 & 1,53 & $9,67 \mathrm{E}-08$ & 1,59 & $8,05 \mathrm{E}-06$ & 1,46 & $9,38 \mathrm{E}-05$ \\
\hline CD70 & 4,49 & $1,77 \mathrm{E}-27$ & 2,47 & $6,01 \mathrm{E}-06$ & 3,09 & $1,20 \mathrm{E}-11$ \\
\hline CD9 & $-4,26$ & $4,40 \mathrm{E}-20$ & $-1,91$ & $5,46 \mathrm{E}-05$ & $-2,73$ & $2,40 \mathrm{E}-09$ \\
\hline CD97 & 1,79 & $6,66 \mathrm{E}-38$ & 1,44 & $2,43 \mathrm{E}-06$ & 0,96 & $4,69 \mathrm{E}-03$ \\
\hline CDC20 & 7,44 & $6,59 \mathrm{E}-111$ & 6,29 & $5,51 \mathrm{E}-45$ & 3,72 & $1,39 \mathrm{E}-11$ \\
\hline CDC20P1 & 8,09 & $6,85 \mathrm{E}-163$ & 6,65 & $2,92 \mathrm{E}-51$ & 4,01 & $2,79 \mathrm{E}-13$ \\
\hline CDC25A & 7,15 & $2,74 \mathrm{E}-105$ & 5,51 & $1,20 \mathrm{E}-32$ & 3,86 & $1,18 \mathrm{E}-14$ \\
\hline CDC25C & 7,55 & $1,77 \mathrm{E}-49$ & 5,84 & $9,63 \mathrm{E}-27$ & 3,01 & $2,38 \mathrm{E}-07$ \\
\hline CDC45 & 6,58 & $1,14 \mathrm{E}-112$ & 5,70 & $1,48 \mathrm{E}-42$ & 3,74 & $4,42 \mathrm{E}-13$ \\
\hline $\mathrm{CDC6}$ & 5,94 & $2,24 \mathrm{E}-149$ & 5,14 & $4,07 \mathrm{E}-40$ & 3,39 & $3,86 \mathrm{E}-12$ \\
\hline CDCA2 & 6,68 & $5,22 \mathrm{E}-67$ & 5,41 & $4,17 \mathrm{E}-28$ & 3,63 & $2,81 \mathrm{E}-11$ \\
\hline CDCA3 & 5,17 & $3,52 \mathrm{E}-79$ & 4,41 & $2,37 \mathrm{E}-25$ & 2,84 & $2,18 \mathrm{E}-07$ \\
\hline CDCA5 & 6,39 & $1,10 \mathrm{E}-180$ & 5,40 & $8,78 \mathrm{E}-48$ & 3,44 & $7,66 \mathrm{E}-11$ \\
\hline CDCA7 & 2,72 & $4,23 \mathrm{E}-07$ & 3,60 & $7,37 \mathrm{E}-11$ & 2,45 & $1,63 \mathrm{E}-05$ \\
\hline CDCA8 & 5,47 & $4,46 \mathrm{E}-99$ & 4,71 & $8,96 \mathrm{E}-26$ & 3,00 & $6,94 \mathrm{E}-08$ \\
\hline $\mathrm{CDH} 1$ & 2,01 & $6,90 \mathrm{E}-10$ & 1,61 & $7,07 \mathrm{E}-05$ & 2,47 & $3,55 \mathrm{E}-07$ \\
\hline $\mathrm{CDH} 23$ & $-4,09$ & $8,30 \mathrm{E}-54$ & $-2,16$ & $1,66 \mathrm{E}-05$ & $-1,48$ & $1,22 \mathrm{E}-03$ \\
\hline $\mathrm{CDH} 3$ & 7,04 & $1,68 \mathrm{E}-55$ & 1,96 & $1,78 \mathrm{E}-03$ & 2,62 & $9,41 \mathrm{E}-07$ \\
\hline CDK1 & 6,34 & $1,46 \mathrm{E}-26$ & 5,21 & $1,26 \mathrm{E}-20$ & 3,73 & $2,67 \mathrm{E}-11$ \\
\hline CDK2 & 2,15 & $3,09 \mathrm{E}-33$ & 1,93 & $4,73 \mathrm{E}-07$ & 1,28 & $3,48 \mathrm{E}-03$ \\
\hline CDK6 & 3,76 & $1,59 \mathrm{E}-23$ & 2,19 & $2,02 \mathrm{E}-06$ & 1,62 & $5,93 \mathrm{E}-05$ \\
\hline CDKN2A & 1,58 & $1,99 \mathrm{E}-07$ & 1,23 & $3,67 \mathrm{E}-03$ & 1,61 & $4,44 \mathrm{E}-05$ \\
\hline CDKN2C & 3,30 & $2,10 \mathrm{E}-22$ & 3,38 & $2,71 \mathrm{E}-17$ & 2,26 & $1,91 \mathrm{E}-05$ \\
\hline CDKN3 & 6,29 & $1,07 \mathrm{E}-76$ & 5,25 & $5,71 \mathrm{E}-33$ & 3,26 & $3,47 \mathrm{E}-09$ \\
\hline CDT1 & 5,99 & $2,27 \mathrm{E}-86$ & 5,59 & $1,06 \mathrm{E}-49$ & 3,77 & $3,85 \mathrm{E}-14$ \\
\hline CEACAM1 & 3,75 & $4,16 \mathrm{E}-46$ & 1,64 & $2,20 \mathrm{E}-04$ & 1,53 & $3,93 \mathrm{E}-04$ \\
\hline CEBPE & $-1,81$ & $6,11 \mathrm{E}-05$ & $-1,31$ & $6,57 \mathrm{E}-03$ & $-1,25$ & $4,94 \mathrm{E}-03$ \\
\hline CECR1 & $-4,49$ & $1,63 \mathrm{E}-32$ & $-1,71$ & $4,32 \mathrm{E}-04$ & $-1,89$ & $3,48 \mathrm{E}-05$ \\
\hline CEND1 & 2,78 & $9,70 \mathrm{E}-06$ & 2,04 & $4,60 \mathrm{E}-04$ & 1,69 & $3,54 \mathrm{E}-03$ \\
\hline CENPA & 5,59 & $3,50 \mathrm{E}-65$ & 4,59 & $2,76 \mathrm{E}-20$ & 3,07 & $4,13 \mathrm{E}-08$ \\
\hline CENPE & 5,16 & $3,97 \mathrm{E}-28$ & 3,91 & $6,50 \mathrm{E}-14$ & 2,51 & $7,37 \mathrm{E}-06$ \\
\hline CENPF & 5,32 & $2,84 \mathrm{E}-97$ & 4,57 & $1,63 \mathrm{E}-24$ & 2,97 & $8,24 \mathrm{E}-08$ \\
\hline CENPH & 2,62 & $1,08 \mathrm{E}-35$ & 2,33 & $2,06 \mathrm{E}-10$ & 1,49 & $1,18 \mathrm{E}-03$ \\
\hline CENPI & 4,03 & $2,27 \mathrm{E}-53$ & 3,31 & $8,11 \mathrm{E}-14$ & 2,00 & $2,11 \mathrm{E}-04$ \\
\hline CENPK & 3,14 & $4,28 \mathrm{E}-13$ & 2,59 & $5,67 \mathrm{E}-08$ & 1,69 & $1,30 \mathrm{E}-03$ \\
\hline CENPM & 4,97 & $9,99 \mathrm{E}-33$ & 4,92 & $3,35 \mathrm{E}-28$ & 3,25 & $9,16 \mathrm{E}-10$ \\
\hline CENPN & 3,45 & $2,61 \mathrm{E}-39$ & 2,92 & $2,06 \mathrm{E}-13$ & 1,79 & $2,18 \mathrm{E}-04$ \\
\hline CENPU & 4,91 & $8,58 \mathrm{E}-104$ & 4,05 & $2,06 \mathrm{E}-24$ & 2,49 & $2,44 \mathrm{E}-06$ \\
\hline CEP170B & 1,71 & $1,54 \mathrm{E}-07$ & 1,64 & $6,72 \mathrm{E}-05$ & 1,33 & $1,73 \mathrm{E}-03$ \\
\hline CEP55 & 6,46 & $4,57 \mathrm{E}-72$ & 5,20 & $1,52 \mathrm{E}-26$ & 3,47 & $3,67 \mathrm{E}-10$ \\
\hline CEP76 & 1,52 & $1,13 \mathrm{E}-11$ & 1,37 & $5,05 \mathrm{E}-04$ & 1,08 & $3,51 \mathrm{E}-03$ \\
\hline CFD & $-6,46$ & $2,85 \mathrm{E}-48$ & $-1,92$ & $1,69 \mathrm{E}-03$ & $-2,24$ & $7,06 \mathrm{E}-05$ \\
\hline CHAC2 & 2,80 & $2,06 \mathrm{E}-30$ & 2,19 & $1,29 \mathrm{E}-08$ & 1,36 & $5,01 \mathrm{E}-04$ \\
\hline CHAF1A & 3,04 & $6,15 \mathrm{E}-66$ & 2,63 & $9,15 \mathrm{E}-17$ & 1,33 & $2,71 \mathrm{E}-03$ \\
\hline CHAF1B & 3,81 & $2,88 \mathrm{E}-48$ & 3,35 & $6,27 \mathrm{E}-18$ & 2,14 & $6,60 \mathrm{E}-06$ \\
\hline CHEK1 & 4,50 & $1,41 \mathrm{E}-70$ & 3,81 & $2,15 \mathrm{E}-20$ & 2,34 & $5,21 \mathrm{E}-06$ \\
\hline CHGB & 3,55 & $2,18 \mathrm{E}-19$ & 2,49 & $7,00 \mathrm{E}-07$ & 2,26 & $5,12 \mathrm{E}-05$ \\
\hline CHIT1 & $-5,80$ & $4,15 \mathrm{E}-122$ & $-2,08$ & $4,73 \mathrm{E}-07$ & $-4,52$ & $5,42 \mathrm{E}-27$ \\
\hline CHN1 & 3,43 & $4,77 \mathrm{E}-17$ & 2,57 & $7,89 \mathrm{E}-08$ & 1,38 & $5,28 \mathrm{E}-03$ \\
\hline CHPF & 2,42 & $7,68 \mathrm{E}-11$ & 1,91 & $2,33 \mathrm{E}-06$ & 1,18 & $3,37 \mathrm{E}-03$ \\
\hline CHPT1 & $-1,34$ & $3,89 \mathrm{E}-04$ & $-1,04$ & $8,80 \mathrm{E}-03$ & $-1,29$ & $1,78 \mathrm{E}-03$ \\
\hline CHRNA5 & 6,02 & $5,55 \mathrm{E}-24$ & 3,84 & $6,96 \mathrm{E}-11$ & 2,58 & $6,80 \mathrm{E}-06$ \\
\hline CHRNA6 & 1,98 & $1,84 \mathrm{E}-03$ & 2,77 & $1,04 \mathrm{E}-05$ & 3,00 & $5,21 \mathrm{E}-08$ \\
\hline CHST13 & $-6,24$ & $1,00 \mathrm{E}-26$ & $-2,93$ & $6,47 \mathrm{E}-09$ & $-2,64$ & $1,26 \mathrm{E}-06$ \\
\hline CHST3 & 2,99 & $1,51 \mathrm{E}-06$ & 3,23 & $1,30 \mathrm{E}-09$ & 1,45 & $8,98 \mathrm{E}-03$ \\
\hline CIT & 5,01 & $1,52 \mathrm{E}-86$ & 4,10 & $2,31 \mathrm{E}-20$ & 2,77 & $1,97 \mathrm{E}-07$ \\
\hline CKAP2 & 2,54 & $2,66 \mathrm{E}-27$ & 2,18 & $7,75 \mathrm{E}-08$ & 1,61 & $5,27 \mathrm{E}-04$ \\
\hline CKAP2L & 5,63 & $4,55 \mathrm{E}-24$ & 4,87 & $6,07 \mathrm{E}-20$ & 3,21 & $1,64 \mathrm{E}-08$ \\
\hline CKS1B & 3,72 & $1,04 \mathrm{E}-39$ & 2,92 & $2,37 \mathrm{E}-13$ & 1,82 & $3,14 \mathrm{E}-04$ \\
\hline CKS1B & 3,42 & $8,78 \mathrm{E}-26$ & 2,64 & $1,04 \mathrm{E}-09$ & 1,51 & $6,20 \mathrm{E}-03$ \\
\hline CKS2 & 3,76 & $3,36 \mathrm{E}-26$ & 3,01 & $2,49 \mathrm{E}-13$ & 1,94 & $9,29 \mathrm{E}-05$ \\
\hline CLMN & $-3,46$ & $4,00 \mathrm{E}-08$ & $-1,74$ & $2,85 \mathrm{E}-03$ & $-1,71$ & $2,27 \mathrm{E}-03$ \\
\hline CLSPN & 6,33 & $1,02 \mathrm{E}-68$ & 5,09 & $1,85 \mathrm{E}-31$ & 3,39 & $3,97 \mathrm{E}-11$ \\
\hline CMAHP & 3,11 & $2,97 \mathrm{E}-12$ & 2,14 & $1,14 \mathrm{E}-05$ & 1,61 & $8,34 \mathrm{E}-04$ \\
\hline $\mathrm{CNIH} 3$ & $-2,67$ & $1,81 \mathrm{E}-08$ & $-2,14$ & $1,42 \mathrm{E}-05$ & $-1,64$ & $1,64 \mathrm{E}-04$ \\
\hline COL20A1 & $-3,15$ & 4,04E-08 & $-1,73$ & $5,81 \mathrm{E}-03$ & $-3,15$ & $3,73 \mathrm{E}-10$ \\
\hline COL27A1 & 1,93 & 1,81E-05 & 1,55 & $6,43 \mathrm{E}-04$ & 2,06 & $1,60 \mathrm{E}-06$ \\
\hline COL5A3 & 3,01 & $1,52 \mathrm{E}-05$ & 1,57 & $8,04 \mathrm{E}-03$ & 2,26 & $3,72 \mathrm{E}-05$ \\
\hline COL6A3 & 3,10 & $4,35 \mathrm{E}-71$ & 3,87 & 4,94E-35 & 3,05 & $1,29 \mathrm{E}-11$ \\
\hline COLEC12 & $-6,14$ & $6,42 \mathrm{E}-62$ & $-3,91$ & $8,56 \mathrm{E}-17$ & $-4,73$ & $2,53 \mathrm{E}-32$ \\
\hline CPVL & $-4,75$ & $1,20 \mathrm{E}-09$ & $-1,73$ & $4,91 \mathrm{E}-03$ & $-1,90$ & $8,14 \mathrm{E}-04$ \\
\hline CPXM1 & 4,41 & $7,51 \mathrm{E}-50$ & 3,43 & $1,23 \mathrm{E}-15$ & 1,92 & $2,32 \mathrm{E}-05$ \\
\hline CR1 & $-5,44$ & $2,36 \mathrm{E}-37$ & $-1,94$ & $5,84 \mathrm{E}-04$ & $-1,97$ & $2,89 \mathrm{E}-04$ \\
\hline CREB3L3 & 4,18 & $2,78 \mathrm{E}-08$ & 5,57 & $2,31 \mathrm{E}-22$ & 4,36 & $4,90 \mathrm{E}-15$ \\
\hline CREM & 3,37 & $1,22 \mathrm{E}-16$ & 2,30 & $3,42 \mathrm{E}-08$ & 1,88 & $9,64 \mathrm{E}-06$ \\
\hline CRYBB1 & $-4,19$ & $3,75 \mathrm{E}-08$ & $-3,74$ & $1,90 \mathrm{E}-09$ & $-2,88$ & $1,93 \mathrm{E}-07$ \\
\hline CSF2 & 4,84 & $6,06 \mathrm{E}-16$ & 2,28 & $4,65 \mathrm{E}-05$ & 1,84 & $1,61 \mathrm{E}-03$ \\
\hline CST3 & $-3,70$ & $1,13 \mathrm{E}-26$ & $-1,55$ & $2,34 \mathrm{E}-03$ & $-2,46$ & $1,00 \mathrm{E}-06$ \\
\hline CTB-70D19,1 & 3,72 & $7,66 \mathrm{E}-14$ & 2,24 & $6,14 \mathrm{E}-05$ & 2,13 & $4,70 \mathrm{E}-05$ \\
\hline
\end{tabular}

\begin{tabular}{|c|c|c|c|c|c|c|}
\hline CTB-92J24,2 & 2,93 & $5,77 \mathrm{E}-07$ & 2,45 & $1,82 \mathrm{E}-05$ & 1,82 & $1,39 \mathrm{E}-03$ \\
\hline CTC-251D13,1 & $-2,00$ & $2,90 \mathrm{E}-04$ & $-1,60$ & $1,53 \mathrm{E}-03$ & $-1,32$ & $6,34 \mathrm{E}-03$ \\
\hline CTC-308K20,3 & 2,38 & $2,49 \mathrm{E}-24$ & 1,53 & $1,09 \mathrm{E}-05$ & 1,14 & $1,43 \mathrm{E}-03$ \\
\hline CTC-820M8,1 & 6,45 & $1,39 \mathrm{E}-59$ & 4,87 & $1,11 \mathrm{E}-21$ & 3,16 & $1,65 \mathrm{E}-08$ \\
\hline CTD-2022H16,2 & 5,18 & $3,98 \mathrm{E}-17$ & 3,56 & $5,37 \mathrm{E}-09$ & 1,75 & $2,59 \mathrm{E}-03$ \\
\hline CTD-2267D19,6 & 5,03 & $1,71 \mathrm{E}-12$ & 3,93 & $1,31 \mathrm{E}-10$ & 1,81 & $1,71 \mathrm{E}-03$ \\
\hline $\begin{array}{r}\text { CTD- } \\
\text { 2306 } 101\end{array}$ & -410 & $479 \mathrm{~F}-08$ & -257 & $3.30 \mathrm{E}-05$ & -183 & $502 F_{-}-4$ \\
\hline CTD-2376|4,2 & $-2,39$ & $2,69 \mathrm{E}-03$ & $-2,28$ & $4,20 \mathrm{E}-04$ & $-1,70$ & $3,59 \mathrm{E}-03$ \\
\hline CTD-2516F10,2 & $-4,01$ & $1,92 \mathrm{E}-08$ & $-1,87$ & $2,22 \mathrm{E}-03$ & $-1,94$ & $6,49 \mathrm{E}-04$ \\
\hline CTD-2571E19,3 & 4,69 & $6,38 \mathrm{E}-23$ & 4,33 & $1,33 \mathrm{E}-17$ & 2,45 & $1,66 \mathrm{E}-05$ \\
\hline CTD-3187F8,14 & $-2,45$ & $2,80 \mathrm{E}-05$ & $-1,54$ & $6,18 \mathrm{E}-03$ & $-2,70$ & $4,19 \mathrm{E}-07$ \\
\hline CTLA4 & 3,86 & $1,26 \mathrm{E}-18$ & 2,79 & $1,84 \mathrm{E}-10$ & 3,12 & $2,93 \mathrm{E}-12$ \\
\hline CTNNAL1 & 4,09 & $1,52 \mathrm{E}-14$ & 3,30 & $2,17 \mathrm{E}-10$ & 2,44 & $2,63 \mathrm{E}-06$ \\
\hline CTPS1 & 2,59 & $4,15 \mathrm{E}-32$ & 1,83 & $3,61 \mathrm{E}-07$ & 1,03 & $4,46 \mathrm{E}-03$ \\
\hline CTSD & $-4,01$ & $5,67 \mathrm{E}-17$ & $-1,50$ & $6,35 \mathrm{E}-03$ & $-2,17$ & $2,51 \mathrm{E}-05$ \\
\hline CTSG & $-3,85$ & $5,14 \mathrm{E}-08$ & $-1,88$ & $2,90 \mathrm{E}-03$ & $-2,64$ & $2,09 \mathrm{E}-06$ \\
\hline CUEDC1 & $-3,88$ & $1,10 \mathrm{E}-17$ & $-1,75$ & $7,61 \mathrm{E}-04$ & $-2,35$ & $2,41 \mathrm{E}-06$ \\
\hline CYBRD1 & $-2,99$ & $4,49 \mathrm{E}-07$ & $-1,72$ & $6,61 \mathrm{E}-04$ & $-1,76$ & $4,75 \mathrm{E}-04$ \\
\hline CYFIP1 & $-2,16$ & $4,62 \mathrm{E}-07$ & $-1,39$ & $1,24 \mathrm{E}-03$ & $-2,01$ & $7,35 \mathrm{E}-06$ \\
\hline CYP1A1 & 2,95 & 4,79E-09 & 3,00 & $7,89 \mathrm{E}-10$ & 1,62 & $3,21 \mathrm{E}-03$ \\
\hline CYP27B1 & 4,06 & $1,05 \mathrm{E}-11$ & 3,37 & $1,20 \mathrm{E}-10$ & 1,71 & $9,63 \mathrm{E}-04$ \\
\hline CYS1 & 5,01 & $9,06 \mathrm{E}-16$ & 2,69 & $2,90 \mathrm{E}-05$ & 2,81 & $1,38 \mathrm{E}-06$ \\
\hline CYTL1 & $-4,31$ & $6,73 \mathrm{E}-17$ & $-1,80$ & $1,59 \mathrm{E}-03$ & $-1,56$ & $1,12 \mathrm{E}-03$ \\
\hline DAB2 & $-3,60$ & $1,09 \mathrm{E}-10$ & $-1,81$ & $1,03 \mathrm{E}-03$ & $-1,79$ & $1,26 \mathrm{E}-03$ \\
\hline DAZL & 1,84 & $7,11 \mathrm{E}-03$ & 1,73 & $5,65 \mathrm{E}-03$ & 2,22 & $1,07 \mathrm{E}-04$ \\
\hline DBN1 & 1,45 & $1,78 \mathrm{E}-04$ & 2,15 & $1,26 \mathrm{E}-07$ & 1,33 & $5,97 \mathrm{E}-03$ \\
\hline DCLRE1A & 1,57 & $2,22 \mathrm{E}-16$ & 1,66 & $2,26 \mathrm{E}-04$ & 1,20 & $9,03 \mathrm{E}-03$ \\
\hline DDIT4 & 2,50 & $4,43 \mathrm{E}-06$ & 1,68 & $7,10 \mathrm{E}-04$ & 1,38 & $3,94 \mathrm{E}-03$ \\
\hline DEF8 & $-2,95$ & $3,28 \mathrm{E}-15$ & $-1,50$ & $1,44 \mathrm{E}-04$ & $-1,15$ & $6,52 \mathrm{E}-03$ \\
\hline DEPDC1 & 6,58 & $2,75 \mathrm{E}-46$ & 4,75 & $4,37 \mathrm{E}-17$ & 3,09 & $7,23 \mathrm{E}-08$ \\
\hline DEPDC1B & 6,10 & $1,16 \mathrm{E}-61$ & 5,21 & $1,28 \mathrm{E}-25$ & 3,55 & $1,20 \mathrm{E}-10$ \\
\hline DFNA5 & $-3,83$ & $1,82 \mathrm{E}-11$ & $-1,56$ & $4,22 \mathrm{E}-03$ & $-1,92$ & $4,43 \mathrm{E}-04$ \\
\hline DHFR & 2,80 & $2,75 \mathrm{E}-19$ & 2,57 & $1,88 \mathrm{E}-10$ & 1,58 & $1,82 \mathrm{E}-03$ \\
\hline DHFRP1 & 3,13 & $2,63 \mathrm{E}-16$ & 2,83 & $1,07 \mathrm{E}-08$ & 1,78 & $8,18 \mathrm{E}-04$ \\
\hline DHRS9 & $-1,52$ & $9,42 \mathrm{E}-03$ & $-1,67$ & $1,13 \mathrm{E}-03$ & $-2,48$ & $1,29 \mathrm{E}-06$ \\
\hline DIAPH3 & 7,94 & $2,21 \mathrm{E}-66$ & 5,76 & $6,00 \mathrm{E}-26$ & 3,92 & $3,16 \mathrm{E}-12$ \\
\hline DIRAS1 & $-2,76$ & $1,83 \mathrm{E}-06$ & $-2,21$ & $8,77 \mathrm{E}-06$ & $-2,25$ & $1,41 \mathrm{E}-05$ \\
\hline DIXDC1 & 4,46 & $3,60 \mathrm{E}-66$ & 3,25 & $3,29 \mathrm{E}-11$ & 2,08 & $1,24 \mathrm{E}-05$ \\
\hline DLEU2 & 1,90 & $1,29 \mathrm{E}-09$ & 1,56 & $1,06 \mathrm{E}-03$ & 1,17 & $7,61 \mathrm{E}-03$ \\
\hline DLEU2L & 3,03 & $2,24 \mathrm{E}-11$ & 2,49 & $6,34 \mathrm{E}-06$ & 1,70 & $9,51 \mathrm{E}-04$ \\
\hline DLGAP5 & 8,05 & $8,96 \mathrm{E}-68$ & 6,54 & $3,19 \mathrm{E}-34$ & 3,89 & $1,15 \mathrm{E}-11$ \\
\hline DMC1 & 6,53 & $6,50 \mathrm{E}-44$ & 5,40 & $1,40 \mathrm{E}-24$ & 3,59 & $1,56 \mathrm{E}-10$ \\
\hline DNA2 & 3,39 & $1,82 \mathrm{E}-16$ & 2,63 & $2,01 \mathrm{E}-08$ & 1,73 & $4,10 \mathrm{E}-04$ \\
\hline DNAJC18 & 1,91 & $5,26 \mathrm{E}-10$ & 1,24 & $2,19 \mathrm{E}-03$ & 1,41 & $1,20 \mathrm{E}-03$ \\
\hline DNASE1L3 & $-3,02$ & $8,52 \mathrm{E}-06$ & $-1,69$ & $5,72 \mathrm{E}-03$ & $-1,78$ & $2,24 \mathrm{E}-03$ \\
\hline DNASE2 & $-2,14$ & $1,45 \mathrm{E}-07$ & $-1,36$ & $3,35 \mathrm{E}-03$ & $-1,51$ & $7,28 \mathrm{E}-04$ \\
\hline DNASE2B & $-3,61$ & $5,25 \mathrm{E}-06$ & $-1,87$ & $2,52 \mathrm{E}-03$ & $-2,62$ & $5,82 \mathrm{E}-06$ \\
\hline DNMT3B & 2,07 & 9,14E-05 & 2,52 & $2,83 \mathrm{E}-06$ & 1,76 & $1,12 \mathrm{E}-03$ \\
\hline DOCK10 & 1,99 & $5,60 \mathrm{E}-28$ & 1,05 & $3,38 \mathrm{E}-03$ & 0,98 & $7,22 \mathrm{E}-03$ \\
\hline DONSON & 2,57 & $8,86 \mathrm{E}-40$ & 1,99 & $4,75 \mathrm{E}-08$ & 1,10 & $8,43 \mathrm{E}-03$ \\
\hline DPEP2 & $-4,73$ & $1,94 \mathrm{E}-71$ & $-2,41$ & $3,95 \mathrm{E}-07$ & $-1,36$ & $5,03 \mathrm{E}-04$ \\
\hline DRP2 & 3,08 & $1,37 \mathrm{E}-06$ & 3,03 & $3,04 \mathrm{E}-08$ & 2,32 & $5,46 \mathrm{E}-05$ \\
\hline DSCC1 & 4,91 & $2,69 \mathrm{E}-21$ & 3,89 & $9,22 \mathrm{E}-16$ & 2,39 & $7,34 \mathrm{E}-06$ \\
\hline DTL & 6,91 & $1,82 \mathrm{E}-126$ & 5,93 & $2,86 \mathrm{E}-44$ & 4,25 & $4,44 \mathrm{E}-17$ \\
\hline DTNA & $-4,75$ & $1,27 \mathrm{E}-12$ & $-2,68$ & $1,26 \mathrm{E}-07$ & $-3,69$ & $8,17 \mathrm{E}-13$ \\
\hline DUSP4 & 4,10 & $1,09 \mathrm{E}-35$ & 3,56 & $1,36 \mathrm{E}-18$ & 2,91 & $8,66 \mathrm{E}-13$ \\
\hline DUSP5 & 2,80 & $3,02 \mathrm{E}-22$ & 1,26 & $3,69 \mathrm{E}-04$ & 1,71 & $2,12 \mathrm{E}-04$ \\
\hline DUT & 2,11 & $2,97 \mathrm{E}-15$ & 1,78 & $4,66 \mathrm{E}-07$ & 1,10 & $8,23 \mathrm{E}-03$ \\
\hline E2F1 & 4,96 & $6,29 \mathrm{E}-33$ & 4,50 & $2,36 \mathrm{E}-23$ & 3,04 & $7,93 \mathrm{E}-09$ \\
\hline E2F2 & 2,47 & $8,80 \mathrm{E}-06$ & 2,73 & $5,03 \mathrm{E}-08$ & 1,53 & $5,14 \mathrm{E}-03$ \\
\hline E2F7 & 6,49 & $6,93 \mathrm{E}-44$ & 5,01 & $1,34 \mathrm{E}-22$ & 3,47 & $2,73 \mathrm{E}-10$ \\
\hline E2F8 & 7,52 & $2,60 \mathrm{E}-43$ & 6,09 & $3,15 E-29$ & 4,10 & $2,57 \mathrm{E}-13$ \\
\hline $\mathrm{EB} / 3$ & 4,64 & $2,39 \mathrm{E}-48$ & 3,24 & $2,67 \mathrm{E}-14$ & 2,96 & $1,06 \mathrm{E}-09$ \\
\hline ECEL1 & 4,02 & $1,04 \mathrm{E}-08$ & 5,70 & $8,46 \mathrm{E}-27$ & 4,89 & $1,34 \mathrm{E}-19$ \\
\hline EDNRB & $-4,97$ & $2,65 \mathrm{E}-11$ & $-3,22$ & $7,32 \mathrm{E}-09$ & $-2,29$ & $5,56 \mathrm{E}-05$ \\
\hline EEPD1 & $-3,96$ & $5,86 \mathrm{E}-23$ & $-1,93$ & $1,23 \mathrm{E}-05$ & $-2,26$ & $3,15 \mathrm{E}-08$ \\
\hline EGR3 & 2,10 & $2,32 \mathrm{E}-06$ & 2,45 & $9,95 \mathrm{E}-08$ & 2,65 & $7,37 \mathrm{E}-08$ \\
\hline EME1 & 3,75 & $6,00 \mathrm{E}-33$ & 3,05 & $5,60 \mathrm{E}-13$ & 1,89 & $3,46 \mathrm{E}-04$ \\
\hline EMP1 & $-2,89$ & $8,70 \mathrm{E}-25$ & $-2,81$ & $3,83 \mathrm{E}-16$ & $-3,50$ & $1,24 \mathrm{E}-16$ \\
\hline EPB41L1 & $-4,04$ & $2,02 \mathrm{E}-08$ & $-2,42$ & $5,01 \mathrm{E}-05$ & $-2,30$ & $6,33 \mathrm{E}-05$ \\
\hline EPHB2 & $-5,97$ & $3,19 \mathrm{E}-57$ & $-2,63$ & $3,08 \mathrm{E}-06$ & $-2,27$ & $1,17 \mathrm{E}-05$ \\
\hline EPHX1 & $-3,95$ & $3,95 \mathrm{E}-16$ & $-1,91$ & $1,40 \mathrm{E}-04$ & $-2,32$ & $1,35 \mathrm{E}-06$ \\
\hline ERCC6L & 4,35 & $2,19 \mathrm{E}-22$ & 3,42 & $7,05 \mathrm{E}-13$ & 2,06 & $1,02 \mathrm{E}-04$ \\
\hline $\mathrm{ESCO} 2$ & 5,17 & $7,31 \mathrm{E}-67$ & 4,46 & $1,77 \mathrm{E}-22$ & 2,99 & $2,55 \mathrm{E}-08$ \\
\hline ESPL1 & 4,77 & $8,40 \mathrm{E}-19$ & 4,57 & $5,55 \mathrm{E}-20$ & 2,81 & $5,51 \mathrm{E}-07$ \\
\hline EXO1 & 6,22 & $5,45 \mathrm{E}-56$ & 5,13 & $1,35 \mathrm{E}-26$ & 3,47 & $3,27 \mathrm{E}-11$ \\
\hline EZH2 & 3,31 & $9,49 \mathrm{E}-82$ & 2,69 & $2,00 \mathrm{E}-12$ & 1,86 & $4,53 \mathrm{E}-05$ \\
\hline EZH2P1 & 2,82 & $3,95 \mathrm{E}-14$ & 2,21 & $5,13 \mathrm{E}-07$ & 1,30 & $7,62 \mathrm{E}-03$ \\
\hline F13A1 & $-3,27$ & $6,27 \mathrm{E}-05$ & $-2,99$ & $3,72 \mathrm{E}-06$ & $-2,13$ & $2,66 \mathrm{E}-04$ \\
\hline $\mathrm{F} 5$ & 4,89 & $1,22 \mathrm{E}-54$ & 4,27 & $8,81 \mathrm{E}-26$ & 3,27 & $2,31 \mathrm{E}-13$ \\
\hline FABP3 & $-5,36$ & $9,03 E-59$ & $-2,71$ & $7,42 \mathrm{E}-08$ & $-5,78$ & $2,43 \mathrm{E}-41$ \\
\hline FABP3P2 & $-6,05$ & $2,18 \mathrm{E}-22$ & $-2,66$ & $3,03 \mathrm{E}-06$ & $-4,49$ & $2,39 \mathrm{E}-18$ \\
\hline FAIM2 & 2,25 & $2,33 \mathrm{E}-03$ & 2,57 & $1,86 \mathrm{E}-05$ & 1,58 & $6,73 \mathrm{E}-03$ \\
\hline FAM109A & $-1,84$ & $1,87 \mathrm{E}-10$ & $-1,26$ & $8,44 \mathrm{E}-04$ & $-1,37$ & $2,08 \mathrm{E}-03$ \\
\hline FAM111B & 5,67 & $1,76 \mathrm{E}-70$ & 4,35 & $2,41 \mathrm{E}-26$ & 3,22 & $6,19 \mathrm{E}-11$ \\
\hline FAM114A1 & $-3,13$ & $3,52 \mathrm{E}-10$ & $-1,39$ & $4,40 \mathrm{E}-03$ & $-2,11$ & $3,41 \mathrm{E}-06$ \\
\hline
\end{tabular}




\begin{tabular}{|c|c|c|c|c|c|c|}
\hline FAM129C & $-3,37$ & $1,26 \mathrm{E}-22$ & $-2,24$ & $7,09 \mathrm{E}-07$ & $-1,55$ & $8,78 \mathrm{E}-04$ \\
\hline FAM167A & 3,86 & $6,32 \mathrm{E}-15$ & 1,76 & $3,05 \mathrm{E}-03$ & 3,25 & $6,73 \mathrm{E}-10$ \\
\hline FAM172BP & 2,49 & $7,67 \mathrm{E}-13$ & 1,86 & $1,48 \mathrm{E}-05$ & 2,09 & $4,82 \mathrm{E}-06$ \\
\hline FAM2OC & $-3,32$ & $2,70 \mathrm{E}-11$ & $-1,34$ & $8,60 \mathrm{E}-03$ & $-1,76$ & $5,39 \mathrm{E}-04$ \\
\hline FAM3D & $-2,81$ & $5,26 \mathrm{E}-04$ & $-2,31$ & $3,71 \mathrm{E}-04$ & $-1,92$ & $1,00 \mathrm{E}-03$ \\
\hline FAM46A & $-2,31$ & $1,41 \mathrm{E}-05$ & $-1,49$ & $5,80 \mathrm{E}-03$ & $-1,63$ & $9,10 \mathrm{E}-04$ \\
\hline FAM57B & 4,21 & $4,33 \mathrm{E}-21$ & 3,54 & $8,02 \mathrm{E}-14$ & 2,32 & $3,74 \mathrm{E}-05$ \\
\hline FAM64A & 4,54 & $5,54 \mathrm{E}-21$ & 4,84 & $2,81 \mathrm{E}-20$ & 2,91 & $4,73 \mathrm{E}-07$ \\
\hline FAM72A & 4,11 & $5,40 \mathrm{E}-15$ & 3,09 & $2,26 \mathrm{E}-08$ & 1,69 & $3,30 \mathrm{E}-03$ \\
\hline FAM72B & 4,87 & $3,98 \mathrm{E}-65$ & 3,58 & $6,34 \mathrm{E}-13$ & 2,01 & $3,96 \mathrm{E}-04$ \\
\hline FAM72C & 5,15 & $2,04 \mathrm{E}-20$ & 3,71 & $6,53 \mathrm{E}-11$ & 1,97 & $7,44 \mathrm{E}-04$ \\
\hline FAM72D & 5,52 & $4,45 \mathrm{E}-50$ & 4,27 & $8,04 \mathrm{E}-18$ & 2,45 & $1,79 \mathrm{E}-05$ \\
\hline FAM83D & 4,50 & $6,75 \mathrm{E}-24$ & 3,45 & $5,47 \mathrm{E}-12$ & 2,57 & $1,10 \mathrm{E}-06$ \\
\hline FAM83F & 3,77 & $1,09 \mathrm{E}-23$ & 4,01 & $9,38 \mathrm{E}-21$ & 3,56 & $4,87 \mathrm{E}-13$ \\
\hline FANCA & 3,66 & $1,87 \mathrm{E}-94$ & 3,16 & $1,41 \mathrm{E}-15$ & 2,11 & $1,20 \mathrm{E}-05$ \\
\hline FANCl & 4,11 & $7,73 \mathrm{E}-88$ & 3,28 & $2,12 \mathrm{E}-16$ & 2,18 & $1,89 \mathrm{E}-05$ \\
\hline FARP1 & $-2,22$ & $1,98 \mathrm{E}-15$ & $-1,63$ & $1,90 \mathrm{E}-05$ & $-1,83$ & $1,94 \mathrm{E}-05$ \\
\hline FAS & 2,07 & $1,63 \mathrm{E}-22$ & 1,26 & $9,99 \mathrm{E}-04$ & 1,39 & $1,02 \mathrm{E}-04$ \\
\hline FBLIM1 & $-4,62$ & $8,68 \mathrm{E}-13$ & $-3,82$ & $5,91 \mathrm{E}-13$ & $-2,19$ & $1,11 \mathrm{E}-04$ \\
\hline FBXO27 & 3,45 & $1,76 \mathrm{E}-09$ & 4,89 & $1,14 \mathrm{E}-21$ & 2,45 & $1,79 \mathrm{E}-05$ \\
\hline FBX043 & 5,83 & $9,37 \mathrm{E}-23$ & 5,07 & $2,01 \mathrm{E}-20$ & 2,72 & $3,22 \mathrm{E}-06$ \\
\hline FBXO5 & 2,44 & $3,84 \mathrm{E}-45$ & 1,84 & $5,30 \mathrm{E}-06$ & 1,28 & $4,69 \mathrm{E}-03$ \\
\hline FCGRT & $-3,81$ & $6,41 \mathrm{E}-17$ & $-1,39$ & $9,24 \mathrm{E}-03$ & $-1,56$ & $3,07 \mathrm{E}-03$ \\
\hline $\mathrm{FCHO} 2$ & $-3,31$ & $1,03 \mathrm{E}-07$ & $-1,65$ & $6,13 \mathrm{E}-03$ & $-1,63$ & $3,92 \mathrm{E}-03$ \\
\hline FCRL2 & $-3,02$ & $2,76 \mathrm{E}-08$ & $-1,65$ & $4,43 \mathrm{E}-03$ & $-1,32$ & $3,60 \mathrm{E}-03$ \\
\hline FCRLB & $-2,40$ & $1,28 \mathrm{E}-04$ & $-1,43$ & $9,38 \mathrm{E}-03$ & $-1,68$ & $1,67 \mathrm{E}-03$ \\
\hline FEN1 & 3,65 & $4,14 \mathrm{E}-69$ & 3,04 & $5,44 \mathrm{E}-17$ & 1,75 & $1,37 \mathrm{E}-04$ \\
\hline FEN1P1 & 3,24 & $1,31 \mathrm{E}-07$ & 2,59 & $7,77 \mathrm{E}-06$ & 1,60 & $5,44 \mathrm{E}-03$ \\
\hline FGD6 & $-1,69$ & $1,49 \mathrm{E}-04$ & $-1,18$ & $6,56 \mathrm{E}-03$ & $-1,92$ & $5,09 \mathrm{E}-05$ \\
\hline FGFR1 & 1,43 & $1,66 \mathrm{E}-04$ & 2,41 & $1,46 \mathrm{E}-06$ & 1,43 & $8,15 \mathrm{E}-03$ \\
\hline FKBP9 & $-2,64$ & $4,31 \mathrm{E}-11$ & $-2,50$ & $1,06 \mathrm{E}-08$ & $-2,10$ & $3,47 \mathrm{E}-06$ \\
\hline FKBP9L & $-3,49$ & $2,55 \mathrm{E}-06$ & $-1,51$ & $6,82 \mathrm{E}-03$ & $-1,94$ & $4,73 \mathrm{E}-04$ \\
\hline FLT1 & 2,32 & $4,86 \mathrm{E}-10$ & 1,48 & $3,76 \mathrm{E}-03$ & 1,15 & $6,58 \mathrm{E}-03$ \\
\hline FNDC9 & 4,22 & $6,77 \mathrm{E}-15$ & 3,51 & $2,75 \mathrm{E}-11$ & 2,56 & $1,69 \mathrm{E}-06$ \\
\hline FOLR2 & $-3,50$ & $4,67 \mathrm{E}-08$ & $-2,06$ & $8,26 \mathrm{E}-04$ & $-2,61$ & $2,07 \mathrm{E}-06$ \\
\hline FOXM1 & 4,63 & $3,33 \mathrm{E}-29$ & 3,82 & $4,09 \mathrm{E}-16$ & 2,40 & $7,85 \mathrm{E}-06$ \\
\hline FOXP3 & 0,88 & $3,42 \mathrm{E}-04$ & 1,37 & $1,56 \mathrm{E}-04$ & 1,73 & $7,94 \mathrm{E}-06$ \\
\hline FRRS1 & $-2,39$ & $4,77 \mathrm{E}-05$ & $-1,31$ & $7,13 \mathrm{E}-03$ & $-1,83$ & $1,70 \mathrm{E}-04$ \\
\hline FSD1 & 1,28 & $1,51 \mathrm{E}-11$ & 1,09 & $1,19 \mathrm{E}-03$ & 1,25 & $9,07 \mathrm{E}-04$ \\
\hline FTL & $-3,63$ & $9,29 \mathrm{E}-17$ & $-1,78$ & $2,64 \mathrm{E}-04$ & $-2,32$ & $1,04 \mathrm{E}-06$ \\
\hline FTLP15 & $-3,10$ & $5,33 \mathrm{E}-09$ & $-1,69$ & $7,39 \mathrm{E}-04$ & $-2,07$ & $1,04 \mathrm{E}-05$ \\
\hline FTLP19 & $-2,77$ & $2,24 \mathrm{E}-05$ & $-1,60$ & $5,17 \mathrm{E}-03$ & $-2,10$ & $1,16 \mathrm{E}-04$ \\
\hline FTLP2 & $-3,73$ & $1,38 \mathrm{E}-17$ & $-1,95$ & $2,84 \mathrm{E}-05$ & $-2,40$ & $2,09 \mathrm{E}-07$ \\
\hline FTLP3 & $-3,52$ & $3,07 \mathrm{E}-15$ & $-1,73$ & $6,25 \mathrm{E}-04$ & $-2,30$ & $1,59 \mathrm{E}-06$ \\
\hline FTLP5 & $-3,52$ & $7,03 \mathrm{E}-10$ & $-1,81$ & $2,79 \mathrm{E}-04$ & $-1,96$ & $1,23 \mathrm{E}-04$ \\
\hline FTLP8 & $-3,49$ & $6,71 \mathrm{E}-06$ & $-2,12$ & $8,72 \mathrm{E}-04$ & $-1,66$ & $2,98 \mathrm{E}-03$ \\
\hline FUCA1 & $-6,59$ & $6,11 \mathrm{E}-292$ & $-2,79$ & $1,10 \mathrm{E}-06$ & $-1,83$ & $9,74 \mathrm{E}-04$ \\
\hline FURIN & 2,66 & $9,31 \mathrm{E}-11$ & 1,45 & $6,39 \mathrm{E}-04$ & 1,72 & $6,60 \mathrm{E}-05$ \\
\hline FUT8 & 2,66 & $5,97 \mathrm{E}-54$ & 2,03 & $1,12 \mathrm{E}-08$ & 1,32 & $1,28 \mathrm{E}-03$ \\
\hline FXYD6P1 & $-3,50$ & $4,90 \mathrm{E}-06$ & $-1,84$ & $2,35 \mathrm{E}-03$ & $-2,20$ & $1,14 \mathrm{E}-04$ \\
\hline FZD6 & 2,49 & $4,00 \mathrm{E}-16$ & 2,28 & $1,24 \mathrm{E}-07$ & 1,48 & $1,88 \mathrm{E}-04$ \\
\hline GADD45A & 1,98 & $3,65 \mathrm{E}-26$ & 1,09 & $9,48 \mathrm{E}-04$ & 1,48 & $1,76 \mathrm{E}-04$ \\
\hline GALR2 & 6,50 & $3,84 \mathrm{E}-76$ & 3,36 & $8,32 \mathrm{E}-09$ & 2,11 & $1,49 \mathrm{E}-04$ \\
\hline GAPDHP38 & 2,71 & $6,02 \mathrm{E}-21$ & 2,41 & $2,76 \mathrm{E}-10$ & 1,31 & $3,32 \mathrm{E}-03$ \\
\hline GAS2L3 & $-2,92$ & $5,80 \mathrm{E}-07$ & $-1,47$ & $6,47 \mathrm{E}-03$ & $-2,12$ & $3,18 \mathrm{E}-05$ \\
\hline GAS7 & $-3,25$ & $9,45 \mathrm{E}-16$ & $-1,26$ & $7,31 \mathrm{E}-03$ & $-1,87$ & $2,91 \mathrm{E}-04$ \\
\hline GBP1 & 1,91 & $2,74 \mathrm{E}-09$ & 2,32 & $1,33 \mathrm{E}-10$ & 1,63 & $5,67 \mathrm{E}-04$ \\
\hline GBP1P1 & 1,89 & $6,86 \mathrm{E}-10$ & 2,41 & $1,06 \mathrm{E}-10$ & 1,68 & $2,32 \mathrm{E}-04$ \\
\hline GBP2 & 1,21 & $7,60 \mathrm{E}-05$ & 1,28 & $5,44 \mathrm{E}-04$ & 1,52 & $3,95 \mathrm{E}-05$ \\
\hline GBP4 & 2,67 & $3,65 \mathrm{E}-63$ & 2,65 & $4,85 \mathrm{E}-14$ & 2,50 & $1,00 \mathrm{E}-12$ \\
\hline GBP5 & 2,52 & $2,23 \mathrm{E}-32$ & 2,49 & $8,34 \mathrm{E}-12$ & 2,47 & $1,66 \mathrm{E}-11$ \\
\hline GBP6 & 3,60 & $2,24 \mathrm{E}-07$ & 1,73 & $7,53 \mathrm{E}-03$ & 2,33 & $6,02 \mathrm{E}-05$ \\
\hline $\mathrm{GCH} 1$ & 2,09 & $3,09 \mathrm{E}-10$ & 1,73 & $6,78 \mathrm{E}-06$ & 1,35 & $6,19 \mathrm{E}-04$ \\
\hline GCNT1 & 2,78 & $1,72 \mathrm{E}-25$ & 1,33 & $6,55 \mathrm{E}-03$ & 1,29 & $5,55 \mathrm{E}-04$ \\
\hline GDF3 & $-3,79$ & $7,59 \mathrm{E}-07$ & $-2,25$ & $1,73 \mathrm{E}-04$ & $-3,00$ & $2,09 \mathrm{E}-07$ \\
\hline GFl1 & 2,64 & $3,66 \mathrm{E}-10$ & 2,20 & $2,49 \mathrm{E}-07$ & 2,01 & $5,23 \mathrm{E}-06$ \\
\hline GGT5 & 3,38 & $1,30 \mathrm{E}-07$ & 3,33 & $6,87 \mathrm{E}-09$ & 1,90 & $4,96 \mathrm{E}-04$ \\
\hline GGTA1P & $-1,99$ & $6,37 \mathrm{E}-03$ & $-1,88$ & $3,14 \mathrm{E}-03$ & $-2,13$ & $2,59 \mathrm{E}-04$ \\
\hline GIMAP4 & 1,17 & $6,07 \mathrm{E}-15$ & 0,79 & $9,75 \mathrm{E}-03$ & 0,90 & $6,30 \mathrm{E}-03$ \\
\hline GINS1 & 3,12 & $2,88 \mathrm{E}-34$ & 2,76 & $2,96 \mathrm{E}-11$ & 1,44 & $3,63 \mathrm{E}-03$ \\
\hline GINS2 & 4,80 & $8,00 \mathrm{E}-20$ & 4,24 & $1,35 \mathrm{E}-16$ & 2,79 & $2,79 \mathrm{E}-07$ \\
\hline GINS3 & 3,31 & $4,70 \mathrm{E}-57$ & 2,91 & $1,15 \mathrm{E}-13$ & 1,87 & $4,55 \mathrm{E}-05$ \\
\hline GINS4 & 3,08 & $1,59 \mathrm{E}-57$ & 2,72 & $1,78 \mathrm{E}-11$ & 1,68 & $2,67 \mathrm{E}-04$ \\
\hline GJC1 & 3,90 & $1,12 \mathrm{E}-10$ & 3,12 & $6,43 \mathrm{E}-08$ & 2,20 & $1,03 \mathrm{E}-04$ \\
\hline GLDC & 4,65 & $1,84 \mathrm{E}-10$ & 1,82 & $4,45 \mathrm{E}-03$ & 1,93 & $8,73 \mathrm{E}-04$ \\
\hline GNG4 & 6,54 & $2,38 \mathrm{E}-45$ & 4,98 & $6,90 \mathrm{E}-19$ & 4,94 & $2,27 \mathrm{E}-26$ \\
\hline GNG8 & 2,98 & $5,58 \mathrm{E}-12$ & 3,40 & $1,13 \mathrm{E}-10$ & 2,90 & $7,72 \mathrm{E}-09$ \\
\hline GPC1 & 2,27 & 1,51E-06 & 1,80 & $9,90 \mathrm{E}-05$ & 1,20 & $8,82 \mathrm{E}-03$ \\
\hline GPNMB & $-6,95$ & $8,61 \mathrm{E}-39$ & $-1,94$ & $1,44 \mathrm{E}-03$ & $-2,33$ & $3,95 \mathrm{E}-05$ \\
\hline GPR125 & 1,72 & $1,42 \mathrm{E}-06$ & 2,41 & $2,32 \mathrm{E}-09$ & 1,45 & $1,81 \mathrm{E}-03$ \\
\hline GPR137C & 2,92 & $1,03 \mathrm{E}-05$ & 3,29 & $2,32 \mathrm{E}-09$ & 1,75 & $2,73 \mathrm{E}-03$ \\
\hline GPR171 & 1,86 & $4,48 \mathrm{E}-08$ & 1,34 & $1,31 \mathrm{E}-03$ & 1,69 & $1,00 \mathrm{E}-05$ \\
\hline GPR19 & 2,38 & $7,95 \mathrm{E}-10$ & 1,44 & $1,16 \mathrm{E}-03$ & 1,57 & $8,19 \mathrm{E}-04$ \\
\hline GPR34 & $-1,11$ & $4,80 \mathrm{E}-04$ & $-2,15$ & $7,14 \mathrm{E}-06$ & $-1,52$ & $1,71 \mathrm{E}-04$ \\
\hline GPR55 & 1,20 & $3,07 \mathrm{E}-03$ & 2,10 & $1,21 \mathrm{E}-06$ & 1,45 & $4,43 \mathrm{E}-03$ \\
\hline GPR68 & 0,64 & $2,34 \mathrm{E}-03$ & 1,28 & $1,97 \mathrm{E}-04$ & 1,17 & $6,64 \mathrm{E}-03$ \\
\hline GPRC5B & $-3,37$ & $1,58 \mathrm{E}-05$ & $-1,83$ & $2,48 \mathrm{E}-03$ & $-2,22$ & $8,52 \mathrm{E}-05$ \\
\hline
\end{tabular}

\begin{tabular}{|c|c|c|c|c|c|c|}
\hline GPX3 & $-2,87$ & $7,36 \mathrm{E}-06$ & $-1,73$ & $2,62 \mathrm{E}-03$ & $-2,22$ & $2,40 \mathrm{E}-05$ \\
\hline GRAMD3 & 1,71 & $2,68 \mathrm{E}-09$ & 1,30 & 4,54E-04 & 1,54 & $2,20 \mathrm{E}-04$ \\
\hline GRAMD4 & $-2,38$ & $8,86 \mathrm{E}-06$ & $-1,41$ & $7,81 \mathrm{E}-03$ & $-1,54$ & $2,33 \mathrm{E}-03$ \\
\hline GRB7 & 6,61 & $2,88 \mathrm{E}-36$ & 5,42 & $6,74 \mathrm{E}-25$ & 4,09 & $5,08 \mathrm{E}-15$ \\
\hline GRN & $-3,86$ & $1,38 \mathrm{E}-11$ & $-1,56$ & $6,72 \mathrm{E}-03$ & $-1,99$ & $3,12 \mathrm{E}-04$ \\
\hline GSDMA & 1,16 & $5,74 \mathrm{E}-03$ & 1,84 & $1,77 \mathrm{E}-05$ & 1,55 & $3,99 \mathrm{E}-03$ \\
\hline GSG1 & $-3,43$ & $7,80 \mathrm{E}-12$ & $-3,17$ & $5,80 \mathrm{E}-11$ & $-2,92$ & $6,83 \mathrm{E}-10$ \\
\hline GSG2 & 2,15 & $5,48 \mathrm{E}-05$ & 2,13 & $9,57 \mathrm{E}-06$ & 1,60 & $3,62 \mathrm{E}-03$ \\
\hline GTSE1 & 6,34 & $3,28 \mathrm{E}-56$ & 5,66 & $2,61 \mathrm{E}-33$ & 3,66 & $3,00 \mathrm{E}-11$ \\
\hline GZMB & 8,18 & $2,35 \mathrm{E}-117$ & 4,69 & $6,72 \mathrm{E}-24$ & 2,78 & $6,78 \mathrm{E}-12$ \\
\hline H2AFX & 3,78 & $5,01 \mathrm{E}-134$ & 3,28 & $1,11 \mathrm{E}-25$ & 2,13 & $1,98 \mathrm{E}-06$ \\
\hline H2AFZP1 & 2,67 & $7,73 \mathrm{E}-26$ & 2,14 & $1,13 \mathrm{E}-07$ & 1,24 & $7,01 \mathrm{E}-03$ \\
\hline HECTD2 & 1,68 & $1,80 \mathrm{E}-10$ & 1,47 & $5,05 \mathrm{E}-05$ & 1,01 & $8,61 \mathrm{E}-03$ \\
\hline HECW2 & 3,78 & $1,33 \mathrm{E}-17$ & 2,86 & $7,21 \mathrm{E}-10$ & 2,47 & $7,96 \mathrm{E}-08$ \\
\hline HELLS & 3,62 & $1,45 \mathrm{E}-44$ & 2,73 & $2,04 \mathrm{E}-10$ & 1,87 & $1,15 \mathrm{E}-04$ \\
\hline HFE & $-2,31$ & $4,12 \mathrm{E}-06$ & $-1,52$ & $2,67 \mathrm{E}-03$ & $-1,65$ & $1,06 \mathrm{E}-03$ \\
\hline HGF & $-4,42$ & $2,94 \mathrm{E}-15$ & $-4,14$ & $9,87 \mathrm{E}-16$ & $-2,76$ & $6,40 \mathrm{E}-09$ \\
\hline $\mathrm{HIC1}$ & 3,03 & $1,22 \mathrm{E}-07$ & 3,33 & $5,91 \mathrm{E}-11$ & 2,37 & $3,09 \mathrm{E}-06$ \\
\hline HILPDA & 1,97 & $7,10 \mathrm{E}-13$ & 1,93 & $2,39 \mathrm{E}-07$ & 1,49 & $9,09 \mathrm{E}-04$ \\
\hline HIST1H1B & 8,19 & $1,62 \mathrm{E}-63$ & 2,16 & $5,34 \mathrm{E}-04$ & 1,64 & $5,12 \mathrm{E}-03$ \\
\hline HIST1H2AI & 7,55 & $2,09 \mathrm{E}-34$ & 2,75 & $1,91 \mathrm{E}-05$ & 1,59 & $5,02 \mathrm{E}-03$ \\
\hline HIST1H2AJ & 6,77 & $1,47 \mathrm{E}-25$ & 3,29 & $1,83 \mathrm{E}-07$ & 1,79 & $1,84 \mathrm{E}-03$ \\
\hline HIST1H2BE & 6,68 & $7,56 \mathrm{E}-32$ & 2,44 & $1,18 \mathrm{E}-04$ & 1,56 & $7,31 \mathrm{E}-03$ \\
\hline HIST1H2BH & 5,90 & $2,64 \mathrm{E}-48$ & 4,72 & $6,38 \mathrm{E}-26$ & 2,59 & $4,85 \mathrm{E}-06$ \\
\hline HIST1H3C & 7,58 & $1,13 \mathrm{E}-34$ & 3,20 & $4,63 \mathrm{E}-07$ & 1,84 & $1,50 \mathrm{E}-03$ \\
\hline HIST1H3F & 7,70 & $8,35 \mathrm{E}-36$ & 2,76 & $1,87 \mathrm{E}-05$ & 1,66 & $3,67 \mathrm{E}-03$ \\
\hline HJURP & 7,25 & $4,21 \mathrm{E}-124$ & 6,23 & $2,18 \mathrm{E}-49$ & 3,96 & $3,84 \mathrm{E}-13$ \\
\hline HMGB1P17 & 4,90 & $8,49 \mathrm{E}-12$ & 3,24 & $3,63 \mathrm{E}-07$ & 2,52 & $1,60 \mathrm{E}-05$ \\
\hline HMGB2 & 2,61 & $5,55 \mathrm{E}-11$ & 2,54 & $6,64 \mathrm{E}-08$ & 1,69 & $1,73 \mathrm{E}-03$ \\
\hline HMGB2P1 & 3,08 & $1,92 \mathrm{E}-23$ & 2,70 & $2,73 \mathrm{E}-09$ & 1,83 & $6,65 \mathrm{E}-04$ \\
\hline HMMR & 6,61 & $5,24 \mathrm{E}-46$ & 5,44 & $9,75 \mathrm{E}-25$ & 3,31 & $7,13 \mathrm{E}-09$ \\
\hline HMOX1 & $-3,38$ & $4,12 \mathrm{E}-17$ & $-1,93$ & $4,86 \mathrm{E}-05$ & $-2,05$ & $2,48 \mathrm{E}-05$ \\
\hline HNRNPA1P21 & 2,22 & 1,74E-07 & 2,44 & $1,92 \mathrm{E}-07$ & 2,10 & $2,04 \mathrm{E}-05$ \\
\hline HOMER3 & $-3,93$ & $6,07 \mathrm{E}-22$ & $-2,01$ & $8,73 \mathrm{E}-05$ & $-2,50$ & $1,29 \mathrm{E}-06$ \\
\hline HPDL & 4,16 & $1,21 \mathrm{E}-41$ & 3,43 & $2,75 \mathrm{E}-17$ & 1,95 & $4,07 \mathrm{E}-06$ \\
\hline HS3ST2 & $-9,58$ & $3,05 \mathrm{E}-71$ & $-2,20$ & $5,68 \mathrm{E}-04$ & $-2,64$ & $5,43 \mathrm{E}-06$ \\
\hline HSD17B4 & $-1,81$ & 2,03E-05 & $-1,16$ & $5,74 \mathrm{E}-03$ & $-1,49$ & $7,37 \mathrm{E}-04$ \\
\hline HSF4 & $-1,77$ & $1,77 \mathrm{E}-11$ & $-1,73$ & $1,18 \mathrm{E}-04$ & $-1,31$ & $7,69 \mathrm{E}-04$ \\
\hline HSPA2 & 3,37 & $2,86 \mathrm{E}-18$ & 2,99 & $5,11 \mathrm{E}-11$ & 1,80 & $1,25 \mathrm{E}-04$ \\
\hline HTR2A & $-2,60$ & $1,50 \mathrm{E}-03$ & $-2,30$ & $3,85 \mathrm{E}-04$ & $-2,04$ & $4,48 \mathrm{E}-04$ \\
\hline ICA1L & 1,83 & $2,50 \mathrm{E}-08$ & 1,91 & $2,89 \mathrm{E}-05$ & 1,52 & $4,59 \mathrm{E}-03$ \\
\hline ID01 & 2,59 & $5,49 \mathrm{E}-04$ & 2,51 & $3,97 \mathrm{E}-05$ & 1,51 & $8,61 \mathrm{E}-03$ \\
\hline IFI30 & $-4,03$ & $8,40 \mathrm{E}-17$ & $-1,62$ & $3,22 \mathrm{E}-03$ & $-2,09$ & $8,60 \mathrm{E}-05$ \\
\hline IFNG & 8,97 & $2,42 \mathrm{E}-137$ & 3,71 & $3,80 \mathrm{E}-16$ & 2,71 & $2,45 \mathrm{E}-06$ \\
\hline IGFBP5 & 2,40 & 1,91E-03 & 1,83 & $4,84 \mathrm{E}-03$ & 2,02 & $5,23 \mathrm{E}-04$ \\
\hline IGLV3-12 & $-4,33$ & $8,62 \mathrm{E}-09$ & $-2,58$ & $1,09 \mathrm{E}-05$ & $-1,73$ & $1,87 \mathrm{E}-03$ \\
\hline IGSF3 & 3,41 & $3,80 \mathrm{E}-20$ & 2,12 & $9,47 \mathrm{E}-06$ & 1,55 & $4,07 \mathrm{E}-03$ \\
\hline IKZF3 & 2,11 & $2,88 \mathrm{E}-10$ & 1,51 & $1,83 \mathrm{E}-04$ & 1,92 & $1,62 \mathrm{E}-06$ \\
\hline IKZF4 & 2,41 & $5,46 \mathrm{E}-41$ & 2,57 & $1,06 \mathrm{E}-13$ & 2,25 & $4,26 \mathrm{E}-07$ \\
\hline IL12RB2 & 6,69 & $2,26 \mathrm{E}-189$ & 3,54 & $8,30 \mathrm{E}-09$ & 3,20 & $7,91 \mathrm{E}-11$ \\
\hline IL15RA & 2,02 & $9,38 \mathrm{E}-21$ & 1,93 & $3,22 \mathrm{E}-08$ & 1,13 & $9,62 \mathrm{E}-03$ \\
\hline IL17A & 6,33 & $6,42 \mathrm{E}-28$ & 3,70 & $2,07 \mathrm{E}-09$ & 3,36 & $5,47 \mathrm{E}-09$ \\
\hline IL17F & 7,67 & $1,27 \mathrm{E}-97$ & 4,40 & $1,38 \mathrm{E}-18$ & 3,64 & $1,92 \mathrm{E}-10$ \\
\hline IL18R1 & 1,82 & $2,36 \mathrm{E}-07$ & 1,38 & $4,99 \mathrm{E}-04$ & 1,73 & $1,35 \mathrm{E}-05$ \\
\hline IL1R2 & 3,37 & $7,69 \mathrm{E}-17$ & 2,35 & $1,68 \mathrm{E}-06$ & 3,12 & $3,77 \mathrm{E}-11$ \\
\hline IL21-AS1 & 3,97 & $1,30 \mathrm{E}-16$ & 2,49 & $3,22 \mathrm{E}-06$ & 3,02 & $1,08 \mathrm{E}-08$ \\
\hline IL21R & 2,29 & $2,24 \mathrm{E}-07$ & 1,52 & $4,96 \mathrm{E}-04$ & 1,50 & $5,17 \mathrm{E}-04$ \\
\hline IL23R & 3,19 & $5,09 \mathrm{E}-06$ & 1,85 & $3,16 \mathrm{E}-03$ & 1,72 & $2,86 \mathrm{E}-03$ \\
\hline IL27RA & 0,72 & $3,52 \mathrm{E}-03$ & 1,02 & $2,82 \mathrm{E}-03$ & 1,09 & $4,03 \mathrm{E}-03$ \\
\hline IL2RA & 6,49 & $2,08 \mathrm{E}-157$ & 4,65 & $2,33 \mathrm{E}-42$ & 3,48 & $5,06 \mathrm{E}-15$ \\
\hline IL2RB & 2,16 & $1,28 \mathrm{E}-10$ & 1,93 & $3,65 \mathrm{E}-07$ & 2,29 & $6,69 \mathrm{E}-08$ \\
\hline IL6 & 3,82 & $3,29 \mathrm{E}-10$ & 1,92 & $1,87 \mathrm{E}-03$ & 2,20 & $1,49 \mathrm{E}-04$ \\
\hline ILDR2 & 3,20 & $8,03 \mathrm{E}-12$ & 2,46 & $5,43 \mathrm{E}-06$ & 2,04 & $1,22 \mathrm{E}-04$ \\
\hline INHBA & 8,16 & $5,01 \mathrm{E}-100$ & 5,20 & $2,76 \mathrm{E}-19$ & 4,74 & $4,09 \mathrm{E}-19$ \\
\hline IQGAP3 & 3,54 & $2,58 \mathrm{E}-33$ & 3,23 & $2,97 \mathrm{E}-10$ & 1,94 & $5,04 \mathrm{E}-04$ \\
\hline IRF4 & 3,72 & $2,69 \mathrm{E}-24$ & 2,66 & $2,29 \mathrm{E}-11$ & 2,32 & $1,43 \mathrm{E}-08$ \\
\hline ITGA4 & 1,52 & $1,87 \mathrm{E}-04$ & 1,67 & $1,04 \mathrm{E}-03$ & 1,33 & $4,42 \mathrm{E}-03$ \\
\hline ITGB5 & $-3,47$ & $5,85 \mathrm{E}-38$ & $-2,45$ & $1,74 \mathrm{E}-11$ & $-1,72$ & $8,90 \mathrm{E}-04$ \\
\hline ITPRIPL1 & 2,84 & $5,02 \mathrm{E}-26$ & 1,76 & $3,63 \mathrm{E}-06$ & 1,56 & $3,39 \mathrm{E}-05$ \\
\hline ITSN1 & $-1,59$ & $1,06 \mathrm{E}-09$ & $-1,53$ & 4,69E-04 & $-1,91$ & $7,54 \mathrm{E}-07$ \\
\hline JAKMIP1 & 2,49 & $3,03 \mathrm{E}-27$ & 1,82 & $4,76 \mathrm{E}-04$ & 1,92 & $1,52 \mathrm{E}-06$ \\
\hline KCNJ5 & $-9,53$ & $2,91 \mathrm{E}-52$ & $-1,80$ & $5,25 \mathrm{E}-03$ & $-4,18$ & $2,20 \mathrm{E}-14$ \\
\hline KCNK5 & 4,14 & $2,37 \mathrm{E}-23$ & 4,19 & $1,93 \mathrm{E}-16$ & 3,09 & $3,42 \mathrm{E}-09$ \\
\hline KCNMA1 & $-3,76$ & $1,38 \mathrm{E}-11$ & $-1,51$ & $8,13 \mathrm{E}-03$ & $-1,62$ & $5,32 \mathrm{E}-03$ \\
\hline KCNQ1 & $-2,36$ & $7,79 \mathrm{E}-19$ & $-1,10$ & $1,52 \mathrm{E}-03$ & $-1,04$ & $4,35 \mathrm{E}-03$ \\
\hline KCTD12 & $-2,46$ & $3,37 \mathrm{E}-06$ & $-1,44$ & $4,08 \mathrm{E}-03$ & $-1,76$ & $9,35 \mathrm{E}-04$ \\
\hline KCTD19 & 3,48 & $2,78 \mathrm{E}-08$ & 3,19 & $1,59 \mathrm{E}-08$ & 1,80 & $1,95 \mathrm{E}-03$ \\
\hline KCTD7 & $-2,81$ & $5,48 \mathrm{E}-21$ & $-1,34$ & $2,40 \mathrm{E}-03$ & $-1,12$ & $5,59 \mathrm{E}-03$ \\
\hline KEL & $-3,60$ & $5,09 \mathrm{E}-10$ & $-1,42$ & $9,02 \mathrm{E}-03$ & $-2,22$ & $2,83 \mathrm{E}-05$ \\
\hline KIAA0101 & 6,60 & $2,33 \mathrm{E}-51$ & 5,81 & $7,73 \mathrm{E}-35$ & 3,71 & $1,69 \mathrm{E}-11$ \\
\hline KIAA0319 & $-1,90$ & $5,99 \mathrm{E}-03$ & $-2,24$ & $1,34 \mathrm{E}-04$ & $-1,78$ & $1,34 \mathrm{E}-03$ \\
\hline KIAA1161 & 3,66 & $9,48 \mathrm{E}-47$ & 3,44 & $1,87 \mathrm{E}-21$ & 2,13 & $6,48 \mathrm{E}-06$ \\
\hline KIAA1524 & 4,17 & $2,68 \mathrm{E}-72$ & 3,16 & $4,78 \mathrm{E}-13$ & 2,01 & $6,58 \mathrm{E}-05$ \\
\hline KIF11 & 5,80 & $2,20 \mathrm{E}-94$ & 4,84 & $1,37 \mathrm{E}-25$ & 3,29 & $1,34 \mathrm{E}-09$ \\
\hline KIF14 & 7,58 & $5,04 \mathrm{E}-79$ & 6,17 & $6,32 \mathrm{E}-34$ & 3,83 & $1,34 \mathrm{E}-11$ \\
\hline KIF15 & 5,85 & $2,06 \mathrm{E}-43$ & 5,12 & $4,44 \mathrm{E}-26$ & 3,31 & $3,62 \mathrm{E}-09$ \\
\hline KIF18A & 5,27 & $5,66 \mathrm{E}-47$ & 4,21 & $5,29 \mathrm{E}-18$ & 3,01 & $2,12 \mathrm{E}-08$ \\
\hline
\end{tabular}




\begin{tabular}{|c|c|c|c|c|c|c|}
\hline KIF18B & 6,81 & $5,93 \mathrm{E}-78$ & 6,13 & $4,28 \mathrm{E}-44$ & 3,94 & $6,81 \mathrm{E}-13$ \\
\hline KIF20A & 7,33 & $1,22 \mathrm{E}-37$ & 6,18 & $1,61 \mathrm{E}-29$ & 3,52 & $1,09 \mathrm{E}-09$ \\
\hline KIF2OB & 2,41 & $7,65 \mathrm{E}-25$ & 1,99 & 1,03E-05 & 1,32 & $5,46 \mathrm{E}-03$ \\
\hline KIF23 & 6,69 & $6,33 \mathrm{E}-105$ & 5,53 & 1,19E-31 & 3,69 & $1,77 \mathrm{E}-11$ \\
\hline KIF24 & 3,78 & $3,04 \mathrm{E}-37$ & 3,22 & $4,74 \mathrm{E}-14$ & 2,01 & $1,66 \mathrm{E}-04$ \\
\hline KIF26B & 2,32 & $7,63 \mathrm{E}-06$ & 4,08 & $3,56 \mathrm{E}-18$ & 2,55 & $1,44 \mathrm{E}-06$ \\
\hline KIF2C & 7,22 & $1,19 \mathrm{E}-246$ & 5,87 & $3,98 \mathrm{E}-49$ & 3,68 & $1,01 \mathrm{E}-11$ \\
\hline KIF4A & 5,13 & $1,42 \mathrm{E}-16$ & 4,23 & $5,43 \mathrm{E}-14$ & 2,82 & $8,61 \mathrm{E}-07$ \\
\hline KIF4B & 7,55 & $6,53 \mathrm{E}-77$ & 5,79 & $9,66 \mathrm{E}-29$ & 3,82 & $1,11 \mathrm{E}-11$ \\
\hline KIF7 & 4,42 & $1,06 \mathrm{E}-26$ & 4,78 & $1,10 \mathrm{E}-26$ & 2,13 & $5,01 \mathrm{E}-05$ \\
\hline KIFC1 & 6,83 & $1,37 \mathrm{E}-90$ & 5,93 & $5,57 \mathrm{E}-45$ & 3,71 & $1,30 \mathrm{E}-11$ \\
\hline $\begin{array}{l}\text { KIRREL2 } \\
\end{array}$ & 2,95 & $2,22 \mathrm{E}-05$ & 2,47 & $3,66 \mathrm{E}-05$ & 1,60 & $5,65 \mathrm{E}-03$ \\
\hline KITLG & $-2,18$ & $3,40 \mathrm{E}-03$ & $-2,34$ & $1,31 \mathrm{E}-04$ & $-2,43$ & $2,61 \mathrm{E}-05$ \\
\hline KLHDC7B & 1,82 & $1,51 \mathrm{E}-11$ & 1,36 & $1,27 \mathrm{E}-04$ & 1,46 & $5,41 \mathrm{E}-05$ \\
\hline KLHDC8B & $-4,28$ & $1,04 \mathrm{E}-11$ & $-2,15$ & $3,57 \mathrm{E}-04$ & $-1,87$ & $1,10 \mathrm{E}-03$ \\
\hline KLHL30 & $-4,72$ & $1,83 \mathrm{E}-11$ & $-3,40$ & $5,27 \mathrm{E}-10$ & $-3,52$ & $3,51 \mathrm{E}-11$ \\
\hline KNTC1 & 2,20 & $2,20 \mathrm{E}-26$ & 1,83 & $3,45 \mathrm{E}-06$ & 1,27 & $5,06 \mathrm{E}-03$ \\
\hline KRT7 & 3,00 & $4,11 \mathrm{E}-07$ & 1,81 & 4,31E-03 & 1,82 & $1,05 \mathrm{E}-03$ \\
\hline LAG3 & 4,75 & $1,22 \mathrm{E}-47$ & 3,28 & $9,86 \mathrm{E}-16$ & 2,39 & $1,15 \mathrm{E}-09$ \\
\hline LAIR1 & $-2,20$ & $1,70 \mathrm{E}-08$ & $-1,60$ & $1,85 \mathrm{E}-04$ & $-1,30$ & $3,01 \mathrm{E}-03$ \\
\hline LAYN & 4,79 & $5,52 \mathrm{E}-53$ & 5,84 & 9,91E-58 & 3,59 & $3,22 \mathrm{E}-12$ \\
\hline LCN2 & $-3,44$ & $1,58 \mathrm{E}-06$ & $-3,02$ & $2,70 \mathrm{E}-07$ & $-2,13$ & $1,23 \mathrm{E}-04$ \\
\hline LDHA & 2,29 & $1,47 \mathrm{E}-64$ & 1,65 & 1,51E-06 & 1,00 & $2,86 \mathrm{E}-03$ \\
\hline LDHAP4 & 2,62 & $3,56 \mathrm{E}-40$ & 1,80 & $2,43 \mathrm{E}-06$ & 1,15 & $1,28 \mathrm{E}-03$ \\
\hline LDHAP5 & 2,63 & $4,44 \mathrm{E}-68$ & 1,73 & $1,37 \mathrm{E}-05$ & 1,11 & $3,83 \mathrm{E}-03$ \\
\hline LDHAP7 & 2,63 & $9,52 \mathrm{E}-44$ & 1,78 & $1,29 \mathrm{E}-06$ & 1,15 & $1,07 \mathrm{E}-03$ \\
\hline LEP & $-6,83$ & $9,35 \mathrm{E}-21$ & $-3,16$ & $8,23 \mathrm{E}-07$ & $-2,12$ & $2,64 \mathrm{E}-04$ \\
\hline LETM2 & 2,01 & $1,00 \mathrm{E}-04$ & 1,81 & $3,99 \mathrm{E}-04$ & 1,48 & $6,17 \mathrm{E}-03$ \\
\hline LGALS3 & $-3,78$ & $1,60 \mathrm{E}-26$ & $-1,88$ & $7,68 \mathrm{E}-05$ & $-2,73$ & $4,43 \mathrm{E}-10$ \\
\hline LGMN & $-5,61$ & $5,86 \mathrm{E}-41$ & $-2,03$ & 5,89E-04 & $-2,12$ & $3,60 \mathrm{E}-05$ \\
\hline LGMNP1 & $-5,55$ & $1,81 \mathrm{E}-35$ & $-2,16$ & $2,06 \mathrm{E}-04$ & $-2,22$ & $1,28 \mathrm{E}-05$ \\
\hline LIF & 5,12 & $1,53 \mathrm{E}-51$ & 3,90 & $9,23 \mathrm{E}-15$ & 2,32 & $8,14 \mathrm{E}-07$ \\
\hline LILRA4 & $-4,98$ & $9,55 \mathrm{E}-24$ & $-2,12$ & $1,53 \mathrm{E}-04$ & $-2,90$ & $7,11 \mathrm{E}-09$ \\
\hline LIMA1 & 2,97 & $1,01 \mathrm{E}-52$ & 1,93 & $2,22 \mathrm{E}-05$ & 1,72 & $2,66 \mathrm{E}-04$ \\
\hline LIN9 & 1,52 & $7,52 \mathrm{E}-05$ & 1,53 & $7,05 \mathrm{E}-04$ & 1,16 & $7,77 \mathrm{E}-03$ \\
\hline LINC00152 & 2,56 & $1,19 \mathrm{E}-46$ & 1,25 & $1,73 \mathrm{E}-04$ & 1,12 & $7,60 \mathrm{E}-03$ \\
\hline LINC00176 & 3,84 & $3,62 E-15$ & 2,81 & 5,83E-09 & 1,56 & $4,09 \mathrm{E}-03$ \\
\hline LINC00422 & 1,61 & $3,63 \mathrm{E}-04$ & 2,18 & $1,19 \mathrm{E}-05$ & 1,54 & $6,60 \mathrm{E}-03$ \\
\hline LINC00599 & 3,75 & $1,21 \mathrm{E}-16$ & 2,97 & $2,45 \mathrm{E}-06$ & 1,87 & $1,31 \mathrm{E}-03$ \\
\hline LINC00900 & $-5,86$ & $1,65 \mathrm{E}-16$ & $-2,27$ & $4,58 \mathrm{E}-06$ & $-2,06$ & $1,08 \mathrm{E}-04$ \\
\hline LINC01132 & 5,38 & $2,06 \mathrm{E}-29$ & 3,97 & $6,62 \mathrm{E}-13$ & 2,89 & $1,95 \mathrm{E}-07$ \\
\hline LIPA & $-3,72$ & $1,24 \mathrm{E}-133$ & $-1,87$ & $1,61 \mathrm{E}-07$ & $-3,00$ & $1,67 \mathrm{E}-16$ \\
\hline LMCD1 & 5,04 & $1,67 \mathrm{E}-41$ & 4,95 & $1,33 \mathrm{E}-21$ & 3,69 & $4,07 \mathrm{E}-12$ \\
\hline LMNB1 & 3,26 & $1,59 \mathrm{E}-87$ & 2,97 & $5,21 \mathrm{E}-13$ & 1,87 & $7,15 \mathrm{E}-05$ \\
\hline LMO2 & $-2,56$ & $1,25 \mathrm{E}-16$ & $-1,47$ & $1,13 \mathrm{E}-04$ & $-1,41$ & $1,57 \mathrm{E}-03$ \\
\hline LRBA & 1,83 & $1,86 \mathrm{E}-17$ & 1,20 & $3,47 \mathrm{E}-03$ & 1,17 & $4,34 \mathrm{E}-03$ \\
\hline LRP1 & $-3,74$ & $2,77 \mathrm{E}-10$ & $-1,48$ & $8,92 \mathrm{E}-03$ & $-1,56$ & $5,45 \mathrm{E}-03$ \\
\hline LRP3 & $-4,80$ & $9,40 \mathrm{E}-23$ & $-1,49$ & $4,71 \mathrm{E}-04$ & $-1,95$ & $2,85 \mathrm{E}-04$ \\
\hline LRP5 & 1,72 & $1,59 \mathrm{E}-13$ & 2,76 & $8,49 \mathrm{E}-11$ & 1,79 & $8,53 \mathrm{E}-05$ \\
\hline LRRC3DN & $-1,33$ & $2,12 \mathrm{E}-03$ & $-1,43$ & $1,56 \mathrm{E}-03$ & $-1,33$ & $2,96 \mathrm{E}-03$ \\
\hline LTA & 4,76 & $1,45 \mathrm{E}-31$ & 1,97 & $3,41 \mathrm{E}-06$ & 1,42 & $6,73 \mathrm{E}-03$ \\
\hline LTF & $-4,72$ & $1,55 \mathrm{E}-10$ & $-2,97$ & $4,10 \mathrm{E}-07$ & $-1,82$ & $9,11 \mathrm{E}-04$ \\
\hline LY86 & $-5,03$ & $1,18 \mathrm{E}-46$ & $-2,52$ & $1,66 \mathrm{E}-07$ & $-2,96$ & $3,64 \mathrm{E}-11$ \\
\hline LYL1 & $-3,32$ & $1,29 \mathrm{E}-19$ & $-1,20$ & $7,67 \mathrm{E}-03$ & $-1,37$ & $3,63 \mathrm{E}-03$ \\
\hline MAD2L1 & 3,41 & $1,61 \mathrm{E}-11$ & 2,69 & $8,04 \mathrm{E}-08$ & 1,82 & $4,32 \mathrm{E}-04$ \\
\hline MAPK11 & 1,64 & $1,08 \mathrm{E}-08$ & 1,39 & $6,74 \mathrm{E}-05$ & 1,81 & $3,49 \mathrm{E}-06$ \\
\hline MARCKSL1 & 0,81 & $8,15 \mathrm{E}-06$ & 0,92 & 4,42E-03 & 0,90 & $6,52 \mathrm{E}-03$ \\
\hline MARVELD1 & $-2,06$ & $8,71 \mathrm{E}-08$ & $-1,12$ & $4,10 \mathrm{E}-03$ & $-1,82$ & $1,33 \mathrm{E}-05$ \\
\hline MCAM & 4,27 & $1,37 \mathrm{E}-35$ & 3,16 & $2,12 \mathrm{E}-11$ & 2,42 & $2,29 \mathrm{E}-06$ \\
\hline MCM10 & 7,99 & $5,40 \mathrm{E}-88$ & 6,36 & $1,39 \mathrm{E}-39$ & 4,38 & $1,27 \mathrm{E}-16$ \\
\hline MCM2 & 3,07 & $1,30 \mathrm{E}-24$ & 2,81 & $2,97 \mathrm{E}-12$ & 1,57 & $9,59 \mathrm{E}-04$ \\
\hline MCM3 & 2,18 & $7,81 \mathrm{E}-55$ & 2,07 & $8,27 \mathrm{E}-09$ & 1,25 & $4,81 \mathrm{E}-03$ \\
\hline MCM4 & 4,22 & $6,77 \mathrm{E}-122$ & 3,82 & $1,95 \mathrm{E}-20$ & 2,64 & $3,41 \mathrm{E}-08$ \\
\hline MCM5 & 2,02 & $6,57 \mathrm{E}-48$ & 2,21 & 1,47E-09 & 1,25 & $5,91 \mathrm{E}-03$ \\
\hline MCM6 & 3,49 & $1,49 \mathrm{E}-103$ & 3,06 & $6,57 \mathrm{E}-17$ & 2,11 & $2,53 \mathrm{E}-06$ \\
\hline MCM8 & 2,75 & $4,26 \mathrm{E}-57$ & 2,09 & $9,14 \mathrm{E}-08$ & 1,38 & $1,32 \mathrm{E}-03$ \\
\hline ME1 & $-2,35$ & $4,11 \mathrm{E}-10$ & $-0,98$ & $7,19 \mathrm{E}-03$ & $-1,11$ & $5,74 \mathrm{E}-03$ \\
\hline ME3 & $-2,02$ & $1,66 \mathrm{E}-07$ & $-1,83$ & $1,20 \mathrm{E}-03$ & $-1,79$ & $2,62 \mathrm{E}-04$ \\
\hline MELK & 6,44 & $2,08 \mathrm{E}-69$ & 5,22 & $3,23 \mathrm{E}-26$ & 3,43 & $4,00 \mathrm{E}-10$ \\
\hline MFSD1 & $-2,37$ & $2,70 \mathrm{E}-08$ & $-1,34$ & $2,62 \mathrm{E}-03$ & $-1,72$ & $9,83 \mathrm{E}-05$ \\
\hline MGLL & $-2,91$ & $5,19 \mathrm{E}-08$ & $-1,41$ & $8,49 \mathrm{E}-03$ & $-1,92$ & $3,83 \mathrm{E}-04$ \\
\hline MICAL2 & 2,30 & $2,79 \mathrm{E}-45$ & 1,27 & $3,72 \mathrm{E}-03$ & 1,69 & $5,53 \mathrm{E}-06$ \\
\hline MIR155HG & 2,81 & $1,61 \mathrm{E}-45$ & 2,65 & $3,93 \mathrm{E}-13$ & 2,30 & $1,46 \mathrm{E}-05$ \\
\hline MKI67 & 8,20 & $6,51 \mathrm{E}-275$ & 6,82 & $5,33 \mathrm{E}-57$ & 4,37 & $9,77 \mathrm{E}-16$ \\
\hline MKI67P1 & 6,04 & $4,12 \mathrm{E}-47$ & 4,84 & $3,24 \mathrm{E}-22$ & 3,09 & $3,32 \mathrm{E}-08$ \\
\hline MLPH & $-3,86$ & $2,50 \mathrm{E}-16$ & $-1,73$ & $3,82 \mathrm{E}-05$ & $-3,36$ & $1,30 \mathrm{E}-15$ \\
\hline MMP8 & $-3,08$ & $1,19 \mathrm{E}-04$ & $-1,70$ & $8,54 \mathrm{E}-03$ & $-1,66$ & $4,09 \mathrm{E}-03$ \\
\hline MND1 & 6,56 & $1,95 \mathrm{E}-73$ & 5,57 & $5,47 \mathrm{E}-34$ & 3,37 & $1,18 \mathrm{E}-09$ \\
\hline MPP1 & $-2,64$ & $8,93 \mathrm{E}-09$ & $-1,38$ & $3,34 \mathrm{E}-03$ & $-1,81$ & $1,30 \mathrm{E}-04$ \\
\hline MPZL2 & 3,08 & $9,96 \mathrm{E}-08$ & 2,42 & $4,79 \mathrm{E}-06$ & 2,08 & $5,34 \mathrm{E}-05$ \\
\hline MPZL3 & 1,46 & $2,69 \mathrm{E}-04$ & 1,35 & $1,67 \mathrm{E}-03$ & 1,23 & $6,15 \mathrm{E}-03$ \\
\hline MS4A6A & $-6,36$ & $1,40 \mathrm{E}-29$ & $-3,14$ & $2,66 \mathrm{E}-07$ & $-2,84$ & $3,72 \mathrm{E}-07$ \\
\hline MSR1 & $-2,03$ & 2,79E-04 & $-2,58$ & $1,14 \mathrm{E}-06$ & $-3,87$ & $4,57 \mathrm{E}-12$ \\
\hline MT1L & 3,74 & $8,23 \mathrm{E}-08$ & 3,27 & $1,25 \mathrm{E}-07$ & 2,46 & $2,50 \mathrm{E}-05$ \\
\hline MT1P3 & 2,75 & $3,79 \mathrm{E}-05$ & 2,33 & $1,06 \mathrm{E}-04$ & 1,76 & $2,53 \mathrm{E}-03$ \\
\hline MT2A & 2,98 & $5,96 \mathrm{E}-08$ & 3,09 & $9,05 \mathrm{E}-09$ & 2,61 & $1,42 \mathrm{E}-06$ \\
\hline MT2P1 & 3,28 & $9,54 \mathrm{E}-08$ & 3,20 & $1,68 \mathrm{E}-08$ & 2,57 & $5,09 \mathrm{E}-06$ \\
\hline
\end{tabular}

\begin{tabular}{|c|c|c|c|c|c|c|}
\hline MTBP & 1,87 & $4,50 \mathrm{E}-18$ & 1,57 & $1,86 \mathrm{E}-04$ & 1,15 & $5,07 \mathrm{E}-03$ \\
\hline MTFR2 & 4,01 & $4,26 \mathrm{E}-68$ & 3,14 & $1,59 \mathrm{E}-12$ & 1,95 & 1,74E-04 \\
\hline MTHFD1L & 3,00 & $3,95 \mathrm{E}-59$ & 2,22 & $2,03 \mathrm{E}-10$ & 1,51 & $1,57 \mathrm{E}-05$ \\
\hline MUC4 & 6,81 & $1,89 \mathrm{E}-26$ & 5,75 & $4,41 \mathrm{E}-25$ & 3,93 & $5,21 \mathrm{E}-12$ \\
\hline MYB & 4,90 & $2,87 \mathrm{E}-31$ & 4,64 & $3,58 \mathrm{E}-23$ & 3,07 & $7,47 \mathrm{E}-09$ \\
\hline MYBL2 & 6,58 & $4,80 \mathrm{E}-200$ & 6,09 & $4,75 \mathrm{E}-47$ & 3,86 & $6,32 \mathrm{E}-13$ \\
\hline MYH10 & 4,62 & $1,14 \mathrm{E}-22$ & 3,97 & $1,48 \mathrm{E}-17$ & 2,41 & $8,31 \mathrm{E}-06$ \\
\hline MYH6 & 5,99 & $7,20 \mathrm{E}-22$ & 2,12 & $1,05 \mathrm{E}-03$ & 1,99 & $6,54 \mathrm{E}-04$ \\
\hline MYL9 & 2,61 & $1,30 \mathrm{E}-06$ & 1,61 & $7,44 \mathrm{E}-03$ & 1,63 & $2,36 \mathrm{E}-03$ \\
\hline MY018B & 4,75 & $1,01 \mathrm{E}-23$ & 3,01 & $6,84 \mathrm{E}-08$ & 1,96 & $5,48 \mathrm{E}-04$ \\
\hline MY01B & 4,36 & $6,93 \mathrm{E}-14$ & 2,87 & $1,16 \mathrm{E}-06$ & 2,84 & $3,06 \mathrm{E}-07$ \\
\hline MY05C & 2,39 & $2,81 \mathrm{E}-06$ & 3,31 & $1,88 \mathrm{E}-12$ & 2,45 & $3,60 \mathrm{E}-06$ \\
\hline $\mathrm{N} / \mathrm{A}$ & $-1,83$ & $4,79 \mathrm{E}-14$ & $-1,23$ & $1,74 \mathrm{E}-04$ & $-1,16$ & $1,10 \mathrm{E}-03$ \\
\hline NAPSA & 4,95 & $1,11 \mathrm{E}-155$ & 2,51 & $1,70 \mathrm{E}-12$ & 1,34 & $1,66 \mathrm{E}-03$ \\
\hline NBPF1 & $-1,81$ & $2,10 \mathrm{E}-14$ & $-1,60$ & $1,74 \mathrm{E}-05$ & $-1,42$ & $1,04 \mathrm{E}-04$ \\
\hline NCAPD2 & 2,46 & $1,38 \mathrm{E}-35$ & 2,27 & $5,50 \mathrm{E}-09$ & 1,45 & $3,01 \mathrm{E}-03$ \\
\hline NCAPD2P1 & 2,45 & $3,61 \mathrm{E}-47$ & 2,16 & $5,94 \mathrm{E}-08$ & 1,38 & $6,40 \mathrm{E}-03$ \\
\hline NCAPG & 6,79 & $1,34 \mathrm{E}-80$ & 5,40 & $1,84 \mathrm{E}-27$ & 3,71 & $6,90 \mathrm{E}-12$ \\
\hline NCAPG2 & 3,87 & $1,57 \mathrm{E}-119$ & 3,29 & $4,05 \mathrm{E}-15$ & 2,17 & $2,12 \mathrm{E}-05$ \\
\hline NCAPH & 4,36 & $6,48 \mathrm{E}-23$ & 3,51 & $1,28 \mathrm{E}-12$ & 2,43 & $5,08 \mathrm{E}-06$ \\
\hline NCMAP & 3,15 & $3,42 \mathrm{E}-05$ & 2,88 & $7,57 \mathrm{E}-06$ & 2,32 & $7,41 \mathrm{E}-05$ \\
\hline NCR2 & 1,87 & $2,29 \mathrm{E}-04$ & 2,81 & $7,30 \mathrm{E}-09$ & 1,85 & $1,49 \mathrm{E}-03$ \\
\hline NDC80 & 4,62 & $1,26 \mathrm{E}-22$ & 3,70 & $4,83 \mathrm{E}-14$ & 2,38 & $1,43 \mathrm{E}-05$ \\
\hline NDFIP2 & 5,47 & $1,26 \mathrm{E}-59$ & 4,33 & $5,54 \mathrm{E}-26$ & 3,41 & $4,34 \mathrm{E}-18$ \\
\hline NDNF & 3,48 & $7,85 \mathrm{E}-07$ & 4,08 & $9,96 \mathrm{E}-12$ & 1,99 & $6,64 \mathrm{E}-04$ \\
\hline NEFH & 2,53 & $1,34 \mathrm{E}-27$ & 1,64 & $1,17 \mathrm{E}-05$ & 1,17 & $8,38 \mathrm{E}-03$ \\
\hline NEIL3 & 6,96 & $4,79 \mathrm{E}-46$ & 5,72 & 1,15E-26 & 3,53 & $7,38 \mathrm{E}-10$ \\
\hline NEK2 & 6,07 & $1,18 \mathrm{E}-43$ & 5,20 & $5,80 \mathrm{E}-25$ & 3,09 & $7,72 \mathrm{E}-08$ \\
\hline NEK2P4 & 6,42 & $9,24 \mathrm{E}-23$ & 5,07 & $6,41 \mathrm{E}-18$ & 3,12 & $8,36 \mathrm{E}-08$ \\
\hline NFE2L3 & 1,99 & $4,47 \mathrm{E}-23$ & 1,22 & $8,59 \mathrm{E}-04$ & 1,13 & $1,29 \mathrm{E}-03$ \\
\hline NFKB1 & 1,56 & $2,19 \mathrm{E}-05$ & 1,57 & $1,11 \mathrm{E}-04$ & 1,36 & $8,20 \mathrm{E}-04$ \\
\hline NKD2 & 5,55 & $1,00 \mathrm{E}-38$ & 4,98 & $9,29 \mathrm{E}-21$ & 3,09 & $4,81 \mathrm{E}-08$ \\
\hline NKX3-1 & 2,80 & $5,97 \mathrm{E}-06$ & 1,88 & $5,72 \mathrm{E}-04$ & 1,56 & $3,10 \mathrm{E}-03$ \\
\hline NLRC4 & $-2,48$ & $2,22 \mathrm{E}-05$ & $-1,40$ & $7,59 \mathrm{E}-03$ & $-1,43$ & $7,68 \mathrm{E}-03$ \\
\hline NLRP12 & $-4,04$ & $3,27 \mathrm{E}-11$ & $-1,98$ & $5,18 \mathrm{E}-04$ & $-2,47$ & $6,67 \mathrm{E}-06$ \\
\hline NMU & 2,21 & $4,01 \mathrm{E}-03$ & 2,62 & $2,10 \mathrm{E}-05$ & 1,68 & $3,98 \mathrm{E}-03$ \\
\hline NOTCH2NL & $-1,04$ & $9,48 \mathrm{E}-04$ & $-1,23$ & $8,48 \mathrm{E}-04$ & $-1,03$ & $7,86 \mathrm{E}-03$ \\
\hline NOV & $-4,57$ & $5,82 \mathrm{E}-10$ & $-2,97$ & $1,06 \mathrm{E}-06$ & $-1,71$ & $3,45 \mathrm{E}-03$ \\
\hline NOXA1 & $-4,19$ & $4,55 \mathrm{E}-37$ & $-1,89$ & $1,48 \mathrm{E}-04$ & $-1,45$ & $2,65 \mathrm{E}-03$ \\
\hline NPC2 & $-3,26$ & 1,87E-11 & $-1,57$ & $3,69 \mathrm{E}-03$ & $-1,59$ & $2,54 \mathrm{E}-03$ \\
\hline $\mathrm{NPL}$ & $-4,32$ & $1,28 \mathrm{E}-17$ & $-1,76$ & $9,13 \mathrm{E}-04$ & $-2,16$ & $2,02 \mathrm{E}-05$ \\
\hline NPTX1 & 3,58 & $5,53 \mathrm{E}-53$ & 4,51 & $6,16 \mathrm{E}-41$ & 2,55 & $1,45 \mathrm{E}-07$ \\
\hline NPW & 4,66 & $5,25 \mathrm{E}-13$ & 5,32 & $1,16 \mathrm{E}-21$ & 4,13 & $4,73 \mathrm{E}-15$ \\
\hline NQO1 & $-2,00$ & $8,55 \mathrm{E}-14$ & $-1,06$ & $7,69 \mathrm{E}-04$ & $-1,83$ & $1,36 \mathrm{E}-05$ \\
\hline NR4A1 & 1,85 & $7,80 \mathrm{E}-06$ & 2,49 & $6,07 \mathrm{E}-08$ & 1,91 & $5,17 \mathrm{E}-05$ \\
\hline NRGN & 2,73 & $3,88 \mathrm{E}-19$ & 2,95 & $9,02 \mathrm{E}-15$ & 1,77 & $3,32 \mathrm{E}-04$ \\
\hline NTRK1 & 5,39 & $3,64 \mathrm{E}-85$ & 4,09 & $1,33 \mathrm{E}-27$ & 2,76 & $2,14 \mathrm{E}-09$ \\
\hline NTRK2 & 4,52 & $9,31 \mathrm{E}-19$ & 2,91 & $4,74 \mathrm{E}-07$ & 3,32 & $1,97 \mathrm{E}-10$ \\
\hline NUF2 & 5,15 & $2,02 \mathrm{E}-69$ & 4,09 & $1,53 \mathrm{E}-20$ & 2,85 & $6,99 \mathrm{E}-08$ \\
\hline NUSAP1 & 4,44 & $2,27 \mathrm{E}-23$ & 3,85 & $2,67 \mathrm{E}-15$ & 2,66 & $1,63 \mathrm{E}-06$ \\
\hline OCRL & $-2,90$ & 5,34E-08 & $-1,17$ & $8,83 \mathrm{E}-03$ & $-1,31$ & $5,84 \mathrm{E}-03$ \\
\hline OGDHL & 5,45 & $3,59 \mathrm{E}-15$ & 4,40 & $2,25 \mathrm{E}-13$ & 1,84 & $1,38 \mathrm{E}-03$ \\
\hline OIP5 & 4,78 & $7,07 \mathrm{E}-44$ & 3,96 & $1,70 \mathrm{E}-17$ & 2,63 & $1,04 \mathrm{E}-06$ \\
\hline OLIG3 & 5,65 & $1,51 \mathrm{E}-16$ & 5,31 & $7,51 \mathrm{E}-21$ & 3,21 & $3,14 \mathrm{E}-08$ \\
\hline ORC1 & 4,68 & $7,88 \mathrm{E}-127$ & 4,09 & $9,83 \mathrm{E}-28$ & 2,45 & $1,97 \mathrm{E}-06$ \\
\hline ORC6 & 4,22 & $9,54 \mathrm{E}-34$ & 3,31 & $3,53 \mathrm{E}-14$ & 2,10 & $1,94 \mathrm{E}-05$ \\
\hline OTOA & $-4,29$ & $2,17 \mathrm{E}-17$ & $-1,85$ & $2,06 \mathrm{E}-03$ & $-2,71$ & $3,62 \mathrm{E}-07$ \\
\hline OXCT1 & 2,66 & $1,14 \mathrm{E}-09$ & 2,00 & $2,91 \mathrm{E}-05$ & 1,32 & $6,83 \mathrm{E}-03$ \\
\hline P2RX1 & $-2,96$ & $3,54 \mathrm{E}-13$ & $-1,55$ & $1,54 \mathrm{E}-03$ & $-1,68$ & $2,14 \mathrm{E}-04$ \\
\hline P2RX5 & 2,47 & $1,71 \mathrm{E}-15$ & 1,93 & $2,31 \mathrm{E}-07$ & 1,89 & $3,43 \mathrm{E}-05$ \\
\hline P2RY13 & $-4,51$ & $1,69 \mathrm{E}-11$ & $-1,71$ & $3,66 \mathrm{E}-03$ & $-2,38$ & $1,54 \mathrm{E}-05$ \\
\hline PACSIN3 & 3,94 & $4,04 \mathrm{E}-16$ & 3,67 & $2,24 \mathrm{E}-14$ & 1,56 & $2,49 \mathrm{E}-03$ \\
\hline PARD3 & 2,88 & $1,13 \mathrm{E}-08$ & 2,60 & $9,55 \mathrm{E}-07$ & 1,64 & $3,53 \mathrm{E}-03$ \\
\hline PARPBP & 3,04 & $6,26 \mathrm{E}-23$ & 2,47 & $9,30 \mathrm{E}-08$ & 1,50 & $4,00 \mathrm{E}-03$ \\
\hline PAWR & 1,84 & $1,12 \mathrm{E}-09$ & 1,17 & $3,39 \mathrm{E}-03$ & 1,12 & $6,33 \mathrm{E}-03$ \\
\hline PAX8 & $-2,67$ & $2,76 \mathrm{E}-05$ & $-1,56$ & $7,22 \mathrm{E}-03$ & $-1,60$ & $3,47 \mathrm{E}-03$ \\
\hline PBK & 7,32 & $4,05 E-52$ & 5,95 & $2,88 \mathrm{E}-26$ & 3,77 & $3,59 \mathrm{E}-11$ \\
\hline $\mathrm{PC}$ & $-2,16$ & $4,31 \mathrm{E}-30$ & $-0,92$ & $4,32 \mathrm{E}-03$ & $-1,01$ & $3,14 \mathrm{E}-03$ \\
\hline PCBP3 & 2,90 & $4,96 \mathrm{E}-14$ & 2,58 & $9,09 \mathrm{E}-11$ & 2,37 & $2,97 \mathrm{E}-07$ \\
\hline PCNA & 3,49 & $9,46 \mathrm{E}-31$ & 3,00 & $3,67 \mathrm{E}-15$ & 1,80 & $1,79 \mathrm{E}-04$ \\
\hline PCNAP3 & 3,34 & $8,56 \mathrm{E}-18$ & 2,71 & $4,71 \mathrm{E}-10$ & 1,57 & $1,91 \mathrm{E}-03$ \\
\hline PCNAP4 & 3,87 & $4,21 \mathrm{E}-08$ & 2,71 & $1,36 \mathrm{E}-05$ & 1,66 & $4,54 \mathrm{E}-03$ \\
\hline PCSK6 & $-3,10$ & $9,79 \mathrm{E}-09$ & $-1,73$ & $1,58 \mathrm{E}-03$ & $-3,01$ & $5,74 \mathrm{E}-10$ \\
\hline PDCD1 & 2,14 & $3,69 \mathrm{E}-05$ & 2,55 & $1,21 \mathrm{E}-07$ & 1,99 & $2,23 \mathrm{E}-05$ \\
\hline PDE2A & $-2,61$ & $6,41 \mathrm{E}-09$ & $-1,95$ & $9,64 \mathrm{E}-04$ & $-2,75$ & $9,68 \mathrm{E}-10$ \\
\hline PDE7B & 2,21 & $6,95 \mathrm{E}-04$ & 2,82 & $8,13 \mathrm{E}-07$ & 2,05 & $2,35 \mathrm{E}-04$ \\
\hline PDGFA & 3,54 & $3,57 \mathrm{E}-21$ & 3,41 & $2,97 \mathrm{E}-15$ & 2,45 & $6,30 \mathrm{E}-08$ \\
\hline PDGFB & $-3,02$ & $6,35 \mathrm{E}-18$ & $-1,44$ & $2,85 \mathrm{E}-03$ & $-1,33$ & $7,41 \mathrm{E}-03$ \\
\hline PDGFC & $-4,89$ & $2,88 \mathrm{E}-14$ & $-2,42$ & $1,38 \mathrm{E}-05$ & $-1,46$ & $8,41 \mathrm{E}-03$ \\
\hline PDGFRB & 1,41 & $4,71 \mathrm{E}-03$ & 2,14 & $1,25 \mathrm{E}-05$ & 1,37 & $5,87 \mathrm{E}-03$ \\
\hline PGAP1 & 2,86 & $3,92 \mathrm{E}-19$ & 1,80 & $2,23 \mathrm{E}-05$ & 1,66 & $1,44 \mathrm{E}-05$ \\
\hline PGM2L1 & 0,78 & $1,24 \mathrm{E}-04$ & 2,33 & $2,80 \mathrm{E}-08$ & 1,38 & $1,88 \mathrm{E}-03$ \\
\hline PHACTR2 & 0,97 & $5,50 \mathrm{E}-07$ & 1,22 & $1,99 \mathrm{E}-04$ & 1,08 & $2,28 \mathrm{E}-03$ \\
\hline PHEX & 4,59 & $5,54 \mathrm{E}-37$ & 5,20 & $2,51 \mathrm{E}-29$ & 1,82 & $1,79 \mathrm{E}-03$ \\
\hline PHKA1 & 4,40 & $5,74 \mathrm{E}-42$ & 2,88 & $8,04 \mathrm{E}-09$ & 1,62 & $1,84 \mathrm{E}-04$ \\
\hline PHYHIP & $-2,81$ & $3,38 \mathrm{E}-04$ & $-2,23$ & $5,25 \mathrm{E}-04$ & $-2,07$ & $3,99 \mathrm{E}-04$ \\
\hline PIF1 & 4.23 & $755 \mathrm{E}-49$ & 3.71 & $244 \mathrm{E}-14$ & 240 & $206 \mathrm{E}-05$ \\
\hline
\end{tabular}




\begin{tabular}{|c|c|c|c|c|c|c|}
\hline PIFO & 1,90 & $4,40 \mathrm{E}-04$ & 1,81 & $1,30 \mathrm{E}-03$ & 1,47 & $8,06 \mathrm{E}-03$ \\
\hline PIGX & 1,58 & $1,52 \mathrm{E}-17$ & 1,71 & $5,80 \mathrm{E}-06$ & 1,31 & $2,51 \mathrm{E}-03$ \\
\hline PIK3CG & 2,40 & $3,58 \mathrm{E}-44$ & 1,51 & $4,33 \mathrm{E}-04$ & 1,26 & $3,38 \mathrm{E}-03$ \\
\hline PKMYT1 & 6,20 & $8,53 \mathrm{E}-90$ & 5,77 & $2,95 \mathrm{E}-52$ & 3,75 & $4,21 \mathrm{E}-13$ \\
\hline PLA2G15 & $-2,31$ & $4,07 \mathrm{E}-08$ & $-1,46$ & $1,40 \mathrm{E}-03$ & $-1,91$ & $1,08 \mathrm{E}-05$ \\
\hline PLBD2 & $-2,29$ & $2,42 \mathrm{E}-06$ & $-1,36$ & $5,33 \mathrm{E}-03$ & $-1,69$ & $6,15 \mathrm{E}-04$ \\
\hline PLD3 & $-3,09$ & $2,35 \mathrm{E}-10$ & $-1,49$ & $3,31 \mathrm{E}-03$ & $-2,25$ & $3,35 \mathrm{E}-06$ \\
\hline PLD4 & $-5,17$ & $1,97 \mathrm{E}-17$ & $-1,90$ & 5,59E-04 & $-1,85$ & $1,44 \mathrm{E}-04$ \\
\hline PLEKHG1 & 2,85 & $1,16 \mathrm{E}-16$ & 1,30 & $1,86 \mathrm{E}-03$ & 1,26 & $4,11 \mathrm{E}-03$ \\
\hline PLEKHG2 & 1,77 & $3,67 \mathrm{E}-08$ & 1,48 & $4,39 \mathrm{E}-05$ & 1,56 & $8,43 \mathrm{E}-05$ \\
\hline $\begin{array}{l}\text { PLIN2 } \\
\end{array}$ & $-2,62$ & $1,90 \mathrm{E}-06$ & $-1,83$ & $3,15 \mathrm{E}-04$ & $-1,45$ & $3,68 \mathrm{E}-03$ \\
\hline PLK1 & 5,18 & $1,20 \mathrm{E}-71$ & 4,66 & $1,49 \mathrm{E}-24$ & 2,82 & $2,81 \mathrm{E}-07$ \\
\hline PLK4 & 4,11 & $1,75 E-33$ & 3,32 & $4,98 \mathrm{E}-12$ & 2,19 & $3,62 \mathrm{E}-05$ \\
\hline PLOD2 & 3,83 & $6,58 \mathrm{E}-07$ & 2,35 & $2,80 \mathrm{E}-04$ & 1,79 & $1,94 \mathrm{E}-03$ \\
\hline PLS3 & 2,64 & $5,06 \mathrm{E}-04$ & 3,07 & $7,05 \mathrm{E}-07$ & 2,21 & $1,53 \mathrm{E}-04$ \\
\hline PLXDC2 & $-3,53$ & $1,60 \mathrm{E}-11$ & $-1,54$ & $3,18 \mathrm{E}-03$ & $-2,02$ & $1,79 \mathrm{E}-04$ \\
\hline PLXNB3 & 2,61 & $1,47 \mathrm{E}-04$ & 2,16 & $5,29 \mathrm{E}-04$ & 1,96 & $6,91 \mathrm{E}-04$ \\
\hline PLXND1 & $-2,54$ & $5,81 \mathrm{E}-10$ & $-1,32$ & $4,75 \mathrm{E}-03$ & $-1,36$ & $3,61 \mathrm{E}-03$ \\
\hline POC1A & 3,06 & $8,56 \mathrm{E}-17$ & 2,83 & $2,15 \mathrm{E}-11$ & 1,54 & $3,61 \mathrm{E}-03$ \\
\hline POLA1 & 2,34 & $9,14 \mathrm{E}-36$ & 2,02 & $3,08 \mathrm{E}-07$ & 1,34 & $2,50 \mathrm{E}-03$ \\
\hline POLE2 & 4,57 & $2,12 \mathrm{E}-83$ & 3,34 & $3,21 \mathrm{E}-14$ & 2,31 & $2,48 \mathrm{E}-06$ \\
\hline POLQ & 4,38 & $1,86 \mathrm{E}-70$ & 3,93 & $1,55 \mathrm{E}-16$ & 2,57 & $3,27 \mathrm{E}-06$ \\
\hline PON3 & 4,41 & $3,40 \mathrm{E}-09$ & 5,07 & $1,78 \mathrm{E}-17$ & 1,94 & $8,03 \mathrm{E}-04$ \\
\hline PPAP2A & 2,47 & $6,30 \mathrm{E}-17$ & 2,18 & $2,16 \mathrm{E}-07$ & 1,31 & $6,21 \mathrm{E}-04$ \\
\hline PPARG & $-2,57$ & $3,74 \mathrm{E}-05$ & $-2,14$ & $2,22 \mathrm{E}-04$ & $-1,54$ & $6,26 \mathrm{E}-03$ \\
\hline PPM1H & $-4,23$ & $1,28 \mathrm{E}-12$ & $-1,67$ & $1,88 \mathrm{E}-03$ & $-1,78$ & $1,04 \mathrm{E}-03$ \\
\hline PRAM1 & $-3,75$ & $6,75 \mathrm{E}-13$ & $-1,34$ & $9,41 \mathrm{E}-03$ & $-2,60$ & $8,03 \mathrm{E}-08$ \\
\hline PRAME & 3,88 & $4,17 \mathrm{E}-10$ & 1,74 & $6,16 \mathrm{E}-03$ & 1,91 & $9,67 \mathrm{E}-04$ \\
\hline PRC1 & 5,01 & $3,65 \mathrm{E}-76$ & 4,02 & $8,20 \mathrm{E}-21$ & 2,71 & $9,43 \mathrm{E}-08$ \\
\hline PROB1 & 3,25 & $5,57 \mathrm{E}-21$ & 2,55 & $1,23 \mathrm{E}-09$ & 1,73 & $9,59 \mathrm{E}-05$ \\
\hline PRR11 & 4,27 & $2,04 \mathrm{E}-26$ & 3,66 & $1,06 \mathrm{E}-12$ & 2,33 & $4,09 \mathrm{E}-05$ \\
\hline PRRX2 & 4,03 & $1,52 \mathrm{E}-07$ & 5,18 & $9,61 \mathrm{E}-19$ & 3,71 & $6,80 \mathrm{E}-11$ \\
\hline PSAP & $-3,87$ & $3,51 \mathrm{E}-17$ & $-1,64$ & $1,97 \mathrm{E}-03$ & $-2,24$ & $9,69 \mathrm{E}-06$ \\
\hline PSAT1 & 2,50 & $5,04 \mathrm{E}-27$ & 2,33 & $1,11 \mathrm{E}-08$ & 1,83 & $2,44 \mathrm{E}-06$ \\
\hline PSAT1P3 & 2,97 & $1,48 \mathrm{E}-21$ & 2,58 & $6,23 \mathrm{E}-08$ & 2,23 & $2,43 \mathrm{E}-07$ \\
\hline PSMC3IP & 3,99 & $3,07 \mathrm{E}-59$ & 2,83 & $5,61 \mathrm{E}-16$ & 1,71 & $4,09 \mathrm{E}-05$ \\
\hline PTCH2 & $-1,89$ & $3,67 \mathrm{E}-06$ & $-1,49$ & $2,45 \mathrm{E}-03$ & $-1,64$ & $3,36 \mathrm{E}-04$ \\
\hline PTGDS & $-6,59$ & $2,40 \mathrm{E}-53$ & $-1,51$ & $2,32 \mathrm{E}-04$ & $-4,67$ & $1,19 \mathrm{E}-34$ \\
\hline PTHLH & 4,06 & $1,68 \mathrm{E}-10$ & 2,44 & $9,49 \mathrm{E}-05$ & 1,59 & $6,55 \mathrm{E}-03$ \\
\hline PTPN22 & 1,20 & $2,35 \mathrm{E}-08$ & 1,46 & $3,15 \mathrm{E}-05$ & 1,19 & $2,34 \mathrm{E}-03$ \\
\hline PTPN3 & 7,73 & $6,71 \mathrm{E}-46$ & 4,15 & $3,40 \mathrm{E}-11$ & 2,51 & $1,69 \mathrm{E}-05$ \\
\hline PTPN7 & 2,86 & $5,59 \mathrm{E}-50$ & 2,70 & $1,27 \mathrm{E}-14$ & 1,83 & $4,14 \mathrm{E}-05$ \\
\hline PTPRK & 1,47 & 1,81E-04 & 1,60 & $3,70 \mathrm{E}-03$ & 1,52 & $4,72 \mathrm{E}-04$ \\
\hline PTPRO & $-2,73$ & $5,07 \mathrm{E}-26$ & $-2,25$ & $5,50 \mathrm{E}-11$ & $-1,85$ & $1,19 \mathrm{E}-04$ \\
\hline PTTG1 & 3,80 & $4,69 \mathrm{E}-48$ & 3,33 & $6,44 \mathrm{E}-13$ & 2,10 & $7,62 \mathrm{E}-05$ \\
\hline PTTG2 & 4,52 & $6,64 \mathrm{E}-24$ & 3,71 & $2,18 \mathrm{E}-13$ & 2,39 & $2,25 \mathrm{E}-05$ \\
\hline PTTG3P & 4,34 & $1,69 \mathrm{E}-55$ & 3,65 & $3,17 \mathrm{E}-15$ & 2,35 & $2,15 \mathrm{E}-05$ \\
\hline PVALB & $-4,69$ & $5,36 \mathrm{E}-11$ & $-3,26$ & $1,11 \mathrm{E}-08$ & $-2,58$ & $4,02 \mathrm{E}-06$ \\
\hline PXDN & 2,37 & $3,07 \mathrm{E}-15$ & 2,69 & $6,66 \mathrm{E}-11$ & 1,43 & $5,27 \mathrm{E}-03$ \\
\hline PYCR1 & 3,24 & $2,10 \mathrm{E}-40$ & 2,94 & $4,63 \mathrm{E}-14$ & 1,94 & $7,21 \mathrm{E}-08$ \\
\hline PYGL & $-3,15$ & $6,67 \mathrm{E}-11$ & $-1,86$ & 9,19E-05 & $-2,07$ & $4,05 \mathrm{E}-05$ \\
\hline RAB32 & $-3,37$ & $3,75 \mathrm{E}-11$ & $-1,45$ & $6,27 \mathrm{E}-03$ & $-1,94$ & $2,12 \mathrm{E}-04$ \\
\hline RAB33A & 1,67 & $2,12 \mathrm{E}-13$ & 1,70 & 1,13E-06 & 1,46 & $3,61 \mathrm{E}-04$ \\
\hline RAB3IL1 & $-5,90$ & $3,78 \mathrm{E}-44$ & $-1,79$ & $1,61 \mathrm{E}-04$ & $-2,19$ & $2,22 \mathrm{E}-05$ \\
\hline RAB42 & $-5,64$ & $1,34 \mathrm{E}-28$ & $-1,75$ & $2,24 \mathrm{E}-03$ & $-2,17$ & $8,36 \mathrm{E}-05$ \\
\hline RAB42P1 & $-4,91$ & $3,91 \mathrm{E}-11$ & $-1,71$ & $7,23 \mathrm{E}-03$ & $-2,61$ & $1,16 \mathrm{E}-06$ \\
\hline RAC2 & 1,22 & $3,25 \mathrm{E}-06$ & 1,52 & $2,48 \mathrm{E}-05$ & 1,15 & $9,98 \mathrm{E}-03$ \\
\hline RAC3 & 2,10 & $1,83 \mathrm{E}-15$ & 1,87 & $1,58 \mathrm{E}-07$ & 1,16 & $5,49 \mathrm{E}-03$ \\
\hline RACGAP1 & 3,49 & $8,20 \mathrm{E}-83$ & 3,00 & $2,28 \mathrm{E}-13$ & 1,89 & $3,00 \mathrm{E}-04$ \\
\hline RAD51 & 4,96 & $7,53 \mathrm{E}-100$ & 4,52 & $1,10 \mathrm{E}-29$ & 2,65 & $1,07 \mathrm{E}-06$ \\
\hline RAD54L & 5,84 & $5,78 \mathrm{E}-90$ & 4,97 & $1,41 \mathrm{E}-29$ & 3,47 & $1,33 \mathrm{E}-11$ \\
\hline RAP2B & $-2,11$ & $1,50 \mathrm{E}-07$ & $-1,32$ & $4,21 \mathrm{E}-03$ & $-1,75$ & $4,86 \mathrm{E}-05$ \\
\hline RARRES1 & $-8,63$ & $7,58 \mathrm{E}-65$ & $-2,61$ & $2,46 \mathrm{E}-05$ & $-1,86$ & $1,49 \mathrm{E}-03$ \\
\hline RBP1 & $-2,91$ & $2,18 \mathrm{E}-04$ & $-2,81$ & $4,29 \mathrm{E}-09$ & $-1,45$ & $1,81 \mathrm{E}-03$ \\
\hline RBP7 & $-6,16$ & $3,63 \mathrm{E}-20$ & $-3,72$ & $1,65 \mathrm{E}-15$ & $-3,03$ & $2,00 \mathrm{E}-08$ \\
\hline RCBTB2 & $-3,27$ & $6,24 \mathrm{E}-15$ & $-1,68$ & $2,15 \mathrm{E}-04$ & $-1,46$ & $1,54 \mathrm{E}-03$ \\
\hline RECQL4 & 4,02 & $2,69 \mathrm{E}-64$ & 3,43 & $6,38 \mathrm{E}-24$ & 2,07 & $7,09 \mathrm{E}-06$ \\
\hline REEP2 & 2,37 & $1,47 \mathrm{E}-04$ & 3,81 & $2,62 \mathrm{E}-13$ & 2,93 & $6,84 \mathrm{E}-08$ \\
\hline RET & $-4,09$ & $1,97 \mathrm{E}-09$ & $-2,05$ & $1,71 \mathrm{E}-04$ & $-1,66$ & $3,16 \mathrm{E}-03$ \\
\hline RFC3 & 3,29 & $1,13 \mathrm{E}-71$ & 2,58 & $3,71 \mathrm{E}-10$ & 1,60 & $6,28 \mathrm{E}-04$ \\
\hline RFC3P1 & 3,47 & $1,10 \mathrm{E}-07$ & 2,55 & $1,94 \mathrm{E}-05$ & 1,72 & $2,79 \mathrm{E}-03$ \\
\hline RFC4 & 2,71 & $7,68 \mathrm{E}-74$ & 1,98 & $1,67 \mathrm{E}-09$ & 1,20 & $3,88 \mathrm{E}-03$ \\
\hline RFX2 & 0,97 & $1,18 \mathrm{E}-03$ & 1,32 & $2,94 \mathrm{E}-04$ & 1,20 & $1,80 \mathrm{E}-03$ \\
\hline RFX8 & 1,85 & $7,76 \mathrm{E}-06$ & 1,86 & 2,03E-05 & 1,92 & $9,82 \mathrm{E}-06$ \\
\hline RGS16 & 5,54 & $4,62 \mathrm{E}-85$ & 3,83 & $5,36 \mathrm{E}-13$ & 3,19 & $1,44 \mathrm{E}-11$ \\
\hline RGS6 & 2,76 & $6,14 \mathrm{E}-04$ & 1,98 & $2,17 \mathrm{E}-03$ & 1,93 & $9,24 \mathrm{E}-04$ \\
\hline RHOBTB1 & $-4,73$ & $2,07 \mathrm{E}-12$ & $-3,53$ & $4,33 \mathrm{E}-11$ & $-1,83$ & $1,55 \mathrm{E}-03$ \\
\hline RHPN2 & 3,14 & $3,10 \mathrm{E}-10$ & 2,76 & $1,72 \mathrm{E}-07$ & 2,00 & $9,64 \mathrm{E}-05$ \\
\hline RIBC2 & 5,09 & $8,66 \mathrm{E}-19$ & 4,49 & $1,11 \mathrm{E}-16$ & 2,25 & $1,15 \mathrm{E}-04$ \\
\hline RIN1 & $-1,82$ & $2,54 \mathrm{E}-06$ & $-1,32$ & $5,98 \mathrm{E}-03$ & $-1,34$ & $1,62 \mathrm{E}-03$ \\
\hline RIN2 & $-4,14$ & $5,13 \mathrm{E}-12$ & $-1,70$ & $2,41 \mathrm{E}-03$ & $-1,52$ & $6,70 \mathrm{E}-03$ \\
\hline RMI2 & 5,09 & $9,96 \mathrm{E}-66$ & 5,14 & $1,17 \mathrm{E}-38$ & 3,48 & $3,50 \mathrm{E}-11$ \\
\hline RNASE1 & $-6,67$ & $1,29 \mathrm{E}-38$ & $-4,85$ & $4,39 \mathrm{E}-18$ & $-2,95$ & $1,19 \mathrm{E}-08$ \\
\hline RNASE6 & $-4,10$ & $2,14 \mathrm{E}-30$ & $-3,26$ & $1,01 \mathrm{E}-13$ & $-3,38$ & $2,61 \mathrm{E}-19$ \\
\hline RND1 & 3,35 & $6,78 \mathrm{E}-13$ & 2,11 & $1,12 \mathrm{E}-04$ & 1,68 & $1,03 \mathrm{E}-03$ \\
\hline RNF207 & 1,92 & $1,19 \mathrm{E}-14$ & 1,16 & $8,56 \mathrm{E}-03$ & 1,58 & $2,08 \mathrm{E}-05$ \\
\hline ROBO1 & 1,07 & $1,61 \mathrm{E}-03$ & 1,44 & $4,18 \mathrm{E}-03$ & 1,22 & $2,75 \mathrm{E}-03$ \\
\hline
\end{tabular}

\begin{tabular}{|c|c|c|c|c|c|c|}
\hline RP11-100E13,1 & $-2,33$ & 4,39E-03 & $-1,78$ & $5,41 \mathrm{E}-03$ & $-1,60$ & $4,84 \mathrm{E}-03$ \\
\hline RP11-1012A1,7 & 2,56 & 1,19E-24 & 2,01 & $5,90 \mathrm{E}-08$ & 1,29 & $2,63 \mathrm{E}-03$ \\
\hline RP11-104019,2 & $-2,16$ & $2,21 \mathrm{E}-06$ & $-1,35$ & $2,82 \mathrm{E}-03$ & $-1,79$ & $7,57 \mathrm{E}-05$ \\
\hline \multicolumn{7}{|l|}{ RP11- } \\
\hline 1081L13,3 & 3,04 & 1,01E-16 & 2,02 & $9,89 \mathrm{E}-06$ & 1,26 & 7,93E-03 \\
\hline RP11-108L7,15 & 2,49 & $5,82 \mathrm{E}-04$ & 2,54 & $2,53 \mathrm{E}-05$ & 1,56 & $7,59 \mathrm{E}-03$ \\
\hline RP11-109E24,1 & 3,53 & $5,31 \mathrm{E}-12$ & 2,68 & $5,94 \mathrm{E}-07$ & 1,65 & $2,79 \mathrm{E}-03$ \\
\hline RP11-1113L8,1 & $-3,07$ & $1,24 \mathrm{E}-04$ & $-1,80$ & $5,40 \mathrm{E}-03$ & $-2,14$ & $2,49 \mathrm{E}-04$ \\
\hline RP11-114G11,2 & 4,72 & $7,56 \mathrm{E}-11$ & 3,45 & $3,88 \mathrm{E}-08$ & 2,24 & $1,26 \mathrm{E}-04$ \\
\hline RP11-120D5,1 & 3,41 & $1,06 \mathrm{E}-08$ & 2,27 & $1,59 \mathrm{E}-04$ & 2,14 & $1,49 \mathrm{E}-04$ \\
\hline RP11-1319K7,1 & $-2,14$ & $2,20 \mathrm{E}-11$ & $-1,56$ & $5,36 \mathrm{E}-06$ & $-0,98$ & $7,28 \mathrm{E}-03$ \\
\hline RP11-136|14,3 & $-3,43$ & $1,40 \mathrm{E}-07$ & $-2,14$ & $5,91 \mathrm{E}-05$ & $-2,48$ & $2,25 \mathrm{E}-06$ \\
\hline \multicolumn{7}{|l|}{ RP11- } \\
\hline 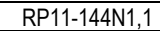 & 2,49 & $2,41 \mathrm{E}-11$ & 2,12 & $1,17 \mathrm{E}-05$ & 1,71 & 4,99E-04 \\
\hline RP11-145M9,4 & $-3,19$ & $3,93 \mathrm{E}-09$ & $-1,75$ & $6,52 \mathrm{E}-04$ & $-1,98$ & $2,95 \mathrm{E}-04$ \\
\hline RP11-14N7,2 & $-1,39$ & $5,08 \mathrm{E}-05$ & $-1,01$ & $6,83 \mathrm{E}-03$ & $-1,20$ & $2,70 \mathrm{E}-03$ \\
\hline RP11-159J3,1 & 2,60 & $5,52 \mathrm{E}-18$ & 2,23 & $2,13 \mathrm{E}-08$ & 1,41 & $1,82 \mathrm{E}-03$ \\
\hline RP11-165H4,3 & 4,17 & $3,78 \mathrm{E}-11$ & 4,08 & $3,37 \mathrm{E}-13$ & 2,32 & $6,28 \mathrm{E}-05$ \\
\hline RP11-18B3,2 & 4,14 & $5,60 \mathrm{E}-14$ & 2,72 & $8,17 \mathrm{E}-06$ & 1,63 & $5,11 \mathrm{E}-03$ \\
\hline RP11-215G15,5 & 3,14 & $1,15 \mathrm{E}-11$ & 1,82 & $2,96 \mathrm{E}-04$ & 1,58 & $1,11 \mathrm{E}-03$ \\
\hline RP11-216N14,7 & $-2,23$ & $6,58 \mathrm{E}-05$ & $-1,77$ & $3,71 \mathrm{E}-04$ & $-1,47$ & $3,60 \mathrm{E}-03$ \\
\hline $\begin{array}{ll}\text { RP11-23B7,3 } \\
\end{array}$ & 4,34 & $6,88 \mathrm{E}-24$ & 3,36 & $6,60 \mathrm{E}-12$ & 2,08 & $1,89 \mathrm{E}-04$ \\
\hline RP11-244H18,4 & 5,84 & $6,84 \mathrm{E}-18$ & 4,19 & $7,02 \mathrm{E}-12$ & 2,02 & $4,68 \mathrm{E}-04$ \\
\hline RP11-265P11,2 & 2,35 & $2,65 \mathrm{E}-08$ & 2,83 & $1,17 \mathrm{E}-10$ & 2,04 & $1,55 \mathrm{E}-05$ \\
\hline RP11-290F20,3 & $-3,61$ & $4,02 \mathrm{E}-10$ & $-1,43$ & $9,49 \mathrm{E}-03$ & $-2,01$ & $2,23 \mathrm{E}-04$ \\
\hline RP11-29B2,5 & $-1,69$ & $1,64 \mathrm{E}-04$ & $-1,85$ & $6,34 \mathrm{E}-04$ & $-1,21$ & $8,18 \mathrm{E}-03$ \\
\hline RP11-303E16,2 & 3,90 & $7,38 \mathrm{E}-28$ & 3,15 & $1,16 \mathrm{E}-12$ & 2,16 & $1,43 \mathrm{E}-05$ \\
\hline RP11-307P22,1 & 4,10 & $5,74 \mathrm{E}-32$ & 3,30 & $8,46 \mathrm{E}-13$ & 2,18 & $2,45 \mathrm{E}-05$ \\
\hline RP11-325F22,2 & 2,34 & $1,97 \mathrm{E}-12$ & 1,36 & $8,40 \mathrm{E}-03$ & 1,84 & $3,56 \mathrm{E}-05$ \\
\hline RP11-325024,5 & 2,67 & 1,78E-06 & 1,78 & $2,83 \mathrm{E}-03$ & 1,74 & 1,49E-03 \\
\hline RP11-328J14,2 & 2,66 & $2,54 \mathrm{E}-22$ & 1,90 & $7,82 \mathrm{E}-06$ & 1,28 & $5,56 \mathrm{E}-03$ \\
\hline RP11-333E13,4 & 2,75 & $4,98 \mathrm{E}-29$ & 2,17 & $1,82 \mathrm{E}-08$ & 1,20 & $6,80 \mathrm{E}-03$ \\
\hline RP11-334C17,5 & $-4,02$ & $3,73 \mathrm{E}-50$ & $-1,90$ & $2,67 \mathrm{E}-04$ & $-1,27$ & $7,25 \mathrm{E}-03$ \\
\hline RP11-336N8,4 & 3,69 & $1,50 \mathrm{E}-23$ & 3,03 & $8,25 \mathrm{E}-12$ & 1,76 & $8,25 \mathrm{E}-04$ \\
\hline \multicolumn{7}{|l|}{ RP11- } \\
\hline 339B21,13 & $-1,74$ & $2,43 \mathrm{E}-03$ & $-1,48$ & $7,62 \mathrm{E}-03$ & $-1,43$ & $7,09 \mathrm{E}-03$ \\
\hline RP11-344B5,2 & $-3,69$ & $2,73 \mathrm{E}-08$ & $-2,44$ & $4,95 \mathrm{E}-06$ & $-2,31$ & $1,09 \mathrm{E}-05$ \\
\hline RP11-368J21,3 & $-5,08$ & $3,10 \mathrm{E}-25$ & $-1,99$ & $5,01 \mathrm{E}-04$ & $-3,26$ & $1,92 \mathrm{E}-12$ \\
\hline RP11-379F4,4 & $-2,22$ & $3,67 \mathrm{E}-07$ & $-1,66$ & $4,17 \mathrm{E}-03$ & $-2,67$ & $1,95 \mathrm{E}-08$ \\
\hline RP11-381E24,1 & 3,86 & $8,09 \mathrm{E}-08$ & 2,68 & $2,45 \mathrm{E}-05$ & 2,45 & $2,45 \mathrm{E}-05$ \\
\hline RP11-402G3,3 & 4,54 & $6,78 \mathrm{E}-10$ & 3,09 & $1,23 \mathrm{E}-06$ & 1,59 & $4,84 \mathrm{E}-03$ \\
\hline RP11-419M24,1 & 4,33 & $1,13 \mathrm{E}-18$ & 3,33 & $4,60 \mathrm{E}-09$ & 2,08 & $3,49 \mathrm{E}-04$ \\
\hline RP11-424C20,2 & 7,39 & $4,41 \mathrm{E}-92$ & 6,80 & $3,08 \mathrm{E}-51$ & 4,43 & $1,30 \mathrm{E}-16$ \\
\hline RP11-43F13,3 & 4,36 & $5,28 \mathrm{E}-09$ & 4,12 & $3,14 \mathrm{E}-11$ & 2,62 & $7,30 \mathrm{E}-06$ \\
\hline RP11-452C13,1 & $-4,00$ & 1,07E-07 & $-1,86$ & $2,64 \mathrm{E}-03$ & $-2,23$ & $5,40 \mathrm{E}-05$ \\
\hline RP11-456J20,1 & 5,04 & $1,91 \mathrm{E}-12$ & 2,74 & $2,24 \mathrm{E}-05$ & 2,34 & $6,35 \mathrm{E}-05$ \\
\hline RP11-459|19,1 & $-3,57$ & $3,32 \mathrm{E}-08$ & $-1,48$ & $6,63 \mathrm{E}-03$ & $-2,24$ & $3,41 \mathrm{E}-05$ \\
\hline RP11-465B22,3 & 1,48 & 5,49E-05 & 1,43 & $9,61 \mathrm{E}-04$ & 1,49 & $1,72 \mathrm{E}-03$ \\
\hline RP11-478B9,3 & 3,40 & $1,38 \mathrm{E}-23$ & 2,90 & $5,90 \mathrm{E}-10$ & 1,85 & 7,47E-04 \\
\hline RP11-493L12,5 & 4,23 & 2,19E-09 & 2,67 & $2,62 \mathrm{E}-05$ & 1,66 & $4,32 \mathrm{E}-03$ \\
\hline RP11-497H16,2 & $-4,43$ & $1,59 \mathrm{E}-15$ & $-1,77$ & $6,35 \mathrm{E}-04$ & $-1,72$ & $3,93 \mathrm{E}-04$ \\
\hline RP11-497H16,7 & $-2,56$ & $1,81 \mathrm{E}-09$ & $-1,86$ & $3,31 \mathrm{E}-06$ & $-1,88$ & $5,03 \mathrm{E}-06$ \\
\hline RP11-500C11,3 & 2,12 & $1,67 \mathrm{E}-17$ & 1,72 & $1,25 \mathrm{E}-06$ & 1,27 & $4,81 \mathrm{E}-04$ \\
\hline RP11-529E10,6 & $-1,46$ & $8,54 \mathrm{E}-06$ & $-2,00$ & $2,91 \mathrm{E}-06$ & $-1,25$ & $2,54 \mathrm{E}-03$ \\
\hline RP1-152L7,5 & 2,67 & $3,64 \mathrm{E}-07$ & 2,34 & $1,46 \mathrm{E}-05$ & 1,79 & $1,13 \mathrm{E}-03$ \\
\hline RP11- & & & & & & \\
\hline $536 \mathrm{C} 10,10$ & 5,44 & 4,79E-15 & 3,52 & $3,08 \mathrm{E}-08$ & 2,24 & $1,25 \mathrm{E}-04$ \\
\hline RP11-5407,18 & 1,46 & 5,59E-03 & 1,59 & $1,81 \mathrm{E}-03$ & 1,48 & $5,56 \mathrm{E}-03$ \\
\hline RP11-568K15,1 & $-2,75$ & $4,27 \mathrm{E}-04$ & $-2,00$ & $8,12 \mathrm{E}-06$ & $-2,46$ & $9,77 \mathrm{E}-09$ \\
\hline RP11-594N15,2 & 2,36 & $1,63 \mathrm{E}-03$ & 1,91 & $2,63 \mathrm{E}-03$ & 1,81 & $1,91 \mathrm{E}-03$ \\
\hline RP11-598F7,3 & $-4,28$ & $2,76 \mathrm{E}-15$ & $-1,43$ & $8,76 \mathrm{E}-03$ & $-3,50$ & $1,85 \mathrm{E}-12$ \\
\hline RP11-598012,1 & 3,57 & $8,81 \mathrm{E}-11$ & 3,10 & $5,24 \mathrm{E}-09$ & 2,02 & $3,52 \mathrm{E}-04$ \\
\hline RP11-616K6,1 & $-4,39$ & $1,11 \mathrm{E}-10$ & $-2,88$ & $3,03 \mathrm{E}-06$ & $-2,50$ & $1,39 \mathrm{E}-05$ \\
\hline $\begin{array}{l}\text { RP11-62901,2 } \\
\end{array}$ & $-1,56$ & $4,04 \mathrm{E}-04$ & $-1,33$ & $5,47 \mathrm{E}-03$ & $-1,38$ & $1,33 \mathrm{E}-03$ \\
\hline RP11-645C24,5 & $-3,14$ & $1,46 \mathrm{E}-19$ & $-1,72$ & $2,59 \mathrm{E}-05$ & $-1,27$ & $2,67 \mathrm{E}-03$ \\
\hline RP11-65J3,1 & $-5,29$ & $3,52 \mathrm{E}-23$ & $-3,68$ & $3,43 \mathrm{E}-15$ & $-2,79$ & $9,15 \mathrm{E}-11$ \\
\hline RP11-701P16,5 & 3,51 & $3,34 \mathrm{E}-13$ & 2,60 & $8,76 \mathrm{E}-07$ & 1,67 & $4,38 \mathrm{E}-03$ \\
\hline RP11-760N9,1 & $-3,68$ & 1,67E-09 & $-2,63$ & $1,07 \mathrm{E}-05$ & $-2,33$ & $3,72 \mathrm{E}-06$ \\
\hline RP11-783K16,5 & 1,94 & $3,20 \mathrm{E}-04$ & 1,42 & $9,82 \mathrm{E}-03$ & 1,54 & $2,58 \mathrm{E}-03$ \\
\hline RP11-803B1,8 & $-2,08$ & $5,68 \mathrm{E}-04$ & $-1,91$ & $1,97 \mathrm{E}-03$ & $-1,63$ & $3,91 \mathrm{E}-03$ \\
\hline RP11-807H22,6 & $-2,80$ & $1,12 \mathrm{E}-04$ & $-1,70$ & $5,26 \mathrm{E}-03$ & $-1,68$ & $3,62 \mathrm{E}-03$ \\
\hline RP11-815J4,6 & 2,75 & $2,54 \mathrm{E}-07$ & 2,63 & $1,61 \mathrm{E}-06$ & 1,78 & $9,28 \mathrm{E}-04$ \\
\hline RP11-838N2,4 & $-4,96$ & $1,16 \mathrm{E}-12$ & $-2,30$ & $1,23 \mathrm{E}-04$ & $-2,72$ & $5,73 \mathrm{E}-07$ \\
\hline RP11-848G14,5 & $-3,99$ & $6,34 \mathrm{E}-19$ & $-1,96$ & $9,08 \mathrm{E}-05$ & $-1,73$ & $1,00 \mathrm{E}-03$ \\
\hline RP11-84D1,1 & 4,44 & $3,20 \mathrm{E}-24$ & 1,79 & $1,11 \mathrm{E}-03$ & 1,53 & $4,41 \mathrm{E}-03$ \\
\hline RP11-93B14,5 & 2,62 & $3,27 \mathrm{E}-07$ & 1,95 & $3,41 \mathrm{E}-04$ & 1,99 & $1,53 \mathrm{E}-04$ \\
\hline RP11-98H4,4 & 4,19 & $2,42 \mathrm{E}-08$ & 3,27 & $2,24 \mathrm{E}-07$ & 1,79 & $2,02 \mathrm{E}-03$ \\
\hline RP3-359N14,1 & 3,78 & $3,58 \mathrm{E}-27$ & 3,21 & $7,86 \mathrm{E}-14$ & 1,83 & $5,58 \mathrm{E}-04$ \\
\hline RP3-439F8,1 & $-2,90$ & $1,84 \mathrm{E}-07$ & $-3,40$ & $2,40 \mathrm{E}-09$ & $-2,31$ & $5,71 \mathrm{E}-05$ \\
\hline RP4-647J21,1 & 3,80 & $2,60 \mathrm{E}-56$ & 2,64 & $1,21 \mathrm{E}-10$ & 1,40 & $1,22 \mathrm{E}-03$ \\
\hline RP4-742C19,12 & 5,12 & $7,33 \mathrm{E}-24$ & 2,73 & $6,35 \mathrm{E}-08$ & 1,38 & $6,17 \mathrm{E}-03$ \\
\hline RP4-794H19,4 & 1,98 & $9,34 \mathrm{E}-04$ & 1,73 & $1,47 \mathrm{E}-03$ & 1,87 & $2,29 \mathrm{E}-04$ \\
\hline RP5-1028K7,2 & 2,45 & $3,90 \mathrm{E}-04$ & 3,09 & $1,34 \mathrm{E}-07$ & 2,07 & $3,29 \mathrm{E}-04$ \\
\hline RP5-104218,7 & $-2,11$ & $2,60 \mathrm{E}-06$ & $-1,63$ & $1,40 \mathrm{E}-03$ & $-1,42$ & $1,45 \mathrm{E}-03$ \\
\hline RP5-1099D15,1 & 2,54 & $1,29 \mathrm{E}-38$ & 1,88 & $5,92 \mathrm{E}-07$ & 1,33 & $1,62 \mathrm{E}-03$ \\
\hline RP5-1100H13,3 & 6,17 & 1,49E-61 & 5,08 & $4,60 \mathrm{E}-25$ & 3,46 & $1,55 \mathrm{E}-10$ \\
\hline
\end{tabular}




\begin{tabular}{|c|c|c|c|c|c|c|}
\hline RP5-1121H13,1 & 3,19 & $3,63 \mathrm{E}-08$ & 2,05 & $4,00 \mathrm{E}-04$ & 1,52 & $6,75 \mathrm{E}-03$ \\
\hline RP5-991C6,3 & $-4,15$ & $8,53 \mathrm{E}-08$ & $-2,08$ & $1,20 \mathrm{E}-03$ & $-2,48$ & $8,29 \mathrm{E}-06$ \\
\hline RPL7AP64 & $-2,74$ & $5,00 \mathrm{E}-05$ & $-2,28$ & $3,81 \mathrm{E}-05$ & $-2,14$ & $7,21 \mathrm{E}-05$ \\
\hline RPS6KA2 & $-4,26$ & $7,09 \mathrm{E}-14$ & $-2,01$ & $5,26 \mathrm{E}-04$ & $-1,92$ & $2,72 \mathrm{E}-04$ \\
\hline RRM1 & 3,51 & $2,41 \mathrm{E}-84$ & 2,82 & $1,33 \mathrm{E}-14$ & 1,72 & $2,61 \mathrm{E}-04$ \\
\hline RRM2 & 8,19 & $2,15 \mathrm{E}-149$ & 6,60 & $1,82 \mathrm{E}-44$ & 4,73 & $1,03 \mathrm{E}-19$ \\
\hline RRM2P2 & 4,60 & $1,24 \mathrm{E}-12$ & 3,16 & 4,01E-07 & 1,56 & $7,39 \mathrm{E}-03$ \\
\hline RRM2P3 & 8,11 & $2,55 \mathrm{E}-143$ & 6,41 & $5,11 \mathrm{E}-41$ & 4,56 & $3,58 \mathrm{E}-18$ \\
\hline RTN4R & $-4,66$ & $5,82 \mathrm{E}-32$ & $-1,52$ & $5,10 \mathrm{E}-03$ & $-2,59$ & $6,61 \mathrm{E}-09$ \\
\hline SAMD10 & 1,20 & $8,53 \mathrm{E}-04$ & 1,24 & $8,45 \mathrm{E}-03$ & 1,21 & $9,99 \mathrm{E}-03$ \\
\hline SAMSN1 & 1,40 & $3,89 \mathrm{E}-09$ & 1,26 & $1,30 \mathrm{E}-03$ & 1,42 & $7,18 \mathrm{E}-05$ \\
\hline SAPCD2 & 5,06 & $2,21 \mathrm{E}-63$ & 4,84 & $1,79 \mathrm{E}-28$ & 2,92 & $7,76 \mathrm{E}-08$ \\
\hline SCIN & $-2,82$ & 4,92E-04 & $-2,27$ & $4,05 \mathrm{E}-04$ & $-2,48$ & $1,27 \mathrm{E}-05$ \\
\hline SDK1 & 2,82 & $1,18 \mathrm{E}-12$ & 2,56 & $9,02 \mathrm{E}-10$ & 2,41 & $2,11 \mathrm{E}-06$ \\
\hline SDS & $-5,99$ & $1,80 \mathrm{E}-70$ & $-2,73$ & $2,18 \mathrm{E}-06$ & $-1,85$ & $1,28 \mathrm{E}-03$ \\
\hline SEMA7A & 3,32 & $1,62 \mathrm{E}-25$ & 2,27 & $2,18 \mathrm{E}-08$ & 2,03 & $5,40 \mathrm{E}-07$ \\
\hline SENP1 & 1,78 & $5,28 \mathrm{E}-23$ & 1,45 & $1,07 \mathrm{E}-04$ & 1,05 & $7,80 \mathrm{E}-03$ \\
\hline SERINC2 & $-2,91$ & $1,42 \mathrm{E}-11$ & $-1,96$ & $3,18 \mathrm{E}-05$ & $-2,01$ & $4,50 \mathrm{E}-05$ \\
\hline SERPINB6 & $-0,99$ & $2,99 \mathrm{E}-04$ & $-0,99$ & $3,96 \mathrm{E}-03$ & $-1,31$ & $3,28 \mathrm{E}-04$ \\
\hline SERPINB9 & 1,78 & $1,40 \mathrm{E}-08$ & 1,49 & $7,78 \mathrm{E}-05$ & 1,37 & $3,58 \mathrm{E}-04$ \\
\hline SERPINE1 & 3,91 & $2,95 \mathrm{E}-31$ & 3,85 & $6,52 \mathrm{E}-21$ & 1,46 & $1,82 \mathrm{E}-03$ \\
\hline SERPINE2 & 3,03 & $8,81 \mathrm{E}-12$ & 2,76 & $4,93 \mathrm{E}-09$ & 2,24 & $4,19 \mathrm{E}-07$ \\
\hline SERPINF1 & $-4,79$ & $6,93 \mathrm{E}-70$ & $-2,87$ & $1,21 \mathrm{E}-09$ & $-3,38$ & $1,56 \mathrm{E}-22$ \\
\hline SFXN1 & 2,62 & $1,70 \mathrm{E}-11$ & 2,54 & $4,44 \mathrm{E}-09$ & 1,49 & $7,60 \mathrm{E}-04$ \\
\hline SGK3 & $-2,86$ & $2,50 \mathrm{E}-08$ & $-1,56$ & $3,33 \mathrm{E}-03$ & $-1,44$ & $8,35 \mathrm{E}-03$ \\
\hline SGOL1 & 5,99 & $2,62 \mathrm{E}-51$ & 4,81 & $1,80 \mathrm{E}-22$ & 3,09 & $2,65 \mathrm{E}-08$ \\
\hline SGOL2 & 3,56 & $9,79 \mathrm{E}-15$ & 2,56 & $6,58 \mathrm{E}-08$ & 1,57 & $3,02 \mathrm{E}-03$ \\
\hline SGSH & $-3,01$ & $2,03 \mathrm{E}-16$ & $-1,56$ & 9,35E-04 & $-1,19$ & $6,89 \mathrm{E}-03$ \\
\hline SH2D2A & 4,33 & $1,54 \mathrm{E}-39$ & 3,11 & $1,88 \mathrm{E}-16$ & 2,43 & $4,55 \mathrm{E}-10$ \\
\hline SH3RF3 & $-4,39$ & $8,99 \mathrm{E}-36$ & $-2,42$ & $1,35 \mathrm{E}-06$ & $-1,60$ & $1,11 \mathrm{E}-03$ \\
\hline SHCBP1 & 5,65 & $3,66 \mathrm{E}-117$ & 4,56 & $8,65 \mathrm{E}-24$ & 3,04 & $6,48 \mathrm{E}-09$ \\
\hline SHD & $-3,33$ & $1,63 \mathrm{E}-06$ & $-3,49$ & $2,39 \mathrm{E}-08$ & $-2,87$ & $4,32 \mathrm{E}-07$ \\
\hline SIGLEC7 & $-4,51$ & $8,65 \mathrm{E}-31$ & $-1,60$ & $3,22 \mathrm{E}-04$ & $-2,81$ & $1,83 \mathrm{E}-12$ \\
\hline SIGLEC9 & $-3,09$ & $1,85 \mathrm{E}-15$ & $-1,34$ & $5,57 \mathrm{E}-03$ & $-1,95$ & $5,47 \mathrm{E}-05$ \\
\hline $\begin{array}{l}\text { SIPA1L1 } \\
\text { SIP }\end{array}$ & 1,99 & $6,31 \mathrm{E}-36$ & 1,17 & $1,75 \mathrm{E}-04$ & 1,31 & $7,39 \mathrm{E}-05$ \\
\hline SKA1 & 5,80 & $5,27 \mathrm{E}-74$ & 4,57 & $1,92 \mathrm{E}-26$ & 2,99 & $9,56 \mathrm{E}-09$ \\
\hline SKA2 & 2,37 & $6,63 \mathrm{E}-11$ & 1,92 & $6,69 \mathrm{E}-06$ & 1,29 & $9,12 \mathrm{E}-03$ \\
\hline SKA3 & 6,99 & 9,69E-84 & 5,78 & $1,42 \mathrm{E}-37$ & 3,68 & $2,27 \mathrm{E}-11$ \\
\hline SLA2 & 1,51 & $4,49 \mathrm{E}-06$ & 1,49 & $9,32 \mathrm{E}-05$ & 1,21 & $3,96 \mathrm{E}-03$ \\
\hline SLAIN1 & 1,75 & $6,38 \mathrm{E}-05$ & 1,37 & $4,54 \mathrm{E}-03$ & 1,21 & $8,12 \mathrm{E}-03$ \\
\hline SLC16A1 & 2,25 & $2,18 \mathrm{E}-29$ & 1,54 & $1,61 \mathrm{E}-05$ & 1,17 & $7,44 \mathrm{E}-04$ \\
\hline SLC16A2 & 5,10 & $1,35 \mathrm{E}-26$ & 3,65 & $2,41 \mathrm{E}-13$ & 2,02 & $2,46 \mathrm{E}-04$ \\
\hline SLC16A5 & $-2,05$ & $1,95 \mathrm{E}-06$ & $-1,17$ & $4,01 \mathrm{E}-03$ & $-1,10$ & $8,94 \mathrm{E}-03$ \\
\hline SLC1A4 & 2,54 & $5,14 \mathrm{E}-28$ & 2,54 & $2,26 \mathrm{E}-08$ & 2,33 & $1,44 \mathrm{E}-05$ \\
\hline SLC24A4 & $-3,42$ & $3,90 \mathrm{E}-06$ & $-1,69$ & $2,98 \mathrm{E}-03$ & $-1,85$ & $1,29 \mathrm{E}-03$ \\
\hline SLC26A11 & $-3,83$ & $1,06 \mathrm{E}-15$ & $-1,58$ & $3,27 \mathrm{E}-03$ & $-2,12$ & $1,90 \mathrm{E}-05$ \\
\hline $\begin{array}{l}\text { SLC27A1 } \\
\text { SLA }\end{array}$ & $-3,25$ & $1,89 \mathrm{E}-09$ & $-1,60$ & $2,03 \mathrm{E}-03$ & $-1,67$ & $6,08 \mathrm{E}-04$ \\
\hline SLC27A2 & 7,57 & $1,47 \mathrm{E}-170$ & 5,20 & $2,25 \mathrm{E}-28$ & 3,63 & $4,95 \mathrm{E}-14$ \\
\hline SLC2A8 & $-2,69$ & $1,59 \mathrm{E}-08$ & $-1,26$ & $5,23 \mathrm{E}-03$ & $-1,84$ & $5,01 \mathrm{E}-05$ \\
\hline SLC2A9 & $-2,25$ & $3,23 \mathrm{E}-09$ & $-1,45$ & $3,60 \mathrm{E}-03$ & $-2,03$ & $1,93 \mathrm{E}-05$ \\
\hline SLC35F2 & 2,70 & $1,30 \mathrm{E}-22$ & 2,34 & $5,90 \mathrm{E}-08$ & 1,79 & $3,94 \mathrm{E}-05$ \\
\hline SLC35F6 & $-1,79$ & $1,78 \mathrm{E}-04$ & $-1,48$ & $2,17 \mathrm{E}-03$ & $-1,76$ & $2,14 \mathrm{E}-04$ \\
\hline SLC36A1 & $-3,08$ & $2,32 \mathrm{E}-14$ & $-1,58$ & $6,41 \mathrm{E}-04$ & $-1,87$ & $4,09 \mathrm{E}-05$ \\
\hline SLC37A2 & $-4,52$ & $7,33 \mathrm{E}-25$ & $-1,91$ & $1,37 \mathrm{E}-04$ & $-2,65$ & $4,93 \mathrm{E}-08$ \\
\hline SLC38A6 & $-3,19$ & $7,64 \mathrm{E}-22$ & $-1,49$ & $2,10 \mathrm{E}-04$ & $-2,25$ & $2,11 \mathrm{E}-08$ \\
\hline SLC39A14 & 3,40 & $2,54 \mathrm{E}-96$ & 2,04 & $2,00 \mathrm{E}-07$ & 1,45 & $1,99 \mathrm{E}-05$ \\
\hline SLC39A8 & 2,69 & $3,66 \mathrm{E}-51$ & 1,76 & $1,02 \mathrm{E}-07$ & 1,81 & $1,87 \mathrm{E}-04$ \\
\hline SLC46A1 & $-1,45$ & $8,75 \mathrm{E}-06$ & $-1,13$ & $8,05 \mathrm{E}-03$ & $-1,61$ & $1,05 \mathrm{E}-04$ \\
\hline SLC46A2 & $-3,62$ & $2,72 \mathrm{E}-06$ & $-1,85$ & $4,35 \mathrm{E}-03$ & $-2,21$ & $1,15 \mathrm{E}-04$ \\
\hline SLC47A1 & $-5,78$ & $1,32 \mathrm{E}-24$ & $-1,90$ & $8,54 \mathrm{E}-04$ & $-3,40$ & $3,88 \mathrm{E}-11$ \\
\hline SLC48A1 & $-2,49$ & $4,64 \mathrm{E}-40$ & $-1,43$ & $5,90 \mathrm{E}-06$ & $-1,70$ & $5,08 \mathrm{E}-07$ \\
\hline SLC7A5 & 3,35 & $4,81 \mathrm{E}-87$ & 2,69 & $2,09 \mathrm{E}-16$ & 2,34 & $6,55 \mathrm{E}-10$ \\
\hline SLCO2B1 & $-4,95$ & $4,21 \mathrm{E}-37$ & $-2,08$ & $1,35 \mathrm{E}-04$ & $-1,87$ & $1,63 \mathrm{E}-04$ \\
\hline SLC04A1 & 3,17 & $2,35 \mathrm{E}-30$ & 2,89 & $4,89 \mathrm{E}-17$ & 2,70 & $2,32 \mathrm{E}-11$ \\
\hline SLIT3 & $-2,93$ & $3,28 \mathrm{E}-05$ & $-1,69$ & $6,41 \mathrm{E}-03$ & $-2,23$ & $9,74 \mathrm{E}-05$ \\
\hline SMC1B & 2,76 & $1,52 \mathrm{E}-05$ & 2,24 & $1,36 \mathrm{E}-04$ & 1,60 & $5,60 \mathrm{E}-03$ \\
\hline SMC2 & 3,01 & $1,40 \mathrm{E}-40$ & 2,53 & $9,72 \mathrm{E}-10$ & 1,62 & $9,33 \mathrm{E}-04$ \\
\hline SMC4 & 2,99 & $5,20 \mathrm{E}-77$ & 2,34 & $3,45 \mathrm{E}-08$ & 1,67 & $3,91 \mathrm{E}-04$ \\
\hline SMO & 2,05 & $5,20 \mathrm{E}-04$ & 2,68 & $1,66 \mathrm{E}-06$ & 1,58 & $4,72 \mathrm{E}-03$ \\
\hline SMTN & 3,78 & $9,41 \mathrm{E}-24$ & 2,87 & $5,48 \mathrm{E}-13$ & 1,76 & $5,79 \mathrm{E}-04$ \\
\hline SNORA67 & $-2,05$ & $1,54 \mathrm{E}-07$ & $-1,28$ & $3,11 \mathrm{E}-03$ & $-1,70$ & $7,74 \mathrm{E}-05$ \\
\hline $\begin{array}{l}\text { SNX24 } \\
\end{array}$ & $-1,91$ & $1,21 \mathrm{E}-04$ & $-1,74$ & $1,64 \mathrm{E}-04$ & $-1,90$ & $5,90 \mathrm{E}-05$ \\
\hline SOX13 & $-2,43$ & $3,95 \mathrm{E}-10$ & $-1,83$ & $4,51 \mathrm{E}-05$ & $-1,61$ & $3,77 \mathrm{E}-04$ \\
\hline SOX4 & 1,35 & $8,32 \mathrm{E}-05$ & 1,11 & 9,92E-03 & 1,39 & $3,35 \mathrm{E}-03$ \\
\hline SPAG5 & 4,76 & $2,46 \mathrm{E}-80$ & 3,76 & $2,24 \mathrm{E}-18$ & 2,43 & $2,67 \mathrm{E}-06$ \\
\hline SPARC & $-5,65$ & $1,64 \mathrm{E}-28$ & $-2,65$ & $6,71 \mathrm{E}-07$ & $-3,00$ & $1,14 \mathrm{E}-09$ \\
\hline SPATA12 & $-4,88$ & $3,03 \mathrm{E}-13$ & $-2,83$ & $1,39 \mathrm{E}-07$ & $-3,13$ & $4,42 \mathrm{E}-11$ \\
\hline SPATA3 & 3,16 & $7,76 \mathrm{E}-05$ & 2,47 & $1,34 \mathrm{E}-04$ & 1,64 & $4,20 \mathrm{E}-03$ \\
\hline SPATA3-AS1 & 5,29 & $2,24 \mathrm{E}-39$ & 5,00 & $3,45 \mathrm{E}-25$ & 3,37 & $1,29 \mathrm{E}-09$ \\
\hline SPC24 & 4,45 & $1,24 \mathrm{E}-11$ & 4,12 & $2,24 \mathrm{E}-13$ & 2,62 & $4,70 \mathrm{E}-06$ \\
\hline SPC25 & 7,57 & $1,92 \mathrm{E}-84$ & 6,39 & $5,95 \mathrm{E}-41$ & 4,10 & $9,38 \mathrm{E}-14$ \\
\hline SRCRB4D & $-1,18$ & $5,09 \mathrm{E}-03$ & $-1,44$ & $1,73 \mathrm{E}-03$ & $-1,60$ & $1,32 \mathrm{E}-03$ \\
\hline SRPX & $-5,46$ & $3,60 \mathrm{E}-13$ & $-1,69$ & $8,26 \mathrm{E}-03$ & $-2,07$ & $3,80 \mathrm{E}-04$ \\
\hline ST5 & $-3,04$ & $5,20 \mathrm{E}-08$ & $-1,41$ & $9,79 \mathrm{E}-03$ & $-2,79$ & $1,28 \mathrm{E}-08$ \\
\hline STAB1 & $-7,93$ & $1,74 \mathrm{E}-107$ & $-3,47$ & $8,06 \mathrm{E}-13$ & $-2,33$ & $1,66 \mathrm{E}-06$ \\
\hline STAT4 & 1,96 & 1,93E-07 & 1,10 & $6,42 \mathrm{E}-03$ & 1,15 & $4,15 \mathrm{E}-03$ \\
\hline STIL & 4,50 & $1,83 \mathrm{E}-95$ & 3,62 & $2,08 \mathrm{E}-18$ & 2,35 & $6,89 \mathrm{E}-06$ \\
\hline
\end{tabular}

\begin{tabular}{|c|c|c|c|c|c|c|}
\hline STMN1 & 3,13 & $1,60 \mathrm{E}-22$ & 3,01 & $2,40 \mathrm{E}-12$ & 1,95 & $2,94 \mathrm{E}-04$ \\
\hline STMND1 & 4,94 & $1,04 \mathrm{E}-13$ & 4,21 & $2,70 \mathrm{E}-11$ & 2,41 & $3,51 \mathrm{E}-05$ \\
\hline STOX2 & $-5,45$ & $4,05 \mathrm{E}-14$ & $-1,84$ & $5,86 \mathrm{E}-04$ & $-1,98$ & $1,89 \mathrm{E}-04$ \\
\hline SUCNR1 & $-2,03$ & $1,38 \mathrm{E}-07$ & $-1,31$ & $6,05 \mathrm{E}-04$ & $-3,62$ & $1,82 \mathrm{E}-18$ \\
\hline SULT1C2 & $-4,82$ & $3,01 \mathrm{E}-16$ & $-1,90$ & $6,12 \mathrm{E}-04$ & $-3,84$ & $4,99 \mathrm{E}-13$ \\
\hline SUV39H2 & 2,87 & $3,59 \mathrm{E}-35$ & 2,21 & $3,48 \mathrm{E}-08$ & 1,28 & $2,06 \mathrm{E}-03$ \\
\hline SWAP70 & $-2,70$ & $3,04 \mathrm{E}-08$ & $-1,74$ & $3,06 \mathrm{E}-04$ & $-1,82$ & $2,67 \mathrm{E}-04$ \\
\hline SYNGR3 & 1,65 & $3,81 \mathrm{E}-04$ & 1,38 & $1,68 \mathrm{E}-03$ & 1,79 & $3,78 \mathrm{E}-05$ \\
\hline TAF9BP1 & 1,42 & $1,62 \mathrm{E}-06$ & 1,20 & $8,74 \mathrm{E}-03$ & 1,44 & $3,62 \mathrm{E}-03$ \\
\hline TBC1D12 & $-3,05$ & $5,26 \mathrm{E}-12$ & $-1,51$ & $2,55 \mathrm{E}-04$ & $-1,41$ & $5,84 \mathrm{E}-03$ \\
\hline TBXAS1 & $-3,54$ & $1,08 \mathrm{E}-16$ & $-1,63$ & $9,90 \mathrm{E}-04$ & $-1,86$ & $8,34 \mathrm{E}-06$ \\
\hline TCF19 & 2,62 & $5,81 \mathrm{E}-23$ & 2,08 & $1,18 \mathrm{E}-08$ & 1,38 & $1,86 \mathrm{E}-03$ \\
\hline TEAD3 & 2,51 & $3,33 \mathrm{E}-08$ & 2,40 & $2,61 \mathrm{E}-07$ & 1,96 & $2,79 \mathrm{E}-05$ \\
\hline TEAD4 & 2,72 & $8,81 \mathrm{E}-04$ & 3,55 & $1,83 \mathrm{E}-08$ & 2,01 & $5,47 \mathrm{E}-04$ \\
\hline TERT & 1,91 & $3,57 \mathrm{E}-04$ & 3,22 & $9,41 \mathrm{E}-10$ & 1,87 & $4,59 \mathrm{E}-04$ \\
\hline TFCP2L1 & $-4,70$ & $1,50 \mathrm{E}-17$ & $-2,77$ & $1,27 \mathrm{E}-09$ & $-2,98$ & $2,46 \mathrm{E}-09$ \\
\hline TGM5 & 3,79 & $1,00 \mathrm{E}-11$ & 2,36 & $1,75 \mathrm{E}-04$ & 1,74 & $1,69 \mathrm{E}-03$ \\
\hline THRA & $-3,11$ & $9,88 \mathrm{E}-63$ & $-1,73$ & $2,09 \mathrm{E}-05$ & $-1,23$ & $1,03 \mathrm{E}-03$ \\
\hline TICRR & 6,98 & $1,52 \mathrm{E}-74$ & 5,80 & $1,66 \mathrm{E}-33$ & 3,61 & $1,04 \mathrm{E}-10$ \\
\hline TIFA & 2,10 & $1,36 \mathrm{E}-13$ & 1,35 & $4,66 \mathrm{E}-04$ & 1,39 & $2,79 \mathrm{E}-04$ \\
\hline TIMP2 & $-3,86$ & $7,83 \mathrm{E}-15$ & $-1,54$ & $2,88 \mathrm{E}-03$ & $-2,06$ & $5,21 \mathrm{E}-05$ \\
\hline TIPIN & 3,36 & $1,04 \mathrm{E}-57$ & 2,51 & $6,72 \mathrm{E}-12$ & 1,40 & $7,45 \mathrm{E}-04$ \\
\hline TK1 & 5,98 & $1,28 \mathrm{E}-213$ & 5,42 & $9,05 \mathrm{E}-43$ & 3,39 & $1,79 \mathrm{E}-10$ \\
\hline TLE6 & 5,21 & $6,51 \mathrm{E}-21$ & 4,01 & $2,76 \mathrm{E}-13$ & 1,70 & $3,66 \mathrm{E}-03$ \\
\hline TLR4 & $-4,12$ & $9,88 \mathrm{E}-15$ & $-1,71$ & $1,18 \mathrm{E}-03$ & $-1,73$ & $1,80 \mathrm{E}-03$ \\
\hline TLR5 & $-3,18$ & $2,63 \mathrm{E}-07$ & $-1,89$ & $1,79 \mathrm{E}-04$ & $-1,66$ & $8,49 \mathrm{E}-04$ \\
\hline TLR6 & $-1,56$ & $3,81 \mathrm{E}-06$ & $-1,43$ & $3,15 \mathrm{E}-05$ & $-1,30$ & $7,17 \mathrm{E}-04$ \\
\hline TLR7 & $-4,49$ & $6,46 \mathrm{E}-18$ & $-2,16$ & $4,13 \mathrm{E}-04$ & $-2,37$ & $1,10 \mathrm{E}-05$ \\
\hline TM4SF19 & $-2,88$ & $2,89 \mathrm{E}-07$ & $-1,71$ & $9,91 \mathrm{E}-04$ & $-2,16$ & $7,59 \mathrm{E}-05$ \\
\hline TM4SF19-AS1 & $-2,43$ & $1,23 \mathrm{E}-05$ & $-1,61$ & $1,57 \mathrm{E}-03$ & $-1,98$ & $1,96 \mathrm{E}-04$ \\
\hline TM6SF1 & $-2,42$ & $3,73 \mathrm{E}-10$ & $-1,36$ & $1,33 \mathrm{E}-03$ & $-2,13$ & $5,51 \mathrm{E}-06$ \\
\hline TMEM106C & 2,58 & $1,57 \mathrm{E}-39$ & 1,85 & $9,25 \mathrm{E}-08$ & 1,12 & $8,73 \mathrm{E}-03$ \\
\hline TMEM170B & $-1,93$ & $2,32 \mathrm{E}-05$ & $-1,18$ & $7,62 \mathrm{E}-03$ & $-1,22$ & $9,66 \mathrm{E}-03$ \\
\hline TMEM178B & 4,89 & $6,16 \mathrm{E}-22$ & 3,06 & $8,57 \mathrm{E}-08$ & 1,85 & $1,06 \mathrm{E}-03$ \\
\hline TMEM194A & 1,47 & $5,88 \mathrm{E}-18$ & 1,03 & $5,53 \mathrm{E}-03$ & 0,96 & $4,71 \mathrm{E}-03$ \\
\hline TMEM198 & 4,14 & $3,00 \mathrm{E}-19$ & 3,22 & $3,23 \mathrm{E}-12$ & 2,08 & $6,66 \mathrm{E}-05$ \\
\hline TMEM220 & $-1,90$ & $4,00 \mathrm{E}-10$ & $-1,37$ & $1,55 \mathrm{E}-03$ & $-1,33$ & $6,77 \mathrm{E}-04$ \\
\hline TMEM255A & $-3,47$ & $3,03 \mathrm{E}-11$ & $-1,37$ & $3,90 \mathrm{E}-03$ & $-2,61$ & $6,10 \mathrm{E}-08$ \\
\hline TMEM37 & $-5,66$ & $1,45 \mathrm{E}-17$ & $-5,51$ & $4,67 \mathrm{E}-22$ & $-3,04$ & $1,45 \mathrm{E}-07$ \\
\hline TMEM52B & $-4,26$ & $4,86 \mathrm{E}-14$ & $-2,39$ & $9,11 \mathrm{E}-06$ & $-1,93$ & $6,91 \mathrm{E}-04$ \\
\hline TMEM86A & $-4,33$ & $8,14 \mathrm{E}-20$ & $-1,59$ & $4,34 \mathrm{E}-03$ & $-2,21$ & $8,46 \mathrm{E}-06$ \\
\hline TMPO & 1,96 & $1,26 \mathrm{E}-08$ & 1,81 & $3,86 \mathrm{E}-05$ & 1,41 & $1,98 \mathrm{E}-03$ \\
\hline TMPO-AS1 & 2,41 & $1,75 \mathrm{E}-06$ & 2,11 & $1,51 \mathrm{E}-05$ & 1,34 & $7,79 \mathrm{E}-03$ \\
\hline TMPRSS3 & 2,69 & $1,02 \mathrm{E}-07$ & 2,03 & $2,51 \mathrm{E}-05$ & 1,80 & $1,54 \mathrm{E}-04$ \\
\hline TMPRSS6 & 3,02 & $5,51 \mathrm{E}-10$ & 1,50 & $5,07 \mathrm{E}-03$ & 2,73 & $1,22 \mathrm{E}-08$ \\
\hline TNFRSF11A & 2,05 & $4,54 \mathrm{E}-17$ & 1,87 & $8,99 \mathrm{E}-05$ & 2,26 & $3,60 \mathrm{E}-08$ \\
\hline TNFRSF18 & 4,37 & $1,45 \mathrm{E}-38$ & 3,57 & $2,66 \mathrm{E}-20$ & 3,55 & $7,31 \mathrm{E}-20$ \\
\hline TNFRSF4 & 4,06 & $5,97 \mathrm{E}-64$ & 2,76 & $7,86 \mathrm{E}-16$ & 2,66 & $3,86 \mathrm{E}-09$ \\
\hline TNFRSF9 & 5,16 & $3,75 \mathrm{E}-45$ & 4,86 & $6,38 \mathrm{E}-30$ & 3,61 & $2,67 \mathrm{E}-18$ \\
\hline TNFSF4 & 4,74 & $1,32 \mathrm{E}-126$ & 3,15 & $1,87 \mathrm{E}-09$ & 1,77 & $3,45 \mathrm{E}-06$ \\
\hline TNIP3 & 3,09 & $2,29 \mathrm{E}-05$ & 3,04 & $3,31 \mathrm{E}-07$ & 2,17 & $1,52 \mathrm{E}-04$ \\
\hline TNN12 & $-4,31$ & $3,42 \mathrm{E}-23$ & $-1,70$ & $8,27 \mathrm{E}-04$ & $-2,83$ & $2,46 \mathrm{E}-08$ \\
\hline TNS4 & 3,78 & $7,45 \mathrm{E}-14$ & 3,86 & $1,91 \mathrm{E}-12$ & 2,99 & $3,32 \mathrm{E}-08$ \\
\hline TOM1L2 & $-2,63$ & $3,92 \mathrm{E}-09$ & $-1,59$ & $7,98 \mathrm{E}-04$ & $-1,54$ & $5,63 \mathrm{E}-04$ \\
\hline TONSL & 2,60 & $1,19 \mathrm{E}-23$ & 2,34 & $2,76 \mathrm{E}-11$ & 1,29 & $3,17 \mathrm{E}-03$ \\
\hline TOP2A & 6,92 & $8,29 \mathrm{E}-57$ & 6,15 & $1,97 \mathrm{E}-33$ & 3,90 & $5,38 \mathrm{E}-12$ \\
\hline TOX2 & 2,52 & $1,60 \mathrm{E}-06$ & 3,54 & $5,91 \mathrm{E}-11$ & 2,66 & $1,68 \mathrm{E}-06$ \\
\hline TPCN1 & $-1,89$ & $2,75 \mathrm{E}-08$ & $-1,61$ & $1,90 \mathrm{E}-04$ & $-1,29$ & $1,63 \mathrm{E}-03$ \\
\hline TPX2 & 7,57 & $5,96 \mathrm{E}-179$ & 6,22 & $1,03 \mathrm{E}-41$ & 4,04 & $2,32 \mathrm{E}-13$ \\
\hline TRAF3IP2 & 1,39 & $3,43 \mathrm{E}-10$ & 1,09 & $1,29 \mathrm{E}-03$ & 1,06 & $2,86 \mathrm{E}-03$ \\
\hline TRAF4 & 2,77 & $4,45 \mathrm{E}-14$ & 1,98 & $2,61 \mathrm{E}-06$ & 1,84 & $3,48 \mathrm{E}-06$ \\
\hline TRAJ52 & 1,21 & $9,49 \mathrm{E}-03$ & 1,38 & $3,49 \mathrm{E}-03$ & 1,31 & $5,27 \mathrm{E}-03$ \\
\hline TRAJ54 & 1,28 & $4,74 \mathrm{E}-03$ & 1,68 & $1,91 \mathrm{E}-04$ & 1,79 & $7,44 \mathrm{E}-05$ \\
\hline TRAV24 & 2,03 & $1,86 \mathrm{E}-03$ & 2,29 & $6,25 \mathrm{E}-05$ & 1,63 & $3,99 \mathrm{E}-03$ \\
\hline TRAV26-1 & 1,30 & $1,45 \mathrm{E}-04$ & 1,62 & $6,47 \mathrm{E}-05$ & 1,53 & $1,60 \mathrm{E}-03$ \\
\hline TRAV26-2 & 1,96 & $1,05 \mathrm{E}-04$ & 1,98 & $2,68 \mathrm{E}-05$ & 1,55 & $1,90 \mathrm{E}-03$ \\
\hline TRAV38-2DV8 & 1,33 & $1,02 \mathrm{E}-04$ & 1,25 & $1,96 \mathrm{E}-03$ & 1,22 & $5,76 \mathrm{E}-03$ \\
\hline TREM2 & $-6,61$ & $8,88 \mathrm{E}-125$ & $-3,33$ & $2,40 \mathrm{E}-10$ & $-4,96$ & $1,00 \mathrm{E}-38$ \\
\hline TRIM59 & 1,85 & $5,45 \mathrm{E}-11$ & 1,53 & $9,78 \mathrm{E}-05$ & 1,21 & $6,70 \mathrm{E}-03$ \\
\hline TRIP13 & 5,25 & $1,22 \mathrm{E}-97$ & 4,19 & $1,41 \mathrm{E}-21$ & 2,72 & $4,39 \mathrm{E}-08$ \\
\hline TROAP & 5,87 & $2,67 \mathrm{E}-107$ & 5,12 & $9,25 \mathrm{E}-31$ & 3,21 & $7,64 \mathrm{E}-09$ \\
\hline TSPAN10 & $-2,44$ & $1,13 \mathrm{E}-03$ & $-2,63$ & $8,56 \mathrm{E}-08$ & $-2,22$ & $1,74 \mathrm{E}-06$ \\
\hline TSPAN5 & 1,63 & $4,52 \mathrm{E}-05$ & 2,07 & $1,09 \mathrm{E}-05$ & 1,74 & $2,52 \mathrm{E}-04$ \\
\hline TTBK1 & 4,51 & $3,20 \mathrm{E}-12$ & 2,68 & $2,15 \mathrm{E}-05$ & 3,53 & $9,55 \mathrm{E}-11$ \\
\hline TTF2 & 2,20 & $5,64 \mathrm{E}-41$ & 1,90 & $3,61 \mathrm{E}-06$ & 1,26 & $1,94 \mathrm{E}-03$ \\
\hline TTK & 6,16 & $4,78 \mathrm{E}-115$ & 5,08 & $1,40 \mathrm{E}-27$ & 3,29 & $1,66 \mathrm{E}-09$ \\
\hline TYMS & 6,69 & $6,24 \mathrm{E}-157$ & 5,61 & $1,04 \mathrm{E}-43$ & 3,62 & $5,71 \mathrm{E}-12$ \\
\hline TYROBP & $-3,41$ & $3,62 \mathrm{E}-13$ & $-1,43$ & $4,92 \mathrm{E}-03$ & $-2,04$ & $3,91 \mathrm{E}-05$ \\
\hline UBE2C & 5,98 & $9,68 \mathrm{E}-17$ & 5,28 & $3,44 \mathrm{E}-19$ & 3,22 & $2,82 \mathrm{E}-08$ \\
\hline UBE2CP1 & 6,99 & $8,47 \mathrm{E}-36$ & 5,32 & $5,10 \mathrm{E}-22$ & 3,00 & $2,25 \mathrm{E}-07$ \\
\hline UBE2CP3 & 6,59 & $1,24 \mathrm{E}-45$ & 4,84 & $1,25 \mathrm{E}-18$ & 3,13 & $4,39 \mathrm{E}-08$ \\
\hline UBE2CP4 & 6,24 & $2,01 \mathrm{E}-26$ & 5,04 & $4,51 \mathrm{E}-20$ & 2,67 & $4,77 \mathrm{E}-06$ \\
\hline UBE2S & 3,21 & $6,13 \mathrm{E}-73$ & 2,40 & $3,95 \mathrm{E}-13$ & 1,32 & $1,16 \mathrm{E}-03$ \\
\hline UBE2SP2 & 3,28 & $4,76 \mathrm{E}-45$ & 2,53 & $1,35 \mathrm{E}-12$ & 1,31 & $3,00 \mathrm{E}-03$ \\
\hline UBE2T & 5,05 & $4,02 \mathrm{E}-140$ & 4,11 & $1,68 \mathrm{E}-29$ & 2,65 & $1,02 \mathrm{E}-07$ \\
\hline UHRF1 & 4,03 & $1,75 \mathrm{E}-20$ & 3,96 & $1,53 \mathrm{E}-18$ & 2,46 & $2,10 \mathrm{E}-06$ \\
\hline UNG & 2,50 & $1,79 \mathrm{E}-37$ & 2,31 & $3,22 \mathrm{E}-10$ & 1,37 & 2,67E-03 \\
\hline
\end{tabular}




\begin{tabular}{|c|c|c|c|c|c|c|}
\hline VAT1 & $-3,16$ & $6,43 \mathrm{E}-11$ & $-1,58$ & $2,28 \mathrm{E}-03$ & $-2,33$ & $2,39 \mathrm{E}-06$ \\
\hline VCAM1 & 4,00 & $2,25 \mathrm{E}-11$ & 3,36 & $5,51 \mathrm{E}-08$ & 2,48 & $1,42 \mathrm{E}-05$ \\
\hline VSTM1 & $-3,41$ & $1,42 \mathrm{E}-05$ & $-2,86$ & $8,79 \mathrm{E}-06$ & $-2,04$ & $4,51 \mathrm{E}-04$ \\
\hline VSTM4 & 2,50 & $1,21 \mathrm{E}-04$ & 1,73 & $4,25 \mathrm{E}-03$ & 1,50 & $8,77 \mathrm{E}-03$ \\
\hline WDHD1 & 3,66 & $2,65 \mathrm{E}-60$ & 3,17 & $3,22 \mathrm{E}-16$ & 2,02 & $2,21 \mathrm{E}-05$ \\
\hline WDR34 & 3,20 & $1,72 \mathrm{E}-43$ & 3,01 & $8,35 \mathrm{E}-20$ & 1,89 & $6,93 \mathrm{E}-05$ \\
\hline WDR62 & 4,02 & $4,98 \mathrm{E}-85$ & 3,35 & $5,21 \mathrm{E}-24$ & 1,82 & $4,88 \mathrm{E}-04$ \\
\hline WDR65 & 6,02 & $4,97 \mathrm{E}-68$ & 2,71 & $2,05 \mathrm{E}-05$ & 2,36 & $4,89 \mathrm{E}-05$ \\
\hline WDR76 & 3,06 & $4.64 \mathrm{E}-20$ & 2,48 & $4,80 \mathrm{E}-10$ & 1,58 & $6.65 \mathrm{E}-04$ \\
\hline WDR91 & $-2,11$ & $3,25 \mathrm{E}-11$ & $-1,28$ & $5,17 \mathrm{E}-04$ & $-1,11$ & $7,53 \mathrm{E}-03$ \\
\hline WEE1 & 2,84 & $3,79 \mathrm{E}-44$ & 2,52 & $1,16 \mathrm{E}-11$ & 1,73 & $1,68 \mathrm{E}-04$ \\
\hline $\mathrm{XCL1}$ & 5,67 & $6,04 \mathrm{E}-47$ & 4,98 & $2,67 \mathrm{E}-31$ & 3,21 & $8,28 \mathrm{E}-14$ \\
\hline $\mathrm{XCL} 2$ & 5,07 & $2,02 \mathrm{E}-21$ & 4,35 & $2,23 \mathrm{E}-18$ & 2,22 & $7,16 \mathrm{E}-06$ \\
\hline XRCC2 & 3,59 & $2,81 \mathrm{E}-43$ & 3,06 & $4,69 \mathrm{E}-13$ & 2,07 & $1,33 \mathrm{E}-05$ \\
\hline $\begin{array}{r}\text { XXBAC- } \\
\text { BPGBPG24018 }\end{array}$ & & & & & & \\
\hline & 2,72 & $5,27 \mathrm{E}-04$ & 2,60 & $5,17 \mathrm{E}-05$ & 1,70 & $3,26 \mathrm{E}-03$ \\
\hline Z83851,1 & $-2,40$ & $1,05 \mathrm{E}-03$ & $-1,88$ & $1,86 \mathrm{E}-03$ & $-2,26$ & $5,10 \mathrm{E}-05$ \\
\hline ZACN & 4,83 & $2,23 E-26$ & 2,68 & $1,16 \mathrm{E}-06$ & 1,66 & $1,37 \mathrm{E}-03$ \\
\hline ZBED2 & 8,43 & $2,68 \mathrm{E}-105$ & 6,79 & $4,00 \mathrm{E}-55$ & 5,71 & $3,57 \mathrm{E}-39$ \\
\hline ZBED3 & $-2,92$ & $4,11 \mathrm{E}-15$ & $-1,55$ & $4,18 \mathrm{E}-04$ & $-1,57$ & $3,99 \mathrm{E}-04$ \\
\hline ZBED3-AS1 & $-2,79$ & $2,69 \mathrm{E}-06$ & $-1,43$ & $9,10 \mathrm{E}-03$ & $-1,89$ & $3,43 \mathrm{E}-04$ \\
\hline ZBTB32 & 5,30 & $4,96 \mathrm{E}-27$ & 4,06 & $6,25 \mathrm{E}-18$ & 2,46 & $5,72 \mathrm{E}-07$ \\
\hline ZC3H12D & 1,52 & $9,60 \mathrm{E}-10$ & 1,38 & $1,83 \mathrm{E}-03$ & 1,79 & $1,09 \mathrm{E}-05$ \\
\hline ZFHX3 & $-1,90$ & $2,31 \mathrm{E}-06$ & $-1,21$ & $2,81 \mathrm{E}-03$ & $-1,23$ & $3,35 \mathrm{E}-03$ \\
\hline ZFYVE26 & $-2,02$ & $1,69 \mathrm{E}-04$ & $-1,41$ & $6,57 \mathrm{E}-03$ & $-1,50$ & $2,64 \mathrm{E}-03$ \\
\hline ZNF165 & 3,37 & $1,06 \mathrm{E}-26$ & 1,85 & $3,86 \mathrm{E}-04$ & 1,26 & $7,23 \mathrm{E}-03$ \\
\hline ZNF257 & 1,76 & $3,78 \mathrm{E}-07$ & 1,39 & $3,74 \mathrm{E}-03$ & 1,16 & $6,26 \mathrm{E}-03$ \\
\hline ZNF282 & 3,33 & $9,40 \mathrm{E}-107$ & 1,99 & $5,74 \mathrm{E}-10$ & 1,36 & $8,51 \mathrm{E}-05$ \\
\hline ZNF367 & 2,45 & $4,20 \mathrm{E}-08$ & 2,17 & 1,44E-06 & 1,48 & $2,25 \mathrm{E}-03$ \\
\hline ZNF703 & $-4,12$ & $3,78 \mathrm{E}-26$ & $-1,80$ & $1,75 \mathrm{E}-04$ & $-1,61$ & $2,06 \mathrm{E}-03$ \\
\hline ZRANB3 & 2,26 & $7,39 \mathrm{E}-23$ & 1,26 & $3,02 \mathrm{E}-04$ & 1,09 & $8,44 \mathrm{E}-03$ \\
\hline ZWINT & 5,37 & 1,17E-182 & 4,50 & 1,04E-24 & 2,95 & $2,93 \mathrm{E}-08$ \\
\hline
\end{tabular}


2) Genes regulados comumente por OKT3 e FvFc $R$

\begin{tabular}{|c|c|c|c|c|}
\hline \multirow[b]{2}{*}{ Gene } & \multicolumn{2}{|c|}{ FvFc R } & \multicolumn{2}{|c|}{ OKT3 } \\
\hline & $F C(\log 2)$ & $p$ value & $F C(\log 2)$ & $\mathrm{p}$ value \\
\hline AACS & 0,91 & $8,24 \mathrm{E}-03$ & 1,29 & $2,10 \mathrm{E}-06$ \\
\hline AATK & $-1,18$ & 4,49E-03 & $-2,54$ & $1,06 \mathrm{E}-11$ \\
\hline ABCA5 & $-0,95$ & $4,31 \mathrm{E}-03$ & $-1,06$ & $4,90 \mathrm{E}-07$ \\
\hline ABCC5 & $-1,26$ & $6,41 \mathrm{E}-05$ & $-1,59$ & $4,66 \mathrm{E}-23$ \\
\hline ABCF2 & 0,86 & $8,23 \mathrm{E}-03$ & 1,39 & $3,90 \mathrm{E}-13$ \\
\hline ABRACL & 0,97 & $6,02 \mathrm{E}-03$ & 1,30 & $3,08 \mathrm{E}-17$ \\
\hline AC002069,5 & 2,11 & $2,71 \mathrm{E}-04$ & 2,97 & $3,05 \mathrm{E}-08$ \\
\hline AC004014,4 & 1,28 & 1,60E-04 & 1,79 & $3,88 \mathrm{E}-17$ \\
\hline AC004158,2 & 1,98 & $1,79 \mathrm{E}-03$ & 3,33 & $2,83 \mathrm{E}-07$ \\
\hline AC005102,1 & 1,52 & 1,84E-05 & 2,12 & $1,26 \mathrm{E}-19$ \\
\hline AC005154,6 & $-1,20$ & 1,23E-03 & $-1,84$ & $5,11 \mathrm{E}-18$ \\
\hline AC005154,7 & $-1,55$ & 1,87E-03 & $-3,02$ & $1,68 \mathrm{E}-10$ \\
\hline AC005943,5 & 1,45 & $1,50 \mathrm{E}-03$ & 2,95 & $1,94 \mathrm{E}-20$ \\
\hline AC006129,2 & $-1,31$ & 5,98E-03 & $-2,38$ & $3,65 \mathrm{E}-06$ \\
\hline AC006369,2 & $-1,65$ & $2,65 \mathrm{E}-03$ & $-2,61$ & $3,59 \mathrm{E}-05$ \\
\hline AC007750,5 & $-1,81$ & 4,93E-03 & $-2,82$ & $5,05 \mathrm{E}-04$ \\
\hline AC008268,2 & 1,11 & $2,66 \mathrm{E}-03$ & 0,94 & $3,38 \mathrm{E}-03$ \\
\hline AC009133,17 & $-1,94$ & $2,64 \mathrm{E}-04$ & $-2,78$ & $5,86 \mathrm{E}-05$ \\
\hline AC010894,4 & 1,98 & $9,82 \mathrm{E}-08$ & 2,11 & $9,91 \mathrm{E}-17$ \\
\hline AC010904,1 & 1,44 & $2,50 \mathrm{E}-03$ & 2,25 & $1,52 \mathrm{E}-07$ \\
\hline AC011747,4 & 1,98 & $1,53 \mathrm{E}-03$ & 2,42 & $4,41 \mathrm{E}-04$ \\
\hline AC016697,2 & 1,55 & $1,62 \mathrm{E}-03$ & 2,16 & $2,61 \mathrm{E}-05$ \\
\hline AC016700,3 & $-1,61$ & $1,30 \mathrm{E}-03$ & $-2,52$ & $6,07 \mathrm{E}-06$ \\
\hline AC018634,9 & 2,14 & $9,41 \mathrm{E}-04$ & 3,14 & $8,69 \mathrm{E}-05$ \\
\hline AC018816,3 & 2,18 & $1,83 \mathrm{E}-07$ & 1,93 & $1,33 \mathrm{E}-06$ \\
\hline AC021860,1 & $-1,82$ & 4,83E-03 & $-3,30$ & $3,08 \mathrm{E}-05$ \\
\hline AC022182,1 & $-2,09$ & $6,14 \mathrm{E}-04$ & $-3,59$ & $3,76 \mathrm{E}-06$ \\
\hline AC022182,2 & 1,65 & 2,31E-06 & 2,02 & $1,17 \mathrm{E}-42$ \\
\hline AC055811,5 & 1,66 & $8,10 \mathrm{E}-04$ & 1,83 & $2,76 \mathrm{E}-04$ \\
\hline AC068282,3 & $-1,68$ & 5,19E-03 & $-1,88$ & $4,99 \mathrm{E}-03$ \\
\hline AC069282,6 & $-1,17$ & 4,81E-03 & $-1,35$ & $4,42 \mathrm{E}-05$ \\
\hline AC073310,4 & 2,00 & $1,18 \mathrm{E}-05$ & 2,69 & $3,04 \mathrm{E}-17$ \\
\hline AC078883,3 & $-1,85$ & $4,39 \mathrm{E}-04$ & $-3,37$ & $2,83 \mathrm{E}-08$ \\
\hline AC079922,3 & $-1,77$ & $8,16 \mathrm{E}-05$ & $-2,06$ & $9,87 \mathrm{E}-07$ \\
\hline AC084018,1 & $-1,52$ & $1,81 \mathrm{E}-03$ & $-2,57$ & $1,51 \mathrm{E}-06$ \\
\hline AC087499,5 & $-1,21$ & $4,56 \mathrm{E}-03$ & $-2,96$ & $6,71 \mathrm{E}-11$ \\
\hline AC092580,4 & 1,30 & $6,83 \mathrm{E}-03$ & 2,03 & $4,28 \mathrm{E}-05$ \\
\hline AC093642,4 & $-1,70$ & 1,90E-03 & $-4,86$ & $1,77 \mathrm{E}-11$ \\
\hline AC093818,1 & $-1,70$ & $8,27 \mathrm{E}-04$ & $-2,06$ & $1,75 \mathrm{E}-04$ \\
\hline AC096579,13 & $-1,74$ & $2,13 \mathrm{E}-03$ & $-2,93$ & $6,47 \mathrm{E}-06$ \\
\hline AC097711,1 & 2,21 & $7,53 \mathrm{E}-06$ & 2,80 & $6,17 \mathrm{E}-10$ \\
\hline AC098592,6 & 1,21 & 1,07E-03 & 1,78 & $7,35 \mathrm{E}-13$ \\
\hline AC104651,1 & 1,33 & $1,55 \mathrm{E}-03$ & 2,19 & $1,06 \mathrm{E}-16$ \\
\hline AC118138,2 & 0,94 & $1,00 \mathrm{E}-02$ & 1,03 & $8,07 \mathrm{E}-04$ \\
\hline AC133528,2 & $-1,13$ & $8,66 \mathrm{E}-03$ & $-1,52$ & $3,47 \mathrm{E}-05$ \\
\hline AC138783,12 & 1,26 & $2,99 \mathrm{E}-03$ & 0,92 & $2,42 \mathrm{E}-04$ \\
\hline ACADM & 1,05 & $7,52 \mathrm{E}-03$ & 1,55 & $2,19 \mathrm{E}-07$ \\
\hline ACAT2 & 1,16 & $3,58 \mathrm{E}-03$ & 1,55 & $5,37 \mathrm{E}-05$ \\
\hline ACCS & $-1,44$ & $9,22 \mathrm{E}-05$ & $-2,85$ & $1,19 \mathrm{E}-16$ \\
\hline ACKR2 & 2,32 & $2,30 \mathrm{E}-05$ & 2,18 & $6,74 \mathrm{E}-04$ \\
\hline ACRV1 & 2,43 & 1,47E-04 & 4,05 & $1,13 \mathrm{E}-08$ \\
\hline ACTBP11 & 0,95 & $5,83 \mathrm{E}-03$ & 0,98 & $2,07 \mathrm{E}-04$ \\
\hline ACTG1 & 1,31 & $1,25 \mathrm{E}-04$ & 1,59 & $2,47 \mathrm{E}-10$ \\
\hline ACTG1P1 & 1,30 & 1,69E-04 & 1,50 & $1,99 \mathrm{E}-08$ \\
\hline ACTG1P11 & 1,32 & $2,41 \mathrm{E}-04$ & 1,42 & $2,98 \mathrm{E}-06$ \\
\hline ACTG1P12 & 1,21 & $1,79 \mathrm{E}-03$ & 1,08 & $2,08 \mathrm{E}-04$ \\
\hline ACTG1P2 & 1,41 & $8,37 \mathrm{E}-04$ & 1,45 & $1,97 \mathrm{E}-05$ \\
\hline ACTG1P9 & 1,38 & 1,34E-04 & 1,51 & $9,60 \mathrm{E}-07$ \\
\hline ACTN1-AS1 & $-2,91$ & $2,32 \mathrm{E}-06$ & $-3,25$ & $3,02 \mathrm{E}-05$ \\
\hline ACTR3B & 0,95 & $6,30 \mathrm{E}-03$ & 1,15 & $3,54 \mathrm{E}-06$ \\
\hline ACVR1C & $-1,49$ & 5,91E-03 & $-2,33$ & $7,78 \mathrm{E}-06$ \\
\hline ADAM23 & $-1,93$ & $2,58 \mathrm{E}-04$ & $-2,19$ & $2,36 \mathrm{E}-04$ \\
\hline ADAM28 & $-1,63$ & $6,23 \mathrm{E}-06$ & $-3,36$ & $8,48 \mathrm{E}-15$ \\
\hline ADAM9 & $-1,35$ & $9,54 \mathrm{E}-03$ & $-2,02$ & $6,79 \mathrm{E}-04$ \\
\hline ADAMTS10 & $-1,65$ & $7,37 \mathrm{E}-04$ & $-3,66$ & $8,51 \mathrm{E}-14$ \\
\hline ADAMTS7 & 2,18 & $1,07 \mathrm{E}-05$ & 1,91 & $4,36 \mathrm{E}-04$ \\
\hline ADARB2 & $-1,20$ & $6,91 \mathrm{E}-03$ & $-2,48$ & $1,02 \mathrm{E}-08$ \\
\hline ADCY1 & 1,80 & $5,29 \mathrm{E}-03$ & 4,54 & $2,84 \mathrm{E}-17$ \\
\hline ADCY10P1 & $-1,62$ & $1,31 \mathrm{E}-03$ & $-2,02$ & $7,96 \mathrm{E}-06$ \\
\hline ADCY4 & $-1,18$ & $6,01 \mathrm{E}-03$ & $-1,55$ & $1,20 \mathrm{E}-07$ \\
\hline ADHFE1 & $-1,54$ & $9,19 \mathrm{E}-04$ & $-2,58$ & $4,89 \mathrm{E}-08$ \\
\hline ADIRF-AS1 & $-2,04$ & $2,35 \mathrm{E}-06$ & $-3,32$ & $3,65 \mathrm{E}-32$ \\
\hline ADRB2 & $-1,42$ & $8,79 \mathrm{E}-03$ & $-2,11$ & $3,95 \mathrm{E}-05$ \\
\hline AEBP1 & 1,22 & 9,79E-03 & 1,54 & $8,38 \mathrm{E}-04$ \\
\hline
\end{tabular}

\begin{tabular}{|c|c|c|c|c|}
\hline AFAP1L2 & 1,43 & $1,08 \mathrm{E}-03$ & 2,45 & $5,69 \mathrm{E}-25$ \\
\hline AFMID & 1,65 & $9,00 \mathrm{E}-05$ & 2,14 & $3,15 \mathrm{E}-12$ \\
\hline AGAP9 & $-1,10$ & $7,95 \mathrm{E}-03$ & $-1,19$ & $1,72 \mathrm{E}-03$ \\
\hline AGO4 & $-0,98$ & $6,77 \mathrm{E}-03$ & $-1,60$ & $8,03 \mathrm{E}-08$ \\
\hline AGRP & $-1,90$ & $2,74 \mathrm{E}-03$ & $-2,80$ & $5,48 \mathrm{E}-04$ \\
\hline AHI1 & 1,40 & $4,97 \mathrm{E}-03$ & 1,58 & $5,82 \mathrm{E}-04$ \\
\hline AlF1L & 2,87 & 1,79E-06 & 2,80 & $2,67 \mathrm{E}-04$ \\
\hline AK5 & $-1,74$ & $2,53 \mathrm{E}-03$ & $-3,24$ & $2,86 \mathrm{E}-06$ \\
\hline AKR1C1 & $-1,60$ & $8,14 \mathrm{E}-05$ & $-2,01$ & $9,62 \mathrm{E}-08$ \\
\hline AKR1C2 & $-1,43$ & $7,15 \mathrm{E}-04$ & $-1,79$ & $1,89 \mathrm{E}-06$ \\
\hline AKR1C3 & $-1,29$ & 1,16E-03 & $-2,23$ & $2,64 \mathrm{E}-13$ \\
\hline AKR1C7P & $-1,76$ & $2,20 \mathrm{E}-04$ & $-1,75$ & $5,92 \mathrm{E}-05$ \\
\hline AKR1CL1 & $-1,61$ & $9,33 \mathrm{E}-03$ & $-2,12$ & $2,01 \mathrm{E}-03$ \\
\hline AL031663,2 & $-1,46$ & $1,77 \mathrm{E}-03$ & $-1,42$ & $6,03 \mathrm{E}-04$ \\
\hline AL627309,1 & $-1,06$ & $8,98 \mathrm{E}-03$ & $-1,93$ & $6,13 \mathrm{E}-12$ \\
\hline ALS2CL & $-1,73$ & $1,78 \mathrm{E}-04$ & $-3,24$ & $2,39 \mathrm{E}-28$ \\
\hline ALYREF & 1,52 & $6,57 \mathrm{E}-06$ & 2,02 & $6,11 \mathrm{E}-17$ \\
\hline $\mathrm{AMH}$ & 1,93 & $7,21 \mathrm{E}-04$ & 3,53 & $3,39 \mathrm{E}-14$ \\
\hline AMIG01 & $-1,36$ & $3,72 \mathrm{E}-03$ & $-2,27$ & $3,11 \mathrm{E}-06$ \\
\hline AMN & $-1,36$ & 7,73E-03 & $-2,97$ & $3,65 \mathrm{E}-08$ \\
\hline AMT & $-1,15$ & $4,12 \mathrm{E}-03$ & $-1,96$ & $2,99 \mathrm{E}-07$ \\
\hline AMY1A & $-1,58$ & 1,10E-03 & $-2,21$ & $3,89 \mathrm{E}-07$ \\
\hline AMY1B & $-1,41$ & $3,35 \mathrm{E}-03$ & $-2,24$ & $1,59 \mathrm{E}-08$ \\
\hline AMY2A & $\begin{array}{ll}-1,33 \\
\end{array}$ & $5,58 \mathrm{E}-03$ & $-2,87$ & $2,26 \mathrm{E}-08$ \\
\hline AMY2B & $-1,46$ & $2,47 \mathrm{E}-03$ & $-2,31$ & $6,89 \mathrm{E}-08$ \\
\hline ANKLE1 & 1,90 & $1,85 \mathrm{E}-07$ & 2,09 & $1,81 \mathrm{E}-12$ \\
\hline ANKRD33B & 1,76 & $4,17 \mathrm{E}-03$ & 3,49 & $6,94 \mathrm{E}-11$ \\
\hline ANKRD35 & 1,85 & $2,35 \mathrm{E}-04$ & 1,89 & $4,05 \mathrm{E}-06$ \\
\hline ANKRD36BP2 & $-1,20$ & $9,35 \mathrm{E}-03$ & $-2,17$ & $1,06 \mathrm{E}-05$ \\
\hline ANKZF1 & $-1,16$ & $6,31 \mathrm{E}-03$ & $-1,38$ & $4,01 \mathrm{E}-04$ \\
\hline ANP32B & 1,16 & $4,16 \mathrm{E}-04$ & 1,06 & $1,31 \mathrm{E}-10$ \\
\hline ANP32BP1 & 1,15 & $9,52 \mathrm{E}-04$ & 1,22 & $4,70 \mathrm{E}-17$ \\
\hline ANP32BP3 & 1,17 & $6,91 \mathrm{E}-04$ & 1,22 & $2,44 \mathrm{E}-16$ \\
\hline ANPEP & $-1,49$ & $4,53 \mathrm{E}-03$ & $-2,22$ & $1,65 \mathrm{E}-04$ \\
\hline ANXA1 & $-1,27$ & $2,63 \mathrm{E}-03$ & $-1,86$ & $1,50 \mathrm{E}-05$ \\
\hline AP000251,3 & 2,88 & $3,22 \mathrm{E}-06$ & 3,56 & $3,58 \mathrm{E}-07$ \\
\hline AP000347,2 & $-1,20$ & 1,33E-03 & $-1,29$ & $4,92 \mathrm{E}-05$ \\
\hline AP000350,4 & 1,24 & 1,39E-03 & 1,27 & $8,54 \mathrm{E}-05$ \\
\hline AP000476,1 & 1,62 & $2,98 \mathrm{E}-03$ & 2,51 & $2,17 \mathrm{E}-06$ \\
\hline AP001055,1 & $-2,22$ & $6,66 \mathrm{E}-05$ & $-2,94$ & $1,28 \mathrm{E}-04$ \\
\hline AP001469,9 & $-1,64$ & $2,59 \mathrm{E}-03$ & $-1,97$ & $1,32 \mathrm{E}-03$ \\
\hline AP002954,4 & $-2,11$ & $9,59 \mathrm{E}-04$ & $-4,46$ & $2,95 \mathrm{E}-09$ \\
\hline AP006222,2 & $-1,44$ & $3,97 \mathrm{E}-03$ & $-1,85$ & $3,19 \mathrm{E}-04$ \\
\hline APBB3 & $-1,16$ & $5,13 \mathrm{E}-03$ & $-1,88$ & $9,35 \mathrm{E}-12$ \\
\hline APITD1 & 1,25 & $2,91 \mathrm{E}-03$ & 1,41 & 9,93E-08 \\
\hline APMAP & $-0,89$ & $5,32 \mathrm{E}-03$ & $-1,06$ & $2,49 \mathrm{E}-08$ \\
\hline APOBEC3B & 3,03 & $1,72 \mathrm{E}-10$ & 3,28 & $7,81 \mathrm{E}-17$ \\
\hline APOBEC3G & 1,31 & 1,60E-04 & 1,95 & $7,99 \mathrm{E}-25$ \\
\hline APOL4 & 3,04 & $6,88 \mathrm{E}-09$ & 2,15 & $2,53 \mathrm{E}-04$ \\
\hline APOLD1 & 1,43 & $3,87 \mathrm{E}-03$ & 1,64 & $9,61 \mathrm{E}-05$ \\
\hline APPL2 & $-1,00$ & 1,76E-03 & $-1,49$ & $6,56 \mathrm{E}-11$ \\
\hline ARF6 & 0,86 & $7,75 \mathrm{E}-03$ & 0,96 & $1,03 \mathrm{E}-07$ \\
\hline ARHGAP12 & $-1,30$ & 7,63E-04 & $-2,05$ & $1,42 \mathrm{E}-19$ \\
\hline ARHGAP19 & 1,11 & $6,31 \mathrm{E}-03$ & 1,08 & $2,73 \mathrm{E}-11$ \\
\hline ARHGEF18 & $-1,06$ & $3,63 \mathrm{E}-03$ & $-1,24$ & $7,63 \mathrm{E}-06$ \\
\hline ARHGEF35 & 1,48 & $8,53 \mathrm{E}-03$ & 2,23 & $3,10 \mathrm{E}-04$ \\
\hline ARHGEF5 & 1,85 & 1,04E-04 & 2,70 & $5,81 \mathrm{E}-08$ \\
\hline ARRDC3 & $-1,62$ & 1,18E-03 & $-2,39$ & $1,34 \mathrm{E}-05$ \\
\hline ARRDC5 & $-2,36$ & $2,48 \mathrm{E}-06$ & $-3,19$ & $2,19 \mathrm{E}-10$ \\
\hline ARSA & $-1,07$ & $5,56 \mathrm{E}-03$ & $-1,97$ & $5,74 \mathrm{E}-15$ \\
\hline ARSG & $-1,58$ & $7,04 \mathrm{E}-05$ & $-2,33$ & $5,38 \mathrm{E}-11$ \\
\hline ASAP2 & 2,31 & $6,80 \mathrm{E}-08$ & 2,05 & $1,38 \mathrm{E}-07$ \\
\hline ASCC1 & 1,46 & 1,15E-04 & 2,05 & $4,37 \mathrm{E}-13$ \\
\hline ASPHD2 & 1,22 & $3,48 \mathrm{E}-03$ & 1,78 & $1,09 \mathrm{E}-06$ \\
\hline ATAD3A & 1,12 & $4,98 \mathrm{E}-04$ & 1,63 & $8,52 \mathrm{E}-14$ \\
\hline ATAD3C & 1,16 & $4,22 \mathrm{E}-03$ & 1,35 & $1,99 \mathrm{E}-05$ \\
\hline ATAD5 & 1,69 & $2,80 \mathrm{E}-04$ & 2,09 & $5,13 \mathrm{E}-10$ \\
\hline ATIC & 1,10 & 1,50E-03 & 1,56 & $2,15 \mathrm{E}-21$ \\
\hline ATP2A1 & 2,38 & 1,41E-08 & 2,95 & $1,24 \mathrm{E}-20$ \\
\hline ATP2B1 & $-1,16$ & $2,51 \mathrm{E}-03$ & $-1,44$ & 3,83E-05 \\
\hline ATP5G3 & 0,88 & $9,21 \mathrm{E}-03$ & 0,91 & $1,84 \mathrm{E}-07$ \\
\hline ATP8B3 & 1,35 & $6,12 \mathrm{E}-05$ & 1,66 & $1,35 \mathrm{E}-10$ \\
\hline ATXN7L1 & $-1,19$ & $6,73 \mathrm{E}-04$ & $-1,50$ & $4,80 \mathrm{E}-12$ \\
\hline AURKAPS1 & 2,24 & $2,13 \mathrm{E}-04$ & 3,11 & $4,35 \mathrm{E}-07$ \\
\hline AXIN2 & $-1,34$ & 8,93E-03 & $-2,74$ & $5,23 \mathrm{E}-06$ \\
\hline B3GAT1 & $-1,52$ & $3,95 \mathrm{E}-04$ & $-1,67$ & $1,06 \mathrm{E}-04$ \\
\hline B4GALT2 & 1,83 & $9,62 \mathrm{E}-07$ & 2,64 & $1,07 \mathrm{E}-20$ \\
\hline B4GALT6 & 1,51 & $2,98 \mathrm{E}-04$ & 1,75 & $1,89 \mathrm{E}-07$ \\
\hline
\end{tabular}




\begin{tabular}{|c|c|c|c|c|}
\hline $\mathrm{BACH} 2$ & 1,20 & $6,36 \mathrm{E}-03$ & 1,84 & 2,04E-05 \\
\hline BAIAP3 & $-1,93$ & $4,51 \mathrm{E}-05$ & $-3,55$ & $6,78 \mathrm{E}-10$ \\
\hline BARD1 & 1,84 & $1,02 \mathrm{E}-05$ & 2,24 & $2,68 \mathrm{E}-20$ \\
\hline BBS2 & $-1,52$ & $5,78 \mathrm{E}-05$ & $-2,14$ & $3,83 \mathrm{E}-11$ \\
\hline BBS5 & $-1,08$ & $4,18 \mathrm{E}-03$ & $-1,67$ & $4,61 \mathrm{E}-07$ \\
\hline BCL2L12 & 1,83 & $1,43 \mathrm{E}-08$ & 2,14 & $5,22 \mathrm{E}-38$ \\
\hline BCL9L & $-1,21$ & 4,44E-03 & $-1,92$ & $6,35 \mathrm{E}-07$ \\
\hline BIK & 1,30 & $3,61 \mathrm{E}-03$ & 1,38 & $4,43 \mathrm{E}-04$ \\
\hline BLMH & 0,89 & $7,51 \mathrm{E}-03$ & 0,94 & $1,95 \mathrm{E}-08$ \\
\hline BORA & 1,32 & $8,12 \mathrm{E}-04$ & 1,63 & $3,82 \mathrm{E}-13$ \\
\hline $\mathrm{BRI3BP}$ & 1,09 & $5,11 \mathrm{E}-03$ & 1,65 & $3,45 \mathrm{E}-12$ \\
\hline BTBD16 & 3,42 & $9,28 \mathrm{E}-08$ & 4,35 & $1,11 \mathrm{E}-08$ \\
\hline BTN3A1 & $-1,32$ & $2,68 \mathrm{E}-03$ & $-2,34$ & $6,31 \mathrm{E}-10$ \\
\hline BX842568,2 & 1,40 & $3,85 \mathrm{E}-03$ & 1,43 & $7,03 \mathrm{E}-03$ \\
\hline BYSL & 1,34 & $3,70 \mathrm{E}-04$ & 2,09 & $8,53 \mathrm{E}-10$ \\
\hline BZW1 & 1,30 & 2,99E-04 & 2,33 & $2,38 \mathrm{E}-23$ \\
\hline BZW1P1 & 1,45 & $1,38 \mathrm{E}-03$ & 2,47 & $1,50 \mathrm{E}-10$ \\
\hline BZW1P2 & 1,33 & $9,16 \mathrm{E}-04$ & 2,40 & $1,81 \mathrm{E}-16$ \\
\hline BZW2 & 0,98 & $9,72 \mathrm{E}-03$ & 1,32 & $2,13 \mathrm{E}-12$ \\
\hline C110RF21 & $-1,64$ & $6,70 \mathrm{E}-04$ & $-2,68$ & $2,84 \mathrm{E}-07$ \\
\hline C110RF84 & 1,52 & $5,89 \mathrm{E}-06$ & 2,06 & $3,25 \mathrm{E}-22$ \\
\hline C110RF89 & $-1,22$ & $2,45 \mathrm{E}-03$ & $-1,96$ & $4,31 \mathrm{E}-07$ \\
\hline C12ORF42 & $-2,28$ & $3,56 \mathrm{E}-05$ & $-3,87$ & $1,87 \mathrm{E}-07$ \\
\hline C12ORF60 & 1,48 & $5,53 \mathrm{E}-04$ & 2,36 & $1,07 \mathrm{E}-12$ \\
\hline C12ORF75 & 1,84 & 5,57E-04 & 2,62 & $5,84 \mathrm{E}-07$ \\
\hline C12ORF79 & $-1,63$ & $8,52 \mathrm{E}-04$ & $-2,10$ & $6,97 \mathrm{E}-05$ \\
\hline C140RF80 & 0,90 & $8,31 \mathrm{E}-03$ & 1,01 & $1,96 \mathrm{E}-05$ \\
\hline C160RF74 & $-2,07$ & $8,60 \mathrm{E}-05$ & $-3,00$ & $8,46 \mathrm{E}-07$ \\
\hline C170RF66 & $-1,75$ & $3,29 \mathrm{E}-04$ & $-2,07$ & $7,14 \mathrm{E}-04$ \\
\hline C190RF26 & 1,77 & $2,32 \mathrm{E}-03$ & 2,21 & $1,24 \mathrm{E}-04$ \\
\hline C190RF40 & 1,16 & $8,01 \mathrm{E}-03$ & 1,91 & $1,75 \mathrm{E}-05$ \\
\hline C19ORF48 & 1,58 & $7,80 \mathrm{E}-05$ & 1,82 & $4,16 \mathrm{E}-07$ \\
\hline C1ORF112 & 2,00 & $1,83 \mathrm{E}-06$ & 2,54 & $3,11 \mathrm{E}-30$ \\
\hline C1ORF132 & $-1,52$ & $7,36 \mathrm{E}-05$ & $-1,75$ & $1,06 \mathrm{E}-08$ \\
\hline C10RF145 & $-2,07$ & $2,72 \mathrm{E}-05$ & $-3,45$ & $1,22 \mathrm{E}-08$ \\
\hline C10RF186 & $-1,79$ & $2,90 \mathrm{E}-03$ & $-1,90$ & $8,51 \mathrm{E}-05$ \\
\hline C1QBP & 1,13 & $6,17 \mathrm{E}-04$ & 1,54 & $1,14 \mathrm{E}-21$ \\
\hline C1RL-AS1 & 1,07 & $1,54 \mathrm{E}-03$ & 1,59 & $4,40 \mathrm{E}-15$ \\
\hline C210RF58 & 1,77 & $8,98 \mathrm{E}-05$ & 1,42 & $1,71 \mathrm{E}-03$ \\
\hline C3ORF14 & 1,20 & $5,56 \mathrm{E}-03$ & 2,12 & $1,32 \mathrm{E}-06$ \\
\hline C4ORF21 & 1,18 & $2,19 \mathrm{E}-03$ & 1,39 & $1,64 \mathrm{E}-07$ \\
\hline C5ORF34 & 1,59 & $5,50 \mathrm{E}-05$ & 2,20 & $1,03 \mathrm{E}-16$ \\
\hline C5ORF45 & $-1,29$ & $2,05 \mathrm{E}-03$ & $-2,40$ & $1,13 \mathrm{E}-17$ \\
\hline C8ORF46 & $-1,59$ & $1,70 \mathrm{E}-03$ & $-1,54$ & $6,60 \mathrm{E}-03$ \\
\hline C9ORF40 & 1,43 & $2,09 \mathrm{E}-05$ & 1,78 & $7,93 \mathrm{E}-21$ \\
\hline C9ORF72 & $-1,19$ & $8,74 \mathrm{E}-03$ & $-2,42$ & $4,87 \mathrm{E}-10$ \\
\hline CA6 & 2,72 & $5,12 \mathrm{E}-10$ & 1,24 & $4,18 \mathrm{E}-03$ \\
\hline CA9 & 3,17 & $5,81 \mathrm{E}-07$ & 4,16 & $3,30 \mathrm{E}-08$ \\
\hline CABP4 & $-1,75$ & $1,24 \mathrm{E}-03$ & $-2,58$ & $1,99 \mathrm{E}-05$ \\
\hline CACNA1I & $-2,69$ & $6,50 \mathrm{E}-07$ & $-5,44$ & $7,86 \mathrm{E}-18$ \\
\hline CACYBP & 0,89 & $8,48 \mathrm{E}-03$ & 1,49 & $1,09 \mathrm{E}-11$ \\
\hline CACYBPP2 & 1,06 & $2,91 \mathrm{E}-03$ & 1,82 & $8,67 \mathrm{E}-11$ \\
\hline CADM1 & $-1,66$ & $3,20 \mathrm{E}-05$ & $-1,35$ & $1,24 \mathrm{E}-05$ \\
\hline CAHM & $-1,41$ & $2,12 \mathrm{E}-03$ & $-2,33$ & $3,63 \mathrm{E}-04$ \\
\hline CALCOCO1 & $-1,00$ & $2,01 \mathrm{E}-03$ & $-1,62$ & $1,15 \mathrm{E}-22$ \\
\hline CALM3 & 1,11 & $1,39 \mathrm{E}-03$ & 0,91 & $1,25 \mathrm{E}-05$ \\
\hline CALY & $-3,26$ & $1,84 \mathrm{E}-07$ & $-4,06$ & $1,72 \mathrm{E}-07$ \\
\hline CAMK1D & $-1,12$ & $6,39 \mathrm{E}-03$ & $-2,37$ & $7,11 \mathrm{E}-19$ \\
\hline CAMK2N1 & $-1,23$ & $5,69 \mathrm{E}-03$ & $-1,56$ & $7,10 \mathrm{E}-04$ \\
\hline CAMK2N2 & 1,71 & $7,77 \mathrm{E}-03$ & 4,00 & $1,43 \mathrm{E}-18$ \\
\hline CAMKV & 2,45 & $1,33 \mathrm{E}-04$ & 2,17 & $7,67 \mathrm{E}-03$ \\
\hline CAPRIN2 & $-1,16$ & $3,86 \mathrm{E}-03$ & $-1,33$ & $5,21 \mathrm{E}-04$ \\
\hline CAPS & $-1,40$ & $2,04 \mathrm{E}-03$ & $-2,63$ & $6,15 \mathrm{E}-10$ \\
\hline CAPSL & 2,06 & $1,38 \mathrm{E}-03$ & 3,20 & $1,15 \mathrm{E}-05$ \\
\hline CARHSP1 & 1,42 & $8,97 \mathrm{E}-04$ & 1,28 & $5,92 \mathrm{E}-04$ \\
\hline CASKIN2 & 1,92 & $1,21 \mathrm{E}-06$ & 2,51 & $1,20 \mathrm{E}-13$ \\
\hline CASP8 & $-1,25$ & $2,62 \mathrm{E}-03$ & $-1,72$ & $2,48 \mathrm{E}-05$ \\
\hline CBLB & 1,34 & $1,56 \mathrm{E}-04$ & 1,56 & $3,48 \mathrm{E}-18$ \\
\hline $\mathrm{CBX} 2$ & 1,96 & $1,90 \mathrm{E}-05$ & 1,94 & $6,57 \mathrm{E}-07$ \\
\hline CBX5 & 1,20 & $7,13 \mathrm{E}-03$ & 0,91 & $4,09 \mathrm{E}-03$ \\
\hline CBX7 & $-1,44$ & $1,58 \mathrm{E}-03$ & $-2,46$ & $4,30 \mathrm{E}-08$ \\
\hline CCDC113 & 1,86 & $1,50 \mathrm{E}-03$ & 2,82 & $1,26 \mathrm{E}-07$ \\
\hline CCDC147 & 1,85 & $8,05 \mathrm{E}-04$ & 2,93 & $1,81 \mathrm{E}-06$ \\
\hline CCDC15 & 1,50 & $4,75 \mathrm{E}-04$ & 2,16 & $2,00 \mathrm{E}-10$ \\
\hline CCDC159 & $-1,24$ & $9,28 \mathrm{E}-04$ & $-1,97$ & $2,55 \mathrm{E}-31$ \\
\hline CCDC18 & 1,06 & $5,44 \mathrm{E}-03$ & 1,20 & $5,53 \mathrm{E}-09$ \\
\hline CCDC180 & $-1,44$ & $8,70 \mathrm{E}-03$ & $-2,44$ & $1,34 \mathrm{E}-04$ \\
\hline CCDC28B & 2,02 & $2,09 \mathrm{E}-07$ & 1,67 & $9,55 \mathrm{E}-08$ \\
\hline CCDC51 & 1,21 & $4,46 \mathrm{E}-04$ & 1,96 & $9,32 \mathrm{E}-16$ \\
\hline
\end{tabular}

\begin{tabular}{|c|c|c|c|c|}
\hline CCDC65 & $-2,35$ & $3,87 \mathrm{E}-05$ & $-2,39$ & $3,82 \mathrm{E}-04$ \\
\hline CCDC66 & $-1,02$ & $9,87 \mathrm{E}-03$ & $-1,00$ & $6,13 \mathrm{E}-03$ \\
\hline CCDC86 & 0,94 & $5,54 \mathrm{E}-03$ & 1,65 & $3,13 \mathrm{E}-11$ \\
\hline CCL22 & 1,76 & $1,35 \mathrm{E}-08$ & 2,73 & 1,07E-76 \\
\hline CCL3L1 & $-1,54$ & $1,46 \mathrm{E}-04$ & $-1,55$ & $4,03 \mathrm{E}-06$ \\
\hline CCL3L3 & $-1,58$ & $1,10 \mathrm{E}-04$ & $-1,38$ & $3,97 \mathrm{E}-05$ \\
\hline CCNB1IP1 & 1,14 & 2,01E-03 & 1,62 & $2,67 \mathrm{E}-08$ \\
\hline CCNB1IP1P1 & 1,12 & $3,33 \mathrm{E}-03$ & 1,77 & $3,84 \mathrm{E}-09$ \\
\hline CCNJL & 2,33 & $4,54 \mathrm{E}-05$ & 2,76 & $1,63 \mathrm{E}-06$ \\
\hline CCNL2 & $-1,16$ & $4,75 \mathrm{E}-03$ & $-1,66$ & $2,82 \mathrm{E}-06$ \\
\hline CCP110 & 1,16 & 1,14E-03 & 1,59 & $1,05 \mathrm{E}-20$ \\
\hline CCR9 & $-2,04$ & $4,20 \mathrm{E}-04$ & $-3,11$ & $9,12 \mathrm{E}-06$ \\
\hline CCRN4L & 1,21 & $4,56 \mathrm{E}-03$ & 1,76 & $9,94 \mathrm{E}-07$ \\
\hline СCT2 & 1,13 & $2,13 \mathrm{E}-03$ & 1,73 & $4,01 \mathrm{E}-10$ \\
\hline ССТ3 & 1,05 & $4,50 \mathrm{E}-03$ & 1,54 & $1,55 \mathrm{E}-15$ \\
\hline CCT4 & 0,96 & 8,11E-03 & 1,52 & $1,93 \mathrm{E}-07$ \\
\hline CCT4P1 & 0,99 & $7,00 \mathrm{E}-03$ & 1,72 & $4,03 \mathrm{E}-12$ \\
\hline CCT4P2 & 1,16 & 9,49E-03 & 1,79 & $1,22 \mathrm{E}-05$ \\
\hline ССТ6А & 0,95 & $8,14 \mathrm{E}-03$ & 1,57 & $4,95 \mathrm{E}-08$ \\
\hline CCT7 & 0,90 & $9,45 \mathrm{E}-03$ & 1,34 & $2,22 \mathrm{E}-15$ \\
\hline ССТ8 & 0,92 & $4,05 \mathrm{E}-03$ & 1,37 & $1,72 \mathrm{E}-11$ \\
\hline CD109 & 1,92 & $1,49 \mathrm{E}-04$ & 1,52 & $8,90 \mathrm{E}-04$ \\
\hline CD163 & $-2,02$ & 1,19E-03 & $-5,60$ & $3,76 \mathrm{E}-30$ \\
\hline CD1B & 2,19 & $6,68 \mathrm{E}-04$ & 5,21 & $1,78 \mathrm{E}-13$ \\
\hline CD244 & $-1,68$ & 1,39E-04 & $-1,71$ & 2,96E-05 \\
\hline $\mathrm{CD} 274$ & 1,51 & $3,23 \mathrm{E}-03$ & 1,50 & $9,68 \mathrm{E}-03$ \\
\hline CD27-AS1 & 1,16 & $2,19 \mathrm{E}-04$ & 1,41 & $8,54 \mathrm{E}-18$ \\
\hline CD302 & $-1,39$ & $3,54 \mathrm{E}-03$ & $-2,56$ & $1,71 \mathrm{E}-06$ \\
\hline CD79B & 0,95 & $4,40 \mathrm{E}-03$ & 1,33 & $3,24 \mathrm{E}-09$ \\
\hline CDC27P2 & 1,28 & $2,38 \mathrm{E}-03$ & 1,91 & $9,68 \mathrm{E}-10$ \\
\hline CDC42EP3 & $-1,34$ & 6,34E-03 & $-1,83$ & 3,60E-04 \\
\hline $\mathrm{CDC7}$ & 1,29 & $2,66 \mathrm{E}-03$ & 1,49 & $4,98 \mathrm{E}-05$ \\
\hline CDCA4 & 1,03 & $7,06 \mathrm{E}-03$ & 1,18 & 3,55E-04 \\
\hline CDCA7L & 1,36 & $6,86 \mathrm{E}-04$ & 1,12 & 5,07E-06 \\
\hline CDHR3 & $-2,10$ & $2,05 \mathrm{E}-05$ & $-2,78$ & 2,69E-07 \\
\hline CDK20 & $-1,04$ & $6,37 \mathrm{E}-03$ & $-2,10$ & $4,58 \mathrm{E}-22$ \\
\hline CDK2AP1 & 1,63 & $7,97 \mathrm{E}-05$ & 2,27 & $4,59 \mathrm{E}-10$ \\
\hline CDK5RAP3 & $-0,96$ & 7,77E-03 & $-1,49$ & $4,77 \mathrm{E}-09$ \\
\hline CDKN1C & $-1,55$ & 2,91E-03 & $-1,85$ & 2,86E-05 \\
\hline CDR2L & 1,76 & 3,97E-03 & 2,76 & $2,58 \mathrm{E}-05$ \\
\hline CEL & 1,64 & $4,21 \mathrm{E}-04$ & 3,14 & $9,61 \mathrm{E}-21$ \\
\hline CELSR1 & $-2,11$ & 1,21E-05 & $-3,54$ & 7,99E-19 \\
\hline CELSR3 & 1,21 & 1,63E-03 & 2,10 & $1,36 \mathrm{E}-10$ \\
\hline CENPL & 1,58 & 3,93E-05 & 2,15 & $1,18 \mathrm{E}-20$ \\
\hline CENPO & 1,46 & $6,22 \mathrm{E}-04$ & 2,02 & $1,06 \mathrm{E}-06$ \\
\hline CENPP & 1,53 & 4,67E-05 & 2,25 & $8,81 \mathrm{E}-29$ \\
\hline CENPQ & 1,19 & 1,35E-03 & 1,62 & $1,98 \mathrm{E}-12$ \\
\hline CENPV & 1,52 & $2,13 \mathrm{E}-04$ & 2,34 & 1,65E-09 \\
\hline CENPW & 2,42 & $2,69 \mathrm{E}-10$ & 3,16 & 2,77E-59 \\
\hline CEP152 & 1,31 & $2,25 \mathrm{E}-03$ & 1,53 & $6,47 \mathrm{E}-11$ \\
\hline CEP41 & 1,49 & $5,77 \mathrm{E}-06$ & 1,30 & $6,78 \mathrm{E}-09$ \\
\hline CEP57L1 & 1,04 & $5,50 \mathrm{E}-03$ & 1,36 & 7,77E-07 \\
\hline CETN3 & 1,14 & 1,69E-03 & 1,66 & $7,75 \mathrm{E}-10$ \\
\hline $\mathrm{CFH}$ & $-1,90$ & $4,55 \mathrm{E}-04$ & $-1,50$ & $3,32 \mathrm{E}-03$ \\
\hline $\mathrm{CHCHD} 2$ & 0,98 & 4,37E-03 & 1,24 & 1,04E-05 \\
\hline CHCHD2P6 & 0,88 & $8,85 \mathrm{E}-03$ & 1,25 & $1,14 \mathrm{E}-06$ \\
\hline CHCHD2P9 & 1,06 & $2,27 \mathrm{E}-03$ & 1,34 & $1,34 \mathrm{E}-06$ \\
\hline CHMP4C & 1,73 & 4,31E-03 & 2,84 & 1,05E-05 \\
\hline CHMP7 & $-1,14$ & $5,95 \mathrm{E}-03$ & $-1,55$ & $5,79 \mathrm{E}-06$ \\
\hline CHRNA2 & 2,33 & $1,58 \mathrm{E}-04$ & 2,76 & $2,63 \mathrm{E}-05$ \\
\hline CIB2 & 1,63 & $2,05 \mathrm{E}-04$ & 1,37 & $1,73 \mathrm{E}-05$ \\
\hline CIRH1A & 0,86 & $6,67 \mathrm{E}-03$ & 1,56 & $9,30 \mathrm{E}-23$ \\
\hline CISD1 & 0,98 & 4,84E-03 & 1,64 & $1,16 \mathrm{E}-12$ \\
\hline CITED2 & $-1,12$ & 1,15E-03 & $-1,43$ & 3,73E-09 \\
\hline CKAP5 & 1,28 & $2,46 \mathrm{E}-03$ & 1,59 & $6,10 \mathrm{E}-06$ \\
\hline CKMT1B & 2,37 & $2,60 \mathrm{E}-04$ & 2,56 & $1,79 \mathrm{E}-03$ \\
\hline CKS1BP7 & 2,66 & $2,48 \mathrm{E}-06$ & 3,44 & $3,87 \mathrm{E}-10$ \\
\hline CLC & $-1,67$ & 7,81E-04 & $-3,52$ & $4,31 \mathrm{E}-26$ \\
\hline CLEC6A & 3,18 & $2,07 \mathrm{E}-08$ & 3,12 & $3,32 \mathrm{E}-06$ \\
\hline CLIC6 & 1,77 & $1,07 \mathrm{E}-03$ & 1,71 & $4,00 \mathrm{E}-03$ \\
\hline CLIP4 & $-1,27$ & 7,19E-03 & $-2,39$ & 1,93E-07 \\
\hline CLK1 & $-1,07$ & $9,45 \mathrm{E}-03$ & $-1,53$ & 1,35E-04 \\
\hline CLK4 & $-1,15$ & $4,81 \mathrm{E}-03$ & $-1,46$ & $3,73 \mathrm{E}-05$ \\
\hline CLLU1OS & 1,84 & $3,67 \mathrm{E}-03$ & 2,47 & $1,71 \mathrm{E}-03$ \\
\hline CLPP & 1,22 & $1,18 \mathrm{E}-04$ & 1,81 & $4,22 \mathrm{E}-36$ \\
\hline CLU & 1,26 & $2,84 \mathrm{E}-03$ & 1,46 & $3,98 \mathrm{E}-04$ \\
\hline CMC2 & 1,03 & $2,42 \mathrm{E}-03$ & 1,53 & $4,31 \mathrm{E}-09$ \\
\hline CMSS1 & 1,19 & $4,29 \mathrm{E}-03$ & 1,08 & $1,08 \mathrm{E}-03$ \\
\hline $\mathrm{CNIH} 2$ & 1,17 & 7,71E-03 & 2,20 & $8,64 \mathrm{E}-10$ \\
\hline
\end{tabular}




\begin{tabular}{|c|c|c|c|c|}
\hline CNR2 & $-1,85$ & $5,10 \mathrm{E}-05$ & $-3,13$ & $2,84 \mathrm{E}-11$ \\
\hline CNTNAP1 & $-1,36$ & $6,31 \mathrm{E}-03$ & $\begin{array}{l}-1,33 \\
\end{array}$ & $1,01 \mathrm{E}-03$ \\
\hline CNTNAP2 & $-1,79$ & $3,64 \mathrm{E}-03$ & $-2,23$ & 1,47E-03 \\
\hline COA1 & $-1,77$ & $4,69 \mathrm{E}-05$ & $-2,48$ & $1,36 \mathrm{E}-08$ \\
\hline COBLL1 & $-1,87$ & $1,60 \mathrm{E}-03$ & $-2,42$ & $2,15 \mathrm{E}-07$ \\
\hline $\mathrm{COCH}$ & 1,96 & 1,16E-04 & 2,37 & $3,90 \mathrm{E}-06$ \\
\hline COL1A1 & 2,64 & 4,99E-07 & 1,66 & $1,65 \mathrm{E}-03$ \\
\hline COL9A2 & 1,27 & $2,13 \mathrm{E}-04$ & 1,79 & $2,29 \mathrm{E}-23$ \\
\hline COLGALT2 & $-1,12$ & $5,90 \mathrm{E}-03$ & $-1,55$ & $4,15 \mathrm{E}-04$ \\
\hline COMTD1 & 1,14 & $2,18 \mathrm{E}-03$ & 1,24 & $3,56 \mathrm{E}-08$ \\
\hline COPG2 & 1,35 & $9,53 \mathrm{E}-05$ & 1,77 & $8,64 \mathrm{E}-19$ \\
\hline COPS3 & 1,00 & $2,82 \mathrm{E}-03$ & 1,40 & $4,16 \mathrm{E}-14$ \\
\hline CORO6 & 2,05 & $1,36 \mathrm{E}-05$ & 1,42 & $2,63 \mathrm{E}-03$ \\
\hline COTL1 & 1,21 & $1,04 \mathrm{E}-03$ & 0,85 & $1,18 \mathrm{E}-08$ \\
\hline CPEB2 & $-1,16$ & $5,69 \mathrm{E}-03$ & $-1,51$ & $1,57 \mathrm{E}-04$ \\
\hline CPNE6 & 2,07 & $1,29 \mathrm{E}-03$ & 3,84 & $2,52 \mathrm{E}-14$ \\
\hline CPOX & 1,21 & $1,24 \mathrm{E}-03$ & 1,80 & $2,25 \mathrm{E}-10$ \\
\hline $\mathrm{CPQ}$ & $-1,36$ & $6,11 \mathrm{E}-03$ & $-2,52$ & $8,48 \mathrm{E}-07$ \\
\hline CR2 & $-1,78$ & $4,21 \mathrm{E}-04$ & $-3,40$ & $1,03 \mathrm{E}-12$ \\
\hline CREB3L4 & 0,93 & $6,63 \mathrm{E}-03$ & 0,84 & $6,92 \mathrm{E}-05$ \\
\hline CREBRF & $-1,24$ & $5,43 \mathrm{E}-04$ & $-1,82$ & $1,11 \mathrm{E}-12$ \\
\hline CRELD1 & $-0,93$ & $7,38 \mathrm{E}-03$ & $-1,52$ & $1,93 \mathrm{E}-16$ \\
\hline CRIP1P2 & 1,77 & $1,83 \mathrm{E}-05$ & 1,89 & $3,83 \mathrm{E}-09$ \\
\hline CRIP1P4 & 1,59 & $1,65 \mathrm{E}-05$ & 1,60 & $1,49 \mathrm{E}-08$ \\
\hline CRIP2 & $-1,83$ & $1,09 \mathrm{E}-05$ & $-1,13$ & $1,61 \mathrm{E}-03$ \\
\hline CROCCP3 & $-1,24$ & $9,14 \mathrm{E}-03$ & $-1,56$ & $1,00 \mathrm{E}-03$ \\
\hline CRTAM & 1,26 & $1,37 \mathrm{E}-03$ & 1,68 & $9,07 \mathrm{E}-17$ \\
\hline CRYL1 & $-0,94$ & $3,27 \mathrm{E}-03$ & $-1,58$ & $1,58 \mathrm{E}-13$ \\
\hline CSE1L & 1,42 & $1,00 \mathrm{E}-04$ & 2,16 & $5,23 \mathrm{E}-23$ \\
\hline CSF3R & $-1,67$ & $3,79 \mathrm{E}-03$ & $-4,50$ & $2,52 \mathrm{E}-16$ \\
\hline CST1 & 3,44 & $4,14 \mathrm{E}-08$ & 3,88 & $4,50 \mathrm{E}-07$ \\
\hline CSTF2 & 1,09 & $6,81 \mathrm{E}-03$ & 1,65 & $2,86 \mathrm{E}-06$ \\
\hline CTA-250D10,23 & $-1,26$ & $2,33 \mathrm{E}-03$ & $-1,74$ & $8,89 \mathrm{E}-07$ \\
\hline CTA-445C 9,15 & $-1,19$ & $6,57 \mathrm{E}-04$ & $-1,35$ & $1,64 \mathrm{E}-05$ \\
\hline CTB-131B5,5 & $-1,24$ & $2,37 \mathrm{E}-03$ & $-2,16$ & $2,14 \mathrm{E}-06$ \\
\hline CTB-133G6,1 & $-2,09$ & $7,97 \mathrm{E}-06$ & $-4,64$ & $2,21 \mathrm{E}-17$ \\
\hline CTB-31N19,2 & $-1,69$ & $7,86 \mathrm{E}-03$ & $-2,27$ & $5,52 \mathrm{E}-03$ \\
\hline CTB-31020,2 & $-1,56$ & $4,05 \mathrm{E}-03$ & $-2,74$ & $1,49 \mathrm{E}-05$ \\
\hline CTB-50L17,5 & 1,63 & $1,27 \mathrm{E}-03$ & 2,18 & 9,37E-06 \\
\hline CTB-5506,12 & $-1,06$ & $5,99 \mathrm{E}-03$ & $-1,78$ & $1,68 \mathrm{E}-12$ \\
\hline CTB-70G10,1 & $-2,02$ & $1,74 \mathrm{E}-03$ & $-2,65$ & $1,08 \mathrm{E}-03$ \\
\hline CTC1 & $-1,11$ & $3,21 \mathrm{E}-03$ & $-1,80$ & $6,42 \mathrm{E}-08$ \\
\hline CTC-260E 6,10 & 2,41 & 1,77E-04 & 3,56 & 1,56E-06 \\
\hline CTC-378H22,2 & $-1,51$ & $3,42 \mathrm{E}-03$ & $-2,53$ & $3,02 E-06$ \\
\hline CTC-428G20,3 & $-1,06$ & $5,48 \mathrm{E}-03$ & $-0,87$ & $4,94 \mathrm{E}-03$ \\
\hline CTC-429P9,3 & $-1,28$ & $4,89 \mathrm{E}-03$ & $-1,74$ & $6,95 \mathrm{E}-05$ \\
\hline CTC-444N24,8 & $-1,31$ & $9,51 \mathrm{E}-04$ & $-1,12$ & $5,10 \mathrm{E}-06$ \\
\hline CTC-471J1,10 & $-1,05$ & $6,03 \mathrm{E}-03$ & $-1,58$ & $2,27 \mathrm{E}-07$ \\
\hline CTC-471J1,2 & $-1,88$ & $1,34 \mathrm{E}-03$ & $-2,50$ & $2,10 \mathrm{E}-04$ \\
\hline CTC-523E23,11 & $-1,80$ & $5,15 \mathrm{E}-04$ & $-2,60$ & $6,29 \mathrm{E}-06$ \\
\hline CTC-523E23,5 & $-1,86$ & $4,03 \mathrm{E}-04$ & $-3,18$ & $1,29 \mathrm{E}-07$ \\
\hline CTC-559E9,5 & $-1,51$ & $1,01 \mathrm{E}-03$ & $-1,67$ & $1,09 \mathrm{E}-04$ \\
\hline CTD-2010|16,1 & $-1,44$ & $9,31 \mathrm{E}-03$ & $-1,89$ & $1,39 \mathrm{E}-03$ \\
\hline CTD-2017D11,1 & $-1,09$ & $5,05 \mathrm{E}-03$ & $-1,30$ & $2,56 \mathrm{E}-05$ \\
\hline CTD-2035E11,5 & $-1,67$ & $1,27 \mathrm{E}-03$ & $-2,87$ & $1,72 \mathrm{E}-05$ \\
\hline CTD-2090|13,2 & 1,07 & $6,75 \mathrm{E}-03$ & 1,06 & $2,16 \mathrm{E}-07$ \\
\hline CTD-2116N20,1 & 2,23 & $5,64 \mathrm{E}-04$ & 2,94 & $2,60 \mathrm{E}-04$ \\
\hline CTD-2179L22,1 & 1,26 & $1,40 \mathrm{E}-03$ & 1,87 & $4,22 \mathrm{E}-10$ \\
\hline CTD-2201/18,1 & $-1,72$ & $3,97 \mathrm{E}-04$ & $-3,42$ & $1,54 \mathrm{E}-07$ \\
\hline CTD-2215E18,1 & $-2,47$ & 1,39E-04 & $-3,08$ & $1,08 \mathrm{E}-04$ \\
\hline CTD-2272G21,1 & 1,91 & $3,05 \mathrm{E}-03$ & 3,28 & 3,83E-05 \\
\hline CTD-2301A4,5 & 1,20 & $1,80 \mathrm{E}-04$ & 1,69 & $1,25 \mathrm{E}-28$ \\
\hline CTD-2313F11,1 & $-1,46$ & $5,85 \mathrm{E}-03$ & $-2,30$ & $6,90 \mathrm{E}-05$ \\
\hline CTD-2331H12,5 & $-1,54$ & $6,37 \mathrm{E}-03$ & $-1,73$ & $3,32 \mathrm{E}-03$ \\
\hline CTD-2357A8,3 & $-1,45$ & $2,77 \mathrm{E}-03$ & $-1,47$ & $1,15 \mathrm{E}-03$ \\
\hline CTD-2376|20,1 & 1,92 & $1,88 \mathrm{E}-03$ & 2,97 & $1,86 \mathrm{E}-07$ \\
\hline CTD-2510F5,4 & 2,36 & $2,00 \mathrm{E}-04$ & 3,34 & $1,30 \mathrm{E}-06$ \\
\hline CTD-2516K3,3 & 1,30 & $3,14 \mathrm{E}-03$ & 1,86 & $5,71 \mathrm{E}-06$ \\
\hline CTD-2517M22,17 & 1,54 & 7,51E-04 & 2,03 & $1,91 \mathrm{E}-08$ \\
\hline CTD-2528L19,6 & $-1,31$ & 4,97E-03 & $-1,54$ & $9,62 \mathrm{E}-03$ \\
\hline CTD-2583A14,8 & $-1,46$ & 2,12E-03 & $-1,39$ & 2,23E-03 \\
\hline CTD-2587H19,1 & $-1,42$ & $1,45 \mathrm{E}-03$ & $-1,63$ & 2,32E-04 \\
\hline
\end{tabular}

\begin{tabular}{|c|c|c|c|c|}
\hline CTD-2587M2,1 & $-1,62$ & $3,14 \mathrm{E}-04$ & $-2,09$ & $1,14 \mathrm{E}-06$ \\
\hline CTD-3051D23,1 & $-1,90$ & 2,69E-03 & $-2,79$ & 4,63E-04 \\
\hline CTD-3145H4,1 & 1,89 & $5,45 \mathrm{E}-04$ & 2,68 & $7,04 \mathrm{E}-07$ \\
\hline CTD-3184A7,4 & $-1,62$ & $9,11 \mathrm{E}-04$ & $-2,34$ & $8,88 \mathrm{E}-06$ \\
\hline CUBN & $-2,10$ & $2,18 \mathrm{E}-06$ & $-2,98$ & $5,47 \mathrm{E}-09$ \\
\hline CXCL10 & 2,57 & $3,44 \mathrm{E}-14$ & 2,03 & $1,70 \mathrm{E}-22$ \\
\hline CXCL2 & $-1,32$ & $2,90 \mathrm{E}-04$ & $-3,08$ & $2,60 \mathrm{E}-24$ \\
\hline CXCL3 & $-1,54$ & $1,25 \mathrm{E}-04$ & $-2,54$ & $1,24 \mathrm{E}-11$ \\
\hline CXCL9 & 3,14 & $7,49 \mathrm{E}-12$ & 5,11 & $1,02 \mathrm{E}-58$ \\
\hline CXCR4 & $-1,49$ & $3,23 \mathrm{E}-04$ & $-1,68$ & $5,94 \mathrm{E}-07$ \\
\hline CXXC11 & $-1,40$ & $4,13 \mathrm{E}-03$ & $-2,90$ & $3,45 \mathrm{E}-07$ \\
\hline CXXC5 & $-1,42$ & 4,34E-03 & $-2,62$ & $2,89 \mathrm{E}-09$ \\
\hline CYB561 & $-1,27$ & $5,89 \mathrm{E}-03$ & $-2,16$ & $3,79 \mathrm{E}-08$ \\
\hline CYP4F29P & $-1,69$ & $2,07 \mathrm{E}-04$ & $-1,28$ & $4,73 \mathrm{E}-03$ \\
\hline CYTH4 & $-1,06$ & $2,42 \mathrm{E}-03$ & $-1,86$ & $4,37 \mathrm{E}-32$ \\
\hline DACT1 & $-1,68$ & $2,36 \mathrm{E}-04$ & $-1,73$ & $1,47 \mathrm{E}-04$ \\
\hline DACT3 & 1,87 & $1,30 \mathrm{E}-05$ & 1,90 & $6,14 \mathrm{E}-07$ \\
\hline DBP & $-1,50$ & $7,05 \mathrm{E}-04$ & $-3,18$ & $1,89 \mathrm{E}-16$ \\
\hline DCLK2 & $-1,63$ & $3,00 \mathrm{E}-03$ & $-2,44$ & $7,72 \mathrm{E}-05$ \\
\hline DCST2 & $-1,72$ & 1,95E-03 & $-1,61$ & $9,45 \mathrm{E}-03$ \\
\hline DCSTAMP & 1,86 & $2,06 \mathrm{E}-03$ & 3,24 & $2,63 \mathrm{E}-12$ \\
\hline DCTPP1 & 1,61 & $6,14 \mathrm{E}-06$ & 2,13 & $4,15 \mathrm{E}-18$ \\
\hline DDB2 & 1,24 & 1,12E-04 & 1,41 & $1,05 \mathrm{E}-12$ \\
\hline DDX25 & 1,66 & $2,60 \mathrm{E}-03$ & 3,64 & $1,86 \mathrm{E}-18$ \\
\hline DEFA1 & $-3,07$ & $1,47 \mathrm{E}-06$ & $-3,93$ & $7,97 \mathrm{E}-07$ \\
\hline DEFA3 & $-2,32$ & 2,95E-04 & $-4,20$ & $6,51 \mathrm{E}-08$ \\
\hline DEK & 1,45 & $1,42 \mathrm{E}-04$ & 1,59 & $8,35 \mathrm{E}-08$ \\
\hline DENND4C & $-0,97$ & $8,63 \mathrm{E}-03$ & $-1,52$ & $3,39 \mathrm{E}-06$ \\
\hline DHRS3 & 1,51 & $6,29 \mathrm{E}-06$ & 1,90 & $8,94 \mathrm{E}-19$ \\
\hline DIRC2 & $-1,32$ & $5,09 \mathrm{E}-03$ & $-1,47$ & $2,41 \mathrm{E}-03$ \\
\hline DISP2 & 1,88 & $9,87 \mathrm{E}-06$ & 2,81 & $1,47 \mathrm{E}-18$ \\
\hline DKFZP761J1410 & $-1,31$ & $5,80 \mathrm{E}-03$ & $-2,53$ & $2,39 \mathrm{E}-11$ \\
\hline DLEC1 & $-1,83$ & $7,35 \mathrm{E}-04$ & $-2,97$ & $8,43 \mathrm{E}-08$ \\
\hline DLEU1 & 1,23 & $2,08 \mathrm{E}-03$ & 2,14 & $1,21 \mathrm{E}-14$ \\
\hline DLGAP1-AS1 & $-1,03$ & $3,78 \mathrm{E}-03$ & $-1,33$ & $1,81 \mathrm{E}-11$ \\
\hline DLL3 & 1,65 & $2,80 \mathrm{E}-03$ & 1,99 & $4,18 \mathrm{E}-04$ \\
\hline DMTN & 1,33 & $6,86 \mathrm{E}-03$ & 1,50 & $4,59 \mathrm{E}-03$ \\
\hline DNAH1 & $-1,03$ & $4,02 \mathrm{E}-03$ & $-1,47$ & $1,01 \mathrm{E}-07$ \\
\hline DNAH17 & $-1,10$ & $7,08 \mathrm{E}-03$ & $-1,03$ & $1,09 \mathrm{E}-04$ \\
\hline DNAJB5 & 1,29 & $6,20 \mathrm{E}-03$ & 1,87 & $1,71 \mathrm{E}-04$ \\
\hline DNAJB9 & $-1,10$ & $7,94 \mathrm{E}-04$ & $-1,50$ & $3,67 \mathrm{E}-11$ \\
\hline DNAJC9 & 1,47 & $1,04 \mathrm{E}-05$ & 2,16 & $8,79 \mathrm{E}-23$ \\
\hline DNHD1 & $-1,18$ & $5,38 \mathrm{E}-03$ & $-1,07$ & $3,23 \mathrm{E}-03$ \\
\hline DNM1P47 & 1,07 & $7,28 \mathrm{E}-03$ & 1,42 & $3,12 \mathrm{E}-05$ \\
\hline DNMT1 & 1,07 & $1,40 \mathrm{E}-03$ & 1,03 & $3,98 \mathrm{E}-10$ \\
\hline DOK5 & 3,21 & $6,09 \mathrm{E}-07$ & 4,31 & $7,40 \mathrm{E}-09$ \\
\hline DPP3 & 1,03 & $6,33 \mathrm{E}-03$ & 1,32 & $2,61 \mathrm{E}-05$ \\
\hline DPYSL4 & 2,36 & $1,08 \mathrm{E}-06$ & 3,59 & $5,25 \mathrm{E}-18$ \\
\hline DRAM2 & $-0,95$ & $5,44 \mathrm{E}-03$ & $-1,16$ & $3,26 \mathrm{E}-05$ \\
\hline DSG2 & 1,45 & $3,47 \mathrm{E}-03$ & 1,48 & $2,67 \mathrm{E}-03$ \\
\hline DSN1 & 1,15 & $9,78 \mathrm{E}-04$ & 1,38 & $1,12 \mathrm{E}-16$ \\
\hline DST & $-1,20$ & $8,37 \mathrm{E}-03$ & $-1,17$ & $9,70 \mathrm{E}-03$ \\
\hline DSTNP1 & $-1,25$ & $6,30 \mathrm{E}-03$ & $-1,78$ & $4,22 \mathrm{E}-05$ \\
\hline DTYMK & 1,74 & 5,93E-07 & 2,01 & $4,76 \mathrm{E}-37$ \\
\hline DUSP14 & 1,14 & $2,90 \mathrm{E}-03$ & 1,62 & $3,46 \mathrm{E}-07$ \\
\hline DUSP8 & $-1,50$ & $2,65 \mathrm{E}-03$ & $-2,16$ & $2,18 \mathrm{E}-06$ \\
\hline DUTP5 & 1,93 & 4,84E-08 & 2,16 & $6,56 \mathrm{E}-22$ \\
\hline DUTP8 & 1,47 & $9,48 \mathrm{E}-03$ & 1,73 & $1,62 \mathrm{E}-03$ \\
\hline DYRK2 & $-1,39$ & $7,28 \mathrm{E}-04$ & $-2,49$ & $1,52 \mathrm{E}-11$ \\
\hline EBNA1BP2 & 1,07 & $4,80 \mathrm{E}-03$ & 1,88 & $5,02 \mathrm{E}-09$ \\
\hline EBP & 1,04 & 1,12E-03 & 1,45 & $9,50 \mathrm{E}-17$ \\
\hline ECT2 & 2,05 & $8,12 \mathrm{E}-05$ & 2,46 & $2,59 \mathrm{E}-06$ \\
\hline EDAR & $-2,56$ & $4,22 \mathrm{E}-07$ & $-4,79$ & $5,43 \mathrm{E}-14$ \\
\hline EEF1E1 & 1,32 & 1,22E-04 & 1,91 & $3,98 \mathrm{E}-18$ \\
\hline EFCAB13 & $-1,12$ & 9,90E-03 & $-1,71$ & $1,68 \mathrm{E}-03$ \\
\hline EFCAB4A & 2,64 & $1,57 \mathrm{E}-11$ & 1,34 & $6,29 \mathrm{E}-04$ \\
\hline EFNA1 & $-1,90$ & $7,96 \mathrm{E}-05$ & $-3,31$ & $3,83 \mathrm{E}-12$ \\
\hline EGFL6 & 1,99 & 1,93E-03 & 3,53 & $6,98 \mathrm{E}-06$ \\
\hline EGR4 & 1,85 & $3,76 \mathrm{E}-03$ & 2,31 & $2,90 \mathrm{E}-03$ \\
\hline EIF5A & 1,02 & 1,84E-03 & 1,19 & $1,37 \mathrm{E}-13$ \\
\hline EIF5AL1 & 1,17 & $4,76 \mathrm{E}-04$ & 1,70 & $4,78 \mathrm{E}-20$ \\
\hline EIF5AP4 & 1,17 & $1,42 \mathrm{E}-03$ & 1,49 & $1,63 \mathrm{E}-10$ \\
\hline ELAVL1 & 1,10 & 1,69E-03 & 1,26 & $7,79 \mathrm{E}-07$ \\
\hline ELOVL6 & 1,13 & 9,77E-04 & 1,53 & $1,83 \mathrm{E}-09$ \\
\hline ELP6 & 0,94 & $4,21 \mathrm{E}-03$ & 1,22 & $5,97 \mathrm{E}-14$ \\
\hline EMC9 & 1,03 & 1,24E-03 & 1,41 & $2,97 \mathrm{E}-18$ \\
\hline ENGASE & $-1,09$ & $7,49 \mathrm{E}-03$ & $-1,91$ & $2,01 \mathrm{E}-07$ \\
\hline
\end{tabular}




\begin{tabular}{|c|c|c|c|c|}
\hline ENPP1 & 1,49 & $2,80 \mathrm{E}-03$ & 3,61 & $1,46 \mathrm{E}-22$ \\
\hline EPB41L2 & 1,54 & $1,56 \mathrm{E}-03$ & 1,85 & $6,51 \mathrm{E}-06$ \\
\hline EPB42 & $-1,41$ & $6,65 \mathrm{E}-03$ & $-1,57$ & $7,52 \mathrm{E}-03$ \\
\hline EPCAM & 2,74 & $2,08 \mathrm{E}-05$ & 3,29 & $3,55 \mathrm{E}-05$ \\
\hline EPHA4 & $-1,81$ & $1,18 \mathrm{E}-04$ & $-2,80$ & $1,01 \mathrm{E}-08$ \\
\hline EPHB4 & $-1,90$ & $5,48 \mathrm{E}-05$ & $-1,84$ & $9,65 \mathrm{E}-05$ \\
\hline EPPK1 & $-1,49$ & $7,05 \mathrm{E}-03$ & $-2,26$ & $1,70 \mathrm{E}-04$ \\
\hline ERH & 1,02 & $1,08 \mathrm{E}-03$ & 1,06 & $5,81 \mathrm{E}-09$ \\
\hline ERHP1 & 1,14 & $8,07 \mathrm{E}-04$ & 1,44 & $4,23 \mathrm{E}-08$ \\
\hline ERMN & $-1,33$ & $3,07 \mathrm{E}-03$ & $-1,22$ & $7,18 \mathrm{E}-03$ \\
\hline ERN1 & $-1,15$ & $3,08 \mathrm{E}-03$ & $-1,45$ & 1,09E-05 \\
\hline ER01LB & $-1,12$ & $2,31 \mathrm{E}-03$ & $-1,28$ & $1,69 \mathrm{E}-11$ \\
\hline ETFB & 0,80 & $8,82 \mathrm{E}-03$ & 0,72 & $6,04 \mathrm{E}-07$ \\
\hline ETHE1 & 1,30 & $2,01 \mathrm{E}-04$ & 1,12 & $6,85 \mathrm{E}-05$ \\
\hline ETV7 & 2,57 & $4,15 \mathrm{E}-06$ & 2,72 & $1,66 \mathrm{E}-05$ \\
\hline EXOSC3 & 0,85 & $8,79 \mathrm{E}-03$ & 1,20 & 1,51E-08 \\
\hline EXOSC3P1 & 1,05 & $8,75 \mathrm{E}-03$ & 1,81 & $4,86 \mathrm{E}-08$ \\
\hline EXOSC9 & 0,93 & $4,75 \mathrm{E}-03$ & 1,70 & $9,33 \mathrm{E}-22$ \\
\hline EZH1 & $-1,44$ & $3,04 \mathrm{E}-04$ & $-2,00$ & $7,32 \mathrm{E}-11$ \\
\hline EZR & 1,13 & $1,46 \mathrm{E}-03$ & 1,20 & $6,30 \mathrm{E}-09$ \\
\hline F3 & 2,50 & $3,64 \mathrm{E}-06$ & 2,61 & $9,88 \mathrm{E}-09$ \\
\hline FABP4 & $-1,67$ & $8,51 \mathrm{E}-03$ & $-2,30$ & $5,01 \mathrm{E}-03$ \\
\hline FABP5P1 & 1,72 & $7,16 \mathrm{E}-04$ & 1,90 & $3,46 \mathrm{E}-04$ \\
\hline FABP5P2 & 1,55 & $6,69 \mathrm{E}-04$ & 1,83 & $4,15 \mathrm{E}-06$ \\
\hline FABP5P7 & 1,59 & $2,22 \mathrm{E}-04$ & 1,89 & 4,81E-06 \\
\hline FAIM3 & $-1,51$ & $9,25 \mathrm{E}-04$ & $-3,31$ & $8,52 \mathrm{E}-14$ \\
\hline FAM13A & $-1,68$ & 1,59E-05 & $-1,61$ & $4,72 \mathrm{E}-05$ \\
\hline FAM13A-AS1 & $-2,25$ & $2,70 \mathrm{E}-07$ & $-2,83$ & $2,05 \mathrm{E}-11$ \\
\hline FAM153A & $-1,39$ & $7,18 \mathrm{E}-03$ & $-1,78$ & $2,04 \mathrm{E}-03$ \\
\hline FAM154B & $-1,71$ & $4,01 \mathrm{E}-03$ & $-1,61$ & $7,37 \mathrm{E}-03$ \\
\hline FAM155B & 2,16 & $4,30 \mathrm{E}-04$ & 3,66 & $1,35 \mathrm{E}-09$ \\
\hline FAM19A1 & $-1,76$ & $6,50 \mathrm{E}-03$ & $-2,83$ & $5,28 \mathrm{E}-04$ \\
\hline FAM207A & 0,94 & $5,83 \mathrm{E}-03$ & 0,99 & $3,02 \mathrm{E}-04$ \\
\hline FAM207BP & 1,05 & $2,09 \mathrm{E}-03$ & 1,30 & $1,05 \mathrm{E}-07$ \\
\hline FAM214A & $-1,28$ & $3,38 \mathrm{E}-04$ & $-1,52$ & $7,33 \mathrm{E}-08$ \\
\hline FAM216A & 1,12 & $8,03 E-03$ & 1,80 & $1,64 \mathrm{E}-06$ \\
\hline FAM228B & $-1,22$ & $5,88 \mathrm{E}-04$ & $-1,59$ & $4,62 \mathrm{E}-10$ \\
\hline FAM53B & $-1,03$ & $8,57 \mathrm{E}-03$ & $-1,61$ & $1,68 \mathrm{E}-06$ \\
\hline FAM57A & 1,44 & $3,30 \mathrm{E}-04$ & 1,77 & $6,70 \mathrm{E}-06$ \\
\hline FAM83E & 2,20 & $5,21 \mathrm{E}-04$ & 5,64 & $3,52 \mathrm{E}-19$ \\
\hline FAM95B1 & $-1,63$ & $3,07 \mathrm{E}-03$ & $-1,64$ & $9,22 \mathrm{E}-03$ \\
\hline FANCB & 1,74 & $8,70 \mathrm{E}-04$ & 2,02 & $6,19 \mathrm{E}-05$ \\
\hline FANCC & 1,09 & $2,14 \mathrm{E}-03$ & 1,07 & $9,80 \mathrm{E}-06$ \\
\hline FANCD2 & 1,38 & 1,34E-03 & 1,53 & $2,89 \mathrm{E}-05$ \\
\hline FANCE & 1,38 & 1,23E-04 & 1,70 & $2,09 \mathrm{E}-10$ \\
\hline FANCG & 2,00 & $1,54 \mathrm{E}-08$ & 2,34 & $1,25 \mathrm{E}-31$ \\
\hline FANCL & 1,47 & $2,14 \mathrm{E}-03$ & 1,99 & $8,87 \mathrm{E}-05$ \\
\hline FARSB & 0,88 & 9,36E-03 & 1,33 & $9,09 \mathrm{E}-16$ \\
\hline FASLG & 1,50 & $9,90 \mathrm{E}-06$ & 4,17 & $2,29 \mathrm{E}-113$ \\
\hline FASN & 1,50 & $1,98 \mathrm{E}-05$ & 1,76 & $8,39 \mathrm{E}-10$ \\
\hline FBLN2 & $-1,69$ & $2,80 \mathrm{E}-03$ & $-3,04$ & $1,58 \mathrm{E}-07$ \\
\hline FBLN5 & $-1,55$ & 1,33E-03 & $-4,24$ & $4,88 \mathrm{E}-13$ \\
\hline FBN2 & $-1,76$ & $2,82 \mathrm{E}-03$ & $-2,54$ & $1,32 \mathrm{E}-03$ \\
\hline FBXL16 & $-1,34$ & $8,72 \mathrm{E}-03$ & $-2,05$ & $3,33 \mathrm{E}-04$ \\
\hline FBX010 & $-1,14$ & $9,23 \mathrm{E}-03$ & $-1,22$ & $3,76 \mathrm{E}-05$ \\
\hline FCRL1 & $-1,29$ & $3,92 \mathrm{E}-03$ & $-3,49$ & $5,43 \mathrm{E}-13$ \\
\hline FCRL6 & $-1,60$ & $5,94 \mathrm{E}-04$ & $-2,99$ & $5,11 \mathrm{E}-18$ \\
\hline FDPSP5 & 0,98 & 7,27E-03 & 1,32 & $2,36 \mathrm{E}-05$ \\
\hline FGF9 & $-1,57$ & $7,14 \mathrm{E}-03$ & $-3,66$ & $1,09 \mathrm{E}-06$ \\
\hline FGFR2 & $-2,60$ & $4,57 \mathrm{E}-05$ & $-2,26$ & $8,37 \mathrm{E}-04$ \\
\hline FHIT & $-1,78$ & $2,95 \mathrm{E}-04$ & $-2,19$ & $2,47 \mathrm{E}-06$ \\
\hline FHOD1 & 0,92 & $2,85 \mathrm{E}-03$ & 1,56 & $1,17 \mathrm{E}-18$ \\
\hline FIGNL1 & 1,42 & 1,57E-04 & 1,88 & $1,53 \mathrm{E}-20$ \\
\hline FKBP1C & 1,07 & $6,63 \mathrm{E}-03$ & 1,11 & $1,89 \mathrm{E}-03$ \\
\hline FKBP5 & 1,19 & $1,04 \mathrm{E}-03$ & 1,14 & $2,32 \mathrm{E}-06$ \\
\hline FLG & 1,91 & $2,58 \mathrm{E}-03$ & 2,58 & $1,13 \mathrm{E}-03$ \\
\hline FLG-AS1 & 2,21 & $4,62 \mathrm{E}-04$ & 2,40 & $2,32 \mathrm{E}-03$ \\
\hline FOXO3 & $-1,16$ & $3,32 \mathrm{E}-03$ & $-1,27$ & $1,00 \mathrm{E}-05$ \\
\hline FRMD6 & 1,41 & $1,98 \mathrm{E}-03$ & 1,98 & $8,21 \mathrm{E}-10$ \\
\hline FRMPD3 & $-1,67$ & $1,01 \mathrm{E}-03$ & $-3,17$ & $4,12 \mathrm{E}-12$ \\
\hline FRY & $-1,29$ & $1,73 \mathrm{E}-03$ & $-1,75$ & $2,06 \mathrm{E}-07$ \\
\hline FSTL4 & $-1,74$ & $4,17 \mathrm{E}-03$ & $-2,75$ & $2,59 \mathrm{E}-04$ \\
\hline FYC01 & $-1,09$ & $2,02 \mathrm{E}-03$ & $-0,74$ & $7,53 \mathrm{E}-06$ \\
\hline FYN & 1,16 & $6,13 \mathrm{E}-03$ & 1,09 & 7,57E-03 \\
\hline GAB3 & $-1,46$ & $2,31 \mathrm{E}-05$ & $-1,70$ & $9,42 \mathrm{E}-26$ \\
\hline GABBR1 & $-0,87$ & $9,91 \mathrm{E}-03$ & $-0,64$ & $4,59 \mathrm{E}-04$ \\
\hline GAL3ST1 & $-2,16$ & $8,64 \mathrm{E}-04$ & $-2,92$ & $3,45 \mathrm{E}-04$ \\
\hline GAL3ST4 & $-2,51$ & $5,32 \mathrm{E}-08$ & $-2,83$ & $4,65 \mathrm{E}-11$ \\
\hline GAPDH & 2,20 & $2,52 \mathrm{E}-12$ & 2,58 & $1,14 \mathrm{E}-38$ \\
\hline
\end{tabular}

\begin{tabular}{|c|c|c|c|c|}
\hline GAPDHP1 & 2,22 & $6,61 \mathrm{E}-11$ & 2,72 & $9,43 \mathrm{E}-27$ \\
\hline GAPDHP21 & 1,95 & $3,74 \mathrm{E}-06$ & 2,24 & $2,14 \mathrm{E}-11$ \\
\hline GAPDHP40 & 2,08 & $2,50 \mathrm{E}-10$ & 2,55 & 6,70 E- 26 \\
\hline GAPDHP41 & 1,83 & 1,67E-04 & 3,02 & $6,61 \mathrm{E}-14$ \\
\hline GAPDHP44 & 2,00 & $6,07 \mathrm{E}-07$ & 2,57 & $3,06 \mathrm{E}-17$ \\
\hline GAPDHP60 & 2,26 & $1,33 \mathrm{E}-11$ & 2,87 & $1,59 \mathrm{E}-31$ \\
\hline GAPDHP61 & 1,63 & 3,61E-04 & 1,92 & $4,53 \mathrm{E}-07$ \\
\hline GAPDHP63 & 2,11 & $9,21 \mathrm{E}-10$ & 2,59 & $3,33 \mathrm{E}-26$ \\
\hline GAPDHP64 & 1,66 & 1,24E-03 & 1,98 & $3,11 \mathrm{E}-05$ \\
\hline GAPDHP65 & 2,20 & $7,42 \mathrm{E}-11$ & 2,77 & $1,34 \mathrm{E}-34$ \\
\hline GAPDHP67 & 1,80 & $1,28 \mathrm{E}-03$ & 2,47 & $6,83 \mathrm{E}-06$ \\
\hline GAPDHP69 & 2,07 & $2,05 \mathrm{E}-10$ & 2,48 & $3,28 \mathrm{E}-28$ \\
\hline GAPDHP70 & 2,09 & $2,24 \mathrm{E}-07$ & 2,34 & $1,47 \mathrm{E}-12$ \\
\hline GAPDHP71 & 1,60 & $2,30 \mathrm{E}-03$ & 1,92 & $4,52 \mathrm{E}-04$ \\
\hline GAPDHP72 & 2,27 & 1,47E-09 & 2,66 & $1,68 \mathrm{E}-16$ \\
\hline GAPDHP73 & 1,78 & 2,01E-03 & 1,82 & $2,78 \mathrm{E}-03$ \\
\hline GAPT & $-1,78$ & $3,13 \mathrm{E}-03$ & $-4,08$ & $1,27 \mathrm{E}-24$ \\
\hline GAR1 & 0,94 & 9,94E-03 & 1,33 & $1,05 \mathrm{E}-06$ \\
\hline GART & 1,24 & $2,82 \mathrm{E}-03$ & 1,63 & $2,30 \mathrm{E}-06$ \\
\hline GAS6 & $-1,49$ & $6,16 \mathrm{E}-04$ & $-1,95$ & $4,67 \mathrm{E}-17$ \\
\hline GCSHP5 & 1,08 & $6,46 \mathrm{E}-03$ & 1,48 & $5,77 \mathrm{E}-08$ \\
\hline GEN1 & 1,45 & $2,68 \mathrm{E}-04$ & 1,88 & $2,79 \mathrm{E}-20$ \\
\hline GFRA3 & 2,88 & $6,88 \mathrm{E}-06$ & 2,52 & $2,08 \mathrm{E}-03$ \\
\hline GGA2 & $-1,12$ & $2,46 \mathrm{E}-03$ & $-1,30$ & $2,58 \mathrm{E}-06$ \\
\hline GGCT & 0,98 & $5,88 \mathrm{E}-03$ & 1,28 & $2,40 \mathrm{E}-05$ \\
\hline GGH & 1,80 & $3,94 \mathrm{E}-05$ & 2,35 & $5,87 \mathrm{E}-11$ \\
\hline GLIPR1 & $-1,24$ & 1,22E-04 & $-1,53$ & $5,85 \mathrm{E}-18$ \\
\hline GLMN & 1,10 & $5,18 \mathrm{E}-03$ & 1,72 & $5,55 \mathrm{E}-09$ \\
\hline GMDS & 0,96 & $3,12 \mathrm{E}-03$ & 1,29 & $5,68 \mathrm{E}-14$ \\
\hline GMNN & 2,29 & $7,48 \mathrm{E}-08$ & 2,98 & $5,54 \mathrm{E}-14$ \\
\hline GMPS & 1,01 & $3,73 \mathrm{E}-03$ & 1,33 & $1,83 \mathrm{E}-17$ \\
\hline GMPSP1 & 0,93 & $6,54 \mathrm{E}-03$ & 1,46 & $5,21 \mathrm{E}-15$ \\
\hline GNAI1 & 1,28 & $3,81 \mathrm{E}-03$ & 1,20 & $1,03 \mathrm{E}-03$ \\
\hline GNAO1 & $-1,24$ & $3,89 \mathrm{E}-03$ & $-2,43$ & $1,33 \mathrm{E}-09$ \\
\hline GNB4 & $-1,45$ & 6,94E-03 & $-2,57$ & 2,87E-05 \\
\hline GNG7 & $-2,15$ & $3,61 \mathrm{E}-07$ & $-4,62$ & $1,18 \mathrm{E}-41$ \\
\hline GNL1 & 1,18 & $1,36 \mathrm{E}-04$ & 1,71 & $8,97 \mathrm{E}-31$ \\
\hline GOLGA6L20 & $-1,65$ & $4,51 \mathrm{E}-03$ & $-1,87$ & $2,31 \mathrm{E}-03$ \\
\hline GOLGA7B & $-1,66$ & $9,29 \mathrm{E}-04$ & $-1,45$ & $1,34 \mathrm{E}-03$ \\
\hline GOLGA7B & $-2,05$ & $2,88 \mathrm{E}-04$ & $-1,81$ & $6,61 \mathrm{E}-04$ \\
\hline GOLGA8N & $-0,93$ & $8,38 \mathrm{E}-03$ & $-1,22$ & $5,46 \mathrm{E}-06$ \\
\hline GOT1 & 0,96 & 7,97E-03 & 1,82 & $2,39 \mathrm{E}-09$ \\
\hline GOT2 & 1,45 & $1,52 \mathrm{E}-04$ & 1,92 & $6,21 \mathrm{E}-26$ \\
\hline GOT2P2 & 1,55 & 1,12E-03 & 2,10 & $4,04 \mathrm{E}-10$ \\
\hline GOT2P3 & 1,53 & $3,50 \mathrm{E}-04$ & 2,09 & $9,28 \mathrm{E}-25$ \\
\hline GPAT2 & 1,06 & $1,06 \mathrm{E}-03$ & 0,90 & $1,66 \mathrm{E}-06$ \\
\hline GPC2 & $-1,35$ & 4,15E-03 & $-2,11$ & $7,23 \mathrm{E}-06$ \\
\hline GPR113 & 1,98 & $2,42 \mathrm{E}-05$ & 1,06 & $4,32 \mathrm{E}-03$ \\
\hline GPRASP1 & $-1,76$ & $1,02 \mathrm{E}-04$ & $-3,00$ & $3,43 \mathrm{E}-10$ \\
\hline GPRIN1 & 1,38 & 1,31E-03 & 2,43 & $3,16 \mathrm{E}-10$ \\
\hline GPSM2 & 1,68 & $5,08 \mathrm{E}-05$ & 1,92 & $1,26 \mathrm{E}-19$ \\
\hline GPT2 & 1,83 & $4,55 \mathrm{E}-06$ & 3,00 & $1,80 \mathrm{E}-22$ \\
\hline GRB10 & $-1,67$ & $2,30 \mathrm{E}-04$ & $-2,39$ & $9,26 \mathrm{E}-11$ \\
\hline GRHL1 & 2,35 & $1,85 \mathrm{E}-05$ & 3,94 & $1,60 \mathrm{E}-20$ \\
\hline GS1-124K5,11 & $-1,29$ & $2,54 \mathrm{E}-03$ & $-2,09$ & $1,11 \mathrm{E}-10$ \\
\hline GS1-72M22,1 & $-1,86$ & $4,11 \mathrm{E}-03$ & $-2,11$ & $6,86 \mathrm{E}-03$ \\
\hline GSTA4 & 1,70 & $2,73 \mathrm{E}-03$ & 1,40 & $2,80 \mathrm{E}-03$ \\
\hline GSTCD & 1,16 & 7,59E-03 & 1,34 & 2,87E-11 \\
\hline GSTM2 & $-1,56$ & $1,83 \mathrm{E}-03$ & $-2,82$ & $2,44 \mathrm{E}-07$ \\
\hline GSTM2P1 & $-1,11$ & $9,89 \mathrm{E}-03$ & $-1,20$ & $2,56 \mathrm{E}-03$ \\
\hline GTF2IRD2 & $-1,03$ & $6,96 \mathrm{E}-03$ & $-2,22$ & $4,62 \mathrm{E}-12$ \\
\hline GTF2IRD2B & $-0,98$ & $7,28 \mathrm{E}-03$ & $-2,22$ & $1,05 \mathrm{E}-13$ \\
\hline GTF2IRD2P1 & $-1,46$ & $2,44 \mathrm{E}-03$ & $-1,49$ & $9,50 \mathrm{E}-04$ \\
\hline GZMK & $-1,56$ & $3,78 \mathrm{E}-04$ & $-1,94$ & $6,45 \mathrm{E}-06$ \\
\hline H2AFY2 & $-0,99$ & $3,37 \mathrm{E}-03$ & $-1,41$ & $4,10 \mathrm{E}-06$ \\
\hline H2AFZ & 1,58 & $8,62 \mathrm{E}-05$ & 2,15 & $1,72 \mathrm{E}-38$ \\
\hline H2AFZP3 & 1,87 & $7,95 \mathrm{E}-06$ & 2,75 & 1,79E-32 \\
\hline HADH & 1,39 & 1,74E-04 & 1,25 & $7,05 \mathrm{E}-07$ \\
\hline HAT1 & 1,29 & $5,36 \mathrm{E}-04$ & 1,66 & $7,34 \mathrm{E}-11$ \\
\hline HAUS1 & 1,54 & $2,23 \mathrm{E}-04$ & 1,89 & $4,68 \mathrm{E}-22$ \\
\hline HAUS1P1 & 1,18 & $2,89 \mathrm{E}-03$ & 1,72 & $1,60 \mathrm{E}-09$ \\
\hline HAUS1P2 & 1,50 & 1,68E-04 & 2,00 & $6,52 \mathrm{E}-19$ \\
\hline HAUS8 & 1,10 & $1,45 \mathrm{E}-03$ & 1,30 & 5,96E-07 \\
\hline HBS1L & 1,80 & $2,05 \mathrm{E}-06$ & 2,13 & $3,14 \mathrm{E}-16$ \\
\hline HCG27 & $-1,72$ & $3,15 \mathrm{E}-04$ & $-2,36$ & 1,56E-05 \\
\hline HCG4P3 & $-1,79$ & $4,45 \mathrm{E}-04$ & $-1,67$ & 3,34E-04 \\
\hline HDAC11 & $-1,05$ & $3,03 \mathrm{E}-03$ & $-1,51$ & $2,50 \mathrm{E}-12$ \\
\hline HGD & $-1,88$ & 1,59E-04 & $-1,53$ & $3,03 \mathrm{E}-03$ \\
\hline HID1 & $-1,40$ & $6,64 \mathrm{E}-03$ & $-2,32$ & 2,03E-05 \\
\hline
\end{tabular}




\begin{tabular}{|c|c|c|c|c|}
\hline HIRIP3 & 1,42 & $3,14 \mathrm{E}-04$ & 1,64 & $2,32 \mathrm{E}-08$ \\
\hline HIST1H2AB & 2,17 & 7,73E-04 & 6,00 & $6,59 \mathrm{E}-22$ \\
\hline HIST1H2AH & 1,84 & $3,31 \mathrm{E}-03$ & 6,35 & $3,79 \mathrm{E}-34$ \\
\hline HIST1H2AL & 2,92 & $4,90 \mathrm{E}-06$ & 7,40 & $1,12 \mathrm{E}-32$ \\
\hline HIST1H2AM & 1,78 & $5,93 \mathrm{E}-03$ & 6,13 & $4,79 \mathrm{E}-23$ \\
\hline HIST1H2BD & 1,15 & $6,13 \mathrm{E}-03$ & 3,69 & $1,10 \mathrm{E}-40$ \\
\hline HIST1H2BG & 1,72 & $1,88 \mathrm{E}-03$ & 5,26 & $1,09 \mathrm{E}-40$ \\
\hline HIST1H2BJ & 1,45 & $3,32 \mathrm{E}-03$ & 4,58 & $1,53 \mathrm{E}-41$ \\
\hline HIST1H2BL & 2,07 & $1,32 \mathrm{E}-03$ & 6,34 & $6,72 \mathrm{E}-28$ \\
\hline HIST1H3B & 2,26 & $4,57 \mathrm{E}-04$ & 7,88 & $2,66 \mathrm{E}-43$ \\
\hline HIST1H3D & 1,85 & $7,13 \mathrm{E}-04$ & 5,35 & $1,26 \mathrm{E}-38$ \\
\hline HIST1H3G & 1,78 & $5,87 \mathrm{E}-03$ & 6,42 & $1,02 \mathrm{E}-28$ \\
\hline HIST1H3H & 1,70 & $3,52 \mathrm{E}-03$ & 5,96 & $1,73 \mathrm{E}-41$ \\
\hline HIST1H4C & 1,82 & $4,32 \mathrm{E}-03$ & 6,56 & 7,07E-34 \\
\hline HKDC1 & $-2,84$ & $3,20 \mathrm{E}-08$ & $-4,17$ & $2,85 \mathrm{E}-09$ \\
\hline HMBS & 1,06 & $3,92 \mathrm{E}-03$ & 1,08 & $1,03 \mathrm{E}-10$ \\
\hline HMCES & 1,20 & $2,73 \mathrm{E}-04$ & 1,37 & $5,68 \mathrm{E}-10$ \\
\hline HMGA1 & 1,20 & $3,10 \mathrm{E}-04$ & 1,44 & $2,32 \mathrm{E}-13$ \\
\hline HMGA1P2 & 1,19 & $3,32 \mathrm{E}-03$ & 1,53 & $4,54 \mathrm{E}-08$ \\
\hline HMGA1P3 & 1,22 & $1,29 \mathrm{E}-03$ & 1,58 & $2,03 \mathrm{E}-07$ \\
\hline HMGA1P6 & 1,51 & $1,52 \mathrm{E}-04$ & 2,05 & $1,13 \mathrm{E}-09$ \\
\hline HMGA1P8 & 1,25 & $2,33 \mathrm{E}-04$ & 1,53 & $5,94 \mathrm{E}-16$ \\
\hline HMGB1P5 & 1,21 & $3,17 \mathrm{E}-03$ & 1,13 & $1,99 \mathrm{E}-15$ \\
\hline HMGB3 & 2,10 & $3,19 \mathrm{E}-05$ & 2,21 & $2,80 \mathrm{E}-06$ \\
\hline HMGB3P32 & 1,72 & $3,61 \mathrm{E}-03$ & 1,59 & $3,45 \mathrm{E}-03$ \\
\hline HMGB3P6 & 2,20 & $1,05 \mathrm{E}-05$ & 2,52 & $8,92 \mathrm{E}-11$ \\
\hline HMGN2 & 0,96 & $3,52 \mathrm{E}-03$ & 1,10 & $1,85 \mathrm{E}-10$ \\
\hline HMGN2P3 & 1,48 & $9,01 \mathrm{E}-05$ & 1,74 & $2,97 \mathrm{E}-08$ \\
\hline HMGN2P4 & 1,50 & $1,00 \mathrm{E}-05$ & 1,70 & $6,37 \mathrm{E}-12$ \\
\hline HMGN2P5 & 1,48 & $4,22 \mathrm{E}-05$ & 1,74 & $2,62 \mathrm{E}-13$ \\
\hline HMGN2P6 & 1,79 & $4,77 \mathrm{E}-05$ & 2,33 & $2,11 \mathrm{E}-13$ \\
\hline HMGN5 & 1,73 & 1,02E-05 & 2,32 & $8,51 \mathrm{E}-24$ \\
\hline $\mathrm{HN} 1$ & 1,05 & $2,80 \mathrm{E}-03$ & 1,69 & $5,37 \mathrm{E}-21$ \\
\hline HNF1B & 2,74 & $2,48 \mathrm{E}-06$ & 6,93 & $7,57 \mathrm{E}-50$ \\
\hline HNRNPA1P10 & 1,06 & 1,99E-03 & 1,03 & $1,90 \mathrm{E}-06$ \\
\hline HNRNPA1P26 & 1,23 & $3,95 \mathrm{E}-04$ & 1,63 & $9,88 \mathrm{E}-17$ \\
\hline HNRNPA1P35 & 1,36 & $6,46 \mathrm{E}-03$ & 1,45 & $2,89 \mathrm{E}-03$ \\
\hline HNRNPA1P39 & 1,54 & $2,65 \mathrm{E}-04$ & 1,79 & $3,31 \mathrm{E}-08$ \\
\hline HNRNPA1P48 & 1,13 & $1,24 \mathrm{E}-03$ & 1,01 & $4,89 \mathrm{E}-06$ \\
\hline HNRNPA1P7 & 1,17 & $5,01 \mathrm{E}-04$ & 1,18 & $7,72 \mathrm{E}-08$ \\
\hline HNRNPA1P8 & 1,45 & $3,71 \mathrm{E}-03$ & 1,54 & $5,96 \mathrm{E}-04$ \\
\hline HNRNPAB & 1,62 & 1,49E-06 & 2,12 & $3,63 \mathrm{E}-17$ \\
\hline HNRNPABP1 & 1,53 & $1,53 \mathrm{E}-04$ & 2,21 & $8,86 \mathrm{E}-11$ \\
\hline HNRNPCP4 & 1,09 & $8,44 \mathrm{E}-03$ & 1,36 & $1,50 \mathrm{E}-07$ \\
\hline HNRNPCP7 & 1,17 & $5,68 \mathrm{E}-03$ & 1,26 & $3,08 \mathrm{E}-06$ \\
\hline HNRNPD & 0,85 & $9,32 \mathrm{E}-03$ & 0,97 & $1,85 \mathrm{E}-12$ \\
\hline HNRNPDP1 & 1,02 & $7,15 \mathrm{E}-03$ & 1,25 & $9,45 \mathrm{E}-07$ \\
\hline HNRNPU-AS1 & $-1,17$ & $2,35 \mathrm{E}-03$ & $-1,35$ & $1,66 \mathrm{E}-05$ \\
\hline HNRNPUL1 & 0,98 & $5,44 \mathrm{E}-03$ & 1,13 & $2,62 \mathrm{E}-16$ \\
\hline HOMER1 & 1,39 & $1,16 \mathrm{E}-03$ & 1,82 & $9,45 \mathrm{E}-09$ \\
\hline HOXB7 & 1,52 & $8,11 \mathrm{E}-03$ & 2,28 & $1,20 \mathrm{E}-05$ \\
\hline $\mathrm{HP}$ & $-2,11$ & 1,19E-04 & $-2,46$ & $1,23 \mathrm{E}-05$ \\
\hline HPCAL4 & $-2,38$ & $7,19 \mathrm{E}-06$ & $-3,54$ & $4,26 \mathrm{E}-08$ \\
\hline HPRT1 & 1,19 & $1,35 \mathrm{E}-03$ & 1,54 & $4,12 \mathrm{E}-07$ \\
\hline HPRTP3 & 1,18 & $4,64 \mathrm{E}-03$ & 1,47 & $2,84 \mathrm{E}-06$ \\
\hline HS3ST1 & $-2,43$ & $7,99 \mathrm{E}-06$ & $-3,89$ & $1,63 \mathrm{E}-09$ \\
\hline HSD11B1 & 3,45 & $7,02 \mathrm{E}-10$ & 3,48 & $3,23 \mathrm{E}-07$ \\
\hline HSP90AB1 & 1,06 & $1,81 \mathrm{E}-03$ & 1,43 & $4,54 \mathrm{E}-09$ \\
\hline HSP90AB3P & 1,12 & $3,07 \mathrm{E}-03$ & 1,63 & $3,43 \mathrm{E}-07$ \\
\hline HSPA14 & 1,07 & $7,83 \mathrm{E}-04$ & 1,61 & $1,24 \mathrm{E}-21$ \\
\hline HSPB6 & 2,14 & $9,41 \mathrm{E}-04$ & 2,17 & $8,19 \mathrm{E}-03$ \\
\hline HSPBAP1 & $-1,12$ & $4,14 \mathrm{E}-03$ & $-1,63$ & $1,37 \mathrm{E}-12$ \\
\hline HSPD1 & 1,70 & $8,39 \mathrm{E}-07$ & 2,45 & $6,18 \mathrm{E}-57$ \\
\hline HSPD1P1 & 1,80 & $3,25 \mathrm{E}-06$ & 2,65 & $1,05 \mathrm{E}-24$ \\
\hline HSPD1P5 & 1,44 & $6,94 \mathrm{E}-03$ & 1,98 & $1,77 \mathrm{E}-04$ \\
\hline HSPD1P6 & 1,65 & $5,01 \mathrm{E}-05$ & 2,49 & $9,08 \mathrm{E}-33$ \\
\hline HSPE1 & 1,00 & $2,33 \mathrm{E}-03$ & 1,58 & $4,07 \mathrm{E}-15$ \\
\hline HSPE1P2 & 1,24 & 1,95E-03 & 2,14 & $1,74 \mathrm{E}-09$ \\
\hline HSPE1P4 & 1,31 & 1,54E-03 & 2,03 & $4,44 \mathrm{E}-09$ \\
\hline HSPE1P6 & 1,28 & $9,19 \mathrm{E}-03$ & 1,44 & $1,87 \mathrm{E}-03$ \\
\hline HTRA1 & $-2,73$ & $7,07 \mathrm{E}-06$ & $-4,63$ & $4,06 \mathrm{E}-09$ \\
\hline HYAL3 & 1,38 & $1,05 \mathrm{E}-04$ & 1,75 & $8,14 \mathrm{E}-12$ \\
\hline ICMT & 0,96 & $3,79 \mathrm{E}-03$ & 1,36 & $4,31 \mathrm{E}-08$ \\
\hline ID3 & 1,48 & $1,20 \mathrm{E}-03$ & 1,01 & $1,15 \mathrm{E}-04$ \\
\hline IDS & $-0,98$ & $1,75 \mathrm{E}-03$ & $-1,41$ & $2,93 \mathrm{E}-16$ \\
\hline IDS & $-1,81$ & $2,09 \mathrm{E}-03$ & $-2,20$ & $6,17 \mathrm{E}-04$ \\
\hline IFFO1 & $-0,95$ & $7,38 \mathrm{E}-03$ & $-2,02$ & $4,71 \mathrm{E}-33$ \\
\hline IFI27L1 & 1,16 & $6,20 \mathrm{E}-04$ & 1,24 & $8,41 \mathrm{E}-09$ \\
\hline IFITM2 & 1,51 & $7,62 \mathrm{E}-06$ & 0,89 & $1,36 \mathrm{E}-04$ \\
\hline
\end{tabular}

\begin{tabular}{|c|c|c|c|c|}
\hline IFNE & $-1,74$ & $6,18 \mathrm{E}-03$ & $-2,17$ & $8,23 \mathrm{E}-03$ \\
\hline IGF1R & $-1,12$ & 1,99E-03 & $-1,97$ & $1,44 \mathrm{E}-19$ \\
\hline IGFBP3 & $-3,04$ & $5,67 \mathrm{E}-11$ & $-3,28$ & $4,43 \mathrm{E}-13$ \\
\hline IGFBP6 & 2,52 & $2,16 \mathrm{E}-07$ & 2,74 & $2,78 \mathrm{E}-09$ \\
\hline IGHD & $-1,67$ & $2,07 \mathrm{E}-03$ & $-3,15$ & $8,50 \mathrm{E}-11$ \\
\hline IGHG1 & $-1,99$ & $4,18 \mathrm{E}-04$ & $-3,80$ & $1,15 \mathrm{E}-08$ \\
\hline IGHG3 & $-1,58$ & 4,43E-03 & $-3,49$ & $1,19 \mathrm{E}-12$ \\
\hline IGHG4 & $-2,08$ & $4,57 \mathrm{E}-04$ & $-3,89$ & $6,31 \mathrm{E}-08$ \\
\hline IGHGP & $-1,95$ & $6,32 \mathrm{E}-04$ & $-3,63$ & $5,50 \mathrm{E}-07$ \\
\hline IGHJ2 & $-1,85$ & $1,00 \mathrm{E}-03$ & $-2,65$ & $5,26 \mathrm{E}-06$ \\
\hline IGHJ3 & $-1,77$ & 1,89E-03 & $-3,45$ & $8,61 \mathrm{E}-12$ \\
\hline IGHV1-18 & $-1,48$ & $9,36 \mathrm{E}-03$ & $-2,82$ & $3,84 \mathrm{E}-09$ \\
\hline IGHV1-2 & $-1,58$ & $1,66 \mathrm{E}-03$ & $-3,05$ & $2,89 \mathrm{E}-10$ \\
\hline IGHV1-24 & $-1,77$ & $4,10 \mathrm{E}-03$ & $-3,86$ & $8,53 \mathrm{E}-07$ \\
\hline IGHV1-46 & $-1,60$ & $2,01 \mathrm{E}-03$ & $-2,80$ & $1,29 \mathrm{E}-06$ \\
\hline IGHV1-69 & $-2,24$ & 2,16E-05 & $-3,15$ & $3,85 \mathrm{E}-09$ \\
\hline IGHV1OR16-3 & $-1,63$ & $6,50 \mathrm{E}-03$ & $-3,45$ & $9,23 \mathrm{E}-06$ \\
\hline IGHV2-5 & $-2,45$ & $9,28 \mathrm{E}-07$ & $-2,61$ & $1,32 \mathrm{E}-05$ \\
\hline IGHV3-21 & $-1,55$ & $8,61 \mathrm{E}-03$ & $-3,07$ & $3,31 \mathrm{E}-11$ \\
\hline IGHV3-23 & $-1,42$ & $9,52 \mathrm{E}-03$ & $-2,78$ & $1,09 \mathrm{E}-19$ \\
\hline IGHV3-30 & $-1,48$ & $6,59 \mathrm{E}-03$ & $-3,04$ & $1,62 \mathrm{E}-23$ \\
\hline IGHV3-43 & $-1,56$ & $5,02 \mathrm{E}-03$ & $-2,69$ & $2,37 \mathrm{E}-05$ \\
\hline IGHV3-48 & $-1,42$ & $8,70 \mathrm{E}-03$ & $-2,69$ & $1,89 \mathrm{E}-12$ \\
\hline IGHV3-49 & $-1,63$ & $4,01 \mathrm{E}-03$ & $-2,35$ & $4,07 \mathrm{E}-07$ \\
\hline IGHV3-64 & $-2,29$ & 1,84E-04 & $-2,94$ & $8,34 \mathrm{E}-05$ \\
\hline IGHV3-9 & $-1,57$ & $4,46 \mathrm{E}-03$ & $-3,57$ & $3,34 \mathrm{E}-11$ \\
\hline IGHV3OR16-12 & $-1,84$ & 1,71E-03 & $-2,79$ & $1,42 \mathrm{E}-05$ \\
\hline IGHV4-31 & $-1,62$ & 1,84E-03 & $-2,85$ & $3,25 \mathrm{E}-08$ \\
\hline IGHV5-51 & $-1,74$ & $2,30 \mathrm{E}-03$ & $-2,70$ & $9,03 \mathrm{E}-07$ \\
\hline IGHV6-1 & $-1,77$ & $1,62 \mathrm{E}-03$ & $-1,57$ & $4,85 \mathrm{E}-03$ \\
\hline IGIP & $-1,26$ & $3,32 \mathrm{E}-03$ & $-1,56$ & $2,34 \mathrm{E}-05$ \\
\hline IGJP1 & $-1,55$ & 5,33E-03 & $-2,43$ & $1,96 \mathrm{E}-06$ \\
\hline IGKJ3 & $-1,53$ & $4,28 \mathrm{E}-03$ & $-2,72$ & $4,10 \mathrm{E}-07$ \\
\hline IGKJ4 & $-1,56$ & 4,89E-03 & $-2,96$ & $2,78 \mathrm{E}-12$ \\
\hline IGKV1-12 & $-2,37$ & $1,53 \mathrm{E}-05$ & $-3,09$ & $1,25 \mathrm{E}-06$ \\
\hline IGKV1-16 & $-1,58$ & $6,29 \mathrm{E}-03$ & $-2,84$ & $1,17 \mathrm{E}-18$ \\
\hline IGKV1-17 & $-1,67$ & 4,17E-03 & $-2,59$ & $3,86 \mathrm{E}-06$ \\
\hline IGKV1-27 & $-1,46$ & 4,97E-03 & $-2,89$ & $2,66 \mathrm{E}-11$ \\
\hline IGKV1-33 & $-1,54$ & $6,24 \mathrm{E}-03$ & $-3,26$ & $9,38 \mathrm{E}-08$ \\
\hline IGKV1-5 & $-1,82$ & $7,12 \mathrm{E}-04$ & $-3,16$ & $1,14 \mathrm{E}-08$ \\
\hline IGKV1-8 & $-1,82$ & $7,42 \mathrm{E}-04$ & $-3,25$ & $1,02 \mathrm{E}-06$ \\
\hline IGKV1D-12 & $-1,87$ & $8,62 \mathrm{E}-04$ & $-2,94$ & $2,78 \mathrm{E}-07$ \\
\hline IGKV1D-16 & $-1,66$ & $3,67 \mathrm{E}-03$ & $-2,62$ & $2,16 \mathrm{E}-06$ \\
\hline IGKV1D-17 & $-1,41$ & $6,22 \mathrm{E}-03$ & $-3,03$ & $3,83 \mathrm{E}-08$ \\
\hline IGKV1D-33 & $-1,96$ & 2,63E-04 & $-3,45$ & $1,22 \mathrm{E}-09$ \\
\hline IGKV1D-39 & $-1,58$ & $2,75 \mathrm{E}-03$ & $-2,72$ & $6,21 \mathrm{E}-18$ \\
\hline IGKV1D-42 & $-1,50$ & $5,28 \mathrm{E}-03$ & $-3,19$ & $3,42 \mathrm{E}-11$ \\
\hline IGKV2D-40 & $-1,65$ & 9,94E-03 & $-2,42$ & $2,36 \mathrm{E}-03$ \\
\hline IGKV3-20 & $-1,64$ & 1,77E-03 & $-3,24$ & $3,45 \mathrm{E}-16$ \\
\hline IGKV3D-15 & $-1,88$ & $1,20 \mathrm{E}-04$ & $-2,78$ & $3,32 \mathrm{E}-10$ \\
\hline IGKV3D-20 & $-1,74$ & 1,07E-03 & $-2,96$ & $6,30 \mathrm{E}-13$ \\
\hline IGKV4-1 & $-1,49$ & $3,62 \mathrm{E}-03$ & $-3,11$ & 5,39E-11 \\
\hline IGLC2 & $-1,43$ & 9,33E-03 & $-3,10$ & $2,78 \mathrm{E}-16$ \\
\hline IGLV1-44 & $-1,54$ & $4,88 \mathrm{E}-03$ & $-2,82$ & $3,42 E-08$ \\
\hline IGLV2-11 & $-1,63$ & 1,32E-03 & $-2,47$ & $6,95 \mathrm{E}-07$ \\
\hline IGLV3-1 & $-1,66$ & $2,01 \mathrm{E}-03$ & $-2,97$ & $7,09 \mathrm{E}-09$ \\
\hline IGLV3-10 & $-1,57$ & 5,67E-03 & $-3,40$ & $5,34 \mathrm{E}-22$ \\
\hline IGLV3-19 & $-1,60$ & $5,71 \mathrm{E}-03$ & $-3,40$ & $9,72 \mathrm{E}-10$ \\
\hline IGLV3-21 & $-1,65$ & 2,97E-03 & $-3,42$ & $4,35 \mathrm{E}-10$ \\
\hline IGLV3-25 & $-1,52$ & $6,49 \mathrm{E}-03$ & $-3,43$ & $2,38 \mathrm{E}-13$ \\
\hline IGLV3-27 & $-1,62$ & $3,76 \mathrm{E}-03$ & $-3,01$ & $1,78 \mathrm{E}-05$ \\
\hline IGLV3-9 & $-2,19$ & $3,64 \mathrm{E}-05$ & $-2,66$ & $1,23 \mathrm{E}-05$ \\
\hline IGLV4-3 & $-2,16$ & 5,17E-04 & $-2,55$ & $2,80 \mathrm{E}-05$ \\
\hline IGLV6-57 & $-1,73$ & $2,30 \mathrm{E}-03$ & $-2,71$ & $1,58 \mathrm{E}-05$ \\
\hline IL10RA & $-1,09$ & 7,39E-03 & $-1,70$ & $4,04 \mathrm{E}-34$ \\
\hline IL11RA & $-1,40$ & $2,76 \mathrm{E}-03$ & $-1,46$ & $2,68 \mathrm{E}-03$ \\
\hline IL12B & 1,89 & $3,49 \mathrm{E}-03$ & 5,65 & $3,75 \mathrm{E}-21$ \\
\hline IL2 & 1,61 & 4,09E-03 & 3,67 & $1,82 \mathrm{E}-15$ \\
\hline IL24 & $-1,60$ & $1,65 \mathrm{E}-03$ & $-2,93$ & 4,34E-08 \\
\hline IL31RA & 2,63 & $9,41 \mathrm{E}-06$ & 3,84 & $1,43 \mathrm{E}-10$ \\
\hline IL32 & 1,18 & $5,89 \mathrm{E}-03$ & 1,95 & $4,42 \mathrm{E}-06$ \\
\hline IL6R & $-1,38$ & 1,95E-03 & $-2,46$ & $1,72 \mathrm{E}-21$ \\
\hline IL7R & $-1,34$ & $6,45 \mathrm{E}-03$ & $-1,36$ & $3,07 \mathrm{E}-03$ \\
\hline ILF2 & 1,12 & 1,77E-03 & 1,47 & $1,49 \mathrm{E}-09$ \\
\hline ILF2P1 & 1,20 & 1,19E-03 & 1,74 & $1,70 \mathrm{E}-09$ \\
\hline ILF3-AS1 & $-1,22$ & 2,07E-03 & $-2,01$ & $1,33 \mathrm{E}-08$ \\
\hline IMPDH2 & 1,45 & 1,81E-06 & 2,08 & $5,19 \mathrm{E}-52$ \\
\hline INCENP & 2,08 & $1,48 \mathrm{E}-07$ & 2,25 & $3,66 \mathrm{E}-24$ \\
\hline INPP4B & 1,54 & $3,10 \mathrm{E}-03$ & 2,31 & $6,95 \mathrm{E}-06$ \\
\hline
\end{tabular}




\begin{tabular}{|c|c|c|c|c|}
\hline INSRR & 2,14 & 1,57E-04 & 4,10 & $3,80 \mathrm{E}-16$ \\
\hline INTS7 & 1,06 & $2,51 \mathrm{E}-03$ & 1,56 & $1,10 \mathrm{E}-12$ \\
\hline IPO5 & 1,31 & 2,61E-04 & 1,86 & $3,99 \mathrm{E}-22$ \\
\hline IP08P1 & 1,08 & $7,69 \mathrm{E}-03$ & 1,52 & $2,37 \mathrm{E}-06$ \\
\hline IQCA1 & 2,16 & $3,35 \mathrm{E}-05$ & 2,39 & $3,60 \mathrm{E}-05$ \\
\hline IRG1 & 3,04 & $2,24 \mathrm{E}-06$ & 5,87 & $3,44 \mathrm{E}-18$ \\
\hline IRS2 & $-1,29$ & $3,55 \mathrm{E}-03$ & $-2,74$ & $3,50 \mathrm{E}-11$ \\
\hline ITFG2 & $-0,88$ & $9,75 \mathrm{E}-03$ & $-1,17$ & $2,97 \mathrm{E}-07$ \\
\hline ITGA5 & $-1,15$ & $7,06 \mathrm{E}-03$ & $-1,85$ & $2,67 \mathrm{E}-10$ \\
\hline ITGA6 & $-2,28$ & 1,24E-08 & $-4,13$ & $3,73 E-51$ \\
\hline JHDM1D-AS1 & $-1,30$ & $4,55 \mathrm{E}-03$ & $-2,03$ & $6,68 \mathrm{E}-06$ \\
\hline JMJD7-PLA2G4B & $-1,52$ & $1,36 \mathrm{E}-03$ & $-2,44$ & $2,19 \mathrm{E}-08$ \\
\hline JMY & $-1,02$ & 7,34E-03 & $-1,08$ & $1,44 \mathrm{E}-03$ \\
\hline KAL1 & $-1,71$ & $1,84 \mathrm{E}-03$ & $-4,74$ & $5,98 \mathrm{E}-11$ \\
\hline KALRN & $-1,91$ & $1,69 \mathrm{E}-04$ & $-2,30$ & $9,82 \mathrm{E}-06$ \\
\hline $\mathrm{KB}-226 \mathrm{~F} 1,1$ & $-1,51$ & 1,77E-03 & $-2,36$ & $1,72 \mathrm{E}-05$ \\
\hline KBTBD11 & $-1,34$ & $1,90 \mathrm{E}-03$ & $-2,08$ & $3,46 \mathrm{E}-08$ \\
\hline KCNN4 & 1,33 & $2,11 \mathrm{E}-04$ & 1,76 & $1,54 \mathrm{E}-08$ \\
\hline KDELC1 & 1,94 & $4,98 \mathrm{E}-04$ & 3,17 & $9,76 \mathrm{E}-16$ \\
\hline KDELC1P1 & 2,05 & $2,29 \mathrm{E}-04$ & 3,20 & $1,36 \mathrm{E}-11$ \\
\hline KDELC2 & 1,31 & $5,09 \mathrm{E}-04$ & 1,76 & $3,05 \mathrm{E}-25$ \\
\hline KDM7A & $-1,38$ & 1,17E-03 & $-1,75$ & $7,42 \mathrm{E}-07$ \\
\hline KHDC1 & 1,71 & $1,84 \mathrm{E}-03$ & 2,17 & $3,17 \mathrm{E}-04$ \\
\hline KIAA0125 & $-1,96$ & $8,96 \mathrm{E}-05$ & $-2,17$ & $2,67 \mathrm{E}-06$ \\
\hline KIAA1549 & 1,74 & $1,06 \mathrm{E}-03$ & 2,35 & $1,05 \mathrm{E}-07$ \\
\hline KIAA1919 & $-0,98$ & $5,57 \mathrm{E}-03$ & $-0,99$ & $7,62 \mathrm{E}-06$ \\
\hline KIF22 & 1,32 & $2,85 \mathrm{E}-03$ & 1,54 & $2,58 \mathrm{E}-04$ \\
\hline KIFAP3 & 0,91 & $5,55 \mathrm{E}-03$ & 1,57 & $2,16 \mathrm{E}-16$ \\
\hline $\mathrm{KLC2}$ & 1,05 & $2,17 \mathrm{E}-03$ & 1,63 & $4,03 E-11$ \\
\hline KLF11 & $-0,95$ & $5,43 \mathrm{E}-03$ & $-1,42$ & $6,13 \mathrm{E}-08$ \\
\hline KLF2 & $-1,74$ & $1,09 \mathrm{E}-03$ & $-3,62$ & $7,94 \mathrm{E}-11$ \\
\hline KLF3 & $-1,54$ & 3,31E-04 & $-2,33$ & $7,65 \mathrm{E}-11$ \\
\hline KLF3P1 & $-1,66$ & $6,28 \mathrm{E}-05$ & $-2,33$ & $4,40 \mathrm{E}-11$ \\
\hline KLHDC1 & $-1,34$ & $2,86 \mathrm{E}-03$ & $-2,22$ & $6,31 \mathrm{E}-06$ \\
\hline KLHL14 & $-1,92$ & $1,81 \mathrm{E}-03$ & $-2,64$ & $4,48 \mathrm{E}-04$ \\
\hline KLHL23 & 1,89 & 6,77E-05 & 2,91 & $3,35 \mathrm{E}-14$ \\
\hline KLHL24 & $-1,05$ & $8,35 \mathrm{E}-03$ & $-1,97$ & $1,41 \mathrm{E}-18$ \\
\hline KLHL36 & $-0,89$ & $9,33 \mathrm{E}-03$ & $-1,05$ & $5,74 \mathrm{E}-06$ \\
\hline KLRC1 & 3,61 & $9,10 \mathrm{E}-12$ & 5,44 & $1,53 \mathrm{E}-43$ \\
\hline KLRC2 & 2,99 & $2,02 \mathrm{E}-10$ & 3,27 & $5,37 \mathrm{E}-14$ \\
\hline KLRC3 & 1,86 & $1,43 \mathrm{E}-04$ & 1,61 & $5,67 \mathrm{E}-04$ \\
\hline KM-PA-2 & 0,83 & $7,43 \mathrm{E}-03$ & 1,00 & $3,87 \mathrm{E}-10$ \\
\hline KNSTRN & 1,84 & $2,16 \mathrm{E}-05$ & 2,58 & $6,15 \mathrm{E}-12$ \\
\hline KPNA2 & 2,34 & $5,57 \mathrm{E}-07$ & 2,82 & $2,72 \mathrm{E}-12$ \\
\hline KRT1 & $-1,87$ & 1,71E-04 & $-3,02$ & $1,18 \mathrm{E}-07$ \\
\hline KRT72 & $-1,76$ & $6,87 \mathrm{E}-04$ & $-4,55$ & $3,08 \mathrm{E}-13$ \\
\hline KRTAP5-1 & $-1,68$ & $6,32 \mathrm{E}-03$ & $-3,18$ & $2,30 \mathrm{E}-05$ \\
\hline L1CAM & $-1,27$ & $1,32 \mathrm{E}-04$ & $-2,21$ & $1,34 \mathrm{E}-15$ \\
\hline L2HGDH & 1,61 & 4,06E-05 & 2,10 & $2,59 \mathrm{E}-16$ \\
\hline L3HYPDH & $-1,20$ & $5,46 \mathrm{E}-03$ & $-1,59$ & $6,35 \mathrm{E}-05$ \\
\hline LA16C-OS12,2 & $-1,94$ & $1,02 \mathrm{E}-04$ & $-2,45$ & $5,82 \mathrm{E}-06$ \\
\hline LACC1 & $-1,85$ & $2,90 \mathrm{E}-04$ & $-3,06$ & $2,04 \mathrm{E}-10$ \\
\hline LCN8 & $-2,36$ & 2,63E-04 & $-2,96$ & 2,17E-04 \\
\hline LCNL1 & $-1,37$ & 4,76E-03 & $-4,64$ & $2,18 \mathrm{E}-10$ \\
\hline LCTL & 1,37 & $5,82 \mathrm{E}-03$ & 1,95 & $2,12 \mathrm{E}-05$ \\
\hline LDHAP1 & 1,89 & $3,58 \mathrm{E}-03$ & 2,78 & 4,79E-04 \\
\hline LDHAP2 & 1,63 & $7,70 \mathrm{E}-05$ & 2,48 & $3,65 \mathrm{E}-20$ \\
\hline LDHAP3 & 1,76 & 4,64E-04 & 2,70 & $3,73 \mathrm{E}-14$ \\
\hline LDLRAD3 & $-1,74$ & 1,88E-03 & $-2,82$ & $8,74 \mathrm{E}-06$ \\
\hline LDLRAP1 & $-1,54$ & $8,27 \mathrm{E}-04$ & $-3,01$ & $1,37 \mathrm{E}-12$ \\
\hline LENG8 & $-1,19$ & $3,22 \mathrm{E}-03$ & $-2,00$ & 4,57E-09 \\
\hline LEPREL2 & $-2,42$ & $7,85 \mathrm{E}-06$ & $-3,66$ & $1,96 \mathrm{E}-09$ \\
\hline LGALS4 & $-1,69$ & $2,85 \mathrm{E}-04$ & $-1,74$ & 1,84E-03 \\
\hline LGALSL & 1,30 & $2,62 \mathrm{E}-03$ & 1,51 & $1,57 \mathrm{E}-05$ \\
\hline LGR4 & $-1,95$ & 1,64E-03 & $-3,97$ & $1,52 \mathrm{E}-10$ \\
\hline LGR6 & $-1,68$ & $8,90 \mathrm{E}-04$ & $-2,25$ & $9,84 \mathrm{E}-05$ \\
\hline LINC00205 & $-1,14$ & 7,49E-03 & $-2,06$ & $1,42 \mathrm{E}-06$ \\
\hline LINC00243 & $-1,74$ & $1,29 \mathrm{E}-03$ & $-2,06$ & $2,11 \mathrm{E}-03$ \\
\hline LINC00304 & $-1,71$ & $4,08 \mathrm{E}-03$ & $-1,86$ & $7,13 \mathrm{E}-03$ \\
\hline LINC00312 & 2,35 & $7,80 \mathrm{E}-05$ & 2,29 & $5,22 \mathrm{E}-04$ \\
\hline LINC00337 & 1,64 & $2,06 \mathrm{E}-03$ & 2,70 & $1,73 \mathrm{E}-08$ \\
\hline LINC00402 & $-2,45$ & $3,82 \mathrm{E}-06$ & $-4,82$ & $1,22 \mathrm{E}-13$ \\
\hline LINC00528 & $-1,42$ & $2,19 \mathrm{E}-03$ & $-2,70$ & $1,03 \mathrm{E}-07$ \\
\hline LINC00565 & $-1,55$ & $5,34 \mathrm{E}-03$ & $-1,91$ & $2,76 \mathrm{E}-03$ \\
\hline LINC00634 & 1,75 & $6,24 \mathrm{E}-03$ & 2,97 & $2,42 \mathrm{E}-04$ \\
\hline LINC00663 & $-1,40$ & 3,87E-03 & $-1,70$ & $9,07 \mathrm{E}-04$ \\
\hline LINC00664 & 2,00 & 7,64E-04 & 3,25 & $1,58 \mathrm{E}-08$ \\
\hline LINC00689 & 1,77 & $4,12 \mathrm{E}-03$ & 2,91 & 1,18E-05 \\
\hline
\end{tabular}

\begin{tabular}{|c|c|c|c|c|}
\hline LINC00861 & $-2,99$ & 7,11E-08 & $-6,22$ & $7,13 \mathrm{E}-32$ \\
\hline LINC00893 & $-1,41$ & $1,08 \mathrm{E}-03$ & $-2,06$ & $2,67 \mathrm{E}-08$ \\
\hline LINC00894 & $-1,50$ & 1,06E-03 & $-2,13$ & $4,68 \mathrm{E}-06$ \\
\hline LINC00943 & $-1,63$ & $6,05 \mathrm{E}-03$ & $-2,10$ & $3,61 \mathrm{E}-03$ \\
\hline LINC01011 & $-1,29$ & $6,83 \mathrm{E}-03$ & $-1,93$ & $9,93 \mathrm{E}-05$ \\
\hline LINC01094 & $-2,50$ & $3,33 \mathrm{E}-06$ & $-4,14$ & $3,72 \mathrm{E}-14$ \\
\hline LIPM & 2,57 & $4,40 \mathrm{E}-05$ & 2,99 & $6,67 \mathrm{E}-05$ \\
\hline LIPT1 & $-1,28$ & 7,31E-03 & $-1,59$ & $1,14 \mathrm{E}-08$ \\
\hline LL0XNC01-7P3,1 & $-1,70$ & 8,37E-04 & $-2,60$ & $1,33 \mathrm{E}-06$ \\
\hline LMNB2 & 1,62 & $6,19 \mathrm{E}-06$ & 1,66 & $3,72 \mathrm{E}-13$ \\
\hline LOH12CR1 & 1,08 & 9,97E-03 & 1,63 & $8,01 \mathrm{E}-05$ \\
\hline LPAR6 & $-2,26$ & $1,16 \mathrm{E}-07$ & $-3,57$ & 9,83E-33 \\
\hline LRR1 & 1,58 & $9,92 \mathrm{E}-05$ & 2,24 & $1,51 \mathrm{E}-14$ \\
\hline LRRC16B & 2,15 & $1,60 \mathrm{E}-06$ & 3,49 & $5,49 \mathrm{E}-17$ \\
\hline LRRC20 & 2,11 & $2,06 \mathrm{E}-06$ & 2,44 & $2,66 \mathrm{E}-08$ \\
\hline LRRC37B & $-1,04$ & $3,35 \mathrm{E}-03$ & $-1,40$ & $1,03 \mathrm{E}-07$ \\
\hline LRRC48 & $-1,10$ & $3,76 \mathrm{E}-03$ & $-1,42$ & $1,76 \mathrm{E}-08$ \\
\hline LRRCC1 & 1,54 & $3,40 \mathrm{E}-04$ & 2,11 & $3,62 \mathrm{E}-14$ \\
\hline LRRN1 & 1,67 & $1,65 \mathrm{E}-03$ & 1,78 & $1,39 \mathrm{E}-03$ \\
\hline LRRN2 & $-1,57$ & $1,26 \mathrm{E}-03$ & $-3,06$ & $5,65 \mathrm{E}-07$ \\
\hline LRTM2 & 2,23 & $3,36 \mathrm{E}-04$ & 2,53 & $3,36 \mathrm{E}-04$ \\
\hline LSM11 & 1,40 & $9,35 \mathrm{E}-05$ & 1,75 & $1,03 \mathrm{E}-08$ \\
\hline LSM2 & 1,00 & $1,30 \mathrm{E}-03$ & 1,31 & $1,07 \mathrm{E}-16$ \\
\hline LSM4 & 1,03 & $1,49 \mathrm{E}-03$ & 1,17 & $1,24 \mathrm{E}-12$ \\
\hline LSM5 & 0,94 & $6,01 \mathrm{E}-03$ & 1,34 & $2,00 \mathrm{E}-08$ \\
\hline LTK & $-2,12$ & $1,17 \mathrm{E}-04$ & $-3,56$ & $6,46 \mathrm{E}-12$ \\
\hline LY9 & $-1,26$ & $6,07 \mathrm{E}-03$ & $-4,62$ & $1,49 \mathrm{E}-31$ \\
\hline LZTS3 & $-1,64$ & $1,84 \mathrm{E}-03$ & $-2,94$ & $1,54 \mathrm{E}-08$ \\
\hline MAD2L2 & 0,99 & 1,71E-03 & 1,14 & $2,39 \mathrm{E}-11$ \\
\hline MAFB & $-1,69$ & $1,86 \mathrm{E}-03$ & $-3,52$ & $2,09 \mathrm{E}-12$ \\
\hline MAFG-AS1 & 2,03 & 5,71E-04 & 2,79 & $3,07 \mathrm{E}-06$ \\
\hline MAGI2-AS3 & $-1,34$ & 7,03E-03 & $-2,72$ & $8,70 \mathrm{E}-07$ \\
\hline MAGOH & 0,93 & 4,69E-03 & 1,35 & $2,74 \mathrm{E}-16$ \\
\hline MAGOHB & 1,02 & 2,03E-03 & 1,57 & $4,42 \mathrm{E}-17$ \\
\hline MAN2C1 & $-1,03$ & 1,41E-03 & $-2,19$ & $4,44 \mathrm{E}-43$ \\
\hline MAP2K3 & 1,13 & $3,93 \mathrm{E}-04$ & 1,25 & $6,08 \mathrm{E}-09$ \\
\hline MAP3K1 & $-1,05$ & $1,01 \mathrm{E}-03$ & $-1,59$ & $1,04 \mathrm{E}-15$ \\
\hline MAP3K6 & $-1,02$ & $5,35 \mathrm{E}-03$ & $-1,50$ & $8,03 \mathrm{E}-07$ \\
\hline MAP7D3 & 1,06 & $1,22 \mathrm{E}-03$ & 1,23 & $6,01 \mathrm{E}-14$ \\
\hline MARCKS & $-1,23$ & $6,40 \mathrm{E}-03$ & $-2,31$ & $4,42 \mathrm{E}-22$ \\
\hline MARCO & $-1,99$ & $2,05 \mathrm{E}-03$ & $-6,15$ & $5,54 \mathrm{E}-17$ \\
\hline MAST1 & 2,01 & 1,31E-05 & 1,60 & $2,85 \mathrm{E}-04$ \\
\hline MASTL & 1,61 & 4,67E-05 & 2,12 & $2,10 \mathrm{E}-14$ \\
\hline MBOAT2 & 0,99 & $8,47 \mathrm{E}-03$ & 1,15 & $3,86 \mathrm{E}-04$ \\
\hline MBOAT4 & $-1,58$ & 7,23E-03 & $-1,99$ & $5,67 \mathrm{E}-03$ \\
\hline MCCC2 & 1,10 & $3,28 \mathrm{E}-03$ & 1,29 & $1,17 \mathrm{E}-08$ \\
\hline MCM7 & 1,94 & $7,86 \mathrm{E}-06$ & 2,18 & $1,82 \mathrm{E}-07$ \\
\hline MCUR1 & 0,98 & $3,61 \mathrm{E}-03$ & 1,44 & $2,00 \mathrm{E}-11$ \\
\hline MDM4 & $-1,03$ & $9,96 \mathrm{E}-03$ & $-1,89$ & $5,48 \mathrm{E}-07$ \\
\hline MED12L & 1,74 & 1,78E-03 & 2,46 & $4,06 \mathrm{E}-06$ \\
\hline MEF2B & $-1,54$ & 1,47E-03 & $-1,52$ & $5,26 \mathrm{E}-03$ \\
\hline MEF2C & $-1,41$ & 1,35E-03 & $-2,39$ & $4,64 \mathrm{E}-10$ \\
\hline MEGF6 & $-1,73$ & 1,37E-03 & $-3,57$ & $4,21 \mathrm{E}-12$ \\
\hline MERTK & $-2,44$ & $1,20 \mathrm{E}-07$ & $-2,57$ & $1,66 \mathrm{E}-08$ \\
\hline MESP1 & 1,94 & $2,77 \mathrm{E}-04$ & 2,94 & $2,42 \mathrm{E}-09$ \\
\hline METAP1D & $-1,16$ & $6,64 \mathrm{E}-03$ & $-1,41$ & $1,69 \mathrm{E}-03$ \\
\hline METTL2A & 0,93 & 7,07E-03 & 1,45 & $2,62 \mathrm{E}-07$ \\
\hline METTL7A & $-1,58$ & $2,67 \mathrm{E}-04$ & $-2,55$ & $2,03 \mathrm{E}-08$ \\
\hline MEX3D & 0,97 & $5,44 \mathrm{E}-03$ & 1,33 & $4,76 \mathrm{E}-09$ \\
\hline MFSD8 & $-1,01$ & $4,26 \mathrm{E}-03$ & $-1,00$ & $2,86 \mathrm{E}-08$ \\
\hline MGAT4A & $-1,10$ & $3,48 \mathrm{E}-04$ & $-1,01$ & $7,22 \mathrm{E}-11$ \\
\hline MGAT5 & $-1,09$ & 3,89E-03 & $-2,29$ & $1,63 \mathrm{E}-34$ \\
\hline MIAT & $-1,83$ & 5,71E-05 & $-1,99$ & $7,94 \mathrm{E}-08$ \\
\hline MICAL3 & 1,05 & $5,13 \mathrm{E}-03$ & 1,89 & $1,22 \mathrm{E}-14$ \\
\hline MIF & 1,05 & 7,24E-03 & 1,09 & 7,69E-04 \\
\hline MIS18A & 1,62 & $3,57 \mathrm{E}-05$ & 1,84 & $6,57 \mathrm{E}-16$ \\
\hline MLH1 & 1,06 & $5,03 \mathrm{E}-03$ & 1,07 & 1,04E-04 \\
\hline MMP19 & $-1,71$ & $1,50 \mathrm{E}-03$ & $-2,50$ & $4,64 \mathrm{E}-05$ \\
\hline MMP28 & $-2,73$ & $2,52 \mathrm{E}-07$ & $-3,17$ & $6,50 \mathrm{E}-05$ \\
\hline MMS22L & 1,74 & 4,61E-05 & 2,22 & $2,55 \mathrm{E}-14$ \\
\hline MOB3B & 1,47 & $5,96 \mathrm{E}-04$ & 1,70 & $2,92 \mathrm{E}-05$ \\
\hline MOCOS & 2,82 & $2,26 \mathrm{E}-07$ & 4,83 & $1,28 \mathrm{E}-25$ \\
\hline MOK & 1,21 & $6,35 \mathrm{E}-03$ & 1,88 & $6,93 \mathrm{E}-06$ \\
\hline MORN3 & $-1,58$ & $2,33 \mathrm{E}-03$ & $-2,43$ & $4,54 \mathrm{E}-05$ \\
\hline MPST & 0,94 & $8,34 \mathrm{E}-03$ & 1,03 & $1,01 \mathrm{E}-03$ \\
\hline MRE11A & 1,17 & $9,11 \mathrm{E}-04$ & 1,38 & $3,65 \mathrm{E}-07$ \\
\hline MRPL12 & 1,10 & $2,64 \mathrm{E}-03$ & 1,14 & $2,82 \mathrm{E}-04$ \\
\hline MRPL16 & 1,00 & $2,51 \mathrm{E}-03$ & 1,45 & $2,11 \mathrm{E}-17$ \\
\hline
\end{tabular}




\begin{tabular}{|c|c|c|c|c|}
\hline MRPL23-AS1 & $-1,62$ & 5,69E-03 & $-2,57$ & 2,31E-04 \\
\hline MRPL3 & 1,00 & $1,98 \mathrm{E}-03$ & 1,27 & $1,55 \mathrm{E}-09$ \\
\hline MRPL37 & 1,14 & $2,26 \mathrm{E}-03$ & 1,39 & $5,54 \mathrm{E}-06$ \\
\hline MRPL3P1 & 1,12 & $2,02 \mathrm{E}-03$ & 1,54 & $2,35 \mathrm{E}-07$ \\
\hline MRPL4 & 0,88 & $6,50 \mathrm{E}-03$ & 1,16 & $3,26 \mathrm{E}-07$ \\
\hline MRPL45 & 0,88 & 7,79E-03 & 1,19 & $7,74 \mathrm{E}-08$ \\
\hline MRPS11P1 & 1,01 & $7,61 \mathrm{E}-03$ & 1,34 & $1,66 \mathrm{E}-07$ \\
\hline MRPS12 & 0,85 & $9,25 \mathrm{E}-03$ & 1,22 & $1,72 \mathrm{E}-07$ \\
\hline MRPS27 & 1,06 & $1,35 \mathrm{E}-03$ & 1,35 & $4,02 \mathrm{E}-19$ \\
\hline MRTO4 & 0,90 & 7,90E-03 & 1,42 & $1,35 \mathrm{E}-08$ \\
\hline MS4A1 & $-1,50$ & 5,38E-03 & $-3,35$ & $5,27 \mathrm{E}-28$ \\
\hline MS4A3 & $-2,34$ & $3,70 \mathrm{E}-06$ & $-2,60$ & $1,65 \mathrm{E}-04$ \\
\hline MSC & 1,54 & $5,04 \mathrm{E}-04$ & 1,45 & $1,98 \mathrm{E}-03$ \\
\hline MSH2 & 1,48 & $4,54 \mathrm{E}-04$ & 1,92 & $7,89 \mathrm{E}-10$ \\
\hline $\mathrm{MSH} 3$ & 1,13 & $2,17 \mathrm{E}-03$ & 1,59 & $8,97 \mathrm{E}-15$ \\
\hline MSH5 & 1,00 & $4,69 \mathrm{E}-03$ & 1,10 & $1,15 \mathrm{E}-05$ \\
\hline MSH6 & 1,41 & 2,83E-05 & 1,66 & $9,85 \mathrm{E}-17$ \\
\hline MST1R & 1,25 & $2,86 \mathrm{E}-03$ & 1,57 & $1,10 \mathrm{E}-06$ \\
\hline MST4 & 1,27 & $2,20 \mathrm{E}-03$ & 1,31 & $1,17 \mathrm{E}-06$ \\
\hline MT1DP & 1,95 & $2,47 \mathrm{E}-03$ & 2,25 & $6,03 \mathrm{E}-03$ \\
\hline MT1G & 2,71 & $8,17 \mathrm{E}-06$ & 5,02 & $1,48 \mathrm{E}-20$ \\
\hline MT1HL1 & 1,48 & 7,89E-03 & 2,61 & $1,29 \mathrm{E}-07$ \\
\hline MTAP & 1,03 & $2,35 \mathrm{E}-03$ & 1,53 & $1,22 \mathrm{E}-10$ \\
\hline MTAPP2 & 1,13 & $5,44 \mathrm{E}-03$ & 1,83 & $4,18 \mathrm{E}-08$ \\
\hline MTHFD1 & 1,56 & $7,84 \mathrm{E}-05$ & 2,27 & $9,55 \mathrm{E}-12$ \\
\hline MTHFD1P1 & 1,53 & $4,95 \mathrm{E}-04$ & 2,35 & $2,89 \mathrm{E}-08$ \\
\hline MTHFD2 & 1,49 & $3,06 \mathrm{E}-04$ & 2,25 & $2,70 \mathrm{E}-09$ \\
\hline MTHFD2P5 & 1,52 & $4,05 \mathrm{E}-03$ & 2,27 & $1,56 \mathrm{E}-05$ \\
\hline MTHFD2P6 & 1,46 & $3,01 \mathrm{E}-03$ & 2,16 & $3,83 \mathrm{E}-05$ \\
\hline MTHFD2P7 & 1,47 & 1,32E-03 & 2,39 & 2,03E-07 \\
\hline MTSS1 & 1,51 & $4,16 \mathrm{E}-04$ & 1,69 & $2,77 \mathrm{E}-05$ \\
\hline MTTP & 1,80 & $4,88 \mathrm{E}-03$ & 3,00 & $1,92 \mathrm{E}-04$ \\
\hline MXI1 & $-1,59$ & $2,22 \mathrm{E}-06$ & $-1,91$ & $1,78 \mathrm{E}-15$ \\
\hline MXRA8 & $-1,77$ & $3,06 \mathrm{E}-04$ & $-2,46$ & $3,36 \mathrm{E}-06$ \\
\hline MYCBP & 1,18 & 1,99E-03 & 1,58 & $5,65 \mathrm{E}-08$ \\
\hline MYEF2 & 1,23 & $8,88 \mathrm{E}-03$ & 1,47 & $6,09 \mathrm{E}-04$ \\
\hline MYEOV & 2,74 & $1,24 \mathrm{E}-09$ & 1,78 & $6,82 \mathrm{E}-05$ \\
\hline MYH15 & 1,66 & $3,44 \mathrm{E}-03$ & 2,08 & $9,04 \mathrm{E}-04$ \\
\hline MYL6B & 1,74 & $1,78 \mathrm{E}-04$ & 2,30 & $1,77 \mathrm{E}-06$ \\
\hline MYLK2 & 2,59 & $2,39 \mathrm{E}-05$ & 4,53 & $2,85 \mathrm{E}-13$ \\
\hline MYLPF & 1,98 & $1,49 \mathrm{E}-03$ & 2,17 & $2,71 \mathrm{E}-03$ \\
\hline MY015B & $-1,24$ & $2,21 \mathrm{E}-03$ & $-2,48$ & $9,87 \mathrm{E}-13$ \\
\hline MY016 & $-2,56$ & $5,15 \mathrm{E}-06$ & $-5,24$ & $1,20 \mathrm{E}-13$ \\
\hline MYO7A & 1,62 & $3,49 \mathrm{E}-04$ & 1,49 & $2,10 \mathrm{E}-11$ \\
\hline MZT1 & 1,07 & $4,15 \mathrm{E}-03$ & 1,73 & $3,81 \mathrm{E}-11$ \\
\hline $\mathrm{N} / \mathrm{A}$ & $-1,68$ & $2,47 \mathrm{E}-04$ & $-1,68$ & $1,19 \mathrm{E}-04$ \\
\hline N4BP2L2 & $-0,86$ & $9,28 \mathrm{E}-03$ & $-1,20$ & $2,58 \mathrm{E}-08$ \\
\hline N6AMT2 & 1,11 & $6,33 \mathrm{E}-03$ & 1,99 & $1,21 \mathrm{E}-17$ \\
\hline NABP2 & 1,86 & $2,24 \mathrm{E}-08$ & 2,73 & $1,69 \mathrm{E}-29$ \\
\hline NAIP & $-1,38$ & 4,44E-04 & $-2,47$ & $9,20 \mathrm{E}-14$ \\
\hline NANOS3 & 2,46 & $1,22 \mathrm{E}-04$ & 3,20 & $4,68 \mathrm{E}-05$ \\
\hline NAP1L4P1 & 1,08 & 4,53E-03 & 1,11 & $4,59 \mathrm{E}-13$ \\
\hline NASP & 1,51 & $2,12 \mathrm{E}-05$ & 1,77 & $5,64 \mathrm{E}-32$ \\
\hline NBPF10 & $-1,18$ & $1,16 \mathrm{E}-03$ & $-1,38$ & $1,46 \mathrm{E}-05$ \\
\hline NBPF11 & $-0,89$ & 7,91E-03 & $-0,98$ & $8,79 \mathrm{E}-05$ \\
\hline NBPF12 & $-0,92$ & $3,91 \mathrm{E}-03$ & $-1,16$ & $7,12 \mathrm{E}-10$ \\
\hline NBPF14 & $-0,85$ & $5,97 \mathrm{E}-03$ & $-1,12$ & $3,39 \mathrm{E}-14$ \\
\hline NBPF15 & $-1,37$ & $6,69 \mathrm{E}-04$ & $-1,45$ & $8,34 \mathrm{E}-05$ \\
\hline NBPF16 & $-1,41$ & $1,28 \mathrm{E}-04$ & $-1,98$ & $2,63 \mathrm{E}-10$ \\
\hline NBPF20 & $-1,01$ & $1,43 \mathrm{E}-03$ & $\begin{array}{ll}-1,38 \\
\end{array}$ & $7,62 \mathrm{E}-16$ \\
\hline NBPF8 & $-1,13$ & $1,17 \mathrm{E}-03$ & $-1,38$ & $3,50 \mathrm{E}-08$ \\
\hline NBPF9 & $-1,24$ & $1,78 \mathrm{E}-04$ & $-1,53$ & $4,01 \mathrm{E}-12$ \\
\hline NCAPD3 & 1,67 & $1,80 \mathrm{E}-05$ & 1,99 & $7,19 \mathrm{E}-38$ \\
\hline $\mathrm{NCL}$ & 0,96 & 5,69E-03 & 1,30 & $4,12 \mathrm{E}-10$ \\
\hline NCS1 & 1,86 & $1,31 \mathrm{E}-03$ & 2,66 & $1,11 \mathrm{E}-04$ \\
\hline NDN & 2,40 & $1,16 \mathrm{E}-06$ & 2,37 & $2,13 \mathrm{E}-09$ \\
\hline NDUFV2 & 1,28 & $4,39 \mathrm{E}-04$ & 1,35 & $2,34 \mathrm{E}-09$ \\
\hline NDUFV2P1 & 1,16 & 1,94E-03 & 1,40 & $9,97 \mathrm{E}-07$ \\
\hline NEAT1 & $-1,38$ & $2,88 \mathrm{E}-04$ & $-1,85$ & $4,04 \mathrm{E}-09$ \\
\hline NECAB1 & 1,61 & $1,74 \mathrm{E}-03$ & 3,22 & $1,94 \mathrm{E}-12$ \\
\hline NECAP1 & $-0,84$ & $9,19 \mathrm{E}-03$ & $-1,05$ & $5,05 \mathrm{E}-08$ \\
\hline NEDD4 & 1,75 & $2,77 \mathrm{E}-05$ & 2,34 & $1,73 \mathrm{E}-28$ \\
\hline NET1 & 1,36 & $4,08 \mathrm{E}-04$ & 1,95 & $1,46 \mathrm{E}-23$ \\
\hline NEURL1 & 1,29 & 1,64E-03 & 1,27 & $5,46 \mathrm{E}-04$ \\
\hline NFKB2 & 1,05 & $7,84 \mathrm{E}-03$ & 1,59 & $2,93 \mathrm{E}-05$ \\
\hline NFU1P1 & 0,97 & $3,25 \mathrm{E}-03$ & 1,16 & $1,48 \mathrm{E}-07$ \\
\hline NHP2P1 & 1,04 & $9,54 \mathrm{E}-04$ & 1,42 & $2,16 \mathrm{E}-17$ \\
\hline NHSL2 & $-2,12$ & $1,30 \mathrm{E}-05$ & $-3,46$ & $1,12 \mathrm{E}-10$ \\
\hline NLRP1 & $-1,69$ & $2,42 \mathrm{E}-04$ & $-2,61$ & $3,29 \mathrm{E}-08$ \\
\hline
\end{tabular}

\begin{tabular}{|c|c|c|c|c|}
\hline NLRX1 & 1,27 & $6,44 \mathrm{E}-05$ & 0,73 & $3,08 \mathrm{E}-04$ \\
\hline NME1 & 1,80 & $1,80 \mathrm{E}-07$ & 2,47 & 1,63E-34 \\
\hline NME4 & $-1,65$ & $2,51 \mathrm{E}-05$ & $-2,96$ & $6,20 \mathrm{E}-17$ \\
\hline NME7 & 0,98 & 5,41E-03 & 1,00 & $2,15 \mathrm{E}-04$ \\
\hline NMUR1 & $-2,14$ & $2,80 \mathrm{E}-04$ & $-3,45$ & $2,18 \mathrm{E}-09$ \\
\hline NOB1 & 1,02 & $3,04 \mathrm{E}-03$ & 1,07 & $1,36 \mathrm{E}-08$ \\
\hline NOG & $-1,82$ & 7,43E-04 & $-6,79$ & $2,48 \mathrm{E}-35$ \\
\hline NOLC1 & 1,16 & $5,15 \mathrm{E}-04$ & 1,66 & $1,41 \mathrm{E}-33$ \\
\hline NOP16 & 1,04 & $1,19 \mathrm{E}-03$ & 1,81 & $8,15 \mathrm{E}-18$ \\
\hline NOP58 & 0,96 & $5,71 \mathrm{E}-03$ & 1,32 & $3,97 \mathrm{E}-18$ \\
\hline NOSTRIN & 2,19 & 4,99E-04 & 2,61 & 4,78E-04 \\
\hline NPEPL1 & $-1,18$ & 5,37E-03 & $-1,90$ & $1,30 \mathrm{E}-08$ \\
\hline NPIPA2 & $-1,12$ & $6,43 \mathrm{E}-03$ & $-0,88$ & $8,32 \mathrm{E}-03$ \\
\hline NPIPA3 & $-1,22$ & $2,53 \mathrm{E}-03$ & $-1,25$ & $8,91 \mathrm{E}-04$ \\
\hline NPIPB15 & $-1,36$ & 5,97E-04 & $-1,78$ & $1,89 \mathrm{E}-18$ \\
\hline NPIPB3 & $-1,24$ & 1,67E-04 & $-1,31$ & $5,02 \mathrm{E}-09$ \\
\hline NPIPB4 & $-0,91$ & $4,18 \mathrm{E}-03$ & $-1,02$ & $3,33 \mathrm{E}-07$ \\
\hline NPIPB5 & $-0,99$ & 3,19E-03 & $-1,22$ & 1,36E-09 \\
\hline NPM1P24 & 1,10 & $6,76 \mathrm{E}-03$ & 1,29 & $5,79 \mathrm{E}-08$ \\
\hline NPM1P27 & 1,03 & 7,37E-03 & 1,26 & $1,78 \mathrm{E}-17$ \\
\hline NPM1P39 & 1,13 & $3,68 \mathrm{E}-03$ & 1,42 & $7,48 \mathrm{E}-24$ \\
\hline NPM1P6 & 1,11 & 4,63E-03 & 1,55 & $3,00 \mathrm{E}-18$ \\
\hline NPM2 & 1,12 & 7,71E-03 & 2,48 & $8,00 \mathrm{E}-14$ \\
\hline NPM3 & 1,49 & $7,56 \mathrm{E}-06$ & 1,76 & $5,90 \mathrm{E}-18$ \\
\hline NR1D1 & $-1,16$ & $9,50 \mathrm{E}-03$ & $-1,27$ & $1,74 \mathrm{E}-06$ \\
\hline NR1D2 & $-1,55$ & $1,30 \mathrm{E}-04$ & $-2,20$ & $7,39 \mathrm{E}-39$ \\
\hline NR3C2 & $-1,27$ & 7,67E-03 & $-1,43$ & $3,93 \mathrm{E}-03$ \\
\hline NR4A3 & 2,19 & $8,02 \mathrm{E}-07$ & 2,12 & $6,19 \mathrm{E}-06$ \\
\hline NRBP2 & $-1,35$ & $1,48 \mathrm{E}-04$ & $-1,86$ & $1,77 \mathrm{E}-10$ \\
\hline NRCAM & $-2,00$ & $1,10 \mathrm{E}-04$ & $-1,93$ & $5,60 \mathrm{E}-04$ \\
\hline NRIP2 & $-1,33$ & $2,35 \mathrm{E}-03$ & $-2,01$ & $3,03 \mathrm{E}-06$ \\
\hline NRM & 1,10 & 3,91E-03 & 1,11 & $6,77 \mathrm{E}-04$ \\
\hline NRN1 & 1,79 & $3,07 \mathrm{E}-03$ & 1,99 & 1,93E-03 \\
\hline NRSN2 & 2,20 & $3,16 \mathrm{E}-07$ & 2,15 & $6,27 \mathrm{E}-08$ \\
\hline NT5DC2 & 1,58 & $1,25 \mathrm{E}-06$ & 2,00 & $6,31 \mathrm{E}-39$ \\
\hline NT5M & 1,51 & 7,27E-05 & 1,24 & $1,31 \mathrm{E}-03$ \\
\hline NTHL1 & 1,24 & 3,07E-04 & 1,69 & $1,80 \mathrm{E}-10$ \\
\hline NTN4 & $-1,70$ & $1,43 \mathrm{E}-03$ & $-2,13$ & 1,79E-04 \\
\hline NUAK2 & $-1,65$ & 2,65E-04 & $-2,52$ & $1,53 \mathrm{E}-10$ \\
\hline NUCB2 & 1,22 & 1,36E-03 & 1,37 & $6,27 \mathrm{E}-05$ \\
\hline NUCKS1 & 1,10 & $4,56 \mathrm{E}-03$ & 0,91 & $9,42 \mathrm{E}-09$ \\
\hline NUDCD1 & 1,11 & $6,18 \mathrm{E}-03$ & 1,59 & $6,61 \mathrm{E}-06$ \\
\hline NUDT10 & 1,99 & $4,30 \mathrm{E}-04$ & 2,16 & $3,69 \mathrm{E}-04$ \\
\hline NUDT14 & $-1,11$ & $6,60 \mathrm{E}-03$ & $-2,11$ & $4,13 \mathrm{E}-09$ \\
\hline NUDT21 & 1,13 & $1,54 \mathrm{E}-03$ & 1,42 & $4,96 \mathrm{E}-19$ \\
\hline NUDT8 & 1,64 & 1,34E-04 & 1,67 & $5,16 \mathrm{E}-05$ \\
\hline NUP155 & 1,14 & 1,78E-03 & 1,80 & $5,27 \mathrm{E}-26$ \\
\hline NUP160 & 1,05 & $7,28 \mathrm{E}-03$ & 1,31 & $9,24 \mathrm{E}-19$ \\
\hline NUP37 & 1,74 & $9,33 \mathrm{E}-06$ & 2,26 & $1,03 \mathrm{E}-23$ \\
\hline NUP88 & 0,90 & $6,72 \mathrm{E}-03$ & 1,08 & $4,02 E-13$ \\
\hline OCM & $-2,37$ & $3,46 \mathrm{E}-05$ & $-3,90$ & $5,42 \mathrm{E}-08$ \\
\hline OCM2 & $-2,04$ & 8,98E-04 & $-3,70$ & $3,73 \mathrm{E}-06$ \\
\hline OCSTAMP & 2,48 & $1,08 \mathrm{E}-04$ & 6,79 & $4,24 \mathrm{E}-36$ \\
\hline ODF2 & 1,14 & $2,29 \mathrm{E}-03$ & 1,33 & $1,87 \mathrm{E}-14$ \\
\hline OLA1P1 & 1,01 & $4,05 \mathrm{E}-03$ & 1,62 & $1,06 \mathrm{E}-11$ \\
\hline OLIG1 & $-2,12$ & $1,00 \mathrm{E}-03$ & $-3,92$ & $2,31 \mathrm{E}-07$ \\
\hline OLR1 & $-2,18$ & $2,15 \mathrm{E}-04$ & $-3,47$ & $7,52 \mathrm{E}-09$ \\
\hline OTUD7B & 1,58 & $4,52 \mathrm{E}-04$ & 2,29 & $1,34 \mathrm{E}-07$ \\
\hline OVGP1 & $-1,70$ & $6,03 \mathrm{E}-04$ & $-1,97$ & $1,88 \mathrm{E}-04$ \\
\hline OXTR & 1,69 & $2,79 \mathrm{E}-03$ & 2,73 & $5,56 \mathrm{E}-08$ \\
\hline PA2G4 & 0,95 & $3,88 \mathrm{E}-03$ & 1,48 & $2,54 \mathrm{E}-18$ \\
\hline PA2G4P1 & 1,23 & $1,70 \mathrm{E}-03$ & 1,90 & $5,65 \mathrm{E}-16$ \\
\hline PA2G4P2 & 1,21 & $9,39 \mathrm{E}-04$ & 1,79 & $1,86 \mathrm{E}-10$ \\
\hline PA2G4P4 & 1,31 & $2,39 \mathrm{E}-04$ & 1,86 & $9,97 \mathrm{E}-17$ \\
\hline PABPC1L & 1,15 & 4,83E-03 & 1,51 & $8,75 \mathrm{E}-05$ \\
\hline PACSIN1 & $-1,72$ & $2,73 \mathrm{E}-04$ & $-3,38$ & $1,09 \mathrm{E}-11$ \\
\hline PAICS & 1,69 & 6,41E-06 & 2,26 & $6,09 \mathrm{E}-56$ \\
\hline PAICSP3 & 1,66 & $1,45 \mathrm{E}-04$ & 2,56 & $4,88 \mathrm{E}-19$ \\
\hline PAICSP4 & 1,95 & $6,13 \mathrm{E}-06$ & 2,76 & $6,97 \mathrm{E}-22$ \\
\hline PAPSS2 & $-1,54$ & $6,08 \mathrm{E}-03$ & $-2,45$ & $1,44 \mathrm{E}-04$ \\
\hline PAQR4 & 1,84 & $1,51 \mathrm{E}-06$ & 1,89 & $1,98 \mathrm{E}-08$ \\
\hline PAQR6 & 1,04 & 5,25E-03 & 1,38 & $2,83 \mathrm{E}-05$ \\
\hline PARD6A & 0,93 & $8,75 \mathrm{E}-03$ & 1,79 & $1,04 \mathrm{E}-14$ \\
\hline PARK7 & 1,29 & $2,29 \mathrm{E}-04$ & 1,26 & $2,09 \mathrm{E}-05$ \\
\hline PARP1 & 1,15 & 4,09E-03 & 1,39 & $5,78 \mathrm{E}-10$ \\
\hline PARP11 & 0,89 & $4,90 \mathrm{E}-03$ & 0,54 & $2,94 \mathrm{E}-03$ \\
\hline PARP1P1 & 1,27 & $1,50 \mathrm{E}-03$ & 1,60 & $5,01 \mathrm{E}-26$ \\
\hline PARP3 & 1,04 & $1,60 \mathrm{E}-03$ & 0,99 & $3,26 \mathrm{E}-05$ \\
\hline PARP8 & $-0,99$ & $2,51 \mathrm{E}-03$ & $-1,24$ & $2,54 \mathrm{E}-09$ \\
\hline
\end{tabular}




\begin{tabular}{|c|c|c|c|c|}
\hline PAX2 & 1,65 & $9,26 \mathrm{E}-03$ & 3,77 & $1,10 \mathrm{E}-06$ \\
\hline PAX8-AS1 & $-1,22$ & $1,05 \mathrm{E}-03$ & $-1,60$ & $3,07 \mathrm{E}-07$ \\
\hline PAXBP1-AS1 & $-1,28$ & $2,58 \mathrm{E}-04$ & $-2,02$ & $6,28 \mathrm{E}-14$ \\
\hline PBX3 & $-0,93$ & $8,10 \mathrm{E}-03$ & $-1,14$ & $9,19 \mathrm{E}-05$ \\
\hline PCNT & 0,86 & $6,85 \mathrm{E}-03$ & 1,18 & $3,80 \mathrm{E}-10$ \\
\hline PCP2 & $-2,27$ & $2,80 \mathrm{E}-06$ & $-2,40$ & $1,32 \mathrm{E}-04$ \\
\hline PCSK5 & $-1,92$ & $3,74 \mathrm{E}-06$ & $-2,31$ & $6,46 \mathrm{E}-09$ \\
\hline PDCD2L & 0,90 & $6,30 \mathrm{E}-03$ & 1,57 & $9,25 \mathrm{E}-16$ \\
\hline PDE6G & 1,57 & $6,67 \mathrm{E}-04$ & 0,87 & $5,02 \mathrm{E}-04$ \\
\hline PDGFD & $-1,39$ & $7,05 \mathrm{E}-03$ & $-2,07$ & $1,57 \mathrm{E}-04$ \\
\hline PDK1 & $-1,42$ & $3,45 \mathrm{E}-04$ & $-1,87$ & $4,03 \mathrm{E}-07$ \\
\hline PDK4 & $-2,36$ & $4,42 \mathrm{E}-05$ & $-4,16$ & $3,46 \mathrm{E}-09$ \\
\hline PDLIM4 & 2,22 & $2,41 \mathrm{E}-04$ & 2,94 & $1,28 \mathrm{E}-05$ \\
\hline PDXDC2P & $-1,45$ & $3,11 \mathrm{E}-05$ & $-1,97$ & $2,71 \mathrm{E}-22$ \\
\hline PDXP & 1,20 & 4,41E-03 & 1,91 & $1,77 \mathrm{E}-09$ \\
\hline PELI2 & $-1,10$ & $2,48 \mathrm{E}-03$ & $-1,38$ & $1,93 \mathrm{E}-05$ \\
\hline PFAS & 1,18 & $3,93 \mathrm{E}-04$ & 1,13 & $4,80 \mathrm{E}-12$ \\
\hline PFDN4 & 1,10 & $8,84 \mathrm{E}-03$ & 1,21 & $3,29 \mathrm{E}-05$ \\
\hline PFKP & 1,30 & 1,22E-04 & 1,65 & $4,12 \mathrm{E}-10$ \\
\hline PFN1 & 0,86 & 5,71E-03 & 0,83 & $2,95 \mathrm{E}-06$ \\
\hline PFN1P9 & 0,99 & $3,84 \mathrm{E}-03$ & 1,11 & $4,49 \mathrm{E}-05$ \\
\hline PFN2 & $-1,85$ & $2,98 \mathrm{E}-04$ & $-3,00$ & $6,82 \mathrm{E}-08$ \\
\hline PGAM5 & 0,88 & 4,96E-03 & 1,33 & $4,52 \mathrm{E}-19$ \\
\hline PGM1 & 0,97 & $6,55 \mathrm{E}-03$ & 1,04 & $8,79 \mathrm{E}-06$ \\
\hline PHACTR1 & $-1,68$ & $2,37 \mathrm{E}-03$ & $-3,17$ & $1,24 \mathrm{E}-07$ \\
\hline PHB2 & 0,98 & $3,64 \mathrm{E}-03$ & 1,40 & $3,52 \mathrm{E}-14$ \\
\hline PHB2P1 & 1,13 & $1,16 \mathrm{E}-03$ & 1,54 & $8,57 \mathrm{E}-17$ \\
\hline PHF1 & $-1,19$ & $2,47 \mathrm{E}-03$ & $-1,48$ & $3,31 \mathrm{E}-06$ \\
\hline PHF19 & 1,99 & $2,07 \mathrm{E}-05$ & 1,94 & $5,67 \mathrm{E}-05$ \\
\hline PHF2P2 & $-1,53$ & $3,89 \mathrm{E}-03$ & $-2,07$ & $1,80 \mathrm{E}-04$ \\
\hline PHF5A & 0,97 & $3,67 \mathrm{E}-03$ & 1,22 & $7,86 \mathrm{E}-13$ \\
\hline PHF6 & 1,03 & $9,48 \mathrm{E}-03$ & 0,91 & $2,42 \mathrm{E}-07$ \\
\hline PHGDH & 1,73 & $1,01 \mathrm{E}-04$ & 1,11 & $6,16 \mathrm{E}-03$ \\
\hline PHLPP1 & 1,45 & $1,98 \mathrm{E}-03$ & 0,91 & $2,65 \mathrm{E}-03$ \\
\hline PHTF1 & 0,94 & $5,97 \mathrm{E}-03$ & 1,28 & $8,94 \mathrm{E}-08$ \\
\hline $\mathrm{PI} 16$ & $-1,79$ & 7,79E-04 & $-3,67$ & $9,88 \mathrm{E}-11$ \\
\hline PI4KAP1 & $-0,96$ & $4,45 \mathrm{E}-03$ & $-1,35$ & $1,72 \mathrm{E}-07$ \\
\hline PIANP & $-1,35$ & $8,94 \mathrm{E}-03$ & $-1,48$ & $5,69 \mathrm{E}-03$ \\
\hline PID1 & $-3,20$ & 1,92E-09 & $-4,97$ & $4,58 \mathrm{E}-12$ \\
\hline PIK3IP1 & $-1,58$ & $8,57 \mathrm{E}-04$ & $-3,72$ & $3,99 \mathrm{E}-16$ \\
\hline PINLYP & 2,21 & $2,96 \mathrm{E}-06$ & 2,88 & $3,62 \mathrm{E}-10$ \\
\hline PKN3 & 1,96 & $5,72 \mathrm{E}-07$ & 1,93 & $4,07 \mathrm{E}-11$ \\
\hline PLA2G4B & $-1,51$ & $4,14 \mathrm{E}-03$ & $-2,29$ & $3,64 \mathrm{E}-05$ \\
\hline PLCB2 & $-1,07$ & $1,98 \mathrm{E}-03$ & $-1,83$ & $1,73 \mathrm{E}-33$ \\
\hline PLCD1 & $-1,16$ & $2,11 \mathrm{E}-03$ & $-1,86$ & $4,98 \mathrm{E}-10$ \\
\hline PLCD3 & 0,96 & $8,87 \mathrm{E}-03$ & 1,37 & $1,25 \mathrm{E}-07$ \\
\hline PLEKHA7 & 2,08 & $9,01 \mathrm{E}-07$ & 1,21 & $2,15 \mathrm{E}-03$ \\
\hline PLEKHM1P & $-0,89$ & $7,27 \mathrm{E}-03$ & $-1,37$ & $1,66 \mathrm{E}-09$ \\
\hline PLLP & $-1,62$ & $2,13 \mathrm{E}-03$ & $-2,74$ & $7,39 \mathrm{E}-06$ \\
\hline PLS1 & 1,40 & $2,56 \mathrm{E}-03$ & 1,75 & $2,91 \mathrm{E}-06$ \\
\hline PLXDC1 & $-1,61$ & $5,77 \mathrm{E}-04$ & $-2,74$ & $8,09 \mathrm{E}-08$ \\
\hline PLXNA2 & $-1,54$ & 9,91E-03 & $-3,07$ & $1,13 \mathrm{E}-06$ \\
\hline PLXNC1 & $-1,51$ & $6,19 \mathrm{E}-03$ & $-3,15$ & $1,29 \mathrm{E}-08$ \\
\hline PNMA3 & $-1,79$ & $3,58 \mathrm{E}-04$ & $-3,16$ & $1,86 \mathrm{E}-10$ \\
\hline PNOC & $-1,65$ & $1,96 \mathrm{E}-03$ & $-1,34$ & 4,67E-03 \\
\hline PNP & 1,17 & 4,94E-04 & 2,16 & $7,83 \mathrm{E}-39$ \\
\hline PNPO & 1,00 & $4,61 \mathrm{E}-03$ & 1,15 & $5,66 \mathrm{E}-05$ \\
\hline POFUT2 & $-1,08$ & $2,38 \mathrm{E}-03$ & $-1,49$ & $3,87 \mathrm{E}-15$ \\
\hline POLA2 & 1,84 & $6,98 \mathrm{E}-07$ & 2,00 & $1,07 \mathrm{E}-27$ \\
\hline POLB & 0,83 & 9,93E-03 & 1,12 & $5,53 \mathrm{E}-08$ \\
\hline POLD1 & 1,35 & $1,38 \mathrm{E}-05$ & 1,35 & $1,68 \mathrm{E}-18$ \\
\hline POLD2P1 & 1,01 & $6,22 \mathrm{E}-03$ & 0,98 & $8,42 \mathrm{E}-06$ \\
\hline POLD3 & 1,45 & $1,28 \mathrm{E}-04$ & 1,61 & $2,40 \mathrm{E}-09$ \\
\hline POLE & 1,25 & $8,60 \mathrm{E}-04$ & 1,53 & $2,86 \mathrm{E}-09$ \\
\hline POLI & $-0,91$ & $4,18 \mathrm{E}-03$ & $-1,11$ & $8,54 \mathrm{E}-10$ \\
\hline POLR3K & 1,04 & $4,64 \mathrm{E}-03$ & 1,49 & $3,96 \mathrm{E}-06$ \\
\hline PON2 & 1,31 & $1,38 \mathrm{E}-03$ & 0,65 & $1,12 \mathrm{E}-03$ \\
\hline POP7 & 1,05 & 9,79E-04 & 1,61 & $4,49 \mathrm{E}-15$ \\
\hline POTEG & 1,06 & $9,42 \mathrm{E}-03$ & 1,20 & $2,93 \mathrm{E}-03$ \\
\hline POTEJ & 1,33 & 1,19E-03 & 1,64 & $2,83 \mathrm{E}-06$ \\
\hline POU2AF1 & 1,26 & $9,68 \mathrm{E}-05$ & 0,83 & $3,76 \mathrm{E}-05$ \\
\hline POU5F1B & $-1,92$ & 1,76E-03 & $-4,19$ & $3,82 \mathrm{E}-08$ \\
\hline POU6F1 & $-1,66$ & $1,21 \mathrm{E}-03$ & $-1,77$ & $5,12 \mathrm{E}-04$ \\
\hline PPA1 & 1,48 & $1,48 \mathrm{E}-04$ & 2,29 & $1,54 \mathrm{E}-13$ \\
\hline PPAPDC2 & $-0,96$ & $4,26 \mathrm{E}-03$ & $-1,71$ & $6,20 \mathrm{E}-13$ \\
\hline PPAT & 0,96 & $7,08 \mathrm{E}-03$ & 1,76 & $4,89 \mathrm{E}-17$ \\
\hline PPATP1 & 1,44 & $8,82 \mathrm{E}-04$ & 2,28 & $7,31 \mathrm{E}-19$ \\
\hline PPFIBP1 & 1,15 & $2,65 \mathrm{E}-03$ & 3,32 & $1,49 \mathrm{E}-43$ \\
\hline PPIAP11 & 1,17 & $8,42 \mathrm{E}-03$ & 1,51 & $8,59 \mathrm{E}-05$ \\
\hline
\end{tabular}

\begin{tabular}{|c|c|c|c|c|}
\hline PPIAP22 & 0,87 & $9,10 \mathrm{E}-03$ & 1,36 & $1,78 \mathrm{E}-10$ \\
\hline PPIHP1 & 0,91 & $6,47 \mathrm{E}-03$ & 1,43 & $1,51 \mathrm{E}-15$ \\
\hline PPIL1 & 1,10 & $4,80 \mathrm{E}-03$ & 1,70 & $2,01 \mathrm{E}-06$ \\
\hline PPIL3 & 0,93 & $5,77 \mathrm{E}-03$ & 1,14 & $3,94 \mathrm{E}-07$ \\
\hline PPM1G & 1,14 & $6,99 \mathrm{E}-04$ & 1,58 & $4,08 \mathrm{E}-10$ \\
\hline PPM1J & $-1,64$ & $2,38 \mathrm{E}-03$ & $-2,27$ & $7,08 \mathrm{E}-04$ \\
\hline PPM1L & $-1,62$ & $7,49 \mathrm{E}-06$ & $-1,76$ & $5,04 \mathrm{E}-09$ \\
\hline PPM1N & $-1,33$ & $5,77 \mathrm{E}-03$ & $-1,57$ & $3,98 \mathrm{E}-03$ \\
\hline PPP1R26-AS1 & $-1,85$ & $4,31 \mathrm{E}-03$ & $-2,08$ & $8,30 \mathrm{E}-03$ \\
\hline PPP1R2P3 & 1,19 & $2,71 \mathrm{E}-03$ & 1,41 & $1,50 \mathrm{E}-08$ \\
\hline PPP2R2B & $-1,67$ & $7,11 \mathrm{E}-04$ & $-1,00$ & $4,94 \mathrm{E}-03$ \\
\hline PPP5C & 1,24 & $1,23 \mathrm{E}-04$ & 1,90 & $9,73 \mathrm{E}-23$ \\
\hline PPP5D1 & 1,66 & $4,18 \mathrm{E}-04$ & 2,41 & $5,88 \mathrm{E}-10$ \\
\hline PPT2 & 1,03 & $3,41 \mathrm{E}-03$ & 1,54 & $8,63 \mathrm{E}-12$ \\
\hline PQLC3 & $-1,07$ & $2,01 \mathrm{E}-03$ & $-1,76$ & $2,48 \mathrm{E}-09$ \\
\hline PRDM5 & 1,94 & $2,20 \mathrm{E}-04$ & 1,75 & $3,17 \mathrm{E}-03$ \\
\hline PRDX2 & 1,40 & $3,84 \mathrm{E}-04$ & 1,84 & $3,35 \mathrm{E}-07$ \\
\hline PRDX2P1 & 1,53 & $8,83 \mathrm{E}-05$ & 2,26 & $4,67 \mathrm{E}-11$ \\
\hline PRDX2P4 & 1,55 & $3,76 \mathrm{E}-05$ & 2,20 & $5,79 \mathrm{E}-12$ \\
\hline PRIM1 & 1,81 & $1,35 \mathrm{E}-04$ & 2,07 & $7,60 \mathrm{E}-06$ \\
\hline PRIM2 & 1,72 & $1,03 \mathrm{E}-05$ & 2,33 & $3,83 \mathrm{E}-34$ \\
\hline PRKAG2-AS1 & $-1,23$ & $2,43 \mathrm{E}-03$ & $-3,06$ & $1,93 \mathrm{E}-17$ \\
\hline PRKAR1B & 1,81 & $1,88 \mathrm{E}-05$ & 1,32 & $1,57 \mathrm{E}-03$ \\
\hline PRKCDBP & 1,76 & $1,60 \mathrm{E}-03$ & 1,84 & $3,65 \mathrm{E}-04$ \\
\hline PRKCH & 1,28 & $5,08 \mathrm{E}-04$ & 1,29 & $1,59 \mathrm{E}-05$ \\
\hline PRKDC & 1,25 & $7,73 \mathrm{E}-04$ & 1,69 & $1,20 \mathrm{E}-13$ \\
\hline PRMT1 & 1,07 & $1,15 \mathrm{E}-03$ & 1,40 & $6,09 \mathrm{E}-23$ \\
\hline PRMT6 & 1,07 & $4,59 \mathrm{E}-03$ & 0,78 & $2,10 \mathrm{E}-04$ \\
\hline PROK2 & $-2,46$ & $1,21 \mathrm{E}-05$ & $-3,54$ & $3,87 \mathrm{E}-07$ \\
\hline PRPS2 & 1,38 & $1,64 \mathrm{E}-04$ & 1,69 & $1,11 \mathrm{E}-14$ \\
\hline PRX & $-1,31$ & $6,78 \mathrm{E}-04$ & $-1,91$ & $7,55 \mathrm{E}-09$ \\
\hline PSAT1P4 & 1,81 & $3,00 \mathrm{E}-03$ & 2,68 & $9,64 \mathrm{E}-06$ \\
\hline PSMA2 & 0,94 & $5,48 \mathrm{E}-03$ & 1,13 & $2,20 \mathrm{E}-07$ \\
\hline PSMA2P3 & 1,17 & $3,04 \mathrm{E}-03$ & 1,48 & $4,35 \mathrm{E}-05$ \\
\hline PSMA8 & 2,39 & $4,20 \mathrm{E}-07$ & 2,32 & $3,02 \mathrm{E}-07$ \\
\hline PSMB11 & $-2,27$ & $6,31 \mathrm{E}-05$ & $-4,25$ & $1,86 \mathrm{E}-08$ \\
\hline PSMB8 & 1,00 & $4,30 \mathrm{E}-03$ & 1,18 & $7,53 \mathrm{E}-05$ \\
\hline PSMB9 & 1,40 & $1,59 \mathrm{E}-05$ & 1,16 & $6,61 \mathrm{E}-13$ \\
\hline PSMC3 & 0,95 & $4,65 \mathrm{E}-03$ & 1,52 & $1,84 \mathrm{E}-09$ \\
\hline PSME2P2 & 1,30 & $1,23 \mathrm{E}-04$ & 1,64 & $7,89 \mathrm{E}-10$ \\
\hline PSORS1C1 & 1,89 & $3,24 \mathrm{E}-03$ & 2,66 & $1,12 \mathrm{E}-03$ \\
\hline PSRC1 & 1,72 & $6,09 \mathrm{E}-05$ & 1,71 & $2,60 \mathrm{E}-08$ \\
\hline PTCD2 & 1,10 & $7,73 \mathrm{E}-03$ & 2,05 & $1,37 \mathrm{E}-10$ \\
\hline PTCH1 & $-1,52$ & $1,47 \mathrm{E}-03$ & $-1,59$ & $1,11 \mathrm{E}-03$ \\
\hline PTGDR & $-2,14$ & $5,61 \mathrm{E}-05$ & $-3,43$ & $2,26 \mathrm{E}-07$ \\
\hline PUS10 & 1,00 & $5,73 \mathrm{E}-03$ & 1,74 & $2,61 \mathrm{E}-09$ \\
\hline PYCRL & 1,10 & $1,11 \mathrm{E}-03$ & 0,99 & $4,61 \mathrm{E}-06$ \\
\hline QPRT & 2,41 & $1,08 \mathrm{E}-10$ & 2,14 & $1,22 \mathrm{E}-14$ \\
\hline RAB27A & 1,09 & $7,46 \mathrm{E}-03$ & 1,51 & $4,17 \mathrm{E}-05$ \\
\hline RAB31 & $-1,32$ & $8,61 \mathrm{E}-03$ & $-2,50$ & $1,96 \mathrm{E}-06$ \\
\hline RAB37 & 1,20 & $7,47 \mathrm{E}-03$ & $-1,27$ & $6,78 \mathrm{E}-03$ \\
\hline RAB38 & 1,66 & $2,67 \mathrm{E}-03$ & 1,65 & $1,76 \mathrm{E}-05$ \\
\hline RAB3B & 2,40 & $7,63 \mathrm{E}-05$ & 3,54 & $2,88 \mathrm{E}-09$ \\
\hline RAD18 & 1,36 & $1,09 \mathrm{E}-04$ & 2,18 & $1,50 \mathrm{E}-33$ \\
\hline RAD51AP1 & 1,18 & $2,95 \mathrm{E}-03$ & 1,46 & $3,70 \mathrm{E}-06$ \\
\hline RAD51-AS1 & $-1,42$ & $1,92 \mathrm{E}-03$ & $-2,24$ & $3,00 \mathrm{E}-06$ \\
\hline RAD51C & 1,44 & $1,91 \mathrm{E}-05$ & 2,46 & $1,36 \mathrm{E}-57$ \\
\hline RAD51D & 1,09 & $2,60 \mathrm{E}-03$ & 1,35 & $2,95 \mathrm{E}-08$ \\
\hline RAD54B & 1,92 & $3,25 \mathrm{E}-04$ & 2,94 & $1,45 \mathrm{E}-07$ \\
\hline RAN & 1,37 & $2,45 \mathrm{E}-05$ & 1,75 & $1,75 \mathrm{E}-36$ \\
\hline RANBP1 & 1,11 & $3,93 \mathrm{E}-03$ & 1,34 & $3,32 \mathrm{E}-05$ \\
\hline RANBP9 & 0,88 & $6,18 \mathrm{E}-03$ & 0,79 & $1,96 \mathrm{E}-06$ \\
\hline RANGAP1 & 1,18 & $1,39 \mathrm{E}-04$ & 1,55 & $9,87 \mathrm{E}-30$ \\
\hline RANP1 & 1,52 & $7,64 \mathrm{E}-05$ & 2,05 & $4,26 \mathrm{E}-16$ \\
\hline RANP6 & 1,57 & $3,53 \mathrm{E}-04$ & 1,90 & $4,31 \mathrm{E}-13$ \\
\hline RASA3 & $-1,04$ & $5,28 \mathrm{E}-03$ & $-2,22$ & $8,97 \mathrm{E}-12$ \\
\hline RASGRP2 & $-1,55$ & $2,23 \mathrm{E}-03$ & $-2,48$ & $9,02 \mathrm{E}-06$ \\
\hline RASSF3 & $-1,07$ & $3,75 \mathrm{E}-03$ & $-1,65$ & $3,63 \mathrm{E}-09$ \\
\hline RBBP4P2 & 1,07 & $9,76 \mathrm{E}-03$ & 1,31 & $1,93 \mathrm{E}-05$ \\
\hline RBBP4P4 & 1,25 & $8,46 \mathrm{E}-03$ & 1,59 & $3,21 \mathrm{E}-04$ \\
\hline RBBP7 & 1,24 & $7,86 \mathrm{E}-04$ & 1,55 & $2,50 \mathrm{E}-27$ \\
\hline RBBP8 & 1,41 & $3,16 \mathrm{E}-03$ & 1,85 & $2,76 \mathrm{E}-04$ \\
\hline RBL1 & 1,34 & $6,06 \mathrm{E}-04$ & 1,26 & $3,04 \mathrm{E}-07$ \\
\hline RCC1 & 1,66 & $3,08 \mathrm{E}-06$ & 2,27 & $1,65 \mathrm{E}-18$ \\
\hline $\mathrm{RCC2}$ & 1,16 & $5,21 \mathrm{E}-04$ & 1,26 & $5,61 \mathrm{E}-07$ \\
\hline RCC2P3 & 1,62 & $1,38 \mathrm{E}-03$ & 2,40 & $1,78 \mathrm{E}-08$ \\
\hline RCC2P6 & 1,33 & $3,55 \mathrm{E}-03$ & 1,46 & $1,81 \mathrm{E}-03$ \\
\hline RCCD1 & 1,35 & $2,00 \mathrm{E}-04$ & 1,34 & $4,65 \mathrm{E}-10$ \\
\hline RDH16 & $-1,55$ & 3,97E-03 & $-1,77$ & $7,26 \mathrm{E}-04$ \\
\hline
\end{tabular}




\begin{tabular}{|c|c|c|c|c|}
\hline RECQL & 1,02 & $7,75 \mathrm{E}-03$ & 1,41 & $1,17 \mathrm{E}-07$ \\
\hline REM2 & $-2,14$ & $1,07 \mathrm{E}-04$ & $-2,56$ & $4,11 \mathrm{E}-04$ \\
\hline REPS2 & $-2,95$ & $4,01 \mathrm{E}-09$ & $-3,79$ & $1,99 \mathrm{E}-08$ \\
\hline RFC1 & 1,00 & $7,61 \mathrm{E}-03$ & 1,32 & $2,03 \mathrm{E}-12$ \\
\hline RFC2 & 1,31 & $5,93 \mathrm{E}-04$ & 1,75 & $5,41 \mathrm{E}-10$ \\
\hline RFC5 & 1,78 & $5,08 \mathrm{E}-06$ & 2,27 & $8,00 \mathrm{E}-28$ \\
\hline RFPL2 & $-2,31$ & $1,62 \mathrm{E}-05$ & $-3,25$ & $9,54 \mathrm{E}-07$ \\
\hline RFWD3 & 1,33 & $1,10 \mathrm{E}-04$ & 1,48 & $1,12 \mathrm{E}-15$ \\
\hline $\mathrm{RFX3}$ & $-1,02$ & $9,48 \mathrm{E}-03$ & $-1,12$ & $2,94 \mathrm{E}-03$ \\
\hline RGL3 & $-1,92$ & $2,90 \mathrm{E}-03$ & $-2,96$ & $1,89 \mathrm{E}-04$ \\
\hline RGMB & $-2,16$ & $1,30 \mathrm{E}-04$ & $-2,70$ & $2,50 \mathrm{E}-06$ \\
\hline RHEBL1 & 1,39 & $7,96 \mathrm{E}-05$ & 2,76 & $1,98 \mathrm{E}-45$ \\
\hline RHOD & 2,25 & $4,63 \mathrm{E}-05$ & 2,56 & $5,06 \mathrm{E}-06$ \\
\hline RHOXF1 & $-2,13$ & $2,03 \mathrm{E}-04$ & $-2,94$ & $5,80 \mathrm{E}-05$ \\
\hline $\mathrm{RIBC} 1$ & 1,02 & $9,50 \mathrm{E}-03$ & 1,26 & $1,42 \mathrm{E}-05$ \\
\hline RILPL1 & $-1,18$ & 8,93E-04 & $-1,30$ & $9,79 \mathrm{E}-08$ \\
\hline RIMKLB & $-1,46$ & $1,32 \mathrm{E}-05$ & $-2,66$ & $5,38 \mathrm{E}-28$ \\
\hline RINL & 1,01 & $9,01 \mathrm{E}-03$ & 1,20 & $3,88 \mathrm{E}-04$ \\
\hline RMI1 & 1,43 & 1,39E-03 & 1,63 & $4,45 \mathrm{E}-05$ \\
\hline RMND1 & 0,91 & $5,72 \mathrm{E}-03$ & 1,27 & $1,36 \mathrm{E}-13$ \\
\hline RNASEH2A & 1,95 & $3,03 \mathrm{E}-08$ & 2,17 & $1,35 \mathrm{E}-17$ \\
\hline RNF112 & $-1,77$ & $2,41 \mathrm{E}-03$ & $-1,33$ & $7,58 \mathrm{E}-03$ \\
\hline RNF157-AS1 & $-1,62$ & $2,66 \mathrm{E}-03$ & $-3,84$ & $8,29 \mathrm{E}-11$ \\
\hline RNPEPL1 & $-0,96$ & $4,26 \mathrm{E}-03$ & $-1,93$ & $9,87 \mathrm{E}-43$ \\
\hline RP1-102K2,8 & 2,44 & $7,95 \mathrm{E}-05$ & 3,87 & $1,30 \mathrm{E}-09$ \\
\hline RP11-102D18,1 & 2,20 & $2,29 \mathrm{E}-06$ & 2,86 & $4,81 \mathrm{E}-10$ \\
\hline RP11-104G3,2 & 1,80 & $4,99 \mathrm{E}-04$ & 2,31 & $2,38 \mathrm{E}-06$ \\
\hline RP11-108B14,4 & 1,51 & $2,55 \mathrm{E}-03$ & 1,61 & $1,95 \mathrm{E}-03$ \\
\hline $\begin{array}{l}\text { RP11-108M9,4 } \\
\end{array}$ & $\begin{array}{ll}-1,72 \\
\end{array}$ & $5,94 \mathrm{E}-03$ & $-2,98$ & $7,34 \mathrm{E}-11$ \\
\hline RP11-108M9,5 & $-1,73$ & 1,76E-03 & $-2,67$ & $1,27 \mathrm{E}-05$ \\
\hline RP11-1094M14,12 & $-2,01$ & $1,09 \mathrm{E}-03$ & $-3,48$ & $1,13 \mathrm{E}-05$ \\
\hline RP11-112H10,6 & 1,19 & $2,42 \mathrm{E}-03$ & 1,55 & $6,05 \mathrm{E}-08$ \\
\hline RP11-118D22,3 & 1,05 & $8,03 \mathrm{E}-03$ & 1,44 & $5,39 \mathrm{E}-05$ \\
\hline RP11-119N19,1 & 1,12 & $1,28 \mathrm{E}-03$ & 2,10 & $2,35 \mathrm{E}-17$ \\
\hline RP11-121L10,3 & 1,06 & $9,10 \mathrm{E}-03$ & 1,28 & 1,17E-04 \\
\hline RP11-122G18,8 & $-1,88$ & $1,43 \mathrm{E}-03$ & $-3,12$ & $4,13 \mathrm{E}-06$ \\
\hline RP11-123C5,5 & 1,68 & $2,50 \mathrm{E}-04$ & 1,91 & $8,23 \mathrm{E}-07$ \\
\hline RP11-1260E13,4 & $-2,08$ & $2,01 \mathrm{E}-04$ & $-4,63$ & $5,63 \mathrm{E}-11$ \\
\hline RP11-126K1,2 & 2,90 & $1,54 \mathrm{E}-06$ & 3,19 & $9,71 \mathrm{E}-06$ \\
\hline RP11-133N21,7 & 1,20 & 1,13E-03 & 1,34 & $2,81 \mathrm{E}-05$ \\
\hline RP11-137N23,1 & 1,02 & $8,66 \mathrm{E}-03$ & 1,13 & $1,82 \mathrm{E}-03$ \\
\hline RP11-1398P2,1 & $-1,29$ & $3,07 \mathrm{E}-03$ & $-1,90$ & $1,25 \mathrm{E}-06$ \\
\hline RP11-141C7,3 & 1,88 & $8,09 \mathrm{E}-04$ & 1,63 & $1,16 \mathrm{E}-03$ \\
\hline RP11-143J12,2 & $-1,30$ & $4,53 \mathrm{E}-03$ & $-2,34$ & $2,42 \mathrm{E}-07$ \\
\hline RP11-144C15,1 & 1,08 & $6,41 \mathrm{E}-03$ & 1,66 & $3,87 \mathrm{E}-09$ \\
\hline RP11-147L13,2 & $-1,58$ & $2,69 \mathrm{E}-03$ & $-1,75$ & $6,49 \mathrm{E}-04$ \\
\hline RP11-147L13,8 & $-2,62$ & $1,82 \mathrm{E}-06$ & $-3,47$ & $3,56 \mathrm{E}-07$ \\
\hline RP11-152C15,1 & 1,98 & $2,95 \mathrm{E}-08$ & 2,41 & $3,19 \mathrm{E}-45$ \\
\hline RP11-153M3,1 & 1,83 & $2,14 \mathrm{E}-06$ & 2,58 & $2,74 \mathrm{E}-21$ \\
\hline RP11-154D3,1 & 1,05 & $3,41 \mathrm{E}-03$ & 1,51 & $1,76 \mathrm{E}-08$ \\
\hline RP11-159N11,4 & $-1,98$ & $1,57 \mathrm{E}-04$ & $-3,17$ & $1,63 \mathrm{E}-07$ \\
\hline RP11-161M6,2 & $-1,48$ & $7,58 \mathrm{E}-03$ & $-2,76$ & $2,64 \mathrm{E}-07$ \\
\hline RP11-161M6,3 & $-2,46$ & $1,50 \mathrm{E}-04$ & $-2,93$ & $2,92 \mathrm{E}-04$ \\
\hline RP11-164J13,1 & $-1,19$ & $4,64 \mathrm{E}-03$ & $-1,78$ & 4,19E-07 \\
\hline RP11-168J18,6 & 0,97 & $2,13 \mathrm{E}-03$ & 0,76 & 2,99E-07 \\
\hline RP11-172C16,4 & 1,08 & $5,37 \mathrm{E}-03$ & 1,28 & $2,34 \mathrm{E}-11$ \\
\hline RP11-173E2,1 & 0,98 & $4,07 \mathrm{E}-03$ & 1,20 & $4,42 \mathrm{E}-14$ \\
\hline RP11-18|14,10 & $-1,25$ & $2,30 \mathrm{E}-03$ & $-1,85$ & $2,31 \mathrm{E}-07$ \\
\hline RP11-192N10,2 & 2,02 & $1,30 \mathrm{E}-03$ & 2,64 & $1,49 \mathrm{E}-04$ \\
\hline RP11-1K3,1 & 1,31 & $2,82 \mathrm{E}-03$ & 1,79 & $9,76 \mathrm{E}-06$ \\
\hline RP11-213G2,3 & $-1,11$ & $9,15 \mathrm{E}-03$ & $-1,25$ & $7,34 \mathrm{E}-04$ \\
\hline RP11-213G21,1 & $-2,89$ & $4,51 \mathrm{E}-06$ & $-3,64$ & $5,06 \mathrm{E}-06$ \\
\hline RP11-220|1,1 & $-1,00$ & $8,35 \mathrm{E}-03$ & $-1,34$ & $7,75 \mathrm{E}-05$ \\
\hline RP11-222K16,2 & $-1,77$ & $6,20 \mathrm{E}-04$ & $-2,14$ & $2,37 \mathrm{E}-06$ \\
\hline RP11-226L15,5 & $-1,10$ & 9,67E-03 & $-1,73$ & $2,05 \mathrm{E}-03$ \\
\hline RP11-228B15,4 & $-1,48$ & $1,47 \mathrm{E}-04$ & $-2,57$ & $2,79 \mathrm{E}-17$ \\
\hline RP11-23P13,6 & $-1,85$ & $1,21 \mathrm{E}-04$ & $-3,07$ & $9,98 \mathrm{E}-11$ \\
\hline RP11-244H3,1 & $-1,30$ & $1,83 \mathrm{E}-03$ & $-1,85$ & $7,63 \mathrm{E}-05$ \\
\hline RP11-258C19,7 & $-1,79$ & $2,14 \mathrm{E}-06$ & $-2,15$ & $3,88 \mathrm{E}-10$ \\
\hline RP11-261P9,4 & $-1,31$ & $7,61 \mathrm{E}-03$ & $-1,66$ & $3,11 \mathrm{E}-04$ \\
\hline $\mathrm{RP} 11-262 \mathrm{H} 14,4$ & 1,85 & $6,98 \mathrm{E}-04$ & 2,44 & $5,10 \mathrm{E}-06$ \\
\hline RP11-263K19,4 & $-1,24$ & $3,65 \mathrm{E}-03$ & $-1,70$ & $7,01 \mathrm{E}-04$ \\
\hline RP11-26819,4 & 1,16 & $6,47 \mathrm{E}-03$ & 1,42 & $1,39 \mathrm{E}-10$ \\
\hline RP11-274B21,4 & $-1,02$ & $4,83 \mathrm{E}-03$ & $-1,40$ & $2,30 \mathrm{E}-06$ \\
\hline RP11-274E7,2 & 1,36 & $6,70 \mathrm{E}-05$ & 1,45 & $9,10 \mathrm{E}-08$ \\
\hline RP11-277P12,20 & 1,39 & $6,48 \mathrm{E}-04$ & 1,68 & $2,06 \mathrm{E}-06$ \\
\hline RP11-281P11,1 & 1,17 & $3,19 \mathrm{E}-03$ & 1,20 & $1,06 \mathrm{E}-04$ \\
\hline
\end{tabular}

\begin{tabular}{|c|c|c|c|c|}
\hline RP11-283G6,4 & 2,32 & 1,14E-04 & 2,39 & $9,99 \mathrm{E}-04$ \\
\hline RP11-284F21,10 & 2,01 & $1,06 \mathrm{E}-03$ & 4,11 & $7,97 \mathrm{E}-14$ \\
\hline RP11-284N8,3 & $-1,31$ & $2,85 \mathrm{E}-03$ & $-1,70$ & $1,14 \mathrm{E}-04$ \\
\hline RP11-285F7,2 & $-2,44$ & $8,03 \mathrm{E}-07$ & $-2,73$ & $1,55 \mathrm{E}-07$ \\
\hline RP11-291B21,2 & 1,75 & $1,60 \mathrm{E}-04$ & 1,85 & $1,45 \mathrm{E}-04$ \\
\hline RP11-295P9,3 & $-1,26$ & $6,20 \mathrm{E}-04$ & $-1,16$ & $8,72 \mathrm{E}-06$ \\
\hline RP11-296014,2 & 1,14 & $3,95 \mathrm{E}-03$ & 1,29 & $2,18 \mathrm{E}-07$ \\
\hline RP11-297B17,3 & $-1,67$ & $8,79 \mathrm{E}-03$ & $-2,28$ & $5,37 \mathrm{E}-03$ \\
\hline RP11-298C3,2 & 1,90 & 8,95E-09 & 2,39 & $5,23 \mathrm{E}-59$ \\
\hline RP11-304F15,3 & $-1,56$ & $5,38 \mathrm{E}-04$ & $-1,73$ & $3,92 \mathrm{E}-04$ \\
\hline RP11-30504,2 & 1,98 & $1,24 \mathrm{E}-07$ & 2,50 & $8,55 \mathrm{E}-21$ \\
\hline RP11-317B7,2 & 1,50 & $3,70 \mathrm{E}-03$ & 1,76 & $1,21 \mathrm{E}-03$ \\
\hline RP11-324I22,4 & $-1,19$ & $4,65 \mathrm{E}-03$ & $-1,45$ & 4,07E-05 \\
\hline RP11-325024,2 & 1,28 & $6,37 \mathrm{E}-03$ & 1,48 & $4,70 \mathrm{E}-04$ \\
\hline RP11-332G1,1 & 1,89 & $6,09 \mathrm{E}-04$ & 3,14 & $6,26 \mathrm{E}-11$ \\
\hline RP11-333E1,1 & $-1,28$ & $3,64 \mathrm{E}-03$ & $-2,29$ & $4,48 \mathrm{E}-08$ \\
\hline RP11-335F8,2 & 1,23 & 4,09E-03 & 1,73 & $5,00 \mathrm{E}-06$ \\
\hline RP11-341N2,1 & $-1,59$ & $9,70 \mathrm{E}-03$ & $-2,25$ & $1,40 \mathrm{E}-03$ \\
\hline RP11-343H19,1 & $-1,68$ & $7,00 \mathrm{E}-03$ & $-3,25$ & $3,78 \mathrm{E}-05$ \\
\hline RP11-347|19,8 & $-1,38$ & $6,55 \mathrm{E}-03$ & $-2,34$ & $4,72 \mathrm{E}-05$ \\
\hline RP11-349A22,5 & $-1,13$ & $1,66 \mathrm{E}-03$ & $-1,68$ & $6,66 \mathrm{E}-11$ \\
\hline RP11-350G8,5 & $-1,87$ & $1,18 \mathrm{E}-03$ & $-2,91$ & $1,23 \mathrm{E}-07$ \\
\hline RP11-368P15,3 & $-1,43$ & $1,98 \mathrm{E}-03$ & $-1,60$ & $3,40 \mathrm{E}-09$ \\
\hline RP11-378G13,2 & 1,97 & $2,64 \mathrm{E}-05$ & 2,43 & $5,74 \mathrm{E}-11$ \\
\hline RP11-383J24,6 & $-1,49$ & $1,32 \mathrm{E}-03$ & $-1,61$ & $6,10 \mathrm{E}-08$ \\
\hline RP11-385M4,3 & 1,38 & $8,79 \mathrm{E}-04$ & 1,47 & $2,50 \mathrm{E}-05$ \\
\hline RP11-386M24,4 & 1,55 & 3,92E-05 & 1,27 & $2,66 \mathrm{E}-12$ \\
\hline RP11-38P22,2 & $-2,29$ & $2,30 \mathrm{E}-04$ & $-2,19$ & $3,83 \mathrm{E}-03$ \\
\hline RP11-395L14,17 & 0,96 & $5,47 \mathrm{E}-03$ & 1,52 & $3,44 \mathrm{E}-07$ \\
\hline RP11-395P17,3 & $-1,37$ & $9,30 \mathrm{E}-04$ & $-1,96$ & $6,46 \mathrm{E}-07$ \\
\hline RP11-39K24,9 & 1,09 & $6,03 \mathrm{E}-03$ & 1,60 & $6,92 \mathrm{E}-07$ \\
\hline RP11-404E6,1 & 1,01 & $7,02 \mathrm{E}-03$ & 1,42 & $5,80 \mathrm{E}-07$ \\
\hline RP11-417L14,1 & 2,15 & $2,99 \mathrm{E}-06$ & 2,89 & $8,17 \mathrm{E}-14$ \\
\hline RP11-426C22,4 & $-1,36$ & $6,17 \mathrm{E}-03$ & $-1,24$ & $5,58 \mathrm{E}-03$ \\
\hline RP11-430C7,5 & $-1,75$ & $3,80 \mathrm{E}-04$ & $-2,71$ & $2,30 \mathrm{E}-07$ \\
\hline RP11-434B12,1 & $-1,53$ & $4,12 \mathrm{E}-03$ & $-2,10$ & $1,06 \mathrm{E}-04$ \\
\hline RP11-435D7,3 & 2,38 & $2,36 \mathrm{E}-04$ & 3,32 & $3,05 \mathrm{E}-05$ \\
\hline RP11-439C15,4 & $-1,64$ & $8,57 \mathrm{E}-03$ & $-2,92$ & $1,64 \mathrm{E}-04$ \\
\hline RP11-43N5,1 & $-1,67$ & 7,93E-03 & $-3,08$ & $1,22 \mathrm{E}-04$ \\
\hline RP11-443B20,1 & 1,05 & 9,50E-03 & 1,64 & $1,33 \mathrm{E}-08$ \\
\hline RP11-448G15,3 & $-1,16$ & $7,92 \mathrm{E}-03$ & $-1,21$ & $2,14 \mathrm{E}-03$ \\
\hline RP11-449I17,5 & 1,55 & $1,00 \mathrm{E}-03$ & 2,28 & $4,33 \mathrm{E}-08$ \\
\hline RP11-44K6,4 & 2,38 & 1,71E-04 & 2,14 & $8,36 \mathrm{E}-03$ \\
\hline RP11-453D16,2 & 1,11 & $5,72 \mathrm{E}-03$ & 1,16 & $4,09 \mathrm{E}-05$ \\
\hline RP11-473N11,2 & 1,40 & $2,47 \mathrm{E}-04$ & 1,83 & $1,19 \mathrm{E}-14$ \\
\hline RP11-474021,5 & 2,23 & $5,68 \mathrm{E}-04$ & 3,28 & $3,83 \mathrm{E}-05$ \\
\hline RP11-476C8,2 & 1,63 & 1,66E-03 & 2,03 & $9,29 \mathrm{E}-06$ \\
\hline RP11-478H16,1 & 1,03 & $6,94 \mathrm{E}-03$ & 1,45 & $1,40 \mathrm{E}-06$ \\
\hline RP11-47F1,1 & 1,09 & $1,30 \mathrm{E}-03$ & 1,60 & $1,77 \mathrm{E}-17$ \\
\hline RP11-486M23,2 & 2,65 & $4,00 \mathrm{E}-05$ & 4,83 & $2,01 \mathrm{E}-11$ \\
\hline RP11-486013,3 & $-1,41$ & $3,53 \mathrm{E}-03$ & $-1,94$ & $1,98 \mathrm{E}-04$ \\
\hline RP11-4K3_A,5 & 1,36 & $1,50 \mathrm{E}-04$ & 1,50 & $2,42 \mathrm{E}-07$ \\
\hline RP11-513M16,8 & $-1,83$ & $1,22 \mathrm{E}-04$ & $-2,30$ & $2,96 \mathrm{E}-07$ \\
\hline RP11-517B11,2 & 1,84 & 1,09E-06 & 2,04 & $3,80 \mathrm{E}-13$ \\
\hline RP11-521B24,3 & 2,16 & $2,38 \mathrm{E}-05$ & 2,27 & $6,67 \mathrm{E}-05$ \\
\hline $\mathrm{RP} 11-529 \mathrm{H} 20,6$ & $-1,56$ & 1,71E-03 & $-1,85$ & $1,04 \mathrm{E}-04$ \\
\hline RP1-153P14,8 & $-1,99$ & $6,78 \mathrm{E}-04$ & $-3,16$ & $2,16 \mathrm{E}-05$ \\
\hline RP11-545E17,3 & 0,89 & $9,72 \mathrm{E}-03$ & 1,11 & $6,15 \mathrm{E}-06$ \\
\hline RP11-551G24,2 & 1,77 & 1,64E-04 & 2,26 & $7,10 \mathrm{E}-09$ \\
\hline RP11-553L6,5 & $-1,69$ & $3,45 \mathrm{E}-04$ & $-3,17$ & $1,08 \mathrm{E}-11$ \\
\hline RP11-563J2,2 & $-1,37$ & 1,03E-03 & $-1,10$ & $2,44 \mathrm{E}-04$ \\
\hline RP11-570P14,1 & 1,55 & 9,95E-06 & 2,12 & $8,06 \mathrm{E}-24$ \\
\hline RP1-159M24,1 & 1,37 & $5,29 \mathrm{E}-04$ & 2,06 & $1,21 \mathrm{E}-09$ \\
\hline RP11-5C23,2 & $-1,57$ & $4,77 \mathrm{E}-04$ & $-2,05$ & $1,19 \mathrm{E}-05$ \\
\hline RP11-606P2,1 & 1,19 & 4,37E-03 & 1,37 & $1,04 \mathrm{E}-15$ \\
\hline RP11-617D20,1 & $-1,89$ & $1,56 \mathrm{E}-03$ & $-3,25$ & $1,45 \mathrm{E}-06$ \\
\hline RP11-620J15,3 & 1,76 & $1,05 \mathrm{E}-05$ & 1,94 & $4,44 \mathrm{E}-10$ \\
\hline RP11-621H8,2 & 1,54 & 1,19E-03 & 1,50 & $2,55 \mathrm{E}-03$ \\
\hline RP11-627G23,1 & $-1,68$ & $7,58 \mathrm{E}-03$ & $-1,82$ & $9,85 \mathrm{E}-03$ \\
\hline RP11-63G10,3 & $-2,57$ & $6,89 \mathrm{E}-05$ & $-2,47$ & 7,94E-04 \\
\hline RP11-641A6,2 & $-2,74$ & 1,94E-07 & $-4,95$ & $4,49 \mathrm{E}-12$ \\
\hline RP11-643G16,3 & 1,54 & $1,59 \mathrm{E}-03$ & 2,05 & $9,87 \mathrm{E}-06$ \\
\hline RP11-658F2,3 & 1,21 & 9,77E-04 & 1,68 & $3,23 \mathrm{E}-18$ \\
\hline RP11-666A1,3 & $-1,81$ & $7,49 \mathrm{E}-04$ & $-3,11$ & $8,38 \mathrm{E}-06$ \\
\hline RP11-669B18,1 & 1,64 & 4,99E-04 & 2,53 & $3,60 \mathrm{E}-11$ \\
\hline RP11-66N5,2 & 1,30 & $4,96 \mathrm{E}-03$ & 1,75 & $1,63 \mathrm{E}-06$ \\
\hline
\end{tabular}




\begin{tabular}{|c|c|c|c|c|}
\hline RP11-673C5,1 & 1,21 & 4,07E-03 & 1,20 & $2,48 \mathrm{E}-12$ \\
\hline RP11-67L2,2 & $-1,52$ & 1,67E-04 & $-2,10$ & $3,94 \mathrm{E}-07$ \\
\hline RP11-680G24,5 & $-1,14$ & $8,28 \mathrm{E}-03$ & $-1,23$ & $3,14 \mathrm{E}-04$ \\
\hline RP11-698N11,4 & $-1,25$ & $3,16 \mathrm{E}-03$ & $-1,83$ & $1,27 \mathrm{E}-05$ \\
\hline RP11-69E11,4 & $-1,55$ & $4,11 \mathrm{E}-04$ & $-2,20$ & $6,62 \mathrm{E}-16$ \\
\hline RP11-69M1,3 & 1,94 & $2,59 \mathrm{E}-05$ & 2,72 & $3,25 \mathrm{E}-14$ \\
\hline RP11-707M3,3 & $-1,89$ & 4,16E-04 & $-2,30$ & $4,26 \mathrm{E}-04$ \\
\hline RP11-70P17,1 & $-1,70$ & 4,79E-03 & $-3,43$ & $1,29 \mathrm{E}-05$ \\
\hline RP11-713M15,2 & $-1,23$ & $9,19 \mathrm{E}-03$ & $-2,46$ & $1,59 \mathrm{E}-06$ \\
\hline RP11-723P16,3 & 1,50 & 4,41E-05 & 2,03 & $2,05 \mathrm{E}-21$ \\
\hline RP1-172B20,6 & 2,19 & $7,19 \mathrm{E}-04$ & 3,57 & $4,97 \mathrm{E}-06$ \\
\hline RP11-733018,1 & $-2,50$ & 1,13E-04 & $-2,94$ & $2,72 \mathrm{E}-04$ \\
\hline RP11-737024,1 & 1,67 & $8,79 \mathrm{E}-03$ & 2,61 & $1,37 \mathrm{E}-03$ \\
\hline RP11-737024,5 & $-1,25$ & 7,79E-03 & $-2,40$ & $2,70 \mathrm{E}-06$ \\
\hline $\mathrm{RP} 11-747 \mathrm{H} 7,3$ & $-1,98$ & $6,37 \mathrm{E}-04$ & $-3,95$ & $1,42 \mathrm{E}-14$ \\
\hline RP11-756G12,1 & $-1,80$ & $2,51 \mathrm{E}-03$ & $-1,81$ & $7,98 \mathrm{E}-03$ \\
\hline RP11-757F18,3 & 2,42 & $1,88 \mathrm{E}-04$ & 2,34 & $4,28 \mathrm{E}-03$ \\
\hline RP11-807E13,3 & 1,10 & 8,34E-03 & 1,75 & $8,12 \mathrm{E}-07$ \\
\hline RP11-815J4,5 & 1,00 & $8,25 \mathrm{E}-03$ & 1,47 & $2,54 \mathrm{E}-05$ \\
\hline RP11-819C21,1 & $-1,58$ & $9,30 \mathrm{E}-04$ & $-1,39$ & $1,63 \mathrm{E}-03$ \\
\hline RP11-849F2,8 & $-1,75$ & $1,81 \mathrm{E}-04$ & $-2,48$ & $6,19 \mathrm{E}-08$ \\
\hline RP11-84D1,2 & 3,18 & $1,61 \mathrm{E}-08$ & 3,26 & $6,93 \mathrm{E}-07$ \\
\hline RP11-85F14,1 & 1,27 & 2,22E-03 & 1,78 & $3,61 \mathrm{E}-06$ \\
\hline RP11-867G23,10 & 2,35 & $2,80 \mathrm{E}-04$ & 3,01 & $1,85 \mathrm{E}-04$ \\
\hline RP11-869B15,1 & $-1,41$ & 2,31E-03 & $-1,40$ & $2,60 \mathrm{E}-03$ \\
\hline RP11-894J14,5 & $-2,05$ & $1,52 \mathrm{E}-03$ & $-2,79$ & $5,77 \mathrm{E}-04$ \\
\hline RP11-89B16,2 & 1,57 & 6,51E-04 & 2,28 & $1,16 \mathrm{E}-07$ \\
\hline RP11-89M16,1 & $-2,35$ & $6,43 \mathrm{E}-05$ & $-1,77$ & $7,72 \mathrm{E}-03$ \\
\hline RP11-91J19,4 & $-1,24$ & $2,56 \mathrm{E}-03$ & $-1,74$ & 4,60E-04 \\
\hline RP11-92C4,4 & 1,50 & $3,57 \mathrm{E}-03$ & 2,55 & $4,52 \mathrm{E}-09$ \\
\hline RP11-933H2,4 & $-3,01$ & 2,54E-06 & $-2,10$ & $5,58 \mathrm{E}-03$ \\
\hline RP11-936|5,1 & $-1,51$ & $7,66 \mathrm{E}-03$ & $-1,78$ & $7,52 \mathrm{E}-03$ \\
\hline RP1-193H18,2 & $-1,45$ & $6,14 \mathrm{E}-03$ & $-2,06$ & 1,95E-04 \\
\hline RP11-96J19,1 & 1,95 & 5,72E-05 & 2,05 & $4,03 \mathrm{E}-06$ \\
\hline RP11-97012,6 & $-1,45$ & 1,01E-03 & $-2,50$ & $4,08 \mathrm{E}-07$ \\
\hline RP11-98J23,1 & $-1,94$ & $2,65 \mathrm{E}-03$ & $-2,10$ & $8,84 \mathrm{E}-03$ \\
\hline RP1-257A7,4 & $-1,26$ & $8,67 \mathrm{E}-03$ & $-1,43$ & 4,95E-04 \\
\hline RP1-305B16,3 & 1,41 & $2,20 \mathrm{E}-03$ & 1,30 & $6,89 \mathrm{E}-05$ \\
\hline RP13-487C10,1 & 1,06 & $8,26 \mathrm{E}-03$ & 1,35 & $2,90 \mathrm{E}-04$ \\
\hline RP13-516M14,1 & $-1,43$ & 9,99E-04 & $-1,67$ & $2,36 \mathrm{E}-05$ \\
\hline RP13-58209,5 & $-1,45$ & $3,15 \mathrm{E}-03$ & $-2,11$ & $8,25 \mathrm{E}-05$ \\
\hline RP13-977J11,2 & $-1,49$ & $3,22 \mathrm{E}-03$ & $-2,73$ & $1,26 \mathrm{E}-07$ \\
\hline RP3-339A18,3 & 2,26 & 4,61E-07 & 3,51 & $2,44 \mathrm{E}-26$ \\
\hline RP3-347M6,2 & 1,10 & $7,30 \mathrm{E}-03$ & 1,12 & $8,00 \mathrm{E}-05$ \\
\hline RP3-368A4,5 & $-1,50$ & $2,43 \mathrm{E}-04$ & $-1,98$ & $7,80 \mathrm{E}-19$ \\
\hline RP3-368A4,6 & $-1,27$ & $1,40 \mathrm{E}-03$ & $-1,34$ & $2,14 \mathrm{E}-07$ \\
\hline RP3-400N23,6 & $-1,78$ & $6,32 \mathrm{E}-04$ & $-3,17$ & $7,00 \mathrm{E}-08$ \\
\hline RP3-475N16,1 & $-1,13$ & $5,03 \mathrm{E}-03$ & $-1,57$ & $4,20 \mathrm{E}-06$ \\
\hline RP4-61404,12 & $-2,29$ & $1,65 \mathrm{E}-04$ & $-2,80$ & $1,65 \mathrm{E}-04$ \\
\hline RP4-635E18,8 & $-1,63$ & $3,35 \mathrm{E}-04$ & $-2,33$ & $8,37 \mathrm{E}-07$ \\
\hline RP4-714D9,5 & $-1,80$ & $3,38 \mathrm{E}-04$ & $-2,39$ & $1,63 \mathrm{E}-05$ \\
\hline RP4-717I23,3 & $-1,26$ & 4,49E-03 & $-2,38$ & $1,49 \mathrm{E}-07$ \\
\hline RP4-725G10,4 & $-1,17$ & 1,81E-03 & $-2,17$ & $1,89 \mathrm{E}-19$ \\
\hline RP4-738P11,4 & 1,95 & $2,43 \mathrm{E}-03$ & 2,24 & $5,37 \mathrm{E}-03$ \\
\hline RP5-1021/20,1 & $-1,33$ & $8,77 \mathrm{E}-03$ & $-3,17$ & $2,10 \mathrm{E}-07$ \\
\hline RP5-1051J4,6 & $-1,95$ & $7,90 \mathrm{E}-04$ & $-2,50$ & $1,09 \mathrm{E}-03$ \\
\hline RP5-1068E13,7 & $-1,47$ & $3,86 \mathrm{E}-03$ & $-2,07$ & 2,49E-04 \\
\hline RP5-1071N3,1 & $-1,65$ & $1,22 \mathrm{E}-03$ & $-1,60$ & $5,08 \mathrm{E}-03$ \\
\hline RP5-1108M17,5 & $-1,79$ & $5,15 \mathrm{E}-03$ & $-2,20$ & $5,15 \mathrm{E}-03$ \\
\hline RP5-1109J22,1 & $-1,75$ & $3,24 \mathrm{E}-03$ & $-1,84$ & $6,34 \mathrm{E}-03$ \\
\hline RP5-882C2,2 & $-1,63$ & 8,91E-04 & $-3,01$ & $1,55 \mathrm{E}-09$ \\
\hline RP5-894D12,3 & $-2,02$ & $3,36 \mathrm{E}-04$ & $-2,21$ & $4,48 \mathrm{E}-03$ \\
\hline RP5-991G20,1 & 1,62 & $9,60 \mathrm{E}-03$ & 1,81 & $9,77 \mathrm{E}-03$ \\
\hline RP5-991G20,4 & 1,54 & $2,45 \mathrm{E}-04$ & 1,26 & $6,76 \mathrm{E}-06$ \\
\hline RP6-159A1,2 & 1,05 & 7,64E-03 & 0,99 & $6,09 \mathrm{E}-05$ \\
\hline RP6-42F4,1 & $-1,41$ & 2,12E-04 & $-1,41$ & $1,80 \mathrm{E}-05$ \\
\hline RP6-65G23,3 & 2,07 & $3,26 \mathrm{E}-04$ & 2,71 & $2,99 \mathrm{E}-06$ \\
\hline RPA3 & 1,21 & $2,44 \mathrm{E}-03$ & 1,28 & $9,91 \mathrm{E}-05$ \\
\hline RPIA & 0,98 & 3,89E-03 & 1,28 & $1,27 \mathrm{E}-08$ \\
\hline RPIAP1 & 1,02 & $9,54 \mathrm{E}-03$ & 1,49 & $8,07 \mathrm{E}-09$ \\
\hline RPL22L1 & 1,24 & $4,25 \mathrm{E}-03$ & 1,46 & $3,44 \mathrm{E}-06$ \\
\hline RPL39L & 1,55 & $6,36 \mathrm{E}-04$ & 1,45 & $1,57 \mathrm{E}-03$ \\
\hline RPP40 & 1,48 & $2,50 \mathrm{E}-04$ & 2,30 & $1,83 \mathrm{E}-21$ \\
\hline RPS24P17 & $-2,29$ & $3,52 \mathrm{E}-06$ & $-3,10$ & $4,41 \mathrm{E}-10$ \\
\hline RPS27 & $-1,38$ & $5,95 \mathrm{E}-03$ & $-1,88$ & $6,55 \mathrm{E}-04$ \\
\hline RRAGB & $-0,99$ & $2,25 \mathrm{E}-03$ & $-1,35$ & $1,98 \mathrm{E}-07$ \\
\hline RRN3P1 & $-1,21$ & $6,26 \mathrm{E}-04$ & $-1,96$ & $9,23 \mathrm{E}-23$ \\
\hline RUVBL1 & 1,20 & $8,59 \mathrm{E}-04$ & 1,76 & $1,16 \mathrm{E}-34$ \\
\hline
\end{tabular}

\begin{tabular}{|c|c|c|c|c|}
\hline RUVBL2 & 1,16 & 3,29E-04 & 1,59 & $2,08 \mathrm{E}-12$ \\
\hline RWDD2A & $-0,94$ & $8,85 \mathrm{E}-03$ & $-1,18$ & $1,06 \mathrm{E}-06$ \\
\hline RWDD2B & 1,25 & $4,01 \mathrm{E}-03$ & 1,33 & $3,78 \mathrm{E}-04$ \\
\hline SAAL1 & 1,08 & $8,90 \mathrm{E}-03$ & 0,93 & $5,75 \mathrm{E}-04$ \\
\hline SAC3D1 & 1,32 & $2,35 \mathrm{E}-04$ & 1,61 & $5,88 \mathrm{E}-12$ \\
\hline SAE1 & 1,17 & $1,13 \mathrm{E}-03$ & 1,57 & $6,08 \mathrm{E}-10$ \\
\hline SASS6 & 1,05 & 9,96E-03 & 1,70 & $2,09 \mathrm{E}-14$ \\
\hline SCAND2P & $-1,03$ & $8,22 \mathrm{E}-03$ & $-1,08$ & $1,84 \mathrm{E}-03$ \\
\hline SCARF1 & 1,40 & $2,09 \mathrm{E}-03$ & 1,30 & $8,48 \mathrm{E}-03$ \\
\hline SCML1 & $-1,22$ & $2,11 \mathrm{E}-03$ & $-1,66$ & $6,50 \mathrm{E}-12$ \\
\hline SCML2 & 1,24 & $2,13 \mathrm{E}-03$ & 1,78 & $7,95 \mathrm{E}-10$ \\
\hline SDC1 & $-1,88$ & $1,66 \mathrm{E}-03$ & $-3,27$ & $1,19 \mathrm{E}-06$ \\
\hline SDC3 & $-1,30$ & $9,28 \mathrm{E}-04$ & $-2,50$ & $2,38 \mathrm{E}-14$ \\
\hline SDCBP2 & 1,31 & $2,69 \mathrm{E}-03$ & 1,48 & $2,71 \mathrm{E}-04$ \\
\hline SDCCAG3 & $-1,14$ & $3,20 \mathrm{E}-03$ & $-1,61$ & $8,23 \mathrm{E}-23$ \\
\hline SDCCAG3P2 & $-0,94$ & 9,11E-03 & $-1,23$ & $1,27 \mathrm{E}-06$ \\
\hline SDK2 & $-2,75$ & $4,10 \mathrm{E}-07$ & $-4,05$ & $3,17 \mathrm{E}-16$ \\
\hline SELPLG & $-1,00$ & 5,89E-03 & $-1,46$ & $3,11 \mathrm{E}-14$ \\
\hline SEMA3C & $-1,71$ & 4,04E-03 & $-3,45$ & $1,01 \mathrm{E}-06$ \\
\hline SEMA4C & $-1,60$ & $7,23 \mathrm{E}-04$ & $-2,39$ & $2,35 \mathrm{E}-06$ \\
\hline SEMA4G & $-1,14$ & $2,66 \mathrm{E}-03$ & $-1,12$ & $7,74 \mathrm{E}-05$ \\
\hline SEPHS1P4 & 1,15 & 2,81E-03 & 1,59 & $2,92 \mathrm{E}-06$ \\
\hline SEPHS1P6 & 1,09 & 4,46E-03 & 1,47 & $1,14 \mathrm{E}-05$ \\
\hline SEPP1 & $-1,81$ & $2,60 \mathrm{E}-03$ & $-2,69$ & $2,75 \mathrm{E}-04$ \\
\hline SEPT8 & 1,26 & $3,03 \mathrm{E}-03$ & 1,16 & $4,39 \mathrm{E}-05$ \\
\hline SERBP1 & 1,04 & $3,27 \mathrm{E}-03$ & 1,35 & $2,28 \mathrm{E}-13$ \\
\hline SERBP1P1 & 1,23 & 1,95E-03 & 1,50 & $3,95 \mathrm{E}-11$ \\
\hline SERBP1P5 & 1,31 & $6,59 \mathrm{E}-04$ & 1,43 & $5,34 \mathrm{E}-08$ \\
\hline SERBP1P6 & 1,39 & 1,11E-03 & 1,83 & $5,56 \mathrm{E}-08$ \\
\hline SERINC5 & $-1,47$ & 1,83E-05 & $-2,12$ & $9,92 \mathrm{E}-26$ \\
\hline SERP2 & 1,67 & $2,85 \mathrm{E}-03$ & 1,92 & $5,64 \mathrm{E}-03$ \\
\hline SERPINB2 & $-2,51$ & $5,01 \mathrm{E}-06$ & $-2,50$ & 4,04E-05 \\
\hline SETP14 & 1,00 & $5,04 \mathrm{E}-03$ & 1,33 & $3,16 \mathrm{E}-15$ \\
\hline SETP22 & 1,09 & $4,22 \mathrm{E}-03$ & 1,34 & $1,00 \mathrm{E}-06$ \\
\hline SETSIP & 1,14 & $3,03 E-03$ & 1,39 & $9,38 \mathrm{E}-06$ \\
\hline SFRP5 & $-3,10$ & 7,35E-09 & $-4,47$ & $4,06 \mathrm{E}-10$ \\
\hline SFXN2 & 1,31 & $6,34 \mathrm{E}-03$ & 1,31 & $2,82 \mathrm{E}-03$ \\
\hline SH2D4A & 2,88 & $2,53 \mathrm{E}-07$ & 3,70 & $3,28 \mathrm{E}-11$ \\
\hline SH2D6 & 2,20 & $3,77 \mathrm{E}-04$ & 2,04 & $4,35 \mathrm{E}-03$ \\
\hline SH3BP4 & $-2,24$ & $8,68 \mathrm{E}-05$ & $-3,24$ & $1,44 \mathrm{E}-05$ \\
\hline SH3BP5-AS1 & $-1,16$ & $2,20 \mathrm{E}-03$ & $-1,54$ & $4,74 \mathrm{E}-11$ \\
\hline SH3GL1P3 & $-1,07$ & $8,27 \mathrm{E}-03$ & $-1,59$ & $2,41 \mathrm{E}-07$ \\
\hline SH3RF3-AS1 & $-1,66$ & $5,53 \mathrm{E}-03$ & $-3,83$ & $9,96 \mathrm{E}-11$ \\
\hline $\mathrm{SHC2}$ & $-1,74$ & $3,67 \mathrm{E}-03$ & $-2,55$ & $2,94 \mathrm{E}-05$ \\
\hline $\mathrm{SHC} 4$ & 2,45 & $1,23 \mathrm{E}-04$ & 3,74 & $5,50 \mathrm{E}-08$ \\
\hline SHMT1 & 1,53 & $8,38 \mathrm{E}-05$ & 1,94 & $1,06 \mathrm{E}-21$ \\
\hline SHMT1P1 & 2,01 & $6,41 \mathrm{E}-08$ & 2,29 & $8,28 \mathrm{E}-21$ \\
\hline SHMT2 & 1,59 & $2,61 \mathrm{E}-06$ & 2,13 & $8,68 \mathrm{E}-25$ \\
\hline SHQ1 & 1,00 & $9,29 \mathrm{E}-03$ & 1,22 & $1,03 \mathrm{E}-04$ \\
\hline SHROOM3 & 2,03 & 1,54E-03 & 5,25 & $9,74 \mathrm{E}-20$ \\
\hline SIAH2 & 1,27 & $2,10 \mathrm{E}-03$ & 1,41 & $6,49 \mathrm{E}-19$ \\
\hline SIAH3 & $-1,53$ & $3,00 \mathrm{E}-04$ & $-3,24$ & $1,38 \mathrm{E}-05$ \\
\hline SIMC1 & 1,34 & $2,20 \mathrm{E}-04$ & 1,87 & $9,57 \mathrm{E}-16$ \\
\hline SIRT1 & $-0,91$ & $4,30 \mathrm{E}-03$ & $-0,84$ & $7,67 \mathrm{E}-06$ \\
\hline SIT1 & 1,37 & $7,36 \mathrm{E}-04$ & 1,28 & $6,62 \mathrm{E}-04$ \\
\hline SIX5 & 1,28 & $4,20 \mathrm{E}-03$ & 1,38 & $4,51 \mathrm{E}-03$ \\
\hline SKA2P1 & 2,33 & $3,94 \mathrm{E}-09$ & 3,16 & $7,81 \mathrm{E}-34$ \\
\hline SLA & 1,37 & $8,33 \mathrm{E}-06$ & 1,15 & $1,58 \mathrm{E}-11$ \\
\hline SLBP & 0,98 & $8,42 \mathrm{E}-03$ & 1,21 & $2,22 \mathrm{E}-04$ \\
\hline SLC13A4 & $-1,67$ & $1,37 \mathrm{E}-03$ & $-2,20$ & $7,66 \mathrm{E}-08$ \\
\hline SLC14A2 & 2,80 & $1,46 \mathrm{E}-05$ & 4,58 & $4,00 \mathrm{E}-10$ \\
\hline SLC16A10 & $-0,95$ & $9,01 \mathrm{E}-03$ & $-1,74$ & $1,13 \mathrm{E}-06$ \\
\hline SLC16A6 & $-1,88$ & $4,63 \mathrm{E}-04$ & $-3,02$ & $4,52 \mathrm{E}-07$ \\
\hline SLC16A6P1 & $-1,72$ & $3,29 \mathrm{E}-03$ & $-2,81$ & 1,00E-04 \\
\hline SLC1A7 & $-2,00$ & $1,65 \mathrm{E}-03$ & $-2,23$ & $2,84 \mathrm{E}-03$ \\
\hline SLC25A10 & 2,50 & $2,36 \mathrm{E}-11$ & 2,72 & $2,44 \mathrm{E}-23$ \\
\hline SLC25A12 & 0,88 & $8,10 \mathrm{E}-03$ & 1,09 & $8,29 \mathrm{E}-12$ \\
\hline SLC25A15 & 2,21 & 9,53E-09 & 1,74 & $5,28 \mathrm{E}-08$ \\
\hline SLC25A22 & 1,10 & $1,41 \mathrm{E}-03$ & 1,38 & $3,09 \mathrm{E}-08$ \\
\hline SLC25A5 & 1,09 & $1,54 \mathrm{E}-03$ & 1,24 & $8,82 \mathrm{E}-07$ \\
\hline SLC25A5-AS1 & 0,90 & $7,89 \mathrm{E}-03$ & 0,80 & $2,21 \mathrm{E}-04$ \\
\hline SLC25A5P1 & 1,29 & $1,36 \mathrm{E}-03$ & 1,28 & $7,05 \mathrm{E}-04$ \\
\hline SLC25A5P2 & 1,10 & $3,42 \mathrm{E}-03$ & 1,38 & 9,17E-06 \\
\hline SLC25A5P3 & 1,32 & 1,56E-04 & 1,57 & $3,15 \mathrm{E}-10$ \\
\hline SLC25A5P5 & 1,06 & $3,03 E-03$ & 1,36 & $1,30 \mathrm{E}-06$ \\
\hline SLC25A5P8 & 1,07 & $2,40 \mathrm{E}-03$ & 1,09 & $2,29 \mathrm{E}-05$ \\
\hline SLC2A5 & $-1,90$ & $1,11 \mathrm{E}-03$ & $-3,18$ & $2,30 \mathrm{E}-17$ \\
\hline SLC35G2 & 1,98 & $8,81 \mathrm{E}-06$ & 4,08 & $5,24 \mathrm{E}-50$ \\
\hline SLC35G3 & 1,86 & $3,69 \mathrm{E}-03$ & 2,40 & 3,44E-03 \\
\hline
\end{tabular}




\begin{tabular}{|c|c|c|c|c|}
\hline SLC38A5 & 1,34 & $8,15 \mathrm{E}-05$ & 2,21 & $4,59 \mathrm{E}-26$ \\
\hline SLC40A1 & $\begin{array}{ll}-1,18 \\
\end{array}$ & $8,11 \mathrm{E}-03$ & $-2,37$ & $6,20 \mathrm{E}-07$ \\
\hline SLC5A10 & $-1,43$ & $5,51 \mathrm{E}-03$ & $-2,17$ & $2,52 \mathrm{E}-04$ \\
\hline SLC6A16 & $-1,25$ & $4,42 \mathrm{E}-03$ & $-2,88$ & $2,69 \mathrm{E}-13$ \\
\hline SLC6A17 & 2,92 & $4,45 \mathrm{E}-07$ & 1,89 & $7,18 \mathrm{E}-03$ \\
\hline SLC6A8 & $-1,38$ & $6,86 \mathrm{E}-03$ & $-1,79$ & $9,35 \mathrm{E}-04$ \\
\hline SLC7A1 & 1,02 & $5,17 \mathrm{E}-03$ & 1,27 & $7,53 \mathrm{E}-05$ \\
\hline SLC7A8 & $-1,36$ & $2,20 \mathrm{E}-04$ & $-0,95$ & $4,13 \mathrm{E}-06$ \\
\hline SLC8A1-AS1 & 2,26 & $4,82 \mathrm{E}-04$ & 3,81 & $2,52 \mathrm{E}-08$ \\
\hline SLC8B1 & $-1,32$ & $1,53 \mathrm{E}-03$ & $-2,21$ & $1,22 \mathrm{E}-12$ \\
\hline SLC9A5 & 1,87 & $4,43 \mathrm{E}-05$ & 2,76 & $1,56 \mathrm{E}-09$ \\
\hline SLC9A9 & $-1,39$ & $7,55 \mathrm{E}-05$ & $-2,14$ & $2,33 \mathrm{E}-27$ \\
\hline SLFN14 & $-1,76$ & $1,51 \mathrm{E}-03$ & $-2,82$ & $1,69 \mathrm{E}-05$ \\
\hline SMAD6 & $-1,86$ & $8,52 \mathrm{E}-04$ & $-3,11$ & $1,77 \mathrm{E}-10$ \\
\hline SMC1A & 1,23 & $2,10 \mathrm{E}-03$ & 1,30 & $3,02 \mathrm{E}-06$ \\
\hline SMPD3 & $-1,73$ & $5,40 \mathrm{E}-04$ & $-3,16$ & $9,72 \mathrm{E}-12$ \\
\hline SMPDL3A & $-2,10$ & $1,02 \mathrm{E}-04$ & $-3,42$ & $3,31 \mathrm{E}-09$ \\
\hline SMPDL3B & 1,63 & $2,51 \mathrm{E}-03$ & 2,23 & $6,58 \mathrm{E}-06$ \\
\hline SNED1 & $-2,01$ & $1,08 \mathrm{E}-04$ & $-3,11$ & $1,01 \mathrm{E}-07$ \\
\hline SNRNP25 & 1,31 & $3,61 \mathrm{E}-04$ & 1,96 & $1,13 \mathrm{E}-14$ \\
\hline SNRNP40 & 0,90 & $7,47 \mathrm{E}-03$ & 1,11 & $6,89 \mathrm{E}-10$ \\
\hline SNRPB & 0,97 & $2,43 \mathrm{E}-03$ & 1,12 & $9,34 \mathrm{E}-13$ \\
\hline SNRPD1 & 1,66 & $3,38 \mathrm{E}-06$ & 2,04 & $1,57 \mathrm{E}-30$ \\
\hline SNRPD3 & 0,91 & $9,01 \mathrm{E}-03$ & 1,21 & $3,11 \mathrm{E}-10$ \\
\hline SNRPEP4 & 1,21 & $9,75 \mathrm{E}-04$ & 1,49 & $2,80 \mathrm{E}-17$ \\
\hline SNRPF & 1,26 & $4,91 \mathrm{E}-05$ & 1,55 & $7,62 \mathrm{E}-19$ \\
\hline SNRPFP1 & 1,18 & $9,75 \mathrm{E}-04$ & 1,65 & $5,54 \mathrm{E}-16$ \\
\hline SNRPG & 1,13 & $2,43 E-03$ & 1,86 & $2,58 \mathrm{E}-13$ \\
\hline SNRPGP10 & 1,32 & $1,31 \mathrm{E}-03$ & 1,70 & $6,15 \mathrm{E}-06$ \\
\hline SNRPGP15 & 1,24 & $7,12 \mathrm{E}-04$ & 1,82 & $5,41 \mathrm{E}-10$ \\
\hline SNX29 & $-1,43$ & $5,82 \mathrm{E}-04$ & $-2,21$ & $6,53 \mathrm{E}-08$ \\
\hline SOAT2 & 2,15 & $6,57 \mathrm{E}-07$ & 1,00 & $6,88 \mathrm{E}-03$ \\
\hline SOCS3 & $-1,25$ & $1,58 \mathrm{E}-03$ & $-1,63$ & $4,89 \mathrm{E}-17$ \\
\hline SPA17P1 & 1,53 & $4,68 \mathrm{E}-03$ & 1,74 & $6,23 \mathrm{E}-04$ \\
\hline SPAG1 & 1,34 & $2,25 \mathrm{E}-03$ & 2,65 & $1,41 \mathrm{E}-18$ \\
\hline SPAG4 & 1,49 & $9,21 \mathrm{E}-05$ & 1,61 & $1,64 \mathrm{E}-06$ \\
\hline SPAG8 & $-1,51$ & $2,30 \mathrm{E}-03$ & $-2,31$ & $2,13 \mathrm{E}-05$ \\
\hline SPDL1 & 1,84 & $1,37 \mathrm{E}-06$ & 2,33 & $1,14 \mathrm{E}-22$ \\
\hline SPIN4 & 1,65 & 1,77E-04 & 1,40 & $6,74 \mathrm{E}-07$ \\
\hline SPN & 1,37 & $8,50 \mathrm{E}-05$ & 1,02 & $1,43 \mathrm{E}-09$ \\
\hline SPON2 & $-1,05$ & $9,10 \mathrm{E}-03$ & $-2,35$ & $3,95 \mathrm{E}-09$ \\
\hline SQLE & 2,03 & $1,72 \mathrm{E}-06$ & 2,75 & $1,96 \mathrm{E}-10$ \\
\hline SRM & 1,41 & $5,57 \mathrm{E}-06$ & 1,51 & $1,53 \mathrm{E}-23$ \\
\hline SRMP1 & 1,45 & $4,87 \mathrm{E}-03$ & 1,89 & $1,81 \mathrm{E}-04$ \\
\hline SRPK1 & 1,33 & $4,28 \mathrm{E}-04$ & 1,89 & $5,91 \mathrm{E}-38$ \\
\hline ST6GALNAC2 & $-1,41$ & $7,99 \mathrm{E}-04$ & $-1,84$ & $3,69 \mathrm{E}-08$ \\
\hline STAP2 & 1,84 & $9,35 \mathrm{E}-05$ & 2,73 & $7,42 \mathrm{E}-08$ \\
\hline STAT3 & 1,01 & $7,70 \mathrm{E}-03$ & 1,06 & $2,55 \mathrm{E}-03$ \\
\hline STEAP1 & 2,05 & $1,50 \mathrm{E}-03$ & 5,30 & $4,33 \mathrm{E}-14$ \\
\hline STK39 & 1,56 & $4,74 \mathrm{E}-04$ & 1,70 & $1,55 \mathrm{E}-15$ \\
\hline STMN1P2 & 1,93 & $2,66 \mathrm{E}-03$ & 2,35 & $1,25 \mathrm{E}-03$ \\
\hline STOML2 & 0,88 & $9,04 \mathrm{E}-03$ & 1,57 & $2,45 \mathrm{E}-13$ \\
\hline STRC & $-2,29$ & $1,32 \mathrm{E}-04$ & $-1,82$ & $5,03 \mathrm{E}-03$ \\
\hline STRCP1 & $-1,76$ & $1,62 \mathrm{E}-03$ & $-3,05$ & $6,73 \mathrm{E}-05$ \\
\hline STX16-NPEPL1 & $-1,47$ & $6,35 \mathrm{E}-04$ & $-2,74$ & $1,21 \mathrm{E}-09$ \\
\hline STX2 & $-0,99$ & $3,72 \mathrm{E}-03$ & $-1,10$ & $1,99 \mathrm{E}-05$ \\
\hline STYK1 & 1,90 & $6,48 \mathrm{E}-04$ & 4,99 & $3,09 \mathrm{E}-31$ \\
\hline SULT1B1 & $-1,73$ & $1,16 \mathrm{E}-04$ & $-3,09$ & $1,66 \mathrm{E}-10$ \\
\hline SUPT16H & 1,17 & $3,92 \mathrm{E}-04$ & 1,44 & $4,94 \mathrm{E}-18$ \\
\hline SUV39H1 & 1,47 & $1,53 \mathrm{E}-05$ & 1,82 & $1,53 \mathrm{E}-23$ \\
\hline SV2A & 1,57 & $5,83 \mathrm{E}-04$ & 2,04 & $1,03 \mathrm{E}-07$ \\
\hline SYDE1 & 2,60 & $6,77 \mathrm{E}-06$ & 3,28 & $3,87 \mathrm{E}-08$ \\
\hline SYNJ2 & 1,06 & $1,30 \mathrm{E}-03$ & 0,96 & $7,96 \mathrm{E}-07$ \\
\hline TACC3 & 1,04 & $4,81 \mathrm{E}-03$ & 1,08 & $2,32 \mathrm{E}-04$ \\
\hline TAF5 & 1,11 & 1,33E-03 & 1,49 & $2,64 \mathrm{E}-08$ \\
\hline TAGLN2 & 1,15 & $7,11 \mathrm{E}-04$ & 1,12 & $5,05 \mathrm{E}-15$ \\
\hline TAGLN2P1 & 1,22 & $6,09 \mathrm{E}-04$ & 1,35 & $3,33 \mathrm{E}-13$ \\
\hline TANC2 & $-1,33$ & $1,33 \mathrm{E}-03$ & $-1,38$ & $1,09 \mathrm{E}-06$ \\
\hline TAP1 & 1,46 & $1,44 \mathrm{E}-04$ & 1,45 & $3,96 \mathrm{E}-05$ \\
\hline TAS2R5 & $-1,89$ & $2,99 \mathrm{E}-04$ & $-1,35$ & $4,80 \mathrm{E}-03$ \\
\hline TBXA2R & $-2,08$ & $9,21 \mathrm{E}-05$ & $-3,69$ & $3,73 \mathrm{E}-11$ \\
\hline TC2N & $-1,74$ & $1,94 \mathrm{E}-04$ & $-2,58$ & $7,26 \mathrm{E}-09$ \\
\hline TCAM1P & 2,37 & $2,24 \mathrm{E}-04$ & 2,73 & $5,78 \mathrm{E}-04$ \\
\hline TCEANC & $-1,09$ & $9,60 \mathrm{E}-03$ & $-1,89$ & $7,06 \mathrm{E}-08$ \\
\hline TCN1 & $-1,43$ & $8,63 \mathrm{E}-03$ & $-4,69$ & $1,31 \mathrm{E}-10$ \\
\hline TCTEX1D2 & 1,14 & $7,94 \mathrm{E}-03$ & 1,74 & $2,55 \mathrm{E}-06$ \\
\hline TDP1 & 1,47 & $9,15 \mathrm{E}-05$ & 1,70 & $6,47 \mathrm{E}-15$ \\
\hline TERC & 3,59 & $2,24 \mathrm{E}-09$ & 6,23 & $7,12 \mathrm{E}-27$ \\
\hline
\end{tabular}

\begin{tabular}{|c|c|c|c|c|}
\hline TESC & 1,37 & $2,23 \mathrm{E}-03$ & 2,00 & $1,76 \mathrm{E}-19$ \\
\hline TESK2 & $-1,19$ & 1,75E-03 & $-1,40$ & $4,69 \mathrm{E}-05$ \\
\hline TEX30 & 1,27 & $3,12 \mathrm{E}-04$ & 1,98 & $1,09 \mathrm{E}-14$ \\
\hline TFDP1 & 1,18 & $3,00 \mathrm{E}-03$ & 1,17 & $1,20 \mathrm{E}-03$ \\
\hline TGFB111 & 1,86 & $2,28 \mathrm{E}-04$ & 2,79 & $1,17 \mathrm{E}-07$ \\
\hline TGFBI & $-1,04$ & 8,76E-04 & $-1,63$ & $1,42 \mathrm{E}-26$ \\
\hline TGFBR2 & $-0,82$ & 8,71E-03 & $-1,05$ & $2,49 \mathrm{E}-10$ \\
\hline TGFBR3 & $-1,46$ & $1,61 \mathrm{E}-03$ & $-2,06$ & $3,09 \mathrm{E}-06$ \\
\hline TGFBR3L & 2,38 & $1,09 \mathrm{E}-05$ & 2,92 & $3,25 \mathrm{E}-08$ \\
\hline THBD & $-2,47$ & 1,36E-05 & $-1,60$ & $7,32 \mathrm{E}-03$ \\
\hline THBS3 & $-1,38$ & $8,10 \mathrm{E}-04$ & $-2,06$ & $1,73 \mathrm{E}-10$ \\
\hline THG1L & 1,21 & 1,51E-03 & 1,15 & $1,25 \mathrm{E}-10$ \\
\hline THOC3 & 1,01 & 5,95E-03 & 1,15 & $5,41 \mathrm{E}-11$ \\
\hline THOP1 & 0,97 & $2,18 \mathrm{E}-03$ & 1,13 & $2,55 \mathrm{E}-10$ \\
\hline TIAM2 & 1,50 & $2,85 \mathrm{E}-03$ & 2,28 & $4,92 \mathrm{E}-14$ \\
\hline TIE1 & 1,93 & 6,86E-05 & 1,31 & $1,15 \mathrm{E}-03$ \\
\hline TIMELESS & 1,99 & 4,35E-06 & 2,11 & $1,48 \mathrm{E}-08$ \\
\hline TLDC2 & $-1,13$ & $2,19 \mathrm{E}-03$ & $-2,29$ & $1,85 \mathrm{E}-19$ \\
\hline TLN2 & 1,59 & $4,22 \mathrm{E}-04$ & 1,71 & $9,96 \mathrm{E}-05$ \\
\hline TMEM14A & 1,45 & 1,17E-03 & 1,66 & $9,85 \mathrm{E}-05$ \\
\hline TMEM175 & $-1,03$ & $8,39 \mathrm{E}-03$ & $-1,97$ & $2,72 \mathrm{E}-10$ \\
\hline TMEM181 & $-0,98$ & 1,67E-03 & $-0,99$ & $2,00 \mathrm{E}-09$ \\
\hline TMEM191C & $-1,31$ & $3,87 \mathrm{E}-03$ & $-1,76$ & $3,06 \mathrm{E}-04$ \\
\hline TMEM198B & $-0,96$ & $2,38 \mathrm{E}-03$ & $-1,86$ & $2,33 \mathrm{E}-20$ \\
\hline TMEM2 & 1,51 & $2,65 \mathrm{E}-04$ & 0,94 & $5,18 \mathrm{E}-10$ \\
\hline TMEM201 & 0,96 & $2,80 \mathrm{E}-03$ & 1,17 & $4,37 \mathrm{E}-11$ \\
\hline TMEM237 & 1,55 & 1,00E-04 & 2,30 & $5,54 \mathrm{E}-22$ \\
\hline TMEM241 & 1,22 & $2,80 \mathrm{E}-03$ & 1,93 & $1,89 \mathrm{E}-12$ \\
\hline TMEM26 & $-1,79$ & $3,12 \mathrm{E}-03$ & $-2,88$ & $6,15 \mathrm{E}-05$ \\
\hline TMEM42 & $-1,08$ & $6,42 \mathrm{E}-03$ & $-1,72$ & $1,79 \mathrm{E}-06$ \\
\hline TMEM44 & 1,31 & $2,72 \mathrm{E}-03$ & 1,70 & $4,26 \mathrm{E}-08$ \\
\hline TMEM45B & $-1,42$ & 8,94E-03 & $-2,84$ & $9,58 \mathrm{E}-06$ \\
\hline TMEM50B & $-1,46$ & 4,95E-04 & $-2,09$ & $3,08 \mathrm{E}-08$ \\
\hline TMEM63A & $-1,67$ & $2,42 \mathrm{E}-05$ & $-2,60$ & $1,38 \mathrm{E}-31$ \\
\hline TMEM91 & $-0,93$ & 9,50E-03 & $-1,49$ & $1,09 \mathrm{E}-07$ \\
\hline TMEM97 & 1,92 & $1,02 \mathrm{E}-08$ & 2,79 & $1,81 \mathrm{E}-52$ \\
\hline TMEM97P2 & 1,98 & $3,64 \mathrm{E}-05$ & 2,81 & $1,28 \mathrm{E}-14$ \\
\hline TMIE & $-2,53$ & $6,18 \mathrm{E}-06$ & $-3,45$ & $4,01 \mathrm{E}-08$ \\
\hline TNF & 1,57 & 9,61E-06 & 3,34 & $2,42 E-67$ \\
\hline TNFRSF10D & $-1,59$ & 5,47E-04 & $-1,90$ & $1,28 \mathrm{E}-10$ \\
\hline TNFRSF13B & $-1,77$ & $3,10 \mathrm{E}-03$ & $-2,00$ & $4,34 \mathrm{E}-04$ \\
\hline TNFRSF17 & $-1,69$ & 8,81E-03 & $-2,55$ & 5,34E-05 \\
\hline TNFRSF21 & $-2,16$ & $5,26 \mathrm{E}-06$ & $-2,80$ & $7,05 \mathrm{E}-08$ \\
\hline TNFSF11 & 3,38 & 1,44E-09 & 3,19 & $6,89 \mathrm{E}-14$ \\
\hline TNK1 & $-1,26$ & $9,17 \mathrm{E}-03$ & $-2,48$ & $6,13 \mathrm{E}-07$ \\
\hline TNNT3 & $-2,15$ & $1,23 \mathrm{E}-05$ & $-3,82$ & $1,12 \mathrm{E}-10$ \\
\hline TNP1 & 2,70 & $2,92 \mathrm{E}-05$ & 4,23 & $1,55 \mathrm{E}-08$ \\
\hline TNRC6C-AS1 & $-1,61$ & 8,39E-04 & $-2,54$ & $4,97 \mathrm{E}-09$ \\
\hline TOE1 & 0,96 & 4,93E-03 & 1,60 & $2,52 \mathrm{E}-11$ \\
\hline TOMM34 & 1,29 & $2,54 \mathrm{E}-04$ & 2,02 & $7,03 \mathrm{E}-13$ \\
\hline TOPBP1 & 1,17 & 1,13E-03 & 1,58 & $6,97 \mathrm{E}-29$ \\
\hline TP53 & 0,99 & 5,03E-03 & 0,80 & 2,63E-07 \\
\hline TP73 & 1,33 & $8,48 \mathrm{E}-04$ & 1,94 & $3,54 \mathrm{E}-12$ \\
\hline TPBGL & $-1,78$ & $2,55 \mathrm{E}-03$ & $-2,77$ & $1,12 \mathrm{E}-04$ \\
\hline TPI1 & 1,20 & 2,99E-04 & 1,53 & $3,44 \mathrm{E}-14$ \\
\hline TPI1P1 & 1,20 & $7,74 \mathrm{E}-04$ & 1,57 & $1,66 \mathrm{E}-12$ \\
\hline TPM2 & $-1,74$ & $6,41 \mathrm{E}-04$ & $-1,99$ & 4,93E-04 \\
\hline TRAIP & 2,30 & 1,50E-09 & 2,87 & $6,80 \mathrm{E}-58$ \\
\hline TRAJ34 & 1,34 & $4,90 \mathrm{E}-03$ & 1,64 & $6,31 \mathrm{E}-04$ \\
\hline TRAM2 & $-1,29$ & $5,39 \mathrm{E}-05$ & $-1,16$ & $7,03 \mathrm{E}-11$ \\
\hline TRAM2-AS1 & $-1,51$ & $2,68 \mathrm{E}-03$ & $-2,14$ & $1,75 \mathrm{E}-04$ \\
\hline TRAV17 & 1,26 & $9,16 \mathrm{E}-03$ & 1,25 & $7,55 \mathrm{E}-03$ \\
\hline TRAV8-4 & 1,23 & $2,69 \mathrm{E}-03$ & 0,99 & $1,84 \mathrm{E}-03$ \\
\hline TRBV23-1 & $-1,84$ & $8,41 \mathrm{E}-04$ & $-2,16$ & 2,14E-03 \\
\hline TRIM2 & $-2,44$ & $3,06 \mathrm{E}-07$ & $-2,08$ & $1,29 \mathrm{E}-05$ \\
\hline TRIM45 & 1,63 & $6,07 \mathrm{E}-03$ & 2,38 & $3,67 \mathrm{E}-04$ \\
\hline TRIM73 & $-1,43$ & $4,08 \mathrm{E}-03$ & $-2,39$ & $6,87 \mathrm{E}-06$ \\
\hline TRIM74 & $-1,47$ & $3,69 \mathrm{E}-03$ & $-2,72$ & 4,67E-07 \\
\hline TRMT6 & 0,94 & $3,58 \mathrm{E}-03$ & 1,60 & $2,88 \mathrm{E}-14$ \\
\hline TRPC1 & $-1,98$ & $4,41 \mathrm{E}-05$ & $-1,41$ & $3,20 \mathrm{E}-03$ \\
\hline TRPM1 & $-2,06$ & $1,43 \mathrm{E}-03$ & $-2,56$ & 1,67E-03 \\
\hline TRPV3 & 1,37 & 3,93E-03 & 1,69 & 6,09E-04 \\
\hline TSC1 & $-0,92$ & $4,78 \mathrm{E}-03$ & $-1,14$ & $2,75 \mathrm{E}-13$ \\
\hline TSPAN15 & $-1,64$ & $1,24 \mathrm{E}-04$ & $-0,82$ & 7,61E-03 \\
\hline TSPAN32 & $-1,52$ & $1,02 \mathrm{E}-03$ & $-3,08$ & $4,93 \mathrm{E}-10$ \\
\hline TST & 1,19 & $3,89 \mathrm{E}-03$ & 1,34 & 8,38E-04 \\
\hline TTC21A & $-1,56$ & $6,28 \mathrm{E}-04$ & $-2,22$ & $3,13 \mathrm{E}-11$ \\
\hline TTC34 & $-1,33$ & 1,32E-03 & $-2,80$ & $5,89 \mathrm{E}-11$ \\
\hline TTLL2 & $-1,66$ & $5,29 \mathrm{E}-03$ & $-3,75$ & 1,61E-06 \\
\hline
\end{tabular}




\begin{tabular}{|c|c|c|c|c|}
\hline TUBA1B & 1,32 & $1,35 \mathrm{E}-03$ & 1,51 & $5,72 \mathrm{E}-06$ \\
\hline TUBA3E & 1,79 & $3,44 \mathrm{E}-03$ & 2,53 & $7,82 \mathrm{E}-05$ \\
\hline TUBB & 1,47 & 1,76E-04 & 1,65 & $1,15 \mathrm{E}-07$ \\
\hline TUBBP1 & 1,60 & 1,06E-04 & 1,77 & $7,92 \mathrm{E}-07$ \\
\hline TUBBP6 & 1,57 & $3,00 \mathrm{E}-04$ & 1,74 & $6,73 \mathrm{E}-05$ \\
\hline TUBG1 & 1,44 & $8,49 \mathrm{E}-04$ & 1,82 & $3,64 \mathrm{E}-05$ \\
\hline TUBG1P & 1,14 & 1,96E-03 & 1,72 & $1,41 \mathrm{E}-07$ \\
\hline TUSC3 & 2,44 & 1,64E-04 & 3,90 & $4,05 \mathrm{E}-07$ \\
\hline TXNIP & $-1,26$ & $2,43 \mathrm{E}-03$ & $-1,27$ & $5,24 \mathrm{E}-15$ \\
\hline U91328,20 & $-1,51$ & 1,77E-03 & $-1,22$ & $3,39 \mathrm{E}-03$ \\
\hline UBA5 & 1,17 & 4,82E-04 & 1,18 & 7,02E-09 \\
\hline UBD & 1,86 & $3,29 \mathrm{E}-03$ & 3,95 & $8,26 \mathrm{E}-11$ \\
\hline UBE2NL & 1,49 & 1,93E-05 & 2,28 & $7,85 \mathrm{E}-21$ \\
\hline UBE2SP1 & 2,15 & 1,84E-07 & 2,96 & $5,32 \mathrm{E}-23$ \\
\hline UBL3 & $-0,99$ & 4,57E-03 & $-1,40$ & $1,78 \mathrm{E}-07$ \\
\hline UBR7 & 1,15 & 1,09E-03 & 1,66 & $8,40 \mathrm{E}-12$ \\
\hline UCHL5 & 1,06 & $4,52 \mathrm{E}-03$ & 1,34 & $7,30 \mathrm{E}-11$ \\
\hline UNGP3 & 1,58 & $6,12 \mathrm{E}-03$ & 1,73 & $2,43 \mathrm{E}-03$ \\
\hline UPK3A & $-1,88$ & $2,87 \mathrm{E}-03$ & $-3,15$ & $7,25 \mathrm{E}-05$ \\
\hline USP1 & 1,17 & $2,99 \mathrm{E}-03$ & 1,34 & $1,43 \mathrm{E}-09$ \\
\hline USPL1 & $-0,93$ & $5,75 \mathrm{E}-03$ & $-1,08$ & $1,10 \mathrm{E}-11$ \\
\hline UTP20 & 0,89 & $8,20 \mathrm{E}-03$ & 1,59 & $3,36 \mathrm{E}-10$ \\
\hline VAMP4 & $-0,91$ & $8,71 \mathrm{E}-03$ & $-1,34$ & $2,12 \mathrm{E}-09$ \\
\hline VAMP5 & 1,79 & $4,07 \mathrm{E}-06$ & 1,73 & $5,41 \mathrm{E}-07$ \\
\hline VANGL1 & 1,78 & $7,48 \mathrm{E}-06$ & 2,15 & $8,25 \mathrm{E}-11$ \\
\hline VDR & 1,56 & $8,66 \mathrm{E}-03$ & 1,97 & $6,50 \mathrm{E}-03$ \\
\hline VIPR1 & $-1,90$ & 1,94E-04 & $-3,73$ & $4,05 \mathrm{E}-11$ \\
\hline VPREB3 & $-2,03$ & $8,18 \mathrm{E}-04$ & $-2,42$ & $1,78 \mathrm{E}-03$ \\
\hline VRK1 & 1,72 & $5,83 \mathrm{E}-06$ & 2,18 & $2,27 \mathrm{E}-27$ \\
\hline VSIG1 & $-2,04$ & $1,20 \mathrm{E}-04$ & $-4,00$ & $4,87 \mathrm{E}-13$ \\
\hline VSIG4 & $-1,94$ & $1,58 \mathrm{E}-03$ & $-5,39$ & $6,34 \mathrm{E}-14$ \\
\hline VWF & $\begin{array}{l}-1,56 \\
\end{array}$ & $4,21 \mathrm{E}-03$ & $-3,98$ & $6,15 \mathrm{E}-11$ \\
\hline WDR19 & $-1,22$ & $1,85 \mathrm{E}-04$ & $-1,48$ & $1,02 \mathrm{E}-15$ \\
\hline WDR86-AS1 & $-2,91$ & $3,10 \mathrm{E}-09$ & $-4,48$ & $3,71 \mathrm{E}-11$ \\
\hline WDR90 & 1,26 & $7,18 \mathrm{E}-05$ & 1,09 & $5,43 \mathrm{E}-11$ \\
\hline WHSC1 & 1,58 & $8,30 \mathrm{E}-05$ & 1,84 & $4,50 \mathrm{E}-35$ \\
\hline WNT10B & $-3,01$ & $6,51 \mathrm{E}-09$ & $-4,41$ & 1,34E-11 \\
\hline WNT7A & $-2,42$ & $8,51 \mathrm{E}-05$ & $-3,22$ & $2,87 \mathrm{E}-06$ \\
\hline XCR1 & $-2,25$ & $4,38 \mathrm{E}-04$ & $-2,73$ & $4,65 \mathrm{E}-04$ \\
\hline XIRP1 & 2,02 & $1,35 \mathrm{E}-03$ & 3,03 & $1,30 \mathrm{E}-06$ \\
\hline $\mathrm{XRCC5}$ & 1,02 & 3,39E-03 & 1,58 & $9,48 \mathrm{E}-15$ \\
\hline XRCC6BP1 & 1,06 & $5,25 \mathrm{E}-03$ & 1,28 & 4,05E-07 \\
\hline XXBAC-B476C20,9 & 1,49 & $5,54 \mathrm{E}-03$ & 2,51 & $1,03 \mathrm{E}-06$ \\
\hline $\begin{array}{c}\text { XXBAC- } \\
\text { BPG252P9,9 } \\
\end{array}$ & 1,56 & $5,26 \mathrm{E}-05$ & 1,80 & $1,56 \mathrm{E}-13$ \\
\hline $\begin{array}{c}\text { XXBAC- } \\
\text { BPG299F13,17 }\end{array}$ & $-1,40$ & $5,79 \mathrm{E}-03$ & $-2,65$ & $3,65 \mathrm{E}-06$ \\
\hline XXCOS-LUCA11,4 & $-1,61$ & $1,70 \mathrm{E}-03$ & $-2,52$ & $3,95 \mathrm{E}-06$ \\
\hline XXYLT1 & 1,13 & $1,02 \mathrm{E}-03$ & 0,88 & $3,12 \mathrm{E}-03$ \\
\hline Y_RNA & $-1,50$ & $2,47 \mathrm{E}-03$ & $-2,02$ & $7,18 \mathrm{E}-05$ \\
\hline YEATS4 & 1,08 & $3,76 \mathrm{E}-03$ & 1,15 & $4,01 \mathrm{E}-11$ \\
\hline YPEL4 & $-0,92$ & $7,09 \mathrm{E}-03$ & $-2,21$ & $1,68 \mathrm{E}-11$ \\
\hline YWHAH & 1,19 & $9,82 \mathrm{E}-04$ & 1,49 & $1,33 \mathrm{E}-06$ \\
\hline Z97634,3 & $-1,40$ & $8,23 \mathrm{E}-03$ & $-2,72$ & $4,86 \mathrm{E}-06$ \\
\hline ZBTB18 & $-1,34$ & $1,00 \mathrm{E}-03$ & $-1,73$ & $2,70 \mathrm{E}-06$ \\
\hline ZBTB22 & $-0,98$ & $6,94 \mathrm{E}-03$ & $-1,77$ & $9,08 \mathrm{E}-14$ \\
\hline ZBTB37 & $-1,20$ & $6,34 \mathrm{E}-04$ & $-1,22$ & $4,01 \mathrm{E}-06$ \\
\hline ZBTB4 & $-1,14$ & $7,02 \mathrm{E}-04$ & $-1,78$ & $2,06 \mathrm{E}-15$ \\
\hline ZBTB40 & $-1,01$ & $3,17 \mathrm{E}-03$ & $-1,34$ & $1,50 \mathrm{E}-11$ \\
\hline ZBTB46 & $-1,14$ & $7,63 \mathrm{E}-03$ & $-1,71$ & $1,33 \mathrm{E}-05$ \\
\hline $\mathrm{ZCCHC14}$ & $-1,14$ & $7,10 \mathrm{E}-03$ & $-2,44$ & $2,81 \mathrm{E}-42$ \\
\hline $\mathrm{ZCCHC} 18$ & $-1,20$ & $8,81 \mathrm{E}-03$ & $-1,91$ & $1,22 \mathrm{E}-04$ \\
\hline ZDHHC11B & $-1,81$ & $4,22 \mathrm{E}-04$ & $-1,58$ & $6,74 \mathrm{E}-04$ \\
\hline ZEB2-AS1 & $-1,67$ & $4,63 \mathrm{E}-04$ & $-2,76$ & 1,71E-06 \\
\hline ZFP14 & $-1,42$ & $3,15 \mathrm{E}-04$ & $-2,46$ & $3,85 \mathrm{E}-09$ \\
\hline ZFP28 & $-0,97$ & $6,69 \mathrm{E}-03$ & $-1,19$ & $4,50 \mathrm{E}-06$ \\
\hline ZFYVE20 & $-1,15$ & $3,84 \mathrm{E}-04$ & $-1,98$ & $4,78 \mathrm{E}-18$ \\
\hline ZFYVE28 & $-1,33$ & $2,27 \mathrm{E}-03$ & $-2,38$ & $1,44 \mathrm{E}-32$ \\
\hline ZMAT1 & $-1,64$ & $6,95 \mathrm{E}-05$ & $-2,84$ & $3,18 \mathrm{E}-13$ \\
\hline ZNF169 & $-1,22$ & $2,62 \mathrm{E}-03$ & $-1,76$ & $3,84 \mathrm{E}-06$ \\
\hline ZNF204P & $-1,78$ & 1,97E-04 & $-2,04$ & $2,88 \mathrm{E}-05$ \\
\hline ZNF248 & $-1,14$ & $4,02 E-03$ & $-1,50$ & $3,18 \mathrm{E}-05$ \\
\hline ZNF25 & $-0,88$ & $6,26 \mathrm{E}-03$ & $-0,79$ & $6,28 \mathrm{E}-05$ \\
\hline ZNF331 & $-0,91$ & $7,29 \mathrm{E}-03$ & $-0,81$ & $1,54 \mathrm{E}-07$ \\
\hline ZNF333 & $-1,00$ & $2,18 \mathrm{E}-03$ & $-1,29$ & $1,79 \mathrm{E}-11$ \\
\hline ZNF334 & 1,60 & $3,59 \mathrm{E}-03$ & 2,75 & $3,24 \mathrm{E}-07$ \\
\hline ZNF33B & $-1,25$ & $1,22 \mathrm{E}-03$ & $-1,47$ & $2,90 \mathrm{E}-05$ \\
\hline
\end{tabular}

\begin{tabular}{|c|c|c|c|c|}
\hline ZNF33B & $-1,42$ & 5,32E-03 & $-1,76$ & $1,13 \mathrm{E}-03$ \\
\hline ZNF354B & $-0,91$ & $5,80 \mathrm{E}-03$ & $-1,35$ & 3,93E-09 \\
\hline ZNF441 & $-1,21$ & $1,32 \mathrm{E}-03$ & $-1,04$ & $8,48 \mathrm{E}-04$ \\
\hline ZNF449 & $-0,97$ & 8,82E-03 & $-1,82$ & $3,14 \mathrm{E}-09$ \\
\hline ZNF467 & $-1,68$ & $8,62 \mathrm{E}-04$ & $-3,29$ & $6,61 \mathrm{E}-14$ \\
\hline ZNF480 & $-0,91$ & 5,41E-03 & $-1,15$ & $8,26 \mathrm{E}-10$ \\
\hline ZNF514 & $-1,14$ & $6,82 \mathrm{E}-04$ & $-1,56$ & $3,13 \mathrm{E}-12$ \\
\hline ZNF528 & $-1,10$ & $3,98 \mathrm{E}-03$ & $-1,54$ & $7,67 \mathrm{E}-06$ \\
\hline ZNF532 & $-1,34$ & 4,84E-03 & $-1,89$ & $8,07 \mathrm{E}-09$ \\
\hline ZNF534 & 1,79 & $2,44 \mathrm{E}-06$ & 2,23 & $1,33 \mathrm{E}-12$ \\
\hline ZNF540 & $-1,94$ & 1,01E-04 & $-2,38$ & $8,24 \mathrm{E}-06$ \\
\hline ZNF548 & $-1,27$ & $2,89 \mathrm{E}-03$ & $-1,63$ & $1,57 \mathrm{E}-04$ \\
\hline ZNF550 & $-1,09$ & $8,42 \mathrm{E}-03$ & $-1,67$ & 1,06E-04 \\
\hline ZNF559 & $-1,08$ & $8,73 \mathrm{E}-03$ & $-1,43$ & $1,31 \mathrm{E}-04$ \\
\hline ZNF577 & $-1,52$ & $2,72 E-04$ & $-2,16$ & $5,28 \mathrm{E}-10$ \\
\hline ZNF589 & $-1,43$ & $4,06 \mathrm{E}-05$ & $-1,97$ & $1,36 \mathrm{E}-12$ \\
\hline ZNF593 & 1,13 & $8,05 \mathrm{E}-03$ & 1,58 & $1,03 \mathrm{E}-05$ \\
\hline ZNF608 & $-1,47$ & $8,63 \mathrm{E}-03$ & $-1,95$ & $5,31 \mathrm{E}-03$ \\
\hline ZNF641 & $-0,92$ & $5,25 \mathrm{E}-03$ & $-1,34$ & $5,48 \mathrm{E}-11$ \\
\hline ZNF652 & $-1,42$ & 1,97E-04 & $-2,14$ & $2,00 \mathrm{E}-15$ \\
\hline ZNF683 & $-1,76$ & 6,62E-04 & $-4,56$ & $7,01 \mathrm{E}-43$ \\
\hline ZNF70 & $-1,21$ & $2,48 \mathrm{E}-03$ & $-2,81$ & $4,94 \mathrm{E}-13$ \\
\hline ZNF704 & 2,27 & $1,05 \mathrm{E}-10$ & 1,08 & $6,03 \mathrm{E}-06$ \\
\hline ZNF726 & 1,75 & $2,23 \mathrm{E}-03$ & 1,86 & $5,50 \mathrm{E}-03$ \\
\hline ZNF738 & 1,19 & $4,72 \mathrm{E}-03$ & 1,20 & $3,29 \mathrm{E}-07$ \\
\hline ZNF767 & $-1,24$ & $4,42 \mathrm{E}-03$ & $-2,28$ & $1,43 \mathrm{E}-07$ \\
\hline ZNF771 & 1,12 & $6,86 \mathrm{E}-03$ & 1,48 & $9,56 \mathrm{E}-05$ \\
\hline ZNF815P & $-1,56$ & $1,24 \mathrm{E}-03$ & $-2,13$ & $4,58 \mathrm{E}-05$ \\
\hline ZNF818P & $-1,71$ & $2,48 \mathrm{E}-03$ & $-1,65$ & $4,28 \mathrm{E}-03$ \\
\hline ZNF83 & $-1,12$ & $3,79 \mathrm{E}-03$ & $-1,62$ & $2,62 \mathrm{E}-06$ \\
\hline ZNF852 & $-1,01$ & $7,96 \mathrm{E}-03$ & $-1,55$ & $6,30 \mathrm{E}-07$ \\
\hline ZNF890P & $-1,82$ & $2,90 \mathrm{E}-04$ & $-3,00$ & $9,08 \mathrm{E}-09$ \\
\hline ZSCAN16-AS1 & $-1,32$ & $9,41 \mathrm{E}-05$ & $-2,31$ & $9,79 \mathrm{E}-23$ \\
\hline ZWILCH & 1,83 & $9,53 \mathrm{E}-06$ & 2,51 & $6,38 \mathrm{E}-16$ \\
\hline
\end{tabular}

\section{3) Genes regulados comumente por OKT3 e FvFc M}

\begin{tabular}{|c|c|c|c|c|}
\hline \multirow[b]{2}{*}{ Gene } & \multicolumn{2}{|c|}{ FvFc M } & \multicolumn{2}{|c|}{ OKT3 } \\
\hline & $\mathrm{FC}(\log 2)$ & $p$ value & $\mathrm{FC}$ (Log2) & $p$ value \\
\hline ABCB5 & $-1,79$ & $2,17 \mathrm{E}-03$ & $-4,05$ & $2,13 \mathrm{E}-08$ \\
\hline$A B C C 3$ & $-1,39$ & $8,61 \mathrm{E}-03$ & $-2,64$ & $7,34 \mathrm{E}-06$ \\
\hline ABHD12 & $-1,78$ & $1,44 \mathrm{E}-04$ & $-2,40$ & $2,33 \mathrm{E}-07$ \\
\hline ABHD6 & $-1,22$ & $4,75 \mathrm{E}-03$ & $-1,91$ & $1,16 \mathrm{E}-05$ \\
\hline $\mathrm{ABR}$ & $-1,31$ & $8,45 \mathrm{E}-03$ & $-2,02$ & $1,49 \mathrm{E}-04$ \\
\hline AC017002,4 & $-2,26$ & $1,09 \mathrm{E}-04$ & $-3,31$ & $3,61 \mathrm{E}-05$ \\
\hline AC023590,1 & $-1,56$ & $7,46 \mathrm{E}-03$ & $-2,72$ & $7,69 \mathrm{E}-04$ \\
\hline AC027612,6 & $-1,13$ & $8,28 \mathrm{E}-03$ & $-1,34$ & $3,53 \mathrm{E}-04$ \\
\hline AC079767,4 & $-2,18$ & 4,97E-05 & $-3,35$ & $1,01 \mathrm{E}-08$ \\
\hline AC135048,1 & $-1,51$ & $4,82 \mathrm{E}-03$ & $-1,74$ & $8,08 \mathrm{E}-03$ \\
\hline ACE & $-1,70$ & $1,41 \mathrm{E}-04$ & $-3,37$ & $4,22 \mathrm{E}-14$ \\
\hline ACOT1 & $-1,54$ & $3,02 \mathrm{E}-03$ & $-1,87$ & $2,39 \mathrm{E}-03$ \\
\hline ACOT11 & $-1,97$ & $9,12 \mathrm{E}-06$ & $-2,56$ & $4,74 \mathrm{E}-09$ \\
\hline ACP5 & $-2,23$ & $7,40 \mathrm{E}-06$ & $-3,38$ & $1,50 \mathrm{E}-11$ \\
\hline ACSS2 & $-1,32$ & $1,45 \mathrm{E}-03$ & $-1,47$ & $5,28 \mathrm{E}-05$ \\
\hline ACTA2 & 1,40 & $9,22 \mathrm{E}-04$ & 1,70 & $3,35 \mathrm{E}-09$ \\
\hline ADAP1 & $-1,15$ & $1,63 \mathrm{E}-03$ & $-1,46$ & $5,77 \mathrm{E}-08$ \\
\hline ADCK1 & $-1,12$ & $5,80 \mathrm{E}-03$ & $-2,21$ & $3,57 \mathrm{E}-09$ \\
\hline AGAP3 & $-1,31$ & $8,48 \mathrm{E}-03$ & $-1,98$ & $1,95 \mathrm{E}-04$ \\
\hline AlFM3 & $-2,09$ & $2,48 \mathrm{E}-05$ & $-2,38$ & $1,52 \mathrm{E}-05$ \\
\hline AKR1A1 & $-1,14$ & $5,28 \mathrm{E}-03$ & $-1,15$ & $1,89 \mathrm{E}-03$ \\
\hline AL450992,2 & 1,88 & 2,97E-05 & 3,23 & 2,04E-20 \\
\hline ALDH1A1 & $-3,35$ & $5,56 \mathrm{E}-10$ & $-5,16$ & $6,66 \mathrm{E}-19$ \\
\hline ALDH3A1 & $-1,45$ & $7,81 \mathrm{E}-03$ & $-2,60$ & $2,06 \mathrm{E}-04$ \\
\hline ALDH3B1 & $-1,97$ & 1,47E-04 & $-3,35$ & $2,81 \mathrm{E}-10$ \\
\hline ALDH3B2 & $-1,79$ & $1,52 \mathrm{E}-03$ & $-3,12$ & $5,08 \mathrm{E}-05$ \\
\hline ALK & $-2,08$ & 3,52E-04 & $-4,78$ & $8,61 \mathrm{E}-12$ \\
\hline ALPK2 & 1,47 & $1,60 \mathrm{E}-03$ & 3,33 & $9,01 \mathrm{E}-14$ \\
\hline AMDHD2 & $-1,26$ & $3,40 \mathrm{E}-03$ & $-2,19$ & $2,55 \mathrm{E}-08$ \\
\hline ANKRD44 & 0,90 & $8,85 \mathrm{E}-03$ & 1,01 & $9,42 \mathrm{E}-09$ \\
\hline ANXA4 & $-1,67$ & $6,50 \mathrm{E}-04$ & $-1,85$ & 7,34E-04 \\
\hline AP001053,11 & $-2,18$ & 1,54E-04 & $-3,76$ & $1,12 \mathrm{E}-07$ \\
\hline AP001056,1 & $-1,63$ & 1,72E-03 & $-4,53$ & $6,29 \mathrm{E}-10$ \\
\hline AP1S2 & $-1,67$ & 1,16E-04 & $-1,82$ & $2,29 \mathrm{E}-05$ \\
\hline APOBR & $-1,29$ & $3,51 \mathrm{E}-03$ & $-1,92$ & 2,34E-05 \\
\hline ARHGAP22 & $-1,82$ & $7,60 \mathrm{E}-04$ & $-3,28$ & $4,96 \mathrm{E}-10$ \\
\hline ARHGEF11 & $-1,45$ & $5,62 \mathrm{E}-03$ & $-2,67$ & $1,70 \mathrm{E}-07$ \\
\hline
\end{tabular}




\begin{tabular}{|c|c|c|c|c|}
\hline ARID3A & $-1,37$ & $6,40 \mathrm{E}-03$ & $-2,05$ & $8,96 \mathrm{E}-05$ \\
\hline ARMCX1 & $-1,36$ & $8,53 \mathrm{E}-03$ & $-2,30$ & $4,05 \mathrm{E}-06$ \\
\hline ASAH1 & $-1,45$ & $8,99 \mathrm{E}-03$ & $-3,22$ & $7,08 \mathrm{E}-09$ \\
\hline ASGR2 & $-1,48$ & $4,31 \mathrm{E}-03$ & $-2,70$ & $1,36 \mathrm{E}-05$ \\
\hline ASIP & $-1,65$ & $3,78 \mathrm{E}-03$ & $-2,76$ & $1,16 \mathrm{E}-04$ \\
\hline ATF3 & $-1,21$ & 4,83E-04 & $-1,16$ & $1,76 \mathrm{E}-07$ \\
\hline ATG7 & $-1,49$ & $1,66 \mathrm{E}-04$ & $-1,47$ & $2,57 \mathrm{E}-05$ \\
\hline ATP6AP1 & $-1,44$ & $3,78 \mathrm{E}-03$ & $-2,02$ & $1,04 \mathrm{E}-04$ \\
\hline ATP6V0A1 & $-1,57$ & $3,66 \mathrm{E}-03$ & $-2,64$ & $7,05 \mathrm{E}-06$ \\
\hline ATP6V0A4 & 1,97 & $4,76 \mathrm{E}-04$ & 2,50 & $1,48 \mathrm{E}-04$ \\
\hline ATP6V0C & $-1,28$ & $3,52 E-03$ & $-1,76$ & $4,69 \mathrm{E}-05$ \\
\hline ATP6V0CP3 & $-1,34$ & $7,43 \mathrm{E}-03$ & $-1,65$ & $9,15 \mathrm{E}-04$ \\
\hline ATP6V0D1 & $-1,58$ & 1,21E-03 & $-1,76$ & $9,43 \mathrm{E}-04$ \\
\hline ATP6V1B2 & $-1,29$ & $7,59 \mathrm{E}-03$ & $-1,61$ & $2,22 \mathrm{E}-03$ \\
\hline ATP6V1F & $-1,40$ & $2,87 \mathrm{E}-03$ & $-1,78$ & $3,67 \mathrm{E}-04$ \\
\hline AVPI1 & $-1,84$ & $8,29 \mathrm{E}-05$ & $-2,04$ & $3,14 \mathrm{E}-05$ \\
\hline BCAP31 & $-1,34$ & $2,08 \mathrm{E}-03$ & $-1,40$ & $1,16 \mathrm{E}-03$ \\
\hline BCL2L11 & 1,04 & $3,97 \mathrm{E}-03$ & 1,25 & $1,49 \mathrm{E}-05$ \\
\hline BHLHE41 & $-1,63$ & $3,18 \mathrm{E}-03$ & $-3,02$ & $3,90 \mathrm{E}-06$ \\
\hline BLNK & $-2,05$ & $8,83 \mathrm{E}-05$ & $-3,25$ & $1,20 \mathrm{E}-09$ \\
\hline BRI3 & $-1,58$ & $2,15 \mathrm{E}-03$ & $-2,84$ & $5,41 \mathrm{E}-08$ \\
\hline BRI3P1 & $-1,83$ & $3,63 \mathrm{E}-04$ & $-2,82$ & $3,19 \mathrm{E}-07$ \\
\hline BST1 & $-2,02$ & $4,93 \mathrm{E}-05$ & $-3,17$ & $2,03 \mathrm{E}-09$ \\
\hline BTK & $-2,01$ & $5,67 \mathrm{E}-05$ & $-2,78$ & $8,66 \mathrm{E}-09$ \\
\hline BX255923,3 & 1,76 & $2,64 \mathrm{E}-03$ & 2,04 & $6,09 \mathrm{E}-03$ \\
\hline C110RF45 & $-1,76$ & 1,07E-03 & $-3,21$ & $1,06 \mathrm{E}-07$ \\
\hline C110RF96 & 1,82 & $1,86 \mathrm{E}-03$ & 2,08 & $2,78 \mathrm{E}-03$ \\
\hline C15ORF38 & $-2,04$ & $2,55 \mathrm{E}-04$ & $-4,11$ & $4,45 \mathrm{E}-09$ \\
\hline C190RF38 & $-1,87$ & $6,10 \mathrm{E}-05$ & $-1,49$ & $2,57 \mathrm{E}-03$ \\
\hline C10RF85 & $-1,35$ & $2,18 \mathrm{E}-03$ & $-2,13$ & $1,34 \mathrm{E}-06$ \\
\hline C1QA & $-1,97$ & $1,72 \mathrm{E}-04$ & $-2,65$ & $8,62 \mathrm{E}-09$ \\
\hline C1QB & $-2,03$ & $3,14 \mathrm{E}-06$ & $-0,85$ & $1,51 \mathrm{E}-04$ \\
\hline $\mathrm{C} 2$ & $-1,60$ & $1,03 \mathrm{E}-03$ & $-2,61$ & $3,72 \mathrm{E}-08$ \\
\hline C2CD4A & 1,70 & $3,47 \mathrm{E}-03$ & 2,96 & $1,46 \mathrm{E}-04$ \\
\hline C2CD4B & 2,18 & $1,97 \mathrm{E}-04$ & 2,76 & $2,55 \mathrm{E}-04$ \\
\hline C2CD4D & 1,69 & $1,65 \mathrm{E}-03$ & 3,34 & $6,69 \mathrm{E}-11$ \\
\hline C5AR2 & $-1,48$ & $1,51 \mathrm{E}-03$ & $-2,50$ & $1,88 \mathrm{E}-09$ \\
\hline C5ORF66 & $-1,17$ & $7,91 \mathrm{E}-03$ & $-1,17$ & $8,80 \mathrm{E}-03$ \\
\hline CAPG & $-2,30$ & $6,51 \mathrm{E}-07$ & $-3,20$ & $3,99 \mathrm{E}-11$ \\
\hline CARD9 & $-1,97$ & $1,06 \mathrm{E}-07$ & $-1,75$ & $1,30 \mathrm{E}-09$ \\
\hline CASR & 2,86 & $6,69 \mathrm{E}-07$ & 4,16 & $3,78 \mathrm{E}-09$ \\
\hline CATSPERG & $-1,09$ & $6,47 \mathrm{E}-03$ & $-1,68$ & $1,04 \mathrm{E}-06$ \\
\hline CBLN3 & 1,30 & $4,89 \mathrm{E}-03$ & 1,09 & $9,49 \mathrm{E}-03$ \\
\hline CBS & $-2,21$ & $1,35 \mathrm{E}-06$ & $-1,79$ & $2,68 \mathrm{E}-04$ \\
\hline CCDC3 & 2,18 & $1,54 \mathrm{E}-04$ & 5,27 & $3,81 \mathrm{E}-18$ \\
\hline CCDC88A & $-1,25$ & $8,08 \mathrm{E}-03$ & $-1,41$ & $6,19 \mathrm{E}-03$ \\
\hline CCL20 & 2,02 & $5,19 \mathrm{E}-04$ & 1,81 & $2,44 \mathrm{E}-03$ \\
\hline CCNYL1 & $-1,26$ & $6,28 \mathrm{E}-03$ & $-1,81$ & $2,68 \mathrm{E}-05$ \\
\hline CCR1 & $-1,74$ & $5,67 \mathrm{E}-04$ & $-1,73$ & $1,21 \mathrm{E}-03$ \\
\hline CD300C & $-1,62$ & $3,77 \mathrm{E}-04$ & $-2,89$ & $4,03 \mathrm{E}-10$ \\
\hline CD300LF & $-1,83$ & $2,55 \mathrm{E}-04$ & $-2,69$ & $8,01 \mathrm{E}-07$ \\
\hline CD33 & $-2,10$ & $1,91 \mathrm{E}-05$ & $-2,85$ & $3,78 \mathrm{E}-09$ \\
\hline CD63 & $-1,73$ & $9,24 \mathrm{E}-04$ & $-2,01$ & $4,18 \mathrm{E}-04$ \\
\hline CD74 & $-1,39$ & $2,25 \mathrm{E}-03$ & $-1,71$ & $3,50 \mathrm{E}-04$ \\
\hline CD81 & $-1,46$ & $1,24 \mathrm{E}-03$ & $-2,02$ & $3,43 \mathrm{E}-06$ \\
\hline CD84 & $-1,24$ & $2,30 \mathrm{E}-03$ & $-2,07$ & $2,74 \mathrm{E}-08$ \\
\hline $\mathrm{CDA}$ & $-1,83$ & $3,69 \mathrm{E}-04$ & $-1,92$ & $5,47 \mathrm{E}-04$ \\
\hline CDK14 & $-1,45$ & $9,54 \mathrm{E}-03$ & $-2,17$ & $1,06 \mathrm{E}-03$ \\
\hline CEACAM8 & $-1,60$ & $6,05 \mathrm{E}-03$ & $-2,17$ & $7,84 \mathrm{E}-03$ \\
\hline CEBPA & $-1,38$ & $7,75 \mathrm{E}-03$ & $-1,50$ & $2,73 \mathrm{E}-05$ \\
\hline CEBPA-AS1 & $-2,15$ & $1,30 \mathrm{E}-04$ & $-2,94$ & $5,62 \mathrm{E}-05$ \\
\hline CEP112 & 1,47 & $1,86 \mathrm{E}-04$ & 0,94 & $4,86 \mathrm{E}-03$ \\
\hline CES1 & $-1,75$ & $2,01 \mathrm{E}-03$ & $-4,22$ & $4,55 \mathrm{E}-11$ \\
\hline CES1P1 & $-1,77$ & $1,68 \mathrm{E}-03$ & $-4,23$ & $2,89 \mathrm{E}-11$ \\
\hline CES1P2 & $-1,54$ & $7,92 \mathrm{E}-03$ & $-2,81$ & $5,71 \mathrm{E}-04$ \\
\hline $\mathrm{CHCHD} 6$ & $-1,72$ & $5,31 \mathrm{E}-07$ & $-1,35$ & $2,82 \mathrm{E}-08$ \\
\hline CIR1 & $-2,02$ & 1,11E-04 & $-2,03$ & $1,27 \mathrm{E}-03$ \\
\hline CLCN4 & $-2,11$ & $7,69 \mathrm{E}-05$ & $-3,45$ & $6,72 \mathrm{E}-09$ \\
\hline CLEC4A & $-1,20$ & $2,83 \mathrm{E}-03$ & $-1,72$ & $3,34 \mathrm{E}-08$ \\
\hline CLEC7A & $-2,47$ & $3,79 \mathrm{E}-09$ & $-2,47$ & $6,26 \mathrm{E}-10$ \\
\hline CLIC5 & 1,82 & $1,21 \mathrm{E}-05$ & 2,51 & $1,41 \mathrm{E}-13$ \\
\hline CLN3 & $-1,11$ & $5,73 \mathrm{E}-03$ & $-1,62$ & $1,36 \mathrm{E}-06$ \\
\hline CMKLR1 & $-1,89$ & $3,18 \mathrm{E}-04$ & $-3,46$ & $8,22 \mathrm{E}-10$ \\
\hline CNOT6LP1 & 1,31 & $7,47 \mathrm{E}-04$ & 0,88 & $2,10 \mathrm{E}-03$ \\
\hline CNPY3 & $-0,89$ & $9,70 \mathrm{E}-03$ & $-1,08$ & $5,41 \mathrm{E}-07$ \\
\hline COL26A1 & $-2,92$ & $4,88 \mathrm{E}-07$ & $-2,95$ & $4,03 \mathrm{E}-05$ \\
\hline COL4A2-AS2 & $-2,43$ & $3,04 \mathrm{E}-05$ & $-5,19$ & $1,31 \mathrm{E}-13$ \\
\hline COL8A2 & $-2,31$ & $5,53 \mathrm{E}-06$ & $-1,97$ & $8,78 \mathrm{E}-04$ \\
\hline COR01C & $-1,74$ & 1,11E-03 & $-1,83$ & $2,77 \mathrm{E}-03$ \\
\hline
\end{tabular}

\begin{tabular}{|c|c|c|c|c|}
\hline CORO7 & $-0,98$ & $6,57 \mathrm{E}-03$ & $-1,61$ & $2,48 \mathrm{E}-24$ \\
\hline CPM & $-1,50$ & $2,26 \mathrm{E}-03$ & $-2,43$ & $6,77 \mathrm{E}-06$ \\
\hline CREB5 & $-1,39$ & $2,72 \mathrm{E}-03$ & $-1,68$ & $5,48 \mathrm{E}-04$ \\
\hline CREG1 & $-1,42$ & $7,91 \mathrm{E}-03$ & $-2,28$ & $1,88 \mathrm{E}-05$ \\
\hline CRIP3 & $-1,35$ & $5,01 \mathrm{E}-03$ & $-2,48$ & $1,71 \mathrm{E}-05$ \\
\hline CRTAP & $-1,10$ & $8,18 \mathrm{E}-03$ & $-1,58$ & $5,57 \mathrm{E}-05$ \\
\hline CSF1R & $-1,05$ & $6,43 \mathrm{E}-03$ & $-1,91$ & $1,77 \mathrm{E}-11$ \\
\hline CSTA & $-2,21$ & $5,23 \mathrm{E}-07$ & $-2,12$ & $2,25 \mathrm{E}-06$ \\
\hline CSTB & $-1,73$ & $9,85 \mathrm{E}-04$ & $-2,81$ & $5,05 \mathrm{E}-08$ \\
\hline CTD-2033D24,2 & $-1,27$ & $5,71 \mathrm{E}-03$ & $-1,81$ & $1,33 \mathrm{E}-04$ \\
\hline CTD-2135D7,5 & $-1,62$ & $4,46 \mathrm{E}-03$ & $-2,42$ & $3,08 \mathrm{E}-03$ \\
\hline CTD-2337J16,1 & $-1,82$ & 4,69E-04 & $-3,54$ & 1,67E-08 \\
\hline CTD-2376/4,1 & $-1,78$ & $1,98 \mathrm{E}-03$ & $-2,52$ & $2,05 \mathrm{E}-03$ \\
\hline CTSB & $-1,43$ & $5,41 \mathrm{E}-03$ & $-2,46$ & $4,40 \mathrm{E}-07$ \\
\hline $\mathrm{CTSH}$ & $-1,21$ & $3,12 \mathrm{E}-03$ & $-1,17$ & $1,50 \mathrm{E}-03$ \\
\hline CTSK & $-2,03$ & $3,18 \mathrm{E}-04$ & $-3,83$ & $2,74 \mathrm{E}-08$ \\
\hline CTSS & $-1,67$ & $1,88 \mathrm{E}-03$ & $-2,97$ & $2,25 \mathrm{E}-07$ \\
\hline CTSZ & $-2,04$ & 1,63E-05 & $-2,71$ & $5,92 \mathrm{E}-10$ \\
\hline CXCR6 & 2,02 & $1,46 \mathrm{E}-08$ & 0,84 & $1,16 \mathrm{E}-05$ \\
\hline CYB561A3 & $-1,96$ & $1,64 \mathrm{E}-04$ & $-2,73$ & $2,76 \mathrm{E}-06$ \\
\hline CYBB & $-1,49$ & $3,41 \mathrm{E}-03$ & $-1,54$ & $8,86 \mathrm{E}-03$ \\
\hline CYP27A1 & $-2,14$ & $6,92 \mathrm{E}-05$ & $-4,26$ & $1,18 \mathrm{E}-12$ \\
\hline CYP7B1 & 1,86 & 1,34E-03 & 2,29 & $5,27 \mathrm{E}-03$ \\
\hline CYSTM1 & $-1,58$ & $1,55 \mathrm{E}-03$ & $-2,04$ & 1,91E-04 \\
\hline CYTH3 & 0,97 & $6,61 \mathrm{E}-03$ & $-1,65$ & $2,40 \mathrm{E}-16$ \\
\hline DAGLA & $-2,16$ & 1,79E-05 & $-1,80$ & $1,75 \mathrm{E}-03$ \\
\hline DAPK2 & 1,40 & $8,43 \mathrm{E}-04$ & $-1,55$ & $1,10 \mathrm{E}-04$ \\
\hline $\mathrm{DDAH} 2$ & $-1,43$ & $4,06 \mathrm{E}-04$ & $-0,97$ & 7,99E-03 \\
\hline DHRS2 & 2,02 & $2,10 \mathrm{E}-06$ & 3,88 & $8,67 \mathrm{E}-34$ \\
\hline DLL4 & 2,09 & $2,49 \mathrm{E}-04$ & 3,01 & $1,97 \mathrm{E}-09$ \\
\hline DNAJC5B & $-1,66$ & $4,16 \mathrm{E}-03$ & $-3,07$ & $2,62 \mathrm{E}-05$ \\
\hline DOK3 & $-1,51$ & $6,76 \mathrm{E}-03$ & $-2,58$ & $2,15 E-05$ \\
\hline DOPEY2 & $-1,53$ & 1,69E-03 & $-2,18$ & $6,21 \mathrm{E}-05$ \\
\hline DTWD2 & $-1,21$ & $6,40 \mathrm{E}-03$ & $-1,17$ & $7,08 \mathrm{E}-03$ \\
\hline DTX4 & $-1,38$ & $3,53 \mathrm{E}-03$ & $-2,18$ & $8,51 \mathrm{E}-07$ \\
\hline DUSP16 & 1,28 & $1,28 \mathrm{E}-03$ & 1,31 & $3,39 \mathrm{E}-04$ \\
\hline DUSP3 & $-1,40$ & $8,98 \mathrm{E}-03$ & $-2,34$ & $6,01 \mathrm{E}-05$ \\
\hline DUSP5P1 & 1,72 & $6,36 \mathrm{E}-04$ & 2,96 & $1,90 \mathrm{E}-13$ \\
\hline ENG & $-1,40$ & $1,63 \mathrm{E}-03$ & $-1,75$ & $3,69 \mathrm{E}-05$ \\
\hline ENOX1 & 2,02 & 1,42E-04 & 2,41 & $2,41 \mathrm{E}-04$ \\
\hline ENTPD2 & 2,04 & $4,72 \mathrm{E}-04$ & 2,94 & $2,82 \mathrm{E}-04$ \\
\hline ERVH48-1 & 1,37 & $5,53 \mathrm{E}-03$ & $-3,55$ & $3,46 \mathrm{E}-13$ \\
\hline FAM127C & $-2,01$ & $1,23 \mathrm{E}-04$ & $-2,65$ & $3,97 \mathrm{E}-05$ \\
\hline FAM195A & $-1,34$ & $2,94 \mathrm{E}-03$ & $-1,33$ & $1,55 \mathrm{E}-03$ \\
\hline FAM213B & $-1,42$ & $1,87 \mathrm{E}-03$ & $-2,32$ & $1,51 \mathrm{E}-06$ \\
\hline FAM27A & $-1,50$ & $7,79 \mathrm{E}-03$ & $-2,49$ & $2,46 \mathrm{E}-04$ \\
\hline FAM27E3 & $-1,56$ & $6,73 \mathrm{E}-03$ & $-1,97$ & 5,59E-03 \\
\hline FBP1 & $-2,36$ & $1,22 \mathrm{E}-06$ & $-2,07$ & $1,65 \mathrm{E}-07$ \\
\hline FCER1G & $-1,50$ & $4,31 \mathrm{E}-03$ & $-1,88$ & 1,37E-04 \\
\hline FCGR1A & $-1,34$ & $8,97 \mathrm{E}-03$ & $-1,80$ & $1,56 \mathrm{E}-03$ \\
\hline FCGR2B & $-1,88$ & $1,25 \mathrm{E}-04$ & $-3,15$ & $1,02 \mathrm{E}-08$ \\
\hline FCGR2C & $-1,60$ & $1,31 \mathrm{E}-03$ & $-3,03$ & $5,67 \mathrm{E}-08$ \\
\hline FEZ1 & 1,60 & $4,43 \mathrm{E}-04$ & 3,77 & $9,98 \mathrm{E}-21$ \\
\hline FGD2 & $-1,88$ & $8,66 \mathrm{E}-06$ & $-1,86$ & $7,86 \mathrm{E}-06$ \\
\hline FGD4 & $-1,61$ & 1,01E-03 & $-1,33$ & $4,42 E-03$ \\
\hline FGR & $-1,87$ & $3,81 \mathrm{E}-04$ & $-2,37$ & $3,86 \mathrm{E}-05$ \\
\hline FKBP15 & $-1,42$ & $7,37 \mathrm{E}-03$ & $-1,64$ & $8,47 \mathrm{E}-03$ \\
\hline FMN1 & $-1,18$ & $9,99 \mathrm{E}-03$ & $-1,59$ & $6,56 \mathrm{E}-04$ \\
\hline FMNL2 & $-1,39$ & $8,32 \mathrm{E}-03$ & $-1,98$ & $8,53 \mathrm{E}-05$ \\
\hline FNBP1L & 1,90 & $5,45 \mathrm{E}-06$ & 1,50 & $2,91 \mathrm{E}-05$ \\
\hline FOLR3 & $-1,62$ & $3,94 \mathrm{E}-03$ & $-3,03$ & $4,70 \mathrm{E}-07$ \\
\hline FPR3 & $-1,80$ & $7,59 \mathrm{E}-04$ & $-2,70$ & $9,05 E-06$ \\
\hline FTCDNL1 & $-1,25$ & $3,12 \mathrm{E}-03$ & $-2,04$ & $7,73 \mathrm{E}-04$ \\
\hline FTH1P27 & $-1,73$ & $3,00 \mathrm{E}-03$ & $-2,69$ & $9,28 \mathrm{E}-04$ \\
\hline FUOM & $-1,23$ & $2,84 \mathrm{E}-03$ & $-1,41$ & $7,60 \mathrm{E}-05$ \\
\hline FUT7 & 1,23 & $7,96 \mathrm{E}-04$ & 2,34 & 5,47E-34 \\
\hline FXYD6 & $-2,68$ & $1,27 \mathrm{E}-06$ & $-4,07$ & $6,85 \mathrm{E}-11$ \\
\hline FXYD6P3 & $-1,94$ & $8,98 \mathrm{E}-04$ & $-2,42$ & $2,44 \mathrm{E}-03$ \\
\hline FZD2 & $-1,46$ & $5,49 \mathrm{E}-03$ & $-2,88$ & 1,67E-07 \\
\hline GAA & $-1,41$ & $2,87 \mathrm{E}-03$ & $-2,60$ & $1,81 \mathrm{E}-10$ \\
\hline GALNT6 & $-1,66$ & $1,57 \mathrm{E}-03$ & $-2,04$ & $6,68 \mathrm{E}-04$ \\
\hline GCGR & 1,83 & $1,60 \mathrm{E}-03$ & 2,66 & $4,31 \mathrm{E}-04$ \\
\hline GCNT2 & $-1,65$ & $4,00 \mathrm{E}-04$ & $-3,16$ & 1,89E-09 \\
\hline GDF15 & $-3,22$ & $6,40 \mathrm{E}-10$ & $-3,04$ & $2,57 \mathrm{E}-08$ \\
\hline GLB1L & $-1,41$ & $5,61 \mathrm{E}-03$ & $-1,55$ & $7,20 \mathrm{E}-03$ \\
\hline GLDCP1 & 1,86 & $8,57 \mathrm{E}-04$ & 3,62 & $1,75 \mathrm{E}-09$ \\
\hline GLUL & $-1,51$ & $5,09 \mathrm{E}-03$ & $-2,46$ & $5,04 \mathrm{E}-05$ \\
\hline GLULP3 & $-1,68$ & $1,89 \mathrm{E}-03$ & $-2,40$ & 9,73E-05 \\
\hline GLULP4 & $-1,66$ & $2,41 \mathrm{E}-03$ & $-2,36$ & $1,90 \mathrm{E}-04$ \\
\hline
\end{tabular}




\begin{tabular}{|c|c|c|c|c|}
\hline GM2A & $-2,04$ & $8,93 \mathrm{E}-05$ & $-2,69$ & $3,65 \mathrm{E}-06$ \\
\hline GM2AP1 & $-2,05$ & $9,52 \mathrm{E}-05$ & $-2,65$ & $8,89 \mathrm{E}-06$ \\
\hline GMPR & $-1,74$ & $2,03 E-03$ & $-2,42$ & $7,44 \mathrm{E}-04$ \\
\hline GNG2 & 1,19 & $4,92 \mathrm{E}-03$ & 1,20 & $3,31 \mathrm{E}-03$ \\
\hline GPC5 & 1,73 & $2,71 \mathrm{E}-03$ & 3,68 & $2,10 \mathrm{E}-06$ \\
\hline GPR15 & 2,34 & $1,42 \mathrm{E}-06$ & 2,66 & $3,66 \mathrm{E}-11$ \\
\hline GPR150 & $-1,32$ & 5,97E-03 & $-2,04$ & $6,58 \mathrm{E}-05$ \\
\hline GPR162 & $-1,44$ & $7,51 \mathrm{E}-04$ & $-3,86$ & $6,60 \mathrm{E}-16$ \\
\hline GPR18 & 1,32 & $1,02 \mathrm{E}-03$ & 1,28 & $2,20 \mathrm{E}-04$ \\
\hline GPR85 & $-2,29$ & $8,98 \mathrm{E}-05$ & $-2,08$ & $7,03 \mathrm{E}-03$ \\
\hline GPX1 & $-1,73$ & 7,31E-05 & $-1,79$ & $5,25 \mathrm{E}-06$ \\
\hline GPX1P1 & $-1,64$ & $2,43 \mathrm{E}-04$ & $-1,66$ & $1,06 \mathrm{E}-05$ \\
\hline $\mathrm{H} 2 \mathrm{AFY}$ & $-1,19$ & $7,30 \mathrm{E}-03$ & $-1,17$ & $9,24 \mathrm{E}-03$ \\
\hline HAAO & $-2,73$ & $8,58 \mathrm{E}-10$ & $-3,28$ & $1,27 \mathrm{E}-12$ \\
\hline HAMP & $-3,14$ & $2,36 \mathrm{E}-08$ & $-7,18$ & $7,94 \mathrm{E}-32$ \\
\hline $\mathrm{HBA1}$ & 1,95 & 7,39E-04 & 2,22 & $6,90 \mathrm{E}-03$ \\
\hline HBA2 & 2,14 & $2,41 \mathrm{E}-04$ & 2,40 & $3,35 \mathrm{E}-03$ \\
\hline $\mathrm{HBD}$ & 3,12 & $3,65 \mathrm{E}-12$ & 3,13 & $4,06 \mathrm{E}-13$ \\
\hline HBG1 & 2,78 & 1,81E-06 & 3,88 & $4,07 \mathrm{E}-07$ \\
\hline HBG2 & 1,68 & $3,95 \mathrm{E}-03$ & 2,52 & $1,14 \mathrm{E}-03$ \\
\hline HDGFRP3 & 1,18 & $7,22 \mathrm{E}-04$ & 2,23 & $9,27 \mathrm{E}-30$ \\
\hline HEBP1 & $-1,69$ & $9,56 \mathrm{E}-05$ & $-2,12$ & $8,95 \mathrm{E}-07$ \\
\hline HEXA & $-1,41$ & $5,57 \mathrm{E}-03$ & $-2,43$ & $7,92 \mathrm{E}-06$ \\
\hline HEXB & $-1,55$ & $3,38 \mathrm{E}-03$ & $-2,59$ & $5,53 \mathrm{E}-06$ \\
\hline HHEX & $-1,27$ & $5,41 \mathrm{E}-03$ & $-1,40$ & $3,90 \mathrm{E}-04$ \\
\hline HIST1H2BC & 1,47 & $2,81 \mathrm{E}-03$ & 4,56 & $5,21 \mathrm{E}-40$ \\
\hline HIST1H2BN & 1,55 & $6,05 \mathrm{E}-03$ & 4,68 & $3,35 \mathrm{E}-26$ \\
\hline HIST1H2BO & 1,52 & $8,62 \mathrm{E}-03$ & 6,90 & $2,56 \mathrm{E}-33$ \\
\hline HLA-DMA & $-2,18$ & $7,42 \mathrm{E}-07$ & $-2,94$ & $5,88 \mathrm{E}-11$ \\
\hline HLA-DMB & $-2,82$ & $5,91 \mathrm{E}-11$ & $-3,75$ & $6,94 \mathrm{E}-19$ \\
\hline HLA-DPA1 & $-1,57$ & $2,87 \mathrm{E}-04$ & $-1,61$ & $2,13 \mathrm{E}-04$ \\
\hline HLA-DPB1 & $-1,51$ & $4,82 \mathrm{E}-04$ & $-2,26$ & $8,38 \mathrm{E}-08$ \\
\hline HLA-DPB2 & $-1,25$ & $8,55 \mathrm{E}-03$ & $-1,60$ & $8,15 \mathrm{E}-04$ \\
\hline HLA-DQA1 & $-1,87$ & $4,32 \mathrm{E}-05$ & $-1,88$ & $1,10 \mathrm{E}-04$ \\
\hline HLA-DQB1 & $-1,56$ & $6,13 \mathrm{E}-04$ & $-2,10$ & $9,44 \mathrm{E}-06$ \\
\hline HLA-DQB1-AS1 & $-1,29$ & $2,05 \mathrm{E}-03$ & $-2,99$ & $1,55 \mathrm{E}-13$ \\
\hline HLA-DRA & $-1,67$ & $3,17 \mathrm{E}-04$ & $-2,17$ & $6,10 \mathrm{E}-06$ \\
\hline HLA-DRB1 & $-1,92$ & $2,31 \mathrm{E}-05$ & $-2,27$ & $1,52 \mathrm{E}-06$ \\
\hline HLA-DRB5 & $-1,89$ & $3,86 \mathrm{E}-05$ & $-2,30$ & $1,72 \mathrm{E}-06$ \\
\hline HLA-DRB6 & $-1,97$ & $7,85 \mathrm{E}-06$ & $-2,35$ & $1,57 \mathrm{E}-07$ \\
\hline HLA-DRB9 & $-1,94$ & $6,76 \mathrm{E}-05$ & $-2,00$ & $1,91 \mathrm{E}-04$ \\
\hline HM13 & $-1,25$ & $1,38 \mathrm{E}-03$ & $-0,93$ & $5,18 \mathrm{E}-03$ \\
\hline HMSD & 2,18 & $5,80 \mathrm{E}-05$ & 3,69 & $2,96 \mathrm{E}-10$ \\
\hline HOXB4 & 1,09 & $8,30 \mathrm{E}-03$ & 1,73 & $1,20 \mathrm{E}-06$ \\
\hline HPS1 & $-1,08$ & $6,79 \mathrm{E}-03$ & $-1,77$ & 9,77E-07 \\
\hline HS1BP3 & $-1,03$ & $8,18 \mathrm{E}-03$ & $-2,06$ & $5,52 \mathrm{E}-10$ \\
\hline HSD17B14 & $-1,62$ & $3,70 \mathrm{E}-03$ & $-3,72$ & $8,94 \mathrm{E}-11$ \\
\hline HSD3B7 & $-2,15$ & $1,13 \mathrm{E}-05$ & $-1,70$ & $2,05 \mathrm{E}-03$ \\
\hline HSPA7 & $-1,50$ & $2,29 \mathrm{E}-03$ & $-2,62$ & $1,82 \mathrm{E}-06$ \\
\hline HSPB1P2 & $-1,76$ & $1,33 \mathrm{E}-04$ & $-1,38$ & $4,62 \mathrm{E}-04$ \\
\hline HTRA4 & $-1,70$ & $3,01 \mathrm{E}-03$ & $-3,39$ & $7,63 \mathrm{E}-07$ \\
\hline ICOS & 1,33 & $7,81 \mathrm{E}-03$ & 1,71 & $3,35 \mathrm{E}-03$ \\
\hline ICOSLG & $-1,93$ & $5,80 \mathrm{E}-06$ & $-2,61$ & $8,40 \mathrm{E}-20$ \\
\hline $\mathrm{IDH} 1$ & $-1,68$ & $3,76 \mathrm{E}-04$ & $-1,63$ & $1,72 \mathrm{E}-03$ \\
\hline IGF2 & 1,53 & $6,92 \mathrm{E}-03$ & 4,54 & $6,78 \mathrm{E}-10$ \\
\hline IGFBP7 & $-1,19$ & $4,03 \mathrm{E}-03$ & $-1,27$ & $1,82 \mathrm{E}-04$ \\
\hline IGSF6 & $-1,95$ & $8,31 \mathrm{E}-09$ & $-1,49$ & $4,10 \mathrm{E}-21$ \\
\hline IL13 & 1,52 & $9,38 \mathrm{E}-03$ & 3,42 & $2,72 \mathrm{E}-09$ \\
\hline IL17RC & $-1,53$ & $8,91 \mathrm{E}-04$ & $-2,08$ & $2,28 \mathrm{E}-05$ \\
\hline IL18BP & $-2,36$ & $3,79 \mathrm{E}-10$ & $-2,73$ & $1,53 \mathrm{E}-19$ \\
\hline IL18RAP & 1,26 & $1,76 \mathrm{E}-03$ & 1,02 & $4,80 \mathrm{E}-03$ \\
\hline IL1B & 1,55 & $7,95 \mathrm{E}-03$ & 1,88 & $3,08 \mathrm{E}-05$ \\
\hline IL22RA2 & $-1,88$ & $1,15 \mathrm{E}-03$ & $-2,58$ & $1,58 \mathrm{E}-03$ \\
\hline IL23A & 1,53 & $4,02 E-03$ & 2,12 & $6,74 \mathrm{E}-17$ \\
\hline IL26 & 1,95 & $5,33 \mathrm{E}-04$ & 2,18 & $5,66 \mathrm{E}-06$ \\
\hline INSR & $-1,21$ & $9,22 \mathrm{E}-03$ & $-2,24$ & $3,66 \mathrm{E}-06$ \\
\hline IRF5 & $-1,56$ & $1,67 \mathrm{E}-03$ & $-1,72$ & $1,23 \mathrm{E}-03$ \\
\hline IRX5 & 1,62 & $5,25 \mathrm{E}-03$ & 3,01 & $8,54 \mathrm{E}-05$ \\
\hline ITGA1 & 1,66 & $7,64 \mathrm{E}-06$ & 0,85 & $7,29 \mathrm{E}-04$ \\
\hline ITGA11 & $-2,64$ & $2,15 \mathrm{E}-06$ & $-2,11$ & 6,67E-04 \\
\hline ITGA2B & 1,35 & $4,62 \mathrm{E}-03$ & 1,72 & $1,08 \mathrm{E}-07$ \\
\hline ITGAM & $-1,84$ & $3,49 \mathrm{E}-05$ & $-1,25$ & $6,06 \mathrm{E}-03$ \\
\hline ITGAX & $-1,99$ & $2,87 \mathrm{E}-05$ & $-1,93$ & $9,39 \mathrm{E}-05$ \\
\hline ITGB2 & $-1,78$ & $2,57 \mathrm{E}-05$ & $-2,03$ & $3,72 \mathrm{E}-07$ \\
\hline ITLN1 & $-2,23$ & $1,30 \mathrm{E}-04$ & $-3,44$ & $1,57 \mathrm{E}-05$ \\
\hline JAKMIP2 & $-1,77$ & $9,18 \mathrm{E}-04$ & $-2,58$ & $4,42 \mathrm{E}-05$ \\
\hline JDP2 & $-2,25$ & $4,21 \mathrm{E}-06$ & $-3,49$ & $9,38 \mathrm{E}-18$ \\
\hline KCNE3 & $-1,47$ & $1,52 \mathrm{E}-03$ & $-2,37$ & $2,09 \mathrm{E}-06$ \\
\hline
\end{tabular}

\begin{tabular}{|c|c|c|c|c|}
\hline KCNK1 & 2,08 & $3,54 \mathrm{E}-04$ & 4,17 & $2,97 \mathrm{E}-08$ \\
\hline KCNMB1 & $-1,82$ & $6,54 \mathrm{E}-04$ & $-2,12$ & $9,19 \mathrm{E}-04$ \\
\hline $\mathrm{KCP}$ & $-1,83$ & $1,59 \mathrm{E}-03$ & $-4,27$ & $4,03 E-10$ \\
\hline KIAA0930 & $-2,35$ & $1,46 \mathrm{E}-06$ & $-3,56$ & $1,68 \mathrm{E}-12$ \\
\hline KIAA1199 & 2,81 & $8,79 \mathrm{E}-07$ & 2,45 & $2,66 \mathrm{E}-07$ \\
\hline KIAA1467 & $-1,32$ & $6,44 \mathrm{E}-03$ & $-1,65$ & $9,70 \mathrm{E}-04$ \\
\hline KIAA1598 & $-1,60$ & $3,34 \mathrm{E}-03$ & $-3,01$ & $3,07 \mathrm{E}-07$ \\
\hline KRT23 & $-1,66$ & $4,57 \mathrm{E}-03$ & $-2,35$ & $2,75 \mathrm{E}-03$ \\
\hline LAMB2 & $-1,58$ & $6,46 \mathrm{E}-03$ & $-3,08$ & $1,17 \mathrm{E}-05$ \\
\hline LBX2-AS1 & $-1,32$ & $9,66 \mathrm{E}-03$ & $-1,85$ & $1,35 \mathrm{E}-03$ \\
\hline LDHD & $-1,66$ & $9,87 \mathrm{E}-05$ & $-2,26$ & $7,90 \mathrm{E}-08$ \\
\hline LGALS9 & $-1,83$ & $1,35 \mathrm{E}-04$ & $-1,95$ & $3,71 \mathrm{E}-05$ \\
\hline LGALS9B & $-1,58$ & 1,76E-03 & $-1,76$ & $1,77 \mathrm{E}-04$ \\
\hline LHFPL2 & $-1,54$ & $4,46 \mathrm{E}-03$ & $-2,99$ & $1,99 \mathrm{E}-07$ \\
\hline LILRA2 & $-1,69$ & $8,96 \mathrm{E}-04$ & $-2,51$ & $2,93 \mathrm{E}-10$ \\
\hline LILRA5 & $-1,68$ & $6,02 \mathrm{E}-05$ & $-2,70$ & $1,48 \mathrm{E}-16$ \\
\hline LILRA6 & $-1,41$ & $9,46 \mathrm{E}-03$ & $-2,77$ & $5,07 \mathrm{E}-08$ \\
\hline LILRB5 & $-1,57$ & $3,68 \mathrm{E}-03$ & $-3,28$ & $9,25 \mathrm{E}-09$ \\
\hline LINGO4 & 2,50 & $5,56 \mathrm{E}-06$ & 3,06 & $3,92 \mathrm{E}-09$ \\
\hline LRPAP1 & $-1,54$ & $3,17 \mathrm{E}-03$ & $-2,27$ & $4,52 \mathrm{E}-05$ \\
\hline LRRC25 & $-1,49$ & $4,90 \mathrm{E}-03$ & $-3,92$ & $3,72 \mathrm{E}-14$ \\
\hline LRRC3 & $-1,27$ & $8,57 \mathrm{E}-03$ & $-1,75$ & $1,15 \mathrm{E}-03$ \\
\hline LSP1 & $-1,18$ & $2,94 \mathrm{E}-03$ & $-1,60$ & $1,54 \mathrm{E}-06$ \\
\hline LSP1P3 & $-1,19$ & $2,96 \mathrm{E}-03$ & $-1,42$ & $2,75 \mathrm{E}-05$ \\
\hline LST1 & $-2,00$ & $6,34 \mathrm{E}-07$ & $-1,36$ & $3,44 \mathrm{E}-06$ \\
\hline LTA4H & $-1,50$ & $4,20 \mathrm{E}-03$ & $-2,23$ & $3,25 \mathrm{E}-04$ \\
\hline LTBR & $-1,62$ & $2,54 \mathrm{E}-03$ & $-2,61$ & $1,49 \mathrm{E}-06$ \\
\hline LURAP1 & $-1,70$ & $3,71 \mathrm{E}-03$ & $-2,38$ & $2,57 \mathrm{E}-03$ \\
\hline LY96 & $-1,75$ & $7,65 \mathrm{E}-05$ & $-2,97$ & $2,75 \mathrm{E}-12$ \\
\hline M1AP & $-1,77$ & $6,49 \mathrm{E}-04$ & $-2,58$ & $1,77 \mathrm{E}-04$ \\
\hline MAD1L1 & $-1,09$ & $7,31 \mathrm{E}-03$ & $-1,46$ & $1,42 \mathrm{E}-05$ \\
\hline MAN2B1 & $-1,22$ & $3,35 \mathrm{E}-03$ & $-1,72$ & $1,51 \mathrm{E}-05$ \\
\hline MARC1 & $-1,75$ & $8,43 \mathrm{E}-04$ & $-4,00$ & $1,06 \mathrm{E}-07$ \\
\hline MARCH1 & $-1,31$ & $6,61 \mathrm{E}-03$ & $-2,37$ & $1,90 \mathrm{E}-06$ \\
\hline MCOLN1 & $-1,42$ & $4,59 \mathrm{E}-03$ & $-1,79$ & $1,44 \mathrm{E}-04$ \\
\hline MEOX1 & 1,13 & $6,05 \mathrm{E}-03$ & $-2,14$ & $1,68 \mathrm{E}-06$ \\
\hline MFSD12 & $-1,38$ & $2,75 \mathrm{E}-03$ & $-1,39$ & $2,29 \mathrm{E}-03$ \\
\hline MFSD2A & $-1,68$ & $1,53 \mathrm{E}-03$ & $-1,64$ & $2,88 \mathrm{E}-03$ \\
\hline MFSD7 & $-1,83$ & $1,14 \mathrm{E}-04$ & $-2,46$ & $9,80 \mathrm{E}-07$ \\
\hline MGST2 & $-1,74$ & $7,32 \mathrm{E}-05$ & $-1,15$ & $6,21 \mathrm{E}-08$ \\
\hline MGST3 & $-1,07$ & $6,89 \mathrm{E}-03$ & $-0,96$ & $4,95 \mathrm{E}-03$ \\
\hline MICAL1 & $-1,26$ & $6,62 \mathrm{E}-03$ & $-1,63$ & $1,09 \mathrm{E}-03$ \\
\hline MILR1 & $-1,54$ & $2,22 \mathrm{E}-03$ & $-3,05$ & $2,00 \mathrm{E}-11$ \\
\hline MITF & $-2,33$ & $3,96 \mathrm{E}-06$ & $-2,72$ & $3,86 \mathrm{E}-06$ \\
\hline MMP12 & 1,73 & $2,86 \mathrm{E}-03$ & 7,56 & $8,17 \mathrm{E}-50$ \\
\hline MMP9 & $-1,77$ & $7,39 \mathrm{E}-05$ & $-1,86$ & $2,18 \mathrm{E}-05$ \\
\hline MNDA & $-2,70$ & $1,08 \mathrm{E}-07$ & $-2,67$ & $6,23 \mathrm{E}-06$ \\
\hline MPEG1 & $-2,20$ & $4,16 \mathrm{E}-06$ & $-4,63$ & $3,03 \mathrm{E}-28$ \\
\hline MRAS & $-1,96$ & $2,70 \mathrm{E}-04$ & $-2,30$ & $1,48 \mathrm{E}-04$ \\
\hline MRC1L1 & $-1,37$ & $9,64 \mathrm{E}-03$ & $-1,63$ & $5,00 \mathrm{E}-03$ \\
\hline MYADM & $-1,19$ & $2,55 \mathrm{E}-03$ & $-1,08$ & $6,87 \mathrm{E}-13$ \\
\hline NAGK & $-1,72$ & $1,45 \mathrm{E}-04$ & $-1,97$ & $7,19 \mathrm{E}-06$ \\
\hline NAGLU & $-1,52$ & $1,81 \mathrm{E}-03$ & $-2,38$ & $5,38 \mathrm{E}-08$ \\
\hline NAV2 & $-1,33$ & $5,33 \mathrm{E}-03$ & $-2,67$ & $7,02 \mathrm{E}-08$ \\
\hline NCDN & 0,96 & $3,55 \mathrm{E}-03$ & 0,93 & $5,15 \mathrm{E}-10$ \\
\hline NDP & 1,49 & $9,41 \mathrm{E}-03$ & 2,61 & $5,23 \mathrm{E}-04$ \\
\hline NEK6 & $-1,40$ & $6,24 \mathrm{E}-03$ & $-1,73$ & $1,30 \mathrm{E}-03$ \\
\hline NFAM1 & $-1,92$ & $4,19 \mathrm{E}-04$ & $-3,25$ & $2,32 \mathrm{E}-08$ \\
\hline NFE2L3P1 & 1,43 & $5,52 \mathrm{E}-03$ & 2,54 & $2,96 \mathrm{E}-07$ \\
\hline NIPAL2 & $-1,15$ & $5,54 \mathrm{E}-03$ & $-1,73$ & $2,56 \mathrm{E}-05$ \\
\hline NLN & $-2,05$ & $7,61 \mathrm{E}-05$ & $-2,03$ & $6,98 \mathrm{E}-04$ \\
\hline NMRK2 & $-4,12$ & $2,34 \mathrm{E}-13$ & $-4,86$ & $9,70 \mathrm{E}-11$ \\
\hline NNMT & 2,09 & $3,45 \mathrm{E}-04$ & 2,49 & $2,40 \mathrm{E}-03$ \\
\hline $\mathrm{NOTCH} 3$ & $-1,74$ & $9,72 \mathrm{E}-05$ & $-1,14$ & $1,48 \mathrm{E}-03$ \\
\hline NPAS4 & 1,47 & $9,46 \mathrm{E}-03$ & 3,28 & $4,51 \mathrm{E}-05$ \\
\hline NRARP & 1,35 & $6,11 \mathrm{E}-03$ & 1,32 & $4,32 \mathrm{E}-03$ \\
\hline NTAN1 & $-1,29$ & $4,14 \mathrm{E}-03$ & $-1,33$ & $4,55 \mathrm{E}-03$ \\
\hline NTAN1P2 & $-1,42$ & $2,04 \mathrm{E}-03$ & $-1,26$ & $9,24 \mathrm{E}-03$ \\
\hline NUDT16P1 & $-1,85$ & $1,07 \mathrm{E}-04$ & $-1,78$ & $2,00 \mathrm{E}-04$ \\
\hline OAF & $-1,70$ & $5,13 \mathrm{E}-04$ & $-2,26$ & $1,09 \mathrm{E}-07$ \\
\hline OAS1 & $-1,50$ & $4,08 \mathrm{E}-03$ & $-1,71$ & $5,57 \mathrm{E}-03$ \\
\hline OLFM2 & 1,08 & $2,78 \mathrm{E}-03$ & $-0,93$ & $5,27 \mathrm{E}-03$ \\
\hline OPHN1 & $-2,02$ & $3,69 \mathrm{E}-04$ & $-2,81$ & $2,65 \mathrm{E}-04$ \\
\hline OPLAH & $-1,41$ & $5,76 \mathrm{E}-03$ & $-2,22$ & $6,55 \mathrm{E}-05$ \\
\hline OR6W1P & $-1,53$ & $7,01 \mathrm{E}-03$ & $-3,24$ & $4,18 \mathrm{E}-05$ \\
\hline OSBPL1A & $-1,76$ & $8,38 \mathrm{E}-04$ & $-3,20$ & $3,95 \mathrm{E}-08$ \\
\hline OSCAR & $-1,70$ & $2,48 \mathrm{E}-03$ & $-2,97$ & $1,70 \mathrm{E}-06$ \\
\hline OSGIN1 & $-2,23$ & $5,25 \mathrm{E}-07$ & $-2,89$ & $2,26 \mathrm{E}-11$ \\
\hline OXER1 & $-2,22$ & $2,14 \mathrm{E}-05$ & $-2,49$ & $7,75 \mathrm{E}-05$ \\
\hline
\end{tabular}




\begin{tabular}{|c|c|c|c|c|}
\hline P2RY2 & $-1,56$ & 5,79E-03 & $-2,62$ & 7,44E-05 \\
\hline PADI2 & $-1,63$ & $3,22 \mathrm{E}-03$ & $-3,28$ & $1,08 \mathrm{E}-07$ \\
\hline PDE4B & 1,23 & $2,19 \mathrm{E}-03$ & 1,48 & $5,39 \mathrm{E}-06$ \\
\hline PDXK & $-1,49$ & $2,27 \mathrm{E}-03$ & $-2,12$ & $2,61 \mathrm{E}-05$ \\
\hline PEPD & $-1,22$ & $6,62 \mathrm{E}-03$ & $-1,96$ & $1,78 \mathrm{E}-05$ \\
\hline PERP & 1,39 & $3,06 \mathrm{E}-03$ & 2,33 & $5,31 \mathrm{E}-06$ \\
\hline PI4K2A & $-1,27$ & $6,80 \mathrm{E}-03$ & $-1,58$ & 1,51E-03 \\
\hline PIR & $-2,13$ & $9,11 \mathrm{E}-06$ & $-2,47$ & $7,00 \mathrm{E}-06$ \\
\hline PKD2L1 & $-2,73$ & 1,72E-06 & $-4,62$ & 1,03E-17 \\
\hline PLA2G2D & $-1,63$ & $3,80 \mathrm{E}-03$ & $-2,91$ & $1,25 \mathrm{E}-04$ \\
\hline PLA2G4A & $-1,73$ & $3,30 \mathrm{E}-04$ & $-2,44$ & 1,67E-06 \\
\hline PLA2G7 & $-1,99$ & $1,02 \mathrm{E}-04$ & $-3,48$ & $3,92 \mathrm{E}-12$ \\
\hline PLAT & 1,84 & $1,75 \mathrm{E}-06$ & 1,70 & $3,81 \mathrm{E}-09$ \\
\hline PLB1 & $-2,61$ & $1,03 \mathrm{E}-08$ & $-1,97$ & $6,62 \mathrm{E}-06$ \\
\hline PLBD1 & $-2,20$ & $4,32 \mathrm{E}-06$ & $-2,67$ & $6,31 \mathrm{E}-07$ \\
\hline PLCXD2 & 1,29 & $4,50 \mathrm{E}-03$ & 1,91 & $1,08 \mathrm{E}-07$ \\
\hline PLEKHO2 & $-1,52$ & $1,04 \mathrm{E}-03$ & $-2,12$ & $5,42 \mathrm{E}-06$ \\
\hline PLOD3 & $-1,55$ & $1,69 \mathrm{E}-04$ & $-1,28$ & $7,62 \mathrm{E}-04$ \\
\hline PLXNA1 & $-1,68$ & $7,92 \mathrm{E}-04$ & $-2,53$ & $2,88 \mathrm{E}-08$ \\
\hline PLXNB1 & 1,12 & $4,42 \mathrm{E}-03$ & 1,12 & 3,96E-04 \\
\hline PMAIP1 & 1,28 & $4,80 \mathrm{E}-03$ & 2,07 & $2,04 \mathrm{E}-05$ \\
\hline PMFBP1 & $-1,41$ & $5,46 \mathrm{E}-03$ & $-2,03$ & $6,21 \mathrm{E}-04$ \\
\hline PNPLA3 & $-1,71$ & $2,75 \mathrm{E}-03$ & $-3,28$ & $2,90 \mathrm{E}-05$ \\
\hline PPFIBP2 & $-1,62$ & $5,50 \mathrm{E}-04$ & $-2,28$ & $7,69 \mathrm{E}-07$ \\
\hline PPP1R16B & 1,15 & $5,46 \mathrm{E}-03$ & 1,15 & $2,50 \mathrm{E}-03$ \\
\hline PPP1R37 & $-1,19$ & $6,14 \mathrm{E}-03$ & $-1,99$ & $3,93 \mathrm{E}-08$ \\
\hline PPT1 & $-1,47$ & $9,99 \mathrm{E}-04$ & $-1,68$ & 2,87E-04 \\
\hline PRCP & $-1,15$ & $5,08 \mathrm{E}-03$ & $-1,39$ & $1,52 \mathrm{E}-04$ \\
\hline PRKAG3 & $-1,58$ & $6,05 \mathrm{E}-03$ & $-3,17$ & $8,45 \mathrm{E}-05$ \\
\hline PRSS36 & $-1,48$ & $2,80 \mathrm{E}-03$ & $-2,54$ & $4,12 \mathrm{E}-05$ \\
\hline PSCA & $-1,46$ & 6,61E-03 & $-2,51$ & 1,14E-03 \\
\hline PTCRA & $-2,13$ & $4,52 \mathrm{E}-05$ & $-1,94$ & 1,21E-03 \\
\hline PTGER2 & $-1,47$ & $6,86 \mathrm{E}-03$ & $-2,89$ & 1,51E-07 \\
\hline PTGR1 & $-1,37$ & $8,03 \mathrm{E}-03$ & $-1,99$ & 2,46E-04 \\
\hline PTGS1 & $-1,42$ & $2,63 \mathrm{E}-03$ & $-2,17$ & $1,09 \mathrm{E}-05$ \\
\hline PTK2 & 0,93 & $8,00 \mathrm{E}-03$ & 1,02 & $2,37 \mathrm{E}-06$ \\
\hline PTK6 & $-1,33$ & $2,27 \mathrm{E}-03$ & $-1,56$ & $1,17 \mathrm{E}-04$ \\
\hline PXDC1 & $-1,50$ & $2,29 \mathrm{E}-03$ & $-1,88$ & $9,49 \mathrm{E}-05$ \\
\hline RAB20 & $-1,61$ & $3,06 \mathrm{E}-03$ & $-2,57$ & $5,56 \mathrm{E}-06$ \\
\hline RAP1GAP2 & $-1,31$ & 7,93E-03 & $-1,84$ & $2,63 \mathrm{E}-06$ \\
\hline RASGRP3 & $-1,45$ & $5,88 \mathrm{E}-03$ & $-1,85$ & 1,82E-03 \\
\hline RBMXP4 & 1,03 & $9,93 \mathrm{E}-03$ & 1,28 & $4,60 \mathrm{E}-06$ \\
\hline $\mathrm{RDH} 12$ & $-1,94$ & $5,45 \mathrm{E}-04$ & $-2,43$ & $6,92 \mathrm{E}-04$ \\
\hline RENBP & $-1,49$ & $1,35 \mathrm{E}-03$ & $-2,83$ & 2,61E-09 \\
\hline RGL1 & $-1,44$ & $7,02 \mathrm{E}-03$ & $-2,88$ & $6,21 \mathrm{E}-08$ \\
\hline RGS12 & $-2,27$ & $1,26 \mathrm{E}-05$ & $-2,53$ & $5,98 \mathrm{E}-06$ \\
\hline RHOBTB2 & $-1,01$ & $9,96 \mathrm{E}-03$ & $-1,05$ & 5,03E-04 \\
\hline $\mathrm{RHOQ}$ & $-1,28$ & $8,15 \mathrm{E}-03$ & $-1,80$ & $9,13 \mathrm{E}-05$ \\
\hline RHOQP2 & $-1,59$ & 2,67E-03 & $-1,91$ & 4,71E-04 \\
\hline RILP & $-1,73$ & $1,54 \mathrm{E}-04$ & $-1,21$ & $5,05 \mathrm{E}-03$ \\
\hline RIMS3 & 1,13 & $6,45 \mathrm{E}-03$ & 1,70 & $1,56 \mathrm{E}-13$ \\
\hline RIPPLY3 & 1,56 & $7,09 \mathrm{E}-03$ & 3,44 & $3,47 \mathrm{E}-06$ \\
\hline RNF130 & $-1,63$ & $2,68 \mathrm{E}-03$ & $-2,92$ & 1,34E-06 \\
\hline RNH1 & $-1,25$ & $2,50 \mathrm{E}-03$ & $-1,30$ & $3,02 \mathrm{E}-04$ \\
\hline RORC & 1,51 & $1,39 \mathrm{E}-03$ & 1,23 & $6,92 \mathrm{E}-03$ \\
\hline RP11-106M3,3 & $-1,40$ & $5,07 \mathrm{E}-03$ & $-2,37$ & $7,45 \mathrm{E}-06$ \\
\hline RP11-1149M10,2 & $-1,36$ & 7,61E-03 & $-2,57$ & 1,93E-06 \\
\hline RP1-111C20,3 & $-1,74$ & $2,72 \mathrm{E}-03$ & $-2,41$ & $3,08 \mathrm{E}-03$ \\
\hline RP11-1391J7,1 & $-1,42$ & $1,35 \mathrm{E}-03$ & $-1,91$ & $6,92 \mathrm{E}-06$ \\
\hline RP11-215G15,4 & $-1,64$ & 1,34E-03 & $-1,54$ & 2,37E-03 \\
\hline RP11-223C24,1 & 1,35 & 7,34E-03 & 1,63 & $1,07 \mathrm{E}-03$ \\
\hline RP11-24F11,2 & $-1,52$ & $4,55 \mathrm{E}-03$ & $-2,00$ & $7,83 \mathrm{E}-04$ \\
\hline RP11-256L6,2 & $-1,47$ & $4,71 \mathrm{E}-03$ & $-2,41$ & $1,35 \mathrm{E}-04$ \\
\hline RP11-257P3,3 & $-1,32$ & 9,17E-03 & $-1,49$ & 9,35E-03 \\
\hline RP11-268J15,5 & $-1,59$ & 5,71E-04 & $-1,78$ & 7,27E-04 \\
\hline RP11-288G3,4 & $-1,65$ & $7,80 \mathrm{E}-04$ & $-1,58$ & $4,49 \mathrm{E}-03$ \\
\hline RP11-288I21,1 & $-1,22$ & 9,91E-03 & $-1,65$ & $1,45 \mathrm{E}-03$ \\
\hline RP11-305E17,6 & $-1,52$ & $6,26 \mathrm{E}-03$ & $-1,46$ & $7,96 \mathrm{E}-03$ \\
\hline RP11-309L24,9 & $-1,68$ & 3,91E-03 & $-3,03$ & $2,48 \mathrm{E}-05$ \\
\hline RP11-420L9,5 & $-1,61$ & $1,98 \mathrm{E}-03$ & $-1,94$ & $8,14 \mathrm{E}-04$ \\
\hline RP11-443P15,2 & $-1,64$ & $1,36 \mathrm{E}-03$ & $-2,87$ & 2,97E-05 \\
\hline RP11-465L10,10 & $-1,71$ & $6,53 \mathrm{E}-05$ & $-1,75$ & $3,29 \mathrm{E}-05$ \\
\hline RP11-46802,1 & $-1,47$ & $1,35 \mathrm{E}-03$ & $-1,88$ & $9,07 \mathrm{E}-05$ \\
\hline RP11-504A18,1 & $-1,79$ & $2,17 \mathrm{E}-03$ & $-2,98$ & $2,32 \mathrm{E}-04$ \\
\hline RP11-512H23,2 & $-1,56$ & $8,41 \mathrm{E}-04$ & $-1,32$ & $7,65 \mathrm{E}-03$ \\
\hline RP11-517C16,2 & 1,42 & 8,57E-03 & 1,78 & $5,49 \mathrm{E}-04$ \\
\hline
\end{tabular}

\begin{tabular}{|c|c|c|c|c|}
\hline RP11-523018,5 & $-1,77$ & $9,34 \mathrm{E}-04$ & $-2,32$ & $1,39 \mathrm{E}-04$ \\
\hline RP11-54C4,2 & $-1,67$ & 1,87E-03 & $-2,55$ & $3,32 \mathrm{E}-05$ \\
\hline RP11-561023,5 & 2,09 & $2,94 \mathrm{E}-04$ & 2,74 & $1,76 \mathrm{E}-07$ \\
\hline RP11-568N6,1 & 1,61 & $2,88 \mathrm{E}-03$ & 1,99 & $3,10 \mathrm{E}-04$ \\
\hline RP11-63P12,6 & $-2,68$ & $1,38 \mathrm{E}-07$ & $-3,81$ & $4,15 \mathrm{E}-10$ \\
\hline RP11-728F11,4 & $-1,93$ & $9,80 \mathrm{E}-04$ & $-3,10$ & $9,71 \mathrm{E}-05$ \\
\hline RP11-73K9,2 & $-1,76$ & $5,16 \mathrm{E}-04$ & $-2,20$ & $1,27 \mathrm{E}-04$ \\
\hline $\mathrm{RP} 11-750 \mathrm{H} 9,5$ & $-1,60$ & $1,74 \mathrm{E}-03$ & $-2,87$ & $4,61 \mathrm{E}-06$ \\
\hline RP11-799B12,4 & $-1,65$ & 4,62E-03 & $-2,12$ & $7,29 \mathrm{E}-03$ \\
\hline RP11-807H22,7 & $-1,78$ & 1,98E-03 & $-2,52$ & $2,05 \mathrm{E}-03$ \\
\hline RP11-848P1,3 & $-1,57$ & $6,47 \mathrm{E}-03$ & $-2,86$ & $2,97 \mathrm{E}-04$ \\
\hline RP11-876N24,5 & $-1,37$ & 4,67E-03 & $-1,63$ & $2,24 \mathrm{E}-03$ \\
\hline RP11-94L15,2 & 1,22 & $4,20 \mathrm{E}-03$ & 1,07 & $5,87 \mathrm{E}-03$ \\
\hline RP11-989E6,2 & $-1,28$ & $5,40 \mathrm{E}-03$ & $-1,41$ & $3,39 \mathrm{E}-03$ \\
\hline RP1-228P16,7 & $-1,33$ & $4,55 \mathrm{E}-03$ & $-1,59$ & $1,65 \mathrm{E}-03$ \\
\hline RP1-257A7,5 & $-1,52$ & $7,03 \mathrm{E}-03$ & $-2,95$ & $8,69 \mathrm{E}-06$ \\
\hline RP1-45N11,1 & 1,62 & 4,67E-03 & 1,89 & $5,60 \mathrm{E}-03$ \\
\hline RP1-66C13,3 & $-1,59$ & $1,14 \mathrm{E}-03$ & $-2,15$ & $4,45 \mathrm{E}-05$ \\
\hline RP1-80N2,2 & $-2,01$ & 3,67E-04 & $-3,34$ & $1,23 \mathrm{E}-05$ \\
\hline RP3-428L16,2 & 1,45 & $2,04 \mathrm{E}-03$ & 2,53 & $6,18 \mathrm{E}-10$ \\
\hline RP3-460G2,2 & $-1,70$ & 2,95E-03 & $-1,94$ & $7,62 \mathrm{E}-03$ \\
\hline RP4-620F22,3 & $-1,25$ & $6,21 \mathrm{E}-03$ & $-2,51$ & $7,73 \mathrm{E}-07$ \\
\hline RP4-647C14,2 & $-1,42$ & $6,55 \mathrm{E}-03$ & $-1,71$ & $6,32 \mathrm{E}-03$ \\
\hline RRAGD & $-1,83$ & 4,29E-04 & $-2,68$ & $2,68 \mathrm{E}-07$ \\
\hline RXRA & $-1,54$ & $2,08 \mathrm{E}-03$ & $-3,07$ & $3,80 \mathrm{E}-13$ \\
\hline RYR1 & 1,40 & $1,50 \mathrm{E}-03$ & 0,55 & $3,40 \mathrm{E}-03$ \\
\hline S100A11 & $-1,52$ & $2,32 \mathrm{E}-03$ & $-1,54$ & $3,77 \mathrm{E}-03$ \\
\hline SAMD4A & $-1,98$ & $3,58 \mathrm{E}-06$ & $-2,68$ & $3,73 \mathrm{E}-09$ \\
\hline SCARA5 & 2,13 & 2,67E-04 & 3,23 & $5,08 \mathrm{E}-05$ \\
\hline SCARB1 & $-2,20$ & 2,24E-05 & $-2,59$ & $4,80 \mathrm{E}-06$ \\
\hline SCARB2 & $-1,34$ & $9,52 \mathrm{E}-03$ & $-2,52$ & $1,11 \mathrm{E}-06$ \\
\hline SCIMP & $-2,24$ & $3,47 \mathrm{E}-06$ & $-2,21$ & $2,18 \mathrm{E}-05$ \\
\hline SCPEP1 & $-1,68$ & 4,61E-04 & $-1,94$ & $1,18 \mathrm{E}-04$ \\
\hline SDCBP & $-1,28$ & $6,26 \mathrm{E}-03$ & $-1,61$ & $9,59 \mathrm{E}-04$ \\
\hline SDSL & $-2,26$ & $1,70 \mathrm{E}-07$ & $-2,46$ & $5,79 \mathrm{E}-10$ \\
\hline SERPINF2 & $-2,22$ & 4,11E-07 & $-2,49$ & $1,36 \mathrm{E}-09$ \\
\hline SGK1 & $-2,20$ & $1,54 \mathrm{E}-05$ & $-3,03$ & $6,41 \mathrm{E}-08$ \\
\hline SH2D1A & 1,36 & 2,01E-03 & 1,75 & $1,20 \mathrm{E}-08$ \\
\hline SH3D21 & $-1,81$ & $8,23 \mathrm{E}-04$ & $-4,13$ & $1,76 \mathrm{E}-13$ \\
\hline SH3RF1 & $-1,47$ & $6,69 \mathrm{E}-03$ & $-1,50$ & $2,36 \mathrm{E}-03$ \\
\hline SHB & $-1,88$ & $2,72 \mathrm{E}-04$ & $-3,15$ & $6,04 \mathrm{E}-09$ \\
\hline SIDT2 & $-1,45$ & $1,26 \mathrm{E}-03$ & $-2,77$ & $4,68 \mathrm{E}-09$ \\
\hline SIGLEC1 & $-2,22$ & $8,26 \mathrm{E}-05$ & $-2,84$ & $2,14 \mathrm{E}-05$ \\
\hline SIGLEC8 & $-1,80$ & $3,51 \mathrm{E}-04$ & $-3,04$ & $1,11 \mathrm{E}-07$ \\
\hline SIRPA & $-1,49$ & $4,36 \mathrm{E}-03$ & $-2,59$ & $3,27 \mathrm{E}-07$ \\
\hline SIRPB1 & $-1,80$ & $6,20 \mathrm{E}-05$ & $-2,52$ & $6,76 \mathrm{E}-08$ \\
\hline SIRPB2 & $-1,71$ & $9,50 \mathrm{E}-04$ & $-3,69$ & $3,97 \mathrm{E}-10$ \\
\hline SLAMF8 & $-1,41$ & $7,26 \mathrm{E}-03$ & $-1,90$ & $1,86 \mathrm{E}-03$ \\
\hline SLC15A3 & $-1,89$ & 1,37E-04 & $-2,53$ & $1,83 \mathrm{E}-07$ \\
\hline SLC1A3 & $-2,26$ & $9,39 \mathrm{E}-06$ & $-2,91$ & $5,48 \mathrm{E}-08$ \\
\hline SLC22A16 & $-2,47$ & $1,10 \mathrm{E}-05$ & $-2,38$ & $5,97 \mathrm{E}-04$ \\
\hline SLC22A18 & $-1,43$ & $5,49 \mathrm{E}-04$ & $-2,59$ & $6,92 \mathrm{E}-12$ \\
\hline SLC22A18AS & $-1,50$ & $9,32 \mathrm{E}-03$ & $-2,73$ & $1,99 \mathrm{E}-05$ \\
\hline SLC29A1 & $-2,00$ & $1,11 \mathrm{E}-04$ & $-1,65$ & $6,44 \mathrm{E}-03$ \\
\hline SLC29A3 & $-2,67$ & $1,38 \mathrm{E}-07$ & $-3,48$ & $2,81 \mathrm{E}-09$ \\
\hline SLC38A7 & $-1,32$ & $3,12 \mathrm{E}-03$ & $-1,71$ & $5,43 \mathrm{E}-05$ \\
\hline SLC39A11 & $-1,70$ & $9,08 \mathrm{E}-04$ & $-2,56$ & $1,46 \mathrm{E}-05$ \\
\hline SLC45A4 & $-1,47$ & $1,67 \mathrm{E}-03$ & $-2,27$ & $2,48 \mathrm{E}-07$ \\
\hline SLC8A1 & $-1,51$ & $3,37 \mathrm{E}-03$ & $-1,89$ & $1,93 \mathrm{E}-03$ \\
\hline SLCO4C1 & $-1,47$ & $9,36 \mathrm{E}-03$ & $-2,33$ & $5,89 \mathrm{E}-04$ \\
\hline SMS & $-1,31$ & $7,56 \mathrm{E}-04$ & $-1,20$ & $2,78 \mathrm{E}-04$ \\
\hline SNCA & $-2,14$ & $1,82 \mathrm{E}-04$ & $-3,83$ & $1,59 \mathrm{E}-09$ \\
\hline SOCS1 & 1,42 & $6,95 \mathrm{E}-03$ & 1,96 & $1,05 \mathrm{E}-05$ \\
\hline SOGA1 & $-1,44$ & $2,01 \mathrm{E}-03$ & $-1,56$ & $1,67 \mathrm{E}-03$ \\
\hline SORBS3 & $-1,84$ & $7,40 \mathrm{E}-05$ & $-2,02$ & $1,81 \mathrm{E}-05$ \\
\hline SORT1 & $-2,02$ & $7,54 \mathrm{E}-05$ & $-1,80$ & $2,65 \mathrm{E}-03$ \\
\hline SOWAHD & $-1,47$ & $5,90 \mathrm{E}-03$ & $-2,88$ & $2,45 \mathrm{E}-06$ \\
\hline SPI1 & $-1,63$ & $1,36 \mathrm{E}-03$ & $-2,52$ & $1,35 \mathrm{E}-06$ \\
\hline SPRED1 & $-1,34$ & 4,39E-03 & $-1,53$ & $1,81 \mathrm{E}-03$ \\
\hline SRD5A3 & $-1,03$ & $5,10 \mathrm{E}-03$ & $-1,58$ & $1,11 \mathrm{E}-09$ \\
\hline SRGN & 1,16 & $1,80 \mathrm{E}-03$ & 1,76 & $3,31 \mathrm{E}-16$ \\
\hline ST14 & $-2,28$ & $2,55 \mathrm{E}-06$ & $-3,69$ & $4,13 \mathrm{E}-13$ \\
\hline ST3GAL6 & $-1,76$ & 1,13E-03 & $-2,76$ & $6,05 \mathrm{E}-07$ \\
\hline STAG3 & 1,18 & $2,60 \mathrm{E}-03$ & 1,27 & $7,68 \mathrm{E}-10$ \\
\hline
\end{tabular}




\begin{tabular}{|c|c|c|c|c|}
\hline STEAP3 & $-1,59$ & 4,61E-03 & $-3,71$ & $4,86 \mathrm{E}-09$ \\
\hline STRIP2 & 1,78 & 1,94E-03 & 3,02 & $4,07 \mathrm{E}-05$ \\
\hline SULF2 & $-1,87$ & $1,07 \mathrm{E}-04$ & $-1,74$ & $1,22 \mathrm{E}-03$ \\
\hline SUSD1 & $-1,33$ & $5,87 \mathrm{E}-03$ & $-1,41$ & $1,68 \mathrm{E}-03$ \\
\hline SYK & $-1,91$ & $3,37 \mathrm{E}-04$ & $-3,03$ & $1,07 \mathrm{E}-07$ \\
\hline TAGLN & $-1,34$ & $2,37 \mathrm{E}-03$ & $-1,93$ & $5,45 \mathrm{E}-06$ \\
\hline TBC1D2 & $-1,57$ & $5,89 \mathrm{E}-03$ & $-2,57$ & $1,76 \mathrm{E}-04$ \\
\hline TCN2 & $-2,66$ & $5,38 \mathrm{E}-08$ & $-3,64$ & $1,25 \mathrm{E}-11$ \\
\hline TDRD6 & $-1,76$ & $1,04 \mathrm{E}-03$ & $-3,55$ & $4,12 \mathrm{E}-10$ \\
\hline TFEB & $-2,04$ & $3,44 \mathrm{E}-05$ & $-2,57$ & $1,57 \mathrm{E}-06$ \\
\hline THEM5 & 1,40 & $3,58 \mathrm{E}-03$ & 2,02 & $4,26 \mathrm{E}-06$ \\
\hline TIFAB & $-2,70$ & $2,52 \mathrm{E}-08$ & $-3,22$ & $1,93 \mathrm{E}-08$ \\
\hline TMEM104 & $-1,46$ & $5,03 \mathrm{E}-04$ & $-1,18$ & $3,18 \mathrm{E}-03$ \\
\hline TMEM138 & $-1,64$ & 1,23E-03 & $-2,62$ & $1,83 \mathrm{E}-06$ \\
\hline TMEM163 & $-2,06$ & 2,07E-04 & $-4,50$ & $8,04 \mathrm{E}-12$ \\
\hline TMEM176B & $-1,37$ & 5,29E-03 & $-2,85$ & $1,52 \mathrm{E}-09$ \\
\hline TMEM251 & $-1,41$ & $6,72 \mathrm{E}-03$ & $-1,92$ & $3,26 \mathrm{E}-04$ \\
\hline TMEM51 & $-1,71$ & $1,42 \mathrm{E}-03$ & $-3,48$ & $2,03 \mathrm{E}-09$ \\
\hline TMOD1 & 1,29 & $4,78 \mathrm{E}-03$ & 1,94 & $1,27 \mathrm{E}-06$ \\
\hline TNFRSF10C & $-2,02$ & 6,81E-05 & $-1,90$ & $4,52 \mathrm{E}-03$ \\
\hline TNFSF13 & $-1,77$ & $3,70 \mathrm{E}-04$ & $-2,35$ & $9,71 \mathrm{E}-06$ \\
\hline TNNT1 & $-1,61$ & 1,65E-03 & $-2,81$ & $7,97 \mathrm{E}-06$ \\
\hline TNS1 & $-2,05$ & 3,97E-04 & $-3,67$ & $1,11 \mathrm{E}-08$ \\
\hline TPCN2 & $-1,55$ & $4,16 \mathrm{E}-04$ & $-2,18$ & $1,21 \mathrm{E}-06$ \\
\hline TPD52L2 & $-1,11$ & $6,50 \mathrm{E}-03$ & $-1,32$ & $2,36 \mathrm{E}-04$ \\
\hline TPPP3 & $-1,60$ & $6,05 \mathrm{E}-03$ & $-2,85$ & $3,88 \mathrm{E}-04$ \\
\hline TPRA1 & $-1,45$ & $4,29 \mathrm{E}-03$ & $-2,13$ & $1,15 \mathrm{E}-04$ \\
\hline TPTE2 & 1,77 & $2,28 \mathrm{E}-03$ & 3,27 & $1,51 \mathrm{E}-06$ \\
\hline TREML1 & $-1,59$ & $2,68 \mathrm{E}-03$ & $-2,36$ & $1,28 \mathrm{E}-05$ \\
\hline TRIM47 & $-1,56$ & $9,71 \mathrm{E}-06$ & $-0,90$ & $8,34 \mathrm{E}-05$ \\
\hline TRPM4 & $-1,37$ & $8,73 \mathrm{E}-03$ & $-1,90$ & $3,56 \mathrm{E}-05$ \\
\hline TRPV4 & $-1,77$ & 1,59E-03 & $-1,97$ & $3,44 \mathrm{E}-03$ \\
\hline TRPV5 & $-2,70$ & $8,59 \mathrm{E}-07$ & $-1,65$ & $7,78 \mathrm{E}-03$ \\
\hline TRPV6 & $-1,75$ & $4,37 \mathrm{E}-04$ & $-2,41$ & $2,46 \mathrm{E}-05$ \\
\hline TSKU & $-2,11$ & $1,88 \mathrm{E}-06$ & $-2,59$ & $3,92 \mathrm{E}-06$ \\
\hline TSPAN4 & $-2,24$ & $4,27 \mathrm{E}-06$ & $-2,41$ & $1,38 \mathrm{E}-07$ \\
\hline TSPO & $-1,40$ & 1,63E-03 & $-1,23$ & $7,23 \mathrm{E}-03$ \\
\hline TTYH2 & $-1,43$ & $1,58 \mathrm{E}-03$ & $-1,42$ & $1,05 \mathrm{E}-03$ \\
\hline TTYH3 & $-1,75$ & 1,09E-04 & $-2,24$ & $2,13 \mathrm{E}-07$ \\
\hline UACA & $-1,68$ & $2,53 \mathrm{E}-04$ & $-1,60$ & $9,48 \mathrm{E}-04$ \\
\hline UCHL1 & $-2,92$ & $1,35 \mathrm{E}-11$ & $-1,97$ & $4,89 \mathrm{E}-07$ \\
\hline UGGT2 & $-1,85$ & $1,34 \mathrm{E}-04$ & $-2,59$ & $4,73 \mathrm{E}-09$ \\
\hline UNC93B1 & $-1,69$ & $6,85 \mathrm{E}-04$ & $-2,83$ & $4,21 \mathrm{E}-08$ \\
\hline UNC93B2 & $-1,96$ & $8,06 \mathrm{E}-04$ & $-2,35$ & $2,54 \mathrm{E}-03$ \\
\hline UNC93B6 & $-1,51$ & $9,87 \mathrm{E}-03$ & $-2,44$ & $2,30 \mathrm{E}-03$ \\
\hline UNC93B7 & $-1,81$ & 5,59E-04 & $-2,92$ & $2,45 \mathrm{E}-06$ \\
\hline UNC93B8 & $-1,61$ & 1,16E-03 & $-2,59$ & $7,97 \mathrm{E}-07$ \\
\hline VNN1 & $-1,53$ & $8,82 \mathrm{E}-03$ & $-3,19$ & $5,80 \mathrm{E}-05$ \\
\hline WDFY4 & $-1,72$ & $7,82 \mathrm{E}-04$ & $-2,25$ & $2,38 \mathrm{E}-05$ \\
\hline WDR81 & $-1,30$ & 4,41E-03 & $-2,02$ & $7,46 \mathrm{E}-06$ \\
\hline WLS & $-1,84$ & $3,04 \mathrm{E}-04$ & $-2,39$ & $4,47 \mathrm{E}-08$ \\
\hline $\begin{array}{l}\text { XXBAC- } \\
\text { B135H6,15 }\end{array}$ & $-2,40$ & $8,16 \mathrm{E}-06$ & $-2,91$ & $3,94 \mathrm{E}-06$ \\
\hline ZBTB47 & $-1,75$ & $4,06 \mathrm{E}-04$ & $-2,39$ & $5,68 \mathrm{E}-05$ \\
\hline ZFYVE16 & $-1,46$ & 4,99E-03 & $-1,62$ & $6,58 \mathrm{E}-03$ \\
\hline ZMIZ1 & $-1,20$ & 9,94E-03 & $-1,50$ & $3,02 \mathrm{E}-03$ \\
\hline ZNF205 & $-1,56$ & 1,95E-03 & $-1,87$ & $1,39 \mathrm{E}-03$ \\
\hline ZNF385A & $-1,88$ & $3,62 \mathrm{E}-04$ & $-2,91$ & $1,95 \mathrm{E}-06$ \\
\hline ZNF804A & $-1,67$ & 8,99E-04 & $-2,06$ & $3,47 \mathrm{E}-04$ \\
\hline ZNRF1 & 1,19 & $3,23 \mathrm{E}-04$ & 1,25 & $1,06 \mathrm{E}-14$ \\
\hline
\end{tabular}

\begin{tabular}{|c|c|c|c|c|}
\hline CASP5 & 1,90 & $3,17 \mathrm{E}-03$ & 1,73 & $2,84 \mathrm{E}-03$ \\
\hline CAV1 & 2,08 & $5,59 \mathrm{E}-04$ & 1,49 & $3,22 \mathrm{E}-03$ \\
\hline CD5 & 1,24 & $3,47 \mathrm{E}-03$ & 1,29 & $5,26 \mathrm{E}-03$ \\
\hline $\mathrm{CDH} 24$ & 1,45 & $4,40 \mathrm{E}-04$ & 1,28 & $6,51 \mathrm{E}-03$ \\
\hline CNN3 & 1,48 & $3,47 \mathrm{E}-04$ & 1,08 & $4,88 \mathrm{E}-03$ \\
\hline CXCR3 & 1,62 & $5,38 \mathrm{E}-06$ & 1,23 & 9,99E-04 \\
\hline DGCR5 & 2,67 & $2,95 \mathrm{E}-06$ & 1,50 & $9,18 \mathrm{E}-03$ \\
\hline DPY19L2P1 & 2,69 & $2,26 \mathrm{E}-05$ & 2,93 & 4,17E-07 \\
\hline DYNLRB2 & 1,73 & $7,53 \mathrm{E}-03$ & 1,70 & $3,47 \mathrm{E}-03$ \\
\hline FCER2 & $-1,23$ & $1,74 \mathrm{E}-03$ & $-1,36$ & $9,74 \mathrm{E}-03$ \\
\hline FGFR3 & 2,10 & $1,15 \mathrm{E}-03$ & 1,67 & $4,12 \mathrm{E}-03$ \\
\hline GPC3 & 2,67 & $2,60 \mathrm{E}-06$ & 2,51 & $7,31 \mathrm{E}-06$ \\
\hline GPR126 & 1,43 & $9,14 \mathrm{E}-04$ & 1,44 & $1,35 \mathrm{E}-03$ \\
\hline GRK5 & 1,01 & $9,06 \mathrm{E}-03$ & 1,28 & $1,37 \mathrm{E}-03$ \\
\hline IGFBP2 & 2,15 & $6,94 \mathrm{E}-07$ & 1,56 & $1,74 \mathrm{E}-03$ \\
\hline IGSF10 & $-1,96$ & $2,52 \mathrm{E}-03$ & $-1,66$ & $4,48 \mathrm{E}-03$ \\
\hline IL12RB1 & 1,01 & $5,30 \mathrm{E}-03$ & 1,06 & $6,63 \mathrm{E}-03$ \\
\hline IL17REL & 2,34 & $2,24 \mathrm{E}-04$ & 1,78 & $2,37 \mathrm{E}-03$ \\
\hline IL9R & 0,99 & 4,99E-03 & 1,17 & $8,49 \mathrm{E}-04$ \\
\hline INTU & $-2,34$ & $9,84 \mathrm{E}-05$ & $-1,87$ & $5,74 \mathrm{E}-04$ \\
\hline $\mathrm{JPH} 2$ & 1,99 & $2,01 \mathrm{E}-03$ & 1,53 & $6,74 \mathrm{E}-03$ \\
\hline KIT & 1,83 & $3,11 \mathrm{E}-05$ & 1,25 & 4,57E-03 \\
\hline KREMEN2 & 1,70 & $2,20 \mathrm{E}-03$ & 1,69 & $2,49 \mathrm{E}-03$ \\
\hline KRT4 & 3,73 & $1,56 \mathrm{E}-09$ & 2,13 & $2,42 \mathrm{E}-04$ \\
\hline KRT79 & 3,15 & 1,11E-07 & 1,99 & $6,28 \mathrm{E}-04$ \\
\hline LAPTM4B & 3,34 & $6,82 \mathrm{E}-15$ & 2,35 & $1,20 \mathrm{E}-06$ \\
\hline LRIG1 & 1,32 & $1,65 \mathrm{E}-03$ & 1,09 & $8,47 \mathrm{E}-03$ \\
\hline MAOB & 4,89 & $1,11 \mathrm{E}-22$ & 2,20 & $1,32 \mathrm{E}-04$ \\
\hline MDH1B & 1,98 & 1,27E-03 & 1,70 & $3,31 \mathrm{E}-03$ \\
\hline MGAT5B & 3,62 & 2,31E-09 & 2,61 & $8,14 \mathrm{E}-06$ \\
\hline MUC5B & $-1,89$ & $1,44 \mathrm{E}-03$ & $-1,71$ & $1,72 \mathrm{E}-03$ \\
\hline NAPSB & $-1,71$ & $3,50 \mathrm{E}-05$ & $-1,29$ & $1,30 \mathrm{E}-03$ \\
\hline NEGR1 & 3,11 & $1,51 \mathrm{E}-08$ & 1,66 & $3,99 \mathrm{E}-03$ \\
\hline NEURL1B & 1,46 & $3,44 \mathrm{E}-03$ & 1,80 & $4,12 \mathrm{E}-04$ \\
\hline NFATC4 & 3,43 & $7,57 \mathrm{E}-11$ & 1,94 & $8,79 \mathrm{E}-04$ \\
\hline PIK3R6 & $-1,44$ & $1,78 \mathrm{E}-03$ & $-2,70$ & $5,51 \mathrm{E}-10$ \\
\hline PKIA & 1,91 & $1,12 \mathrm{E}-04$ & 1,61 & $1,68 \mathrm{E}-03$ \\
\hline RDM1 & 2,26 & $2,93 \mathrm{E}-06$ & 1,51 & $7,17 \mathrm{E}-03$ \\
\hline RGS20 & $-2,05$ & $1,38 \mathrm{E}-03$ & $-1,76$ & $2,10 \mathrm{E}-03$ \\
\hline RLN2 & 1,42 & $6,02 \mathrm{E}-03$ & 1,62 & $7,84 \mathrm{E}-04$ \\
\hline RNF144A-AS1 & 1,38 & $4,34 \mathrm{E}-03$ & 1,39 & $4,22 \mathrm{E}-03$ \\
\hline RP11-27K13,3 & 2,04 & $2,07 \mathrm{E}-05$ & 1,77 & $1,52 \mathrm{E}-03$ \\
\hline RP11-316P17,2 & 2,19 & $2,15 \mathrm{E}-04$ & 1,72 & $2,49 \mathrm{E}-03$ \\
\hline RP11-664D1,1 & 1,81 & $9,85 \mathrm{E}-04$ & 2,04 & $6,22 \mathrm{E}-05$ \\
\hline SEPT5 & 1,49 & $1,36 \mathrm{E}-03$ & 1,21 & $3,23 \mathrm{E}-03$ \\
\hline SPTBN2 & 3,10 & $2,71 \mathrm{E}-10$ & 1,69 & $1,88 \mathrm{E}-03$ \\
\hline STOX1 & 2,44 & $2,36 \mathrm{E}-05$ & 1,56 & $5,68 \mathrm{E}-03$ \\
\hline TRAJ17 & 1,70 & 1,84E-03 & 1,41 & $7,91 \mathrm{E}-03$ \\
\hline TRAV12-2 & 1,16 & 9,89E-03 & 1,27 & $6,26 \mathrm{E}-03$ \\
\hline TSPAN2 & 1,71 & $9,33 \mathrm{E}-04$ & 1,54 & $1,47 \mathrm{E}-03$ \\
\hline ZYG11A & 2,10 & $1,16 \mathrm{E}-03$ & 1,61 & $5,06 \mathrm{E}-03$ \\
\hline
\end{tabular}

\section{4) Genes regulados comumente por FvFc R e FvFc M}

\begin{tabular}{|c|c|c|c|c|}
\cline { 2 - 5 } \multicolumn{1}{c|}{} & \multicolumn{2}{c|}{ FvFc R } & \multicolumn{2}{c|}{ FvFc M } \\
\hline Gene & FC (Log2) & $p$ value & FC (Log2) & $p$ value \\
\hline AC003102,3 & 2,09 & $9,13 \mathrm{E}-04$ & 1,77 & $2,46 \mathrm{E}-03$ \\
\hline AC144831,1 & $-1,71$ & $5,85 \mathrm{E}-04$ & $-1,47$ & $4,89 \mathrm{E}-03$ \\
\hline ANGPTL2 & $-1,84$ & $4,43 \mathrm{E}-03$ & $-2,11$ & $2,78 \mathrm{E}-04$ \\
\hline APOBEC3A & 1,32 & $5,99 \mathrm{E}-03$ & $-1,66$ & $6,41 \mathrm{E}-04$ \\
\hline ASIC1 & 2,04 & $3,01 \mathrm{E}-05$ & 1,63 & $3,33 \mathrm{E}-03$ \\
\hline BEND4 & 1,78 & $1,23 \mathrm{E}-03$ & 1,71 & $1,30 \mathrm{E}-03$ \\
\hline BTBD11 & 1,52 & $2,59 \mathrm{E}-04$ & 1,43 & $1,58 \mathrm{E}-03$ \\
\hline C10ORF128 & $-1,48$ & $1,13 \mathrm{E}-03$ & $-1,19$ & $2,30 \mathrm{E}-03$ \\
\hline C19ORF77 & 3,36 & $6,86 \mathrm{E}-11$ & 1,99 & $5,15 \mathrm{E}-04$ \\
\hline C2ORF72 & 1,72 & $6,90 \mathrm{E}-03$ & 1,55 & $6,32 \mathrm{E}-03$ \\
\hline CAMK2B & 3,67 & $1,61 \mathrm{E}-10$ & 2,69 & $1,50 \mathrm{E}-06$ \\
\hline
\end{tabular}


5) Genes regulados somente por OKT3

\begin{tabular}{|c|c|c|}
\hline Gene & FC (Log2) & $p$ value \\
\hline $7 \mathrm{SK}$ & $-1,26$ & 4,04E-03 \\
\hline A2M-AS1 & $-2,31$ & 1,31E-03 \\
\hline A2MP1 & $-2,29$ & 2,19E-03 \\
\hline A4GALT & $-1,82$ & $5,05 \mathrm{E}-03$ \\
\hline AAGAB & 1,04 & $2,24 \mathrm{E}-05$ \\
\hline AANAT & 1,60 & $8,76 \mathrm{E}-04$ \\
\hline $\begin{array}{r}\text { ABC7- } \\
42389800 N 19,1\end{array}$ & $-1,27$ & $1,90 \mathrm{E}-06$ \\
\hline $\mathrm{ABCA} 1$ & $-2,19$ & $6,33 \mathrm{E}-04$ \\
\hline $\mathrm{ABCA7}$ & $-1,45$ & $5,46 \mathrm{E}-04$ \\
\hline$A B C C 10$ & $-1,01$ & $7,31 \mathrm{E}-07$ \\
\hline $\mathrm{ABCD} 1$ & $-1,40$ & $9,29 \mathrm{E}-03$ \\
\hline $\mathrm{ABCD} 4$ & $-1,22$ & $2,42 \mathrm{E}-12$ \\
\hline ABCF2P1 & 1,45 & $1,75 \mathrm{E}-06$ \\
\hline ABHD13 & $-1,15$ & $1,06 \mathrm{E}-08$ \\
\hline ABHD16B & $-1,63$ & $2,56 \mathrm{E}-07$ \\
\hline ABHD17A & $-1,02$ & 4,11E-03 \\
\hline $\mathrm{ABHD} 17 \mathrm{C}$ & 1,35 & $3,51 \mathrm{E}-06$ \\
\hline $\mathrm{ABI} 2$ & 1,20 & $2,60 \mathrm{E}-04$ \\
\hline ABTB1 & $-1,66$ & $1,48 \mathrm{E}-06$ \\
\hline AC000110,1 & 1,54 & $3,50 \mathrm{E}-06$ \\
\hline AC002056,3 & 1,36 & $2,88 \mathrm{E}-10$ \\
\hline AC002454,1 & 3,60 & $6,56 \mathrm{E}-10$ \\
\hline AC002467,7 & 1,36 & $6,69 \mathrm{E}-06$ \\
\hline AC004449,6 & 3,44 & 1,61E-06 \\
\hline AC004538,3 & 2,62 & $1,08 \mathrm{E}-03$ \\
\hline AC004540,5 & $-1,96$ & 9,97E-03 \\
\hline AC004797,1 & 1,22 & $6,62 \mathrm{E}-04$ \\
\hline AC004840,9 & $-1,40$ & $3,58 \mathrm{E}-04$ \\
\hline AC004941,5 & 1,58 & 1,51E-05 \\
\hline AC004951,5 & $-2,01$ & 5,92E-03 \\
\hline AC004988,1 & $-3,28$ & 1,31E-06 \\
\hline AC005082,12 & $-3,01$ & 1,14E-04 \\
\hline AC005253,2 & $-1,29$ & $1,00 \mathrm{E}-04$ \\
\hline AC005306,3 & $-2,05$ & $6,57 \mathrm{E}-06$ \\
\hline AC005387,2 & $-2,07$ & $5,10 \mathrm{E}-03$ \\
\hline AC005519,4 & $-1,89$ & $1,52 \mathrm{E}-04$ \\
\hline AC005618,6 & $-2,31$ & 2,47E-03 \\
\hline AC005740,4 & 1,28 & $6,40 \mathrm{E}-05$ \\
\hline AC005780,1 & $-2,62$ & 1,33E-03 \\
\hline AC005841,1 & $-1,51$ & $9,48 \mathrm{E}-03$ \\
\hline AC006026,9 & 1,54 & $4,16 \mathrm{E}-04$ \\
\hline AC006486,1 & 2,15 & 7,32E-07 \\
\hline AC006538,1 & 1,92 & $5,87 \mathrm{E}-05$ \\
\hline AC006547,13 & $-1,07$ & $1,00 \mathrm{E}-03$ \\
\hline AC007040,6 & 2,62 & $1,38 \mathrm{E}-03$ \\
\hline AC007041,2 & 1,10 & $2,08 \mathrm{E}-07$ \\
\hline AC007163,3 & 2,14 & $8,00 \mathrm{E}-03$ \\
\hline AC007163,6 & 3,34 & $8,02 E-06$ \\
\hline AC007246,3 & $-1,21$ & $5,89 \mathrm{E}-03$ \\
\hline AC007318,5 & 1,15 & $6,09 \mathrm{E}-05$ \\
\hline AC007362,1 & $-1,92$ & $3,20 \mathrm{E}-04$ \\
\hline AC007395,4 & 1,10 & $3,10 \mathrm{E}-03$ \\
\hline AC007551,3 & $-2,00$ & 1,31E-03 \\
\hline AC008592,3 & 1,16 & $2,43 \mathrm{E}-03$ \\
\hline AC009093,1 & $-1,14$ & $9,75 \mathrm{E}-03$ \\
\hline AC009299,3 & 1,10 & $5,33 \mathrm{E}-03$ \\
\hline AC009506,1 & $-2,09$ & $8,85 \mathrm{E}-04$ \\
\hline AC009948,7 & 1,28 & 2,83E-06 \\
\hline AC010240,3 & 1,09 & $1,68 \mathrm{E}-05$ \\
\hline AC010492,5 & 1,06 & 2,23E-03 \\
\hline AC010525,4 & $-2,46$ & $2,56 \mathrm{E}-03$ \\
\hline AC010878,3 & 1,29 & $6,95 \mathrm{E}-06$ \\
\hline AC010883,5 & $-2,16$ & 1,72E-03 \\
\hline AC010970,2 & 3,22 & 1,21E-05 \\
\hline AC010980,2 & $-2,86$ & $1,06 \mathrm{E}-06$ \\
\hline AC011330,5 & $-1,16$ & $5,30 \mathrm{E}-06$ \\
\hline AC012066,1 & 1,52 & $1,66 \mathrm{E}-13$ \\
\hline AC012442,6 & $-2,75$ & $6,47 \mathrm{E}-04$ \\
\hline AC016700,4 & 1,80 & 1,41E-03 \\
\hline AC016708,2 & $-2,26$ & 4,07E-04 \\
\hline
\end{tabular}

\begin{tabular}{|c|c|c|} 
AC016724,6 & 1,29 & $5,44 \mathrm{E}-05$ \\
\hline AC016732,2 & 1,72 & $6,74 \mathrm{E}-05$ \\
\hline AC016757,3 & $-1,52$ & $8,40 \mathrm{E}-04$ \\
\hline AC017076,5 & $-1,95$ & $9,73 \mathrm{E}-03$ \\
\hline AC019097, & 1,06 & $7,40 \mathrm{E}-07$ \\
\hline
\end{tabular}

\begin{tabular}{|c|c|c|}
\hline AC019097,7 & 1,06 & $7,40 \mathrm{E}-07$ \\
\hline AC020571,3 & 2,34 & $1,65 \mathrm{E}-06$ \\
\hline AC021224,1 & 1,20 & $8,19 \mathrm{E}-11$ \\
\hline AC023490,1 & $-2,49$ & $2,23 \mathrm{E}-05$ \\
\hline AC025171,1 & $-2,23$ & $8,01 \mathrm{E}-09$ \\
\hline AC025335, & $-1,46$ & $1,8 \mathrm{E}-08$ \\
\hline
\end{tabular}

\begin{tabular}{|c|c|c|}
\hline AC025335,1 & $-1,46$ & $1,85 \mathrm{E}-08$ \\
\hline $\mathrm{AC} 026150,6$ & $-1,48$ & $3,44 \mathrm{E}-03$ \\
\hline $\mathrm{AC} 026202,3$ & 2,25 & $1,25 \mathrm{E}-03$ \\
\hline
\end{tabular}

\begin{tabular}{|c|c|c|}
\hline $\mathrm{AC} 026202,3$ & 2,25 & $1,25 \mathrm{E}-03$ \\
\hline $\mathrm{AC} 026882,1$ & 1,25 & $7,30 \mathrm{E}-06$ \\
\hline $\mathrm{AC} 027307,3$ & 1,72 & $9,31 \mathrm{E}-04$ \\
\hline $\mathrm{AC} 027601,1$ & $-1,41$ & $2,91 \mathrm{E}-07$ \\
\hline
\end{tabular}

\begin{tabular}{|c|c|c|}
\hline AC027612,1 & 1,24 & $7,69 \mathrm{E}-11$ \\
\hline $\mathrm{AC} 027763,2$ & $-1,60$ & $7,50 \mathrm{E}-09$ \\
\hline $\mathrm{AC} 034220,3$ & $-1,45$ & $3,90 \mathrm{E}-03$ \\
\hline $\mathrm{ACO} 2017,1$ & $-1,80$ & $1,21 \mathrm{E}-03$ \\
\hline
\end{tabular}

\begin{tabular}{|c|c|c|}
\hline AC062017,1 & $-1,80$ & $1,21 \mathrm{E}-03$ \\
\hline AC064834,2 & $-2,74$ & $1,83 \mathrm{E}-04$ \\
\hline AC068580,5 & $-2,47$ & $2,00 \mathrm{E}-04$ \\
\hline
\end{tabular}

\begin{tabular}{|r|r|r|}
\hline AC068580,5 & $-2,47$ & $2,00 \mathrm{E}-04$ \\
\hline $\mathrm{AC} 068831,6$ & 1,08 & $3,32 \mathrm{E}-04$ \\
\hline $\mathrm{AC} 069513,4$ & 2,38 & $5,29 \mathrm{E}-04$ \\
\hline $\mathrm{AC} 073003,10$ & 1,30 & $4,27 \mathrm{E}-05$ \\
\hline
\end{tabular}

\begin{tabular}{|r|r|r|}
\hline AC073063,10 & 1,30 & $4,27 \mathrm{E}-05$ \\
\hline AC073091,2 & 3,00 & $1,87 \mathrm{E}-04$ \\
\hline AC073150,6 & 1,73 & $1,34 \mathrm{E}-05$ \\
\hline
\end{tabular}

\begin{tabular}{|c|c|c|}
\hline AC 073150,6 & 1,73 & $1,34 \mathrm{E}-05$ \\
\hline AC 073333,8 & 1,51 & $2,97 E-05$ \\
\hline
\end{tabular}

\begin{tabular}{|r|r|r|}
\hline AC073333,8 & 1,51 & $2,97 \mathrm{E}-05$ \\
\hline $\mathrm{AC} 073465,1$ & 1,69 & $1,02 \mathrm{E}-15$ \\
\hline
\end{tabular}

\begin{tabular}{|r|r|r|}
\hline $\mathrm{AC} 073465,1$ & 1,69 & $1,02 \mathrm{E}-15$ \\
\hline $\mathrm{AC} 074212,3$ & 3,52 & $8,86 \mathrm{E}-06$ \\
\hline $\mathrm{AC} 079248,1$ & 1,15 & $4,66 \mathrm{E}-04$ \\
\hline
\end{tabular}

\begin{tabular}{c|c|c|}
\hline$A C 079248,1$ & 1,15 & $4,66 \mathrm{E}-04$ \\
\hline AC 079807,2 & $-2,76$ & $5,21 \mathrm{E}-05$ \\
\hline
\end{tabular}

\begin{tabular}{|c|c|c|}
\hline AC079949,1 & 3,07 & $1,49 \mathrm{E}-05$ \\
\hline AC 083843,1 & $-1,63$ & $1,69 \mathrm{E}-04$ \\
\hline
\end{tabular}

\begin{tabular}{c|c|c|}
\hline AC083843,1 & $-1,63$ & $1,69 \mathrm{E}-04$ \\
\hline AC090627,1 & 2,39 & $2,25 \mathrm{E}-03$ \\
\hline
\end{tabular}

\begin{tabular}{|c|c|c|}
\hline AC092106,1 & 1,01 & $7,03 \mathrm{E}-05$ \\
\hline
\end{tabular}

\begin{tabular}{|c|c|c|}
\hline AC092580,3 & 3,13 & $2,63 \mathrm{E}-05$ \\
\hline
\end{tabular}

\begin{tabular}{l|l|l|} 
AC093063,2 & $-2,25$ & $1,58 \mathrm{E}-03$ \\
\hline
\end{tabular}

\begin{tabular}{l|l|l|} 
AC093375,1 & $-2,15$ & $2,91 \mathrm{E}-03$ \\
\hline AC093484,4 & $-2,14$ & $4,37 \mathrm{E}-03$ \\
\hline
\end{tabular}

\begin{tabular}{c|c|c|}
$\mathrm{AC} 093484,4$ & $-2,14$ & $4,37 \mathrm{E}-03$ \\
\hline $\mathrm{AC} 093642,3$ & $-2,50$ & $2,13 \mathrm{E}-05$ \\
\hline $\mathrm{AC} 096579,7$ & $-2,01$ & $2,34 \mathrm{E}-07$ \\
\hline
\end{tabular}

\begin{tabular}{|c|c|c|}
\hline $\mathrm{AC} 096579,7$ & $-2,01$ & $2,34 \mathrm{E}-07$ \\
\hline $\mathrm{AC} 097523,3$ & 1,15 & $1,36 \mathrm{E}-04$ \\
\hline
\end{tabular}

\begin{tabular}{c|c|c|} 
AC097523,3 & 1,15 & $1,36 \mathrm{E}-04$ \\
\hline AC099668,5 & $-2,12$ & $9,90 \mathrm{E}-03$ \\
\hline
\end{tabular}

\begin{tabular}{r|r|r|}
\hline AC103563,9 & $-2,98$ & $1,44 \mathrm{E}-04$ \\
\hline
\end{tabular}

\begin{tabular}{|c|c|c|}
\hline AC104135,3 & $-1,38$ & $1,35 \mathrm{E}-08$ \\
\hline
\end{tabular}

\begin{tabular}{|c|c|c|} 
AC112198,1 & 2,17 & $8,23 \mathrm{E}-03$ \\
\hline
\end{tabular}

\begin{tabular}{l|r|r|} 
AC114494,1 & $-1,86$ & $4,96 \mathrm{E}-03$ \\
\hline AC116366,6 & $-1,58$ & $3,13 \mathrm{E}-04$ \\
\hline
\end{tabular}

\begin{tabular}{r|r|r|}
\hline AC116366,6 & $-1,58$ & $3,13 \mathrm{E}-04$ \\
\hline AC123768,4 & $-1,48$ & $3,02 \mathrm{E}-03$ \\
\hline
\end{tabular}

\begin{tabular}{r|r|r|}
\hline AC129492,6 & $-1,88$ & $3,47 \mathrm{E}-03$ \\
\hline
\end{tabular}

\begin{tabular}{|l|l|l|}
\hline AC131056,3 & $-2,32$ & $3,23 \mathrm{E}-03$ \\
\hline
\end{tabular}

\begin{tabular}{|c|c|c|}
\hline AC135048,13 & $-2,28$ & $5,33 \mathrm{E}-03$ \\
\hline
\end{tabular}

\begin{tabular}{|l|l|l|}
\hline AC135178,1 & $-1,26$ & $5,06 \mathrm{E}-04$ \\
\hline
\end{tabular}

\begin{tabular}{l|l|l|} 
AC137932,1 & $-1,50$ & $9,00 \mathrm{E}-03$ \\
\hline
\end{tabular}

\begin{tabular}{c|c|c|}
\hline AC137932,6 & $-2,13$ & $9,41 \mathrm{E}-03$ \\
\hline AC138035,2 & $-1,32$ & $1,30 \mathrm{E}-03$ \\
\hline
\end{tabular}

\begin{tabular}{l|l|l|}
$\mathrm{AC} 139100,2$ & $-1,69$ & $8,00 \mathrm{E}-03$ \\
\hline
\end{tabular}

\begin{tabular}{l|r|r} 
AC142381,1 & $-2,59$ & $8,26 \mathrm{E}-04$ \\
\hline
\end{tabular}

\begin{tabular}{l|l|l|} 
AC145676,2 & $-2,46$ & $2,67 \mathrm{E}-03$ \\
\hline
\end{tabular}

\begin{tabular}{r|r|r|}
\hline AC147651,4 & 1,27 & $8,68 \mathrm{E}-11$ \\
\hline ACACA & 1,04 & $9,69 \mathrm{E}-03$ \\
\hline ACAD10 & $-1,6$ & $3,82 \mathrm{E}-06$
\end{tabular}

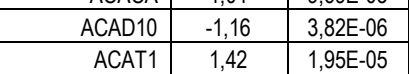

\begin{tabular}{c|c|c|}
\hline ACBD4 & $-1,14$ & $6,23 \mathrm{E}-03$ \\
\hline
\end{tabular}

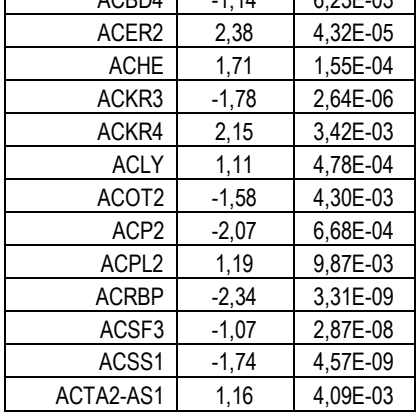

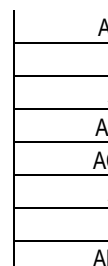

\begin{tabular}{l|l|l|} 
ACTL6A & 1,03 & $4,12 \mathrm{E}-10$ \\
\hline ACTL & 2,17 & $8,19 E-03$
\end{tabular} \begin{tabular}{l|l|l|} 
ACTL8 & 2,17 & $8,19 \mathrm{E}-03$ \\
\hline
\end{tabular} \begin{tabular}{c|c|c|} 
ACTRT3 & 1,97 & $3,83 \mathrm{E}-04$ \\
\hline
\end{tabular} \begin{tabular}{c|c|c|} 
ACVR2A & $-1,33$ & $4,72 \mathrm{E}-06$ \\
\hline
\end{tabular} \begin{tabular}{c|c|c|} 
ACYP1 & 1,02 & $6,90 \mathrm{E}-05$ \\
\hline
\end{tabular} \begin{tabular}{r|r|r|} 
ADA & $-1,61$ & $5,10 \mathrm{E}-03$ \\
\hline
\end{tabular} \begin{tabular}{l|l|l|} 
ADAM8 & $-1,30$ & $9,37 \mathrm{E}-03$ \\
\hline
\end{tabular} \begin{tabular}{l|l|r} 
ADAMDEC1 & $-2,72$ & $3,51 \mathrm{E}-05$ \\
\hline
\end{tabular} \begin{tabular}{c|c|c} 
ADAMTS17 & $-1,76$ & $4,30 \mathrm{E}-03$ \\
\hline
\end{tabular} \begin{tabular}{c|c|c|} 
ADAMTS2 & $-2,36$ & $2,54 \mathrm{E}-03$ \\
\hline
\end{tabular}

\begin{tabular}{|r|r|r|}
\hline ADAMTS2 & $-2,36$ & $2,54 \mathrm{E}-03$ \\
\hline ADAMTS7P2 & $-1,88$ & $3,57 \mathrm{E}-03$ \\
\hline ADAMTS7P4 & $-1,58$ & $5,81 \mathrm{E}-03$ \\
\hline ADAMTSL2 & $-3,32$ & $1,72 \mathrm{E}-07$ \\
\hline
\end{tabular}

\begin{tabular}{c|c|c|}
\hline ADAMTSL2 & $-3,32$ & $1,72 \mathrm{E}-07$ \\
\hline
\end{tabular}

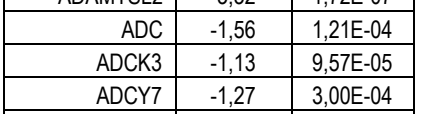

\begin{tabular}{|r|c|c|}
\hline ADD3 & $-1,49$ & $1,51 \mathrm{E}-04$ \\
\hline ADM & $-2,98$ & $5,35 \mathrm{E}-06$ \\
\hline ADM5 & 1,42 & $7,35 \mathrm{E}-03$ \\
\hline ADORA2BP & 2,68 & $9,82 \mathrm{E}-04$ \\
\hline ADRB3 & 2,17 & $8,23 E-03$ \\
\hline
\end{tabular}
\begin{tabular}{c|c|c|}
\hline ADRB3 & 2,17 & $8,23 \mathrm{E}-03$ \\
\hline
\end{tabular} \begin{tabular}{c|c|c|} 
ADSL & 1,04 & $4,84 \mathrm{E}-06$ \\
\hline
\end{tabular}

\begin{tabular}{r|r|r} 
AE 000658,27 & 1,79 & $2,01 \mathrm{E}-04$ \\
\hline
\end{tabular} \begin{tabular}{l|l|l} 
AF015262,2 & 2,95 & $2,62 \mathrm{E}-04$ \\
\hline
\end{tabular} \begin{tabular}{l|l|l} 
AF127936,7 & $-2,44$ & $9,53 \mathrm{E}-06$ \\
\hline
\end{tabular} \begin{tabular}{l|l|l|} 
AGAP1 & $-1,58$ & $7,46 \mathrm{E}-03$ \\
\hline
\end{tabular}

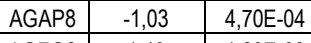

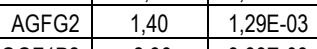
\begin{tabular}{l|l|l|} 
AGGF1P2 & $-2,36$ & $3,88 \mathrm{E}-03$ \\
\hline
\end{tabular} \begin{tabular}{r|r|r|} 
AGO2 & 1,11 & $3,28 \mathrm{E}-12$ \\
\hline
\end{tabular} \begin{tabular}{l|l|l} 
AGPAT4 & $-2,09$ & $5,05 \mathrm{E}-04$ \\
\hline
\end{tabular} \begin{tabular}{l|l|l} 
AGPAT5 & 1,43 & $2,85 \mathrm{E}-05$ \\
\hline
\end{tabular} \begin{tabular}{c|c|c} 
AGTRAP & $-2,06$ & $4,39 \mathrm{E}-05$ \\
\hline
\end{tabular} \begin{tabular}{l|l|l} 
AHCYL2 & 1,40 & $6,65 \mathrm{E}-05$ \\
\hline
\end{tabular} \begin{tabular}{c|c|c|} 
AHSA1 & 1,20 & $7,40 \mathrm{E}-04$ \\
\hline
\end{tabular} \begin{tabular}{l|l|l} 
AHSA2 & $-1,13$ & $8,27 \mathrm{E}-06$ \\
\hline AIM1L & $-2,01$ & $1,07 \mathrm{E}-03$
\end{tabular} \begin{tabular}{l|l|l} 
AIM1L & $-2,01$ & $1,07 \mathrm{E}-03$ \\
\hline
\end{tabular} \begin{tabular}{c|c|c|} 
AIMP2 & 1,22 & $5,40 \mathrm{E}-03$ \\
\hline
\end{tabular} \begin{tabular}{r|r|r} 
AIRN & 2,09 & $3,26 \mathrm{E}-03$ \\
\hline
\end{tabular}

\begin{tabular}{l|l|l} 
AK2 & 1,22 & $1,59 \mathrm{E}-16$ \\
\hline AK7 & 2,04 & $2,21 \mathrm{E}-03$
\end{tabular}
\begin{tabular}{r|c|r|} 
AK7 & 2,04 & $2,21 \mathrm{E}-03$ \\
\hline AKR1D1P1 & $-3,38$ & $1,51 \mathrm{E}-05$ \\
\hline AL133458 & $-2,74$ & $1,81 \mathrm{E}-06$
\end{tabular} \begin{tabular}{c|c|c|} 
AL133458,1 & $-2,74$ & $1,81 \mathrm{E}-06$ \\
\hline
\end{tabular} \begin{tabular}{l|l|l} 
AL136419,6 & $-1,33$ & $4,49 \mathrm{E}-05$ \\
\hline
\end{tabular} \begin{tabular}{l|l|l} 
AL137059,1 & $-1,61$ & $4,66 \mathrm{E}-03$ \\
\hline
\end{tabular} \begin{tabular}{|l|l|l|}
\hline AL139099,1 & 2,71 & $3,11 \mathrm{E}-04$ \\
\hline
\end{tabular} \begin{tabular}{l|l|l} 
AL161626,1 & 2,98 & $5,77 \mathrm{E}-05$ \\
\hline
\end{tabular} \begin{tabular}{c|c|c|} 
AL360004,1 & 2,53 & $9,01 \mathrm{E}-04$ \\
\hline
\end{tabular} \begin{tabular}{|l|l|l}
\hline AL590762,7 & 2,34 & $4,36 \mathrm{E}-03$ \\
\hline
\end{tabular} \begin{tabular}{l|l|l|} 
AL591479,1 & $-1,73$ & $2,40 \mathrm{E}-03$ \\
\hline
\end{tabular} \begin{tabular}{l|l|l|}
\hline AL928768,3 & $-1,93$ & $2,21 \mathrm{E}-03$ \\
\hline
\end{tabular} \begin{tabular}{l|l|l} 
ALDH1B1 & 1,17 & $3,43 \mathrm{E}-04$ \\
\hline
\end{tabular} \begin{tabular}{c|c|c|} 
ALDH2 & $-2,83$ & $3,22 \mathrm{E}-05$ \\
\hline
\end{tabular} \begin{tabular}{c|c|c|}
\hline ALDH8A1 & 1,15 & $7,94 \mathrm{E}-03$ \\
\hline
\end{tabular} \begin{tabular}{l|l|l} 
ALOX12 & $-1,33$ & $6,33 \mathrm{E}-03$ \\
\hline
\end{tabular} \begin{tabular}{c|c|c|} 
ALOX12P2 & 1,77 & $7,22 \mathrm{E}-04$ \\
\hline ALOX5 & $-4,55$ & $1,04 \mathrm{E}-12$
\end{tabular} \begin{tabular}{l|l|l} 
ALOX5 & $-4,55$ & $1,04 \mathrm{E}-12$ \\
\hline
\end{tabular} \begin{tabular}{c|c|c} 
AMIGO2 & 1,11 & $4,41 \mathrm{E}-04$ \\
\hline
\end{tabular} \begin{tabular}{l|l|l} 
AMY1C & $-2,11$ & $4,87 \mathrm{E}-04$ \\
\hline
\end{tabular} \begin{tabular}{l|l|l} 
AMYP1 & $-1,86$ & $4,47 \mathrm{E}-04$ \\
\hline
\end{tabular} \begin{tabular}{l|l|l} 
ANAPC1 & 1,16 & $1,34 \mathrm{E}-09$ \\
\hline
\end{tabular} \begin{tabular}{l|l|l} 
ANGEL1 & $-1,79$ & $2,22 \mathrm{E}-05$ \\
\hline
\end{tabular} \begin{tabular}{l|c|c} 
ANGPT2 & 1,68 & $2,35 \mathrm{E}-03$ \\
\hline
\end{tabular} \begin{tabular}{c|c|c} 
ANGPTL6 & $-1,42$ & $5,90 \mathrm{E}-05$ \\
\hline
\end{tabular} \begin{tabular}{c|c|c|} 
ANKDD1A & $-1,19$ & $4,58 \mathrm{E}-06$ \\
\hline
\end{tabular} \begin{tabular}{l|l|l} 
ANKFN1 & 2,27 & $5,74 \mathrm{E}-03$ \\
\hline
\end{tabular} \begin{tabular}{l|l|l} 
ANKK1 & $-4,63$ & $8,85 \mathrm{E}-10$ \\
\hline
\end{tabular} \begin{tabular}{|r|r|r|} 
ANKMY1 & $-1,27$ & $1,29 \mathrm{E}-03$ \\
\hline
\end{tabular} \begin{tabular}{l|l|l} 
ANKRD12 & $-1,01$ & $1,44 \mathrm{E}-11$ \\
\hline
\end{tabular} \begin{tabular}{l|l|l} 
ANKRD29 & $-2,17$ & $3,24 \mathrm{E}-03$ \\
\hline
\end{tabular} \begin{tabular}{c|c|c|} 
ANKRD30BL & 3,25 & $2,29 \mathrm{E}-06$ \\
\hline
\end{tabular} \begin{tabular}{c|c|c|} 
ANKRD32 & 1,08 & $1,59 \mathrm{E}-04$ \\
\hline
\end{tabular} \begin{tabular}{l|l|l} 
ANKRD46 & $-1,30$ & $1,63 \mathrm{E}-05$ \\
\hline
\end{tabular} \begin{tabular}{l|l|l} 
ANKRD55 & $-1,54$ & $6,09 \mathrm{E}-03$ \\
\hline
\end{tabular}

\begin{tabular}{|c|c|c|}
\hline ANKRD6 & $-1,32$ & $1,83 \mathrm{E}-03$ \\
\hline ANKUB1 & $-2,13$ & $7,80 \mathrm{E}-03$ \\
\hline AN010 & $-1,28$ & $3,56 \mathrm{E}-03$ \\
\hline ANO7 & 1,30 & $7,08 \mathrm{E}-03$ \\
\hline ANO8 & $-1,81$ & 4,77E-09 \\
\hline ANO9 & $-1,26$ & $2,94 \mathrm{E}-03$ \\
\hline ANTXRLP1 & $-2,63$ & $3,72 \mathrm{E}-04$ \\
\hline ANXA2R & $-1,98$ & $1,44 \mathrm{E}-05$ \\
\hline ANXA8L1 & 2,49 & $2,38 \mathrm{E}-03$ \\
\hline $\mathrm{AOAH}$ & $-1,57$ & 5,82E-09 \\
\hline $\mathrm{AOC1}$ & $-2,86$ & $1,26 \mathrm{E}-05$ \\
\hline $\mathrm{AOC2}$ & 1,96 & $2,40 \mathrm{E}-11$ \\
\hline $\mathrm{AOC} 3$ & 2,23 & 4,97E-06 \\
\hline AOC4P & 2,19 & $6,56 \mathrm{E}-03$ \\
\hline AOX1 & 3,71 & 9,71E-08 \\
\hline AP000318,1 & 2,84 & $4,15 \mathrm{E}-05$ \\
\hline AP000351,10 & $-2,34$ & $1,43 \mathrm{E}-05$ \\
\hline AP000593,6 & 1,21 & $2,50 \mathrm{E}-03$ \\
\hline AP000783,1 & 1,82 & $6,24 \mathrm{E}-10$ \\
\hline AP000936,5 & 1,54 & $6,17 \mathrm{E}-06$ \\
\hline AP001062,7 & $-1,65$ & $9,52 \mathrm{E}-08$ \\
\hline AP001372,2 & $-1,32$ & $2,94 \mathrm{E}-03$ \\
\hline AP003068,23 & $-1,45$ & $4,32 \mathrm{E}-03$ \\
\hline AP006621,1 & $-1,33$ & $1,04 \mathrm{E}-03$ \\
\hline AP2A2 & $-1,25$ & $1,41 \mathrm{E}-08$ \\
\hline AP3B2 & 2,28 & 1,87E-05 \\
\hline AP3S2 & $-1,76$ & $1,02 \mathrm{E}-07$ \\
\hline APBA2 & $-2,30$ & $1,21 \mathrm{E}-06$ \\
\hline APEX2 & 1,02 & $1,13 \mathrm{E}-03$ \\
\hline APH1B & $-1,90$ & $2,36 \mathrm{E}-05$ \\
\hline APLP2 & $-2,25$ & 1,87E-04 \\
\hline APOBEC3D & 1,20 & $1,28 \mathrm{E}-03$ \\
\hline APOBEC4 & 2,26 & $5,81 \mathrm{E}-03$ \\
\hline APOE & $-6,85$ & $7,25 \mathrm{E}-33$ \\
\hline APOOP1 & 2,46 & $2,72 \mathrm{E}-03$ \\
\hline APOOP4 & 1,07 & $7,82 \mathrm{E}-03$ \\
\hline APOOP5 & 1,48 & $8,76 \mathrm{E}-04$ \\
\hline ARAP1 & $-1,64$ & $1,13 \mathrm{E}-03$ \\
\hline ARAP1-AS2 & $-1,37$ & $7,44 \mathrm{E}-03$ \\
\hline ARG2 & 1,21 & $9,18 \mathrm{E}-06$ \\
\hline ARHGAP18 & $-2,01$ & $6,24 \mathrm{E}-05$ \\
\hline ARHGAP24 & $-3,46$ & 1,71E-05 \\
\hline ARHGAP25 & $-1,15$ & 3,96E-04 \\
\hline ARHGAP4 & $-1,66$ & $1,20 \mathrm{E}-05$ \\
\hline ARHGAP44 & $-1,58$ & $3,15 \mathrm{E}-03$ \\
\hline ARHGEF10L & $-2,39$ & $7,40 \mathrm{E}-05$ \\
\hline ARHGEF12 & 1,65 & $4,73 \mathrm{E}-11$ \\
\hline ARHGEF4 & $-1,89$ & $3,09 \mathrm{E}-04$ \\
\hline ARL17B & $-1,06$ & $8,31 \mathrm{E}-05$ \\
\hline ARL3 & 1,72 & $1,38 \mathrm{E}-16$ \\
\hline ARL4C & $-2,40$ & $4,26 \mathrm{E}-09$ \\
\hline ARL5A & 1,22 & $1,04 \mathrm{E}-10$ \\
\hline ARL5AP4 & 1,30 & $3,60 \mathrm{E}-03$ \\
\hline ARL5B-AS1 & $-2,33$ & $1,03 \mathrm{E}-03$ \\
\hline ARL6IP4 & $-1,16$ & $2,73 \mathrm{E}-04$ \\
\hline ARMCX2 & 1,30 & $6,70 \mathrm{E}-06$ \\
\hline ARMCX5 & $-1,21$ & $4,29 \mathrm{E}-05$ \\
\hline ARPC5L & 1,56 & 1,96E-08 \\
\hline ARRDC2 & $-1,15$ & $1,36 \mathrm{E}-10$ \\
\hline ARSD & $-1,49$ & $1,06 \mathrm{E}-03$ \\
\hline ARSJ & $-2,23$ & $6,49 \mathrm{E}-03$ \\
\hline ARVCF & $-1,60$ & $1,20 \mathrm{E}-08$ \\
\hline ASAH2 & 1,36 & $1,28 \mathrm{E}-03$ \\
\hline ASB13 & $-2,61$ & $2,78 \mathrm{E}-12$ \\
\hline ASB16-AS1 & $-1,16$ & $2,39 \mathrm{E}-03$ \\
\hline ASCC3 & 1,23 & 1,03E-05 \\
\hline $\mathrm{ASPH}$ & $-1,37$ & $3,99 \mathrm{E}-03$ \\
\hline ASPHD1 & 3,50 & $1,86 \mathrm{E}-23$ \\
\hline ASPN & 2,15 & $8,59 \mathrm{E}-03$ \\
\hline ASPSCR1 & $-1,16$ & $4,97 \mathrm{E}-13$ \\
\hline ASTN2 & 1,41 & 1,73E-04 \\
\hline ASUN & 1,03 & $4,28 \mathrm{E}-07$ \\
\hline ATF7IP2 & $-1,36$ & $8,02 \mathrm{E}-04$ \\
\hline ATG14 & $-1,24$ & $6,95 \mathrm{E}-07$ \\
\hline ATG16L2 & $-1,17$ & $1,25 \mathrm{E}-06$ \\
\hline ATG9B & $-2,23$ & $1,93 \mathrm{E}-05$ \\
\hline
\end{tabular}




\begin{tabular}{|c|c|c|}
\hline ATL1 & 1,14 & $1,73 \mathrm{E}-04$ \\
\hline ATM & $-1,43$ & $1,24 \mathrm{E}-03$ \\
\hline ATP13A4 & 1,14 & $5,68 \mathrm{E}-03$ \\
\hline ATP5B & 1,28 & $5,14 \mathrm{E}-09$ \\
\hline ATP5BP1 & 1,43 & $8,28 \mathrm{E}-07$ \\
\hline ATP5G1P4 & 1,91 & $2,84 \mathrm{E}-04$ \\
\hline ATP6V0E1P2 & $-1,06$ & $9,56 \mathrm{E}-03$ \\
\hline ATP6V1E2 & $-2,09$ & $2,80 \mathrm{E}-10$ \\
\hline ATP6V1G1 & $-1,10$ & $1,24 \mathrm{E}-04$ \\
\hline ATP8A2P2 & 2,61 & $1,39 \mathrm{E}-03$ \\
\hline ATP8B4 & 2,73 & $1,04 \mathrm{E}-19$ \\
\hline ATP9B & $-1,41$ & $3,37 \mathrm{E}-06$ \\
\hline ATRN & $-1,34$ & $2,54 \mathrm{E}-04$ \\
\hline ATXN7L3B & $-1,26$ & $4,42 E-05$ \\
\hline AUH & 1,36 & $1,41 \mathrm{E}-09$ \\
\hline AUTS2 & $-1,16$ & $1,92 \mathrm{E}-03$ \\
\hline AWAT1 & 2,91 & $3,18 \mathrm{E}-04$ \\
\hline B3GALT4 & $-1,17$ & $5,48 \mathrm{E}-03$ \\
\hline B3GNT9 & 1,48 & $1,78 \mathrm{E}-03$ \\
\hline B4GALNT3 & 1,90 & $2,97 \mathrm{E}-05$ \\
\hline B4GALNT4 & $-1,88$ & $5,63 \mathrm{E}-04$ \\
\hline B4GALT7 & $-1,75$ & $4,85 \mathrm{E}-17$ \\
\hline BAALC & $-1,32$ & $7,64 \mathrm{E}-03$ \\
\hline BACE1 & $-1,20$ & $4,60 \mathrm{E}-05$ \\
\hline $\mathrm{BACH} 1$ & $-1,43$ & $7,75 \mathrm{E}-03$ \\
\hline BAG3 & 1,00 & $1,19 \mathrm{E}-07$ \\
\hline BAG4 & 1,00 & $2,56 \mathrm{E}-03$ \\
\hline BAK1 & 1,16 & $2,95 \mathrm{E}-07$ \\
\hline BANK1 & $-1,36$ & $8,71 \mathrm{E}-05$ \\
\hline BARX2 & 4,12 & $4,88 \mathrm{E}-08$ \\
\hline $\mathrm{BCCIP}$ & 1,28 & $2,12 \mathrm{E}-07$ \\
\hline BCDIN3D-AS1 & $-1,32$ & $6,50 \mathrm{E}-03$ \\
\hline BCL11A & $-2,12$ & $1,58 \mathrm{E}-03$ \\
\hline BCL2L2 & $-1,82$ & $3,74 \mathrm{E}-04$ \\
\hline $\mathrm{BCL6B}$ & 3,43 & $3,72 \mathrm{E}-07$ \\
\hline BCL7A & $-1,57$ & $2,35 \mathrm{E}-05$ \\
\hline $\mathrm{BDH} 2$ & $-1,21$ & $5,15 \mathrm{E}-03$ \\
\hline BEND3 & 1,30 & $3,69 \mathrm{E}-06$ \\
\hline BEST1 & $-2,58$ & $7,37 \mathrm{E}-06$ \\
\hline BEST2 & 2,17 & $8,23 \mathrm{E}-03$ \\
\hline BEX4 & $-1,20$ & $4,87 \mathrm{E}-10$ \\
\hline BICC1 & 2,00 & $5,58 \mathrm{E}-04$ \\
\hline BID & $-1,14$ & $3,11 \mathrm{E}-03$ \\
\hline BIVM & 1,05 & $5,35 \mathrm{E}-03$ \\
\hline BLCAP & $-1,11$ & $2,10 \mathrm{E}-08$ \\
\hline BLK & $-2,29$ & $2,85 \mathrm{E}-11$ \\
\hline BMF & $-2,41$ & $3,00 \mathrm{E}-05$ \\
\hline BMP8A & $-1,85$ & $6,11 \mathrm{E}-03$ \\
\hline BMS1 & 1,01 & $3,93 \mathrm{E}-08$ \\
\hline BMS1P10 & 1,05 & $9,27 \mathrm{E}-03$ \\
\hline BNIP1 & 1,10 & $8,70 \mathrm{E}-04$ \\
\hline BNIP3L & $-1,43$ & $4,28 \mathrm{E}-04$ \\
\hline BOLA2B & 1,11 & $4,68 \mathrm{E}-04$ \\
\hline BOP1 & 1,10 & $4,88 \mathrm{E}-10$ \\
\hline BRIX1 & 1,61 & $1,84 \mathrm{E}-14$ \\
\hline BSN & 1,74 & $2,42 \mathrm{E}-04$ \\
\hline BTBD2 & $-1,21$ & $5,02 \mathrm{E}-09$ \\
\hline BTG2 & $-1,95$ & $6,39 \mathrm{E}-04$ \\
\hline BTN3A2 & $-1,24$ & 3,57E-04 \\
\hline BTN3A3 & $-1,40$ & $1,92 \mathrm{E}-05$ \\
\hline BUB3 & 1,05 & $8,12 \mathrm{E}-06$ \\
\hline BUD13 & 1,02 & $8,12 \mathrm{E}-07$ \\
\hline BUD31 & 1,04 & $9,01 \mathrm{E}-05$ \\
\hline BX322557,10 & $-2,20$ & $4,50 \mathrm{E}-05$ \\
\hline BX649597,1 & 1,15 & $7,10 \mathrm{E}-03$ \\
\hline BZRAP1 & 3,83 & 1,07E-16 \\
\hline C10ORF12 & 1,10 & $9,75 \mathrm{E}-03$ \\
\hline C100RF2 & 1,11 & $4,33 \mathrm{E}-07$ \\
\hline C10ORF25 & $-1,57$ & $7,81 \mathrm{E}-04$ \\
\hline C100RF35 & 1,84 & $6,64 \mathrm{E}-04$ \\
\hline C10ORF55 & $-2,62$ & 4,21E-04 \\
\hline C110RF35 & $-1,64$ & $2,35 \mathrm{E}-05$ \\
\hline C11ORF48 & 1,05 & $3,84 \mathrm{E}-10$ \\
\hline C110RF68 & $-1,40$ & $1,28 \mathrm{E}-13$ \\
\hline C11ORF74 & $-1,89$ & $2,89 \mathrm{E}-03$ \\
\hline C11ORF83 & $-1,42$ & $8,51 \mathrm{E}-05$ \\
\hline
\end{tabular}

\begin{tabular}{|c|c|c|}
\hline C12ORF76 & $-1,17$ & $2,73 \mathrm{E}-03$ \\
\hline C14ORF1 & 1,06 & $1,18 \mathrm{E}-05$ \\
\hline C14ORF132 & $-1,76$ & $9,67 \mathrm{E}-03$ \\
\hline C140RF159 & $-1,53$ & $4,60 \mathrm{E}-13$ \\
\hline C14ORF166 & 1,05 & $3,74 \mathrm{E}-12$ \\
\hline C160RF54 & $-2,10$ & $1,34 \mathrm{E}-03$ \\
\hline C16ORF58 & $-1,61$ & $1,55 \mathrm{E}-09$ \\
\hline C16ORF70 & $-1,28$ & $4,88 \mathrm{E}-03$ \\
\hline C16ORF80 & 1,18 & $5,60 \mathrm{E}-04$ \\
\hline C16ORF86 & $-1,05$ & $1,06 \mathrm{E}-03$ \\
\hline C16ORF95 & 1,48 & $8,26 \mathrm{E}-04$ \\
\hline C17ORF58 & 1,96 & $7,97 \mathrm{E}-07$ \\
\hline C17ORF82 & 2,22 & $6,90 \mathrm{E}-03$ \\
\hline C18ORF32 & $-1,13$ & $7,06 \mathrm{E}-04$ \\
\hline C18ORF54 & 2,22 & $1,18 \mathrm{E}-08$ \\
\hline C19ORF59 & $-2,08$ & $3,05 \mathrm{E}-03$ \\
\hline C190RF60 & $-1,53$ & $1,38 \mathrm{E}-04$ \\
\hline C190RF71 & $-1,59$ & $1,25 \mathrm{E}-03$ \\
\hline C1GALT1C1 & 1,17 & $6,69 \mathrm{E}-03$ \\
\hline C1ORF115 & $-2,24$ & $1,11 \mathrm{E}-04$ \\
\hline C1ORF141 & 3,00 & $1,87 \mathrm{E}-04$ \\
\hline C1ORF170 & 1,36 & $1,03 \mathrm{E}-03$ \\
\hline C1ORF172 & $-3,25$ & $8,76 \mathrm{E}-09$ \\
\hline C1ORF204 & $-2,44$ & $2,53 \mathrm{E}-08$ \\
\hline C1ORF213 & $-1,42$ & $2,13 \mathrm{E}-05$ \\
\hline C1ORF233 & $-2,08$ & $7,38 \mathrm{E}-08$ \\
\hline C1ORF63 & $-1,53$ & $1,80 \mathrm{E}-04$ \\
\hline C1ORF95 & $-2,75$ & $6,60 \mathrm{E}-04$ \\
\hline C1QTNF6 & $-1,51$ & $2,13 \mathrm{E}-03$ \\
\hline C21ORF2 & $-1,92$ & $1,08 \mathrm{E}-14$ \\
\hline C21ORF49 & $-2,44$ & $6,21 \mathrm{E}-04$ \\
\hline C22ORF29 & $-1,09$ & $5,32 \mathrm{E}-04$ \\
\hline C22ORF39 & $-1,05$ & $3,93 \mathrm{E}-10$ \\
\hline C2ORF40 & $-2,71$ & $9,30 \mathrm{E}-04$ \\
\hline C2ORF62 & $-2,35$ & $2,79 \mathrm{E}-03$ \\
\hline C2ORF66 & 2,00 & $7,79 \mathrm{E}-03$ \\
\hline C2ORF76 & 1,07 & $4,61 \mathrm{E}-04$ \\
\hline C2ORF78 & 2,60 & $1,48 \mathrm{E}-03$ \\
\hline $\mathrm{C} 3$ & $-4,29$ & $3,23 \mathrm{E}-11$ \\
\hline C3AR1 & $-1,92$ & $5,51 \mathrm{E}-05$ \\
\hline C4ORF27 & 1,10 & $4,69 \mathrm{E}-04$ \\
\hline C4ORF3 & $-1,06$ & $5,81 \mathrm{E}-12$ \\
\hline C4ORF36 & $-1,66$ & $1,23 \mathrm{E}-03$ \\
\hline C4ORF50 & 2,14 & $4,96 \mathrm{E}-04$ \\
\hline C5AR1 & $-2,67$ & $2,03 \mathrm{E}-07$ \\
\hline C5ORF30 & 1,53 & $3,02 \mathrm{E}-07$ \\
\hline C5ORF38 & 4,39 & $3,60 \mathrm{E}-11$ \\
\hline C6ORF1 & $-1,25$ & $1,18 \mathrm{E}-04$ \\
\hline C6ORF132 & 2,43 & $1,25 \mathrm{E}-03$ \\
\hline C6ORF52 & 1,78 & $9,47 \mathrm{E}-04$ \\
\hline C7ORF43 & $-1,04$ & $1,15 \mathrm{E}-03$ \\
\hline C8ORF47 & 2,65 & $1,16 \mathrm{E}-03$ \\
\hline C8ORF88 & 2,35 & $2,18 \mathrm{E}-03$ \\
\hline C9ORF84 & 2,05 & $5,69 \mathrm{E}-03$ \\
\hline CA8 & $-2,14$ & $7,90 \mathrm{E}-03$ \\
\hline CACFD1 & $-1,08$ & $4,41 \mathrm{E}-03$ \\
\hline ACNA1C-AS1 & $-1,59$ & $6,73 \mathrm{E}-03$ \\
\hline CACNA1E & 3,38 & $1,85 \mathrm{E}-05$ \\
\hline CACNA1F & $-1,73$ & $1,57 \mathrm{E}-04$ \\
\hline CACNA1H & $-2,95$ & $1,31 \mathrm{E}-07$ \\
\hline CACNA2D2 & $-1,38$ & $2,98 \mathrm{E}-03$ \\
\hline CACNG6 & $-2,66$ & $1,01 \mathrm{E}-03$ \\
\hline CAMK2G & $-1,23$ & $2,30 \mathrm{E}-04$ \\
\hline CAMSAP2 & $-1,45$ & $6,25 \mathrm{E}-03$ \\
\hline CAND1 & 1,12 & $2,61 \mathrm{E}-06$ \\
\hline CAPN10 & $-1,00$ & $1,63 \mathrm{E}-06$ \\
\hline CAPN10-AS1 & $-1,12$ & $6,92 \mathrm{E}-03$ \\
\hline CAPN5 & $-1,83$ & $1,53 \mathrm{E}-04$ \\
\hline CARF & $-1,16$ & $2,11 \mathrm{E}-04$ \\
\hline CASP1P2 & $-2,08$ & $5,64 \mathrm{E}-03$ \\
\hline CASP3 & 1,44 & $1,68 \mathrm{E}-04$ \\
\hline CASP3P1 & 1,48 & $7,37 \mathrm{E}-03$ \\
\hline CASP6 & 1,23 & $8,47 \mathrm{E}-13$ \\
\hline CAT & $-1,39$ & $1,52 \mathrm{E}-06$ \\
\hline CATSPER2 & $-2,07$ & $1,50 \mathrm{E}-08$ \\
\hline CBX3P1 & 1,05 & $5,31 \mathrm{E}-03$ \\
\hline
\end{tabular}

\begin{tabular}{|c|c|c|}
\hline CBX3P5 & 1,83 & $1,81 \mathrm{E}-04$ \\
\hline CBX3P9 & 1,32 & $5,93 \mathrm{E}-06$ \\
\hline CBX4 & $-1,54$ & $1,03 \mathrm{E}-04$ \\
\hline CBX5P1 & 1,79 & $5,85 \mathrm{E}-04$ \\
\hline CBX8 & $-1,00$ & $2,26 \mathrm{E}-03$ \\
\hline CBY1 & $-1,13$ & $1,79 \mathrm{E}-03$ \\
\hline CCDC101 & $-1,54$ & $1,03 \mathrm{E}-18$ \\
\hline CCDC106 & $-1,10$ & $5,38 \mathrm{E}-03$ \\
\hline CCDC11 & 1,82 & $9,87 \mathrm{E}-07$ \\
\hline CCDC121 & $-1,65$ & $1,46 \mathrm{E}-03$ \\
\hline $\mathrm{CCDC13}$ & $-1,59$ & $7,33 \mathrm{E}-04$ \\
\hline CCDC130 & $-1,04$ & 1,64E-04 \\
\hline CCDC136 & 2,14 & $1,42 \mathrm{E}-07$ \\
\hline CCDC138 & 1,60 & $6,18 \mathrm{E}-07$ \\
\hline CCDC147-AS1 & $-1,20$ & $6,96 \mathrm{E}-03$ \\
\hline CCDC153 & $-2,01$ & $2,56 \mathrm{E}-05$ \\
\hline CCDC162P & $-2,71$ & $3,85 \mathrm{E}-05$ \\
\hline CCDC183 & $-1,62$ & $7,26 \mathrm{E}-03$ \\
\hline CCDC183-AS1 & $-1,55$ & $8,71 \mathrm{E}-06$ \\
\hline CCDC57 & $-1,01$ & $9,26 \mathrm{E}-05$ \\
\hline CCDC58P3 & 1,66 & $2,52 \mathrm{E}-06$ \\
\hline CCDC6 & 1,16 & $3,40 \mathrm{E}-10$ \\
\hline CCDC64B & 2,90 & $1,89 \mathrm{E}-05$ \\
\hline CCDC69 & $-1,07$ & $4,27 \mathrm{E}-09$ \\
\hline CCDC70 & 2,55 & $1,22 \mathrm{E}-04$ \\
\hline CCDC75P1 & 1,78 & $8,88 \mathrm{E}-07$ \\
\hline CCDC77 & 1,25 & $7,82 \mathrm{E}-04$ \\
\hline CCDC78 & $-1,33$ & $1,49 \mathrm{E}-08$ \\
\hline CCDC92 & $-1,27$ & $6,64 \mathrm{E}-09$ \\
\hline CCDC96 & $-1,83$ & $7,14 \mathrm{E}-08$ \\
\hline CCL1 & 2,11 & $3,06 \mathrm{E}-05$ \\
\hline CLL15 & 3,24 & $5,09 \mathrm{E}-05$ \\
\hline CCL17 & 1,99 & $2,67 \mathrm{E}-03$ \\
\hline CCL19 & 2,26 & $5,94 \mathrm{E}-03$ \\
\hline $\mathrm{CCL} 2$ & $-1,95$ & $1,20 \mathrm{E}-03$ \\
\hline CCNB3 & 1,43 & $5,83 \mathrm{E}-03$ \\
\hline CCND3 & 1,32 & $3,74 \mathrm{E}-03$ \\
\hline $\mathrm{CCNH}$ & 1,09 & $1,46 \mathrm{E}-07$ \\
\hline CCNI2 & $-1,53$ & $4,02 \mathrm{E}-03$ \\
\hline CCNL1 & $-1,08$ & $3,41 \mathrm{E}-03$ \\
\hline CCNT2-AS1 & 1,46 & $1,90 \mathrm{E}-04$ \\
\hline CCPG1 & $-1,78$ & $1,85 \mathrm{E}-04$ \\
\hline CCR12P & 1,87 & $6,10 \mathrm{E}-04$ \\
\hline CCR3 & $-1,20$ & $6,02 \mathrm{E}-03$ \\
\hline $\mathrm{CCS}$ & $-1,37$ & $1,55 \mathrm{E}-10$ \\
\hline СCT5 & 1,22 & $1,39 \mathrm{E}-03$ \\
\hline CCT5P1 & 1,34 & $4,89 \mathrm{E}-03$ \\
\hline ССТ5Р2 & 1,33 & $6,08 \mathrm{E}-03$ \\
\hline ССТ6Р2 & 1,63 & 1,11E-05 \\
\hline ССТ7P1 & 1,41 & $2,33 \mathrm{E}-10$ \\
\hline ССT7P2 & 1,44 & $1,01 \mathrm{E}-08$ \\
\hline ССТ8P1 & 1,54 & $1,10 \mathrm{E}-05$ \\
\hline CD19 & $-1,73$ & $1,13 \mathrm{E}-12$ \\
\hline CD248 & $-1,43$ & $2,14 \mathrm{E}-05$ \\
\hline CD320 & 1,24 & $5,16 \mathrm{E}-03$ \\
\hline CD34 & $-1,73$ & $6,87 \mathrm{E}-03$ \\
\hline CD37 & $-1,88$ & $9,26 \mathrm{E}-16$ \\
\hline CD3EAP & 1,78 & $2,69 \mathrm{E}-06$ \\
\hline CD48 & $-1,13$ & $1,06 \mathrm{E}-14$ \\
\hline CD59 & $-2,07$ & $3,40 \mathrm{E}-04$ \\
\hline $\mathrm{CDC} 123$ & 1,60 & $6,10 \mathrm{E}-05$ \\
\hline CDC25B & $-1,24$ & $9,08 \mathrm{E}-04$ \\
\hline $\mathrm{CDC27}$ & 1,16 & $4,54 \mathrm{E}-08$ \\
\hline CDC27P1 & 1,35 & $6,49 \mathrm{E}-06$ \\
\hline $\mathrm{CDC} 42 \mathrm{BPB}$ & $-1,70$ & $1,17 \mathrm{E}-03$ \\
\hline CDC42BPG & $-1,94$ & $1,62 \mathrm{E}-08$ \\
\hline CDHR1 & $-3,60$ & $2,09 \mathrm{E}-12$ \\
\hline CDK7 & 1,28 & $6,44 \mathrm{E}-06$ \\
\hline CDKAL1 & 1,58 & $1,35 \mathrm{E}-12$ \\
\hline CDKN2D & 1,15 & $9,89 \mathrm{E}-03$ \\
\hline CDRT4 & $-1,57$ & $4,85 \mathrm{E}-03$ \\
\hline CEACAM19 & 1,61 & $1,44 \mathrm{E}-04$ \\
\hline CEACAM4 & $-2,68$ & $3,14 \mathrm{E}-04$ \\
\hline CEBPD & $-1,52$ & $1,84 \mathrm{E}-03$ \\
\hline CEBPZ & 1,26 & $2,81 \mathrm{E}-06$ \\
\hline CECR5 & $-1,70$ & $3,06 \mathrm{E}-07$ \\
\hline
\end{tabular}

\begin{tabular}{|c|c|c|}
\hline CECR7 & $-1,28$ & $8,81 \mathrm{E}-03$ \\
\hline CELSR2 & $-1,48$ & $6,98 \mathrm{E}-05$ \\
\hline CEP164P1 & $-2,00$ & $5,65 \mathrm{E}-05$ \\
\hline CEP57L1P1 & 1,82 & $3,41 \mathrm{E}-06$ \\
\hline CEP68 & $-1,10$ & $1,76 \mathrm{E}-03$ \\
\hline CEP97 & 1,19 & $1,25 \mathrm{E}-03$ \\
\hline CFP & $-1,46$ & $8,67 \mathrm{E}-13$ \\
\hline CGN & 1,92 & $7,70 \mathrm{E}-11$ \\
\hline CGNL1 & 2,22 & $6,90 \mathrm{E}-03$ \\
\hline $\mathrm{CH} 17-132 \mathrm{~F} 21,1$ & $-2,06$ & 1,04E-03 \\
\hline CHAC1 & 2,15 & $1,39 \mathrm{E}-09$ \\
\hline CHCHD4 & 1,20 & $5,24 \mathrm{E}-06$ \\
\hline CHD9 & $-1,11$ & $3,86 \mathrm{E}-04$ \\
\hline $\mathrm{CHDH}$ & $-2,25$ & $3,94 \mathrm{E}-03$ \\
\hline CHKB & $-1,71$ & $1,27 \mathrm{E}-07$ \\
\hline CHN2 & $-1,25$ & $1,14 \mathrm{E}-06$ \\
\hline CHRNA10 & 1,28 & $1,02 \mathrm{E}-06$ \\
\hline CHRNA7 & $-2,25$ & $4,95 \mathrm{E}-03$ \\
\hline CHRNB1 & 1,18 & $1,54 \mathrm{E}-03$ \\
\hline CHST15 & $-1,77$ & $8,78 \mathrm{E}-07$ \\
\hline CHST7 & $-1,83$ & $9,96 \mathrm{E}-04$ \\
\hline CIAPIN1P & 1,06 & $5,33 \mathrm{E}-04$ \\
\hline ClB3 & 3,22 & $2,06 \mathrm{E}-05$ \\
\hline $\mathrm{CIC}$ & $-1,13$ & $2,55 \mathrm{E}-09$ \\
\hline CICP14 & $-1,13$ & $1,06 \mathrm{E}-03$ \\
\hline CILP2 & 2,21 & $2,51 \mathrm{E}-06$ \\
\hline CIPC & $-1,72$ & $1,16 \mathrm{E}-04$ \\
\hline CIRBP & $-1,25$ & $1,53 \mathrm{E}-04$ \\
\hline CISD1P1 & 2,15 & $2,23 \mathrm{E}-04$ \\
\hline CITED4 & $-1,61$ & $4,25 \mathrm{E}-03$ \\
\hline CITF22-1A6,3 & $-1,10$ & $1,15 \mathrm{E}-03$ \\
\hline CKAP4 & $-1,54$ & 4,11E-07 \\
\hline CKMT2 & 2,46 & $2,05 \mathrm{E}-03$ \\
\hline CLCN2 & 1,37 & 4,41E-05 \\
\hline CLCN5 & $-1,27$ & $8,11 \mathrm{E}-03$ \\
\hline CLCN6 & $-1,47$ & $2,59 \mathrm{E}-05$ \\
\hline CLCN7 & $-1,63$ & $8,27 \mathrm{E}-04$ \\
\hline CLDN23 & $-1,94$ & $6,62 E-03$ \\
\hline CLDND2 & 1,53 & $5,79 \mathrm{E}-04$ \\
\hline CLEC11A & $-1,18$ & $7,48 \mathrm{E}-07$ \\
\hline CLEC2B & $-1,22$ & 4,74E-11 \\
\hline CLEC4C & $-2,56$ & $1,65 \mathrm{E}-03$ \\
\hline CLEC5A & 1,84 & $1,22 \mathrm{E}-05$ \\
\hline CLIP2 & $-1,96$ & 9,11E-04 \\
\hline CLN8 & $-1,75$ & $4,08 \mathrm{E}-06$ \\
\hline CLNS1AP1 & 1,21 & $1,75 \mathrm{E}-10$ \\
\hline CLUAP1 & $-1,51$ & $5,57 \mathrm{E}-05$ \\
\hline CLYBL & $-1,21$ & $2,25 \mathrm{E}-04$ \\
\hline CMAS & 1,17 & $1,24 \mathrm{E}-03$ \\
\hline CMTM2 & 1,82 & $1,33 \mathrm{E}-03$ \\
\hline CMTM5 & 2,45 & $1,86 \mathrm{E}-03$ \\
\hline CMTM8 & $-1,84$ & $9,78 \mathrm{E}-06$ \\
\hline CNBD2 & 1,42 & $5,41 \mathrm{E}-03$ \\
\hline CNGA1 & 2,00 & $3,04 \mathrm{E}-03$ \\
\hline CNN2P8 & 1,60 & $6,79 \mathrm{E}-03$ \\
\hline CNNM4 & $-1,16$ & $1,86 \mathrm{E}-03$ \\
\hline CNR1 & $-1,94$ & $1,41 \mathrm{E}-03$ \\
\hline CNRIP1 & $-1,53$ & $4,77 \mathrm{E}-03$ \\
\hline CNTF & 2,01 & $6,80 \mathrm{E}-08$ \\
\hline COBL & 2,78 & $2,32 \mathrm{E}-05$ \\
\hline COL18A1 & $-1,59$ & $1,40 \mathrm{E}-03$ \\
\hline COL23A1 & $-2,64$ & $2,22 E-05$ \\
\hline COL24A1 & $-2,36$ & $8,88 \mathrm{E}-04$ \\
\hline COL28A1 & $-2,33$ & $4,41 \mathrm{E}-03$ \\
\hline COL3A1 & 2,27 & $5,74 \mathrm{E}-03$ \\
\hline COL4A2 & $-2,69$ & $9,94 \mathrm{E}-05$ \\
\hline COL4A3BP & $-2,11$ & $1,52 \mathrm{E}-04$ \\
\hline COL5A1 & $-2,22$ & $5,94 \mathrm{E}-04$ \\
\hline COL6A4P2 & $-1,55$ & $9,34 \mathrm{E}-03$ \\
\hline COL7A1 & 2,01 & $4,05 E-13$ \\
\hline COL9A3 & $-1,86$ & $8,70 \mathrm{E}-06$ \\
\hline COLGALT1 & $-1,46$ & $1,62 \mathrm{E}-03$ \\
\hline COMMD10 & $-1,32$ & $2,67 \mathrm{E}-04$ \\
\hline CORIN & 2,02 & $3,06 \mathrm{E}-03$ \\
\hline COX20P2 & 1,57 & $5,83 \mathrm{E}-03$ \\
\hline CPA3 & $-1,62$ & $3,36 \mathrm{E}-07$ \\
\hline
\end{tabular}




\begin{tabular}{|c|c|c|}
\hline CPAMD8 & $-3,15$ & $2,11 \mathrm{E}-11$ \\
\hline CPED1 & $-1,93$ & $6,44 \mathrm{E}-03$ \\
\hline CPNE2 & $-1,42$ & $5,76 \mathrm{E}-04$ \\
\hline CPNE7 & $-3,11$ & $9,90 \mathrm{E}-19$ \\
\hline CPSF3 & 1,29 & $3,02 \mathrm{E}-03$ \\
\hline CPT1A & $-1,29$ & $1,82 \mathrm{E}-03$ \\
\hline CPT1C & 2,84 & $2,08 \mathrm{E}-05$ \\
\hline CRABP2 & 1,77 & $1,49 \mathrm{E}-08$ \\
\hline CRB3 & $-1,83$ & $6,11 \mathrm{E}-03$ \\
\hline CRHBP & $-4,06$ & $6,68 \mathrm{E}-08$ \\
\hline CRIPAK & $-1,68$ & $1,21 \mathrm{E}-06$ \\
\hline CRISPLD2 & 1,84 & $4,62 \mathrm{E}-08$ \\
\hline CROCC & $-1,23$ & $2,87 \mathrm{E}-03$ \\
\hline CROCCP2 & $-1,02$ & $2,04 \mathrm{E}-03$ \\
\hline CRTC1 & $-1,74$ & $1,12 \mathrm{E}-18$ \\
\hline CRY2 & $-1,18$ & $1,32 \mathrm{E}-06$ \\
\hline CRYBG3 & $-1,45$ & $8,05 \mathrm{E}-03$ \\
\hline CRYGS & $-1,22$ & $1,28 \mathrm{E}-03$ \\
\hline CSAD & $-1,37$ & $8,77 \mathrm{E}-04$ \\
\hline CSF1 & 1,09 & $8,91 \mathrm{E}-03$ \\
\hline CSF3 & 5,05 & $1,39 \mathrm{E}-18$ \\
\hline CSGALNACT2 & $-1,14$ & $9,50 \mathrm{E}-03$ \\
\hline CSNK1G2 & $-1,34$ & $3,05 \mathrm{E}-04$ \\
\hline CSNK2A3 & 1,08 & $7,82 \mathrm{E}-04$ \\
\hline CTA-211A9,5 & $-1,60$ & $9,09 E-05$ \\
\hline CTA-217C2,1 & $-1,77$ & $1,92 \mathrm{E}-05$ \\
\hline CTA-292E 10,6 & $-2,30$ & $1,17 \mathrm{E}-03$ \\
\hline CTA-293F 17,1 & $-2,66$ & $7,15 \mathrm{E}-04$ \\
\hline CTA-373H7,7 & $-2,20$ & $4,00 \mathrm{E}-05$ \\
\hline CTA-384D8,35 & 2,17 & $1,00 \mathrm{E}-05$ \\
\hline CTB-118N6,3 & $-2,08$ & $2,30 \mathrm{E}-04$ \\
\hline CTB-138E5,1 & $-2,16$ & $8,54 \mathrm{E}-03$ \\
\hline CTB-167B5,1 & 1,25 & $1,22 \mathrm{E}-04$ \\
\hline CTB-187L3,1 & 1,33 & $1,40 \mathrm{E}-03$ \\
\hline CTB-25B13,12 & $-1,22$ & $1,80 \mathrm{E}-04$ \\
\hline CTB-36H16,2 & $-1,55$ & $7,84 \mathrm{E}-04$ \\
\hline CTB-39G8,3 & $-1,16$ & $8,65 \mathrm{E}-03$ \\
\hline CTB-52|2,4 & 1,28 & $2,08 \mathrm{E}-05$ \\
\hline CTB-83J4,2 & $-1,91$ & $6,71 \mathrm{E}-03$ \\
\hline CTBP2 & $-2,23$ & $5,32 \mathrm{E}-05$ \\
\hline CTBP2P4 & $-2,50$ & $2,17 \mathrm{E}-05$ \\
\hline СТВР2Р8 & $-2,19$ & $1,86 \mathrm{E}-05$ \\
\hline CTBS & $-1,14$ & $5,59 \mathrm{E}-03$ \\
\hline СТC-205M6,5 & $-1,89$ & $1,05 \mathrm{E}-04$ \\
\hline CTC-228N24,3 & $-1,44$ & $1,49 \mathrm{E}-05$ \\
\hline CTC-248019,1 & 2,25 & $5,36 \mathrm{E}-03$ \\
\hline CTC-277H 1,7 & 1,64 & $1,43 \mathrm{E}-04$ \\
\hline CTC-281F24,1 & $-1,88$ & $1,29 \mathrm{E}-03$ \\
\hline CTC-297N7,5 & $-1,84$ & $8,22 \mathrm{E}-03$ \\
\hline CTC-308K20,1 & $-2,01$ & $3,64 \mathrm{E}-03$ \\
\hline CTC-359D24,3 & 1,11 & $2,92 \mathrm{E}-03$ \\
\hline CTC-378H 22,1 & $-2,21$ & $4,72 \mathrm{E}-06$ \\
\hline CTC-429P9,2 & $-1,47$ & $4,10 \mathrm{E}-03$ \\
\hline CTC-444N24,6 & $-2,09$ & $3,83 \mathrm{E}-03$ \\
\hline CTC-453G23,5 & 1,31 & $8,62 \mathrm{E}-03$ \\
\hline CTC-457L16,2 & $-3,70$ & $1,65 \mathrm{E}-06$ \\
\hline СТC-487M23,5 & 2,05 & $1,47 \mathrm{E}-03$ \\
\hline CTC-524C5,2 & $-1,37$ & $3,11 \mathrm{E}-04$ \\
\hline CTD-2003C8,2 & $-2,26$ & $5,72 \mathrm{E}-03$ \\
\hline CTD-2006C1,6 & 2,39 & $1,98 \mathrm{E}-03$ \\
\hline CTD-2023N9,1 & 2,17 & $8,19 \mathrm{E}-03$ \\
\hline CTD-2035E11,4 & $-2,22$ & $3,94 \mathrm{E}-05$ \\
\hline CTD-2037K23,2 & $-1,73$ & $2,56 \mathrm{E}-07$ \\
\hline CTD-2089024,2 & $-1,27$ & $4,71 \mathrm{E}-08$ \\
\hline CTD-2124B8,2 & 1,45 & $8,15 \mathrm{E}-03$ \\
\hline CTD-2132N18,4 & $-2,18$ & $7,71 \mathrm{E}-03$ \\
\hline CTD-2162K18,4 & 1,32 & $6,09 \mathrm{E}-03$ \\
\hline CTD-2184D3,5 & $-2,46$ & $1,34 \mathrm{E}-03$ \\
\hline CTD- & & \\
\hline 2192J16,15 & $-1,26$ & $7,19 \mathrm{E}-03$ \\
\hline $\begin{array}{r}\text { CTD- } \\
2192 J 16,22\end{array}$ & $-1,14$ & $2,66 \mathrm{E}-03$ \\
\hline CTD-2196E14,6 & $-1,64$ & $1,29 \mathrm{E}-03$ \\
\hline CTD-2201E18,5 & $-2,24$ & $2,95 \mathrm{E}-03$ \\
\hline CTD-2256P15,4 & 1,00 & $7,83 \mathrm{E}-03$ \\
\hline CTD-2265021,7 & $-1,81$ & $3,98 \mathrm{E}-04$ \\
\hline
\end{tabular}

\begin{tabular}{|c|c|c|} 
CTD-2267D19,2 & 1,76 & $1,24 \mathrm{E}-04$ \\
\hline CTD-2284J15,1 & $-2,46$ & $3,74 \mathrm{E}-04$ \\
\hline CTD-2287016,5 & $-2,22$ & $4,43 \mathrm{E}-05$ \\
\hline CTD-2291D10,4 & 2,17 & $8,23 \mathrm{E}-03$ \\
\hline
\end{tabular}

\begin{tabular}{|r|c|c|}
\hline CTD-2291D10,4 & 2,17 & $8,23 \mathrm{E}-03$ \\
\hline CTD- & & \\
\end{tabular}

\begin{tabular}{r|r|r|}
\hline $2292 \mathrm{M} 16,8$ & $-1,97$ & $1,76 \mathrm{E}-03$ \\
\hline CTD-2313J17,3 & $-2,10$ & $9,27 \mathrm{E}-03$ \\
\hline CTD 23191121 & -290 & $4,04 \mathrm{E}-05$ \\
\hline
\end{tabular}

\begin{tabular}{|c|c|c|}
\hline CTD-2319112,1 & $-2,90$ & $4,04 \mathrm{E}-05$ \\
\hline CTD-23912, & -316 & $2,04 \mathrm{E}-05$ \\
\hline
\end{tabular}

\begin{tabular}{|c|c|c|}
\hline CTD-2319112,2 & $-3,16$ & $2,04 \mathrm{E}-05$ \\
\hline
\end{tabular}

\begin{tabular}{|c|c|c|}
\hline CTD-2319112,4 & $-2,15$ & $2,13 \mathrm{E}-04$ \\
\hline CTD-232021, & 2,03 & $7,5 E-05$ \\
\hline
\end{tabular}

\begin{tabular}{|c|c|c|}
\hline CTD-2320J21,1 & 2,03 & $7,51 \mathrm{E}-05$ \\
\hline
\end{tabular}

\begin{tabular}{|c|c|c|}
\hline CTD-2325K12,1 & 1,07 & $1,05 E-05$ \\
\hline CTD-2328D & 2,87 & $1,28 E$ \\
\hline
\end{tabular}

\begin{tabular}{|c|c|c|}
\hline CTD-2328D6,1 & 2,87 & $1,28 \mathrm{E}-04$ \\
\hline CTD-233602,1 & $-2,09$ & $4,65 \mathrm{E}-06$ \\
\hline CTD-2366F & 1,15 & $6,43 \mathrm{E}-04$ \\
\hline
\end{tabular}

\begin{tabular}{l|l|l}
\hline CTD-2366F13,1 & 1,15 & $6,43 \mathrm{E}-04$ \\
\hline
\end{tabular}

\begin{tabular}{|l|l|l|}
\hline CTD-2380F24,1 & $-2,55$ & $1,78 \mathrm{E}-03$ \\
\hline
\end{tabular}

\begin{tabular}{|r|r|r|}
\hline CTD- & & \\
$2517 \mathrm{M} 22,14$ & $-1,94$ & $4,38 \mathrm{E}-04$ \\
\hline
\end{tabular}

\begin{tabular}{|r|r|r|}
\hline CTD-2517010,6 & $-2,71$ & $3,03 E-04$ \\
\hline CTD-2522A2, & 1,51 & $9,53 E-03$ \\
\hline
\end{tabular}

\begin{tabular}{|c|c|c|}
\hline CTD-2526A2,6 & 1,51 & $9,53 \mathrm{E}-03$ \\
\hline CTD-253719,12 & $-1,03$ & $1,22 \mathrm{E}-04$ \\
\hline
\end{tabular}

\begin{tabular}{|c|c|c|}
\hline CTD-2538A21,1 & 1,13 & $7,49 \mathrm{E}-05$ \\
\hline
\end{tabular}

\begin{tabular}{l|l|l}
\hline CTD-2555A7,3 & $-1,22$ & $1,32 \mathrm{E}-03$ \\
\hline
\end{tabular}

\begin{tabular}{l|l|l}
\hline CTD-2561B21,5 & 2,06 & $2,34 \mathrm{E}-05$ \\
\hline CTD-257K13, & $-2,13$ & $2,73 E-09$ \\
\hline
\end{tabular}

\begin{tabular}{|c|c|c|}
\hline CTD-2575K13,6 & $-2,13$ & $2,73 \mathrm{E}-09$ \\
\hline CTD-2593A12.4 & 1,25 & $7,77 \mathrm{E}-03$ \\
\hline
\end{tabular}

\begin{tabular}{|r|c|c|}
\hline CTD-2593A12,4 & 1,25 & $7,77 \mathrm{E}-03$ \\
\hline CTD- & & $1,64 \mathrm{E}-03$ \\
\hline 2616J11,11 & 2,23 & \\
\hline
\end{tabular} CTD-

2619J13,14

\begin{tabular}{r|r|r} 
& $-1,51$ & $5,60 \mathrm{E}-04$ \\
\hline $\mathrm{CTD}-2619113,8$ & $-1,65$ & $3,78 \mathrm{E}-03$ \\
\hline
\end{tabular}

\begin{tabular}{|c|c|c|}
\hline CTD-2647E 9,3 & 3,21 & $6,00 \mathrm{E}-05$ \\
\hline
\end{tabular}

\begin{tabular}{|c|c|c|}
\hline CTD-3018017,3 & $-1,39$ & $2,27 \mathrm{E}-03$ \\
\hline
\end{tabular}

\begin{tabular}{|c|c|c|}
\hline CTD-3035D6,2 & 2,29 & $3,38 \mathrm{E}-03$ \\
\hline
\end{tabular}

\begin{tabular}{|c|c|c|}
\hline CTD-3065J16,6 & $-2,01$ & $5,51 \mathrm{E}-03$ \\
\hline
\end{tabular}

\begin{tabular}{|c|c|c|}
\hline CTD-307407,5 & $-1,31$ & $2,03 \mathrm{E}-03$ \\
\hline CTD-3088G 3 & $-1,77$ & $1,89 \mathrm{E}-05$ \\
\hline
\end{tabular}

\begin{tabular}{|c|c|c|}
\hline CTD-3092A11,1 & $-1,18$ & $4,72 \mathrm{E}-04$ \\
\hline
\end{tabular}

\begin{tabular}{|c|c|c|}
\hline CTD-3092A11,2 & $-1,36$ & $3,11 \mathrm{E}-04$ \\
\hline CTD
\end{tabular}

\begin{tabular}{|c|c|c|}
\hline CTD-3131K8,2 & $-1,35$ & $1,75 \mathrm{E}-03$ \\
\hline
\end{tabular}

\begin{tabular}{|c|c|c|}
\hline $\begin{array}{r}\text { CTD- } \\
3232 \mathrm{M} 19,2\end{array}$ & $-1,10$ & $1,94 \mathrm{E}-04$ \\
\hline CTDP1 & 1,31 & $2,14 \mathrm{E}-14$ \\
\hline CTGLF12P & $-1,96$ & $2,18 \mathrm{E}-03$ \\
\hline CTH & 1,91 & $1,10 \mathrm{E}-08$ \\
\hline CTIF & $-1,77$ & $2,39 \mathrm{E}-04$ \\
\hline CTNND1 & $-1,33$ & $6,69 \mathrm{E}-03$ \\
\hline CTNND2 & $-2,27$ & $5,11 \mathrm{E}-03$ \\
\hline CTNS & $-1,17$ & $6,27 \mathrm{E}-03$ \\
\hline CTSA & $-1,85$ & $9,36 \mathrm{E}-05$ \\
\hline CTSL & $-2,06$ & $8,89 \mathrm{E}-04$ \\
\hline CTSLP1 & $-2,05$ & $2,04 \mathrm{E}-03$ \\
\hline CTSO & $-1,84$ & $2,38 \mathrm{E}-09$ \\
\hline CTSW & 1,53 & $1,93 \mathrm{E}-03$ \\
\hline CUL9 & $-1,13$ & $1,36 \mathrm{E}-08$ \\
\hline CUX1 & $-2,07$ & $1,36 \mathrm{E}-10$ \\
\hline CXCL11 & 3,98 & $6,66 \mathrm{E}-12$ \\
\hline CXCL16 & $-1,90$ & $2,78 \mathrm{E}-03$ \\
\hline CXXC4 & $-2,72$ & $8,19 \mathrm{E}-04$ \\
\hline CYB561D1 & $-1,38$ & $5,83 \mathrm{E}-06$ \\
\hline CYB5B & 1,17 & $5,06 \mathrm{E}-06$ \\
\hline CYB5R1 & $-1,60$ & $3,07 \mathrm{E}-05$ \\
\hline CYBA & $-1,63$ & $2,10 \mathrm{E}-09$ \\
\hline CYCS & 1,37 & $1,25 \mathrm{E}-15$ \\
\hline CYCSP45 & 1,71 & $3,41 \mathrm{E}-11$ \\
\hline CYCSP55 & 1,14 & $3,60 \mathrm{E}-05$ \\
\hline CYFIP2 & 1,44 & $4,46 \mathrm{E}-05$ \\
\hline CYHR1 & $-1,28$ & $2,81 \mathrm{E}-06$ \\
\hline CYP11A1 & 1,89 & $5,67 \mathrm{E}-04$ \\
\hline CYP2C18 & 3,58 & $4,43 \mathrm{E}-06$ \\
\hline CYP2D7P & $-1,31$ & $4,07 \mathrm{E}-03$ \\
\hline CYP2E1 & $-2,14$ & $4,46 \mathrm{E}-05$ \\
\hline CYP2F2P & $-2,33$ & $4,39 \mathrm{E}-03$ \\
\hline CYP4F12 & $-3,18$ & $3,00 \mathrm{E}-05$ \\
\hline CYTH1 & $-1,03$ & $7,00 \mathrm{E}-08$ \\
\hline CYTIP & 1,20 & $3,14 \mathrm{E}-06$ \\
\hline & $-1,93$ & $2,37 \mathrm{E}-08$ \\
\hline
\end{tabular}

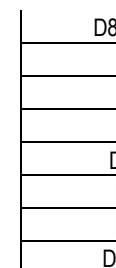

D87007, \begin{tabular}{l|l|l|} 
DAG1 & $-1,33$ & $2,19 \mathrm{E}-04$ \\
\hline & $8,29 \mathrm{E}-07$ \\
\hline
\end{tabular} \begin{tabular}{r|c|c|} 
DAK & $-1,65$ & $1,66 \mathrm{E}-04$ \\
\hline DANCR & 1,31 & $1,47 \mathrm{E}-03$ \\
\hline
\end{tabular} \begin{tabular}{|c|c|c|} 
DAPK1 & $-3,17$ & $2,57 \mathrm{E}-08$ \\
\hline
\end{tabular}

\begin{tabular}{|c|c|c|}
\hline DAPP1 & 1,50 & $4,63 \mathrm{E}-04$ \\
\hline
\end{tabular}

\begin{tabular}{c|c|c|}
\hline DAZAP2 & $-1,12$ & $3,57 \mathrm{E}-16$ \\
\hline DBF4B & 1,05 & $2,88 \mathrm{E}-06$ \\
\hline
\end{tabular}

\begin{tabular}{c|c|c|}
\hline DBH & $-2,47$ & $2,46 \mathrm{E}-06$ \\
\hline
\end{tabular}

\begin{tabular}{c|c|c|} 
DBH-AS1 & $-2,98$ & $2,24 \mathrm{E}-12$ \\
\hline
\end{tabular}

\begin{tabular}{|c|c|c|} 
DCBLD1 & $-1,30$ & $7,66 \mathrm{E}-05$ \\
\hline
\end{tabular}

\begin{tabular}{|c|c|c|} 
DCDC2 & $-2,40$ & $3,03 \mathrm{E}-03$ \\
\hline
\end{tabular}

\begin{tabular}{|c|c|c|}
\hline DCLRE1B & 1,09 & $7,62 \mathrm{E}-03$ \\
\hline DCUN1D5 & 1,61 & $8,01 \mathrm{E}-05$ \\
\hline DDT3 & $-1,14$ & $3,44 \mathrm{E}-07$ \\
\hline
\end{tabular}

\begin{tabular}{l|l|l|} 
DDIT3 & $-1,14$ & $3,44 \mathrm{E}-07$ \\
\hline
\end{tabular}

\begin{tabular}{c|c|c} 
DDN & 2,23 & $2,33 \mathrm{E}-05$ \\
\hline
\end{tabular}

\begin{tabular}{|r|c|c|}
\hline DDX11 & 1,01 & $9,53 \mathrm{E}-04$ \\
\hline $\mathrm{DDX} 1112$ & $-1,33$ & $291 \mathrm{E}-04$ \\
\hline
\end{tabular}

\begin{tabular}{l|l|l} 
DDX17 & $-1,18$ & $1,12 \mathrm{E}-04$ \\
\hline
\end{tabular}

\begin{tabular}{c|c|c|}
\hline DDX21 & 1,56 & $6,81 \mathrm{E}-07$ \\
\hline
\end{tabular}

\begin{tabular}{l|l|l|}
\hline DDX43 & $-1,29$ & $6,52 \mathrm{E}-03$ \\
\hline
\end{tabular}

\begin{tabular}{|c|c|c|}
\hline DDX52 & 1,20 & $4,56 \mathrm{E}-05$ \\
\hline
\end{tabular}

\begin{tabular}{|c|c|c|}
\hline DDX60L & $-1,35$ & $2,96 \mathrm{E}-05$ \\
\hline
\end{tabular}

\begin{tabular}{|c|c|c|}
\hline DEDD2 & $-1,46$ & $3,72 \mathrm{E}-04$ \\
\hline
\end{tabular}

\begin{tabular}{l|l|l|}
\hline DENND6A & $-1,06$ & $1,52 \mathrm{E}-09$ \\
\hline
\end{tabular}

\begin{tabular}{r|r|r|} 
DET1 & $-1,25$ & $5,90 \mathrm{E}-04$ \\
\hline DGAT1 & $-1,09$ & $1,48 \mathrm{E}-06$ \\
\hline
\end{tabular}

\begin{tabular}{l|l|l|}
\hline DGCR2 & $-1,09$ & $1,06 \mathrm{E}-13$ \\
\hline
\end{tabular}

\begin{tabular}{|c|c|c|}
\hline DGCR6 & $-1,07$ & $1,34 \mathrm{E}-03$ \\
\hline
\end{tabular}

\begin{tabular}{r|c|c|}
\hline DGKI & 4,44 & $5,84 \mathrm{E}-14$ \\
\hline DGKZ & $-1,37$ & $5,76 \mathrm{E}-06$ \\
\hline
\end{tabular}

\begin{tabular}{|c|c|c|}
\hline DHCR7 & 1,17 & $2,43 \mathrm{E}-05$ \\
\hline
\end{tabular}

\begin{tabular}{l|c|c|} 
DHRS1 & $-1,07$ & $3,68 \mathrm{E}-07$ \\
\hline
\end{tabular}

\begin{tabular}{l|c|c|} 
DHRS11 & 1,12 & $9,82 \mathrm{E}-03$ \\
\hline
\end{tabular}

\begin{tabular}{l|l|l|} 
DHRS12 & $-1,15$ & $3,24 \mathrm{E}-03$ \\
\hline
\end{tabular}

\begin{tabular}{|c|c|c|}
\hline DHX33 & 1,08 & $4,88 \mathrm{E}-07$ \\
\hline
\end{tabular}

\begin{tabular}{c|c|c|}
\hline DHX9P1 & 1,14 & $3,90 E-06$ \\
\hline
\end{tabular}

\begin{tabular}{|c|c|c|}
\hline DIAPH1 & 1,03 & $3,57 \mathrm{E}-13$ \\
\hline
\end{tabular}

\begin{tabular}{|r|c|c|}
\hline DICER1-AS1 & $-1,23$ & $4,46 \mathrm{E}-03$ \\
\hline DIP2A & $-1,08$ & $3,25 \mathrm{E}-04$ \\
\hline DIP2C & $-1,41$ & $9,84 \mathrm{E}-03$ \\
\hline
\end{tabular}

\begin{tabular}{l|l|l|}
\hline DIP2C & $-1,41$ & $9,84 \mathrm{E}-03$ \\
\hline
\end{tabular}

\begin{tabular}{|c|c|c|} 
DISC1 & $-1,82$ & $2,97 \mathrm{E}-05$ \\
\hline DKC1 & 1,13 & $1,76 \mathrm{E}-06$ \\
\hline
\end{tabular}

\begin{tabular}{l|l|l} 
DKK3 & $-1,82$ & $4,76 \mathrm{E}-08$ \\
\hline
\end{tabular}

\begin{tabular}{c|c|c} 
DLAT & 1,02 & $4,72 \mathrm{E}-03$ \\
\hline
\end{tabular}

\begin{tabular}{l|l|l|}
\hline DLEU7 & $-2,97$ & $3,01 \mathrm{E}-05$ \\
\hline
\end{tabular}

\begin{tabular}{|c|c|c|}
\hline DLEU7-AS1 & $-2,57$ & $1,28 \mathrm{E}-03$ \\
\hline DLG5 & $-1,71$ & $1,71 \mathrm{E}-08$ \\
\hline DLL1 & $-2,89$ & $7,96 \mathrm{E}-09$ \\
\hline DMBX1 & $-2,21$ & $5,55 \mathrm{E}-03$ \\
\hline $\mathrm{DMD}$ & 1,75 & $9,41 \mathrm{E}-03$ \\
\hline DMRTA1 & 2,06 & $8,90 \mathrm{E}-03$ \\
\hline DMXL1 & $-1,19$ & $9,41 \mathrm{E}-03$ \\
\hline DMXL2 & $-2,63$ & $2,17 \mathrm{E}-05$ \\
\hline DNAAF3 & 2,27 & $5,74 \mathrm{E}-03$ \\
\hline DNAH14 & 1,58 & $2,44 \mathrm{E}-04$ \\
\hline DNAH2 & 1,83 & $8,30 \mathrm{E}-03$ \\
\hline DNAJA4 & 1,23 & $1,93 \mathrm{E}-12$ \\
\hline DNAJC12 & 2,44 & $2,36 \mathrm{E}-04$ \\
\hline DNAJC27-AS1 & $-3,15$ & $9,30 \mathrm{E}-05$ \\
\hline DNAJC3-AS1 & $-1,29$ & $5,85 \mathrm{E}-04$ \\
\hline DNASE1L1 & $-1,15$ & $5,81 \mathrm{E}-06$ \\
\hline DNASE1L2 & 1,20 & $4,45 \mathrm{E}-04$ \\
\hline DOCK5 & $-1,62$ & $8,74 \mathrm{E}-03$ \\
\hline DOHH & 1,22 & $4,66 \mathrm{E}-06$ \\
\hline DOK2 & 1,61 & $3,58 \mathrm{E}-26$ \\
\hline DOK4 & 1,87 & $2,86 \mathrm{E}-05$ \\
\hline DOPEY1 & $-1,18$ & $2,02 \mathrm{E}-07$ \\
\hline DPEP3 & $-2,31$ & $3,01 \mathrm{E}-04$ \\
\hline DPH1 & $-1,26$ & $1,32 \mathrm{E}-04$ \\
\hline DPH2 & 1,02 & $1,06 \mathrm{E}-06$ \\
\hline DPP7 & $-1,58$ & $9,81 \mathrm{E}-07$ \\
\hline DPRXP4 & $-2,23$ & $4,90 \mathrm{E}-03$ \\
\hline DPY19L2P2 & 1,24 & $3,05 \mathrm{E}-03$ \\
\hline DPYD & $-1,13$ & $7,47 \mathrm{E}-03$ \\
\hline
\end{tabular}

\begin{tabular}{|c|c|c|}
\hline DRD4 & $-2,09$ & $1,31 \mathrm{E}-03$ \\
\hline DSC2 & $-3,67$ & $4,18 \mathrm{E}-07$ \\
\hline DSCR9 & 1,48 & $9,86 \mathrm{E}-03$ \\
\hline DTNB & $-1,60$ & $7,56 \mathrm{E}-05$ \\
\hline DUOX1 & $-1,42$ & $9,33 \mathrm{E}-03$ \\
\hline DUSP1 & $-3,30$ & $7,40 \mathrm{E}-07$ \\
\hline DUSP28 & $-1,38$ & $2,61 \mathrm{E}-04$ \\
\hline DUTP6 & $-2,08$ & $2,34 \mathrm{E}-03$ \\
\hline DYRK4 & $-1,35$ & $2,46 \mathrm{E}-05$ \\
\hline DYSF & $-4,09$ & $4,09 \mathrm{E}-10$ \\
\hline ECE1 & 1,06 & $1,44 \mathrm{E}-07$ \\
\hline ECE2 & 1,67 & $2,94 \mathrm{E}-06$ \\
\hline ECM2 & 2,55 & $1,88 \mathrm{E}-03$ \\
\hline ECSCR & 1,94 & $5,01 \mathrm{E}-04$ \\
\hline EDA2R & 2,51 & $4,28 \mathrm{E}-08$ \\
\hline EDARADD & 1,06 & $1,78 \mathrm{E}-03$ \\
\hline EDEM1 & 1,09 & $6,11 \mathrm{E}-11$ \\
\hline EDN1 & 1,29 & $1,07 \mathrm{E}-03$ \\
\hline EED & 1,65 & $1,63 \mathrm{E}-12$ \\
\hline EFCAB11 & 1,66 & $2,21 \mathrm{E}-05$ \\
\hline EFHC1 & $-1,81$ & $4,11 \mathrm{E}-09$ \\
\hline EFHD2 & $-1,03$ & $1,71 \mathrm{E}-03$ \\
\hline EFS & 2,93 & $3,04 \mathrm{E}-04$ \\
\hline EGFL7 & $-1,95$ & $8,77 \mathrm{E}-06$ \\
\hline EGLN2 & $-1,17$ & $3,67 \mathrm{E}-09$ \\
\hline EGOT & 3,34 & $2,52 \mathrm{E}-05$ \\
\hline EIF1AXP1 & 1,35 & $1,69 \mathrm{E}-04$ \\
\hline EIF2S1 & 1,06 & $9,35 \mathrm{E}-04$ \\
\hline EIF2S2 & 1,25 & $1,98 \mathrm{E}-07$ \\
\hline EIF2S2P2 & 1,60 & $3,80 \mathrm{E}-07$ \\
\hline EIF2S2P3 & 1,17 & $4,14 \mathrm{E}-03$ \\
\hline EIF2S2P4 & 1,34 & $2,72 \mathrm{E}-05$ \\
\hline EIF3| & 1,08 & $5,97 \mathrm{E}-06$ \\
\hline EIF3IP1 & 1,15 & $3,33 \mathrm{E}-05$ \\
\hline EIF3J & 1,03 & $5,71 \mathrm{E}-05$ \\
\hline EIF4A2P4 & $-1,00$ & $5,56 \mathrm{E}-04$ \\
\hline EIF4E & 1,06 & $2,59 \mathrm{E}-07$ \\
\hline EIF4EBP3 & $-1,92$ & $2,17 \mathrm{E}-04$ \\
\hline EIF4G1 & 1,02 & $3,72 \mathrm{E}-03$ \\
\hline EIF5B & 1,49 & $3,69 \mathrm{E}-05$ \\
\hline ELANE & $-2,25$ & $3,73 \mathrm{E}-03$ \\
\hline ELAVL4 & 2,66 & $1,12 \mathrm{E}-03$ \\
\hline ELL2 & $-1,51$ & $9,90 \mathrm{E}-03$ \\
\hline ELL3 & 1,64 & $5,08 \mathrm{E}-03$ \\
\hline ELM01 & 1,28 & $2,68 \mathrm{E}-11$ \\
\hline EMILIN2 & $-2,21$ & $8,92 \mathrm{E}-06$ \\
\hline EML3 & $-1,02$ & $2,12 \mathrm{E}-03$ \\
\hline EMR4P & $-1,80$ & $1,49 \mathrm{E}-04$ \\
\hline ENAH & 2,00 & $3,11 \mathrm{E}-03$ \\
\hline ENDOU & 3,34 & $2,52 \mathrm{E}-05$ \\
\hline ENO1 & 1,02 & $1,41 \mathrm{E}-03$ \\
\hline ENO4 & $-2,02$ & $4,29 \mathrm{E}-03$ \\
\hline ENPP5 & $-1,71$ & $1,84 \mathrm{E}-04$ \\
\hline ENTHD2 & $-1,41$ & $2,64 \mathrm{E}-08$ \\
\hline ENTPD1 & 1,66 & $1,10 \mathrm{E}-29$ \\
\hline ENTPD1-AS1 & 1,40 & $6,95 \mathrm{E}-05$ \\
\hline ENTPD4 & $-1,08$ & $6,83 \mathrm{E}-11$ \\
\hline ENTPD6 & $-1,28$ & $1,44 \mathrm{E}-16$ \\
\hline EOMES & $-1,90$ & $1,37 \mathrm{E}-24$ \\
\hline EPB41 & $-1,19$ & $1,27 \mathrm{E}-08$ \\
\hline EPB41L3 & $-2,53$ & $2,13 \mathrm{E}-06$ \\
\hline EPB41L4B & 2,55 & $8,21 \mathrm{E}-04$ \\
\hline EPC1 & $-1,09$ & $8,49 \mathrm{E}-03$ \\
\hline EPHA1 & $-2,02$ & $1,74 \mathrm{E}-08$ \\
\hline EPHA10 & 1,83 & $6,54 \mathrm{E}-03$ \\
\hline EPHA2 & $-2,11$ & $7,57 \mathrm{E}-03$ \\
\hline EPHB1 & $-2,69$ & $3,48 \mathrm{E}-04$ \\
\hline EPM2AIP1 & $-1,08$ & $7,67 \mathrm{E}-05$ \\
\hline EPT1 & 1,03 & $6,08 \mathrm{E}-09$ \\
\hline ERBB2IP & $-1,15$ & $1,13 \mathrm{E}-07$ \\
\hline ERCC1 & $-1,34$ & 1,71E-06 \\
\hline ERI1 & 1,42 & $3,00 \mathrm{E}-06$ \\
\hline ERV3-1 & $-1,18$ & $2,16 \mathrm{E}-06$ \\
\hline ESPN & $-1,89$ & $5,75 \mathrm{E}-04$ \\
\hline ESPNL & 2,61 & $4,20 \mathrm{E}-06$ \\
\hline ESPNP & $-4,32$ & $5,96 \mathrm{E}-09$ \\
\hline
\end{tabular}




\begin{tabular}{|c|c|c|}
\hline ESR1 & $-1,98$ & $8,02 \mathrm{E}-09$ \\
\hline ESRP2 & 2,03 & $3,00 \mathrm{E}-05$ \\
\hline ESRRB & 3,02 & $1,10 \mathrm{E}-04$ \\
\hline ETF1 & 1,06 & $4,62 \mathrm{E}-03$ \\
\hline ETF1P1 & 1,20 & $7,08 \mathrm{E}-03$ \\
\hline ETNPPL & 2,26 & $5,81 \mathrm{E}-03$ \\
\hline ETV5 & $-1,82$ & $4,88 \mathrm{E}-07$ \\
\hline EVI2B & $-1,55$ & $4,81 \mathrm{E}-13$ \\
\hline EVI5 & 1,66 & $1,35 \mathrm{E}-03$ \\
\hline EVISL & $-1,07$ & $4,29 \mathrm{E}-04$ \\
\hline EVL & $-1,29$ & $8,40 \mathrm{E}-03$ \\
\hline EXD3 & $-2,20$ & $4,29 \mathrm{E}-10$ \\
\hline EXOC3L4 & 1,78 & $2,88 \mathrm{E}-03$ \\
\hline EXTL2 & 1,68 & $7,95 \mathrm{E}-08$ \\
\hline EXTL3-AS1 & $-2,02$ & $3,07 \mathrm{E}-03$ \\
\hline F2RL1 & $-2,20$ & $9,33 \mathrm{E}-11$ \\
\hline $\mathrm{F9}$ & 2,11 & $8,24 \mathrm{E}-03$ \\
\hline FABP6 & 2,17 & $8,19 \mathrm{E}-03$ \\
\hline FAM101B & 1,91 & $2,54 \mathrm{E}-25$ \\
\hline FAM102A & $-2,14$ & $3,97 \mathrm{E}-06$ \\
\hline FAM102B & $-1,06$ & $2,35 \mathrm{E}-03$ \\
\hline FAM105B & 1,08 & $1,40 \mathrm{E}-12$ \\
\hline FAM110B & $-2,11$ & $1,13 \mathrm{E}-03$ \\
\hline FAM115A & 1,07 & $5,28 \mathrm{E}-05$ \\
\hline FAM115B & 1,22 & $4,65 \mathrm{E}-03$ \\
\hline FAM118A & $-1,57$ & $7,69 \mathrm{E}-07$ \\
\hline FAM124A & 2,10 & $6,27 \mathrm{E}-03$ \\
\hline FAM126A & 1,15 & $6,88 \mathrm{E}-08$ \\
\hline FAM129A & 1,38 & $1,30 \mathrm{E}-09$ \\
\hline FAM131A & $-1,25$ & $3,97 \mathrm{E}-05$ \\
\hline FAM132B & 2,41 & $1,00 \mathrm{E}-04$ \\
\hline FAM136BP & 1,38 & $2,07 \mathrm{E}-08$ \\
\hline FAM157B & $-1,77$ & $5,23 \mathrm{E}-06$ \\
\hline FAM157C & $-1,34$ & $7,53 \mathrm{E}-06$ \\
\hline FAM159A & $-1,83$ & $1,15 \mathrm{E}-04$ \\
\hline FAM159B & $-1,13$ & $6,95 \mathrm{E}-03$ \\
\hline FAM160A2 & $-1,62$ & $7,43 \mathrm{E}-09$ \\
\hline FAM160B2 & $-1,12$ & $1,88 \mathrm{E}-05$ \\
\hline FAM161A & 1,56 & $1,69 \mathrm{E}-06$ \\
\hline FAM162A & 1,05 & $6,90 \mathrm{E}-13$ \\
\hline FAM166B & 1,57 & $3,98 \mathrm{E}-03$ \\
\hline FAM173A & $-1,08$ & $5,47 \mathrm{E}-09$ \\
\hline FAM177B & $-1,66$ & $8,72 \mathrm{E}-03$ \\
\hline FAM185A & 1,09 & $3,70 \mathrm{E}-06$ \\
\hline FAM185BP & 1,32 & $5,48 \mathrm{E}-04$ \\
\hline FAM189A1 & 4,10 & $6,44 \mathrm{E}-13$ \\
\hline FAM193B & $-1,54$ & $8,23 \mathrm{E}-06$ \\
\hline FAM196B & 1,64 & 7,77E-03 \\
\hline FAM198B & $-4,04$ & $1,49 \mathrm{E}-08$ \\
\hline FAM200B & $-1,10$ & $5,50 \mathrm{E}-08$ \\
\hline FAM210A & 1,06 & $1,90 \mathrm{E}-03$ \\
\hline FAM210B & $-1,64$ & $1,74 \mathrm{E}-14$ \\
\hline FAM221A & 1,59 & $1,15 \mathrm{E}-09$ \\
\hline FAM221B & $-2,13$ & $9,35 \mathrm{E}-03$ \\
\hline FAM227A & 1,96 & $8,75 \mathrm{E}-04$ \\
\hline FAM231D & $-1,50$ & $9,01 \mathrm{E}-04$ \\
\hline FAM53A & $-1,57$ & $5,26 \mathrm{E}-04$ \\
\hline FAM65B & $-1,86$ & $1,44 \mathrm{E}-04$ \\
\hline FAM69B & $-2,90$ & $4,41 \mathrm{E}-07$ \\
\hline FAM71B & 2,78 & $6,00 \mathrm{E}-04$ \\
\hline FAM78A & $-1,80$ & $5,60 \mathrm{E}-37$ \\
\hline FAM84B & $-1,18$ & $8,25 \mathrm{E}-03$ \\
\hline FAM86B3P & $-1,26$ & $4,01 \mathrm{E}-05$ \\
\hline FAM8A1 & $-1,19$ & $1,21 \mathrm{E}-05$ \\
\hline FAM96B & 1,22 & $1,14 \mathrm{E}-04$ \\
\hline FAM98B & 1,52 & 3,11E-04 \\
\hline FAM98C & $-1,14$ & $4,39 \mathrm{E}-03$ \\
\hline FAN1 & $-1,15$ & $5,42 \mathrm{E}-05$ \\
\hline FANCM & 1,19 & $9,70 \mathrm{E}-08$ \\
\hline FANK1 & $-1,42$ & $8,98 \mathrm{E}-03$ \\
\hline FARSA & 1,13 & $1,96 \mathrm{E}-03$ \\
\hline FARSBP1 & 1,44 & $5,85 \mathrm{E}-04$ \\
\hline FASTK & $-1,17$ & $5,27 \mathrm{E}-06$ \\
\hline FBRSL1 & $-1,02$ & 1,13E-04 \\
\hline FBXL19 & 1,22 & $6,49 \mathrm{E}-08$ \\
\hline FBXL19-AS1 & 1,15 & $6,35 \mathrm{E}-03$ \\
\hline
\end{tabular}

\begin{tabular}{|c|c|c|}
\hline FBX015 & $-1,25$ & $2,53 \mathrm{E}-03$ \\
\hline FBX016 & 2,68 & $1,07 \mathrm{E}-03$ \\
\hline $\mathrm{FBXO44}$ & $-1,99$ & $4,35 \mathrm{E}-07$ \\
\hline FBX045 & 1,47 & $3,36 \mathrm{E}-05$ \\
\hline FCER1A & $-3,00$ & $1,14 \mathrm{E}-14$ \\
\hline FCGR1B & $-1,86$ & $1,15 \mathrm{E}-03$ \\
\hline FCGR1C & $-1,96$ & $8,63 \mathrm{E}-04$ \\
\hline FCGR2A & $-1,94$ & $1,71 \mathrm{E}-03$ \\
\hline FCGR3A & $-3,39$ & $9,81 \mathrm{E}-07$ \\
\hline FCGR3B & $-3,34$ & $2,24 \mathrm{E}-06$ \\
\hline FCN1 & $-3,38$ & $7,51 \mathrm{E}-20$ \\
\hline FCN2 & $-3,30$ & $1,16 \mathrm{E}-10$ \\
\hline FCRL5 & $-2,94$ & $2,84 \mathrm{E}-09$ \\
\hline $\begin{array}{l}\text { FCRLA } \\
\end{array}$ & $-2,05$ & $4,71 \mathrm{E}-09$ \\
\hline FDFT1 & 1,21 & $3,17 \mathrm{E}-17$ \\
\hline FDPS & 1,01 & $4,05 \mathrm{E}-09$ \\
\hline FDPSP1 & 1,34 & $1,88 \mathrm{E}-07$ \\
\hline FDPSP4 & 1,21 & $6,74 \mathrm{E}-03$ \\
\hline FDPSP7 & 1,50 & $3,72 \mathrm{E}-07$ \\
\hline FDPSP8 & 1,68 & $1,20 \mathrm{E}-05$ \\
\hline FDXR & 1,81 & $9,32 \mathrm{E}-11$ \\
\hline FEM1B & $-1,19$ & $7,07 \mathrm{E}-04$ \\
\hline FERMT2 & 1,68 & $4,11 \mathrm{E}-05$ \\
\hline FFAR2 & $-2,54$ & $9,99 \mathrm{E}-04$ \\
\hline FGD3 & $-2,15$ & $7,25 \mathrm{E}-09$ \\
\hline FGF1 & 3,08 & $1,18 \mathrm{E}-04$ \\
\hline FGFBP2 & $-1,98$ & $1,89 \mathrm{E}-05$ \\
\hline FGGY & 1,60 & $1,52 \mathrm{E}-05$ \\
\hline $\mathrm{FH}$ & 1,26 & $7,92 \mathrm{E}-04$ \\
\hline FHAD1 & $-2,34$ & $5,14 \mathrm{E}-04$ \\
\hline FHP1 & 1,06 & $2,13 \mathrm{E}-03$ \\
\hline FIGF & $-1,92$ & $8,78 \mathrm{E}-03$ \\
\hline FITM1 & $-1,37$ & $1,03 \mathrm{E}-03$ \\
\hline FITM2 & $-1,44$ & $3,16 \mathrm{E}-05$ \\
\hline FJX1 & $-2,83$ & $3,18 \mathrm{E}-04$ \\
\hline FKBP4 & 1,10 & $8,47 \mathrm{E}-05$ \\
\hline FKBP4P1 & 1,48 & $4,54 \mathrm{E}-04$ \\
\hline FKBP7 & 1,43 & $4,23 \mathrm{E}-05$ \\
\hline FKBPL & 1,52 & $1,52 \mathrm{E}-04$ \\
\hline FKTN & $-1,26$ & $1,65 \mathrm{E}-04$ \\
\hline FLCN & $-1,68$ & $2,22 \mathrm{E}-10$ \\
\hline FLNB-AS1 & $-1,70$ & $7,01 \mathrm{E}-03$ \\
\hline FLT3LG & $-1,82$ & $3,15 \mathrm{E}-04$ \\
\hline FLT4 & $-1,87$ & $1,84 \mathrm{E}-04$ \\
\hline FMO5 & $-1,46$ & $1,29 \mathrm{E}-03$ \\
\hline FN3K & $-1,12$ & $8,13 \mathrm{E}-06$ \\
\hline FNIP2 & $-1,93$ & $3,92 \mathrm{E}-03$ \\
\hline FOS & $-3,92$ & $2,73 \mathrm{E}-11$ \\
\hline FOSB & $-2,72$ & $5,71 \mathrm{E}-04$ \\
\hline FOSL1 & 1,90 & $3,59 \mathrm{E}-04$ \\
\hline FOXA3 & 3,00 & $1,07 \mathrm{E}-06$ \\
\hline FOXB1 & 4,24 & $1,59 \mathrm{E}-09$ \\
\hline FOXE1 & 2,26 & $5,81 \mathrm{E}-03$ \\
\hline FOXO3B & 1,12 & $6,54 \mathrm{E}-03$ \\
\hline FRAS1 & 3,57 & $2,43 \mathrm{E}-07$ \\
\hline FRAT1 & $-1,14$ & $4,36 \mathrm{E}-03$ \\
\hline FRG1B & $-1,12$ & $6,87 \mathrm{E}-04$ \\
\hline FRMD4A & $-1,60$ & $2,78 \mathrm{E}-03$ \\
\hline FRMD5 & 2,93 & $4,84 \mathrm{E}-07$ \\
\hline FSIP2 & $-2,35$ & $1,62 \mathrm{E}-03$ \\
\hline FST & $-4,28$ & $6,37 \mathrm{E}-09$ \\
\hline FTH1 & $-1,42$ & $3,72 \mathrm{E}-04$ \\
\hline FTH1P1 & $-1,82$ & $5,72 \mathrm{E}-03$ \\
\hline FTH1P10 & $-1,48$ & $2,48 \mathrm{E}-03$ \\
\hline FTH1P11 & $-1,49$ & $3,63 \mathrm{E}-03$ \\
\hline FTH1P15 & $-1,88$ & $4,35 \mathrm{E}-04$ \\
\hline FTH1P16 & $-1,62$ & $2,25 \mathrm{E}-04$ \\
\hline $\begin{array}{l}\text { FTH1P2 } \\
\end{array}$ & $-1,51$ & $3,38 \mathrm{E}-03$ \\
\hline FTH1P20 & $-1,41$ & $4,45 \mathrm{E}-03$ \\
\hline FTH1P22 & 1,24 & $1,56 \mathrm{E}-03$ \\
\hline FTH1P23 & $-1,93$ & $1,01 \mathrm{E}-05$ \\
\hline FTH1P3 & $-1,31$ & $7,71 \mathrm{E}-03$ \\
\hline FTH1P5 & $-1,63$ & $2,19 \mathrm{E}-03$ \\
\hline FTH1P7 & $-1,49$ & $3,09 \mathrm{E}-03$ \\
\hline FTH1P8 & $-1,62$ & $1,17 \mathrm{E}-03$ \\
\hline FTLP1 & $-2,71$ & $8,46 \mathrm{E}-04$ \\
\hline
\end{tabular}

\begin{tabular}{|c|c|c|}
\hline FTSJ3 & 1,27 & $3,10 \mathrm{E}-06$ \\
\hline FUK & $-1,17$ & $1,41 \mathrm{E}-11$ \\
\hline FUNDC1 & 1,37 & $2,76 \mathrm{E}-14$ \\
\hline FUNDC2P4 & 2,39 & $3,63 \mathrm{E}-03$ \\
\hline FXYD7 & $-2,77$ & $1,96 \mathrm{E}-09$ \\
\hline FZD7 & $-1,79$ & $2,29 \mathrm{E}-03$ \\
\hline GoS2 & 1,10 & $1,34 \mathrm{E}-08$ \\
\hline GAB1 & $-2,38$ & $1,66 \mathrm{E}-05$ \\
\hline GAB2 & $-1,67$ & $2,58 \mathrm{E}-03$ \\
\hline GABARAP & $-1,03$ & $3,33 \mathrm{E}-03$ \\
\hline GABARAPL1 & $-1,26$ & $3,00 \mathrm{E}-08$ \\
\hline GABPB1 & 1,37 & $1,26 \mathrm{E}-06$ \\
\hline GABPB2 & $-1,41$ & $1,52 \mathrm{E}-03$ \\
\hline GADD45B & $-1,81$ & $7,68 \mathrm{E}-08$ \\
\hline GALNS & $-1,25$ & $4,14 \mathrm{E}-05$ \\
\hline GAPDHP28 & 2,61 & $1,39 \mathrm{E}-03$ \\
\hline GATSL2 & 1,89 & $4,22 \mathrm{E}-03$ \\
\hline GBGT1 & $-2,25$ & $7,82 \mathrm{E}-05$ \\
\hline GCHFR & $-1,58$ & $2,73 \mathrm{E}-03$ \\
\hline GCLC & $-1,07$ & $5,86 \mathrm{E}-06$ \\
\hline GCSAML & $-1,59$ & $1,04 \mathrm{E}-03$ \\
\hline GCSAML-AS1 & $-2,52$ & $2,11 \mathrm{E}-03$ \\
\hline GDAP1 & 1,81 & $2,30 \mathrm{E}-05$ \\
\hline GDF11 & 1,12 & $7,71 \mathrm{E}-03$ \\
\hline GDPD5 & $-1,03$ & $4,28 \mathrm{E}-03$ \\
\hline GEMIN5 & 1,43 & $2,08 \mathrm{E}-04$ \\
\hline GEMIN6 & 1,29 & $9,93 \mathrm{E}-04$ \\
\hline GEMIN8P4 & 1,25 & $6,88 \mathrm{E}-03$ \\
\hline GFM2 & 1,09 & $2,73 \mathrm{E}-06$ \\
\hline GFPT1 & 1,09 & $6,34 \mathrm{E}-04$ \\
\hline GFPT2 & $-2,61$ & $1,20 \mathrm{E}-06$ \\
\hline GFRA2 & $-1,79$ & $2,89 \mathrm{E}-03$ \\
\hline GGA1 & $-1,23$ & $1,15 \mathrm{E}-03$ \\
\hline GGACT & $-1,24$ & $4,59 \mathrm{E}-03$ \\
\hline GGT7 & $-1,77$ & $1,06 \mathrm{E}-05$ \\
\hline GIGYF1 & $-1,35$ & $1,47 \mathrm{E}-10$ \\
\hline GIMAP1 & $-1,61$ & $5,39 \mathrm{E}-07$ \\
\hline GIPC3 & $-1,21$ & $8,04 \mathrm{E}-04$ \\
\hline GJA1 & 2,26 & $5,81 \mathrm{E}-03$ \\
\hline GJB2 & $-2,69$ & $6,51 \mathrm{E}-04$ \\
\hline GJB6 & 2,00 & $9,74 \mathrm{E}-13$ \\
\hline GLB1L3 & 1,47 & $1,95 \mathrm{E}-03$ \\
\hline GLI4 & $-1,80$ & $5,52 \mathrm{E}-07$ \\
\hline GLIPR2 & $-1,81$ & $6,06 \mathrm{E}-04$ \\
\hline GLIS3 & 1,84 & $7,39 \mathrm{E}-06$ \\
\hline GL01 & 1,28 & $8,67 \mathrm{E}-11$ \\
\hline GLP1R & 3,13 & $9,14 \mathrm{E}-05$ \\
\hline GLRX3 & 1,00 & $1,12 \mathrm{E}-04$ \\
\hline GNA11 & $-1,65$ & $5,86 \mathrm{E}-11$ \\
\hline GNAL & $-1,21$ & $1,60 \mathrm{E}-04$ \\
\hline GNAQ & $-1,49$ & $1,08 \mathrm{E}-04$ \\
\hline GNGT2 & 1,26 & $3,45 \mathrm{E}-05$ \\
\hline GNL3 & 1,20 & $2,72 E-17$ \\
\hline GNPDA1 & $-1,22$ & $7,04 \mathrm{E}-03$ \\
\hline GNPNAT1 & 1,66 & $3,71 \mathrm{E}-15$ \\
\hline GNPTG & $-1,94$ & $1,70 \mathrm{E}-06$ \\
\hline GNRH2 & 1,99 & $1,73 \mathrm{E}-03$ \\
\hline GNS & $-1,95$ & $6,83 \mathrm{E}-04$ \\
\hline GOLGA1 & $-1,05$ & $1,87 \mathrm{E}-08$ \\
\hline GOLGA6L10 & $-1,47$ & $3,57 \mathrm{E}-03$ \\
\hline GOLGA6L18 & $-1,61$ & $4,35 \mathrm{E}-03$ \\
\hline GOLGA6L19 & $-2,13$ & $9,24 \mathrm{E}-03$ \\
\hline GOLGA6L4 & $-1,41$ & $2,82 \mathrm{E}-03$ \\
\hline GOLGA6L5P & $-1,08$ & $8,72 \mathrm{E}-04$ \\
\hline GOLGA6L9 & $-2,35$ & $2,65 \mathrm{E}-06$ \\
\hline GOLGA8A & $-1,19$ & $1,93 \mathrm{E}-03$ \\
\hline GOLGA8B & $-1,14$ & $6,45 \mathrm{E}-03$ \\
\hline GOLGA8CP & $-2,06$ & $4,30 \mathrm{E}-03$ \\
\hline GOLGA8J & $-1,70$ & $1,12 \mathrm{E}-03$ \\
\hline GOLGA8M & $-2,60$ & $3,96 \mathrm{E}-06$ \\
\hline GOLGA8Q & $-1,16$ & $1,05 \mathrm{E}-03$ \\
\hline GOLGA8R & $-1,14$ & $8,32 \mathrm{E}-05$ \\
\hline GORASP1 & $-1,72$ & $4,51 \mathrm{E}-09$ \\
\hline GP5 & $-1,83$ & $1,55 \mathrm{E}-04$ \\
\hline GPA33 & $-4,79$ & 4,39E-14 \\
\hline GPAA1 & $-1,13$ & $6,12 \mathrm{E}-06$ \\
\hline
\end{tabular}

\begin{tabular}{|c|c|c|}
\hline GPATCH11 & 1,01 & $1,58 \mathrm{E}-06$ \\
\hline GPCPD1 & $-2,01$ & $6,41 \mathrm{E}-09$ \\
\hline GPD1 & 2,57 & $3,66 \mathrm{E}-13$ \\
\hline GPHA2 & $-2,36$ & $3,99 \mathrm{E}-03$ \\
\hline GPI & 1,23 & $6,59 \mathrm{E}-09$ \\
\hline GPN3 & 1,34 & $7,05 \mathrm{E}-05$ \\
\hline GPN3P1 & 1,90 & $7,19 \mathrm{E}-04$ \\
\hline GPR114 & 1,94 & $1,24 \mathrm{E}-07$ \\
\hline GPR132 & 1,37 & $1,49 \mathrm{E}-20$ \\
\hline GPR137B & $-1,80$ & $5,74 \mathrm{E}-03$ \\
\hline GPR141 & $-1,61$ & $8,59 \mathrm{E}-05$ \\
\hline GPR146 & $-2,40$ & $8,87 \mathrm{E}-06$ \\
\hline GPR155 & $-1,34$ & $1,33 \mathrm{E}-04$ \\
\hline GPR161 & 1,54 & $5,27 \mathrm{E}-04$ \\
\hline GPR180 & 1,23 & $4,36 \mathrm{E}-09$ \\
\hline GPR27 & $-1,81$ & $1,81 \mathrm{E}-03$ \\
\hline GPR35 & $-1,55$ & $3,55 \mathrm{E}-05$ \\
\hline GPR83 & 2,14 & $1,12 \mathrm{E}-03$ \\
\hline GPR87 & 4,80 & $2,34 \mathrm{E}-13$ \\
\hline GPRASP2 & $-1,65$ & $2,31 \mathrm{E}-03$ \\
\hline GPRC5D & $-2,28$ & $5,37 \mathrm{E}-03$ \\
\hline GRAMD1B & 2,36 & $4,54 \mathrm{E}-06$ \\
\hline GRAMD1C & $-1,92$ & $2,95 \mathrm{E}-05$ \\
\hline GRAP & $-1,12$ & $5,14 \mathrm{E}-03$ \\
\hline GRAPL & $-1,29$ & $1,41 \mathrm{E}-03$ \\
\hline GREB1 & 1,57 & $2,34 \mathrm{E}-03$ \\
\hline GRIN1 & 2,43 & $6,49 \mathrm{E}-06$ \\
\hline GRIN3B & $-1,61$ & $1,50 \mathrm{E}-04$ \\
\hline GRINA & $-2,29$ & $1,62 \mathrm{E}-04$ \\
\hline GRK4 & 1,10 & $4,92 \mathrm{E}-03$ \\
\hline GRK6 & $-1,45$ & $2,18 \mathrm{E}-17$ \\
\hline GRK6P1 & $-1,19$ & $1,03 \mathrm{E}-13$ \\
\hline GRSF1 & 1,14 & $9,32 \mathrm{E}-06$ \\
\hline GRWD1 & 1,00 & $2,20 \mathrm{E}-04$ \\
\hline GSAP & $-1,98$ & $6,83 \mathrm{E}-06$ \\
\hline GSPT2 & 1,07 & $2,88 \mathrm{E}-05$ \\
\hline GTF2A2 & 1,10 & $1,78 \mathrm{E}-04$ \\
\hline GTF2H2 & 1,04 & $9,29 \mathrm{E}-03$ \\
\hline GTPBP4 & 1,43 & $3,81 \mathrm{E}-06$ \\
\hline GTPBP8 & 1,10 & $5,00 E-10$ \\
\hline GTSCR1 & $-4,16$ & $7,92 \mathrm{E}-08$ \\
\hline GTSF1 & 1,60 & $1,63 \mathrm{E}-16$ \\
\hline GZMH & 1,46 & $3,75 \mathrm{E}-04$ \\
\hline $\mathrm{H} 1 \mathrm{FO}$ & $-2,09$ & $8,62 \mathrm{E}-04$ \\
\hline H1FX & $-1,20$ & $5,41 \mathrm{E}-03$ \\
\hline H6PD & $-1,18$ & $3,04 \mathrm{E}-05$ \\
\hline HAGHL & $-1,88$ & $2,07 \mathrm{E}-28$ \\
\hline HAL & $-1,84$ & $7,12 \mathrm{E}-05$ \\
\hline HARS & 1,11 & $4,13 \mathrm{E}-15$ \\
\hline HAUS2 & 1,49 & $1,40 \mathrm{E}-05$ \\
\hline HAUS4P1 & 1,08 & $1,81 \mathrm{E}-06$ \\
\hline HAUS6 & 1,06 & $4,24 \mathrm{E}-11$ \\
\hline HAUS6P1 & 1,30 & $3,06 \mathrm{E}-04$ \\
\hline HCAR1 & 1,71 & $9,40 \mathrm{E}-04$ \\
\hline HCG4P11 & $-1,10$ & $3,83 \mathrm{E}-07$ \\
\hline HCK & $-2,60$ & $1,56 \mathrm{E}-06$ \\
\hline $\mathrm{HCN} 3$ & 1,33 & $1,13 \mathrm{E}-05$ \\
\hline HDAC10 & $-1,03$ & $1,66 \mathrm{E}-09$ \\
\hline HDAC5 & $-1,21$ & $4,35 \mathrm{E}-11$ \\
\hline HEATR4 & $-1,68$ & $5,41 \mathrm{E}-03$ \\
\hline HEG1 & 2,03 & $8,70 \mathrm{E}-26$ \\
\hline HEMK1 & $-1,45$ & $3,20 \mathrm{E}-05$ \\
\hline HERC1 & $-1,09$ & $4,52 \mathrm{E}-08$ \\
\hline HERC2P2 & $-1,12$ & $4,91 \mathrm{E}-13$ \\
\hline HERC3 & $-1,11$ & $2,83 \mathrm{E}-07$ \\
\hline HES1 & $-3,59$ & $6,71 \mathrm{E}-06$ \\
\hline HEXDC & $-1,82$ & $1,29 \mathrm{E}-08$ \\
\hline HEXIM2 & 1,27 & $3,14 \mathrm{E}-04$ \\
\hline HGSNAT & $-1,46$ & $1,32 \mathrm{E}-22$ \\
\hline HHAT & $-1,23$ & $1,95 \mathrm{E}-03$ \\
\hline $\mathrm{HIBCH}$ & 1,10 & $1,46 \mathrm{E}-06$ \\
\hline $\mathrm{HIC2}$ & $-1,13$ & $1,02 \mathrm{E}-05$ \\
\hline HIF1A-AS2 & $-2,42$ & $8,25 \mathrm{E}-04$ \\
\hline HIN1L & 1,26 & $3,29 \mathrm{E}-04$ \\
\hline HIST1H1A & 4,28 & $1,00 \mathrm{E}-08$ \\
\hline HIST1H1C & 2,73 & $9,28 \mathrm{E}-53$ \\
\hline
\end{tabular}




\begin{tabular}{|c|c|c|}
\hline HIST1H1D & 2,82 & $5,54 \mathrm{E}-04$ \\
\hline HIST1H1E & 4,19 & $5,73 \mathrm{E}-10$ \\
\hline HIST1H2AE & 5,24 & $1,11 \mathrm{E}-49$ \\
\hline HIST1H2AG & 4,16 & $5,88 \mathrm{E}-20$ \\
\hline HIST1H2AK & 4,19 & $2,34 \mathrm{E}-12$ \\
\hline HIST1H2APS4 & 2,27 & $5,74 \mathrm{E}-03$ \\
\hline HIST1H2BB & 6,63 & $1,49 \mathrm{E}-24$ \\
\hline HIST1H2BF & 6,23 & $8,74 \mathrm{E}-30$ \\
\hline HIST1H2BI & 6,37 & $2,32 \mathrm{E}-27$ \\
\hline HIST1H2BK & 1,30 & 4,68E-04 \\
\hline HIST1H2BM & 6,82 & $1,82 \mathrm{E}-33$ \\
\hline HIST1H3A & 3,83 & $1,33 \mathrm{E}-14$ \\
\hline HIST1H3I & 6,54 & $1,05 \mathrm{E}-26$ \\
\hline HIST1H3J & 6,47 & $1,00 \mathrm{E}-25$ \\
\hline HIST1H4A & 5,38 & $2,19 \mathrm{E}-18$ \\
\hline HIST1H4B & 5,90 & $3,07 E-32$ \\
\hline HIST1H4D & 5,82 & $1,85 \mathrm{E}-27$ \\
\hline HIST1H4E & 4,08 & $3,00 \mathrm{E}-17$ \\
\hline HIST1H4F & 6,83 & $2,83 \mathrm{E}-26$ \\
\hline HIST1H4H & 3,13 & $5,75 \mathrm{E}-31$ \\
\hline HIST1H4I & 4,74 & $1,95 \mathrm{E}-18$ \\
\hline HIST1H4J & 4,16 & $3,30 \mathrm{E}-08$ \\
\hline HIST1H4K & 3,67 & $1,99 \mathrm{E}-07$ \\
\hline HIST1H4L & 5,27 & $5,43 \mathrm{E}-14$ \\
\hline HIST2H2AA4 & 1,79 & $4,09 \mathrm{E}-03$ \\
\hline HIST2H2AB & 4,47 & $4,19 \mathrm{E}-19$ \\
\hline HIST2H2AC & 2,56 & $1,44 \mathrm{E}-07$ \\
\hline HIST2H2BF & 5,68 & $3,07 E-46$ \\
\hline HIST2H3A & 3,12 & $4,19 \mathrm{E}-05$ \\
\hline HIST2H3C & 3,21 & $5,38 \mathrm{E}-05$ \\
\hline HIST2H3D & 5,47 & $4,19 \mathrm{E}-22$ \\
\hline HIST3H2BA & 3,65 & $2,74 \mathrm{E}-06$ \\
\hline HIVEP1 & 1,15 & $3,42 E-03$ \\
\hline HLA-DOA & $-1,63$ & $5,56 \mathrm{E}-06$ \\
\hline HLA-E & $-1,43$ & $1,02 \mathrm{E}-22$ \\
\hline HLA-T & $-1,14$ & $9,75 \mathrm{E}-04$ \\
\hline HMGB3P8 & 2,52 & $2,08 \mathrm{E}-03$ \\
\hline HMGCS1 & 1,17 & $5,28 \mathrm{E}-03$ \\
\hline HMGN2P32 & 2,49 & $1,82 \mathrm{E}-03$ \\
\hline HMHA1 & $-1,28$ & $5,74 \mathrm{E}-04$ \\
\hline HNF1A & 1,17 & $2,71 \mathrm{E}-03$ \\
\hline HNMT & $-2,50$ & $1,67 \mathrm{E}-05$ \\
\hline HNRNPA1P30 & 1,41 & $2,34 \mathrm{E}-03$ \\
\hline HNRNPA1P4 & 1,34 & $8,07 \mathrm{E}-03$ \\
\hline HNRNPA2B1 & 1,01 & $1,91 \mathrm{E}-07$ \\
\hline HNRNPCP2 & 1,04 & $1,32 \mathrm{E}-13$ \\
\hline HNRNPF & 1,03 & $4,38 \mathrm{E}-03$ \\
\hline HNRNPMP1 & 1,09 & $1,10 \mathrm{E}-04$ \\
\hline $\begin{array}{r}\text { HNRNPUL2- } \\
\text { BSCL2 }\end{array}$ & 2,63 & $2,64 \mathrm{E}-05$ \\
\hline HOMER2P2 & $-2,16$ & $8,54 \mathrm{E}-03$ \\
\hline HOPX & 1,83 & $1,08 \mathrm{E}-03$ \\
\hline HOXA-AS2 & $-2,35$ & $4,12 \mathrm{E}-03$ \\
\hline HOXB6 & 2,27 & $4,00 \mathrm{E}-03$ \\
\hline HPCAL1 & $-1,58$ & $1,78 \mathrm{E}-17$ \\
\hline HPGD & 1,34 & $3,04 \mathrm{E}-07$ \\
\hline HPS4 & $-1,01$ & $4,75 \mathrm{E}-03$ \\
\hline HPSE & $-1,14$ & $7,08 \mathrm{E}-08$ \\
\hline $\mathrm{HRH} 2$ & 1,77 & $3,95 \mathrm{E}-08$ \\
\hline HRNR & 2,72 & $6,21 \mathrm{E}-07$ \\
\hline HRSP12 & 1,17 & $5,33 \mathrm{E}-11$ \\
\hline HS6ST1 & $-1,73$ & $9,77 \mathrm{E}-17$ \\
\hline HS6ST2 & 2,40 & $3,35 \mathrm{E}-03$ \\
\hline HSA-MIR-6080 & $-1,49$ & $3,34 \mathrm{E}-08$ \\
\hline HSBP1L1 & $-2,52$ & $1,41 \mathrm{E}-30$ \\
\hline HSD17B11 & $-1,35$ & $1,89 \mathrm{E}-14$ \\
\hline HSD17B6 & 2,27 & $1,04 \mathrm{E}-12$ \\
\hline HSDL1 & $-1,08$ & $1,15 \mathrm{E}-08$ \\
\hline HSF2BP & 1,16 & $5,68 \mathrm{E}-03$ \\
\hline HSF5 & 1,60 & $3,71 \mathrm{E}-03$ \\
\hline $\mathrm{HSH} 2 \mathrm{D}$ & 1,22 & $2,21 \mathrm{E}-12$ \\
\hline HSP90AA1 & 1,31 & $1,20 \mathrm{E}-03$ \\
\hline HSP90AA4P & 1,44 & $2,52 \mathrm{E}-04$ \\
\hline HSP90AB2P & 1,43 & $5,34 \mathrm{E}-06$ \\
\hline HSP90AB6P & 1,77 & $6,60 \mathrm{E}-04$ \\
\hline HSPA4L & 3,13 & $1,97 \mathrm{E}-15$ \\
\hline
\end{tabular}

\begin{tabular}{|c|c|c|}
\hline HSPA8P8 & 1,11 & $8,52 \mathrm{E}-03$ \\
\hline HSPA8P9 & 1,05 & $3,28 \mathrm{E}-03$ \\
\hline HSPB11 & 1,48 & $2,82 \mathrm{E}-06$ \\
\hline HSPBP1 & 1,08 & $1,64 \mathrm{E}-05$ \\
\hline HSPE1P3 & 1,78 & $2,00 \mathrm{E}-05$ \\
\hline HSPE1P7 & 2,29 & $1,24 \mathrm{E}-05$ \\
\hline HSPH1 & 1,34 & $2,72 \mathrm{E}-03$ \\
\hline HTR7P1 & $-2,43$ & $8,55 \mathrm{E}-04$ \\
\hline HTRA2 & 1,42 & $5,49 \mathrm{E}-22$ \\
\hline HTRA3 & $-2,58$ & $9,61 \mathrm{E}-04$ \\
\hline HYLS1 & 1,04 & $7,41 \mathrm{E}-05$ \\
\hline IARS & 1,46 & $1,83 \mathrm{E}-25$ \\
\hline ID2 & 1,35 & $5,31 \mathrm{E}-18$ \\
\hline IDH3A & 1,23 & $7,35 \mathrm{E}-04$ \\
\hline IDI2-AS1 & 2,01 & $6,05 \mathrm{E}-04$ \\
\hline IDUA & $-2,23$ & $4,42 \mathrm{E}-10$ \\
\hline IER5L & $-3,36$ & $1,38 \mathrm{E}-18$ \\
\hline IFIT1 & $-2,50$ & $1,03 \mathrm{E}-03$ \\
\hline IFITM1 & $-1,14$ & $1,12 \mathrm{E}-04$ \\
\hline IFNGR1 & $-2,43$ & $7,82 \mathrm{E}-06$ \\
\hline IFNGR2 & $-2,21$ & $7,68 \mathrm{E}-12$ \\
\hline IGF1 & 1,66 & $3,31 \mathrm{E}-03$ \\
\hline IGFL2 & 3,15 & $7,77 \mathrm{E}-05$ \\
\hline IGHA1 & $-3,34$ & $3,11 \mathrm{E}-31$ \\
\hline IGHA2 & $-2,79$ & $8,61 \mathrm{E}-48$ \\
\hline IGHG2 & $-3,33$ & $1,64 \mathrm{E}-107$ \\
\hline IGHJ1 & $-2,86$ & $6,16 \mathrm{E}-05$ \\
\hline IGHJ4 & $-3,27$ & $1,40 \mathrm{E}-27$ \\
\hline IGHJ5 & $-3,29$ & $3,97 \mathrm{E}-15$ \\
\hline IGHJ6 & $-2,80$ & $7,12 \mathrm{E}-11$ \\
\hline IGHM & $-2,03$ & $1,90 \mathrm{E}-41$ \\
\hline IGHV1-12 & $-2,49$ & $2,30 \mathrm{E}-03$ \\
\hline IGHV1-8 & $-2,06$ & $1,00 \mathrm{E}-03$ \\
\hline IGHV1OR15-1 & $-2,33$ & $4,72 \mathrm{E}-04$ \\
\hline IGHV2-70 & $-2,58$ & $8,81 \mathrm{E}-05$ \\
\hline IGHV3-11 & $-3,54$ & $3,35 \mathrm{E}-16$ \\
\hline IGHV3-15 & $-3,06$ & $5,22 \mathrm{E}-24$ \\
\hline IGHV3-20 & $-3,15$ & $4,42 \mathrm{E}-06$ \\
\hline IGHV3-33 & $-2,91$ & $2,20 \mathrm{E}-09$ \\
\hline IGHV3-41 & $-2,63$ & $2,67 \mathrm{E}-04$ \\
\hline IGHV3-53 & $-2,26$ & $2,28 \mathrm{E}-04$ \\
\hline IGHV3-66 & $-3,55$ & $1,66 \mathrm{E}-07$ \\
\hline IGHV3-7 & $-2,93$ & $1,41 \mathrm{E}-23$ \\
\hline IGHV3-71 & $-2,48$ & $1,79 \mathrm{E}-03$ \\
\hline IGHV3-72 & $-2,55$ & $1,17 \mathrm{E}-06$ \\
\hline IGHV3-74 & $-2,39$ & $3,70 \mathrm{E}-08$ \\
\hline IGHV3OR16-13 & $-2,59$ & $2,80 \mathrm{E}-13$ \\
\hline IGHV3OR16-15 & $-2,88$ & $3,42 \mathrm{E}-04$ \\
\hline IGHV3OR16-6 & $-2,01$ & $9,79 \mathrm{E}-03$ \\
\hline IGHV3OR16-8 & $-2,85$ & $7,96 \mathrm{E}-07$ \\
\hline IGHV3OR16-9 & $-2,78$ & $1,99 \mathrm{E}-05$ \\
\hline IGHV4-34 & $-2,69$ & $3,61 \mathrm{E}-06$ \\
\hline IGHV4-39 & $-2,69$ & $2,47 \mathrm{E}-15$ \\
\hline IGHV4-4 & $-2,12$ & $1,58 \mathrm{E}-05$ \\
\hline IGHV4-55 & $-2,46$ & $1,91 \mathrm{E}-06$ \\
\hline IGHV4-59 & $-2,78$ & $6,74 \mathrm{E}-10$ \\
\hline IGHV4-61 & $-3,41$ & $4,56 \mathrm{E}-10$ \\
\hline IGJ & $-2,39$ & $1,21 \mathrm{E}-25$ \\
\hline IGKC & $-3,09$ & $1,86 \mathrm{E}-12$ \\
\hline IGKJ5 & $-2,95$ & $1,55 \mathrm{E}-10$ \\
\hline IGKV1-39 & $-2,70$ & $1,14 \mathrm{E}-21$ \\
\hline IGKV1-6 & $-2,52$ & $8,88 \mathrm{E}-07$ \\
\hline IGKV1-9 & $-2,92$ & $7,77 \mathrm{E}-10$ \\
\hline IGKV1D-13 & $-3,02$ & $2,85 \mathrm{E}-07$ \\
\hline IGKV1D-27 & $-2,32$ & $1,57 \mathrm{E}-05$ \\
\hline IGKV1D-37 & $-3,21$ & $1,48 \mathrm{E}-05$ \\
\hline IGKV1D-43 & $-2,56$ & $9,18 \mathrm{E}-05$ \\
\hline IGKV1D-8 & $-3,63$ & $3,60 \mathrm{E}-08$ \\
\hline IGKV1OR22-5 & $-1,98$ & $8,55 \mathrm{E}-04$ \\
\hline IGKV2-24 & $-2,64$ & $3,11 \mathrm{E}-09$ \\
\hline IGKV2-28 & $-2,72$ & $3,17 \mathrm{E}-10$ \\
\hline IGKV2-30 & $-2,84$ & $2,08 \mathrm{E}-09$ \\
\hline IGKV2-40 & $-2,19$ & $6,80 \mathrm{E}-03$ \\
\hline IGKV2D-24 & $-2,03$ & $3,46 \mathrm{E}-05$ \\
\hline IGKV2D-28 & $-2,41$ & $3,14 \mathrm{E}-09$ \\
\hline IGKV2D-29 & $-2,32$ & 4,61E-04 \\
\hline
\end{tabular}

\begin{tabular}{|c|c|c|}
\hline IGKV2D-30 & $-2,17$ & 7,67E-07 \\
\hline IGKV3-11 & $-3,27$ & $1,41 \mathrm{E}-41$ \\
\hline IGKV3-15 & $-2,73$ & $2,82 \mathrm{E}-08$ \\
\hline IGKV3D-11 & $-2,64$ & $1,95 \mathrm{E}-08$ \\
\hline IGKV3D-7 & $-2,00$ & $6,56 \mathrm{E}-05$ \\
\hline IGKV5-2 & $-2,81$ & $5,30 \mathrm{E}-04$ \\
\hline IGKV6-21 & $-1,85$ & $6,59 \mathrm{E}-04$ \\
\hline IGKV6D-21 & $-1,86$ & $3,37 \mathrm{E}-03$ \\
\hline IGLC3 & $-3,15$ & $5,44 \mathrm{E}-20$ \\
\hline IGLC7 & $-2,76$ & $9,18 \mathrm{E}-14$ \\
\hline IGLJ2 & $-3,07$ & $1,58 \mathrm{E}-14$ \\
\hline IGLJ3 & $-3,02$ & $2,79 \mathrm{E}-16$ \\
\hline IGLJ6 & $-2,54$ & $1,82 \mathrm{E}-03$ \\
\hline IGLL5 & $-3,83$ & $8,53 \mathrm{E}-08$ \\
\hline IGLON5 & 2,68 & $1,41 \mathrm{E}-12$ \\
\hline IGLV10-54 & $-1,42$ & $3,27 \mathrm{E}-03$ \\
\hline IGLV1-36 & $-3,73$ & $5,61 \mathrm{E}-12$ \\
\hline IGLV1-40 & $-2,88$ & $2,97 \mathrm{E}-08$ \\
\hline IGLV1-47 & $-2,13$ & $1,78 \mathrm{E}-04$ \\
\hline IGLV1-51 & $-2,56$ & $2,66 \mathrm{E}-15$ \\
\hline IGLV2-14 & $-2,87$ & $1,81 \mathrm{E}-49$ \\
\hline IGLV2-18 & $-2,95$ & $3,88 \mathrm{E}-05$ \\
\hline IGLV2-23 & $-2,69$ & $4,12 \mathrm{E}-09$ \\
\hline IGLV2-8 & $-2,65$ & $2,62 \mathrm{E}-23$ \\
\hline IGLV3-16 & $-2,42$ & $7,83 \mathrm{E}-04$ \\
\hline IGLV3-30 & $-2,21$ & $7,02 \mathrm{E}-03$ \\
\hline IGLV4-60 & $-2,60$ & $3,13 \mathrm{E}-05$ \\
\hline IGLV4-69 & $-2,15$ & $1,02 \mathrm{E}-07$ \\
\hline IGLV5-45 & $-1,59$ & $1,01 \mathrm{E}-03$ \\
\hline IGLV7-43 & $-2,20$ & $2,59 \mathrm{E}-07$ \\
\hline IGLV7-46 & $-1,82$ & $3,96 \mathrm{E}-03$ \\
\hline IGLV8-61 & $-2,00$ & $6,21 \mathrm{E}-07$ \\
\hline IGLV9-49 & $-2,60$ & $2,18 \mathrm{E}-06$ \\
\hline IGSF22 & $-2,47$ & $4,12 \mathrm{E}-05$ \\
\hline IGSF9B & 1,98 & $1,45 \mathrm{E}-04$ \\
\hline IKBIP & 1,39 & $2,39 \mathrm{E}-05$ \\
\hline IL10 & $-2,07$ & $7,64 \mathrm{E}-04$ \\
\hline IL10RB & $-1,27$ & $5,30 \mathrm{E}-03$ \\
\hline IL1ORB-AS1 & $-1,80$ & $2,14 \mathrm{E}-04$ \\
\hline IL13RA1 & $-1,78$ & $1,65 \mathrm{E}-03$ \\
\hline IL16 & $-1,37$ & $3,30 \mathrm{E}-04$ \\
\hline IL17RA & $-1,13$ & $5,05 \mathrm{E}-04$ \\
\hline IL18 & $-1,95$ & $6,00 \mathrm{E}-04$ \\
\hline IL1R1 & $-1,96$ & $4,32 \mathrm{E}-03$ \\
\hline IL21 & 4,43 & $4,37 \mathrm{E}-09$ \\
\hline IL22 & 3,33 & $2,57 \mathrm{E}-05$ \\
\hline IL3 & 4,69 & $6,99 \mathrm{E}-23$ \\
\hline IL5 & 2,40 & $3,44 \mathrm{E}-03$ \\
\hline IL6ST & $-1,36$ & $4,90 \mathrm{E}-12$ \\
\hline IL9 & 6,61 & $6,82 \mathrm{E}-23$ \\
\hline ILF2P2 & 1,20 & $2,11 \mathrm{E}-05$ \\
\hline IMMTP1 & 1,12 & $7,33 \mathrm{E}-04$ \\
\hline IMPDH1 & $-1,24$ & $1,55 \mathrm{E}-10$ \\
\hline INA & 2,95 & $7,94 \mathrm{E}-05$ \\
\hline ING4 & $-1,38$ & $5,05 \mathrm{E}-06$ \\
\hline INMT & $-2,69$ & $6,21 \mathrm{E}-04$ \\
\hline INPP1 & 1,33 & $9,10 \mathrm{E}-03$ \\
\hline INPP4A & $-1,19$ & $6,28 \mathrm{E}-15$ \\
\hline INPP5A & $-1,09$ & $2,18 \mathrm{E}-06$ \\
\hline INPP5E & $-1,10$ & $2,84 \mathrm{E}-04$ \\
\hline IP011 & 1,46 & $4,65 \mathrm{E}-07$ \\
\hline IPO4 & 1,04 & $4,14 \mathrm{E}-08$ \\
\hline IP07 & 1,10 & $2,11 \mathrm{E}-06$ \\
\hline IP07P1 & 1,20 & 1,94E-05 \\
\hline IP07P2 & 1,54 & $6,74 \mathrm{E}-05$ \\
\hline IPPK & 1,36 & $1,11 \mathrm{E}-03$ \\
\hline IPPKP1 & 1,54 & $1,01 \mathrm{E}-03$ \\
\hline IQCC & 1,19 & $2,03 \mathrm{E}-04$ \\
\hline IQCG & 1,11 & $6,46 \mathrm{E}-03$ \\
\hline IQGAP2 & $-1,13$ & $2,93 \mathrm{E}-03$ \\
\hline IQSEC1 & $-1,28$ & $7,01 \mathrm{E}-04$ \\
\hline IQSEC2 & $-2,41$ & $8,45 \mathrm{E}-05$ \\
\hline IRAK3 & $-2,07$ & $3,32 \mathrm{E}-03$ \\
\hline IRF6 & 1,61 & $1,50 \mathrm{E}-04$ \\
\hline IRGM & 1,44 & $2,80 \mathrm{E}-05$ \\
\hline ISOC2 & 1,16 & $2,09 \mathrm{E}-04$ \\
\hline
\end{tabular}

\begin{tabular}{|c|c|c|}
\hline ISPD & 2,04 & $9,29 \mathrm{E}-04$ \\
\hline ITFG3 & $-2,47$ & $1,03 \mathrm{E}-03$ \\
\hline ITFG3 & $-2,28$ & $1,78 \mathrm{E}-11$ \\
\hline ITGAD & $-2,43$ & $1,33 \mathrm{E}-06$ \\
\hline ITGB1BP2 & 1,50 & $6,93 \mathrm{E}-03$ \\
\hline ITGB3BP & 1,20 & $5,81 \mathrm{E}-05$ \\
\hline ITM2B & $-1,90$ & $3,60 \mathrm{E}-25$ \\
\hline ITPKA & 1,67 & $4,32 \mathrm{E}-03$ \\
\hline ITPKB & $-1,47$ & $7,47 \mathrm{E}-04$ \\
\hline JAM2 & 1,61 & $9,11 \mathrm{E}-03$ \\
\hline JAZF1 & $-1,15$ & $5,41 \mathrm{E}-08$ \\
\hline JMJD8 & $-1,01$ & $5,15 \mathrm{E}-06$ \\
\hline $\mathrm{JPH} 1$ & 2,61 & $1,37 \mathrm{E}-03$ \\
\hline JUN & $-1,87$ & $1,93 \mathrm{E}-04$ \\
\hline JUP & $-1,78$ & $6,90 \mathrm{E}-04$ \\
\hline KANK1 & $-1,03$ & $2,79 \mathrm{E}-03$ \\
\hline KANSL1-AS1 & $-2,41$ & $3,32 \mathrm{E}-08$ \\
\hline KATNAL1 & 1,12 & $8,00 \mathrm{E}-04$ \\
\hline KAZN & $-1,92$ & $4,50 \mathrm{E}-03$ \\
\hline KB-1208A12,3 & $-1,37$ & $7,16 \mathrm{E}-03$ \\
\hline KB-1440D3,14 & 2,27 & $5,74 \mathrm{E}-03$ \\
\hline KB-1562D12,2 & 1,23 & $1,06 \mathrm{E}-04$ \\
\hline KB-1732A1,1 & $-2,06$ & $1,10 \mathrm{E}-03$ \\
\hline KB-173C10,2 & 4,60 & $3,13 \mathrm{E}-10$ \\
\hline KCND1 & 2,30 & $4,44 \mathrm{E}-24$ \\
\hline KCNG3 & 1,53 & $3,32 \mathrm{E}-03$ \\
\hline KCNJ11 & $-1,63$ & $7,21 \mathrm{E}-03$ \\
\hline KCNK10 & $-2,19$ & $7,63 \mathrm{E}-03$ \\
\hline KCNK17 & $-2,46$ & $9,77 \mathrm{E}-04$ \\
\hline KCNQ3 & $-1,84$ & $4,69 \mathrm{E}-03$ \\
\hline KCNQ5 & 1,39 & $7,83 \mathrm{E}-03$ \\
\hline KCNS1 & 1,72 & $8,63 \mathrm{E}-03$ \\
\hline KCTD10 & 1,04 & $2,71 \mathrm{E}-03$ \\
\hline KCTD3 & $-1,24$ & $3,73 \mathrm{E}-03$ \\
\hline KCTD6 & $-2,43$ & $4,54 \mathrm{E}-17$ \\
\hline KCTD9 & 1,12 & $5,15 \mathrm{E}-09$ \\
\hline KCTD9P1 & 1,25 & $2,25 \mathrm{E}-03$ \\
\hline KCTD9P2 & 1,23 & $5,70 \mathrm{E}-03$ \\
\hline KDM1B & $-1,22$ & $4,63 \mathrm{E}-04$ \\
\hline KDM4A-AS1 & 1,59 & $1,94 \mathrm{E}-03$ \\
\hline KDM4D & 1,47 & $4,15 \mathrm{E}-05$ \\
\hline $\mathrm{KHK}$ & 1,04 & $5,44 \mathrm{E}-04$ \\
\hline KIAA0020 & 1,46 & $1,97 \mathrm{E}-07$ \\
\hline KIAA0355 & $-1,06$ & $6,32 \mathrm{E}-04$ \\
\hline KIAA0513 & $-2,73$ & $9,51 \mathrm{E}-10$ \\
\hline KIAA0754 & 3,03 & $3,27 \mathrm{E}-13$ \\
\hline KIAA1147 & $-1,49$ & $1,18 \mathrm{E}-03$ \\
\hline KIAA1244 & 2,43 & $2,35 \mathrm{E}-03$ \\
\hline KIAA1407 & $-1,05$ & $2,12 \mathrm{E}-04$ \\
\hline KIAA1456 & $-2,43$ & $2,91 \mathrm{E}-03$ \\
\hline KIAA1468 & $-1,05$ & $1,32 \mathrm{E}-09$ \\
\hline KIAA1731 & 1,21 & $5,10 \mathrm{E}-14$ \\
\hline $\mathrm{KIF} 12$ & 2,13 & $9,27 \mathrm{E}-03$ \\
\hline KIF13A & $-2,34$ & $8,65 \mathrm{E}-05$ \\
\hline KIF1A & 1,99 & $8,20 \mathrm{E}-03$ \\
\hline KIF21A & 1,35 & $1,23 \mathrm{E}-04$ \\
\hline $\mathrm{KIF} 2 \mathrm{~A}$ & 1,19 & $1,70 \mathrm{E}-06$ \\
\hline KIF3B & 1,40 & $2,07 E-15$ \\
\hline KIF5C & 1,49 & $5,36 \mathrm{E}-04$ \\
\hline KIF9 & 1,26 & $2,04 \mathrm{E}-06$ \\
\hline $\mathrm{KIFC2}$ & $-1,68$ & $1,87 \mathrm{E}-08$ \\
\hline KIFC3 & $-2,65$ & $4,59 \mathrm{E}-05$ \\
\hline KISS1R & 1,81 & $1,06 \mathrm{E}-04$ \\
\hline KLF13 & $-1,01$ & $5,99 \mathrm{E}-04$ \\
\hline KLF15 & $-1,89$ & $6,87 \mathrm{E}-03$ \\
\hline KLF4 & $-3,86$ & $1,07 \mathrm{E}-16$ \\
\hline KLF6 & $-1,64$ & $2,60 \mathrm{E}-06$ \\
\hline KLHDC7A & $-2,36$ & $3,88 \mathrm{E}-03$ \\
\hline KLHL15 & 1,03 & $1,66 \mathrm{E}-07$ \\
\hline KLHL6 & $-1,47$ & $6,84 \mathrm{E}-03$ \\
\hline KLRB1 & $-1,70$ & $2,01 \mathrm{E}-03$ \\
\hline KLRF1 & $-2,71$ & $2,05 \mathrm{E}-04$ \\
\hline $\mathrm{KMO}$ & $-2,41$ & $1,11 \mathrm{E}-04$ \\
\hline KMT2E-AS1 & $-1,66$ & $1,78 \mathrm{E}-03$ \\
\hline KPNA5 & $-1,32$ & $6,03 \mathrm{E}-05$ \\
\hline KPNB1 & 1,36 & $7,91 \mathrm{E}-05$ \\
\hline
\end{tabular}




\begin{tabular}{|c|c|c|}
\hline KRT18P34 & 2,64 & $2,43 \mathrm{E}-07$ \\
\hline KRT36 & $-3,65$ & $2,98 \mathrm{E}-06$ \\
\hline KRT73 & $-2,81$ & $1,06 \mathrm{E}-05$ \\
\hline KRT8P12 & $-1,02$ & $2,39 \mathrm{E}-04$ \\
\hline KRT8P42 & $-2,37$ & $3,79 \mathrm{E}-03$ \\
\hline KSR1 & 1,87 & $3,03 \mathrm{E}-18$ \\
\hline L3MBTL1 & $-1,50$ & $1,38 \mathrm{E}-04$ \\
\hline L3MBTL3 & $-1,10$ & $3,40 \mathrm{E}-06$ \\
\hline L3MBTL4 & $-1,63$ & $7,28 \mathrm{E}-04$ \\
\hline LA16C-306A4,2 & $-2,29$ & $4,84 \mathrm{E}-03$ \\
\hline LA16C-390E6,4 & $-1,63$ & $9,28 \mathrm{E}-05$ \\
\hline LAMB4 & 2,29 & $5,27 \mathrm{E}-03$ \\
\hline LAMC3 & $-2,05$ & $3,60 \mathrm{E}-03$ \\
\hline LAMP1 & $-1,60$ & $6,89 \mathrm{E}-04$ \\
\hline LAMP2 & $-1,50$ & $2,04 \mathrm{E}-03$ \\
\hline LAMTOR4 & $-1,30$ & $1,37 \mathrm{E}-16$ \\
\hline LAPTM4A & $-1,71$ & $3,10 \mathrm{E}-05$ \\
\hline LAPTM5 & $-1,81$ & $9,07 \mathrm{E}-07$ \\
\hline LCLAT1 & 1,37 & $1,33 \mathrm{E}-04$ \\
\hline LCT & 3,19 & $1,00 \mathrm{E}-07$ \\
\hline LENG8-AS1 & $-2,13$ & $1,04 \mathrm{E}-04$ \\
\hline LE01 & 1,03 & $2,97 \mathrm{E}-03$ \\
\hline LEPREL4 & $-1,84$ & $1,25 \mathrm{E}-03$ \\
\hline LEPROT & $-1,51$ & $6,54 \mathrm{E}-03$ \\
\hline LEPROTL1 & $-1,11$ & $2,72 \mathrm{E}-09$ \\
\hline LETM1P2 & 1,29 & $2,70 \mathrm{E}-03$ \\
\hline LHFP & 2,06 & $8,75 \mathrm{E}-04$ \\
\hline LHPP & $-1,90$ & $6,62 \mathrm{E}-15$ \\
\hline LIG1 & 1,09 & $9,59 \mathrm{E}-03$ \\
\hline LIG3 & 1,03 & $1,03 \mathrm{E}-07$ \\
\hline LILRB1 & $-1,66$ & $2,96 \mathrm{E}-03$ \\
\hline LILRB2 & $-1,79$ & $1,29 \mathrm{E}-03$ \\
\hline LILRB3 & $-2,34$ & $9,43 \mathrm{E}-05$ \\
\hline LILRB4 & $-2,34$ & $1,84 \mathrm{E}-04$ \\
\hline LILRP1 & $-2,37$ & $1,45 \mathrm{E}-04$ \\
\hline LIMCH1 & 1,32 & $2,69 \mathrm{E}-03$ \\
\hline LIME1 & $-1,76$ & $4,13 \mathrm{E}-04$ \\
\hline LIMS1 & $-1,27$ & $5,81 \mathrm{E}-03$ \\
\hline LIN7A & $-2,96$ & $2,23 \mathrm{E}-04$ \\
\hline LINC00086 & $-2,09$ & $6,89 \mathrm{E}-04$ \\
\hline LINC00092 & $-1,16$ & $8,84 \mathrm{E}-03$ \\
\hline LINC00240 & 2,26 & $5,81 \mathrm{E}-03$ \\
\hline LINC00264 & $-2,57$ & $5,00 \mathrm{E}-04$ \\
\hline LINC00273 & 2,67 & $5,61 \mathrm{E}-04$ \\
\hline LINC00299 & 1,95 & $2,24 \mathrm{E}-03$ \\
\hline LINC00315 & $-2,30$ & $4,91 \mathrm{E}-03$ \\
\hline LINC00338 & $-1,31$ & $4,09 \mathrm{E}-03$ \\
\hline LINC00339 & $-1,29$ & $3,31 \mathrm{E}-04$ \\
\hline LINC00426 & $-1,64$ & $7,55 \mathrm{E}-06$ \\
\hline LINC00441 & 1,89 & $9,37 \mathrm{E}-03$ \\
\hline LINC00467 & 1,16 & $2,58 \mathrm{E}-04$ \\
\hline LINC00475 & 2,04 & $1,13 \mathrm{E}-03$ \\
\hline LINC00476 & $-1,61$ & $2,52 \mathrm{E}-03$ \\
\hline LINC00482 & $-2,57$ & $1,61 \mathrm{E}-03$ \\
\hline LINC00484 & 3,47 & $1,53 \mathrm{E}-09$ \\
\hline LINC00610 & $-1,58$ & $6,36 \mathrm{E}-03$ \\
\hline LINC00649 & $-2,02$ & $7,29 \mathrm{E}-05$ \\
\hline LINC00657 & $-1,13$ & $4,24 \mathrm{E}-13$ \\
\hline LINC00667 & $-1,42$ & 4,76E-07 \\
\hline LINC00680 & $-1,04$ & $3,86 \mathrm{E}-04$ \\
\hline LINC00847 & $-1,52$ & $7,97 \mathrm{E}-07$ \\
\hline LINC00852 & $-1,33$ & $6,27 \mathrm{E}-03$ \\
\hline LINC00854 & $-1,55$ & $8,16 \mathrm{E}-04$ \\
\hline LINC00865 & $-2,61$ & 7,61E-06 \\
\hline LINC00869 & $-2,29$ & $2,74 \mathrm{E}-04$ \\
\hline LINC00880 & 1,94 & $9,50 \mathrm{E}-03$ \\
\hline LINC00884 & $-1,54$ & $9,45 \mathrm{E}-03$ \\
\hline LINC00886 & $-1,81$ & $6,99 \mathrm{E}-04$ \\
\hline LINC00892 & 2,70 & $1,09 \mathrm{E}-07$ \\
\hline LINC00926 & $-3,46$ & $1,47 \mathrm{E}-11$ \\
\hline LINC00936 & $-2,36$ & $1,86 \mathrm{E}-04$ \\
\hline LINC00954 & $-2,41$ & $2,60 \mathrm{E}-05$ \\
\hline LINC00959 & $-1,98$ & $3,09 \mathrm{E}-08$ \\
\hline LINC00963 & $-1,82$ & $5,34 \mathrm{E}-06$ \\
\hline LINC00984 & $-1,71$ & $9,29 \mathrm{E}-04$ \\
\hline LINC01002 & $-1,57$ & $2,26 \mathrm{E}-03$ \\
\hline
\end{tabular}

\begin{tabular}{|c|c|c|}
\hline LINC01003 & $-1,34$ & $3,50 \mathrm{E}-06$ \\
\hline LINC01023 & $-2,31$ & $3,37 \mathrm{E}-03$ \\
\hline LINC01059 & 2,30 & $3,06 \mathrm{E}-04$ \\
\hline LINC01091 & $-3,18$ & $8,60 \mathrm{E}-05$ \\
\hline LINC01134 & 1,14 & $6,17 \mathrm{E}-03$ \\
\hline LINC01160 & 2,03 & $6,57 \mathrm{E}-06$ \\
\hline LINGO3 & $-2,32$ & $1,25 \mathrm{E}-05$ \\
\hline LIPE-AS1 & $-1,28$ & $1,17 \mathrm{E}-03$ \\
\hline LIPN & $-3,17$ & $8,59 \mathrm{E}-05$ \\
\hline LITAF & $-1,37$ & $2,46 \mathrm{E}-03$ \\
\hline LMAN2L & $-1,07$ & $2,73 \mathrm{E}-03$ \\
\hline LMBRD1 & $-1,04$ & $1,07 \mathrm{E}-03$ \\
\hline LMF1 & $-1,81$ & $5,04 \mathrm{E}-10$ \\
\hline LMLN & $-1,03$ & $7,87 \mathrm{E}-07$ \\
\hline LONRF3 & $-1,90$ & $1,67 \mathrm{E}-03$ \\
\hline LPCAT2 & $-1,67$ & $7,53 \mathrm{E}-04$ \\
\hline LPHN1 & $-1,77$ & $1,31 \mathrm{E}-04$ \\
\hline LRCH4 & $-1,12$ & $3,13 \mathrm{E}-03$ \\
\hline LRIT3 & 1,49 & $3,86 \mathrm{E}-04$ \\
\hline LRP11 & 1,22 & $2,12 \mathrm{E}-08$ \\
\hline LRP5L & $-1,26$ & $1,33 \mathrm{E}-08$ \\
\hline LRP8 & 1,24 & $2,38 \mathrm{E}-06$ \\
\hline LRPPRC & 1,10 & $2,78 \mathrm{E}-05$ \\
\hline LRRC2 & $-4,98$ & $1,44 \mathrm{E}-11$ \\
\hline LRRC32 & 1,02 & $6,82 \mathrm{E}-03$ \\
\hline LRRC34 & 1,16 & $2,81 \mathrm{E}-04$ \\
\hline LRRC36 & 2,72 & $4,20 \mathrm{E}-05$ \\
\hline LRRC37A & $-1,17$ & $2,50 \mathrm{E}-05$ \\
\hline LRRC37A11P & 3,14 & $8,69 \mathrm{E}-05$ \\
\hline LRRC37A2 & $-1,01$ & $1,18 \mathrm{E}-03$ \\
\hline LRRC37A9P & 2,55 & 4,94E-04 \\
\hline LRRC40 & 1,14 & $2,34 \mathrm{E}-05$ \\
\hline LRRC42 & 1,22 & $3,45 \mathrm{E}-03$ \\
\hline LRRC61 & 1,40 & $1,27 \mathrm{E}-04$ \\
\hline LRRK1 & $-1,99$ & $6,85 \mathrm{E}-04$ \\
\hline LRRN4CL & 2,72 & 4,67E-04 \\
\hline LSM3P3 & 1,23 & $6,52 \mathrm{E}-08$ \\
\hline LSMD1 & 1,07 & $1,51 \mathrm{E}-12$ \\
\hline LSS & $-1,65$ & $4,28 \mathrm{E}-04$ \\
\hline LTBP2 & $-1,25$ & $2,48 \mathrm{E}-05$ \\
\hline LTBP3 & $-2,05$ & $1,04 \mathrm{E}-05$ \\
\hline LTV1 & 1,02 & $5,46 \mathrm{E}-09$ \\
\hline LUC7L & $-1,20$ & $1,51 \mathrm{E}-04$ \\
\hline LUC7L3 & $-1,01$ & $6,45 \mathrm{E}-03$ \\
\hline LUCAT1 & $-1,49$ & $1,94 \mathrm{E}-04$ \\
\hline LY6K & $-2,68$ & $9,17 \mathrm{E}-04$ \\
\hline LY86-AS1 & 2,57 & $8,52 \mathrm{E}-06$ \\
\hline LYNX1 & $-1,65$ & $1,77 \mathrm{E}-03$ \\
\hline LYRM9 & $-2,48$ & $3,97 \mathrm{E}-08$ \\
\hline LYSMD1 & 1,36 & $3,02 \mathrm{E}-07$ \\
\hline LYZ & $-1,82$ & $2,30 \mathrm{E}-03$ \\
\hline LZTR1 & $-1,10$ & $1,17 \mathrm{E}-11$ \\
\hline LZTS2 & $-1,19$ & $1,25 \mathrm{E}-08$ \\
\hline MAB21L2 & 2,68 & $1,07 \mathrm{E}-03$ \\
\hline MADCAM1 & $-2,52$ & $8,40 \mathrm{E}-04$ \\
\hline MAGI3 & 1,16 & $3,83 \mathrm{E}-03$ \\
\hline $\mathrm{MAGOH} 2$ & 1,11 & $8,76 \mathrm{E}-08$ \\
\hline MAK16 & 1,36 & $4,46 \mathrm{E}-08$ \\
\hline MAL & $-1,60$ & $4,78 \mathrm{E}-04$ \\
\hline MALSU1 & 1,22 & $5,18 \mathrm{E}-07$ \\
\hline MALT1 & 1,65 & $8,66 \mathrm{E}-19$ \\
\hline MAML3 & 1,06 & $9,90 \mathrm{E}-05$ \\
\hline MAN1B1 & $-1,26$ & $2,06 \mathrm{E}-15$ \\
\hline MANBA & $-2,13$ & $2,30 \mathrm{E}-06$ \\
\hline MANEAL & 1,68 & $1,43 \mathrm{E}-06$ \\
\hline MANF & 1,08 & $3,10 \mathrm{E}-09$ \\
\hline MAP3К15 & 3,23 & $1,44 \mathrm{E}-05$ \\
\hline MAP3K2 & $-1,01$ & $5,80 \mathrm{E}-03$ \\
\hline MAP3K9 & 1,28 & $1,06 \mathrm{E}-03$ \\
\hline MAP9 & 1,28 & $1,25 \mathrm{E}-03$ \\
\hline MAPK12 & $-1,53$ & $1,57 \mathrm{E}-05$ \\
\hline MAPK7 & $-1,18$ & $3,92 \mathrm{E}-08$ \\
\hline MAPK8IP3 & $-1,44$ & $1,22 \mathrm{E}-06$ \\
\hline $\begin{array}{r}\text { MAPKAPK5- } \\
\text { AS1 }\end{array}$ & & \\
\hline MARC2 & $-2,85$ & $3,88 \mathrm{E}-04$ \\
\hline
\end{tabular}

\begin{tabular}{|c|c|c|}
\hline MARCH10 & $-3,08$ & $1,08 \mathrm{E}-04$ \\
\hline MARCH2 & $-1,84$ & $2,43 \mathrm{E}-06$ \\
\hline MARCH8 & $-1,46$ & $7,13 \mathrm{E}-21$ \\
\hline MASP2 & $-1,35$ & $6,21 \mathrm{E}-03$ \\
\hline MAST4 & 1,26 & $1,18 \mathrm{E}-03$ \\
\hline MATK & $-1,31$ & $1,76 \mathrm{E}-12$ \\
\hline MATN1-AS1 & $-1,98$ & $9,60 \mathrm{E}-05$ \\
\hline MATN4 & 2,37 & $3,32 \mathrm{E}-03$ \\
\hline$M B$ & 3,16 & $7,76 \mathrm{E}-05$ \\
\hline MB21D1 & 1,27 & $5,61 \mathrm{E}-03$ \\
\hline MC1R & $-1,26$ & $4,43 \mathrm{E}-03$ \\
\hline MCAT & 1,29 & $1,58 \mathrm{E}-05$ \\
\hline MCC & 1,25 & $1,11 \mathrm{E}-03$ \\
\hline MCF2L & $-2,90$ & $2,35 \mathrm{E}-09$ \\
\hline MCF2L-AS1 & $-2,09$ & $2,38 \mathrm{E}-03$ \\
\hline MCOLN2 & 1,84 & $1,86 \mathrm{E}-12$ \\
\hline MCTP1 & $-2,17$ & $5,05 \mathrm{E}-06$ \\
\hline MCTP2 & 3,08 & $5,55 \mathrm{E}-30$ \\
\hline MDK & 1,71 & $6,55 \mathrm{E}-10$ \\
\hline MEA1 & 1,07 & $1,20 \mathrm{E}-11$ \\
\hline MEF2BNB & $-1,22$ & $7,59 \mathrm{E}-09$ \\
\hline MEGF8 & $-1,07$ & $5,04 \mathrm{E}-08$ \\
\hline MEGF9 & $-1,19$ & $8,45 \mathrm{E}-03$ \\
\hline METTL10 & $-2,01$ & $4,10 \mathrm{E}-11$ \\
\hline METTL15P1 & 1,07 & $9,28 \mathrm{E}-03$ \\
\hline METTL24 & $-2,13$ & $9,41 \mathrm{E}-03$ \\
\hline MFAP1 & 1,35 & 4,64E-04 \\
\hline MFSD3 & $-1,21$ & $3,71 \mathrm{E}-04$ \\
\hline MFSD6 & 1,07 & $1,07 \mathrm{E}-04$ \\
\hline MGAT1 & $-1,73$ & $7,00 \mathrm{E}-04$ \\
\hline MGAT4B & $-1,23$ & $2,08 \mathrm{E}-05$ \\
\hline MGC10955 & $-2,37$ & $3,73 \mathrm{E}-03$ \\
\hline MID1 & 3,24 & $5,09 \mathrm{E}-05$ \\
\hline MINK1 & $-1,43$ & $4,70 \mathrm{E}-25$ \\
\hline MIR146A & $-2,04$ & $3,26 \mathrm{E}-05$ \\
\hline MIR181A2HG & $-2,32$ & $4,64 \mathrm{E}-03$ \\
\hline MIR22HG & $-1,73$ & $1,18 \mathrm{E}-04$ \\
\hline MIR24-2 & $-2,68$ & $3,87 \mathrm{E}-04$ \\
\hline MIR3180-1 & $-2,09$ & $6,66 \mathrm{E}-03$ \\
\hline MIR320A & 3,49 & $3,91 \mathrm{E}-07$ \\
\hline MIR3648 & 5,63 & $2,87 \mathrm{E}-18$ \\
\hline MIR3654 & 1,83 & $3,87 \mathrm{E}-11$ \\
\hline MIR4435-1HG & 2,21 & $7,70 \mathrm{E}-14$ \\
\hline MIR4453 & $-1,68$ & $2,92 \mathrm{E}-03$ \\
\hline MIR497HG & 1,41 & $9,49 \mathrm{E}-11$ \\
\hline MIR600HG & $-1,00$ & $9,48 \mathrm{E}-03$ \\
\hline MIR663A & 3,40 & $1,02 \mathrm{E}-06$ \\
\hline MIR940 & $-2,05$ & $7,71 \mathrm{E}-05$ \\
\hline MISP & 5,27 & $8,99 \mathrm{E}-18$ \\
\hline MKKS & $-1,18$ & $6,83 \mathrm{E}-06$ \\
\hline MKNK1 & $-1,11$ & $1,16 \mathrm{E}-03$ \\
\hline MKNK2P1 & $-1,28$ & 2,01E-03 \\
\hline MKRN1 & $-1,02$ & $1,90 \mathrm{E}-12$ \\
\hline MKX & 3,18 & $7,84 \mathrm{E}-06$ \\
\hline MLLT10 & $-1,01$ & $2,91 \mathrm{E}-11$ \\
\hline MLLT6 & $-1,05$ & $5,06 \mathrm{E}-03$ \\
\hline MLXIP & $-1,06$ & $1,73 \mathrm{E}-04$ \\
\hline MME & $-2,06$ & $2,68 \mathrm{E}-03$ \\
\hline MMEL1 & $-2,73$ & $1,13 \mathrm{E}-04$ \\
\hline MMP11 & $-2,81$ & $1,70 \mathrm{E}-06$ \\
\hline MMP14 & $-1,93$ & $9,67 \mathrm{E}-03$ \\
\hline MMP17 & $-2,45$ & $1,03 \mathrm{E}-05$ \\
\hline MMP2 & $-4,06$ & $5,20 \mathrm{E}-08$ \\
\hline MMP21 & $-2,31$ & $3,37 \mathrm{E}-03$ \\
\hline MMP24-AS1 & $-1,28$ & $5,46 \mathrm{E}-08$ \\
\hline MN1 & $-2,43$ & $2,79 \mathrm{E}-08$ \\
\hline MNS1 & 3,23 & $8,94 \mathrm{E}-09$ \\
\hline MOCS1P1 & 1,64 & $7,77 \mathrm{E}-03$ \\
\hline MPO & $-1,61$ & $2,80 \mathrm{E}-03$ \\
\hline MPP3 & $-1,95$ & $7,33 \mathrm{E}-03$ \\
\hline MPP7 & $-1,15$ & $2,29 \mathrm{E}-05$ \\
\hline MRC1 & $-1,47$ & $7,90 \mathrm{E}-03$ \\
\hline MRGPRX2 & 2,34 & $4,28 \mathrm{E}-03$ \\
\hline MROH1 & $-1,19$ & $8,52 \mathrm{E}-06$ \\
\hline MROH3P & 2,30 & $5,10 \mathrm{E}-03$ \\
\hline $\mathrm{MROH} 7$ & $-2,85$ & $8,34 \mathrm{E}-05$ \\
\hline
\end{tabular}

\begin{tabular}{|c|c|c|}
\hline MRPL1 & 1,07 & $2,46 \mathrm{E}-12$ \\
\hline MRPL11 & 1,29 & $1,30 \mathrm{E}-18$ \\
\hline MRPL13 & 1,06 & $5,80 \mathrm{E}-03$ \\
\hline MRPL14 & 1,02 & $2,39 \mathrm{E}-04$ \\
\hline MRPL17 & 1,57 & $3,38 \mathrm{E}-06$ \\
\hline MRPL18 & 1,15 & $1,71 \mathrm{E}-06$ \\
\hline MRPL19 & 1,27 & $1,86 \mathrm{E}-03$ \\
\hline MRPL22 & 1,52 & $1,44 \mathrm{E}-12$ \\
\hline MRPL22P1 & 1,81 & $1,21 \mathrm{E}-03$ \\
\hline MRPL27 & 1,14 & $4,61 \mathrm{E}-05$ \\
\hline MRPL2P1 & 1,21 & $1,42 \mathrm{E}-08$ \\
\hline MRPL35P2 & 1,10 & $1,60 \mathrm{E}-03$ \\
\hline MRPL36 & 1,12 & $4,88 \mathrm{E}-04$ \\
\hline MRPL37P1 & 1,82 & $2,22 \mathrm{E}-03$ \\
\hline MRPL39 & 1,05 & $4,78 \mathrm{E}-05$ \\
\hline MRPL45P1 & 1,20 & $2,42 \mathrm{E}-07$ \\
\hline MRPL47 & 1,59 & $1,75 \mathrm{E}-06$ \\
\hline MRPL51 & 1,31 & $2,20 \mathrm{E}-05$ \\
\hline MRPL51P2 & 1,64 & $9,60 \mathrm{E}-10$ \\
\hline MRPL9P1 & 1,11 & $1,88 \mathrm{E}-05$ \\
\hline MRPS11 & 1,16 & $3,01 \mathrm{E}-05$ \\
\hline MRPS31 & 1,10 & $3,16 \mathrm{E}-06$ \\
\hline MRPS33 & 1,17 & $1,29 \mathrm{E}-11$ \\
\hline MRPS36 & 1,06 & 4,96E-05 \\
\hline MRPS36P1 & 1,22 & $2,65 \mathrm{E}-04$ \\
\hline MRPS9 & 1,06 & $4,02 \mathrm{E}-08$ \\
\hline MS4A4A & $-5,42$ & $6,04 \mathrm{E}-16$ \\
\hline MS4A4E & $-3,64$ & $1,54 \mathrm{E}-06$ \\
\hline MS4A7 & $-3,20$ & $5,93 \mathrm{E}-06$ \\
\hline MSL3 & $-1,50$ & $1,12 \mathrm{E}-04$ \\
\hline MSLN & $-2,18$ & $5,27 \mathrm{E}-03$ \\
\hline MSS51 & $-1,48$ & $4,16 \mathrm{E}-07$ \\
\hline MST1P2 & $-1,20$ & $3,32 \mathrm{E}-03$ \\
\hline MSX2P1 & $-2,12$ & $8,43 \mathrm{E}-05$ \\
\hline MT1H & 3,99 & $1,67 \mathrm{E}-07$ \\
\hline MT1M & 2,30 & $5,10 \mathrm{E}-03$ \\
\hline MTA2 & 1,18 & $3,98 \mathrm{E}-18$ \\
\hline MTATP6P2 & 1,20 & $5,01 \mathrm{E}-05$ \\
\hline MTERFD2 & $-1,36$ & $4,77 \mathrm{E}-03$ \\
\hline MTERFD3 & $-1,10$ & $1,53 \mathrm{E}-03$ \\
\hline MTHFD2P1 & 2,27 & 4,12E-04 \\
\hline MTHFR & $-1,65$ & 7,47E-08 \\
\hline MTMR10 & $-1,45$ & $1,64 \mathrm{E}-04$ \\
\hline MTMR11 & 1,43 & $5,35 \mathrm{E}-07$ \\
\hline MTMR3 & $-1,02$ & $1,33 \mathrm{E}-03$ \\
\hline MTMR9LP & 1,42 & $8,50 \mathrm{E}-03$ \\
\hline MT-RNR1 & 2,59 & $1,15 \mathrm{E}-10$ \\
\hline MT-RNR2 & 1,71 & $1,06 \mathrm{E}-18$ \\
\hline MTRNR2L12 & 1,41 & $1,63 \mathrm{E}-06$ \\
\hline MTRNR2L2 & 1,97 & $4,26 \mathrm{E}-08$ \\
\hline MTRNR2L8 & 1,26 & $2,67 \mathrm{E}-04$ \\
\hline MT-TS2 & 2,06 & $8,90 \mathrm{E}-03$ \\
\hline MTURN & $-1,26$ & $7,57 \mathrm{E}-10$ \\
\hline MTX2 & 1,01 & 7,07E-08 \\
\hline MUC1 & 1,58 & $5,43 \mathrm{E}-03$ \\
\hline MUCL1 & 3,29 & $4,08 \mathrm{E}-05$ \\
\hline MX2 & $-2,34$ & $9,41 \mathrm{E}-09$ \\
\hline MXD4 & $-2,03$ & $5,08 \mathrm{E}-09$ \\
\hline MYB-AS1 & 2,17 & $8,19 \mathrm{E}-03$ \\
\hline MYCL & $-1,75$ & $9,53 \mathrm{E}-03$ \\
\hline MYCN & $-2,29$ & $4,04 \mathrm{E}-03$ \\
\hline MYCT1 & $-2,23$ & $6,49 \mathrm{E}-03$ \\
\hline MYH7 & 3,03 & $1,15 \mathrm{E}-05$ \\
\hline MYLIP & $-1,60$ & $5,53 \mathrm{E}-04$ \\
\hline MYLK4 & $-1,96$ & $3,32 \mathrm{E}-06$ \\
\hline MY019 & 1,41 & $7,46 \mathrm{E}-22$ \\
\hline MY01D & 1,19 & $8,71 \mathrm{E}-04$ \\
\hline MYO1F & $-2,11$ & $3,91 \mathrm{E}-10$ \\
\hline MYO5B & 3,87 & $5,27 \mathrm{E}-07$ \\
\hline MY05BP1 & 4,25 & $1,38 \mathrm{E}-08$ \\
\hline MYO5BP2 & 3,00 & $1,87 \mathrm{E}-04$ \\
\hline MYO9B & $-1,21$ & $9,51 \mathrm{E}-04$ \\
\hline MYRFL & 2,32 & $3,70 \mathrm{E}-03$ \\
\hline MZF1 & $-1,53$ & $5,90 \mathrm{E}-06$ \\
\hline $\mathrm{N} / \mathrm{A}$ & $-1,53$ & $8,47 \mathrm{E}-05$ \\
\hline$N / A$ & $-1,11$ & $6,89 \mathrm{E}-05$ \\
\hline
\end{tabular}




\begin{tabular}{|c|c|c|}
\hline $\mathrm{N} / \mathrm{A}$ & 1,09 & $6,86 \mathrm{E}-03$ \\
\hline N4BP3 & $-1,42$ & $1,37 \mathrm{E}-04$ \\
\hline NAA11 & 1,19 & $4,20 \mathrm{E}-04$ \\
\hline NAA15 & 1,55 & $1,30 \mathrm{E}-09$ \\
\hline NAA35 & 1,01 & $4,78 \mathrm{E}-03$ \\
\hline NAAA & $-1,87$ & $1,91 \mathrm{E}-11$ \\
\hline NAE1 & 1,24 & $7,03 \mathrm{E}-09$ \\
\hline NAP1L2 & $-1,62$ & $1,12 \mathrm{E}-03$ \\
\hline NAP1L5 & 1,60 & $4,15 \mathrm{E}-05$ \\
\hline NAPRT1 & $-1,84$ & $7,40 \mathrm{E}-09$ \\
\hline NAT8L & $-1,79$ & $1,34 \mathrm{E}-03$ \\
\hline NBEAL2 & $-1,39$ & $3,66 \mathrm{E}-14$ \\
\hline NBPF2P & $-1,26$ & $3,32 \mathrm{E}-04$ \\
\hline NCALD & 1,90 & $6,49 \mathrm{E}-06$ \\
\hline NCAPH2 & 1,07 & $1,67 \mathrm{E}-06$ \\
\hline NCBP1 & 1,30 & $3,42 \mathrm{E}-06$ \\
\hline NCCRP1 & $-2,28$ & $5,17 \mathrm{E}-04$ \\
\hline NCEH1 & $-1,97$ & $9,73 \mathrm{E}-04$ \\
\hline NCF1 & $-1,59$ & $9,81 \mathrm{E}-03$ \\
\hline NCF1B & $-1,64$ & $3,44 \mathrm{E}-03$ \\
\hline NCF1C & $-1,64$ & $8,45 \mathrm{E}-03$ \\
\hline NCKAP1 & 1,81 & $2,21 \mathrm{E}-06$ \\
\hline NCKAP5L & $-1,39$ & $5,54 \mathrm{E}-03$ \\
\hline NCLP1 & 1,48 & $1,25 \mathrm{E}-07$ \\
\hline NDC1 & 1,07 & $3,00 \mathrm{E}-12$ \\
\hline NDRG4 & 1,26 & $3,63 \mathrm{E}-03$ \\
\hline NDUFAB1 & 1,12 & $2,00 \mathrm{E}-06$ \\
\hline NDUFAF4 & 1,00 & $2,60 \mathrm{E}-07$ \\
\hline NEDD1 & 1,24 & $6,83 \mathrm{E}-11$ \\
\hline NEFHP1 & 2,33 & $3,55 \mathrm{E}-03$ \\
\hline NEFL & $-2,16$ & $6,48 \mathrm{E}-03$ \\
\hline NEIL2 & $-1,25$ & $5,52 \mathrm{E}-09$ \\
\hline NEK2P2 & 2,25 & $6,03 \mathrm{E}-03$ \\
\hline NEK3 & $-1,82$ & $1,30 \mathrm{E}-07$ \\
\hline NEUROD2 & 2,65 & $2,20 \mathrm{E}-05$ \\
\hline NFATC2 & 1,11 & $1,85 \mathrm{E}-04$ \\
\hline NFE2 & $-1,14$ & $8,95 \mathrm{E}-05$ \\
\hline NFIC & $-1,11$ & $7,05 \mathrm{E}-05$ \\
\hline NFIX & $-1,51$ & $9,81 \mathrm{E}-07$ \\
\hline NFKBIB & 1,15 & $2,89 \mathrm{E}-03$ \\
\hline NGFRAP1 & $-1,56$ & $2,89 \mathrm{E}-06$ \\
\hline $\mathrm{NHLH} 1$ & 2,17 & $1,54 \mathrm{E}-05$ \\
\hline NHLRC1 & $-2,31$ & $2,03 \mathrm{E}-03$ \\
\hline NHLRC3 & $-1,42$ & $1,66 \mathrm{E}-08$ \\
\hline NHLRC4 & $-1,81$ & $7,55 \mathrm{E}-04$ \\
\hline NID1 & $-3,57$ & $1,16 \mathrm{E}-07$ \\
\hline NID2 & $-1,48$ & $3,94 \mathrm{E}-03$ \\
\hline NIFK & 1,10 & $3,27 \mathrm{E}-08$ \\
\hline NIFKP1 & 1,30 & $5,98 \mathrm{E}-05$ \\
\hline NIFKP3 & 1,24 & $3,46 \mathrm{E}-04$ \\
\hline NIFKP4 & 1,48 & $7,14 \mathrm{E}-06$ \\
\hline NIFKP6 & 1,24 & $1,13 \mathrm{E}-04$ \\
\hline NIP7 & 1,12 & $4,65 \mathrm{E}-07$ \\
\hline NIPAL1 & 2,19 & $3,14 \mathrm{E}-04$ \\
\hline NIPAL3 & 1,11 & $1,06 \mathrm{E}-04$ \\
\hline NIPAL4 & $-2,22$ & $4,60 \mathrm{E}-03$ \\
\hline NKD1 & $-1,29$ & $7,68 \mathrm{E}-03$ \\
\hline NKG7 & 1,66 & $6,13 \mathrm{E}-06$ \\
\hline NKTR & $-1,17$ & $2,11 \mathrm{E}-04$ \\
\hline NLRP2 & 1,18 & $7,66 \mathrm{E}-05$ \\
\hline NME3 & $-1,39$ & $5,67 \mathrm{E}-04$ \\
\hline NME8 & $-3,33$ & $2,31 \mathrm{E}-06$ \\
\hline NMNAT3 & $-1,01$ & $6,39 \mathrm{E}-04$ \\
\hline NMRK1 & $-1,11$ & $1,73 \mathrm{E}-04$ \\
\hline NMT2 & $-1,45$ & $4,84 \mathrm{E}-11$ \\
\hline NOL10 & 1,45 & $2,58 \mathrm{E}-06$ \\
\hline NOL3 & $-1,13$ & $6,90 \mathrm{E}-03$ \\
\hline NOL5BP & 1,39 & $1,05 \mathrm{E}-05$ \\
\hline NONOP2 & 1,74 & $4,71 \mathrm{E}-07$ \\
\hline NOP14 & 1,04 & $1,53 \mathrm{E}-10$ \\
\hline NOP56 & 1,22 & $7,30 \mathrm{E}-16$ \\
\hline NOS1 & $-3,07$ & $1,60 \mathrm{E}-05$ \\
\hline NPBWR1 & 2,70 & $2,73 \mathrm{E}-06$ \\
\hline NPC1 & $-1,82$ & $4,94 \mathrm{E}-03$ \\
\hline NPHP1 & 1,04 & $5,07 \mathrm{E}-03$ \\
\hline NPHP3 & $-1,16$ & $6,55 \mathrm{E}-04$ \\
\hline
\end{tabular}

\begin{tabular}{|c|c|c|}
\hline NPIPA7 & $-1,28$ & $3,91 \mathrm{E}-06$ \\
\hline NPM1 & 1,09 & $3,40 \mathrm{E}-06$ \\
\hline NPM1P19 & 1,20 & $7,03 \mathrm{E}-03$ \\
\hline NPM1P21 & 1,29 & $6,00 \mathrm{E}-05$ \\
\hline NPM1P32 & 1,24 & 4,43E-04 \\
\hline NPM1P46 & 1,28 & $2,19 \mathrm{E}-07$ \\
\hline NPR2 & 1,38 & $3,77 \mathrm{E}-03$ \\
\hline NPTXR & $-1,47$ & $1,01 \mathrm{E}-05$ \\
\hline $\mathrm{NR} 1 \mathrm{H} 3$ & $-2,22$ & $8,31 \mathrm{E}-04$ \\
\hline NR2F6 & 1,53 & $2,07 \mathrm{E}-10$ \\
\hline NREP & $-1,20$ & $1,27 \mathrm{E}-03$ \\
\hline NRP2 & $-1,76$ & $1,51 \mathrm{E}-03$ \\
\hline NSMF & $-1,04$ & $7,05 \mathrm{E}-08$ \\
\hline NSUN5P1 & $-1,32$ & $3,22 \mathrm{E}-03$ \\
\hline NSUN5P2 & $-1,71$ & $7,80 \mathrm{E}-04$ \\
\hline NT5C3B & 1,11 & $8,11 \mathrm{E}-08$ \\
\hline NT5CP1 & $-2,11$ & $6,18 \mathrm{E}-03$ \\
\hline NT5DC4 & $-2,05$ & $8,05 \mathrm{E}-03$ \\
\hline NTN1 & 2,26 & $4,80 \mathrm{E}-04$ \\
\hline NTN5 & $-1,88$ & $1,94 \mathrm{E}-03$ \\
\hline NTNG2 & $-2,17$ & $2,16 \mathrm{E}-04$ \\
\hline NTSR1 & $-2,78$ & $3,21 \mathrm{E}-05$ \\
\hline NUDC & 1,04 & $5,76 \mathrm{E}-08$ \\
\hline NUDT13 & $-1,22$ & $3,60 \mathrm{E}-06$ \\
\hline NUDT4 & 1,13 & $1,87 \mathrm{E}-12$ \\
\hline NUDT4P1 & 1,38 & $2,66 \mathrm{E}-04$ \\
\hline NUDT5 & 1,24 & $3,17 \mathrm{E}-15$ \\
\hline NUP107 & 1,24 & $6,66 \mathrm{E}-11$ \\
\hline NUP188 & 1,25 & $1,72 \mathrm{E}-04$ \\
\hline NUP35 & 1,55 & $1,63 \mathrm{E}-16$ \\
\hline NUP54 & 1,02 & $2,17 \mathrm{E}-11$ \\
\hline NUPL2 & 1,16 & $4,96 \mathrm{E}-06$ \\
\hline NUPR1 & $-6,20$ & $7,28 \mathrm{E}-18$ \\
\hline $\mathrm{NXPH4}$ & $-3,78$ & $1,29 \mathrm{E}-28$ \\
\hline NYAP1 & $-2,08$ & $2,89 \mathrm{E}-04$ \\
\hline OAZ3 & 1,47 & $1,10 \mathrm{E}-05$ \\
\hline OBSCN & $-1,54$ & $1,59 \mathrm{E}-03$ \\
\hline ODC1 & 1,14 & $5,55 \mathrm{E}-14$ \\
\hline ODCP & 1,28 & $2,10 \mathrm{E}-04$ \\
\hline OGFOD1P1 & 1,23 & $4,59 \mathrm{E}-03$ \\
\hline OGFOD3 & $-1,39$ & $1,83 \mathrm{E}-14$ \\
\hline OGT & $-1,12$ & $5,10 \mathrm{E}-03$ \\
\hline OLA1 & 1,20 & $4,48 \mathrm{E}-08$ \\
\hline OLFM4 & $-2,35$ & $4,19 \mathrm{E}-03$ \\
\hline OLFML2A & $-2,03$ & $8,68 \mathrm{E}-03$ \\
\hline OLFML2B & $-4,88$ & $1,05 \mathrm{E}-10$ \\
\hline OMD & 2,40 & $3,44 \mathrm{E}-03$ \\
\hline OPA1 & 1,38 & $6,10 \mathrm{E}-05$ \\
\hline OPRL1 & $-1,57$ & $2,40 \mathrm{E}-06$ \\
\hline OR10AH1P & $-3,00$ & $1,88 \mathrm{E}-04$ \\
\hline OR211P & 3,61 & $3,90 \mathrm{E}-06$ \\
\hline OR5K2 & 1,73 & $1,94 \mathrm{E}-04$ \\
\hline ORM1 & $-3,58$ & $1,25 \mathrm{E}-06$ \\
\hline OSBP2 & 2,83 & $1,70 \mathrm{E}-22$ \\
\hline OSBPL10 & $-1,07$ & $5,89 \mathrm{E}-03$ \\
\hline OSBPL5 & $-2,63$ & $1,30 \mathrm{E}-19$ \\
\hline OSER1-AS1 & $-1,51$ & $2,15 \mathrm{E}-04$ \\
\hline OSTM1 & $-1,23$ & $8,21 \mathrm{E}-03$ \\
\hline OTUD1 & $-1,78$ & $6,82 \mathrm{E}-21$ \\
\hline OVCH1-AS1 & $-3,32$ & $2,32 \mathrm{E}-05$ \\
\hline OVOL3 & 2,19 & $7,01 \mathrm{E}-03$ \\
\hline OXCT2 & 2,14 & $7,27 \mathrm{E}-05$ \\
\hline OXLD1 & $-1,08$ & $5,51 \mathrm{E}-03$ \\
\hline P2RX4 & $-1,85$ & $2,37 \mathrm{E}-05$ \\
\hline P2RY11 & $-1,72$ & $1,78 \mathrm{E}-07$ \\
\hline P2RY6 & $-2,56$ & $8,76 \mathrm{E}-09$ \\
\hline PABPC1P7 & $-2,49$ & $1,56 \mathrm{E}-04$ \\
\hline PACS2 & $-1,61$ & $3,76 \mathrm{E}-23$ \\
\hline PAF1 & 1,12 & $7,08 \mathrm{E}-07$ \\
\hline PAICSP5 & 1,97 & $5,66 \mathrm{E}-10$ \\
\hline PALD1 & $-2,77$ & $4,37 \mathrm{E}-08$ \\
\hline PALM2 & 2,30 & $3,25 \mathrm{E}-03$ \\
\hline PAN2 & $-1,69$ & $2,84 \mathrm{E}-07$ \\
\hline PANK1 & 1,81 & $3,20 \mathrm{E}-03$ \\
\hline PAPLN & $-2,04$ & $8,08 \mathrm{E}-03$ \\
\hline PAQR7 & 1,20 & $1,37 \mathrm{E}-04$ \\
\hline
\end{tabular}

\begin{tabular}{|c|c|c|}
\hline PAQR8 & $-1,27$ & $5,94 \mathrm{E}-05$ \\
\hline PARK2 & $-3,74$ & $1,57 \mathrm{E}-06$ \\
\hline PARP10 & $-1,44$ & $4,44 \mathrm{E}-07$ \\
\hline PARP12 & $-1,19$ & $4,54 \mathrm{E}-03$ \\
\hline PARP15 & $-1,05$ & $5,00 \mathrm{E}-04$ \\
\hline PARP2 & 1,40 & $5,32 \mathrm{E}-14$ \\
\hline PARP6 & $-1,68$ & $2,27 \mathrm{E}-07$ \\
\hline PARVG & $-1,97$ & $2,15 \mathrm{E}-11$ \\
\hline PASK & $-1,62$ & $3,09 \mathrm{E}-03$ \\
\hline PATL2 & $-1,33$ & $3,20 \mathrm{E}-03$ \\
\hline PAXIP1 & 1,19 & $8,64 \mathrm{E}-13$ \\
\hline PAXIP1-AS1 & $-1,31$ & $2,17 \mathrm{E}-03$ \\
\hline PBXIP1 & $-1,28$ & $2,03 \mathrm{E}-03$ \\
\hline PCDHGB7 & $-2,22$ & $6,72 \mathrm{E}-03$ \\
\hline PCED1A & $-1,73$ & $8,28 \mathrm{E}-05$ \\
\hline PCED1B-AS1 & $-1,47$ & $1,67 \mathrm{E}-03$ \\
\hline PCGF6 & 1,15 & $1,34 \mathrm{E}-05$ \\
\hline PCGF7P & 1,87 & $1,94 \mathrm{E}-10$ \\
\hline PCMTD1 & $-1,13$ & $2,59 \mathrm{E}-10$ \\
\hline PCMTD2 & $-1,88$ & $1,19 \mathrm{E}-07$ \\
\hline PCNXL2 & $-1,50$ & $6,47 \mathrm{E}-04$ \\
\hline PCOLCE2 & $-2,64$ & $1,27 \mathrm{E}-03$ \\
\hline PDCD11 & 1,33 & $4,31 \mathrm{E}-10$ \\
\hline PDCD4-AS1 & $-2,39$ & $1,26 \mathrm{E}-06$ \\
\hline PDCL3 & 1,22 & $9,44 \mathrm{E}-08$ \\
\hline PDCL3P5 & 1,37 & $2,66 \mathrm{E}-11$ \\
\hline PDDC1 & $-1,02$ & $2,43 \mathrm{E}-06$ \\
\hline PDE1B & 1,52 & $1,63 \mathrm{E}-13$ \\
\hline PDE4DIP & $-1,46$ & $2,49 \mathrm{E}-03$ \\
\hline PDE7A & $-1,06$ & $4,12 \mathrm{E}-03$ \\
\hline PDE9A & $-2,11$ & $3,54 \mathrm{E}-07$ \\
\hline PDK3 & 1,17 & $9,15 \mathrm{E}-05$ \\
\hline PDLIM1P4 & $-2,33$ & $3,48 \mathrm{E}-03$ \\
\hline PDLIM2 & $-1,04$ & $3,37 \mathrm{E}-03$ \\
\hline PDLIM3 & 2,68 & $1,00 \mathrm{E}-03$ \\
\hline PDP2 & 1,70 & $1,02 \mathrm{E}-13$ \\
\hline PDPN & $-3,37$ & $3,56 \mathrm{E}-07$ \\
\hline PDSS1 & 1,37 & $2,41 \mathrm{E}-09$ \\
\hline PDZD7 & $-1,33$ & $3,57 \mathrm{E}-03$ \\
\hline PECR & 1,06 & $5,07 \mathrm{E}-04$ \\
\hline PEG10 & $-2,08$ & $4,18 \mathrm{E}-03$ \\
\hline PELI3 & $-1,42$ & $4,53 \mathrm{E}-03$ \\
\hline PER3 & $-1,79$ & $2,11 \mathrm{E}-04$ \\
\hline PFDN5 & $-1,01$ & $1,08 \mathrm{E}-04$ \\
\hline PFKFB2 & $-1,50$ & $4,20 \mathrm{E}-05$ \\
\hline PFKFB4 & $-1,44$ & $8,56 \mathrm{E}-03$ \\
\hline PGAM1 & 1,43 & $1,58 \mathrm{E}-04$ \\
\hline PGAM4 & 1,46 & $2,98 \mathrm{E}-03$ \\
\hline PGAP3 & $-1,37$ & $4,25 \mathrm{E}-05$ \\
\hline PGLYRP2 & $-3,84$ & $8,65 \mathrm{E}-07$ \\
\hline PGM2 & 1,28 & $1,88 \mathrm{E}-06$ \\
\hline PHC1 & $-1,24$ & $2,93 \mathrm{E}-08$ \\
\hline PHC1P1 & $-1,01$ & $6,60 \mathrm{E}-06$ \\
\hline PHF14 & 1,02 & $2,85 \mathrm{E}-07$ \\
\hline PHF21B & 2,46 & $2,72 \mathrm{E}-03$ \\
\hline PHF5CP & 1,26 & $1,46 \mathrm{E}-04$ \\
\hline PHKA1P1 & 2,37 & $2,31 \mathrm{E}-05$ \\
\hline PHLDA2 & 1,65 & $2,24 \mathrm{E}-03$ \\
\hline PHYKPL & $-1,16$ & $2,03 \mathrm{E}-07$ \\
\hline Pl15 & 2,40 & $3,35 \mathrm{E}-03$ \\
\hline PIIK2B & 1,22 & $5,92 \mathrm{E}-07$ \\
\hline PI4KAP2 & $-1,39$ & $1,04 \mathrm{E}-09$ \\
\hline PIGO & $-1,13$ & $4,43 \mathrm{E}-09$ \\
\hline$P I G Q$ & $-1,07$ & $2,16 \mathrm{E}-09$ \\
\hline PIGZ & $-1,59$ & $4,19 \mathrm{E}-03$ \\
\hline $\mathrm{PIH1D2}$ & 1,57 & $5,63 \mathrm{E}-03$ \\
\hline PIK3R3 & 1,34 & $5,72 \mathrm{E}-05$ \\
\hline PIK3R5 & $-1,07$ & $8,11 \mathrm{E}-03$ \\
\hline PILRA & $-1,65$ & $9,93 \mathrm{E}-04$ \\
\hline PINX1 & 1,00 & $7,06 \mathrm{E}-06$ \\
\hline PIP5KL1 & 1,34 & $3,95 \mathrm{E}-03$ \\
\hline PITX3 & 2,47 & $1,95 \mathrm{E}-03$ \\
\hline PKP3 & $-2,18$ & $7,82 \mathrm{E}-03$ \\
\hline PLA1A & 3,50 & $1,55 \mathrm{E}-06$ \\
\hline PLA2G4D & $-2,37$ & $3,73 \mathrm{E}-03$ \\
\hline PLA2G6 & $-1,54$ & $1,43 \mathrm{E}-03$ \\
\hline
\end{tabular}

\begin{tabular}{|c|c|c|}
\hline PLAA & 1,30 & $4,76 \mathrm{E}-04$ \\
\hline PLAG1 & $-1,48$ & $2,25 \mathrm{E}-03$ \\
\hline PLAGL2 & 1,46 & $1,51 \mathrm{E}-05$ \\
\hline PLAU & $-3,64$ & $1,11 \mathrm{E}-08$ \\
\hline $\mathrm{PLCH} 2$ & $-1,72$ & $1,02 \mathrm{E}-04$ \\
\hline PLCL1 & $-1,70$ & $1,84 \mathrm{E}-13$ \\
\hline PLCL2 & $-1,12$ & $2,74 \mathrm{E}-03$ \\
\hline PLD1 & $-2,32$ & $1,38 \mathrm{E}-03$ \\
\hline PLEC & $-1,71$ & $7,22 \mathrm{E}-28$ \\
\hline PLEKHA1 & $-1,01$ & $2,26 \mathrm{E}-03$ \\
\hline PLEKHB1 & $-1,31$ & $5,08 \mathrm{E}-03$ \\
\hline PLEKHF2 & $-1,59$ & $7,86 \mathrm{E}-05$ \\
\hline PLEKHG3 & $-1,37$ & $3,54 \mathrm{E}-03$ \\
\hline PLEKHM1 & $-1,13$ & $3,78 \mathrm{E}-06$ \\
\hline PLEKHM2 & $-1,47$ & $1,36 \mathrm{E}-03$ \\
\hline PLEKHM3 & 1,94 & $5,74 \mathrm{E}-11$ \\
\hline PLEKHO1 & $-1,19$ & $1,22 \mathrm{E}-04$ \\
\hline PLIN4 & $-1,40$ & $7,59 \mathrm{E}-05$ \\
\hline PLK3 & $-1,16$ & $1,24 \mathrm{E}-04$ \\
\hline PLXNA4 & 2,05 & $6,71 \mathrm{E}-11$ \\
\hline PM20D1 & $-1,59$ & $3,41 \mathrm{E}-03$ \\
\hline PMP22 & $-3,66$ & $7,61 \mathrm{E}-11$ \\
\hline PMS2P3 & $-1,29$ & $8,29 \mathrm{E}-04$ \\
\hline PNISR & $-1,09$ & $1,60 \mathrm{E}-04$ \\
\hline PNKD & $-1,93$ & $2,81 \mathrm{E}-03$ \\
\hline PNLDC1 & 2,15 & $3,43 E-05$ \\
\hline PNMA5 & $-2,15$ & $6,92 \mathrm{E}-03$ \\
\hline PNMA6C & $-2,35$ & $1,86 \mathrm{E}-03$ \\
\hline PNMAL2 & $-1,29$ & $4,48 \mathrm{E}-03$ \\
\hline PNO1 & 1,06 & $1,92 \mathrm{E}-03$ \\
\hline PNPLA1 & $-1,57$ & $9,16 \mathrm{E}-03$ \\
\hline PNPT1P1 & 1,35 & $2,11 \mathrm{E}-03$ \\
\hline PNRC1 & $-1,37$ & $2,64 \mathrm{E}-03$ \\
\hline PODXL2 & $-1,69$ & $3,06 \mathrm{E}-08$ \\
\hline POLD4 & $-1,24$ & $1,06 \mathrm{E}-10$ \\
\hline POLR1B & 1,37 & $5,17 \mathrm{E}-09$ \\
\hline POLR1E & 1,13 & 4,01E-05 \\
\hline POLR2D & 1,36 & $4,79 \mathrm{E}-10$ \\
\hline POLR2H & 1,40 & $1,20 \mathrm{E}-09$ \\
\hline POLR2J3 & $-1,22$ & $3,38 \mathrm{E}-03$ \\
\hline POLR2K & 1,11 & $5,06 \mathrm{E}-07$ \\
\hline POLR2KP1 & 1,83 & $2,48 \mathrm{E}-03$ \\
\hline POLR3DP1 & 1,16 & $1,18 \mathrm{E}-03$ \\
\hline POLR3KP2 & 1,44 & $4,98 \mathrm{E}-03$ \\
\hline POMK & 1,66 & $2,82 \mathrm{E}-03$ \\
\hline POP1 & 1,53 & $1,06 \mathrm{E}-09$ \\
\hline POR & $-2,16$ & $1,27 \mathrm{E}-06$ \\
\hline POT1-AS1 & $-2,52$ & $7,84 \mathrm{E}-04$ \\
\hline POTEKP & 1,00 & $1,12 \mathrm{E}-03$ \\
\hline POU3F1 & $-2,17$ & $2,86 \mathrm{E}-04$ \\
\hline POU4F1 & 1,88 & $1,26 \mathrm{E}-03$ \\
\hline PP13439 & $-2,40$ & $2,61 \mathrm{E}-04$ \\
\hline PPAP2B & $-3,67$ & $2,23 \mathrm{E}-08$ \\
\hline PPDPF & $-1,38$ & $4,40 \mathrm{E}-15$ \\
\hline PPEF1 & $-2,09$ & $5,64 \mathrm{E}-03$ \\
\hline PPFIA3 & 1,03 & $9,80 \mathrm{E}-03$ \\
\hline PPFIA4 & $-2,09$ & $4,07 \mathrm{E}-04$ \\
\hline PPIA & 1,04 & $3,90 \mathrm{E}-13$ \\
\hline PPIAP19 & 2,07 & $3,22 \mathrm{E}-04$ \\
\hline PPIAP29 & 1,34 & $3,38 \mathrm{E}-09$ \\
\hline PPIAP31 & 1,08 & $8,23 \mathrm{E}-08$ \\
\hline PPIEL & $-1,89$ & $8,32 \mathrm{E}-04$ \\
\hline PPIL1P1 & 1,80 & $2,12 \mathrm{E}-05$ \\
\hline PPIP5K1 & $-1,28$ & $1,16 \mathrm{E}-12$ \\
\hline PPM1E & 3,21 & $5,38 \mathrm{E}-05$ \\
\hline PPP1R13L & 1,06 & $1,11 \mathrm{E}-05$ \\
\hline PPP1R14B & 1,00 & $2,81 \mathrm{E}-10$ \\
\hline PPP1R14BP3 & 1,18 & $9,74 \mathrm{E}-15$ \\
\hline PPP1R14C & $-3,92$ & $5,85 \mathrm{E}-07$ \\
\hline PPP1R15A & $-2,13$ & $3,74 \mathrm{E}-06$ \\
\hline PPP1R1A & 1,26 & $5,67 \mathrm{E}-03$ \\
\hline PPP1R26 & $-1,41$ & $4,43 \mathrm{E}-03$ \\
\hline PPP1R3E & $-1,82$ & $1,41 \mathrm{E}-05$ \\
\hline PPP1R3G & $-2,14$ & $9,08 \mathrm{E}-03$ \\
\hline PPP2R1B & 1,61 & $8,20 \mathrm{E}-20$ \\
\hline PPP2R5D & 1,19 & $7,10 \mathrm{E}-11$ \\
\hline
\end{tabular}




\begin{tabular}{|c|c|c|}
\hline PQLC1 & $-1,50$ & $8,66 \mathrm{E}-16$ \\
\hline PRB3 & $-2,85$ & $4,54 \mathrm{E}-04$ \\
\hline PRDM1 & 1,35 & $8,34 \mathrm{E}-12$ \\
\hline PRELID2P1 & $-1,78$ & $9,09 \mathrm{E}-03$ \\
\hline PRF1 & 2,38 & $1,80 \mathrm{E}-11$ \\
\hline PRIMPOL & 1,16 & $2,34 \mathrm{E}-06$ \\
\hline PRKAB2 & $-1,89$ & $8,57 \mathrm{E}-08$ \\
\hline PRKAG2 & $-1,12$ & $6,58 \mathrm{E}-04$ \\
\hline PRKAR2B & 1,76 & $9,15 \mathrm{E}-08$ \\
\hline PRKCQ & 1,58 & $3,44 \mathrm{E}-04$ \\
\hline PRKG2 & $-2,52$ & $2,45 \mathrm{E}-04$ \\
\hline PRMT2 & $-1,39$ & $2,27 \mathrm{E}-08$ \\
\hline PRMT3 & 1,38 & $6,21 \mathrm{E}-05$ \\
\hline PRMT5 & 1,07 & $1,49 \mathrm{E}-06$ \\
\hline PRMT5-AS1 & 1,12 & $1,66 \mathrm{E}-04$ \\
\hline PROC & $-2,06$ & $1,47 \mathrm{E}-03$ \\
\hline PRODH & 2,48 & $6,12 \mathrm{E}-07$ \\
\hline PRPF4 & 1,36 & 4,05E-05 \\
\hline PRPS1L1 & 1,21 & $2,40 \mathrm{E}-09$ \\
\hline PRR22 & 1,02 & $9,19 \mathrm{E}-07$ \\
\hline PRR5 & $-1,84$ & $5,95 \mathrm{E}-05$ \\
\hline PRRC2B & $-1,10$ & $1,85 \mathrm{E}-04$ \\
\hline PRRG1 & $-2,69$ & $4,65 \mathrm{E}-04$ \\
\hline PRSS12 & 2,07 & $8,55 \mathrm{E}-03$ \\
\hline PRSS27 & 1,24 & $7,65 \mathrm{E}-03$ \\
\hline PRSS35 & $-2,68$ & $3,48 \mathrm{E}-12$ \\
\hline PRSS3P2 & 2,37 & $2,35 \mathrm{E}-03$ \\
\hline PRTN3 & $-3,36$ & $1,73 \mathrm{E}-05$ \\
\hline PSD & $-1,58$ & $5,91 \mathrm{E}-07$ \\
\hline PSD3 & $-2,28$ & $2,80 \mathrm{E}-04$ \\
\hline PSMA3 & 1,14 & $3,33 \mathrm{E}-04$ \\
\hline PSMA3P & 1,32 & $1,97 \mathrm{E}-03$ \\
\hline PSMA4 & 1,02 & $4,05 \mathrm{E}-03$ \\
\hline PSMA5 & 1,18 & $1,49 \mathrm{E}-03$ \\
\hline PSMB2 & 1,27 & $1,01 \mathrm{E}-04$ \\
\hline PSMB5 & 1,45 & $4,64 \mathrm{E}-06$ \\
\hline PSMD12 & 1,16 & $2,39 \mathrm{E}-10$ \\
\hline PSMD12P & 1,77 & $9,22 \mathrm{E}-05$ \\
\hline PSMD13 & 1,23 & $1,85 \mathrm{E}-09$ \\
\hline PSMD5-AS1 & $-1,06$ & $5,86 \mathrm{E}-04$ \\
\hline PSMG1 & 1,34 & $6,53 \mathrm{E}-03$ \\
\hline PSMG3-AS1 & $-1,02$ & $2,25 \mathrm{E}-03$ \\
\hline PSPH & 1,35 & $2,25 \mathrm{E}-10$ \\
\hline PSPHP1 & 1,98 & $1,52 \mathrm{E}-03$ \\
\hline PTAFR & $-1,57$ & $9,75 \mathrm{E}-03$ \\
\hline PTCD2P1 & 1,99 & $3,11 \mathrm{E}-04$ \\
\hline PTGDR2 & $-1,26$ & $8,10 \mathrm{E}-03$ \\
\hline PTGES2 & $-1,59$ & $1,48 \mathrm{E}-23$ \\
\hline PTGES3L & 1,97 & $6,62 \mathrm{E}-05$ \\
\hline PTGES3P1 & 1,07 & $1,15 \mathrm{E}-03$ \\
\hline PTGES3P3 & 1,24 & $1,77 \mathrm{E}-04$ \\
\hline PTGFRN & 1,37 & $1,40 \mathrm{E}-04$ \\
\hline PTGIS & 2,42 & $2,44 \mathrm{E}-03$ \\
\hline PTK7 & $-1,17$ & $5,53 \mathrm{E}-03$ \\
\hline PTMS & 1,59 & $3,35 \mathrm{E}-06$ \\
\hline PTPLAD1 & 1,25 & $1,12 \mathrm{E}-03$ \\
\hline PTPLAD2 & $-1,20$ & $6,81 \mathrm{E}-09$ \\
\hline PTPN12 & $-1,41$ & $4,56 \mathrm{E}-03$ \\
\hline PTPN14 & 3,13 & $2,50 \mathrm{E}-07$ \\
\hline PTPN5 & $-2,40$ & $3,39 \mathrm{E}-03$ \\
\hline PTPRG & 1,94 & $5,78 \mathrm{E}-03$ \\
\hline PTPRG-AS1 & 2,04 & $1,88 \mathrm{E}-03$ \\
\hline PTPRS & $-2,60$ & $3,72 \mathrm{E}-11$ \\
\hline PTS & 1,68 & $8,35 \mathrm{E}-14$ \\
\hline PTTG1IP & $-1,23$ & $7,17 \mathrm{E}-05$ \\
\hline PUS7 & 1,24 & $8,09 \mathrm{E}-05$ \\
\hline PUS7L & 1,33 & $2,30 \mathrm{E}-07$ \\
\hline PVRL1 & $-1,84$ & $7,92 \mathrm{E}-05$ \\
\hline PVRL3 & 1,47 & $3,56 \mathrm{E}-05$ \\
\hline PVRL4 & $-2,81$ & $5,15 \mathrm{E}-05$ \\
\hline PWP2 & 1,17 & $2,97 \mathrm{E}-06$ \\
\hline PXN & $-1,34$ & $1,57 \mathrm{E}-12$ \\
\hline PXT1 & 2,26 & $5,81 \mathrm{E}-03$ \\
\hline PYCARD & $-1,62$ & $1,66 \mathrm{E}-11$ \\
\hline PYROXD2 & $-1,63$ & $5,66 \mathrm{E}-04$ \\
\hline QKI & $-1,28$ & $5,19 \mathrm{E}-04$ \\
\hline
\end{tabular}

\begin{tabular}{|c|c|c|}
\hline R3HCC1 & $-1,42$ & $6,42 \mathrm{E}-14$ \\
\hline R3HDM1 & 1,15 & $7,45 \mathrm{E}-15$ \\
\hline R3HDM2 & $-1,43$ & $2,45 \mathrm{E}-08$ \\
\hline R3HDM2P2 & $-1,13$ & $4,56 \mathrm{E}-04$ \\
\hline RAB11FIP1P1 & $-1,22$ & $2,26 \mathrm{E}-03$ \\
\hline RAB12 & $-1,14$ & $4,07 E-05$ \\
\hline RAB23 & 1,71 & $4,01 \mathrm{E}-05$ \\
\hline RAB27B & $-1,86$ & $6,88 \mathrm{E}-04$ \\
\hline RAB39B & 1,26 & $2,88 \mathrm{E}-04$ \\
\hline RAB3D & $-1,42$ & $2,89 \mathrm{E}-03$ \\
\hline RAB3IP & 1,30 & $3,42 E-13$ \\
\hline RAB5C & $-1,22$ & $9,04 \mathrm{E}-04$ \\
\hline RAB9B & 2,06 & $5,65 \mathrm{E}-06$ \\
\hline RABL2A & $-1,30$ & $1,55 \mathrm{E}-06$ \\
\hline RABL2B & $-1,15$ & $3,89 \mathrm{E}-05$ \\
\hline RAD1P1 & 1,30 & $8,18 \mathrm{E}-05$ \\
\hline RAD52 & $-1,07$ & $5,50 \mathrm{E}-03$ \\
\hline RAD9B & 2,09 & $7,20 \mathrm{E}-11$ \\
\hline RAE1 & 1,22 & $5,01 \mathrm{E}-05$ \\
\hline RAET1K & 2,52 & $2,08 \mathrm{E}-03$ \\
\hline RALGDS & $-1,27$ & $5,91 \mathrm{E}-04$ \\
\hline RAP2C-AS1 & $-1,29$ & $7,87 \mathrm{E}-03$ \\
\hline RARA & $-1,13$ & $8,59 \mathrm{E}-08$ \\
\hline RARS & 1,02 & $4,42 \mathrm{E}-05$ \\
\hline RASA4 & $-1,63$ & $1,30 \mathrm{E}-08$ \\
\hline RASA4DP & $-1,16$ & $4,99 \mathrm{E}-04$ \\
\hline RASAL1 & $-2,43$ & $1,92 \mathrm{E}-32$ \\
\hline RASD1 & 4,52 & $1,55 \mathrm{E}-26$ \\
\hline RASGEF1B & $-1,99$ & $1,51 \mathrm{E}-06$ \\
\hline RASL11A & 1,30 & $2,52 \mathrm{E}-05$ \\
\hline RASSF4 & $-2,24$ & $3,33 \mathrm{E}-04$ \\
\hline RASSF5 & 1,05 & $2,06 \mathrm{E}-03$ \\
\hline RBBP4P1 & 1,29 & $2,37 \mathrm{E}-05$ \\
\hline RBFOX2 & 1,64 & $1,64 \mathrm{E}-06$ \\
\hline RBL2 & $-1,25$ & $3,39 \mathrm{E}-05$ \\
\hline RBM15 & 1,43 & $5,11 \mathrm{E}-11$ \\
\hline RBM24 & $-2,07$ & $8,74 \mathrm{E}-03$ \\
\hline RBM43 & $-1,48$ & $2,08 \mathrm{E}-06$ \\
\hline RBM47 & $-2,36$ & $8,28 \mathrm{E}-05$ \\
\hline RBM8B & 1,27 & $4,67 \mathrm{E}-04$ \\
\hline RBPJP2 & 1,42 & $8,55 \mathrm{E}-03$ \\
\hline RBPJP5 & 1,58 & $2,99 \mathrm{E}-05$ \\
\hline RBPJP6 & 2,82 & $2,94 \mathrm{E}-04$ \\
\hline RBPMS & $-1,35$ & $2,99 \mathrm{E}-03$ \\
\hline RCAN2 & 2,71 & $1,82 \mathrm{E}-09$ \\
\hline RCBTB2P1 & $-2,70$ & $5,85 \mathrm{E}-04$ \\
\hline RCC2P8 & 1,56 & $1,58 \mathrm{E}-04$ \\
\hline RCN3 & $-3,04$ & $6,76 \mathrm{E}-10$ \\
\hline RCVRN & $-2,34$ & $4,30 \mathrm{E}-03$ \\
\hline $\mathrm{RDH} 10$ & 2,65 & $7,04 \mathrm{E}-51$ \\
\hline RDH8 & 2,85 & $4,87 \mathrm{E}-04$ \\
\hline RELL1 & 1,15 & $4,45 \mathrm{E}-04$ \\
\hline RELT & $-1,10$ & $7,89 \mathrm{E}-04$ \\
\hline REPIN1 & $-1,53$ & $1,04 \mathrm{E}-13$ \\
\hline RETN & $-2,32$ & $3,97 \mathrm{E}-03$ \\
\hline RFESD & $-1,37$ & $4,64 \mathrm{E}-03$ \\
\hline RFKP1 & 1,66 & $9,72 \mathrm{E}-03$ \\
\hline RFNG & $-1,16$ & $2,13 \mathrm{E}-13$ \\
\hline RFTN1 & 1,05 & $1,65 \mathrm{E}-04$ \\
\hline RGAG4 & $-3,03$ & $2,35 \mathrm{E}-08$ \\
\hline RGMA & $-2,21$ & $7,54 \mathrm{E}-04$ \\
\hline RGPD2 & $-1,17$ & $2,17 \mathrm{E}-03$ \\
\hline RGS14 & $-1,57$ & $4,71 \mathrm{E}-04$ \\
\hline RGS18 & $-1,41$ & $1,14 \mathrm{E}-04$ \\
\hline RHAG & 2,40 & $3,44 \mathrm{E}-03$ \\
\hline RHBDL3 & 2,92 & $9,07 \mathrm{E}-07$ \\
\hline RHOQP3 & $-1,67$ & $4,80 \mathrm{E}-03$ \\
\hline RIMBP3 & $-1,75$ & $5,58 \mathrm{E}-04$ \\
\hline RIMKLA & 2,88 & $1,66 \mathrm{E}-06$ \\
\hline RIMKLBP1 & $-1,94$ & $6,09 \mathrm{E}-06$ \\
\hline RIN3 & $-1,18$ & $6,36 \mathrm{E}-08$ \\
\hline RIOK1 & 1,11 & $3,50 \mathrm{E}-05$ \\
\hline RIPK3 & $-1,71$ & $9,03 \mathrm{E}-07$ \\
\hline RLIMP1 & 1,65 & $4,53 \mathrm{E}-03$ \\
\hline RMDN2 & $-1,39$ & $2,26 \mathrm{E}-05$ \\
\hline RMRP & 3,02 & $8,39 \mathrm{E}-05$ \\
\hline
\end{tabular}

\begin{tabular}{|c|c|c|}
\hline RN7SK & 3,06 & $3,98 \mathrm{E}-05$ \\
\hline RN7SKP203 & 2,84 & $3,71 \mathrm{E}-04$ \\
\hline RN7SKP255 & 2,46 & $2,72 \mathrm{E}-03$ \\
\hline RN7SL1 & 3,41 & $7,86 \mathrm{E}-08$ \\
\hline $\begin{array}{l}\text { RN7SL128P } \\
\end{array}$ & 2,70 & $8,81 \mathrm{E}-04$ \\
\hline RN7SL138P & $-1,92$ & $5,33 \mathrm{E}-03$ \\
\hline RN7SL2 & 2,88 & $1,81 \mathrm{E}-05$ \\
\hline RN7SL3 & 5,14 & $5,29 \mathrm{E}-18$ \\
\hline RN7SL396P & 2,28 & $2,85 \mathrm{E}-03$ \\
\hline RN7SL471P & 7,94 & $4,75 E-39$ \\
\hline RN7SL4P & 2,36 & $6,84 \mathrm{E}-04$ \\
\hline RN7SL5P & 2,48 & $2,36 \mathrm{E}-04$ \\
\hline RN7SL732P & 2,17 & $8,19 \mathrm{E}-03$ \\
\hline RN7SL834P & 1,65 & $5,33 \mathrm{E}-03$ \\
\hline RNA5-8SP4 & 2,57 & $4,42 \mathrm{E}-04$ \\
\hline RNA5-8SP5 & 2,97 & $1,28 \mathrm{E}-04$ \\
\hline RNA5-8SP6 & 3,27 & $1,65 \mathrm{E}-05$ \\
\hline RNA5S1 & 3,54 & $5,96 \mathrm{E}-06$ \\
\hline RNA5S6 & 2,66 & $8,27 \mathrm{E}-06$ \\
\hline RNA5SP145 & 2,31 & $2,57 \mathrm{E}-03$ \\
\hline RNA5SP149 & 4,67 & $1,71 \mathrm{E}-10$ \\
\hline RNA5SP202 & 4,19 & $2,84 \mathrm{E}-13$ \\
\hline RNA5SP429 & 2,61 & $1,39 \mathrm{E}-03$ \\
\hline RNASE2 & $-2,29$ & $1,11 \mathrm{E}-03$ \\
\hline RNASET2 & $-2,31$ & $5,07 \mathrm{E}-11$ \\
\hline RND3 & $-2,72$ & $7,69 \mathrm{E}-04$ \\
\hline RNF13 & $-2,13$ & $1,72 \mathrm{E}-04$ \\
\hline RNF135 & $-1,62$ & $2,77 \mathrm{E}-03$ \\
\hline RNF141 & $-1,03$ & $1,09 \mathrm{E}-04$ \\
\hline RNF165 & $-3,27$ & $3,20 \mathrm{E}-05$ \\
\hline RNF166 & $-1,83$ & $3,61 \mathrm{E}-09$ \\
\hline RNF175 & $-1,96$ & $2,41 \mathrm{E}-03$ \\
\hline RNF216 & $-1,41$ & $2,09 \mathrm{E}-06$ \\
\hline RNF217 & $-1,53$ & $4,34 \mathrm{E}-03$ \\
\hline RNFT2 & 1,66 & $6,84 \mathrm{E}-05$ \\
\hline RNMTL1 & 1,18 & $9,64 \mathrm{E}-11$ \\
\hline RNPC3 & $-1,32$ & $1,31 \mathrm{E}-06$ \\
\hline RNU1-1 & 2,22 & $3,15 \mathrm{E}-03$ \\
\hline RNU1-106P & $-2,27$ & $5,60 \mathrm{E}-03$ \\
\hline $\begin{array}{l}\mathrm{RNU} 2-26 \mathrm{P} \\
\end{array}$ & 2,47 & $1,27 \mathrm{E}-03$ \\
\hline RNU2-59P & 4,07 & $7,76 \mathrm{E}-08$ \\
\hline RNU2-61P & 2,32 & $3,70 \mathrm{E}-03$ \\
\hline RNU2-6P & 2,14 & $8,00 \mathrm{E}-03$ \\
\hline RNVU1-18 & 2,66 & $4,22 \mathrm{E}-04$ \\
\hline RNY1 & 3,74 & $2,71 \mathrm{E}-07$ \\
\hline ROM1 & $-1,30$ & $2,85 \mathrm{E}-04$ \\
\hline RP1-107N3,1 & 1,72 & $3,81 \mathrm{E}-03$ \\
\hline $\begin{array}{r}\text { RP11- } \\
1017 \mathrm{G} 21,5\end{array}$ & $-1,78$ & $1,50 \mathrm{E}-06$ \\
\hline RP11- & 100 & 110507 \\
\hline RP11- & & \\
\hline 1020A11,1 & $-2,16$ & 4,37E-04 \\
\hline RP11-102N12,3 & $-2,17$ & $5,57 \mathrm{E}-03$ \\
\hline RP11- & & \\
\hline $1033 \mathrm{~A} 18,1$ & 1,42 & $2,96 \mathrm{E}-03$ \\
\hline RP11-105C19,1 & $-1,69$ & $2,43 \mathrm{E}-03$ \\
\hline RP11-106M3,2 & $-1,95$ & $4,57 \mathrm{E}-03$ \\
\hline RP11-108K14,4 & $-1,70$ & $8,77 \mathrm{E}-05$ \\
\hline RP11-108P20,1 & 1,25 & $4,01 \mathrm{E}-04$ \\
\hline RP11-10L12,2 & 1,09 & $1,13 \mathrm{E}-03$ \\
\hline RP11- & & \\
\hline 1112J20,1 & 1,34 & $3,69 \mathrm{E}-04$ \\
\hline $\begin{array}{r}\text { RP11- } \\
1112 J 20,2\end{array}$ & 1.45 & $1.81 \mathrm{E}-07$ \\
\hline RP11-111M22,2 & $-1,94$ & $2,55 \mathrm{E}-03$ \\
\hline RP11-111M22,4 & $-1,72$ & $7,34 \mathrm{E}-03$ \\
\hline RP11- & 1.5 & רم \\
\hline$\frac{1136 \mathrm{G} 11,8}{\mathrm{RP} 11-}$ & $-1,51$ & \\
\hline 1149023,3 & $-1,81$ & $9,39 \mathrm{E}-03$ \\
\hline RP11- & & \\
\hline 1151B14,4 & 2,46 & $2,72 \mathrm{E}-03$ \\
\hline RP11-115C21,2 & 1,01 & $3,74 \mathrm{E}-05$ \\
\hline RP11-115L11,1 & $-1,79$ & $2,42 \mathrm{E}-03$ \\
\hline RP11-117D22,2 & $-2,66$ & 1,01E-03 \\
\hline RP11-118B22,4 & $-1,92$ & $6,72 \mathrm{E}-03$ \\
\hline RP11-1191J2,5 & $-1,67$ & $5,56 \mathrm{E}-03$ \\
\hline
\end{tabular}

\begin{tabular}{|c|c|c|}
\hline RP1-111C20,4 & $-1,92$ & \\
\hline RP11-120K24,3 & $-2,91$ & $2,90 \mathrm{E}-04$ \\
\hline RP11- & & \\
\hline 1212A22,1 & $-1,02$ & 4,57E-04 \\
\hline RP11-1217F2,1 & $-1,56$ & $4,80 \mathrm{E}-03$ \\
\hline RP11-121A8,1 & $-2,23$ & 54E-05 \\
\hline $\begin{array}{r}\mathrm{RP} 11- \\
122 \mathrm{~K} 13,12\end{array}$ & $-1,77$ & $9,26 \mathrm{E}-04$ \\
\hline $\begin{array}{r}\text { RP11- } \\
\end{array}$ & 128 & $54 \mathrm{E}-\cap 3$ \\
\hline $\begin{array}{r}\text { 1259L22,2 } \\
\text { RP11-125H8, }\end{array}$ & $\frac{1,20}{1.12}$ & $1,75 E-04$ \\
\hline RP11- & & \\
\hline $1267 \mathrm{H} 10,2$ & $-2,30$ & $5,44 \mathrm{E}-04$ \\
\hline $\begin{array}{r}\text { RP11- } \\
1275 \text { 24, }\end{array}$ & $-3,08$ & $1,38 \mathrm{E}-04$ \\
\hline RP11- & & \\
\hline $1275 \mathrm{H} 24,3$ & $-2,33$ & $2,66 \mathrm{E}-03$ \\
\hline RP11-1277A3,1 & $-1,71$ & $9,93 \mathrm{E}-04$ \\
\hline RP11-12A20,7 & $-2,52$ & ,34E-03 \\
\hline RP11-130L8,2 & $-2,27$ & $5,60 \mathrm{E}-03$ \\
\hline RP11-132A1,4 & 2,73 & $4,07 E-04$ \\
\hline RP11-132N15,3 & 2,73 & $8,21 \mathrm{E}-04$ \\
\hline RP11- & & \\
\hline $1334 \mathrm{~A} 24,6$ & $-2,14$ & $1,80 \mathrm{E}-03$ \\
\hline RP11-133K1,7 & 2,56 & ,79E-03 \\
\hline $\begin{array}{r}\text { RP11- } \\
1376 \mathrm{P} 16 \text { ? }\end{array}$ & -180 & \\
\hline RP11-137L10,6 & $-1,54$ & $09 \mathrm{E}-08$ \\
\hline RP11-138A9,1 & 2,82 & $88 \mathrm{E}-06$ \\
\hline RP11-140K17,3 & $-1,21$ & $72 \mathrm{E}-04$ \\
\hline RP11-142L4,2 & 1,29 & ,40E-03 \\
\hline RP11-142L4,3 & 1,29 & $22 \mathrm{E}-03$ \\
\hline RP11-144L1,8 & 1,47 & $06 \mathrm{E}-03$ \\
\hline RP11-146D12,2 & $-1,59$ & $1 \mathrm{E}-03$ \\
\hline RP11-147|3,1 & $-1,52$ & $3 \mathrm{E}-04$ \\
\hline RP11-14I17,3 & $-2,98$ & $96 \mathrm{E}-04$ \\
\hline RP11-150L8,4 & 1,41 &, $60 \mathrm{E}-12$ \\
\hline RP11-151A6,4 & $-2,13$ & $9,24 \mathrm{E}-03$ \\
\hline RP11-151F5,2 & $-1,76$ & \\
\hline RP11-157E21,1 & $-3,87$ & $2 \mathrm{E}-07$ \\
\hline RP11-158C21,3 & 1,76 & $2 \mathrm{E}-07$ \\
\hline RP11-15E18,5 & 1,27 & $55 \mathrm{E}-07$ \\
\hline RP11-162J8,3 & 2,75 & $99 \mathrm{E}-04$ \\
\hline RP11-16 & 2,39 & \\
\hline RP11-168016,1 & 2,96 & $21 \mathrm{E}-05$ \\
\hline RP11-169K16,7 & 1,16 & 39E-16 \\
\hline RP11-16E12,1 & $-2,64$ &, $52 \mathrm{E}-06$ \\
\hline RP11-170L3,7 & $-2,90$ &, $57 \mathrm{E}-08$ \\
\hline RP11-1 & $-1,03$ & \\
\hline RP11-174G6,5 & $-1,51$ & $97 \mathrm{E}-03$ \\
\hline RP11-179B2,2 & $-1,96$ & $99 \mathrm{E}-03$ \\
\hline RP11-182N22,7 & 1,18 & ,49E-03 \\
\hline RP11-183E9,2 & 2,04 & $46 \mathrm{E}-08$ \\
\hline RP11. & 1,08 & \\
\hline RP1-118J21,25 & $-2,23$ & $76 \mathrm{E}-03$ \\
\hline RP11-192M23,1 & 1,06 & $1,98 \mathrm{E}-03$ \\
\hline & & \\
\hline $195 \mathrm{~F} 19,30$ & 1,68 &, $81 \mathrm{E}-03$ \\
\hline RP11-195F19,5 & 1,36 & $09 \mathrm{E}-04$ \\
\hline RP11-196G11,2 & $-2,41$ & $60 \mathrm{E}-05$ \\
\hline RP11-196G18,1 & $-2,02$ & ,76E-03 \\
\hline & -174 & \\
\hline RP11-196016,1 & 1,96 & $72 \mathrm{E}-04$ \\
\hline RP11-1E1,2 & 1,57 & $01 \mathrm{E}-08$ \\
\hline RP11-204H9,2 & 1,32 & \\
\hline RP11-205M3,1 & 1,04 & $38 \mathrm{E}-09$ \\
\hline RP11-206L10,9 & $-1,51$ & $53 \mathrm{E}-03$ \\
\hline RP11-20B24,7 & $-2,18$ & $7,75 \mathrm{E}-03$ \\
\hline RP11-211A18,1 & 1,10 & $3,21 \mathrm{E}-03$ \\
\hline RP11-211N8,2 & 2,24 & \\
\hline RP11-212|21,2 & $-2,72$ & $16 \mathrm{E}-04$ \\
\hline RP11-214C8,2 & 2,40 & $44 \mathrm{E}-03$ \\
\hline RP11-214K3,24 & $-2,22$ & $6,71 \mathrm{E}-03$ \\
\hline RP11-21401,2 & 1,18 & $4,73 \mathrm{E}-05$ \\
\hline RP11-216N14,1 & 1,51 & $1,30 \mathrm{E}-03$ \\
\hline RP11-218M22,1 & $-1,89$ & $4,10 \mathrm{E}-11$ \\
\hline RP11-219G17,4 & $-2,36$ & $3,99 \mathrm{E}-03$ \\
\hline RP11-227D13,4 & 2,24 & $5,26 \mathrm{E}-03$ \\
\hline
\end{tabular}




\begin{tabular}{|c|c|c|}
\hline $\begin{array}{r}\mathrm{RP} 11- \\
229 \mathrm{P} 13,25 \\
\end{array}$ & 1,64 & $5,32 \mathrm{E}-03$ \\
\hline RP11-231C14,3 & 1,11 & $5,37 \mathrm{E}-03$ \\
\hline RP11-23D24,2 & 2,34 & $4,28 \mathrm{E}-03$ \\
\hline RP11-23F23,2 & 2,26 & $5,81 \mathrm{E}-03$ \\
\hline RP11-23J18,1 & $-1,84$ & $3,78 \mathrm{E}-03$ \\
\hline RP11-23N2,4 & $-1,81$ & $6,03 \mathrm{E}-03$ \\
\hline RP11-240M16,1 & 3,22 & $4,04 \mathrm{E}-06$ \\
\hline RP11-244K5,8 & 2,13 & $6,65 \mathrm{E}-03$ \\
\hline RP11-248E9,7 & 2,14 & $8,00 \mathrm{E}-03$ \\
\hline RP11-252A24,7 & $-1,22$ & $2,62 \mathrm{E}-06$ \\
\hline RP11-25202,2 & 1,22 & $4,54 \mathrm{E}-05$ \\
\hline RP11-253M7,1 & 2,82 & $1,55 \mathrm{E}-04$ \\
\hline RP11-254F7,2 & $-1,32$ & $6,10 \mathrm{E}-03$ \\
\hline RP11-254F7,4 & 2,72 & $8,69 \mathrm{E}-04$ \\
\hline RP11-254|22,1 & $-2,12$ & $9,77 \mathrm{E}-03$ \\
\hline RP11-259P15,4 & $-2,00$ & $9,34 \mathrm{E}-04$ \\
\hline RP11-260E18,1 & $-2,57$ & $5,96 \mathrm{E}-04$ \\
\hline RP11-262A12,1 & $-2,68$ & $9,50 \mathrm{E}-04$ \\
\hline RP11-262H14,1 & $-1,35$ & $2,36 \mathrm{E}-03$ \\
\hline RP11-264B17,3 & $-1,67$ & $1,29 \mathrm{E}-05$ \\
\hline RP11-264B17,4 & $-1,77$ & $2,73 \mathrm{E}-04$ \\
\hline RP11-274B21,2 & $-1,22$ & $6,24 \mathrm{E}-05$ \\
\hline RP11-274B21,3 & $-1,50$ & $1,25 \mathrm{E}-04$ \\
\hline RP11-274J2,1 & 1,92 & $5,26 \mathrm{E}-05$ \\
\hline RP11-288L9,4 & $-2,15$ & $8,38 \mathrm{E}-03$ \\
\hline RP11-291L19,1 & 2,78 & $6,00 \mathrm{E}-04$ \\
\hline RP11-292F9,1 & $-2,45$ & $2,81 \mathrm{E}-03$ \\
\hline RP11-294L13,1 & 1,19 & $1,01 \mathrm{E}-04$ \\
\hline RP11-295G20,2 & 3,11 & $2,88 \mathrm{E}-10$ \\
\hline RP11-296P7,4 & 1,25 & 2,82E-05 \\
\hline RP11-297L6,2 & 1,29 & $3,62 \mathrm{E}-03$ \\
\hline RP11-29G8,3 & 1,99 & $3,13 \mathrm{E}-03$ \\
\hline RP11-2B6,2 & $-2,91$ & $2,90 \mathrm{E}-04$ \\
\hline RP11-2E11,9 & 1,50 & $2,76 \mathrm{E}-04$ \\
\hline RP11-304F15,5 & 1,53 & $6,44 \mathrm{E}-08$ \\
\hline RP11-305L7,1 & 1,73 & $1,74 \mathrm{E}-04$ \\
\hline RP11-305L7,3 & 1,99 & $2,01 \mathrm{E}-03$ \\
\hline RP11-305L7,6 & 3,88 & $4,63 \mathrm{E}-07$ \\
\hline RP11-309G3,3 & 1,44 & $5,93 \mathrm{E}-04$ \\
\hline RP1-130G2,1 & 1,05 & $9,03 \mathrm{E}-03$ \\
\hline RP11-313D6,3 & $-2,30$ & $1,71 \mathrm{E}-03$ \\
\hline RP11-313P13,4 & 1,11 & $2,21 \mathrm{E}-03$ \\
\hline RP11-314A15,2 & $-1,55$ & $6,02 \mathrm{E}-03$ \\
\hline RP11-314013,1 & 2,52 & $2,08 \mathrm{E}-03$ \\
\hline RP11-317N8,4 & 1,35 & $8,55 \mathrm{E}-03$ \\
\hline RP11-317N8,5 & 1,13 & $3,51 \mathrm{E}-03$ \\
\hline RP11-320L11,2 & 1,42 & $3,83 \mathrm{E}-04$ \\
\hline RP11-324122,3 & 1,92 & $1,02 \mathrm{E}-03$ \\
\hline RP11-325E14,5 & 1,06 & $1,24 \mathrm{E}-03$ \\
\hline RP11-325K4,2 & $-1,43$ & $2,49 \mathrm{E}-03$ \\
\hline RP11-326C3,11 & $-1,92$ & $2,11 \mathrm{E}-03$ \\
\hline RP11-326C3,7 & $-2,98$ & $1,60 \mathrm{E}-08$ \\
\hline RP11-326G21,1 & $-2,36$ & $2,72 \mathrm{E}-04$ \\
\hline RP11-326l11,1 & 1,66 & $1,80 \mathrm{E}-08$ \\
\hline RP11-329J18,4 & 1,66 & $6,01 \mathrm{E}-04$ \\
\hline RP11-330011,3 & $-2,79$ & $3,15 \mathrm{E}-06$ \\
\hline RP11-333E1,2 & $-1,96$ & $6,92 \mathrm{E}-03$ \\
\hline RP11-334A14,2 & 2,77 & $5,28 \mathrm{E}-08$ \\
\hline RP11-337C18,4 & $-1,91$ & $8,50 \mathrm{E}-03$ \\
\hline RP11-338C15,3 & 2,43 & $2,31 \mathrm{E}-03$ \\
\hline RP11-340F14,5 & $-1,55$ & $3,82 \mathrm{E}-03$ \\
\hline RP11-342D11,3 & $-2,20$ & $6,61 \mathrm{E}-03$ \\
\hline RP11-342M1,7 & $-1,51$ & $4,46 \mathrm{E}-06$ \\
\hline RP11-345J4,3 & $-1,57$ & $8,09 \mathrm{E}-07$ \\
\hline RP11-345J4,5 & 1,52 & $8,34 \mathrm{E}-05$ \\
\hline RP11-345P4,9 & $-1,80$ & $2,37 \mathrm{E}-06$ \\
\hline RP11-347C12,3 & $-2,52$ & $1,98 \mathrm{E}-06$ \\
\hline RP11-347C18,3 & 1,48 & $7,79 \mathrm{E}-03$ \\
\hline RP11-348N5,7 & $-2,46$ & $1,56 \mathrm{E}-04$ \\
\hline RP11-34P13,13 & $-1,22$ & $1,97 \mathrm{E}-03$ \\
\hline RP11-34P13,14 & $-1,35$ & $4,94 \mathrm{E}-03$ \\
\hline RP11-34P13,7 & $-2,09$ & $9,01 \mathrm{E}-03$ \\
\hline RP11-350N15,6 & 2,67 & $4,84 \mathrm{E}-04$ \\
\hline RP11-352E6,2 & 1,29 & $1,56 \mathrm{E}-04$ \\
\hline RP11-353N14,5 & 2,30 & $5,10 \mathrm{E}-03$ \\
\hline
\end{tabular}

\begin{tabular}{|c|c|c|}
\hline & $-2,26$ & \\
\hline RP11-35501,11 & $-1,31$ & $7,95 \mathrm{E}-03$ \\
\hline $\begin{array}{r}\mathrm{RP} 11- \\
356 \mathrm{~B} 19,11\end{array}$ & $-2,15$ & $8,66 \mathrm{E}-03$ \\
\hline RP11-356J5,12 & $-1,69$ & $7,00 \mathrm{E}-03$ \\
\hline RP11-357C3,3 & $-1,23$ & $2,27 \mathrm{E}-05$ \\
\hline RP11-361A21,1 & $-2,55$ & $1,68 \mathrm{E}-03$ \\
\hline RP11-365H23,1 & 1,19 & $1,33 \mathrm{E}-04$ \\
\hline RP11-365H8,2 & 1,40 & $1,59 \mathrm{E}-04$ \\
\hline RP11-367J11,3 & $-2,96$ & $2,36 \mathrm{E}-04$ \\
\hline $\mathrm{RP} 11-379 \mathrm{H} 18,1$ & $-1,46$ & $1,36 \mathrm{E}-03$ \\
\hline RP11-379K17,2 & 1,29 & $3,94 \mathrm{E}-03$ \\
\hline RP11-383|23,2 & $-2,85$ & $4,43 \mathrm{E}-04$ \\
\hline RP11-384B12,3 & 1,14 & $5,46 \mathrm{E}-04$ \\
\hline RP11-384K6,2 & $-1,10$ & $3,00 \mathrm{E}-09$ \\
\hline RP11-38408,1 & $-4,00$ & $1,44 \mathrm{E}-07$ \\
\hline RP11-385F5,5 & $-1,26$ & $3,87 \mathrm{E}-03$ \\
\hline RP11-388C12,8 & $-1,86$ & $7,84 \mathrm{E}-03$ \\
\hline RP11-390K5,6 & $-1,72$ & $7,05 \mathrm{E}-03$ \\
\hline RP11-3 & 1,21 & $7,29 \mathrm{E}-03$ \\
\hline RP11-3 & 2,25 &, $03 E-03$ \\
\hline RP11-392018,2 & 1,57 & $4,71 \mathrm{E}-04$ \\
\hline RP11-394|13,1 & $-2,51$ & $2,18 \mathrm{E}-03$ \\
\hline RP11-395|6,3 & $-1,73$ & $1,34 \mathrm{E}-03$ \\
\hline RP11-39H3,1 & 1,05 & $3,40 \mathrm{E}-04$ \\
\hline RP11-39K24,2 & $-1,37$ & $2,22 \mathrm{E}-07$ \\
\hline $\begin{array}{r}\text { RP11- } \\
\text { 400F19,18 } \\
\end{array}$ & $-1,84$ & \\
\hline RP11-401P9,4 & $-2,90$ & $1,05 \mathrm{E}-09$ \\
\hline $02 \mathrm{~J} 7,2$ & $-2,25$ & $1,40 \mathrm{E}-03$ \\
\hline RP11-4 & $-2,55$ & $1,97 \mathrm{E}-04$ \\
\hline RP11-403113,8 & $-2,09$ & $1,98 \mathrm{E}-05$ \\
\hline RP11-405A12,1 & 1,75 & $3,82 \mathrm{E}-08$ \\
\hline RP11-405L18,2 & 1,27 & $1,63 \mathrm{E}-04$ \\
\hline RP11. & $-1,67$ & \\
\hline RP11. & $-2,20$ & \\
\hline RP11-417B4,3 & 1,99 & 1,89E-03 \\
\hline RP11-419C5,2 & $-1,62$ & $1,99 \mathrm{E}-03$ \\
\hline RP11-420A23,1 & $-2,02$ & $1,23 \mathrm{E}-03$ \\
\hline RP11- & $-1,32$ & \\
\hline RP11. & $-1,73$ & $=-05$ \\
\hline RP11-423H2,1 & 1,12 & \\
\hline RP11-426C22,5 & $-2,15$ & $1,44 \mathrm{E}-03$ \\
\hline RP11-428G5,5 & $-2,73$ & $1,84 \mathrm{E}-04$ \\
\hline RP11-4 & $-2,87$ & \\
\hline RP11. & $-2,19$ & $6,35 \mathrm{E}-03$ \\
\hline RP11-434H6,7 & $-1,48$ & \\
\hline RP11-43505,4 & $-2,37$ & $3,67 \mathrm{E}-03$ \\
\hline RP11-440L14,1 & $-1,31$ & $4,37 \mathrm{E}-03$ \\
\hline RP11-441015,3 & $-1,54$ & $6,44 \mathrm{E}-03$ \\
\hline RP11- & 2,36 & $2,09 \mathrm{E}-05$ \\
\hline RP11-443N24,1 & 1,18 & $36 \mathrm{E}-03$ \\
\hline RP11-444K7,8 & 1,43 & $2,24 \mathrm{E}-04$ \\
\hline RP11-445H22,3 & $-1,41$ & \\
\hline RP11- & 2,38 & \\
\hline RP11- & $-3,04$ & \\
\hline RP11-449P15,2 & $-1,25$ & $95 \mathrm{E}-03$ \\
\hline RP1-144F13,4 & 1,12 & $2,86 \mathrm{E}-06$ \\
\hline RP11-452D12,1 & 1,55 & \\
\hline RP11-452L6,1 & $-2,33$ & $1,96 \mathrm{E}-03$ \\
\hline & & \\
\hline 453F18_B, 1 & 2,00 & \\
\hline RP11-453N18,1 & 2,27 & \\
\hline RP11-455F5,3 & 340 & $3,02 E-20$ \\
\hline RP11-455G16,1 & $-2,20$ & $5,05 E-03$ \\
\hline RP11-45J1,1 & 1,30 & $7,70 \mathrm{E}-05$ \\
\hline RP11-45022,1 & 2,18 & $1,16 \mathrm{E}-04$ \\
\hline RP11-46309,9 & 1,45 & $4,55 \mathrm{E}-03$ \\
\hline RP11-467J12,4 & 3,15 & \\
\hline RP11-469A15,2 & 2,56 &, $75 \mathrm{E}-03$ \\
\hline RP11-469M7,1 & 1,67 & $2,04 E-12$ \\
\hline RP11-46C24,7 & $-1,29$ & $5,32 \mathrm{E}-04$ \\
\hline RP11-46H11,2 & 1,26 & $1,52 \mathrm{E}-07$ \\
\hline RP11-472B18,1 & 1,01 & $1,69 \mathrm{E}-06$ \\
\hline & & \\
\hline & $-1,35$ & \\
\hline RP11-473M20,9 & 1,16 & $3,29 \mathrm{E}-06$ \\
\hline
\end{tabular}

\begin{tabular}{|c|c|c|}
\hline RP11-474B16,1 & 2,61 & $1,40 \mathrm{E}-03$ \\
\hline RP11-475J5,4 & 1,35 & $3,04 \mathrm{E}-03$ \\
\hline RP11-47506,1 & $-2,43$ & $2,13 \mathrm{E}-03$ \\
\hline RP11-477J21,2 & $-1,63$ & $4,16 \mathrm{E}-03$ \\
\hline RP11-47A8,5 & 1,23 & $1,30 \mathrm{E}-03$ \\
\hline RP11-480112,5 & 3,73 & $1,61 \mathrm{E}-06$ \\
\hline RP11-480N24,4 & 2,61 & $1,63 \mathrm{E}-08$ \\
\hline RP11-482D24,3 & 2,15 & $6,04 \mathrm{E}-03$ \\
\hline RP11-486G15,1 & 1,04 & $3,04 \mathrm{E}-08$ \\
\hline RP11-486G15,2 & $-1,88$ & $6,17 \mathrm{E}-03$ \\
\hline RP11-486M23,1 & 3,36 & $6,53 \mathrm{E}-06$ \\
\hline RP11-488C13,5 & $-1,88$ & $1,07 \mathrm{E}-10$ \\
\hline RP11-488L18,1 & 1,00 & $6,47 \mathrm{E}-03$ \\
\hline RP11-489C13,1 & 1,15 & $6,33 \mathrm{E}-03$ \\
\hline RP11-489E7,4 & $-1,83$ & $3,22 \mathrm{E}-04$ \\
\hline RP11-490H24,5 & 1,43 & $1,08 \mathrm{E}-03$ \\
\hline RP11-493K19,3 & $-1,55$ & $1,16 \mathrm{E}-03$ \\
\hline RP11-49619,1 & $-1,94$ & $5,57 \mathrm{E}-05$ \\
\hline RP11-498C9,15 & 1,96 & $4,15 \mathrm{E}-14$ \\
\hline RP11-498D10,6 & $-1,24$ & $3,68 \mathrm{E}-03$ \\
\hline RP11-49C24,1 & 1,64 & $5,81 \mathrm{E}-05$ \\
\hline RP11-49C9,2 & 1,20 & $5,76 \mathrm{E}-07$ \\
\hline RP11-4F5,2 & 1,62 & $1,91 \mathrm{E}-06$ \\
\hline RP11-509E16,1 & 2,50 & $1,02 \mathrm{E}-06$ \\
\hline RP11-510121,1 & 1,17 & $3,47 \mathrm{E}-04$ \\
\hline RP11-510J16,5 & $-2,60$ & $1,34 \mathrm{E}-03$ \\
\hline RP11-51C14,1 & 2,21 & $5,23 \mathrm{E}-18$ \\
\hline RP11-51E20,1 & 1,18 & $1,79 \mathrm{E}-03$ \\
\hline RP11-51J9,5 & $-1,78$ & $5,98 \mathrm{E}-03$ \\
\hline RP11-51L5,3 & 1,29 & $5,84 \mathrm{E}-04$ \\
\hline RP11-527L4,2 & $-2,06$ & $7,46 \mathrm{E}-03$ \\
\hline RP11-529J17,3 & $-1,60$ & $2,00 \mathrm{E}-03$ \\
\hline RP11-530A18,1 & 1,37 & $4,62 \mathrm{E}-06$ \\
\hline RP11-533K11,1 & 1,03 & $1,74 \mathrm{E}-03$ \\
\hline RP11-536K7,5 & 3,61 & $1,25 \mathrm{E}-09$ \\
\hline RP11-539L10,2 & $-2,40$ & $1,16 \mathrm{E}-05$ \\
\hline RP11-53019,3 & $-1,10$ & 2,63E-03 \\
\hline RP11-540B6,6 & $-1,65$ & $1,24 \mathrm{E}-05$ \\
\hline RP11-540E16,1 & 1,57 & $8,96 \mathrm{E}-06$ \\
\hline RP11-541N10,3 & $-1,63$ & $4,76 \mathrm{E}-04$ \\
\hline RP11-543B16,1 & $-1,73$ & $4,50 \mathrm{E}-03$ \\
\hline RP11-54C4,1 & $-1,25$ & $2,65 \mathrm{E}-03$ \\
\hline RP11-54F2,1 & 2,38 & $4,25 \mathrm{E}-04$ \\
\hline RP11-552F3,10 & $-1,94$ & $3,20 \mathrm{E}-04$ \\
\hline RP11-552M11,8 & $-1,53$ & $3,28 \mathrm{E}-03$ \\
\hline RP11-55204,2 & 1,15 & $2,78 \mathrm{E}-08$ \\
\hline RP11-554D14,2 & 1,08 & $2,08 \mathrm{E}-05$ \\
\hline RP11-554J4,1 & $-1,93$ & $4,41 \mathrm{E}-04$ \\
\hline RP11-555M1,3 & 3,05 & $6,94 \mathrm{E}-05$ \\
\hline RP11-556N21,1 & 1,30 & $3,16 \mathrm{E}-04$ \\
\hline RP11-558F24,6 & 1,68 & $4,71 \mathrm{E}-03$ \\
\hline RP11-561C5,4 & $-1,52$ & 2,32E-03 \\
\hline RP11-566E18,3 & 1,35 & $4,32 \mathrm{E}-04$ \\
\hline RP11-573D15,2 & 1,92 & $9,13 \mathrm{E}-03$ \\
\hline RP11-574K11,5 & $-2,08$ & $7,57 \mathrm{E}-03$ \\
\hline RP11-576N17,3 & $-1,35$ & $8,55 \mathrm{E}-03$ \\
\hline RP11-578F21,9 & $-2,24$ & $1,94 \mathrm{E}-03$ \\
\hline RP11-589C21,6 & $-2,30$ & $4,28 \mathrm{E}-03$ \\
\hline RP11-589N15,2 & $-1,87$ & $1,33 \mathrm{E}-03$ \\
\hline RP11-589P10,5 & $-1,44$ & $8,52 \mathrm{E}-03$ \\
\hline RP11-58E21,3 & 2,15 & $5,88 \mathrm{E}-15$ \\
\hline RP11-597D13,9 & $-3,33$ & $1,89 \mathrm{E}-05$ \\
\hline RP11-5C23,1 & $-1,58$ & $2,23 \mathrm{E}-06$ \\
\hline RP11-5N19,3 & 1,60 & $1,21 \mathrm{E}-03$ \\
\hline RP11-600F24,7 & $-1,42$ & $8,84 \mathrm{E}-03$ \\
\hline RP11-601115,1 & 1,59 & $1,29 \mathrm{E}-06$ \\
\hline RP11-609L23,2 & 1,94 & $1,59 \mathrm{E}-08$ \\
\hline RP11-611L7,1 & $-1,62$ & $8,68 \mathrm{E}-06$ \\
\hline RP11-61A14,3 & 1,04 & $6,74 \mathrm{E}-07$ \\
\hline RP11-61J19,4 & $-2,12$ & $5,04 \mathrm{E}-05$ \\
\hline RP11-6101,2 & $-3,08$ & $1,10 \mathrm{E}-04$ \\
\hline RP1-161P9,5 & $-2,18$ & $7,75 \mathrm{E}-03$ \\
\hline RP11-620J15,1 & 2,61 & $1,40 \mathrm{E}-03$ \\
\hline RP11-626A1,1 & 1,77 & $6,67 \mathrm{E}-05$ \\
\hline RP11-626A5,2 & $-2,20$ & $2,13 \mathrm{E}-03$ \\
\hline RP11-626K17,5 & $-2,37$ & $3,73 \mathrm{E}-03$ \\
\hline
\end{tabular}

\begin{tabular}{|c|c|c|}
\hline & 1,06 & \\
\hline RP11-632K20,7 & $-1,32$ & $4,07 \mathrm{E}-04$ \\
\hline RP11-63E16,1 & 1,19 & $2,51 \mathrm{E}-04$ \\
\hline RP11-644L4,1 & 2,56 & $1,75 \mathrm{E}-03$ \\
\hline RP11-654E17,2 & 1,13 & $3,80 \mathrm{E}-06$ \\
\hline RP11-658F2,8 & $-1,82$ & $1,36 \mathrm{E}-04$ \\
\hline $\begin{array}{r}\text { RP11- } \\
661 \mathrm{~A} 12,12\end{array}$ & $-2,19$ & $7,63 \mathrm{E}-03$ \\
\hline RP11-662113,1 & $-2,91$ & $1,78 \mathrm{E}-04$ \\
\hline RP11-666A1,5 & $-2,68$ & $5,95 \mathrm{E}-04$ \\
\hline RP11-667K14,8 & 1,25 & $3,06 \mathrm{E}-04$ \\
\hline RP11-677M14,7 & $-1,77$ & $1,70 \mathrm{E}-03$ \\
\hline RP11-678G14,3 & $-2,85$ & $3,93 \mathrm{E}-04$ \\
\hline RP11-67C2,2 & $-2,12$ & $9,01 \mathrm{E}-03$ \\
\hline RP11-680G24,4 & $-1,03$ & $2,05 \mathrm{E}-03$ \\
\hline RP11-68606,2 & $-2,04$ & , 25E-04 \\
\hline RP11-690G19,3 & $-1,19$ & $7,79 \mathrm{E}-04$ \\
\hline RP11-692C23,1 & 1,24 & $1,93 \mathrm{E}-06$ \\
\hline RP11-693N9,2 & $-1,83$ & $6,00 \mathrm{E}-07$ \\
\hline RP11-694115,7 & $-2,54$ & $5,87 \mathrm{E}-04$ \\
\hline RP11-697N18,2 & 1,63 & $4,14 \mathrm{E}-07$ \\
\hline RP11-699L21,1 & $-2,19$ & $7,63 \mathrm{E}-03$ \\
\hline RP11-69113,1 & 1,20 & $4,94 \mathrm{E}-03$ \\
\hline RP11-69M1,4 & 2,26 & $6,36 \mathrm{E}-04$ \\
\hline RP11-6B6,3 & $-1,15$ & $3,44 \mathrm{E}-03$ \\
\hline RP11-612,3 & $-2,55$ & $9,85 \mathrm{E}-04$ \\
\hline RP11-701P16,1 & $-2,31$ & $3,09 \mathrm{E}-03$ \\
\hline RP11-704M14,1 & $-2,13$ & $9,41 \mathrm{E}-03$ \\
\hline RP11-705C15,5 & 1,53 & $1,75 \mathrm{E}-03$ \\
\hline RP11-7 & 2,51 & $2,29 \mathrm{E}-04$ \\
\hline RP11-707P17,2 & $-2,34$ & $1,45 \mathrm{E}-03$ \\
\hline RP11-710E1,1 & 1,87 & $1,72 \mathrm{E}-05$ \\
\hline RP11-712C7,2 & 1,44 & $9,75 \mathrm{E}-03$ \\
\hline RP11-713P17,3 & $-2,20$ & $1,47 \mathrm{E}-04$ \\
\hline RP11-7 & $-2,23$ & $6,43 \mathrm{E}-03$ \\
\hline RP11-728G15,1 & 2,46 & ,72E-03 \\
\hline RP11-731C17,2 & $-2,04$ & $7,20 \mathrm{E}-06$ \\
\hline RP11-744H18,1 & $-1,65$ & $4,07 \mathrm{E}-05$ \\
\hline RP11-7 & 1,12 & $3,95 \mathrm{E}-07$ \\
\hline RP11-752P2,2 & 2,21 & $73 \mathrm{E}-04$ \\
\hline RP11-75706,4 & 1,62 & $54 \mathrm{E}-03$ \\
\hline RP11-759L5,2 & 1,55 & $2,39 \mathrm{E}-05$ \\
\hline RP11-762B21,5 & 1,24 & $2,18 \mathrm{E}-05$ \\
\hline RP11-7 & 2,88 & $3,29 E-05$ \\
\hline RP11-77P16,4 & $-1,65$ & ,63E-04 \\
\hline RP11-789C17,1 & $-2,41$ & $10 \mathrm{E}-03$ \\
\hline RP11-791G16,4 & 1,11 & $5,98 \mathrm{E}-03$ \\
\hline $\mathrm{RP} 11-791 \mathrm{G} 16,5$ & 1,95 & $33 \mathrm{E}-08$ \\
\hline RP11-795F19,5 & 1,75 & ,95E-03 \\
\hline RP11-796E2,4 & $-2,42$ & $83 \mathrm{E}-04$ \\
\hline RP11-796G6,2 & $-1,28$ & $90 \mathrm{E}-04$ \\
\hline RP11-798M19,6 & $-1,37$ & $5,77 \mathrm{E}-03$ \\
\hline RP11-799D4,4 & $-1,52$ & $2,13 \mathrm{E}-03$ \\
\hline RP1-179N16,3 & 1,62 & $28 \mathrm{E}-05$ \\
\hline RP1-179 & $-1,65$ & $5,07 \mathrm{E}-03$ \\
\hline RP11-800A3,4 & $-2,61$ & $07 \mathrm{E}-03$ \\
\hline RP11-804A23,2 & 1,68 & $5,05 \mathrm{E}-03$ \\
\hline RP11-804H8,6 & $-1,44$ & \\
\hline RP11-809017,1 & 1,45 & $06 \mathrm{E}-03$ \\
\hline RP11-815|9,4 & 1,63 & ,17E-04 \\
\hline RP11-815N9,2 & 1,14 & $4,38 \mathrm{E}-05$ \\
\hline RP11-81A1,3 & 1,66 & $1,04 \mathrm{E}-04$ \\
\hline RP11-82L18,2 & 2,67 & $1,10 \mathrm{E}-03$ \\
\hline RP11-83N9,5 & 1,50 & $85 \mathrm{E}-05$ \\
\hline RP11-844P9,2 & 2,32 & $33 \mathrm{E}-03$ \\
\hline RP11-847H18,3 & 2,61 & $1,39 \mathrm{E}-03$ \\
\hline RP11-848G14,2 & $-1,77$ & $7,43 \mathrm{E}-04$ \\
\hline RP11-848P1,2 & $-2,95$ & $8,19 \mathrm{E}-06$ \\
\hline RP11-855A2,5 & 3,65 & $3,00 \mathrm{E}-06$ \\
\hline RP11-857B24,3 & 1,00 & $66 \mathrm{E}-05$ \\
\hline RP11-85K15,2 & $-1,36$ & $5,42 \mathrm{E}-03$ \\
\hline RP11-876N24,4 & $-2,30$ & $5,13 \mathrm{E}-05$ \\
\hline RP11-887P2,3 & 1,53 & $3,59 \mathrm{E}-04$ \\
\hline RP11-890B15,3 & $-1,25$ & $8,25 \mathrm{E}-04$ \\
\hline RP11-895M11,2 & 1,38 & $4,98 \mathrm{E}-03$ \\
\hline RP11-89F3,2 & $-1,92$ & $5,22 \mathrm{E}-03$ \\
\hline
\end{tabular}




\begin{tabular}{|c|c|c|}
\hline RP1-191J18,66 & 1,48 & \\
\hline RP11-91J3,1 & 1,67 & $2,46 \mathrm{E}-03$ \\
\hline RP11-94H18,1 & $-2,19$ & $5,94 \mathrm{E}-03$ \\
\hline RP11-94I2,1 & $-1,02$ & $5,29 \mathrm{E}-03$ \\
\hline RP11-950C14,3 & 1,26 & $6,04 \mathrm{E}-03$ \\
\hline RP11-958N24,2 & $-1,04$ & $7,12 \mathrm{E}-05$ \\
\hline RP11-959F10,5 & 2,23 & $1,85 \mathrm{E}-04$ \\
\hline RP11-95M15,2 & 1,55 & $3,23 \mathrm{E}-03$ \\
\hline RP11-96K19,2 & $-1,60$ & $5,59 \mathrm{E}-03$ \\
\hline RP11-96L14,7 & 1,46 & $5,74 \mathrm{E}-04$ \\
\hline RP11-981G7,6 & $-1,89$ & $4,48 \mathrm{E}-04$ \\
\hline RP1-261G23,4 & 1,44 & $9,31 \mathrm{E}-09$ \\
\hline RP1-266L20,9 & $-1,58$ & $2,59 \mathrm{E}-03$ \\
\hline RP1-273G13,2 & 1,43 & $6,61 \mathrm{E}-12$ \\
\hline RP1-283E3,4 & $-1,59$ & $1,77 \mathrm{E}-05$ \\
\hline RP1-283E3,8 & $-1,46$ & $1,01 \mathrm{E}-03$ \\
\hline RP1-28010,1 & 2,40 & $8,50 \mathrm{E}-07$ \\
\hline RP1-29C18,8 & 1,45 & $1,38 \mathrm{E}-05$ \\
\hline RP13-1032I1,7 & $-1,13$ & $6,15 \mathrm{E}-03$ \\
\hline $\begin{array}{r}\mathrm{RP} 13- \\
1056 \mathrm{D} 16,2 \\
\end{array}$ & 1,62 & \\
\hline RP13-13A3,1 & $-1,39$ & $1,08 \mathrm{E}-06$ \\
\hline RP13-200J3,2 & 1,40 & $5,07 \mathrm{E}-04$ \\
\hline RP13-297E16,4 & $-2,36$ & $3,99 \mathrm{E}-03$ \\
\hline RP13-317D12,3 & $-1,28$ & $9,19 \mathrm{E}-03$ \\
\hline RP13-452N2,1 & $-1,95$ & $6,96 \mathrm{E}-03$ \\
\hline RP13-516M14,2 & $-1,86$ & $2,16 \mathrm{E}-03$ \\
\hline RP13-516M14,4 & $-1,77$ & $9,46 \mathrm{E}-03$ \\
\hline RP13-75G22,1 & 2,87 & $1,15 \mathrm{E}-04$ \\
\hline RP13-7D7,1 & 1,49 & $8,75 \mathrm{E}-05$ \\
\hline RP1-38C16,2 & 2,29 & $4,56 \mathrm{E}-03$ \\
\hline RP1-39G22,7 & $-1,51$ & $1,17 \mathrm{E}-05$ \\
\hline RP1-55C23,7 & $-2,05$ & $8,27 \mathrm{E}-03$ \\
\hline RP1-59D14,5 & $-1,60$ & $3,21 \mathrm{E}-04$ \\
\hline RP1-74M1,3 & $-3,11$ & $8,88 \mathrm{E}-05$ \\
\hline RP1-86C11,7 & 2,13 & $7,00 \mathrm{E}-03$ \\
\hline RP1-90L6,2 & $-2,69$ & $4,20 \mathrm{E}-05$ \\
\hline RP3-322G13,5 & $-2,21$ & 1,73E-04 \\
\hline RP3-324017,4 & 1,03 & $1,04 \mathrm{E}-03$ \\
\hline RP3-337018,9 & $-1,72$ & $2,75 \mathrm{E}-03$ \\
\hline RP3-395C13,1 & $-3,93$ & $2,10 \mathrm{E}-07$ \\
\hline RP3-395M20,12 & $-2,92$ & $6,33 \mathrm{E}-33$ \\
\hline RP3-395M20,7 & $-1,72$ & $4,02 \mathrm{E}-03$ \\
\hline RP3-395M20,9 & $-1,23$ & $3,22 \mathrm{E}-04$ \\
\hline RP3-402G11,26 & $-1,39$ & 7,87E-04 \\
\hline RP3-406P24,1 & 1,18 & $1,55 \mathrm{E}-03$ \\
\hline RP3-419C19,2 & 1,23 & $1,32 \mathrm{E}-05$ \\
\hline RP3-481A17,1 & 1,39 & $2,65 \mathrm{E}-04$ \\
\hline RP3-508115,14 & $-1,29$ & $2,21 \mathrm{E}-04$ \\
\hline RP3-508115,19 & $-1,43$ & ,28E-04 \\
\hline RP3-512E2,2 & 2,32 & $3,70 \mathrm{E}-03$ \\
\hline RP4-536B24,4 & 2,14 & $8,37 \mathrm{E}-03$ \\
\hline RP4-569D19,5 & 1,05 & $9,35 \mathrm{E}-06$ \\
\hline RP4-580019,2 & 1,10 & $5,13 \mathrm{E}-03$ \\
\hline RP4-581F12,1 & 1,18 & $1,26 \mathrm{E}-04$ \\
\hline RP4-592A1,2 & 1,20 & $7,62 \mathrm{E}-04$ \\
\hline RP4-607J23,2 & $-1,55$ & $3,73 \mathrm{E}-03$ \\
\hline RP4-621B10,8 & $-2,41$ & $2,10 \mathrm{E}-03$ \\
\hline RP4-654C18,1 & 1,02 & $7,04 \mathrm{E}-04$ \\
\hline RP4-680D5,2 & $-2,61$ & $1,38 \mathrm{E}-03$ \\
\hline RP4-694A7,2 & 2,55 & $1,88 \mathrm{E}-03$ \\
\hline RP4-738P 15,1 & $-2,53$ & $1,96 \mathrm{E}-03$ \\
\hline RP4-740C4,6 & $-1,37$ & $1,02 \mathrm{E}-03$ \\
\hline RP4-756H11,3 & $-1,45$ & $7,27 \mathrm{E}-03$ \\
\hline RP4-758J24,5 & $-1,71$ & $3,93 \mathrm{E}-05$ \\
\hline RP4-761J14,10 & $-3,51$ & $7,64 \mathrm{E}-06$ \\
\hline RP4-773N10,4 & $-1,16$ & $4,97 \mathrm{E}-05$ \\
\hline RP4-791M13,3 & $-1,62$ & $9,44 \mathrm{E}-04$ \\
\hline RP4-798A10,4 & $-2,15$ & $6,66 \mathrm{E}-03$ \\
\hline RP4-800G7,2 & $-2,19$ & $5,48 \mathrm{E}-07$ \\
\hline RP5-1021120,2 & 4,56 & $5,81 \mathrm{E}-10$ \\
\hline RP5-1057J7,6 & $-1,62$ & $8,84 \mathrm{E}-05$ \\
\hline RP5-1092A3,4 & $-1,37$ & $8,90 \mathrm{E}-03$ \\
\hline RP5-1112D6,4 & $-1,38$ & $1,52 \mathrm{E}-03$ \\
\hline RP5-1115A15,1 & $-1,88$ & $7,01 \mathrm{E}-03$ \\
\hline RP5-1119A7 & $-1,51$ & \\
\hline
\end{tabular}

\begin{tabular}{|c|c|c|}
\hline RP5-1125A11,1 & 1,63 & $6,15 \mathrm{E}-03$ \\
\hline RP5-115904,1 & $-1,77$ & $3,27 \mathrm{E}-04$ \\
\hline RP5-1180C10,2 & $-1,82$ & $9,18 \mathrm{E}-05$ \\
\hline RP5-849L7,1 & 1,10 & $8,04 \mathrm{E}-05$ \\
\hline RP5-855D21,1 & $-2,12$ & $5,01 \mathrm{E}-03$ \\
\hline RP5-857K21,7 & 1,46 & $1,60 \mathrm{E}-05$ \\
\hline RP5-864K19,4 & $-2,29$ & $1,33 \mathrm{E}-04$ \\
\hline RP5-874C20,3 & $-1,94$ & $5,96 \mathrm{E}-11$ \\
\hline $\begin{array}{l}\text { RP5-887A10,1 } \\
\end{array}$ & $-2,22$ & $6,71 \mathrm{E}-03$ \\
\hline RP5-894A10,2 & $-1,54$ & $8,46 \mathrm{E}-03$ \\
\hline RP5-943J3,2 & $-1,64$ & $2,94 \mathrm{E}-03$ \\
\hline RP5-983L19,2 & 2,77 & $2,10 \mathrm{E}-04$ \\
\hline RP5-996D20,3 & 1,22 & $2,32 \mathrm{E}-03$ \\
\hline RP6-145B8,3 & 1,67 & $1,05 \mathrm{E}-04$ \\
\hline RP6-99M1,2 & 1,24 & 1,79E-05 \\
\hline RPA2 & 1,11 & $1,83 \mathrm{E}-06$ \\
\hline RPA2P2 & 1,28 & $2,70 \mathrm{E}-13$ \\
\hline RPA2P3 & 1,38 & $4,77 \mathrm{E}-12$ \\
\hline RPGRIP1L & 1,59 & $1,55 \mathrm{E}-06$ \\
\hline RPH3AL & $-1,05$ & $3,83 \mathrm{E}-04$ \\
\hline RPL32P1 & $-2,28$ & $3,49 \mathrm{E}-03$ \\
\hline RPL7P21 & 1,00 & $7,58 \mathrm{E}-03$ \\
\hline RPP21 & $-1,01$ & $1,07 E-03$ \\
\hline RPP30 & 1,43 & $7,89 \mathrm{E}-07$ \\
\hline RPPH1 & 3,92 & $2,44 \mathrm{E}-08$ \\
\hline RPS10P7 & $-1,66$ & $8,23 \mathrm{E}-03$ \\
\hline RPS20P10 & $-1,21$ & $8,95 \mathrm{E}-03$ \\
\hline RPS6KA4 & $-1,43$ & $4,14 \mathrm{E}-09$ \\
\hline RPS7P3 & $-1,51$ & $7,28 \mathrm{E}-03$ \\
\hline RPSAP9 & 2,03 & $1,78 \mathrm{E}-08$ \\
\hline RPUSD2 & 1,06 & $2,00 \mathrm{E}-08$ \\
\hline RQCD1 & 1,12 & $1,19 \mathrm{E}-12$ \\
\hline RRAD & 5,13 & $1,08 \mathrm{E}-44$ \\
\hline RRAS2 & 2,49 & $1,69 \mathrm{E}-08$ \\
\hline RREB1 & $-1,23$ & $1,86 \mathrm{E}-04$ \\
\hline RRP36 & 1,23 & $1,12 \mathrm{E}-07$ \\
\hline RRS1 & 1,20 & $4,80 \mathrm{E}-13$ \\
\hline RSAD1 & $-1,17$ & $3,30 \mathrm{E}-05$ \\
\hline RSL24D1P2 & 1,82 & $1,83 \mathrm{E}-03$ \\
\hline RSPO4 & $-2,29$ & $1,74 \mathrm{E}-03$ \\
\hline RTKN & 1,85 & $1,45 \mathrm{E}-07$ \\
\hline S100A14 & 2,52 & $2,08 \mathrm{E}-03$ \\
\hline S100A8 & $-2,20$ & $3,23 \mathrm{E}-04$ \\
\hline S100A9 & $-2,39$ & $1,08 \mathrm{E}-06$ \\
\hline S100B & $-1,85$ & $2,43 \mathrm{E}-06$ \\
\hline S1PR5 & $-1,70$ & $1,81 \mathrm{E}-07$ \\
\hline SACS & 1,04 & $1,33 \mathrm{E}-04$ \\
\hline SAMD14 & 2,18 & $5,53 \mathrm{E}-08$ \\
\hline SAMD15 & 2,21 & $4,01 \mathrm{E}-03$ \\
\hline SAMD3 & $-1,10$ & $8,21 \mathrm{E}-03$ \\
\hline SAMHD1 & $-1,77$ & $1,46 \mathrm{E}-05$ \\
\hline SAP30 & 1,32 & 1,82E-04 \\
\hline SARDH & $-1,86$ & $3,86 \mathrm{E}-07$ \\
\hline SAT1 & $-1,28$ & $2,12 \mathrm{E}-03$ \\
\hline SAT2 & $-1,05$ & $1,14 \mathrm{E}-04$ \\
\hline SATB1 & 1,24 & $1,78 \mathrm{E}-03$ \\
\hline SATB2 & $-2,37$ & $1,18 \mathrm{E}-04$ \\
\hline SBK1 & $-2,11$ & $5,17 \mathrm{E}-05$ \\
\hline SCAMP4 & $-1,18$ & $8,11 \mathrm{E}-03$ \\
\hline SCAMP5 & 1,58 & $4,23 \mathrm{E}-08$ \\
\hline SCARNA10 & 1,98 & $8,37 \mathrm{E}-03$ \\
\hline SCARNA12 & 1,65 & $2,42 \mathrm{E}-03$ \\
\hline SCARNA6 & 2,57 & $3,47 \mathrm{E}-05$ \\
\hline SCD5 & 1,48 & $7,25 \mathrm{E}-04$ \\
\hline SCFD2 & 1,22 & $5,28 \mathrm{E}-07$ \\
\hline SCG5 & 1,77 & $4,14 \mathrm{E}-03$ \\
\hline SCGB3A1 & $-2,12$ & $9,86 \mathrm{E}-03$ \\
\hline SCLT1 & 1,28 & $1,02 \mathrm{E}-13$ \\
\hline SCML4 & $-1,77$ & $7,43 \mathrm{E}-05$ \\
\hline SCN2A & 2,21 & $4,64 \mathrm{E}-03$ \\
\hline SCN3B & 1,68 & $9,71 \mathrm{E}-04$ \\
\hline $\mathrm{SCO} 1$ & 1,12 & $3,81 \mathrm{E}-03$ \\
\hline SCRN2 & $-1,01$ & $2,66 \mathrm{E}-04$ \\
\hline SDCBPP3 & $-1,49$ & $3,77 \mathrm{E}-03$ \\
\hline SECISBP2 & $-1,08$ & $6,89 \mathrm{E}-07$ \\
\hline SEH1L & 1,08 & $1,24 \mathrm{E}-04$ \\
\hline
\end{tabular}

\begin{tabular}{|c|c|c|}
\hline SELM & $-1,61$ & $4,25 \mathrm{E}-04$ \\
\hline SEMA3G & $-2,48$ & $1,01 \mathrm{E}-05$ \\
\hline SEMA5A & $-2,37$ & $1,68 \mathrm{E}-03$ \\
\hline SEMA5B & $-2,13$ & $2,31 \mathrm{E}-04$ \\
\hline SEMA6A & $-1,92$ & $5,38 \mathrm{E}-07$ \\
\hline SEMA6B & $-3,84$ & $5,51 \mathrm{E}-12$ \\
\hline SENP3-EIF4A1 & 3,24 & $2,59 \mathrm{E}-08$ \\
\hline SENP7 & $-1,20$ & $3,25 \mathrm{E}-03$ \\
\hline SEPHS1 & 1,01 & $2,00 \mathrm{E}-09$ \\
\hline SEPT10 & $-1,66$ & $6,04 \mathrm{E}-03$ \\
\hline SEPT11 & 1,22 & $1,38 \mathrm{E}-04$ \\
\hline SEPT9 & $-1,14$ & $2,61 \mathrm{E}-08$ \\
\hline SERBP1P3 & $-2,10$ & $8,84 \mathrm{E}-03$ \\
\hline SERPINB10 & 2,23 & $3,20 \mathrm{E}-04$ \\
\hline SERTAD3 & $-1,27$ & $4,42 \mathrm{E}-04$ \\
\hline SET & 1,06 & $1,75 \mathrm{E}-09$ \\
\hline SETBP1 & 1,81 & $1,11 \mathrm{E}-08$ \\
\hline SETD1B & $-1,05$ & $1,20 \mathrm{E}-03$ \\
\hline SETD8 & 1,05 & $1,61 \mathrm{E}-05$ \\
\hline SETDB2 & $-1,88$ & $1,61 \mathrm{E}-05$ \\
\hline SETP21 & 1,43 & $2,60 \mathrm{E}-03$ \\
\hline SF3A3 & 1,08 & $3,68 \mathrm{E}-13$ \\
\hline SF3A3P1 & 1,42 & $4,37 \mathrm{E}-09$ \\
\hline SF3A3P2 & 1,49 & $1,98 \mathrm{E}-08$ \\
\hline SF3B14 & 1,16 & $8,46 \mathrm{E}-05$ \\
\hline SFPQP1 & 1,33 & $8,68 \mathrm{E}-05$ \\
\hline SFXN3 & $-1,46$ & $2,88 \mathrm{E}-06$ \\
\hline SFXN4 & 1,01 & $4,69 \mathrm{E}-04$ \\
\hline SGCB & 1,54 & $4,45 \mathrm{E}-09$ \\
\hline SGSM2 & $-1,44$ & $5,49 \mathrm{E}-06$ \\
\hline SGSM3 & $-1,26$ & $6,68 \mathrm{E}-10$ \\
\hline SGTB & $-1,97$ & $4,12 \mathrm{E}-05$ \\
\hline SH2B1 & $-1,34$ & $5,04 \mathrm{E}-05$ \\
\hline SH2D1B & $-2,31$ & $1,56 \mathrm{E}-14$ \\
\hline SH3BGRL & $-1,62$ & $1,36 \mathrm{E}-05$ \\
\hline SH3BGRL2 & $-1,56$ & $1,30 \mathrm{E}-03$ \\
\hline SH3PXD2A & $-1,39$ & $4,76 \mathrm{E}-04$ \\
\hline SH3PXD2B & $-3,06$ & $2,89 \mathrm{E}-05$ \\
\hline SH3TC1 & $-1,99$ & $9,78 \mathrm{E}-12$ \\
\hline SHARPIN & $-1,09$ & $4,36 \mathrm{E}-11$ \\
\hline $\mathrm{SHC} 3$ & 2,21 & $5,34 \mathrm{E}-03$ \\
\hline SHISA2 & $-2,38$ & $1,03 \mathrm{E}-03$ \\
\hline SHISA5 & $-1,49$ & $2,54 \mathrm{E}-07$ \\
\hline SIDT1 & $-1,21$ & $5,97 \mathrm{E}-03$ \\
\hline SIGIRR & $-2,03$ & $3,31 \mathrm{E}-05$ \\
\hline SIGLEC10 & $-1,83$ & $9,03 \mathrm{E}-04$ \\
\hline SIGLEC12 & 1,20 & $5,41 \mathrm{E}-03$ \\
\hline SIGLEC14 & $-3,29$ & $5,78 \mathrm{E}-11$ \\
\hline SIGLEC18P & $-2,56$ & $8,92 \mathrm{E}-04$ \\
\hline SIGLEC22P & $-1,92$ & $9,39 \mathrm{E}-03$ \\
\hline SIGLEC5 & $-2,10$ & $8,87 \mathrm{E}-04$ \\
\hline SIK1 & $-2,25$ & $2,72 \mathrm{E}-04$ \\
\hline SIN3B & $-1,32$ & $9,53 \mathrm{E}-12$ \\
\hline SIRPAP1 & $-2,15$ & $5,58 \mathrm{E}-05$ \\
\hline SKI & $-1,63$ & $1,84 \mathrm{E}-10$ \\
\hline SKOR1 & $-1,76$ & $6,42 \mathrm{E}-03$ \\
\hline SLAMF1 & 2,29 & $1,17 \mathrm{E}-06$ \\
\hline SLC11A1 & $-1,96$ & $9,49 \mathrm{E}-03$ \\
\hline SLC11A2 & $-1,55$ & $2,64 \mathrm{E}-04$ \\
\hline SLC12A2 & 1,37 & $2,04 \mathrm{E}-14$ \\
\hline SLC12A9 & $-1,58$ & $7,92 \mathrm{E}-29$ \\
\hline SLC16A3 & $-1,36$ & $4,44 \mathrm{E}-03$ \\
\hline SLC17A2 & 2,17 & $8,19 \mathrm{E}-03$ \\
\hline SLC17A5 & $-1,69$ & $7,05 \mathrm{E}-04$ \\
\hline SLC1A1 & $-2,37$ & $1,91 \mathrm{E}-03$ \\
\hline SLC1A2 & 2,40 & $1,45 \mathrm{E}-03$ \\
\hline SLC1A5 & 1,37 & $1,96 \mathrm{E}-03$ \\
\hline SLC22A15 & $-2,49$ & $9,31 \mathrm{E}-06$ \\
\hline SLC22A17 & $-1,70$ & $2,26 \mathrm{E}-03$ \\
\hline SLC22A20 & 1,32 & $6,31 \mathrm{E}-03$ \\
\hline SLC22A5 & $-1,33$ & $1,23 \mathrm{E}-07$ \\
\hline SLC23A2 & $-1,53$ & $2,11 \mathrm{E}-07$ \\
\hline SLC25A17 & 1,19 & $9,45 \mathrm{E}-09$ \\
\hline SLC25A23 & $-1,35$ & $1,89 \mathrm{E}-03$ \\
\hline SLC25A30 & $-1,03$ & $1,26 \mathrm{E}-05$ \\
\hline SLC25A37 & $-1,46$ & $9,96 \mathrm{E}-11$ \\
\hline
\end{tabular}

\begin{tabular}{|c|c|c|}
\hline SLC25A4 & 1,38 & $5,60 \mathrm{E}-04$ \\
\hline SLC25A44 & 1,06 & $4,90 \mathrm{E}-04$ \\
\hline SLC25A45 & $-1,97$ & $4,17 \mathrm{E}-06$ \\
\hline SLC25A53 & $-1,42$ & 9,58E-05 \\
\hline SLC26A1 & $-1,22$ & $1,40 \mathrm{E}-03$ \\
\hline SLC26A4 & 2,07 & $8,15 \mathrm{E}-03$ \\
\hline SLC26A5 & $-2,91$ & $2,80 \mathrm{E}-04$ \\
\hline SLC29A2 & $-1,89$ & $1,85 \mathrm{E}-04$ \\
\hline SLC29A4 & $-2,24$ & $4,05 \mathrm{E}-04$ \\
\hline SLC2A1 & 2,05 & $3,07 E-08$ \\
\hline SLC2A11 & $-1,39$ & $1,41 \mathrm{E}-03$ \\
\hline SLC2A3 & $-1,01$ & $4,32 \mathrm{E}-04$ \\
\hline SLC2A4RG & $-2,06$ & $3,17 \mathrm{E}-06$ \\
\hline SLC30A1 & $-2,18$ & $2,18 \mathrm{E}-07$ \\
\hline SLC35A1 & $-1,15$ & $4,57 \mathrm{E}-05$ \\
\hline SLC35D1 & 1,16 & $3,54 \mathrm{E}-07$ \\
\hline SLC35D2 & $-1,38$ & $4,88 \mathrm{E}-10$ \\
\hline SLC35E2B & $-1,06$ & 1,74E-04 \\
\hline SLC35F3 & 2,04 & $9,83 \mathrm{E}-03$ \\
\hline SLC39A13 & $-1,50$ & $2,19 \mathrm{E}-07$ \\
\hline SLC39A2 & 3,58 & $4,43 \mathrm{E}-06$ \\
\hline SLC41A1 & 1,23 & 4,41E-04 \\
\hline SLC43A2 & $-1,69$ & $4,14 \mathrm{E}-03$ \\
\hline SLC45A3 & $-1,41$ & $1,34 \mathrm{E}-06$ \\
\hline SLC46A3 & $-1,79$ & $1,76 \mathrm{E}-09$ \\
\hline SLC52A1 & $-3,04$ & $1,02 \mathrm{E}-06$ \\
\hline SLC6A6 & $-1,41$ & $3,86 \mathrm{E}-03$ \\
\hline SLC6A9 & 2,06 & $1,35 \mathrm{E}-07$ \\
\hline SLC7A7 & $-2,35$ & $5,94 \mathrm{E}-06$ \\
\hline SLC9B1 & $-1,23$ & $2,95 \mathrm{E}-03$ \\
\hline SLC9B2 & 1,00 & $2,72 \mathrm{E}-03$ \\
\hline SLCO3A1 & $-1,49$ & $4,78 \mathrm{E}-04$ \\
\hline SLIRP & 1,06 & $5,93 \mathrm{E}-03$ \\
\hline SLMO2 & 1,14 & $1,25 \mathrm{E}-07$ \\
\hline SLPI & $-2,12$ & $9,90 \mathrm{E}-03$ \\
\hline SMAD3 & $-1,68$ & $1,40 \mathrm{E}-03$ \\
\hline SMAD7 & $-1,65$ & $7,12 \mathrm{E}-06$ \\
\hline SMARCD3 & $-3,56$ & $9,46 E-31$ \\
\hline SMC3 & 1,33 & $1,86 \mathrm{E}-04$ \\
\hline SMIM13 & 1,15 & $1,26 \mathrm{E}-07$ \\
\hline SMPD1 & $-1,44$ & $8,53 \mathrm{E}-08$ \\
\hline SNAI3 & $-1,40$ & $3,10 \mathrm{E}-07$ \\
\hline SNAP25 & 2,32 & $5,21 \mathrm{E}-04$ \\
\hline SNHG11 & $-1,50$ & $5,05 \mathrm{E}-09$ \\
\hline SNHG15 & 1,88 & $1,35 \mathrm{E}-07$ \\
\hline SNN & $-2,17$ & $4,62 \mathrm{E}-06$ \\
\hline $\begin{array}{r}\text { SNORA23 } \\
\end{array}$ & 3,22 & $1,43 \mathrm{E}-05$ \\
\hline SNORA73B & 3,83 & $1,83 \mathrm{E}-08$ \\
\hline SNORA74A & 3,97 & $3,84 \mathrm{E}-09$ \\
\hline SNORA76 & 2,86 & $3,71 \mathrm{E}-06$ \\
\hline SNORD17 & 2,17 & $5,61 \mathrm{E}-03$ \\
\hline SNORD3A & 3,61 & $1,06 \mathrm{E}-06$ \\
\hline SNORD3B-1 & 2,74 & $9,85 \mathrm{E}-06$ \\
\hline SNORD3B-2 & 3,37 & $4,67 \mathrm{E}-13$ \\
\hline SNORD3C & 3,97 & $1,39 \mathrm{E}-11$ \\
\hline SNORD3D & 2,88 & $2,66 \mathrm{E}-05$ \\
\hline SNPH & $-1,65$ & $9,14 \mathrm{E}-04$ \\
\hline SNRK & $-1,00$ & $5,38 \mathrm{E}-03$ \\
\hline SNRPEP2 & 1,34 & $5,11 \mathrm{E}-06$ \\
\hline SNRPGP2 & 1,90 & $3,24 \mathrm{E}-06$ \\
\hline SNRPN & $-1,35$ & $4,88 \mathrm{E}-03$ \\
\hline SNTB1 & $-2,53$ & $1,08 \mathrm{E}-06$ \\
\hline SNX18 & $-1,67$ & $5,23 \mathrm{E}-05$ \\
\hline SNX2 & $-1,26$ & $3,40 \mathrm{E}-03$ \\
\hline SNX21 & $-1,37$ & $3,10 \mathrm{E}-06$ \\
\hline SNX27 & $-1,22$ & $7,35 \mathrm{E}-03$ \\
\hline SNX29P1 & $-1,79$ & $6,98 \mathrm{E}-05$ \\
\hline SNX3 & $-1,03$ & $7,67 \mathrm{E}-03$ \\
\hline SNX30 & $-1,96$ & $8,20 \mathrm{E}-06$ \\
\hline socs2 & 1,46 & $2,63 \mathrm{E}-05$ \\
\hline SOCS6 & $-1,81$ & $1,97 \mathrm{E}-03$ \\
\hline SORBS1 & 2,87 & $1,04 \mathrm{E}-09$ \\
\hline SORL1 & $-1,57$ & $1,53 \mathrm{E}-04$ \\
\hline SOWAHC & $-2,70$ & $9,58 \mathrm{E}-06$ \\
\hline SOX8 & $-1,40$ & $2,28 \mathrm{E}-03$ \\
\hline SPACA4 & 4,44 & $1,81 \mathrm{E}-09$ \\
\hline
\end{tabular}




\begin{tabular}{|c|c|c|}
\hline SPACA6P & $-1,23$ & $6,82 \mathrm{E}-03$ \\
\hline SPAG6 & 2,10 & $6,69 \mathrm{E}-03$ \\
\hline SPATA1 & $-1,12$ & $7,09 \mathrm{E}-03$ \\
\hline SPATA2L & $-1,51$ & $6,81 \mathrm{E}-09$ \\
\hline SPATA5 & 1,20 & $3,06 \mathrm{E}-09$ \\
\hline SPATS2 & 1,38 & $1,23 \mathrm{E}-13$ \\
\hline SPDYE6 & $-1,63$ & $6,06 \mathrm{E}-05$ \\
\hline SPEF1 & 1,68 & 7,61E-03 \\
\hline SPEG & $-2,38$ & $5,57 \mathrm{E}-06$ \\
\hline SPIN3 & $-1,41$ & $1,98 \mathrm{E}-03$ \\
\hline SPNS1 & $-1,46$ & $5,64 \mathrm{E}-05$ \\
\hline SPON1 & $-3,12$ & $3,37 \mathrm{E}-14$ \\
\hline SPP1 & $-1,23$ & $1,38 \mathrm{E}-03$ \\
\hline SPPL2B & $-1,17$ & $4,24 \mathrm{E}-03$ \\
\hline SPSB1 & $-1,27$ & $7,52 \mathrm{E}-03$ \\
\hline SQSTM1 & $-1,69$ & $6,58 \mathrm{E}-04$ \\
\hline SRD5A3P1 & $-1,64$ & $2,70 \mathrm{E}-03$ \\
\hline SRGAP2 & 1,02 & $4,70 \mathrm{E}-04$ \\
\hline SRGAP2B & 1,23 & $8,00 \mathrm{E}-04$ \\
\hline SRGAP2C & 1,12 & $1,32 \mathrm{E}-03$ \\
\hline SRI & 1,20 & $2,39 \mathrm{E}-09$ \\
\hline SRIP1 & 1,28 & $6,70 \mathrm{E}-05$ \\
\hline SRIP3 & 1,31 & $1,46 \mathrm{E}-05$ \\
\hline SRP54 & 1,29 & $1,45 \mathrm{E}-03$ \\
\hline SRR & 1,25 & $1,56 \mathrm{E}-03$ \\
\hline SRSF5 & $-1,31$ & $3,24 \mathrm{E}-04$ \\
\hline SSBP1 & 1,00 & $2,78 \mathrm{E}-08$ \\
\hline SSSCA1-AS1 & $-2,14$ & $4,05 \mathrm{E}-04$ \\
\hline SSTR3 & $-1,76$ & $8,76 \mathrm{E}-06$ \\
\hline SSUH2 & 2,72 & $8,69 \mathrm{E}-04$ \\
\hline ST18 & $-3,19$ & $2,50 \mathrm{E}-06$ \\
\hline ST3GAL1 & $-1,32$ & $5,99 \mathrm{E}-03$ \\
\hline ST6GALNAC1 & $-2,45$ & $1,83 \mathrm{E}-04$ \\
\hline ST8SIA1 & $-1,39$ & $7,31 \mathrm{E}-03$ \\
\hline ST8SIA4 & 1,05 & $2,07 \mathrm{E}-03$ \\
\hline STAG1 & 1,00 & $1,49 \mathrm{E}-03$ \\
\hline STAP1 & 1,03 & $2,45 \mathrm{E}-05$ \\
\hline STARD13 & $-3,90$ & $7,68 \mathrm{E}-10$ \\
\hline STARD5 & $-1,30$ & $6,72 \mathrm{E}-05$ \\
\hline STEAP4 & 2,59 & $1,00 \mathrm{E}-03$ \\
\hline STIP1 & 1,42 & $1,20 \mathrm{E}-04$ \\
\hline STK10 & $-1,41$ & $1,51 \mathrm{E}-20$ \\
\hline STK25 & $-1,08$ & $2,28 \mathrm{E}-08$ \\
\hline STK31 & 1,21 & $5,08 \mathrm{E}-03$ \\
\hline STK38 & $-1,23$ & $3,95 \mathrm{E}-06$ \\
\hline STMN3 & $-1,50$ & $4,99 \mathrm{E}-03$ \\
\hline STRA6 & 3,59 & 4,31E-06 \\
\hline STRAP & 1,01 & 7,91E-05 \\
\hline STX3 & $-1,98$ & $4,96 \mathrm{E}-04$ \\
\hline STX7 & $-1,79$ & $5,15 \mathrm{E}-04$ \\
\hline STXBP1 & $-1,12$ & $7,22 \mathrm{E}-04$ \\
\hline STXBP2 & $-1,10$ & $1,93 \mathrm{E}-03$ \\
\hline STXBP4 & 1,07 & $7,93 \mathrm{E}-05$ \\
\hline STXBP5L & 3,43 & $1,44 \mathrm{E}-05$ \\
\hline STXBP6 & 2,79 & $5,77 \mathrm{E}-04$ \\
\hline SUB1P1 & 1,15 & $1,26 \mathrm{E}-05$ \\
\hline SUB1P3 & 1,11 & $4,18 \mathrm{E}-04$ \\
\hline SUMF1 & $-1,64$ & $1,77 \mathrm{E}-04$ \\
\hline SUN2 & $-1,44$ & $2,05 \mathrm{E}-05$ \\
\hline SURF4 & 1,31 & $3,92 \mathrm{E}-07$ \\
\hline SUSD3 & $-1,00$ & $1,86 \mathrm{E}-03$ \\
\hline SVILP1 & 3,05 & $3,47 \mathrm{E}-31$ \\
\hline SYCP2L & $-4,30$ & $1,39 \mathrm{E}-08$ \\
\hline SYN1 & 2,97 & $4,60 \mathrm{E}-17$ \\
\hline SYNE1 & $-1,11$ & $1,45 \mathrm{E}-03$ \\
\hline SYNE3 & 1,11 & $5,88 \mathrm{E}-08$ \\
\hline SYNGR1 & $-1,95$ & $6,53 \mathrm{E}-07$ \\
\hline SYNM & $-2,05$ & $1,54 \mathrm{E}-10$ \\
\hline SYNPO & 1,64 & $1,36 \mathrm{E}-08$ \\
\hline SYNPO2 & 2,59 & $2,35 \mathrm{E}-04$ \\
\hline SYP & 3,05 & $1,26 \mathrm{E}-07$ \\
\hline SYPL2 & $-2,42$ & $3,23 \mathrm{E}-03$ \\
\hline SYS1 & $-1,31$ & $2,67 \mathrm{E}-03$ \\
\hline SYT11 & 1,55 & $2,31 \mathrm{E}-08$ \\
\hline SYTL1 & $-1,98$ & $9,95 \mathrm{E}-05$ \\
\hline SYTL3 & 2,88 & $1,02 \mathrm{E}-52$ \\
\hline
\end{tabular}

\begin{tabular}{|c|c|c|}
\hline TAC1 & 2,79 & $5,77 \mathrm{E}-04$ \\
\hline TAC3 & 2,29 & $4,68 \mathrm{E}-05$ \\
\hline TADA2B & $-1,30$ & $1,87 \mathrm{E}-13$ \\
\hline TAF1A & 1,09 & $3,33 \mathrm{E}-05$ \\
\hline TAF1B & 1,10 & $6,48 \mathrm{E}-04$ \\
\hline TAF9P1 & 1,20 & $2,56 \mathrm{E}-04$ \\
\hline TAGAP & $-1,61$ & $1,92 \mathrm{E}-05$ \\
\hline TANC1 & 1,45 & $1,82 \mathrm{E}-03$ \\
\hline TANGO2 & $-1,64$ & $5,40 \mathrm{E}-10$ \\
\hline TARM1 & 2,10 & $5,42 \mathrm{E}-03$ \\
\hline TARS & 1,77 & $4,30 \mathrm{E}-05$ \\
\hline TAZ & $-1,17$ & 4,94E-06 \\
\hline TBC1D10C & $-1,30$ & $7,22 \mathrm{E}-03$ \\
\hline TBC1D16 & $-1,15$ & $1,65 \mathrm{E}-03$ \\
\hline TBC1D20 & $-1,24$ & $1,14 \mathrm{E}-05$ \\
\hline TBC1D4 & $-1,16$ & $9,36 \mathrm{E}-03$ \\
\hline TBC1D9B & $-1,50$ & $6,66 \mathrm{E}-06$ \\
\hline TBL1X & $-1,04$ & $2,59 \mathrm{E}-09$ \\
\hline TBX19 & $-1,02$ & $1,85 \mathrm{E}-03$ \\
\hline TBX21 & 2,13 & $1,09 \mathrm{E}-05$ \\
\hline TBX3 & $-2,23$ & $6,38 \mathrm{E}-03$ \\
\hline TCEB1P31 & 2,68 & $1,00 \mathrm{E}-03$ \\
\hline TCF4 & $-2,76$ & $1,62 \mathrm{E}-08$ \\
\hline TCF7L2 & $-1,25$ & $5,93 \mathrm{E}-03$ \\
\hline TCIRG1 & $-1,22$ & $5,93 \mathrm{E}-04$ \\
\hline TCL1A & $-2,44$ & $3,95 \mathrm{E}-15$ \\
\hline TCL6 & $-4,63$ & $3,16 \mathrm{E}-10$ \\
\hline TCOF1 & 1,22 & $4,73 \mathrm{E}-14$ \\
\hline TCP1 & 1,59 & $5,62 \mathrm{E}-11$ \\
\hline TCP11L2 & $-1,83$ & $8,91 \mathrm{E}-04$ \\
\hline TCP1P1 & 1,88 & $1,49 \mathrm{E}-06$ \\
\hline TCTA & $-1,47$ & $1,22 \mathrm{E}-17$ \\
\hline TCTN2 & $-1,02$ & $1,79 \mathrm{E}-04$ \\
\hline TCTN3 & 1,98 & $1,77 \mathrm{E}-32$ \\
\hline TDO2 & $-3,17$ & $1,09 \mathrm{E}-04$ \\
\hline TDRKH & 1,53 & $7,59 \mathrm{E}-08$ \\
\hline TEC & $-1,21$ & $4,53 \mathrm{E}-03$ \\
\hline TECPR1 & $-1,22$ & $2,47 \mathrm{E}-08$ \\
\hline TEF & $-1,18$ & $1,02 \mathrm{E}-08$ \\
\hline TENM1 & $-1,44$ & $8,91 \mathrm{E}-03$ \\
\hline TEPP & $-1,89$ & $5,69 \mathrm{E}-04$ \\
\hline TET3 & $-1,19$ & $4,65 \mathrm{E}-04$ \\
\hline TEX14 & $-1,76$ & $3,76 \mathrm{E}-03$ \\
\hline TF & 3,46 & $1,61 \mathrm{E}-09$ \\
\hline TFAP2E & $-1,39$ & $7,45 \mathrm{E}-06$ \\
\hline TFB1M & 1,08 & $2,40 \mathrm{E}-06$ \\
\hline TFB2M & 1,33 & $1,53 \mathrm{E}-11$ \\
\hline TFEC & $-1,93$ & $1,24 \mathrm{E}-03$ \\
\hline TFP1 & 2,53 & $1,12 \mathrm{E}-03$ \\
\hline TFR2 & 2,24 & $1,18 \mathrm{E}-06$ \\
\hline $\mathrm{TG}$ & 1,77 & $3,01 \mathrm{E}-05$ \\
\hline TGFBR1 & $-1,03$ & $5,70 \mathrm{E}-03$ \\
\hline TGOLN2 & $-1,01$ & $6,77 \mathrm{E}-06$ \\
\hline THBS1 & $-2,27$ & $4,35 \mathrm{E}-05$ \\
\hline THEM6 & $-1,61$ & $1,66 \mathrm{E}-05$ \\
\hline THEMIS2 & $-1,26$ & $5,34 \mathrm{E}-03$ \\
\hline THNSL1 & 1,06 & $2,89 \mathrm{E}-04$ \\
\hline THTPA & $-1,32$ & $1,90 \mathrm{E}-04$ \\
\hline TIAF1 & $-1,11$ & $8,34 \mathrm{E}-05$ \\
\hline TIGD3 & 2,17 & $1,73 \mathrm{E}-09$ \\
\hline TIGD6 & $-1,44$ & $1,88 \mathrm{E}-03$ \\
\hline TIMD4 & 4,03 & $1,11 \mathrm{E}-07$ \\
\hline TIMM10 & 1,33 & $3,39 \mathrm{E}-06$ \\
\hline TIMM21 & 1,09 & $1,73 \mathrm{E}-11$ \\
\hline TIMM23 & 1,22 & $4,04 \mathrm{E}-04$ \\
\hline TIMM23B & 1,15 & $2,04 \mathrm{E}-03$ \\
\hline TIMM8AP1 & 1,24 & $3,00 \mathrm{E}-03$ \\
\hline TINCR & $-1,83$ & $4,45 \mathrm{E}-04$ \\
\hline TIPARP & $-1,67$ & $6,61 \mathrm{E}-16$ \\
\hline TIPRL & 1,09 & $1,62 \mathrm{E}-03$ \\
\hline TJP3 & $\begin{array}{l}-1,31 \\
\end{array}$ & $5,66 \mathrm{E}-03$ \\
\hline TK2 & $-1,61$ & $3,65 \mathrm{E}-07$ \\
\hline TLCD1 & 2,40 & $1,55 \mathrm{E}-04$ \\
\hline TLE1 & $-1,56$ & $1,55 \mathrm{E}-05$ \\
\hline TLE2 & $-1,43$ & $1,87 \mathrm{E}-03$ \\
\hline TLR1 & $-1,21$ & $5,46 \mathrm{E}-03$ \\
\hline
\end{tabular}

\begin{tabular}{|c|c|c|}
\hline TLR10 & $-1,96$ & $2,47 \mathrm{E}-04$ \\
\hline TLR2 & $-1,33$ & $4,24 \mathrm{E}-03$ \\
\hline TMBIM4 & $-1,47$ & $1,37 \mathrm{E}-04$ \\
\hline TMC4 & $-1,68$ & $8,90 \mathrm{E}-03$ \\
\hline TMC6 & $-1,50$ & $4,76 \mathrm{E}-06$ \\
\hline TMCC2 & 1,13 & $4,38 \mathrm{E}-03$ \\
\hline TMCC3 & $-2,63$ & $3,23 \mathrm{E}-04$ \\
\hline TMEM106A & $-1,60$ & $8,18 \mathrm{E}-06$ \\
\hline TMEM119 & $-2,99$ & $1,32 \mathrm{E}-07$ \\
\hline TMEM123 & $-1,28$ & $5,58 \mathrm{E}-20$ \\
\hline TMEM134 & $-1,19$ & $7,54 \mathrm{E}-06$ \\
\hline TMEM144 & $-2,90$ & $1,98 \mathrm{E}-05$ \\
\hline TMEM145 & 4,14 & $4,03 \mathrm{E}-08$ \\
\hline TMEM150A & $-1,64$ & $3,26 \mathrm{E}-05$ \\
\hline TMEM150B & $-1,48$ & $9,51 \mathrm{E}-03$ \\
\hline TMEM168 & $-1,12$ & $2,52 \mathrm{E}-10$ \\
\hline TMEM176A & $-3,04$ & $1,97 \mathrm{E}-13$ \\
\hline TMEM179B & $-1,18$ & $5,82 \mathrm{E}-05$ \\
\hline TMEM191A & $-2,64$ & $1,08 \mathrm{E}-07$ \\
\hline TMEM205 & $-1,16$ & $5,01 \mathrm{E}-03$ \\
\hline TMEM213 & 2,40 & $3,35 \mathrm{E}-03$ \\
\hline TMEM219 & $-1,06$ & $2,27 \mathrm{E}-05$ \\
\hline TMEM229B & $-2,58$ & $2,02 \mathrm{E}-09$ \\
\hline TMEM234 & $-1,24$ & $1,40 \mathrm{E}-05$ \\
\hline TMEM254 & $-1,30$ & $3,08 \mathrm{E}-05$ \\
\hline TMEM255B & $-3,67$ & $2,87 \mathrm{E}-11$ \\
\hline TMEM259 & $-1,25$ & $1,93 \mathrm{E}-08$ \\
\hline TMEM260 & $-1,16$ & $1,62 \mathrm{E}-07$ \\
\hline TMEM262 & $-1,13$ & $3,96 \mathrm{E}-05$ \\
\hline TMEM41B & $-1,14$ & $1,95 \mathrm{E}-09$ \\
\hline TMEM53 & $-1,07$ & $8,61 \mathrm{E}-03$ \\
\hline TMEM55A & $-1,28$ & $5,96 \mathrm{E}-03$ \\
\hline TMEM66 & $-1,43$ & $1,15 \mathrm{E}-13$ \\
\hline TMEM71 & $-1,68$ & $1,61 \mathrm{E}-05$ \\
\hline TMEM80 & $-1,59$ & $2,11 \mathrm{E}-08$ \\
\hline TMEM8A & $-1,10$ & $7,92 \mathrm{E}-09$ \\
\hline TMEM8B & $-1,63$ & $6,63 \mathrm{E}-04$ \\
\hline TMEM99 & 1,37 & $1,82 \mathrm{E}-04$ \\
\hline TMEM9B-AS1 & $-1,10$ & $1,41 \mathrm{E}-03$ \\
\hline TMIGD2 & $-1,37$ & $1,27 \mathrm{E}-03$ \\
\hline TMOD2 & $-1,44$ & $4,66 \mathrm{E}-05$ \\
\hline TMTC1 & $-2,08$ & $1,91 \mathrm{E}-03$ \\
\hline TNC & 4,14 & $4,52 \mathrm{E}-11$ \\
\hline TNFAIP8 & 1,33 & $3,63 \mathrm{E}-06$ \\
\hline TNFRSF10A & $-1,53$ & $6,73 \mathrm{E}-12$ \\
\hline TNFRSF12A & 1,39 & $4,72 \mathrm{E}-05$ \\
\hline TNFRSF14 & $-2,52$ & $2,40 \mathrm{E}-09$ \\
\hline TNFRSF1A & $-1,24$ & $1,75 \mathrm{E}-04$ \\
\hline TNFRSF 25 & $-1,62$ & $5,45 \mathrm{E}-04$ \\
\hline TNFSF 10 & 1,25 & $1,95 \mathrm{E}-13$ \\
\hline TNFSF12 & $-1,27$ & $1,27 \mathrm{E}-03$ \\
\hline TNFSF13B & $-1,63$ & $3,18 \mathrm{E}-08$ \\
\hline TNFSF15 & 2,96 & $3,01 \mathrm{E}-12$ \\
\hline TNKS1BP1 & $-1,10$ & $2,15 \mathrm{E}-05$ \\
\hline TNS3 & $-2,37$ & $3,88 \mathrm{E}-04$ \\
\hline TNXB & $-1,72$ & $5,07 \mathrm{E}-03$ \\
\hline TOLLIP & $-1,04$ & $7,63 \mathrm{E}-03$ \\
\hline TOM1 & $-1,99$ & $1,51 \mathrm{E}-04$ \\
\hline TOMM7 & $-1,48$ & $2,62 \mathrm{E}-03$ \\
\hline TOMM70A & 1,07 & $1,41 \mathrm{E}-05$ \\
\hline TP63 & 2,32 & $8,64 \mathrm{E}-04$ \\
\hline TPH1 & $-1,06$ & $3,77 \mathrm{E}-03$ \\
\hline TPM1 & $-1,07$ & $9,25 \mathrm{E}-03$ \\
\hline TPP1 & $-1,98$ & $1,92 \mathrm{E}-06$ \\
\hline TPRG1L & $-1,43$ & $6,46 \mathrm{E}-13$ \\
\hline TPRKBP1 & 1,20 & $2,95 \mathrm{E}-09$ \\
\hline TPSAB1 & $-1,46$ & $1,80 \mathrm{E}-07$ \\
\hline TPSB2 & $-1,47$ & $3,27 \mathrm{E}-09$ \\
\hline TPSD1 & $-1,34$ & $5,15 \mathrm{E}-04$ \\
\hline TPSG1 & 2,27 & $5,74 \mathrm{E}-03$ \\
\hline TPT1-AS1 & $-1,04$ & $6,90 \mathrm{E}-03$ \\
\hline TPTEP1 & $-1,42$ & $4,52 \mathrm{E}-07$ \\
\hline TRAM1L1 & $-1,47$ & $1,01 \mathrm{E}-04$ \\
\hline TRANK1 & $-1,13$ & $8,10 \mathrm{E}-08$ \\
\hline TRAPPC4 & 1,03 & $2,56 \mathrm{E}-11$ \\
\hline TRAPPC6A & $-1,40$ & $3,27 \mathrm{E}-18$ \\
\hline
\end{tabular}

\begin{tabular}{|c|c|c|}
\hline TRDMT1 & $-1,03$ & $2,33 \mathrm{E}-03$ \\
\hline TREML2 & 1,35 & $3,19 \mathrm{E}-05$ \\
\hline TRERF1 & 1,04 & $2,97 \mathrm{E}-06$ \\
\hline TRGV4 & $-1,06$ & $1,04 \mathrm{E}-03$ \\
\hline TRIAP1 & 1,13 & $8,43 \mathrm{E}-07$ \\
\hline TRIB2 & $-2,39$ & $1,64 \mathrm{E}-07$ \\
\hline TRIM15 & 2,40 & 3,35E-03 \\
\hline TRIM22 & $-1,11$ & $1,86 \mathrm{E}-06$ \\
\hline TRIM29 & 2,27 & $2,01 \mathrm{E}-03$ \\
\hline TRIM3 & $-1,63$ & $4,54 \mathrm{E}-09$ \\
\hline TRIM36 & $-3,22$ & $9,12 \mathrm{E}-08$ \\
\hline TRIM50 & $-2,52$ & $1,54 \mathrm{E}-03$ \\
\hline TRIM51BP & $-2,01$ & $3,46 \mathrm{E}-03$ \\
\hline TRIM52 & $-1,72$ & $1,79 \mathrm{E}-08$ \\
\hline TRIM52-AS1 & $-1,96$ & $2,26 \mathrm{E}-05$ \\
\hline TRIM65 & $-1,14$ & $1,92 \mathrm{E}-04$ \\
\hline TRIO & $-1,89$ & $2,44 E-03$ \\
\hline TRIQK & $-1,88$ & $8,27 \mathrm{E}-04$ \\
\hline TRMT10A & 1,39 & $1,35 \mathrm{E}-10$ \\
\hline TRMT10C & 1,04 & $2,74 \mathrm{E}-06$ \\
\hline TRO & 1,19 & 4,14E-04 \\
\hline TRPC3 & 2,67 & $1,66 \mathrm{E}-05$ \\
\hline TRPM2 & $-3,23$ & $1,55 \mathrm{E}-07$ \\
\hline TSC22D1 & $-1,94$ & $1,27 \mathrm{E}-25$ \\
\hline TSC22D3 & $-2,31$ & $9,86 \mathrm{E}-04$ \\
\hline TSHZ1 & $-1,03$ & 1,73E-06 \\
\hline TSKS & $-1,73$ & $4,59 \mathrm{E}-05$ \\
\hline TSNARE1 & $-1,63$ & $9,69 \mathrm{E}-10$ \\
\hline TSPAN11 & 1,89 & $9,24 \mathrm{E}-03$ \\
\hline TSPAN14 & $-1,65$ & $1,25 \mathrm{E}-17$ \\
\hline TSPAN18 & $-1,37$ & $3,40 \mathrm{E}-05$ \\
\hline TSR1 & 1,36 & $6,56 \mathrm{E}-06$ \\
\hline TSSC1-IT1 & 2,34 & $4,28 \mathrm{E}-03$ \\
\hline TTBK2 & $-1,32$ & 2,83E-05 \\
\hline TTC12 & $-1,72$ & $1,40 \mathrm{E}-06$ \\
\hline TTC14 & $-1,50$ & $4,19 \mathrm{E}-06$ \\
\hline TTC25 & 2,23 & $2,04 \mathrm{E}-04$ \\
\hline TTC28 & $-1,43$ & $4,81 \mathrm{E}-05$ \\
\hline TTC3 & $-1,29$ & $1,02 \mathrm{E}-05$ \\
\hline TTC32 & $-1,05$ & $6,56 \mathrm{E}-04$ \\
\hline TTC33 & 1,09 & $3,78 \mathrm{E}-06$ \\
\hline TTC39B & $-1,27$ & $5,99 \mathrm{E}-06$ \\
\hline TTF1 & 1,21 & $1,36 \mathrm{E}-11$ \\
\hline TTI2 & 1,12 & $6,79 \mathrm{E}-03$ \\
\hline TTLL5 & 1,01 & $1,72 \mathrm{E}-07$ \\
\hline TTLL7 & 1,92 & $4,33 \mathrm{E}-03$ \\
\hline TUBA1A & $-1,08$ & $8,91 \mathrm{E}-08$ \\
\hline TUBA4A & 1,83 & $1,56 \mathrm{E}-07$ \\
\hline TUBA4B & 1,81 & $1,51 \mathrm{E}-03$ \\
\hline TUBA8 & 3,13 & $5,52 \mathrm{E}-16$ \\
\hline TUBB4A & $-1,13$ & $5,69 \mathrm{E}-03$ \\
\hline TUBB4B & 1,02 & $5,46 \mathrm{E}-03$ \\
\hline TUBBP2 & 1,48 & $2,00 \mathrm{E}-03$ \\
\hline TUBGCP2 & $-1,10$ & $5,52 \mathrm{E}-03$ \\
\hline TUBGCP6 & $-1,42$ & $1,05 \mathrm{E}-04$ \\
\hline TUFM & 1,16 & $3,02 \mathrm{E}-09$ \\
\hline TUFMP1 & 1,13 & $1,16 \mathrm{E}-05$ \\
\hline TUG1 & $-1,05$ & 1,11E-05 \\
\hline TULP4 & $-1,76$ & 3,03E-07 \\
\hline TWISTNB & 1,33 & $2,25 \mathrm{E}-16$ \\
\hline TXNDC17 & 1,07 & $1,87 \mathrm{E}-03$ \\
\hline TXNRD2 & $-1,77$ & $2,08 \mathrm{E}-28$ \\
\hline U3 & $-2,73$ & $8,35 \mathrm{E}-05$ \\
\hline U3 & 2,55 & 1,79E-03 \\
\hline U62631,5 & $-2,59$ & $1,50 \mathrm{E}-03$ \\
\hline U82671,8 & $-1,92$ & $4,66 \mathrm{E}-03$ \\
\hline U82695,10 & 1,28 & $8,23 \mathrm{E}-03$ \\
\hline UAP1L1 & $-2,18$ & $7,53 \mathrm{E}-07$ \\
\hline UBA7 & $-1,38$ & $8,57 \mathrm{E}-06$ \\
\hline UBAP1L & $-1,30$ & $5,36 \mathrm{E}-04$ \\
\hline UBAP2 & 1,06 & $1,86 \mathrm{E}-08$ \\
\hline UBE2D4 & $-1,74$ & $3,47 \mathrm{E}-07$ \\
\hline UBE2M & 1,02 & $2,19 \mathrm{E}-06$ \\
\hline UBE2MP1 & 1,23 & $9,97 \mathrm{E}-05$ \\
\hline UBE2N & 1,46 & $8,87 \mathrm{E}-25$ \\
\hline UBE2Q2P1 & $-1,05$ & $5,14 \mathrm{E}-03$ \\
\hline
\end{tabular}




\begin{tabular}{|c|c|c|}
\hline UBE2Q2P3 & $-1,76$ & $7,52 \mathrm{E}-03$ \\
\hline UBE2V1P1 & 1,77 & $2,05 \mathrm{E}-03$ \\
\hline UBE2V1P2 & 1,40 & $1,50 \mathrm{E}-05$ \\
\hline UBE2V2 & 1,23 & $4,57 \mathrm{E}-07$ \\
\hline UBE2V2P3 & 1,04 & $8,30 \mathrm{E}-04$ \\
\hline UBL7-AS1 & 1,04 & $3,10 \mathrm{E}-03$ \\
\hline UBQLNL & $-1,64$ & $8,98 \mathrm{E}-03$ \\
\hline UBXN11 & $-2,09$ & $5,25 \mathrm{E}-11$ \\
\hline UBXN6 & $-1,03$ & $8,14 \mathrm{E}-04$ \\
\hline UCK2 & 1,62 & $4,52 \mathrm{E}-04$ \\
\hline UFSP1 & $-1,71$ & $9,24 \mathrm{E}-04$ \\
\hline UGCG & $-1,99$ & $1,06 \mathrm{E}-03$ \\
\hline UGDH & 1,12 & $4,09 \mathrm{E}-03$ \\
\hline UGDH-AS1 & $-2,26$ & $3,50 \mathrm{E}-04$ \\
\hline ULBP2 & 2,17 & $4,31 \mathrm{E}-04$ \\
\hline ULK2 & $-1,07$ & $1,05 \mathrm{E}-04$ \\
\hline UMPS & 1,44 & $2,73 \mathrm{E}-07$ \\
\hline UNC93B3 & $-2,18$ & $6,24 \mathrm{E}-03$ \\
\hline UNKL & $-1,02$ & $8,08 \mathrm{E}-03$ \\
\hline UPB1 & 1,69 & $3,77 \mathrm{E}-06$ \\
\hline UPF3B & 1,50 & $3,69 \mathrm{E}-06$ \\
\hline UPK1B & 2,97 & $5,98 \mathrm{E}-05$ \\
\hline UPK2 & $-2,67$ & $1,02 \mathrm{E}-03$ \\
\hline UQCRFS1P1 & 1,08 & $6,95 \mathrm{E}-04$ \\
\hline URB1 & 1,14 & $4,55 \mathrm{E}-13$ \\
\hline URB2 & 1,32 & $1,02 \mathrm{E}-08$ \\
\hline USF2 & $-1,98$ & $7,99 \mathrm{E}-06$ \\
\hline USP12PX & 1,08 & $6,96 \mathrm{E}-03$ \\
\hline USP14 & 1,15 & $4,34 \mathrm{E}-06$ \\
\hline USP27X & $-1,00$ & $1,21 \mathrm{E}-03$ \\
\hline USP2-AS1 & 1,71 & $9,71 \mathrm{E}-03$ \\
\hline USP37 & 1,11 & $3,50 \mathrm{E}-07$ \\
\hline UTP11L & 1,75 & $1,60 \mathrm{E}-05$ \\
\hline UTP15 & 1,05 & $1,03 \mathrm{E}-06$ \\
\hline UVSSA & $-1,31$ & $3,35 \mathrm{E}-13$ \\
\hline VAMP2 & $-1,53$ & $1,34 \mathrm{E}-03$ \\
\hline VAMP3 & $-1,38$ & $1,22 \mathrm{E}-03$ \\
\hline VASH1 & $-1,78$ & $1,79 \mathrm{E}-09$ \\
\hline VAT1L & 2,34 & $3,07 \mathrm{E}-04$ \\
\hline VBP1 & 1,06 & $4,56 \mathrm{E}-06$ \\
\hline VCAN & $-1,94$ & $7,36 \mathrm{E}-03$ \\
\hline VCP & 1,01 & $7,30 \mathrm{E}-03$ \\
\hline VDAC1P2 & 1,23 & $4,65 \mathrm{E}-03$ \\
\hline VDAC3P1 & 1,26 & $1,52 \mathrm{E}-09$ \\
\hline VEGFB & $-1,65$ & $2,25 \mathrm{E}-06$ \\
\hline VENTX & $-2,65$ & $5,55 \mathrm{E}-04$ \\
\hline VIM-AS1 & $-1,55$ & $3,25 \mathrm{E}-06$ \\
\hline VMAC & $-1,79$ & $9,84 \mathrm{E}-06$ \\
\hline VPS28 & $-1,34$ & $1,44 \mathrm{E}-18$ \\
\hline VPS37C & $-1,78$ & $6,95 \mathrm{E}-04$ \\
\hline VPS9D1 & $-1,33$ & $5,21 \mathrm{E}-05$ \\
\hline VTI1B & $-1,16$ & $4,62 \mathrm{E}-04$ \\
\hline VWA5A & $-1,86$ & $5,53 \mathrm{E}-04$ \\
\hline VWA7 & 1,84 & $2,00 \mathrm{E}-04$ \\
\hline VWA9 & 1,25 & $1,13 \mathrm{E}-08$ \\
\hline VWCE & 1,97 & $1,28 \mathrm{E}-03$ \\
\hline WAC-AS1 & $-1,34$ & $1,64 \mathrm{E}-08$ \\
\hline WARS2 & 1,03 & $4,25 \mathrm{E}-04$ \\
\hline WASF1 & 1,52 & $3,60 \mathrm{E}-07$ \\
\hline WASH2P & $-1,30$ & $1,53 \mathrm{E}-07$ \\
\hline WASH3P & $-1,28$ & $1,51 \mathrm{E}-07$ \\
\hline WASH4P & $-1,23$ & $1,92 \mathrm{E}-09$ \\
\hline WASH6P & $-1,02$ & $9,24 \mathrm{E}-03$ \\
\hline WASH7P & $-1,38$ & $1,16 \mathrm{E}-10$ \\
\hline WBP1L & $-1,00$ & $9,66 \mathrm{E}-03$ \\
\hline WBSCR17 & 2,94 & $5,99 \mathrm{E}-05$ \\
\hline WBSCR27 & $-1,75$ & $1,05 \mathrm{E}-03$ \\
\hline WDFY3 & $-2,41$ & $1,53 \mathrm{E}-04$ \\
\hline WDPCP & $-1,23$ & $1,04 \mathrm{E}-03$ \\
\hline WDR27 & $-1,33$ & $1,77 \mathrm{E}-03$ \\
\hline WDR3 & 1,42 & $3,09 \mathrm{E}-06$ \\
\hline WDR46 & 1,00 & $5,24 \mathrm{E}-06$ \\
\hline WDR52 & $-1,05$ & $8,95 \mathrm{E}-03$ \\
\hline WDR5B & $-1,51$ & $9,98 \mathrm{E}-12$ \\
\hline WDR63 & 2,39 & $5,96 \mathrm{E}-05$ \\
\hline WDR66 & 1,65 & $2,64 \mathrm{E}-03$ \\
\hline
\end{tabular}

\begin{tabular}{|c|c|c|}
\hline WDYHV1 & 1,53 & $7,81 \mathrm{E}-16$ \\
\hline WHAMM & $-1,38$ & $5,45 \mathrm{E}-05$ \\
\hline WHAMMP2 & $-2,13$ & $1,57 \mathrm{E}-04$ \\
\hline WHAMMP3 & $-1,43$ & $6,27 \mathrm{E}-03$ \\
\hline WI2-1896014,1 & $-1,77$ & $4,25 \mathrm{E}-03$ \\
\hline WIPF3 & 2,84 & $1,89 \mathrm{E}-11$ \\
\hline WISP3 & $-2,53$ & $5,01 \mathrm{E}-04$ \\
\hline WNT11 & 3,60 & $1,43 \mathrm{E}-09$ \\
\hline WNT2B & $-1,49$ & $3,43 E-05$ \\
\hline WNT8B & 2,44 & $1,40 \mathrm{E}-05$ \\
\hline WRAP53 & 1,20 & $1,42 \mathrm{E}-06$ \\
\hline XKR7 & 2,08 & $4,40 \mathrm{E}-04$ \\
\hline XPO5 & 1,29 & $3,69 \mathrm{E}-06$ \\
\hline XRCC6 & 1,05 & $2,79 \mathrm{E}-08$ \\
\hline XRCC6P1 & 1,22 & $1,96 \mathrm{E}-04$ \\
\hline XRCC6P2 & 1,15 & $8,32 \mathrm{E}-08$ \\
\hline $\begin{array}{r}\text { XXBAC- } \\
\text { BPG157A10,21 } \\
\end{array}$ & 1,75 & $4,37 \mathrm{E}-04$ \\
\hline $\begin{array}{r}\text { XXBAC- } \\
\text { BPG181B23,7 }\end{array}$ & $-1,24$ & $5,93 \mathrm{E}-03$ \\
\hline $\begin{array}{r}\text { XXBAC- } \\
\text { BPGBPG55C20 } \\
, 2\end{array}$ & $-1,79$ & $4,10 \mathrm{E}-04$ \\
\hline $\begin{array}{r}\text { XXYAC- } \\
\text { YRM2039,2 }\end{array}$ & $-1,11$ & $5,05 \mathrm{E}-07$ \\
\hline $\begin{array}{r}\text { XXYAC- } \\
Y X 155 B 6,2 \\
\end{array}$ & $-1,21$ & $1,62 \mathrm{E}-03$ \\
\hline XYLT1 & $-1,28$ & $2,86 \mathrm{E}-03$ \\
\hline Y_RNA & 2,56 & $1,75 \mathrm{E}-03$ \\
\hline YAP1 & 2,87 & $1,06 \mathrm{E}-05$ \\
\hline YARS2 & 1,19 & $8,66 \mathrm{E}-13$ \\
\hline YPEL1 & $-1,37$ & $9,01 \mathrm{E}-03$ \\
\hline YPEL2 & $-1,50$ & $5,37 \mathrm{E}-04$ \\
\hline YPEL5 & $-1,02$ & $9,11 \mathrm{E}-03$ \\
\hline YRDC & 1,55 & $4,07 \mathrm{E}-20$ \\
\hline YWHAQ & 1,18 & $1,33 \mathrm{E}-17$ \\
\hline$Z 69890,1$ & 2,53 & $3,08 \mathrm{E}-04$ \\
\hline Z83851,3 & 1,66 & 7,77E-04 \\
\hline Z95704,3 & 2,76 & $2,85 \mathrm{E}-04$ \\
\hline ZBED5 & $-1,38$ & $3,60 \mathrm{E}-07$ \\
\hline ZBED5-AS1 & $-2,40$ & $7,47 \mathrm{E}-10$ \\
\hline ZBED6 & 1,22 & $1,60 \mathrm{E}-03$ \\
\hline ZBP1 & $-1,82$ & $1,19 \mathrm{E}-05$ \\
\hline ZBTB25 & $-1,39$ & $1,76 \mathrm{E}-03$ \\
\hline ZBTB9 & 1,24 & $4,01 \mathrm{E}-03$ \\
\hline ZC3H12C & $-2,54$ & $5,70 \mathrm{E}-06$ \\
\hline $\mathrm{ZC} 3 \mathrm{H} 6$ & $-2,14$ & $1,99 \mathrm{E}-07$ \\
\hline ZC3HAV1L & 2,13 & $2,34 \mathrm{E}-04$ \\
\hline ZC3HC1 & 1,19 & $4,10 \mathrm{E}-05$ \\
\hline $\mathrm{ZDHHC11}$ & 2,32 & $1,74 \mathrm{E}-10$ \\
\hline $\mathrm{ZDHHC13}$ & 1,13 & $3,54 \mathrm{E}-08$ \\
\hline ZDHHC7 & $-1,48$ & $7,85 \mathrm{E}-04$ \\
\hline ZDHHC8 & $-1,52$ & $4,94 \mathrm{E}-10$ \\
\hline ZEB2 & $-1,95$ & $1,45 \mathrm{E}-04$ \\
\hline ZFAND2B & $-1,12$ & $1,67 \mathrm{E}-04$ \\
\hline ZFAND5 & $-1,07$ & $5,37 \mathrm{E}-03$ \\
\hline ZFHX2 & 1,82 & $1,64 \mathrm{E}-04$ \\
\hline ZFP3 & $-2,11$ & $1,23 \mathrm{E}-13$ \\
\hline ZFP36 & $-2,70$ & $2,32 \mathrm{E}-06$ \\
\hline ZFP36L1 & $-1,49$ & $6,17 \mathrm{E}-25$ \\
\hline ZFP36L2 & $-2,36$ & $1,23 \mathrm{E}-12$ \\
\hline ZFP62 & $-1,51$ & 2,60 E-05 \\
\hline ZGPAT & $-1,45$ & $2,82 \mathrm{E}-10$ \\
\hline ZKSCAN3 & $-1,60$ & $2,17 \mathrm{E}-05$ \\
\hline ZKSCAN4 & $-1,94$ & $8,84 \mathrm{E}-13$ \\
\hline ZKSCAN8 & $-1,13$ & $5,03 \mathrm{E}-05$ \\
\hline ZMIZ1-AS1 & $-2,50$ & $9,21 \mathrm{E}-05$ \\
\hline ZMYM1 & $-1,90$ & $9,29 \mathrm{E}-08$ \\
\hline ZMYM6 & $-1,01$ & $9,45 \mathrm{E}-08$ \\
\hline ZMYND10 & 1,24 & $1,96 \mathrm{E}-06$ \\
\hline ZNF10 & $-1,33$ & $2,24 \mathrm{E}-03$ \\
\hline ZNF112 & $-1,97$ & $7,49 \mathrm{E}-03$ \\
\hline ZNF114 & 1,90 & $8,66 \mathrm{E}-04$ \\
\hline ZNF140 & $-1,02$ & $3,97 \mathrm{E}-06$ \\
\hline ZNF154 & $-2,08$ & $1,15 \mathrm{E}-04$ \\
\hline ZNF160 & $-1,29$ & $1,17 \mathrm{E}-05$ \\
\hline ZNF181 & $-1,27$ & $1,67 \mathrm{E}-03$ \\
\hline
\end{tabular}

\begin{tabular}{|c|c|c|}
\hline ZNF19 & $-1,31$ & $3,12 \mathrm{E}-04$ \\
\hline ZNF211 & $-1,10$ & $2,43 \mathrm{E}-06$ \\
\hline ZNF22 & $-1,68$ & $2,82 \mathrm{E}-12$ \\
\hline ZNF224 & $-1,32$ & $1,02 \mathrm{E}-05$ \\
\hline ZNF226 & $-1,37$ & $3,04 \mathrm{E}-09$ \\
\hline ZNF23 & $-1,54$ & $4,12 \mathrm{E}-04$ \\
\hline ZNF230 & $-1,01$ & $5,51 \mathrm{E}-04$ \\
\hline ZNF233 & $-1,52$ & $1,27 \mathrm{E}-03$ \\
\hline ZNF234 & $-1,04$ & $2,40 \mathrm{E}-06$ \\
\hline ZNF235 & $-1,04$ & $4,16 \mathrm{E}-05$ \\
\hline ZNF239 & $-1,81$ & $1,04 \mathrm{E}-04$ \\
\hline ZNF252P & $-2,19$ & $2,65 \mathrm{E}-12$ \\
\hline ZNF252P-AS1 & $-2,14$ & $6,99 \mathrm{E}-03$ \\
\hline ZNF276 & $-1,53$ & $2,41 \mathrm{E}-04$ \\
\hline ZNF284 & $-1,14$ & $2,39 \mathrm{E}-03$ \\
\hline ZNF295-AS1 & 2,28 & $1,29 \mathrm{E}-03$ \\
\hline ZNF302 & $-1,15$ & $1,44 \mathrm{E}-04$ \\
\hline ZNF316 & $-1,37$ & $8,04 \mathrm{E}-04$ \\
\hline ZNF318 & $-1,22$ & $7,10 \mathrm{E}-11$ \\
\hline ZNF319 & $-1,08$ & $8,68 \mathrm{E}-07$ \\
\hline ZNF32 & $-2,02$ & $2,90 \mathrm{E}-09$ \\
\hline ZNF320 & $-1,33$ & $3,25 \mathrm{E}-11$ \\
\hline ZNF32-AS1 & $-2,23$ & $6,49 \mathrm{E}-03$ \\
\hline ZNF337 & $-1,25$ & $2,16 \mathrm{E}-07$ \\
\hline ZNF345 & $-1,44$ & $3,04 \mathrm{E}-06$ \\
\hline ZNF350 & $-1,18$ & $3,79 \mathrm{E}-09$ \\
\hline ZNF358 & $-1,65$ & $7,20 \mathrm{E}-07$ \\
\hline ZNF362 & $-1,23$ & $1,00 \mathrm{E}-06$ \\
\hline ZNF37BP & $-1,02$ & $6,77 \mathrm{E}-03$ \\
\hline ZNF382 & $-1,01$ & $8,63 \mathrm{E}-03$ \\
\hline ZNF383 & $-1,03$ & $2,69 \mathrm{E}-03$ \\
\hline ZNF385C & $-1,71$ & $9,71 \mathrm{E}-04$ \\
\hline ZNF395 & $-1,40$ & $8,01 \mathrm{E}-04$ \\
\hline ZNF397 & $-1,66$ & $4,32 \mathrm{E}-07$ \\
\hline ZNF404 & $-1,68$ & $9,66 \mathrm{E}-04$ \\
\hline ZNF414 & $-1,24$ & $2,64 \mathrm{E}-08$ \\
\hline ZNF418 & $-2,61$ & $2,26 \mathrm{E}-09$ \\
\hline ZNF438 & $-1,52$ & $8,54 \mathrm{E}-03$ \\
\hline ZNF44 & $-1,04$ & $6,94 \mathrm{E}-03$ \\
\hline ZNF443 & 1,25 & $3,45 \mathrm{E}-04$ \\
\hline ZNF445 & $-1,69$ & $2,25 \mathrm{E}-07$ \\
\hline ZNF460 & 1,20 & $3,05 \mathrm{E}-05$ \\
\hline ZNF471 & $-1,32$ & $3,08 \mathrm{E}-03$ \\
\hline ZNF493 & $-1,26$ & $6,28 \mathrm{E}-03$ \\
\hline ZNF496 & $-1,28$ & $2,37 \mathrm{E}-05$ \\
\hline ZNF500 & $-1,45$ & $2,48 \mathrm{E}-07$ \\
\hline ZNF503 & $-1,38$ & $4,00 \mathrm{E}-03$ \\
\hline ZNF506 & $-1,31$ & $1,56 \mathrm{E}-03$ \\
\hline ZNF512 & $-1,29$ & $3,80 \mathrm{E}-05$ \\
\hline ZNF516 & $-2,16$ & $5,93 \mathrm{E}-11$ \\
\hline ZNF517 & $-2,21$ & $1,66 \mathrm{E}-06$ \\
\hline ZNF529 & $-1,57$ & $3,61 \mathrm{E}-06$ \\
\hline ZNF541 & $-2,14$ & $2,54 \mathrm{E}-04$ \\
\hline ZNF549 & $-1,19$ & $8,24 \mathrm{E}-04$ \\
\hline ZNF554 & $-1,40$ & $4,91 \mathrm{E}-03$ \\
\hline ZNF555 & $-1,06$ & $6,97 \mathrm{E}-05$ \\
\hline ZNF560 & 3,72 & $1,74 \mathrm{E}-06$ \\
\hline ZNF566 & $-1,36$ & $1,91 \mathrm{E}-04$ \\
\hline ZNF582-AS1 & $-1,43$ & $2,97 \mathrm{E}-03$ \\
\hline ZNF585B & $-1,22$ & $2,61 \mathrm{E}-04$ \\
\hline ZNF586 & $-1,02$ & $5,81 \mathrm{E}-04$ \\
\hline ZNF600 & $-1,11$ & $7,14 \mathrm{E}-04$ \\
\hline ZNF606 & $-1,53$ & $3,30 \mathrm{E}-04$ \\
\hline ZNF616 & $-1,07$ & $8,44 \mathrm{E}-06$ \\
\hline ZNF619 & $-1,62$ & $2,51 \mathrm{E}-07$ \\
\hline ZNF629 & $-2,03$ & $6,78 \mathrm{E}-08$ \\
\hline ZNF649 & $-1,30$ & $1,50 \mathrm{E}-05$ \\
\hline ZNF658 & $-1,06$ & $3,44 \mathrm{E}-04$ \\
\hline ZNF662 & $-3,77$ & $1,58 \mathrm{E}-10$ \\
\hline ZNF671 & $-1,31$ & $5,07 \mathrm{E}-07$ \\
\hline ZNF674 & $-1,02$ & $3,91 \mathrm{E}-03$ \\
\hline ZNF674-AS1 & $-1,47$ & $7,22 \mathrm{E}-03$ \\
\hline ZNF677 & $-1,08$ & $1,40 \mathrm{E}-03$ \\
\hline ZNF695 & 2,76 & $2,20 \mathrm{E}-04$ \\
\hline ZNF701 & $-1,09$ & $1,23 \mathrm{E}-05$ \\
\hline ZNF710 & $-1,47$ & $3,47 \mathrm{E}-03$ \\
\hline
\end{tabular}

\begin{tabular}{|r|c|c|} 
ZNF714 & 1,45 & $6,50 \mathrm{E}-06$ \\
\hline ZNF724P & 1,29 & $9,12 \mathrm{E}-04$ \\
\hline ZNF75D & $-1,02$ & $1,26 \mathrm{E}-04$ \\
\hline ZNF763 & $-1,01$ & $2,04 \mathrm{E}-03$ \\
\hline ZNF768 & $-1,27$ & $3,58 \mathrm{E}-06$ \\
\hline ZNF775 & $-1,84$ & $1,93 \mathrm{E}-05$ \\
\hline ZNF780B & $-1,24$ & $7,90 \mathrm{E}-04$ \\
\hline ZNF783 & $-1,32$ & $3,00 \mathrm{E}-05$ \\
\hline ZNF784 & $-1,18$ & $9,64 \mathrm{E}-08$ \\
\hline ZNF785 & $-1,07$ & $2,37 \mathrm{E}-03$ \\
\hline ZNF786 & $-1,04$ & $2,74 \mathrm{E}-04$ \\
\hline ZNF791 & $-1,05$ & $1,89 \mathrm{E}-03$ \\
\hline ZNF826P & 1,29 & $4,48 \mathrm{E}-04$ \\
\hline ZNF833P & 3,24 & $1,99 \mathrm{E}-05$ \\
\hline ZNF836 & $-1,39$ & $1,56 \mathrm{E}-03$ \\
\hline ZNF84 & $-1,50$ & $3,52 \mathrm{E}-06$ \\
\hline ZNF841 & $-1,05$ & $2,77 \mathrm{E}-03$ \\
\hline ZNF85 & 1,02 & $6,14 \mathrm{E}-04$ \\
\hline ZNF862 & $-1,67$ & $9,08 \mathrm{E}-04$ \\
\hline ZNF879 & $-1,22$ & $1,96 \mathrm{E}-03$ \\
\hline ZNF883 & $-1,52$ & $3,37 \mathrm{E}-03$ \\
\hline ZNF93 & 1,65 & $2,91 \mathrm{E}-13$ \\
\hline ZNRD1-AS1 & $-1,89$ & $1,51 \mathrm{E}-05$ \\
\hline ZSCAN12P1 & 2,31 & $4,36 \mathrm{E}-07$ \\
\hline ZSCAN18 & $-1,19$ & $9,20 \mathrm{E}-03$ \\
\hline ZSCAN21 & $-1,17$ & $7,90 \mathrm{E}-05$ \\
\hline ZSCAN9 & $-1,17$ & $9,19 \mathrm{E}-07$ \\
\hline ZSWIM5 & $-1,89$ & $2,45 \mathrm{E}-06$ \\
\hline ZW10 & 1,24 & $1,38 \mathrm{E}-04$ \\
\hline ZXDA & $-1,39$ & $1,04 \mathrm{E}-03$ \\
\hline ZXDB & $-1,24$ & $7,39 \mathrm{E}-03$ \\
\hline ZXDC & $-1,08$ & $6,81 \mathrm{E}-05$ \\
\hline ZYG11B & $-1,04$ & $3,36 \mathrm{E}-03$ \\
\hline & & \\
\hline & \\
\hline & \\
\hline & \\
\hline & \\
\hline &
\end{tabular}

\section{6) Genes regulados somente por FvFc $\mathbf{R}$}

\begin{tabular}{|l|c|c|}
\hline \multicolumn{1}{|c|}{ Gene } & FC (Log2) & $p$ value \\
\hline ABCB4 & $-1,77$ & $5,93 \mathrm{E}-03$ \\
\hline AC002059,10 & $-1,88$ & $3,55 \mathrm{E}-03$ \\
\hline AC005307,3 & 2,1 & $1,17 \mathrm{E}-03$ \\
\hline AC005624,2 & 1,79 & $5,36 \mathrm{E}-03$ \\
\hline AC006129,4 & 1,33 & $3,99 \mathrm{E}-04$ \\
\hline AC007249,3 & $-1,64$ & $9,65 \mathrm{E}-03$ \\
\hline AC016586,1 & $-1,87$ & $1,19 \mathrm{E}-03$ \\
\hline AC016683,5 & 1,83 & $2,79 \mathrm{E}-03$ \\
\hline AC016700,5 & 1,9 & $3,28 \mathrm{E}-03$ \\
\hline AC024937,4 & 1,73 & $4,74 \mathrm{E}-03$ \\
\hline AC064836,3 & 1,87 & $8,91 \mathrm{E}-04$ \\
\hline AC092198,1 & 1,72 & $6,85 \mathrm{E}-03$ \\
\hline AC093495,4 & $-1,88$ & $1,81 \mathrm{E}-03$ \\
\hline AC097499,2 & 1,54 & $7,12 \mathrm{E}-03$ \\
\hline AC112721,1 & 1,91 & $1,44 \mathrm{E}-03$ \\
\hline AC127904,2 & $-1,67$ & $8,23 \mathrm{E}-03$ \\
\hline AF064858,8 & 1,65 & $9,43 \mathrm{E}-03$ \\
\hline AFF2 & 1,27 & $4,47 \mathrm{E}-03$ \\
\hline AFF3 & 1,34 & $3,86 \mathrm{E}-03$ \\
\hline ALDH7A1P3 & $-1,61$ & $9,66 \mathrm{E}-03$ \\
\hline ANK3 & $-1,41$ & $4,09 \mathrm{E}-04$ \\
\hline ANKRD2 & 2,41 & $1,98 \mathrm{E}-04$ \\
\hline BMP4 & $-1,73$ & $6,49 \mathrm{E}-03$ \\
\hline C15ORF27 & $-1,65$ & $9,39 \mathrm{E}-03$ \\
\hline C19ORF81 & 1,66 & $9,97 \mathrm{E}-03$ \\
\hline C10RF228 & 1,41 & $3,49 \mathrm{E}-03$ \\
\hline C210RF62 & $-2,16$ & $8,51 \mathrm{E}-04$ \\
\hline C6ORF3 & $-1,7$ & $1,07 \mathrm{E}-03$ \\
\hline C9ORF135 & 2,37 & $2,59 \mathrm{E}-04$ \\
\hline C9ORF16 & 0,96 & $4,80 \mathrm{E}-03$ \\
\hline C9ORF24 & 1,71 & $7,59 \mathrm{E}-03$ \\
\hline CABLES1 & 1,81 & $1,77 \mathrm{E}-03$ \\
\hline CABP1 & 1,69 & $9,15 \mathrm{E}-03$ \\
\hline CAPN8 & $-1,76$ & $1,81 \mathrm{E}-03$ \\
\hline CCDC152 & 1,55 & $4,51 \mathrm{E}-03$ \\
\hline CCDC42B & 1,1 & $3,23 \mathrm{E}-03$ \\
\hline
\end{tabular}




\begin{tabular}{|c|c|c|c|c|c|}
\hline CCL5 & $-1,32$ & $3,66 \mathrm{E}-03$ & KCNQ10T1 & $-1,45$ & $4,88 \mathrm{E}-03$ \\
\hline CCND1 & 1,34 & $2,61 \mathrm{E}-03$ & KCNT1 & $-1,57$ & $2,69 \mathrm{E}-03$ \\
\hline CCR2 & $-1,25$ & $3,17 \mathrm{E}-03$ & KIAA1324 & 1,85 & $1,34 \mathrm{E}-03$ \\
\hline $\mathrm{CD} 40$ & 1,32 & $3,85 \mathrm{E}-03$ & KIF6 & 1,6 & $8,33 \mathrm{E}-03$ \\
\hline $\mathrm{CD} 8 \mathrm{~A}$ & 1,09 & $6,02 \mathrm{E}-03$ & KRT3 & 2,23 & $5,85 \mathrm{E}-04$ \\
\hline CD93 & $-1,67$ & $7,55 \mathrm{E}-04$ & LARP6 & 1,78 & $4,45 \mathrm{E}-03$ \\
\hline CEACAMP3 & $-1,71$ & $3,38 \mathrm{E}-03$ & LINC00271 & 1,7 & $8,12 \mathrm{E}-03$ \\
\hline CHI3L1 & 1,2 & $7,05 \mathrm{E}-03$ & LINC00643 & 1,94 & $2,65 \mathrm{E}-03$ \\
\hline CHRFAM7A & $-2,04$ & 1,01E-03 & LINC00996 & 1,24 & $3,41 \mathrm{E}-04$ \\
\hline CICP22 & $-1,58$ & $2,80 \mathrm{E}-03$ & LINC01057 & $-2,02$ & 6,60E-04 \\
\hline CLEC2D & 1,13 & $3,63 \mathrm{E}-03$ & LL22NC03- & & \\
\hline CLNK & 1,67 & $1,42 \mathrm{E}-03$ & $75 \mathrm{H} 12,2$ & $-1,52$ & 7,13E-03 \\
\hline CLTCL1 & $-1,23$ & $6,81 \mathrm{E}-03$ & LPPR3 & $-2,88$ & $1,35 \mathrm{E}-06$ \\
\hline CNN3P1 & 1,58 & $9,66 \mathrm{E}-03$ & LZTS1 & 2,1 & $5,23 \mathrm{E}-04$ \\
\hline COL6A1 & 1,39 & 1,06E-03 & MAGEH1 & 1,3 & $1,13 \mathrm{E}-04$ \\
\hline CPS1 & 1,78 & $5,35 \mathrm{E}-03$ & MALAT1 & $-1,3$ & $7,33 \mathrm{E}-03$ \\
\hline CRABP1 & 1,79 & $5,72 \mathrm{E}-03$ & MAP2 & 1,63 & $9,03 \mathrm{E}-03$ \\
\hline CREG2 & $-1,88$ & $3,19 \mathrm{E}-03$ & MEST & 1,3 & $4,99 \mathrm{E}-03$ \\
\hline CRYGN & $-1,82$ & $4,44 \mathrm{E}-03$ & MESTP1 & 1,46 & $2,24 \mathrm{E}-03$ \\
\hline CSRP2 & 1,74 & $4,80 \mathrm{E}-03$ & MESTP3 & 1,67 & $3,80 \mathrm{E}-03$ \\
\hline CST2 & 1,83 & $4,43 \mathrm{E}-03$ & METTL7B & $-1,76$ & $5,79 \mathrm{E}-03$ \\
\hline CTA-29F11,1 & $-1,42$ & $5,80 \mathrm{E}-03$ & MMACHC & 1,03 & $6,48 \mathrm{E}-03$ \\
\hline CTA-407F 11,8 & 1,69 & $7,92 \mathrm{E}-03$ & MPP2 & 1,34 & $2,52 \mathrm{E}-03$ \\
\hline CTB-131B5,2 & $-1,74$ & $6,49 \mathrm{E}-03$ & MT1F & 1,25 & $5,70 \mathrm{E}-03$ \\
\hline CTB-175E 5,7 & $-1,74$ & $7,18 \mathrm{E}-03$ & MT3 & 2,21 & $1,48 \mathrm{E}-04$ \\
\hline CTB-178M22,2 & 1,64 & $9,98 \mathrm{E}-03$ & MVB12B & 1,03 & 9,84E-03 \\
\hline CTB-31N19,3 & 1,43 & $5,22 \mathrm{E}-03$ & MXD3 & 1,64 & $1,21 \mathrm{E}-04$ \\
\hline CTB-75G16,3 & $-1,59$ & $7,83 \mathrm{E}-03$ & NBL1 & 1,38 & 1,96E-03 \\
\hline CTC-459F4,1 & $-1,74$ & $7,26 \mathrm{E}-03$ & NEBL & 2,75 & $2,01 \mathrm{E}-07$ \\
\hline \multirow{2}{*}{$\begin{array}{l}\text { CTD- } \\
\text { 2267D19,3 }\end{array}$} & \multirow{2}{*}{1,27} & \multirow{2}{*}{ 7,94E-03 } & NFASC & 1,6 & $9,08 \mathrm{E}-03$ \\
\hline & & & NFATC1 & 1,52 & $6,76 \mathrm{E}-06$ \\
\hline \multirow{2}{*}{$\begin{array}{l}\text { CTD- } \\
\text { 2377D24,4 }\end{array}$} & \multirow{2}{*}{2,15} & \multirow{2}{*}{$9,05 \mathrm{E}-04$} & NFIA & $-1,91$ & $1,44 \mathrm{E}-04$ \\
\hline & & & $\mathrm{NHS}$ & 1,71 & $2,52 \mathrm{E}-03$ \\
\hline $\begin{array}{l}\text { CTD- } \\
\text { 2547E10,2 }\end{array}$ & $-0,95$ & 4,61E-03 & NME9 & $-1,68$ & $4,00 \mathrm{E}-04$ \\
\hline CYP4F35P & $-2,03$ & 4,83E-05 & NNAT & 1,56 & $3,48 \mathrm{E}-03$ \\
\hline DENND6B & 1,25 & $6,45 \mathrm{E}-04$ & NOS3 & 1,19 & $4,68 \mathrm{E}-03$ \\
\hline DEXI & $-1,43$ & $8,61 \mathrm{E}-03$ & NRADDP & $-1,84$ & $2,58 \mathrm{E}-03$ \\
\hline DIRAS3 & 2,52 & $7,99 \mathrm{E}-05$ & NTNG1 & 1,66 & 9,74E-03 \\
\hline DNM1P46 & 1,61 & $1,31 \mathrm{E}-03$ & OR7E14P & 2,19 & 4,99E-04 \\
\hline ENC1 & $-0,94$ & $9,42 \mathrm{E}-03$ & P2RY1 & $-1,81$ & $4,42 \mathrm{E}-03$ \\
\hline ENHO & $-1,54$ & $4,97 \mathrm{E}-03$ & PART1 & -2 & $1,91 \mathrm{E}-03$ \\
\hline EPAS1 & $-1,61$ & $5,27 \mathrm{E}-03$ & PAX5 & $-1,08$ & $4,50 \mathrm{E}-03$ \\
\hline ERCC6 & 1,26 & $7,25 \mathrm{E}-03$ & PIP5K1B & 2,27 & $2,10 \mathrm{E}-04$ \\
\hline ETV4 & 2,43 & $1,54 \mathrm{E}-04$ & PODN & $-1,76$ & $6,49 \mathrm{E}-03$ \\
\hline FAM222A & 1,66 & $8,31 \mathrm{E}-05$ & PON1 & 3,01 & $1,48 \mathrm{E}-06$ \\
\hline FAM26F & 1,87 & 6,69E-06 & PRL & 1,8 & $1,67 \mathrm{E}-03$ \\
\hline FAM66B & 1,57 & $2,93 \mathrm{E}-03$ & PRSS23 & $-1,52$ & $5,18 \mathrm{E}-03$ \\
\hline FAM69C & 3,85 & $3,39 \mathrm{E}-10$ & PSD4 & 1 & $8,02 \mathrm{E}-03$ \\
\hline FAM92A1P1 & 1,64 & $3,68 \mathrm{E}-03$ & PTGER1 & 1,78 & $5,37 \mathrm{E}-03$ \\
\hline FAM9B & 1,81 & $5,19 \mathrm{E}-03$ & PTPRVP & 1,7 & $3,84 \mathrm{E}-03$ \\
\hline FBXO4 & 1,06 & $2,75 \mathrm{E}-03$ & PWAR6 & $-1,41$ & $2,52 \mathrm{E}-03$ \\
\hline FPR2 & 1,74 & 6,31E-03 & RAB26 & 1,81 & $1,99 \mathrm{E}-03$ \\
\hline FZD3 & 1,57 & $1,88 \mathrm{E}-03$ & \begin{tabular}{|l|} 
RFPL1S \\
\end{tabular} & $-1,8$ & $2,98 \mathrm{E}-03$ \\
\hline GDF10 & 3,49 & $2,55 \mathrm{E}-09$ & RGS10 & 1,49 & $4,10 \mathrm{E}-05$ \\
\hline GEM & 1,61 & $7,95 \mathrm{E}-03$ & $\begin{array}{l}\text { RP11- } \\
\text { 1024P17,1 }\end{array}$ & $-1,31$ & $7,04 \mathrm{E}-03$ \\
\hline GJC2 & 1,41 & $7,81 \mathrm{E}-03$ & & & \\
\hline GPR183 & $-1,01$ & $2,05 \mathrm{E}-03$ & $1079 K 10,3$ & $-1,67$ & 9,96E-03 \\
\hline GREM1 & $-1,73$ & 6,46E-03 & RP11-10J5,1 & 2,23 & $2,82 \mathrm{E}-04$ \\
\hline HBEGF & $-1,06$ & $1,10 \mathrm{E}-03$ & RP11-126K1,6 & 1,32 & $9,34 \mathrm{E}-03$ \\
\hline HCAR2 & 1,65 & 1,83E-03 & RP11-128P10,1 & 1,73 & $7,48 \mathrm{E}-03$ \\
\hline HCAR3 & 1,3 & $8,22 \mathrm{E}-03$ & RP11-16C1,2 & $-1,91$ & $2,91 \mathrm{E}-03$ \\
\hline HEY1 & $-1,84$ & $3,33 \mathrm{E}-03$ & RP11-173B14,4 & $-1,82$ & $2,68 \mathrm{E}-03$ \\
\hline HIVEP3 & 1,29 & 1,53E-04 & RP11-190A12,8 & $-1,66$ & $6,88 \mathrm{E}-03$ \\
\hline HSD11B2 & 2,38 & $8,63 \mathrm{E}-05$ & RP11- & 1,71 & $8,04 \mathrm{E}-03$ \\
\hline IGKV3-7 & $-2,15$ & 5,38E-04 & 202G18,1 & $1, r 1$ & $0,04 L-U$ \\
\hline IL27 & 2,03 & $9,83 \mathrm{E}-04$ & RP11-22P6,3 & 2,07 & $1,28 \mathrm{E}-04$ \\
\hline IL36A & 1,7 & $7,52 \mathrm{E}-03$ & \begin{tabular}{|l} 
RP11-247A12,2 \\
\end{tabular} & 1,34 & $4,58 \mathrm{E}-03$ \\
\hline INPP5F & 1,65 & 7,91E-04 & RP11- & $-1,66$ & $9,98 \mathrm{E}-03$ \\
\hline IQCD & $-2,41$ & $1,96 \mathrm{E}-05$ & 247|13,11 & & \\
\hline IRF1 & 0,95 & $9,53 \mathrm{E}-03$ & RP11-26C10,1 & $-1,68$ & $7,70 \mathrm{E}-03$ \\
\hline ISM1 & 1,98 & $8,25 \mathrm{E}-04$ & RP11-326C3,2 & 1,41 & 3,93E-03 \\
\hline ITGB1P1 & $-1,08$ & $6,20 \mathrm{E}-03$ & $\begin{array}{l}\text { RP11- } \\
\text { 350N15,4 }\end{array}$ & 1,87 & $2,47 \mathrm{E}-03$ \\
\hline ITGB4 & 1,1 & $6,82 \mathrm{E}-03$ & & & \\
\hline ITM2C & 1,35 & $1,55 \mathrm{E}-03$ & $396 \mathrm{M} 11,1$ & 1,61 & $1,56 \mathrm{E}-03$ \\
\hline KB-1460A1,5 & $-1,22$ & $7,39 \mathrm{E}-03$ & RP11- & $-1,72$ & 7,35E-03 \\
\hline KCNIP2 & $-1,27$ & $3,88 \mathrm{E}-03$ & 408019,5 & & \\
\hline
\end{tabular}

\begin{tabular}{|c|c|c|c|c|c|}
\hline RP11-423H2,3 & $-1,49$ & $3,04 \mathrm{E}-03$ & TTLL6 & 1,7 & $7,52 \mathrm{E}-03$ \\
\hline \multirow{2}{*}{$\begin{array}{l}\text { RP11- } \\
\text { 446N19,1 }\end{array}$} & \multirow{2}{*}{1,93} & \multirow{2}{*}{$1,69 \mathrm{E}-03$} & ULBP3 & 1,81 & $5,15 \mathrm{E}-03$ \\
\hline & & & USP30-AS1 & 1,06 & $8,02 \mathrm{E}-03$ \\
\hline RP11-44K6,2 & 1,92 & 2,51E-03 & VANGL2 & 2,08 & $9,83 \mathrm{E}-05$ \\
\hline $\begin{array}{l}\text { RP11- } \\
\text { R7115 }\end{array}$ & $-1,52$ & 6,63E-03 & WARS & 1,35 & $6,75 \mathrm{E}-03$ \\
\hline RP11-46F15,2 & $-1,62$ & $6,90 \mathrm{E}-03$ & XKR5 & 1,96 & $2,37 \mathrm{E}-03$ \\
\hline RP11- & & & YBX2 & 2,72 & $1,92 \mathrm{E}-06$ \\
\hline $479 \mathrm{G} 22,8$ & $-1,35$ & 5,88E-03 & ZCCHC12 & 2,33 & $3,25 \mathrm{E}-04$ \\
\hline RP11-485G7,6 & 2,5 & $7,16 \mathrm{E}-05$ & ZNF155 & $-1,13$ & $6,76 \mathrm{E}-03$ \\
\hline RP11-401,2 & $-1,36$ & $9,00 \mathrm{E}-03$ & ZNF462 & $-1,6$ & $2,33 \mathrm{E}-03$ \\
\hline RP11-53B2,6 & 1,64 & 1,92E-03 & ZNF469 & 1,08 & $4,31 \mathrm{E}-03$ \\
\hline RP11-728B21,3 & 2,19 & $3,52 \mathrm{E}-04$ & ZSCAN31 & 1,34 & $2,23 \mathrm{E}-03$ \\
\hline
\end{tabular}

\section{7) Genes regulados somente por FvFc M}

\begin{tabular}{|c|c|c|}
\hline Gene & FC (Log2) & $p$ value \\
\hline ABLIM3 & $-1,55$ & $5,95 \mathrm{E}-03$ \\
\hline AC006033,22 & $-1,33$ & 2,69E-03 \\
\hline AC006483,5 & $-1,56$ & $2,40 \mathrm{E}-03$ \\
\hline AC007278,3 & 1,27 & $3,20 \mathrm{E}-03$ \\
\hline AC008984,2 & $-1,77$ & $2,39 \mathrm{E}-03$ \\
\hline AC083949,1 & 1,45 & $9,36 \mathrm{E}-03$ \\
\hline $\mathrm{ACOX} 2$ & $-1,80$ & $1,80 \mathrm{E}-03$ \\
\hline ADAD2 & 1,49 & $8,46 \mathrm{E}-03$ \\
\hline ADAM12 & 1,41 & $6,38 \mathrm{E}-04$ \\
\hline AFAP1 & 1,36 & 1,76E-03 \\
\hline ANXA2P1 & $-2,03$ & $1,30 \mathrm{E}-04$ \\
\hline ANXA2P3 & $-1,75$ & $2,54 \mathrm{E}-03$ \\
\hline AP003774,4 & $-1,68$ & $3,16 \mathrm{E}-03$ \\
\hline AP005482,1 & $-1,60$ & $6,12 \mathrm{E}-03$ \\
\hline AP1B1 & $-0,88$ & 9,29E-03 \\
\hline ARHGAP10 & $-1,33$ & $2,22 \mathrm{E}-03$ \\
\hline ARRB1 & $-1,19$ & $7,86 \mathrm{E}-03$ \\
\hline ATOX1 & $-1,34$ & $5,62 \mathrm{E}-03$ \\
\hline ATP6V0B & $-1,25$ & $7,59 \mathrm{E}-03$ \\
\hline ATP8B1 & $-1,42$ & $7,46 \mathrm{E}-03$ \\
\hline BCAT1 & $-1,36$ & $8,95 \mathrm{E}-03$ \\
\hline BMP6 & 2,19 & 4,74E-05 \\
\hline BZRAP1-AS1 & 1,38 & $6,29 \mathrm{E}-03$ \\
\hline C12ORF4 & $-1,16$ & $7,60 \mathrm{E}-03$ \\
\hline C12ORF55 & 1,72 & 3,07E-03 \\
\hline C19ORF10 & $-1,38$ & $1,98 \mathrm{E}-03$ \\
\hline C10RF54 & $-1,23$ & $6,80 \mathrm{E}-04$ \\
\hline C200RF194 & $-1,35$ & 3,47E-03 \\
\hline CALR & $-1,04$ & $7,72 \mathrm{E}-03$ \\
\hline CALU & $-1,32$ & $6,59 \mathrm{E}-03$ \\
\hline CAPN11 & $-1,54$ & $8,10 \mathrm{E}-03$ \\
\hline CCDC64 & 1,13 & $6,43 \mathrm{E}-03$ \\
\hline CCNA1 & $-1,36$ & $6,96 \mathrm{E}-03$ \\
\hline CCSER1 & $-1,53$ & $8,78 \mathrm{E}-03$ \\
\hline CD276 & $-1,41$ & 1,52E-03 \\
\hline CD28 & 1,22 & $9,91 \mathrm{E}-03$ \\
\hline CDS1 & $-1,45$ & $3,21 \mathrm{E}-03$ \\
\hline CEP19 & 0,92 & $9,25 \mathrm{E}-03$ \\
\hline $\mathrm{CHCHD} 10$ & $-0,97$ & $6,07 \mathrm{E}-03$ \\
\hline CLEC12A & $-1,62$ & $5,47 \mathrm{E}-03$ \\
\hline CLIC3 & 1,96 & $1,58 \mathrm{E}-07$ \\
\hline CLN6 & $-1,46$ & 7,30 E-04 \\
\hline CPNE8 & $-1,42$ & $4,76 \mathrm{E}-03$ \\
\hline CPNE9 & $-1,98$ & $4,78 \mathrm{E}-04$ \\
\hline CSPG5 & 2,86 & 1,67E-08 \\
\hline CTD-2006K23,1 & 1,89 & 1,17E-03 \\
\hline CTD-2377D24,8 & 1,61 & $5,06 \mathrm{E}-03$ \\
\hline CYP4F59P & $-1,61$ & $1,85 \mathrm{E}-03$ \\
\hline $\mathrm{DBI}$ & $-1,28$ & $4,91 \mathrm{E}-03$ \\
\hline DBIP1 & $-1,19$ & 7,99E-03 \\
\hline DDO & $-1,51$ & $9,26 \mathrm{E}-03$ \\
\hline DEC1 & 2,24 & 1,27E-04 \\
\hline DOCK1 & $-1,41$ & $6,42 \mathrm{E}-03$ \\
\hline DPY19L2 & 1,32 & $1,29 \mathrm{E}-03$ \\
\hline DPYSL2 & $-1,12$ & $7,69 \mathrm{E}-03$ \\
\hline DUSP23 & $-1,13$ & $7,39 \mathrm{E}-03$ \\
\hline DZIP1L & $-1,53$ & 3,47E-03 \\
\hline
\end{tabular}




\begin{tabular}{|c|c|c|}
\hline ECM1 & $-1,59$ & $2,44 \mathrm{E}-04$ \\
\hline EIF4EBP1 & $-1,25$ & $3,03 E-03$ \\
\hline ELK3 & 1,04 & $3,33 \mathrm{E}-03$ \\
\hline EMP3 & $-1,30$ & $2,01 \mathrm{E}-03$ \\
\hline EMR1 & 1,72 & $2,61 \mathrm{E}-06$ \\
\hline F2R & 1,07 & $6,50 \mathrm{E}-03$ \\
\hline FADS1 & $-1,49$ & $7,72 \mathrm{E}-03$ \\
\hline $\mathrm{FAH}$ & $-1,21$ & $9,73 \mathrm{E}-03$ \\
\hline FAM115C & 1,35 & $8,57 \mathrm{E}-04$ \\
\hline FAM124B & 1,53 & $7,46 \mathrm{E}-03$ \\
\hline FAM180B & $-1,67$ & $2,06 \mathrm{E}-03$ \\
\hline FAM212B & $-1,22$ & $7,23 \mathrm{E}-03$ \\
\hline FAM27E2 & $-1,67$ & $3,62 \mathrm{E}-03$ \\
\hline FBLN7 & 1,38 & $1,27 \mathrm{E}-03$ \\
\hline FDX1 & $-1,34$ & $7,18 \mathrm{E}-03$ \\
\hline FUCA2 & $-1,59$ & $4,37 \mathrm{E}-04$ \\
\hline GALE & $-1,09$ & $5,54 \mathrm{E}-03$ \\
\hline GAS2L1 & $-1,39$ & $2,68 \mathrm{E}-03$ \\
\hline GLA & $-1,54$ & $2,89 \mathrm{E}-03$ \\
\hline GOLGA8G & 1,52 & $7,57 \mathrm{E}-03$ \\
\hline GRIP1 & $-1,50$ & $9,29 \mathrm{E}-03$ \\
\hline GUSB & $-1,02$ & $6,58 \mathrm{E}-03$ \\
\hline HAS1 & 1,75 & $2,60 \mathrm{E}-03$ \\
\hline $\mathrm{HBB}$ & 1,76 & $2,64 \mathrm{E}-03$ \\
\hline HES2 & $-2,02$ & $4,72 \mathrm{E}-04$ \\
\hline HES6 & $-1,28$ & $9,57 \mathrm{E}-03$ \\
\hline HK3 & $-1,37$ & $2,64 \mathrm{E}-03$ \\
\hline HLA-DQA2 & $-1,50$ & $7,60 \mathrm{E}-03$ \\
\hline HLF & 1,59 & $2,31 \mathrm{E}-03$ \\
\hline HVCN1 & $-1,27$ & $5,91 \mathrm{E}-03$ \\
\hline ICA1 & 1,51 & $2,05 \mathrm{E}-03$ \\
\hline $\mathrm{IF|} 27$ & $-1,83$ & $1,11 \mathrm{E}-03$ \\
\hline IFI6 & $-1,58$ & $4,04 \mathrm{E}-03$ \\
\hline $\mathrm{IQCH}$ & 1,45 & $3,96 \mathrm{E}-03$ \\
\hline KCNAB1 & $-1,44$ & $3,58 \mathrm{E}-03$ \\
\hline KIF17 & $-2,00$ & $1,17 \mathrm{E}-04$ \\
\hline LAX1 & 1,15 & $6,05 \mathrm{E}-03$ \\
\hline LBP & 2,29 & $8,86 \mathrm{E}-05$ \\
\hline LDLRAD4 & 1,28 & $3,18 \mathrm{E}-03$ \\
\hline LGALS1 & $-1,59$ & $2,67 \mathrm{E}-04$ \\
\hline LGALS14 & 1,59 & $6,38 \mathrm{E}-03$ \\
\hline LINC00511 & 1,83 & $4,03 \mathrm{E}-04$ \\
\hline LINC00520 & $-1,58$ & $6,73 \mathrm{E}-03$ \\
\hline LINC01010 & $-1,60$ & $5,47 \mathrm{E}-03$ \\
\hline LINC01050 & $-1,50$ & $9,74 \mathrm{E}-03$ \\
\hline LMNA & $-1,23$ & $3,71 \mathrm{E}-03$ \\
\hline LPL & $-1,67$ & $1,64 \mathrm{E}-04$ \\
\hline MARCH3 & 1,23 & $1,92 \mathrm{E}-03$ \\
\hline MCF2L2 & 1,26 & $4,58 \mathrm{E}-03$ \\
\hline MCOLN3 & $-1,86$ & $1,00 \mathrm{E}-03$ \\
\hline MEP1A & $-1,78$ & $2,10 \mathrm{E}-03$ \\
\hline MMP1 & 2,05 & $4,40 \mathrm{E}-04$ \\
\hline MMP3 & 1,66 & $3,73 \mathrm{E}-03$ \\
\hline MREG & $-1,31$ & $8,78 \mathrm{E}-03$ \\
\hline MYBPC3 & $-1,48$ & $5,58 \mathrm{E}-03$ \\
\hline MY01A & $-1,42$ & $9,73 \mathrm{E}-03$ \\
\hline MY01E & $-1,44$ & $3,93 \mathrm{E}-04$ \\
\hline $\mathrm{N} / \mathrm{A}$ & $-1,11$ & $9,21 \mathrm{E}-03$ \\
\hline NAGA & $-1,10$ & $6,81 \mathrm{E}-03$ \\
\hline NCF2 & $-1,69$ & $1,04 \mathrm{E}-03$ \\
\hline NCF4 & $-1,31$ & $4,34 \mathrm{E}-03$ \\
\hline NRIP3 & $-1,35$ & $6,98 \mathrm{E}-03$ \\
\hline NRROS & $-1,39$ & $5,30 \mathrm{E}-03$ \\
\hline NTRK3 & 2,06 & $2,49 \mathrm{E}-04$ \\
\hline P2RY10 & 1,12 & $6,64 \mathrm{E}-03$ \\
\hline PARVB & $-1,34$ & $2,01 \mathrm{E}-03$ \\
\hline PDE3B & 1,16 & $5,47 \mathrm{E}-03$ \\
\hline PDE4D & 1,44 & $1,13 \mathrm{E}-03$ \\
\hline PGBD4P1 & 1,67 & $4,31 \mathrm{E}-03$ \\
\hline PIK3C2B & 1,24 & $1,46 \mathrm{E}-03$ \\
\hline PLEK & $-1,36$ & $8,55 \mathrm{E}-03$ \\
\hline PLOD1 & $-1,82$ & $4,11 \mathrm{E}-05$ \\
\hline PLVAP & $-1,98$ & $4,81 \mathrm{E}-04$ \\
\hline PMEPA1 & 1,21 & $2,48 \mathrm{E}-03$ \\
\hline PPARGC1B & $-1,07$ & $2,80 \mathrm{E}-03$ \\
\hline PRG2 & 1,37 & $3,81 \mathrm{E}-03$ \\
\hline
\end{tabular}

\begin{tabular}{|c|c|c|}
\hline PTPN13 & 1,51 & $3,09 \mathrm{E}-03$ \\
\hline PTPN21 & $-1,67$ & $4,20 \mathrm{E}-03$ \\
\hline RASAL2 & $-1,62$ & $1,30 \mathrm{E}-03$ \\
\hline RASGRF1 & $-2,21$ & $2,07 \mathrm{E}-06$ \\
\hline RN7SKP214 & 1,49 & $8,26 \mathrm{E}-03$ \\
\hline ROR1 & 1,74 & $2,56 \mathrm{E}-03$ \\
\hline $\begin{array}{l}\text { RP11- } \\
\text { 1029J19,4 }\end{array}$ & 1,58 & $1,18 \mathrm{E}-03$ \\
\hline $\begin{array}{l}\text { RP11- } \\
\text { 1029J19,5 } \\
\end{array}$ & 2,15 & $1,89 \mathrm{E}-04$ \\
\hline RP11-134K13,2 & $-1,08$ & $8,11 \mathrm{E}-03$ \\
\hline RP11-157D23,1 & $-1,47$ & $8,32 \mathrm{E}-03$ \\
\hline RP11-16K12,1 & $-1,56$ & $6,61 \mathrm{E}-03$ \\
\hline RP11-20G13,3 & $-1,99$ & $2,16 \mathrm{E}-04$ \\
\hline RP11-20I23,13 & $-1,24$ & $8,60 \mathrm{E}-03$ \\
\hline RP11-253I19,4 & $-1,75$ & $2,65 \mathrm{E}-03$ \\
\hline RP11-266L9,3 & $-1,56$ & $5,80 \mathrm{E}-03$ \\
\hline RP11-288H12,4 & $-1,53$ & $1,46 \mathrm{E}-03$ \\
\hline RP11-312J18,5 & $-1,09$ & $8,61 \mathrm{E}-03$ \\
\hline RP11-330A16,1 & 1,55 & $5,36 \mathrm{E}-03$ \\
\hline RP11-371A19,2 & 1,54 & $7,94 \mathrm{E}-03$ \\
\hline RP11-394J1,2 & 1,69 & $1,56 \mathrm{E}-03$ \\
\hline RP11-401P9,6 & 1,53 & $7,93 \mathrm{E}-03$ \\
\hline RP11-403A21,1 & 1,67 & $3,23 \mathrm{E}-03$ \\
\hline RP11-440D17,3 & 1,49 & $5,37 \mathrm{E}-03$ \\
\hline RP11-466P24,6 & $-1,66$ & $3,38 \mathrm{E}-03$ \\
\hline RP11-59808,1 & $-1,29$ & $5,50 \mathrm{E}-03$ \\
\hline RP11-61L23,2 & 1,10 & $8,96 \mathrm{E}-03$ \\
\hline RP11-712B9,2 & 1,30 & $6,02 \mathrm{E}-03$ \\
\hline RP11-74E22,3 & $-1,96$ & $8,17 \mathrm{E}-04$ \\
\hline $\mathrm{RP} 11-79 \mathrm{H} 23,3$ & 1,77 & $2,50 \mathrm{E}-03$ \\
\hline RP11-93K22,13 & 1,55 & $7,87 \mathrm{E}-03$ \\
\hline RP4-576H24,2 & $-1,70$ & $3,53 \mathrm{E}-03$ \\
\hline RP4-644L1,2 & $-1,48$ & $8,16 \mathrm{E}-03$ \\
\hline RP5-1096J16,1 & $-1,77$ & $2,02 \mathrm{E}-03$ \\
\hline RP9P & $-1,06$ & $8,75 \mathrm{E}-03$ \\
\hline RRBP1 & $-1,28$ & $4,62 \mathrm{E}-03$ \\
\hline S100A11P1 & $-1,44$ & $4,11 \mathrm{E}-03$ \\
\hline S100A11P2 & $-1,51$ & $3,20 \mathrm{E}-03$ \\
\hline S100A6 & $-1,24$ & $4,71 \mathrm{E}-03$ \\
\hline SAMD11 & 1,61 & $4,31 \mathrm{E}-03$ \\
\hline SCD & $-2,02$ & $1,55 \mathrm{E}-04$ \\
\hline SCDP1 & $-1,72$ & 1,94E-03 \\
\hline SEMA3A & $-1,62$ & $2,82 \mathrm{E}-03$ \\
\hline SESN3 & 1,22 & $4,84 \mathrm{E}-03$ \\
\hline SHBG & $-1,43$ & 9,67E-03 \\
\hline SIGLEC17P & $-1,94$ & 1,07E-04 \\
\hline SIL1 & $-1,13$ & $6,58 \mathrm{E}-03$ \\
\hline SIRPD & $-1,52$ & $6,73 \mathrm{E}-03$ \\
\hline SLC12A3 & $-1,74$ & $1,67 \mathrm{E}-03$ \\
\hline SLC17A9 & $-1,62$ & $5,62 \mathrm{E}-05$ \\
\hline SLC4A8 & $-1,46$ & $3,69 \mathrm{E}-03$ \\
\hline SMAD1 & 1,18 & $2,35 \mathrm{E}-03$ \\
\hline SMIM4 & $-1,02$ & $4,94 \mathrm{E}-03$ \\
\hline SMOX & 0,93 & $8,45 \mathrm{E}-03$ \\
\hline SNX8 & $-1,34$ & $5,48 \mathrm{E}-03$ \\
\hline SOX5 & 1,74 & $2,49 \mathrm{E}-03$ \\
\hline SPIRE1 & $-1,47$ & $4,25 \mathrm{E}-03$ \\
\hline STEAP1B & 1,53 & $8,64 \mathrm{E}-03$ \\
\hline STK17B & 1,08 & $9,66 \mathrm{E}-03$ \\
\hline SYT8 & $-1,56$ & $7,15 \mathrm{E}-03$ \\
\hline SYTL2 & 1,08 & $4,58 \mathrm{E}-03$ \\
\hline TBC1D8B & 1,29 & 6,71E-03 \\
\hline TCEAL4 & $-1,27$ & $3,57 \mathrm{E}-03$ \\
\hline TIGIT & 1,36 & 1,17E-03 \\
\hline TKT & $-1,24$ & $7,59 \mathrm{E}-03$ \\
\hline TMEM147 & $-1,20$ & $5,14 \mathrm{E}-03$ \\
\hline TMEM158 & $-1,77$ & $1,26 \mathrm{E}-03$ \\
\hline TRAJ7 & 1,47 & 4,97E-03 \\
\hline TTC39A & $-1,68$ & $2,56 \mathrm{E}-03$ \\
\hline TTC7B & $-1,59$ & $5,11 \mathrm{E}-04$ \\
\hline TUBB2A & $-1,04$ & $4,86 \mathrm{E}-03$ \\
\hline TUBB6 & $-1,47$ & $2,29 \mathrm{E}-03$ \\
\hline TUBBP5 & $-1,46$ & $5,45 \mathrm{E}-03$ \\
\hline UBE2QL1 & 1,67 & $3,21 \mathrm{E}-03$ \\
\hline UNC13B & $-1,91$ & $2,21 \mathrm{E}-04$ \\
\hline
\end{tabular}

